PNNL-13582

\title{
High-Level Waste Melter Study Report
}

$\begin{array}{ll}\text { J.M. Perez, Jr. } & \text { D.K. Peeler } \\ \text { D.F. Bickford } & \text { D.M. Strachan } \\ \text { D.E. Day } & \text { M.B. Triplett } \\ \text { D.S. Kim } & \text { J.D. Vienna } \\ \text { S.L. Lambert } & \text { R.S. Wittman } \\ \text { S.L. Marra } & \end{array}$

July 2001

Prepared for the U.S. Department of Energy under Contract DE-AC06-76RL01830

Pacific Northwest National Laboratory

Richland, Washington 99352 


\title{
Disclaimer
}

This report was prepared as an account of work sponsored by an agency of the United States Government. Neither the United States Government nor any agency thereof, nor Battelle Memorial Institute, nor any of their employees, makes any warranty, express or implied, or assumes any legal liability or responsibility for the accuracy, completeness, or usefulness of any information, apparatus, product, or process disclosed, or represents that its use would not infringe privately owned rights. Reference herein to any specific commercial product, process, or service by trade name, trademark, manufacturer, or otherwise does not necessarily constitute or imply its endorsement, recommendation, or favoring by the United States Government or any agency thereof, or Battelle Memorial Institute. The views and opinions of authors expressed herein do not necessarily state or reflect those of the United States Government or any agency thereof.

\author{
PACIFIC NORTHWEST NATIONAL LABORATORY \\ operated by \\ BATTELLE \\ for the \\ UNITED STATES DEPARTMENT OF ENERGY \\ under Contract DE-AC06-76RLO1830
}

Printed in the United States of America

Available to DOE and DOE contractors from the

Office of Scientific and Technical Information,

P.O. Box 62, Oak Ridge, TN 37831-0062

$\mathrm{Ph}:(865)$ 576-8401

Fax: (865) 576-5728

Email: reports@adonis.osti.gov

Available to the public from the National Technical Information Service,

U.S. Department of Commerce, 5285 Port Royal Rd., Springfield, VA 22161

Ph: (800) 553-6847

Fax: (703) 605-6900

Email: orders@ntis.fedworld.gov

Online ordering: http://www.ntis.gov/ordering.htm 
PNNL-13582

\section{High-Level Waste} Melter Study Report
J.M. Perez, Jr.
D.K. Peeler
D.F. Bickford
D.M. Strachan
D.E. Day
M.B. Triplett
D.S. Kim
J.D. Vienna
S.L. Lambert
R.S. Wittman
S.L. Marra

July 2001

Prepared for

the U.S. Department of Energy, under Contract DE-AC06-76RL01830 


\begin{abstract}
At the Hanford Site in Richland, Washington, the path to site cleanup involves vitrification of the majority of the wastes that currently reside in large underground tanks. A Joule-heated glass melter is the equipment of choice for vitrifying the high-level fraction of these wastes. Even though this technology has general national and international acceptance, opportunities may exist to improve or change the technology to reduce the enormous cost of accomplishing the mission of site cleanup. Consequently, the U.S. Department of Energy requested the staff of the Tanks Focus Area to review immobilization technologies, waste forms, and modifications to requirements for solidification of the high-level waste fraction at Hanford to determine what aspects could affect cost reductions with reasonable long-term risk. The results of this study are summarized in this report.
\end{abstract}




\section{Executive Summary}

At the Hanford Site in Richland, Washington, the path to site cleanup involves vitrification of the majority of the wastes that currently reside in large underground tanks. A Joule-heated glass melter is the equipment of choice for vitrifying the high-level fraction of these wastes. Even though this technology has general national and international acceptance, opportunities may exist to improve or change the technology to reduce the enormous cost of accomplishing the mission of site cleanup. Consequently, the U.S. Department of Energy (DOE) requested the staff of the Tanks Focus Area (TFA) to review immobilization technologies, waste forms, and modifications to requirements for solidification of the high-level waste (HLW) fraction at Hanford to determine what aspects could affect cost reductions with reasonable long-term risk. The results of this study are summarized in this report and are further distilled in this Executive Summary.

It should be noted that there is a degree of uncertainty with the analyses that were performed in this study. Although we recognize the need for a propagation of error analysis, it was outside the scope of this task. Hence, we have taken the base case as certain even though there exists a significant uncertainty. Numbers and cases are treated accordingly. As a result, there are many more significant figures reported than could be supported had an error analysis been performed, e.g. 1833 canisters containing glass of a particular composition. The conclusions that are based on these numbers are indicative of where and the magnitude of the potential savings. The numbers that are show should be taken in that context.

The vitrified product will be destined to a mined geologic repository. The current candidate repository is at Yucca Mountain, Nevada. Several requirements must be met to successfully emplace the waste glass in the repository. These are listed in the Waste Acceptance Systems Requirements. These requirements were reviewed to evaluate the bases for the requirements and the potential impact of changes or modifications. We conclude that modification or deletion of several of these requirements would have minor effects on waste loading or cost reductions but may simplify plant operations.

In addition to product requirements, several processing requirements are impacted by the waste form or melter technology used. These requirements are imposed by the operating facility but can have a major impact on waste loading and production costs. Thus, processing requirements were considered in this review.

It was concluded from this effort that the following requirements should be further evaluated to determine the extent to which they could be challenged such that waste loadings could be increased or costs could be reduced:

- Waste form type (i.e., borosilicate glass)

- Product Consistency requirement and strategy for compliance

- Liquidus temperature limit.

An evaluation of waste forms for Hanford high-level waste (HLW) was conducted. Waste compositions representative of those to be delivered to the HLW vitrification plant after retrieval, incidental blending, pretreatment, and separations were combined into groups of like-composition by cluster analyses. A review of literature and previous waste form-evaluation/down-selection activities were used to assess nearly 70 possible waste forms, some more thoroughly than others. The waste forms for which there is sufficient information and which can be fabricated in a HLW glass melter were selected for further consideration:

- alkali-alumino-borosilicate (AABS) glasses

- alkali-aluminosilicate (AAS) glasses 
- $\quad$ iron-phosphate $(\mathrm{FeP})$ glasses

- titanate based ceramics.

Of these waste forms, the most complete information was available for Hanford's reference waste formAABS glasses. The loadings for each of the waste clusters in AABS glasses were estimated with existing glass property models and expert judgment for 21 different sets of property and composition constraints. The resulting glass-volume estimates were compared to those calculated for each individual waste composition before cluster analysis. This analysis showed roughly a $2.5 \%$ increase in the estimated glass volumes based on individual batch compositions. The impact of chromium leach factor, which is the fraction of chromium in the waste that is leached from the HLW, was also estimated; it had the largest influence on glass volume. Aside from the chromium leach factor, the volume of glass was most influenced by the limits set by liquidus temperature $\left(\mathrm{T}_{\mathrm{L}}\right)$ in the spinel primary phase field, by the $\mathrm{Cr}_{2} \mathrm{O}_{3}$ concentration, and by the melting temperature $\left(T_{M}\right)$ (because $T_{L}$ constraint increases with $\left.T_{M}\right)$. The product consistency test (PCT) response constraint had little impact on estimated glass volume. The relaxation of constraints due only to glass-property-model validity and the allowance of multiple phase formation had a moderate impact on estimated glass volume. We conclude that melters that can tolerate crystals or an increase in $\mathrm{T}_{\mathrm{M}}$ would give the biggest glass-volume impacts of any technology/constraint studied.

Available data suggested that the addition of boron to AAS glasses melting at low temperatures would be beneficial. It is possible that low boron or boron-free AAS glasses would give an advantage over AABS glasses at high temperatures. Waste forms obtained from melting Hanford $\mathrm{HLW}$ and enough $\mathrm{SiO}_{2}$ to meet PCT response constraints were found to give the highest waste loading ( $\sim 80$ mass $\%$ ).

The loading of waste clusters in FeP glasses was estimated with expert judgment and results from roughly 500 crucible melts. The waste loadings were estimated for both single-phase FeP glasses and partially crystallized FeP waste forms. The total glass volume for single-phase FeP glasses was slightly higher than that estimated from the reference case of AABS glasses. However, the glass volume for a few of the clusters was lower for FeP glasses. The glass volume estimated for partially crystallized FeP waste forms was lower than those estimated for AABS glasses.

Waste-loadings in titanate ceramics that are produced in glass melter could not be reliably estimated. Significant technical issues must be resolved before implementing any waste form other than the reference-case AABS glass. This report gives some indication of the relative value that may be obtained by investing in these other waste forms or technologies in terms of waste-form volume savings.

This report is structured around the five tasks that comprised the TFA study to evaluate HLW melters and the waste forms that could potentially be produced from them. The comparisons are made relative to the base case of an AABS glass. We start with a discussion of the changes to the glass volumes that would result from changes to the Waste Acceptance Systems Requirements Document (Section 3.0). We then discuss the waste types at Hanford and identify the components that limit waste loading for various waste form types. We discuss how we limited the evaluation to three waste forms and how the volumes of waste glass may be lowered under certain conditions relative to the existing baseline (Section 4.0). We follow these discussions with a discussion of the operational requirements at Hanford (Section 5.0) and the international experience with existing and new generation melters (Section 6.0). In the last section, we discuss the cost savings associated with the regulatory, technical, and operational possibilities to reduce waste glass volume or improve operations of the high-level waste processing (Section 7.0).

Several individuals are responsible for the expertise provided in this report: Joe Perez, Jr. of Washington Group International, Inc. (employed by the Pacific Northwest National Laboratory during development of 
this report); Dong-Sang Kim, Denis Strachan, Mark Triplett, and John Vienna of the Pacific Northwest National Laboratory; Dennis Bickford, Sharon Marra, and David Peeler of the Westinghouse Savannah River Company; Delbert Day of the University of Missouri-Rolla; and Steve Lambert and Richard Wittman, Numatec Hanford Company. 


\section{Glossary}

\begin{tabular}{|c|c|}
\hline $\begin{array}{l}\text { AABS } \\
\text { AAS } \\
\text { ACCM }\end{array}$ & $\begin{array}{l}\text { alkali-alumino-borosilicate (glass) } \\
\text { alkali-aluminosilicate (glass) } \\
\text { advanced cold crucible melter }\end{array}$ \\
\hline BBI & Best Basis Inventory \\
\hline BNFL & British Nuclear Fuels, Limited \\
\hline BNI & Bechtel National, Inc. \\
\hline CCM & cold crucible melter \\
\hline CEA & Commissariate a L'Energie Atomique (French Atomic Energy Commission) \\
\hline $\mathrm{CIC}$ & Consolidated Information Center (Hanford Technical Library) \\
\hline CSB & Canister Storage Building \\
\hline CSSF & calcine solids storage facility \\
\hline DF & decontamination factor \\
\hline DOE & U.S. Department of Energy \\
\hline DST & double-shell tank \\
\hline DWPF & Defense Waste Processing Facility \\
\hline EA & Environmental Assessment [glass] \\
\hline EIS & environmental impact statement \\
\hline EM & DOE Office of Environmental Management \\
\hline EUREX & Enriched Uranium Extaction \\
\hline $\mathrm{FeP}$ & iron phosphate \\
\hline FUETAP & formed under elevated temperature and pressure (concrete) \\
\hline FY & Fiscal Year \\
\hline FZK & Forschungszentrum Karlsruhe \\
\hline GFCE & Government Fair Cost Estimate \\
\hline HAW & high-activity waste \\
\hline HIP & hot isostatic pressing \\
\hline HLW & high-level waste \\
\hline HTWOS & Hanford Tank Waste Optimization Simulator \\
\hline HWVP & Hanford Waste Vitrification Plant \\
\hline ICCM & induction-heated cold crucible melter \\
\hline IHLW & immobilized high-level waste \\
\hline INEEL & Idaho National Engineering and Environmental Laboratory \\
\hline INTEC & Idaho Nuclear Technology and Engineering Center \\
\hline LAW & low-activity waste \\
\hline LCM & Life-Cycle Model \\
\hline LIP & lead-iron phosphate \\
\hline $\begin{array}{l}\text { M } \\
\text { MTG/day }\end{array}$ & $\begin{array}{l}\text { Molar } \\
\text { metric tons glass/day }\end{array}$ \\
\hline
\end{tabular}




\begin{tabular}{|c|c|}
\hline $\begin{array}{l}\text { NETL } \\
\text { NGLW }\end{array}$ & $\begin{array}{l}\text { National Environmental Technology Laboratory } \\
\text { newly generated liquid waste }\end{array}$ \\
\hline ORP & DOE Office of River Protection \\
\hline ORR & Oak Ridge Reservation \\
\hline PCT & product consistency test \\
\hline PHA & precipitate hydrolysis aqueous product \\
\hline PNNL & Pacific Northwest National Laboratory \\
\hline PVA & Prototype Vitrificatons Test facility \\
\hline RCRA & Resource Conservation and Recovery Act \\
\hline RFI & Request for Information \\
\hline RW & DOE Office of Civilian Radioactive Waste Management \\
\hline SAIC & Science Applications International Corporation \\
\hline SBW & sodium-bearing waste \\
\hline SEM & scanning electron microscopy \\
\hline SME & Slurry Mix Evaporator \\
\hline SNF & spent nuclear fuel \\
\hline SRAT & Sludge Receipt and Adjustment Tank \\
\hline SRS & Savannah River Site \\
\hline SST & single-shell tank \\
\hline SYNROC & $\begin{array}{l}\text { synthetic rock - a ceramic material composed primarily of zirconolite, hollandite, } p \\
\text { perovskite, and various titanium oxides }\end{array}$ \\
\hline TAC & Technical Advisory Committee \\
\hline TCLP & toxicity characteristic leaching procedure \\
\hline TFA & Tanks Focus Area \\
\hline $\mathrm{T}_{\mathrm{L}}$ & liquidus temperature \\
\hline $\mathrm{T}_{\mathrm{M}}$ & melting temperature \\
\hline TOE & total operating efficiency \\
\hline TPA & Tri-Party Agreement \\
\hline TRU & transuranic (waste) \\
\hline TVF & Tokai Vitrification Facility \\
\hline TWRS & Tank Waste Remediation System \\
\hline UDS & undissolved solids \\
\hline VEK & Karlsruhe Vitrification Facility \\
\hline WAK & Reprocessing Plant Karlsruhe \\
\hline WA-SRD & Waste Acceptance Systems Requirements Document \\
\hline WAPS & Waste Acceptance Product Specifications \\
\hline WTP & Waste Treatment Plant \\
\hline WVDP & West Valley Demonstration Project \\
\hline XRD & $\mathrm{x}$-ray diffraction \\
\hline
\end{tabular}




\section{Contents}

Abstract

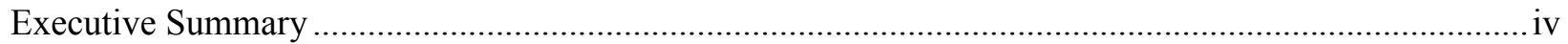

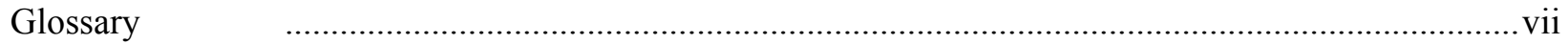

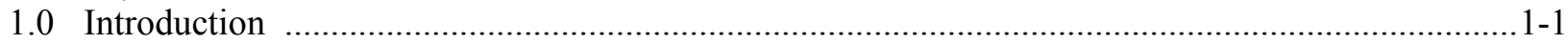

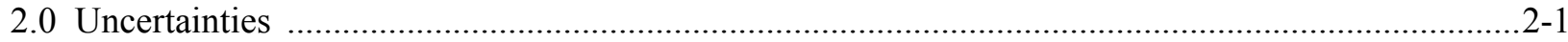

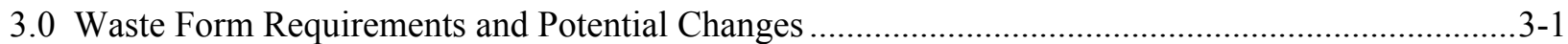

3.1 Current Waste Form Product and Processing Requirements ........................................................

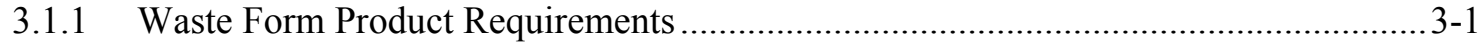

3.1.2 Waste Form Processing Requirements .................................................................. 3-2

3.2 Potential Impact of Modifications to Requirements ..........................................................................

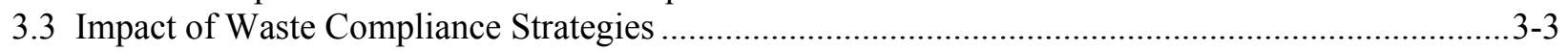

3.3.1 DWPF Approach to Product Control..................................................................... 3-3

3.3.2 WVDP Approach to Product Control .................................................................. 3-3

3.4 Input on Waste Loading Limitations from Waste Form Producers ....................................................3-4

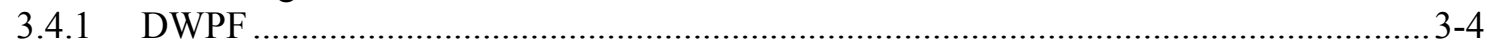

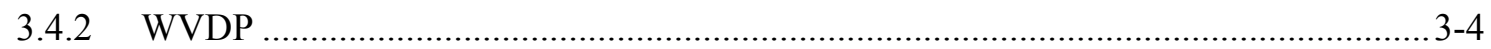

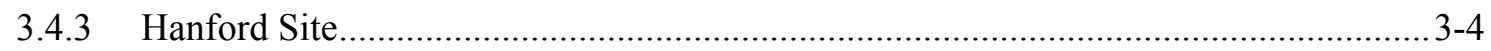

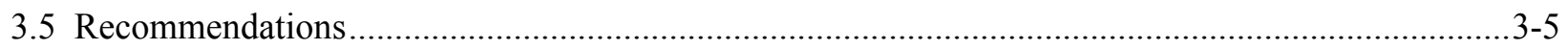

4.0 Waste Form Evaluations for Hanford High-Level Waste .............................................................

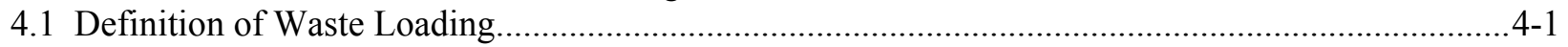

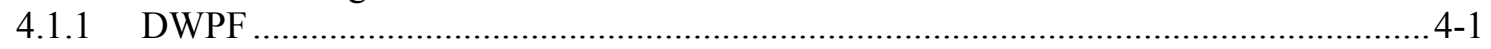

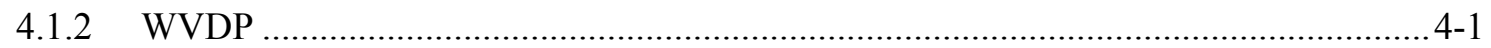

4.1.3 Hanford Waste Vitrification Plant ........................................................................... 4-1

4.1.4 Hanford Waste Treatment Plant .................................................................................. 4-2

4.1.5 Waste Loading Definition Used for this Study....................................................... 4-3

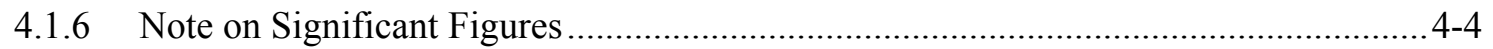

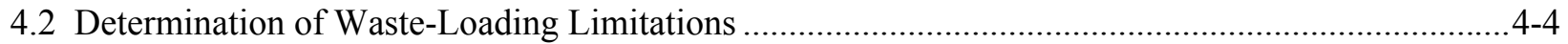

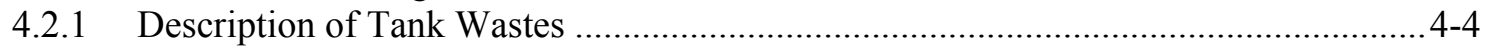

4.2.2 Baseline Waste Feed Delivery Assessments/Hanford Tank Waste Optimization

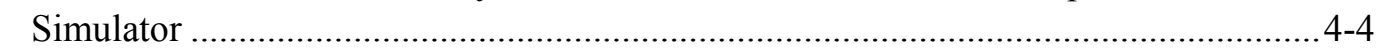

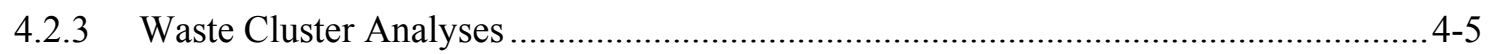

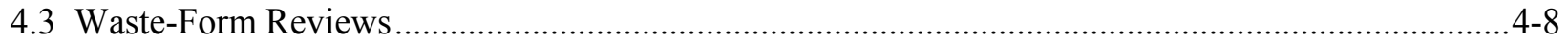

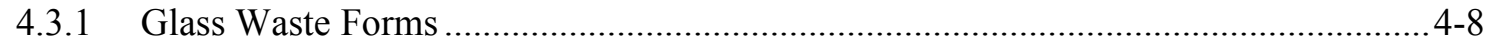

4.3.2 Glass-Ceramic Waste Forms ............................................................................... 4-11

4.3.3 Crystalline Ceramic Waste Forms ......................................................................... 4-12

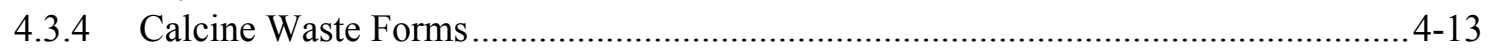

4.3.5 Cementitious Material Waste Forms ......................................................................... 4-14

4.3.6 Metallic Alloy Waste Forms................................................................................. 4-15

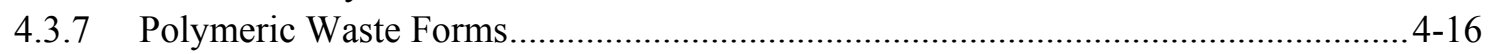

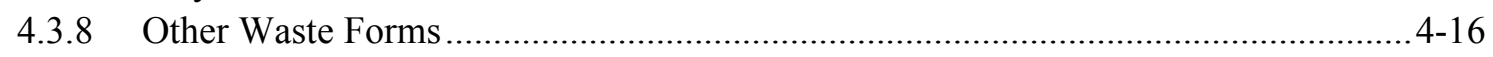

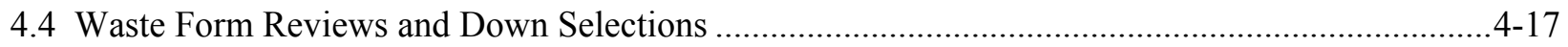

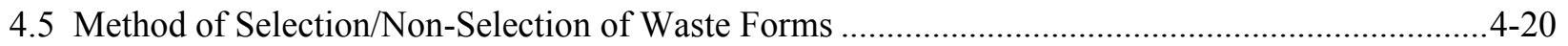

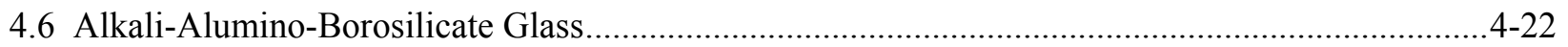

4.6.1 Glass Property Models and Assumptions on Solubilities ......................................... 4-22

4.6.2 Reference Property Constraint Set................................................................. 4-22 


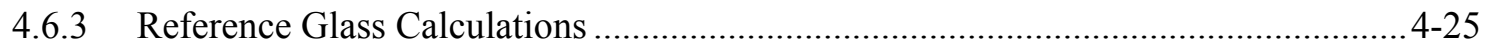

4.6.4 Influence of Constraint Changes on Glass Volumes ............................................. 4-26

4.6.5 Glass Volume Changes from Different Constraint Set Changes .................................4-34

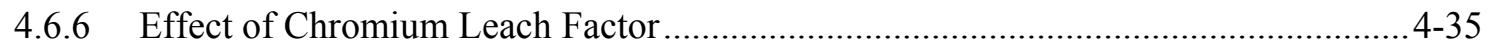

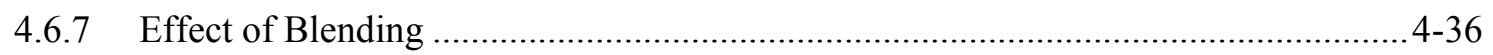

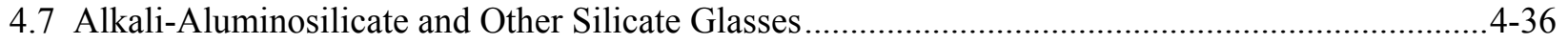

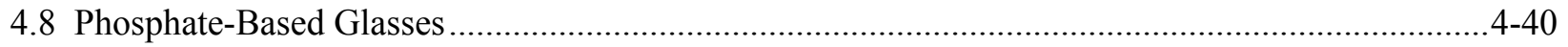

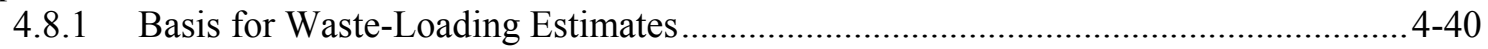

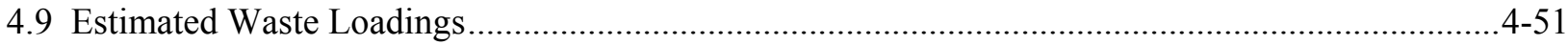

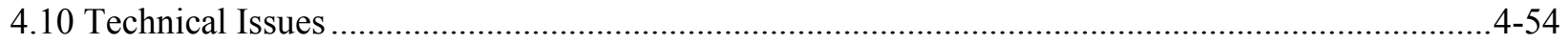

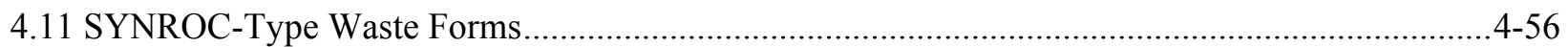

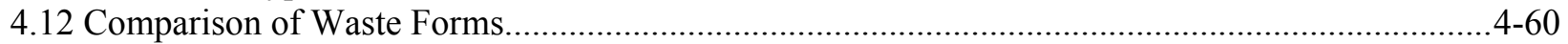

4.12.1 Comparative Table of Glass Volumes from Different Waste Types.........................4-60

4.13 Comparison of the Certainty of Waste Loading Assessment/Knowledge Base .............................4-64

4.13.1 Alkali-Alumino-Borosilicate Glass Reference Case ..............................................4-64

4.13.2 Alkali-Alumino-Borosilicate Glass with Crystals in the Melter ................................4-64

4.13.3 Alkali-Alumino-Borosilicate Glass with Multiple Phases in the Canister ..................4-65

4.13.4 Alkali-Alumino-Borosilicate Glass for High-Temperature Melters........................... 4-65

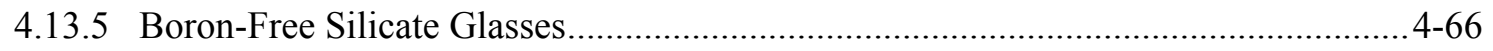

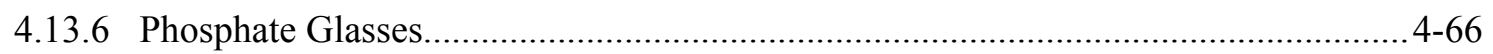

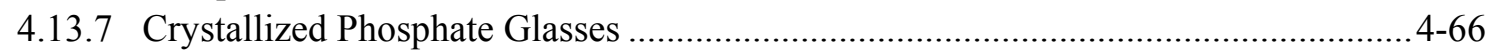

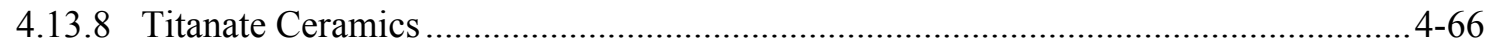

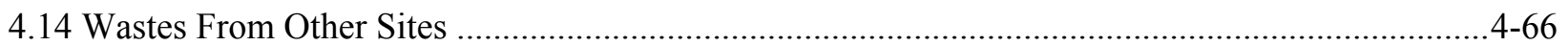

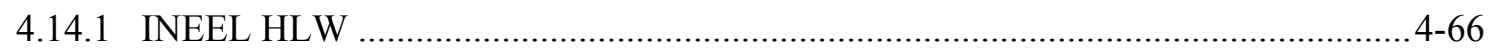

4.14.2 Savannah River Site HLW ................................................................................ 4-75

5.0 Design and Operational Requirements for Immobilization Technologies for Hanford High-Level

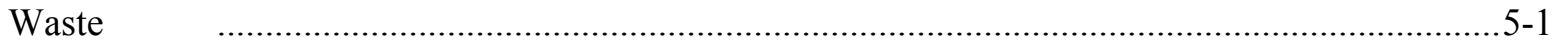

5.1 Prior Experience

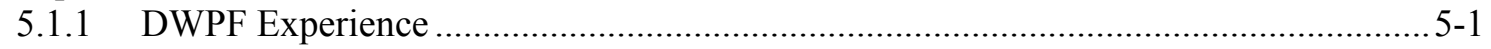

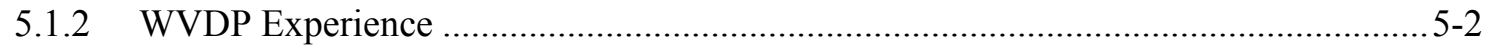

5.2 Design and Operational Requirements to be Evaluated..................................................................

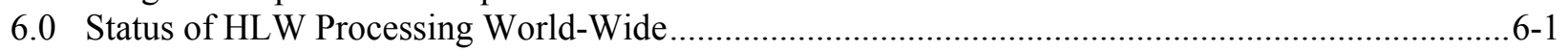

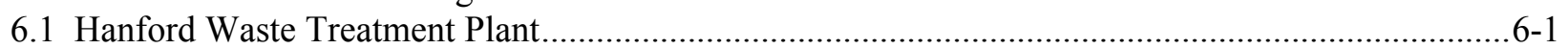

6.1.1 Waste Treatment Plant....................................................................................................

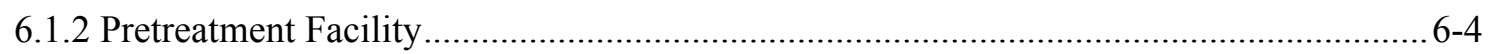

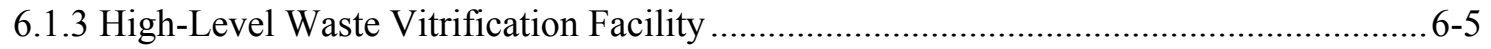

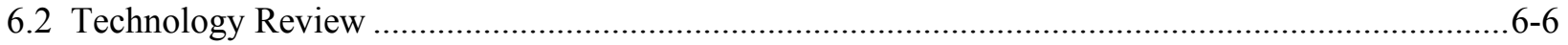

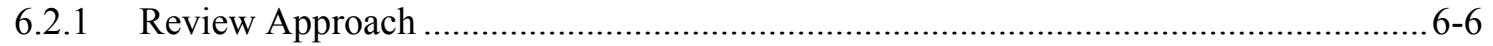

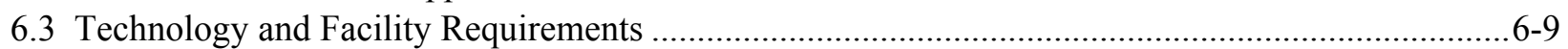

6.3.1 Hanford WTP Baseline and Schedule Descriptions .................................................. 6-9

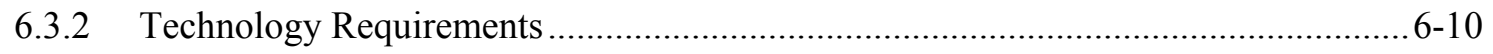

6.3.3 Methods and Criteria Used in Assessment Activities.............................................. 6-11

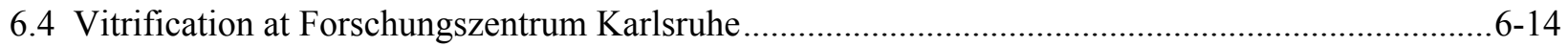

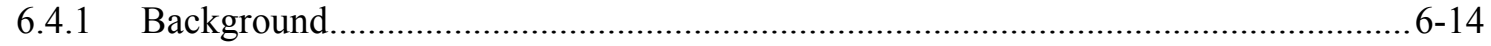

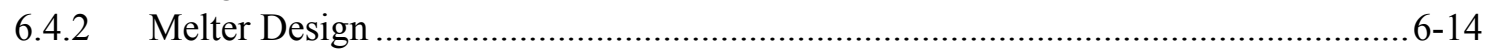

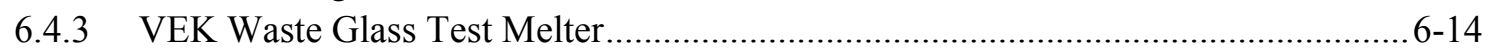

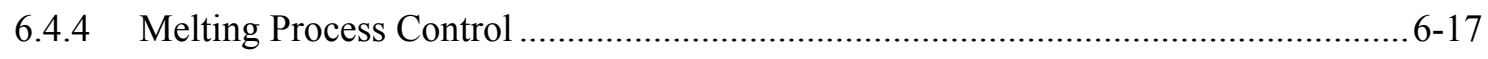

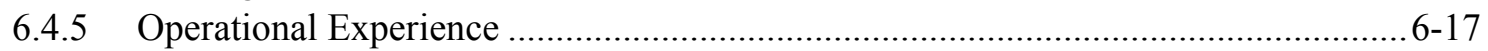




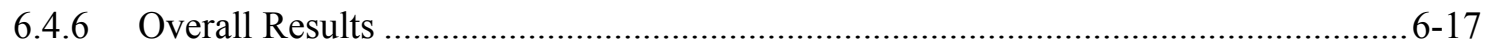

6.4.7 Melter Performance and Noble Metals Compatibility .............................................. 6-18

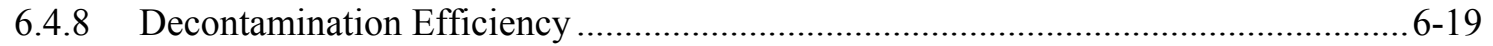

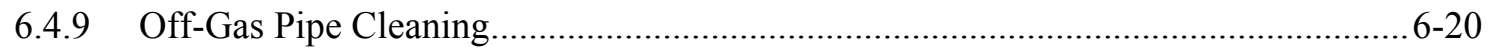

6.4.10 Level Detection Probe ......................................................................................... 6-20

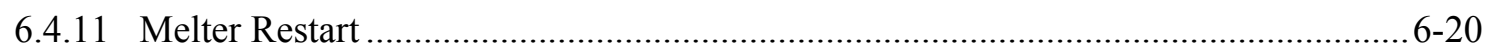

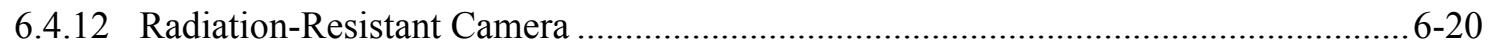

6.5 Experience from Europe (other than Germany) and Asia..........................................................6-21

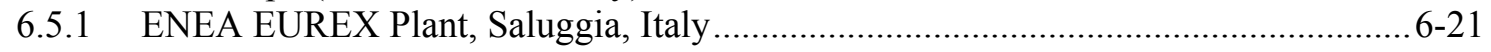

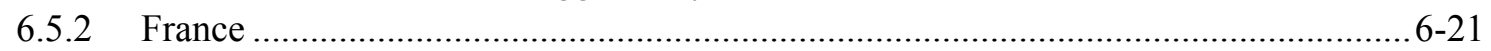

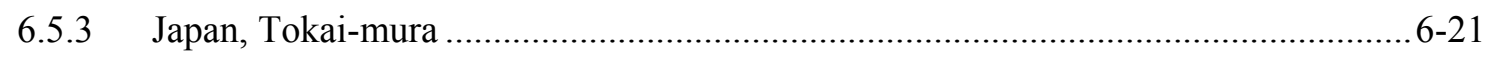

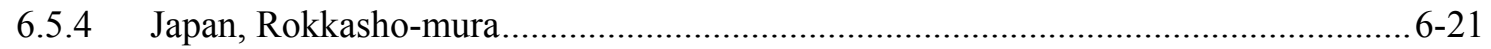

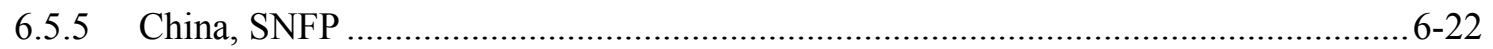

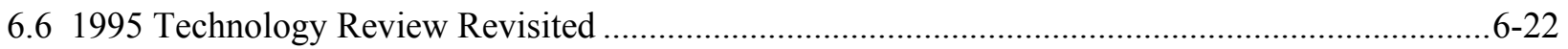

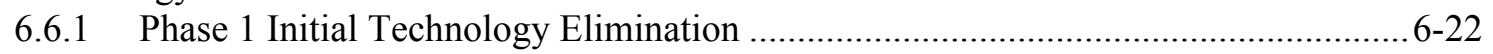

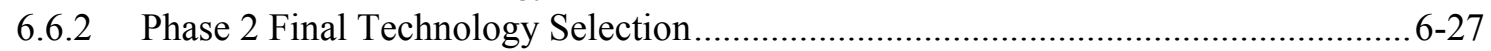

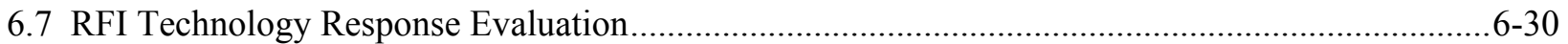

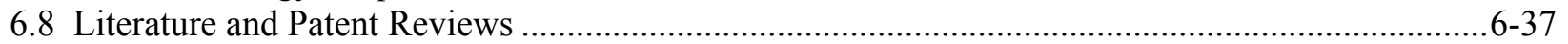

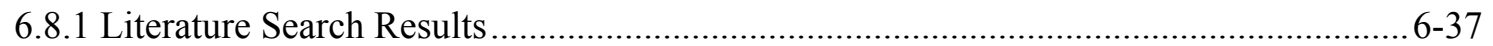

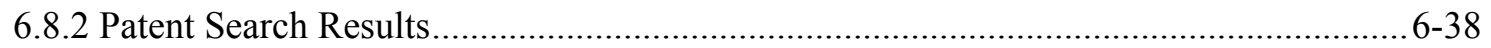

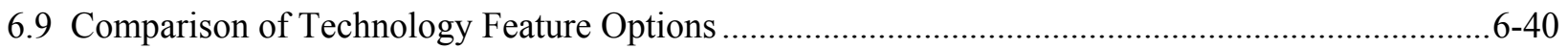

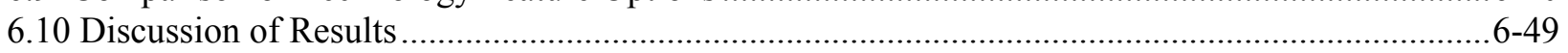

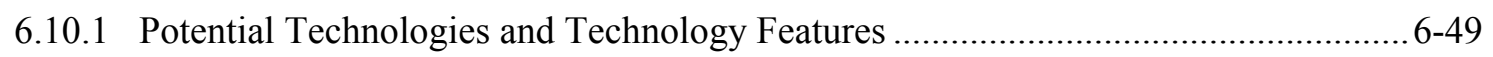

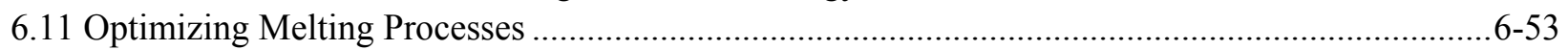

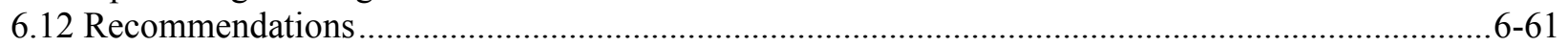

7.0 Cost Benefit Analysis ........................................................................................................

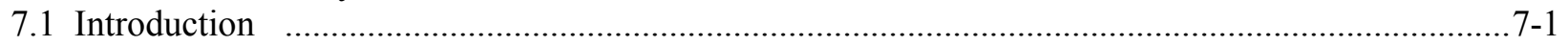

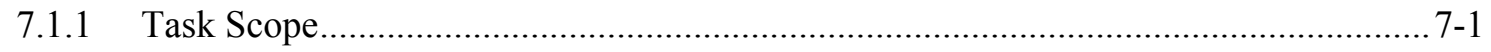

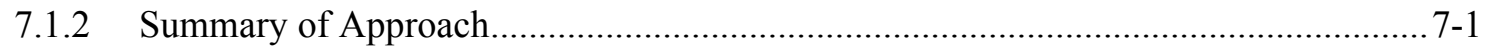

7.1.3 Overview of Prior Cost Analyses ...................................................................... $7-2$

7.1.4 Vitrification Operations ........................................................................................

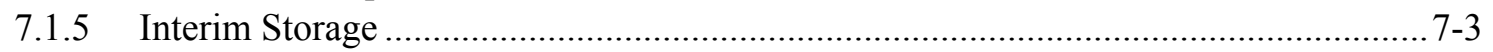

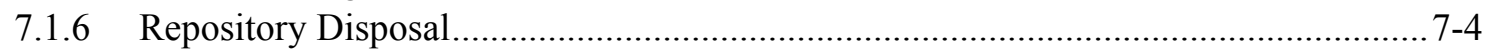

7.2 Hanford Waste Treatment Plant Cost and Performance Baseline....................................................

7.2.1 Baseline Assumptions for Hanford's WTP ................................................................. 7-6

7.2.2 Basis for Estimating WTP Cost and Performance..................................................... 7-8

7.2.3 Description and Summary of Design, Operational, and Cost Parameters .................... 7-8

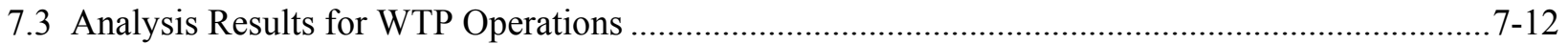

7.4 Impact of Uncertainties in Glass Volume Projections ..................................................................16

7.4.1 Variability in Prior Glass Volume Estimates......................................................... 7-16

7.4.2 Glass Volume Uncertainty due to Chromium Assumptions...................................... 7-16

7.4.3 Variability of Glass Volume Estimates due to Melter Operational Assumptions ...... 7-16

7.4.4 Variability Glass Volume Estimates due to Waste Form Assumptions ..................... 7-16

7.4.5 Variability Glass Volume Estimates due to Phosphate Waste Form Assumptions .... 7-16

7.5 Impact of Uncertainties in WTP Operational Costs .................................................................. 7-16

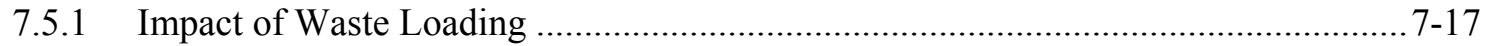

7.5.2 Impact of Melter Design Capacity and Operating Efficiency ................................ 7-17 
7.5.3 Impact of Melter Life, Replacement Cost, and Disposal Cost

7.6 Impact of Future Technology and Glass Volume Uncertainties on WTP Expansion Decisions ....7-21

7.7 Potential Cost Impacts of Melter Technologies and Waste Forms ...............................................7-21

7.7.1 Summary Assessment of Operating Cost Impacts of Alternate Melter Technologies 7-21

7.7.2 WTP Capital Cost Impacts of Alternate Melter Technologies .................................... 7-23

7.7.3 Cost Impact of Alternate Waste Forms .............................................................

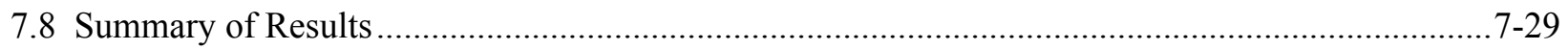

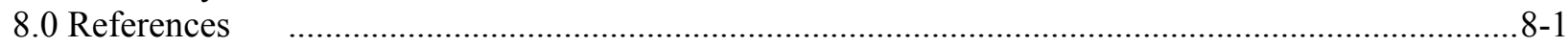

\section{Appendices}

Appendix A - Evaluation of Existing Product and Processing Requirements for Potential Impact ......... A-1 Appendix B - Questions for HLW Vitrification Personnel................................................................. B-1 Appendix C - Compositions of 89 Waste Batches in Mass Percent of Oxides and Summary of Cluster

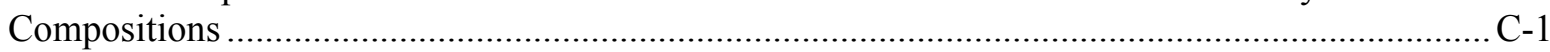
Appendix D - Detailed Results of Waste Loading Calculations with Varying Property Constraints....... D-1 Appendix E - Estimated Waste Loading for Each Cluster.................................................................. E-1 Appendix F - Questions for High-Level Waste Vitrification Personnel ................................................ F-1 Appendix G - Process and Design Requirement Impacts on Vitrification Technology Comparisons ..... G-1

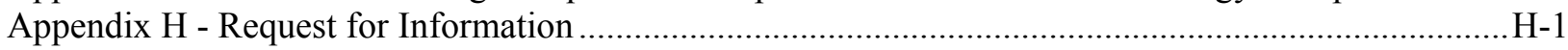
Appendix I - Workshop Agenda and Participants ............................................................................ I-1 Appendix J - HLW Candidate Melter Evaluation Criteria................................................................ J-1 Appendix K - Information Provided by RFI Respondents ...........................................................

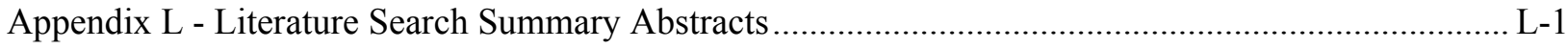


This page left blank intentionally. 


\subsection{Introduction}

The U.S. Department of Energy (DOE) Headquarters directed the Tanks Focus Area (TFA) to conduct a technical review of alternatives for solidification of high-level waste (HLW) that could achieve major cost reductions with reasonable long-term risks. In response, TFA chartered an independent Review Team to lead and guide the technical review, review the products from a Study Team that will collect and analyze data and perform specific analyses, and recommend a research and development program, as warranted, for future waste form and melter advancements.

The focus of this effort is on HLW at the Hanford Site in Richland, Washington, and on evaluating the impact of modifications to product requirements, modification of processing constraints potentially through alternate technologies, alternate waste forms, and evaluation of alternate melter technologies to increase waste loading and reduce costs. This report documents the evaluation of existing product requirements and the potential impact of modifications to those requirements. This report also identifies the major processing constraints that have limited waste loading at existing vitrification facilities.

Based on results from the Study Team, the Review Team will address the following:

- Are there other glasses or glass-ceramic compositions, including borosilicate glass, which could handle segments of DOE HLW with greater efficiency, cost savings, or lower program risk?

- Are there other vitrification technologies, including modifications of current DOE approaches, that could handle segments of DOE HLW with greater efficiency, cost savings, or lower program risk?

The study will address whether modifying current requirements, including those established by the DOE Office of Civilian Radioactive Waste Management (RW), could significantly reduce program costs. To develop a path forward for advanced melter and waste-form materials, the Review Team will recommend "which studies should be done and on what."

This report is structured around the five tasks that comprised the TFA study to evaluate HLW melters and the waste forms that could potentially be produced from them. The comparisons are made relative to the base case of an alkali-alumino-borosilicate (AABS) glass. We start with a discussion of the changes to the glass volumes that would result from changes to the Waste Acceptance Systems Requirements Document (WA-SRD) (Section 3.0). We then discuss the waste types at Hanford and identify the components that limit waste loading for various waste form types. We discuss how we limited the evaluation to three waste forms and how the volumes of waste glass may be lowered under certain conditions relative to the existing baseline (Section 4.0). We follow these discussions with a discussion of the operational requirements at Hanford (Section 5.0) and the international experience with existing and new generation melters (Section 6.0). In the last section, we discuss the cost savings associated with the regulatory, technical, and operational possibilities to reduce waste glass volume or improve operations of the HLW processing (Section 7.0). 
This page intentionally left blank. 


\subsection{Uncertainties}

A word is needed about the uncertainties associated with the results of this study. A rigorous treatment of the uncertainties either through a propagation of error analyses or some other technique was not performed and was outside the scope of this study. Within that context, then, the baseline was taken as certain irrespective of how uncertain it is. The results become relative to that baseline. If, as an example, the baseline number of canisters increases, then the number of canisters and savings associated with the various scenarios treated here also change and probably in the same direction.

Uncertainties exist in the baseline, the volume of waste, the composition of the various waste types, the costs used to calculate savings/expenses for each scenario, construction costs, production rates, etc. The Study Team has selected values for these parameters and treated them as certain (i.e., given no uncertainties); they are the best available numbers. The results are equally certain (uncertain). The results become relative and indicative of where the cost savings can be best achieved. If an investment in technology is shown here as resulting in an overall reduction of $14.6 \%$ in the number of canisters, then the return on investment is high and the technology is one that should be pursued. Conversely, a technology that, when implemented, results in a 5\% reduction in canisters is one with a low potential return on investment. Whether the reduction is $14.6 \%$ or $20 \%$ is immaterial. For the baseline and the assumptions used in this document, the return on investment is potentially high. The value of this work is not diminished because we did not account for uncertainties.

There are some uncertainties that are implicit to this study. The results for chromium are a prime example. It is recognized that the 'leach factor' for chrome is uncertain. That is why the Study Team has included cases with different values for the leach factor. However, to make this study manageable, the Study Team had to fix the composition of the wastes containing chrome and the volume of these wastes, in spite of the fact that the location and inventory of chrome have a large degree of uncertainty.

Therefore, while the Study Team indicates that 1833 canisters of glass with a certain composition will be made, the value is a result of the assumptions that were made in this study. Taking this number out of the context of this study results in a number with little meaning.

Finally, a note regarding baselines and number of projected HLW canisters. Two reference cases are considered in this report. The first is the current "Office of River Protection (ORP) Baseline" with a projected 12700 canisters. The second reference case is the "Study Reference" that is defined by Case 1 from Task 2, about 9300 canisters ( 8452 before 10\% contingency). The Study Reference produces a very substantial $(\sim 25 \%)$ reduction in the expected number of canisters, which results from higher waste loading that could be achieved primarily from enhanced chromium leaching during pretreatment. Prior glass volume estimates [Tank Waste Remediation System (TWRS) Environmental Impact Statement (EIS) 1996 and Kirkbride 2000) included a wide range of estimates. For example, TWRS EIS considered pretreatment alternatives that varied from minimal to extensive separations and thus caused the observed range of variation. These estimates were refined and confirmed by an independent review team. The variation in cases produced by the most recent Tank Farm Contractor Operations and Utilization Plan (Kirkbride 2000) is due primarily to the assumptions regarding the nature and efficiency of sludge washing and its impact on removal of chromium. This uncertainty with respect to the baseline, emphasizes the problems underlying a valid discussion of the uncertainties of the material presented in this report. 
This page intentionally left blank 


\subsection{Waste Form Requirements and Potential Changes}

\subsection{Current Waste Form Product and Processing Requirements}

\subsubsection{Waste Form Product Requirements}

DOE-RW is responsible for construction and operation of the federal HLW repository. The requirements for accepting materials for disposal into the Civilian Radioactive Waste Management System is defined by RW in the WA-SRD, Revision 3, dated April 1999 (Revision 4 will be issued later this year). The WA-SRD also includes requirements for spent fuel and HLW (including the Immobilized Plutonium Waste Form). These requirements are based on existing regulations, and it is anticipated that these regulations will be adequate for repository licensing; however, the U.S. Nuclear Regulatory Commission will make the final determination of the adequacy of acceptance criteria as related to repository licensing. The requirements for HLW are much more specific than those for spent fuel. Based on initial drafts, Revision 4 of the WA-SRD will remove several of the specific requirements on HLW and use a more performance-based approach for the repository. The draft changes in Revision 4 of the WA-SRD were not in requirements that are of concern to this review; however, Revision 3 of the WA-SRD is used for the purpose of this study.

The DOE Office of Environmental Management (EM) used the WA-SRD to develop specific requirements for the HLW form producers, which are contained in the Waste Acceptance Product Specifications (WAPS), Revision 2 (December 1996). The WAPS will be revised when Revision 4 of the WA-SRD is issued. The current operating waste form producers are the West Valley Demonstration Project (WVDP) in West Valley, New York, and the Defense Waste Processing Facility (DWPF) at the Savannah River Site in Aiken, South Carolina.

Appendix A lists existing product requirements from the WA-SRD and the WAPS. The bases for these requirements are also included along with impacts of modifications or deletions. It was concluded, based on this review, that several of the existing product requirements have little impact on this study.

Modifications or deletion of these requirements would not have a major effect on waste loading or cost reductions. However, there are a few product requirements that should be considered further during the remaining phases of this study. In some cases, the strategies for compliance with the requirements may also impact waste loading. The product requirements that have the most influence on this study are as follows:

- Waste form is borosilicate glass (WAPS 1.1): Other waste forms will potentially allow increased waste loading and also may involve alternative processing technologies.

- Project chemical compositions and crystalline phases (WAPS 1.1.1): This requirement is not expected to have a major impact; however, it may need to be modified depending on alternate waste forms.

- Product Consistency (WAPS 1.3): Relaxation of this requirement by removing the confidence limit requirements could potentially allow an increase in waste loading. Complete removal of this requirement could allow highly soluble waste forms. However, it is expected that a test to demonstrate product consistency of some type would still be necessary and an understanding of the fate of the radionuclides would be needed. The product consistency test (PCT) may not be an accurate measure of product consistency for alternative waste forms, such as glass-ceramic. Therefore, modification of this requirement to include an alternate test may be necessary. 
- Glass transition temperature and time/temperature transformation diagrams (WAPS 1.4): Elimination or modification of this requirement would be necessary if a non-glass waste form were used.

- Hazardous waste limitations (WAPS 1.5): Elimination or modification of the requirement to pass the toxicity characteristic leach procedure (TCLP) may allow higher waste loading, but additional work would be necessary. If WAPS 1.3 were significantly modified, this requirement may in some cases be the determining factor in maximum waste loading. However, due to the strong political and regulatory influence related to this requirement, it is unlikely that any progress could be made in modifying this requirement

- Exclusion of organic materials (WAPS 3.4): This requirement will not be considered further unless an alternate waste form is identified that may contain organic materials.

Canister requirements, such as dimensions, will not be considered further in this study unless the cost analysis determines that a benefit exists from an alternate canister design.

\subsubsection{Waste Form Processing Requirements}

In addition to product requirements, several processing requirements are impacted by the waste form or melter technology used. These requirements are imposed by the operating facility but can also have a major impact on waste loading and production costs. The requirements considered in this study are

- liquidus temperature

- glass viscosity

- $\quad$ solubility limits in glass

- materials of construction limitations

- volatility of components from the melter.

In addition to these product requirements, Appendix A lists the processing constraints with existing technology used by the waste form producers. The bases for these requirements are also included along with impacts of modifications. The melter technology used can have a major impact on these processing requirements and must be considered when evaluating any alternate designs.

The requirement that currently has the largest impact on waste loading is the liquidus temperature, which is the limiting factor in waste loading for DWPF. This constraint may be relaxed through use of alternate melter technologies as well as alternate waste forms. Sections 4 and 6 of this study report consider the impacts. In addition, collecting additional data to better define a model may also allow the safety factor of $100^{\circ} \mathrm{C}$ (difference between limit and typical Joule-heated melter operating temperature) to be reduced, thus allowing an increase in waste loading.

\subsection{Potential Impact of Modifications to Requirements}

Since the product requirements listed in Appendix A were developed prior to repository selection, design, or licensing, they are focused on producing a consistent product that can be used to bound what the repository can expect to receive. While the requirements in the WA-SRD and WAPS are often based on federal regulations, as presented they are often more prescriptive than actually defined in the regulations. 
Thus, the requirements in the WA-SRD and WAPS could be modified without violating an existing federal regulation.

In addition, processing requirements are often determined based on available data or known limitations of the processing technology. In several cases, data limitations and the need for conservatism have determined requirements.

\subsection{Impact of Waste Compliance Strategies}

The interpretation of the waste form product requirements, as well as the requirements themselves, can also impact waste loading and costs. The HLW Form Producer is required to document its compliance strategies for compliance with the WAPS and WA-SRD in a Waste Form Compliance Plan. Further, these compliance strategies must be demonstrated and documented in a Waste Form Qualification Report.

One example of a requirement that may be interpreted too restrictively is WAPS 1.3, Product consistency. This specification requires the HLW Form Producer to produce a glass more durable than a benchmark glass [DWPF Environmental Assessment (EA) glass] and demonstrate this acceptability through product sampling or process control. DWPF and WVDP both use the relationship of the chemical composition to PCT results to control the process; however, the facilities use different approaches to demonstrating compliance during production.

\subsubsection{DWPF Approach to Product Control}

DWPF implements this product consistency requirement by controlling the composition of the melter feed before it is transferred to the melter. Each batch of melter feed is sampled and analyzed for chemical composition. A correlation relating PCT results to chemical composition is used to predict the PCT results from the measured chemical composition of the melter feed and then compared to those of the benchmark EA glass. The appropriate statistical approach is used to ensure that the required confidence limits are met. DWPF personnel then perform only occasional glass sampling and performance of an actual PCT to confirm this approach. The predicted PCT results from the melter feed composition are reported to the repository to demonstrate compliance.

\subsubsection{WVDP Approach to Product Control}

WVDP also controls melter feed composition prior to transferring the waste to the melter similar to DWPF. However, this information is not reported to the repository to demonstrate compliance. WVDP collects glass samples more frequently and measures their chemical composition. This chemical composition is then used to predict a PCT result using a PCT/chemical composition correlation. These results are then reported to the repository to demonstrate compliance.

The Product Consistency Specification requires that the HLW Form Producer understand the process and glass behavior to ensure that the glass PCT results are below those of the EA glass to a specified confidence level. However, the specification does not require that the actual PCT value be reported. Modeling PCT response over a wide compositional range in a manner that can be easily implemented (e.g., linear model) is difficult. A large uncertainty may be placed on the model, which may result in limitations to waste loading.

An approach to bound the durability results to ensure they are adequately below the EA glass rather than predict the actual results may allow for more flexibility and an increase in waste loading. Additional 
work would be needed to evaluate the statistical confidence level issues. A better understanding of the use of this data by the repository would also be needed.

\subsection{Input on Waste Loading Limitations from Waste Form Producers}

A questionnaire (see Appendix B) was developed and distributed to the waste form producers (DWPF, WVDP, and the Waste Treatment Project at the Hanford Site), and input received from these three sites is summarized below. The product specifications discussed above did not exist during the process development stage of DWPF and WVDP; thus, these two sites developed glass composition formulations to produce the best glass possible (most durable, lowest crystalline content, etc.).

\subsubsection{DWPF}

DWPF personnel agree that the major limiting factor to waste loading currently is liquidus temperature. For some sludge batches, glass viscosity or the constraints imposed on the glass durability model were a factor, but overall the limiting constraint was liquidus temperature. However, glass viscosity has also been a limiting factor for glass production rate (i.e., too high a viscosity can limit glass production rate).

From a product requirements perspective, DWPF personnel felt that the limiting factor to production rate was the time required to perform analysis of each melter feed batch. If process knowledge could be used, then glass production rate could be increased and costs ultimately reduced. Personnel also agreed that if limitations on the liquidus temperature were overcome or major changes in frit composition were made, waste loading would be limited by the PCT results. As discussed previously, these limitations are related to the large uncertainty in being able to predict PCT results rather than the glass PCT results approaching those of the EA glass.

A melter that could operate at higher temperatures could lead to increased waste loading, especially for some of the sludge batches (e.g., high aluminum) found at the Savannah River Site (SRS). Other waste forms for DWPF were considered in the late 1970s and early 1980s, as documented in the 1982 report on selection of waste form for HLW (DOE 1982b).

\subsubsection{WVDP}

The target glass compositional region developed for WVDP is limited by liquidus temperature. Other troublesome components include chromium, zirconium, and titanium and the avoidance of lithium phosphate phases. WAPS 1.3, Product consistency, is also determined to be a limiting factor. Although limited data are available, WVDP personnel believe that WAPS 1.5, Hazardous waste limitations, would be the next most limiting requirement. WVDP personnel also stated that a high-temperature melter would be beneficial to increased waste loading.

\subsubsection{Hanford Site}

Based on current available data, liquidus temperature and chromium content are the limiting factors for Hanford waste streams, followed by WAPS 1.3 and WAPS 1.5, which would limit waste loading. Additional limiting factors include stringent requirements for demonstrating compliance with the requirements (especially WAPS 1.3 -- based on efforts to date to develop compliance strategies) and the "zero risk" approach to product requirements. The facilities cannot make an unacceptable glass, yet personnel believe that the repository uses an average HLW glass for their evaluations. 


\subsection{Recommendations}

The following requirements should be further evaluated to determine the extent to which they can be challenged to increase waste loading or reduce costs:

- Waste form type (i.e. borosilicate glass)

- Product Consistency requirement and strategy for compliance

- Liquidus temperature limit 
This page intentionally left blank 


\subsection{Waste Form Evaluations for Hanford High-Level Waste}

\subsection{Definition of Waste Loading}

Waste loading is defined differently, depending on the program. Therefore, the Study Team deemed it appropriate to clearly state the definition of waste loading used in this study. To determine an appropriate definition, the Study Team first considered those currently used.

\subsubsection{DWPF}

The DWPF Waste Form Qualification Report (WSRC-IM-91-116-1), Part 3, Item 100 states "On an oxide weight basis, DWPF glass will consist of approximately $64 \%$ glass frit, $8 \%$ precipitate hydrolysis aqueous product, and $28 \%$ sludge. The glass frit and the precipitate hydrolysis aqueous product (PHA) together make up what is called the glass-former composition." There is no indication that sludge components also present in the PHA or frit (e.g., $\mathrm{SiO}_{2}$ and $\mathrm{Na}_{2} \mathrm{O}$ ) are excluded from the waste-loading estimate. There is also no indication that any correction factor is used to account for minor component losses of volatile species such as mercury to the off-gas system. However, the du Pont Chemical Process Evaluation System runs do document the loss of these constituents to the overheads.

However, the Waste Form Qualification Report presents general information that was used for a discussion of the chemical composition projections. Unfortunately, DWPF does not have a well-defined description of waste loading. From a process/product control perspective, it is simply waste oxides (amount of sludge and eventually PHA coming in) divided by the quantity of waste + frit (not accounting for any volatility, but there really is not much). It is easy to compare waste loadings within the same sludge batch composition. However, it becomes more difficult when referring to the level of sludge washing. One can wash less (remove less sodium) and increase waste loading per this definition. This does not make any practical sense. The HLW System Plan, which is the planning document for sludge tank blending and budget evaluations, simply uses the total amount of sludge coming into DWPF after washing.

\subsubsection{WVDP}

Waste loading accounts for all waste constituents at WVDP, including silicon, sodium, and zeolite used in pretreatment.

Waste Loading $=[$ purex oxides + thorax oxides + zeolite (pretreatment products) $] /$ glass oxides $0.4064=(92155 \mathrm{~kg}+21565 \mathrm{~kg}+82770 \mathrm{~kg}) / 483500 \mathrm{~kg}$ total glass oxides

1. If zeolite is subtracted, waste loading $=23.5 \%$.

2. If $\mathrm{SiO}_{2}(7160 \mathrm{~kg})$ and $\mathrm{Na}_{2} \mathrm{O}(7240 \mathrm{~kg})$ are subtracted, waste loading $\%=20.4 \%$.

\subsubsection{Hanford Waste Vitrification Plant}

The Westinghouse Hanford Company report, Hanford Waste Vitrification Plant (HWVP) - Hanford Waste Vitrification Plant Technical Data Package (WHC-SD-HWV-DP-001), Section 13, Item 300, dated April 1986, defines waste loading as "the total oxides" that are the sum of the chemicals present in the waste plus the chemicals present as glass frit expressed as their oxides. Total oxides are those oxides that remain in the glass matrix after heating to $1150^{\circ} \mathrm{C}$ under conditions existing in the melter. The current HWVP reference for glass-former content (i.e., frit) in the melter feed is 75 mass $\%$ of total oxides 
fed to the melter. Waste components that are also present in frit (e.g., $\mathrm{SiO}_{2}$ and $\mathrm{Na}_{2} \mathrm{O}$ ) are shown in the waste tables within SD-HWV-DP-001, so they are clearly included in the waste-loading estimate.

\subsubsection{Hanford Waste Treatment Plant}

The WTP Request for Proposal Contract No. DE-AC27-01RV14136, dated December 2000, defines waste loading as "Loading of non-volatile components in Envelope D, and, if directed by DOE, entrained solids after washing in accordance with Specification 12, Number of High-Level Waste Canisters per Batch of Waste Envelope D, shall be achieved, such that, the concentration of at least one of the waste components or waste component combinations in Table TS-1.1 [Table 4.1], Minimum Component Limits in High-Level Waste Glass, exceeds its minimum mass\% in HLW glass as identified in Table TS-1.1 (e.g., for a high-iron waste, the waste product shall incorporate at least 12.5 mass $\% \mathrm{Fe}_{2} \mathrm{O}_{3}$ from the waste into the glass). The product loading shall not cause the limits in any other requirement of this specification to be violated. Product waste loading shall be calculated on an average basis for each batch transfer of Waste Envelope D. The waste loading may be adjusted downward if necessary to comply with Universal Treatment Standards leaching requirements."

This definition is based on work by Hrma et al. (1994) and other recent studies to increase the waste loading based on the selected HLW tanks (AZ-101, AZ-102, C-106, and C-104). Per Table 4.1, sodium may be used as a limiting component condition in combination with potassium. However, sodium and silica may not be used in the limiting component condition where all waste oxides are summed and tested to exceed 40 mass $\%$. Per this contract calculation, species lost to volatilization are not considered.

For purposes of reporting waste loading in project testing activities, waste loading is reported based on calculating the HLW oxide fraction of the final glass. This calculation includes sodium and silica and does not account for volatility or other losses. It also does not account for pretreatment stream products [e.g., cesium, technetium, strontium/manganese, and transuranic (TRU) streams]. 
Table 4.1. Minimum Component Limits in HLW Glass

\begin{tabular}{|c|c|}
\hline Component & Mass Percent in HLW Glass \\
\hline $\mathrm{Fe}_{2} \mathrm{O}_{3}$ & 12.5 \\
\hline $\mathrm{Al}_{2} \mathrm{O}_{3}$ & 11.0 \\
\hline $\mathrm{Na}_{2} \mathrm{O}+\mathrm{K}_{2} \mathrm{O}$ & 15.0 \\
\hline $\mathrm{ZrO}_{2}$ & 10.0 \\
\hline $\mathrm{UO}_{2}$ & 8.0 \\
\hline $\mathrm{CaO}$ & 7.0 \\
\hline $\mathrm{MgO}$ & 5.0 \\
\hline $\mathrm{BaO}$ & 4.0 \\
\hline $\mathrm{CdO}$ & 3.0 \\
\hline $\mathrm{NiO}$ & 3.0 \\
\hline $\mathrm{PbO}$ & 1.0 \\
\hline $\mathrm{TiO}_{2}$ & 1.0 \\
\hline $\mathrm{Bi}_{2} \mathrm{O}_{3}$ & 2.0 \\
\hline $\mathrm{P}_{2} \mathrm{O}_{5}$ & 3.0 \\
\hline $\mathrm{F}$ & 1.7 \\
\hline $\mathrm{Al}_{2} \mathrm{O}_{3}+\mathrm{ZrO}_{2}$ & 14.0 \\
\hline $\mathrm{Al}_{2} \mathrm{O}_{3}+\mathrm{ZrO}_{2}+\mathrm{Fe}_{2} \mathrm{O}_{3}$ & 21.0 \\
\hline $\mathrm{MgO}+\mathrm{CaO}$ & 8.0 \\
\hline $\mathrm{Cr}_{2} \mathrm{O}_{3}$ & 0.5 \\
\hline $\mathrm{SO}_{3}$ & 0.5 \\
\hline $\mathrm{Ag}_{2} \mathrm{O}$ & 0.25 \\
\hline $\mathrm{Rh}_{2} \mathrm{O}_{3}+\mathrm{Ru}_{2} \mathrm{O}_{3}+\mathrm{PdO}$ & 0.25 \\
\hline $\begin{array}{c}\text { Any single waste oxide (exclusive of Si) not } \\
\text { specifically identified in Specification } 8 \text {, TS-8.1 } \\
\text { and } 8.4\end{array}$ & 0.2 \\
\hline $\begin{array}{l}\text { Total of all other waste oxides (exclusive of } \mathrm{Si} \text { ) } \\
\text { not specifically identified in this table. }\end{array}$ & 8.0 \\
\hline $\begin{array}{l}\text { Total of all waste oxides, excluding } \mathrm{Na}_{2} \mathrm{O} \text { and } \\
\mathrm{SiO}_{2}\end{array}$ & 40.0 \\
\hline
\end{tabular}

\subsubsection{Waste Loading Definition Used for this Study}

The DWPF and Hanford Site have a history of including all HLW sludge waste constituents and excluding pretreatment streams in their estimates of waste loading. The WVDP included zeolite in their estimate, perhaps in part because it was premixed with HLW in Tank 8D-2 before transfer. For this review, waste-loading calculations were to be based on the following: 
- For non-volatile metals: Includes all HLW sludge components converted to their oxides, including oxides also added as glass-formers. For the purposes of waste-loading estimation, the most abundant single metal oxide form in equilibrium in glass under air at $1150^{\circ} \mathrm{C}$ will be assumed for multivalent elements (even for higher temperature melting). Examples of those multivalent oxides in their most abundant state include $\mathrm{Fe}_{2} \mathrm{O}_{3}, \mathrm{Ce}_{2} \mathrm{O}_{3}, \mathrm{Cr}_{2} \mathrm{O}_{3}, \mathrm{U}_{3} \mathrm{O}_{8}, \mathrm{CoO}, \mathrm{TcO}_{2}, \mathrm{P}_{2} \mathrm{O}_{5}, \mathrm{SO}_{3}$, and $\mathrm{MnO}$.

- For volatile metals: Excludes mercury and iodine, as these constituents have been shown to have essentially no retention in the glass during vitrification.

- For semi-volatile components: Only partially incorporates components such as cesium, chloride, and fluoride into the glass. Semi-volatile material captured in the off-gas condensate as soluble species may also not be recycled to the HLW process. However, to remain conservative, waste loading should account for $100 \%$ of these species. Halogens that are largely retained in the glass will be reported in elemental form (e.g., chloride and fluoride). The over-counting of anions is not expected to significantly impact waste loading estimates.

\subsubsection{Note on Significant Figures}

This report contains several estimates of glass volumes, waste and glass compositions, waste loadings and property values. It was outside of the scope of this work to track uncertainties throughout all calculations and therefore, the appropriate number of significant figures were not determined and reported. There may be more significant figures reported than the data will support.

\subsection{Determination of Waste-Loading Limitations}

This subsection first discusses Hanford Site wastes in some detail, followed by historical information on previous waste form reviews and down-selection decisions.

\subsubsection{Description of Tank Wastes}

The Hanford Site contains 177 underground waste tanks containing $204400 \mathrm{~m}^{3}$ of HLW generated from over four decades of nuclear fuel processing and actinide separations (Kirkbride 2000). These wastes will be retrieved from the tanks, separated into HLW and low-activity waste (LAW) fractions, and separately vitrified. Washed and leached tank solids and radionuclides separated from the liquid fraction of the waste will comprise the HLW fraction, which is the focus of this study.

\subsubsection{Baseline Waste Feed Delivery Assessments/Hanford Tank Waste Optimization Simulator}

Garfield et al. (2000) describe Hanford's current baseline waste-retrieval scenario. This scenario was used in this study as a reference from which a number of sensitivity calculations were made. It is expected that the actual Hanford retrieval schedules and separations methods will evolve with time. However, this particular "slice-in-time" should lead to an adequate assessment of the impacts of major vitrification process/product changes on the scale of waste cleanup costs.

All Hanford tank wastes will be retrieved, staged for delivery, incidentally blended, and leached in the baseline scenario. Solids will be washed, and waste feeds will be delivered. The resulting waste volumes and compositions were estimated using the Hanford Tank Waste Optimization Simulator (HTWOS), which tracks the details of tank farm and waste treatment operations and develops schedules and cost estimates while tracking details such as tank volumes, waste compositions, tank-transfer infrastructure, and manpower requirements (Kirkbride 2000). 
The details of the baseline retrieval sequence and delivery scenario are described in Garfield et al. (2000). Allowance was provided for incidental blending of wastes as they were transferred from tank to tank and staged for delivery. The resulting composition changes will obviously vary with the sequence of tanks that are retrieved. The retrieval sequence was determined by risk-minimization considerations and does not represent a system-wide optimum.

The starting compositions of tank wastes were taken from Hanford's Best Basis Inventory (BBI), which is frequently updated and maintained at http://twins/twins.htm. The specific compositions used for this study were those available in March 2001. The compositions of waste in the tanks are uncertain and are known to vary by location in the tank. The BBI represents the best available estimate of averaged tank compositions. The data were derived from analyses of core and grab-sample data, historical process and purchase records, and knowledge of tank-to-tank transfers.

Estimates of the fractions of each chemical component that partition to the liquid or LAW fraction from water washing and caustic leaching are known as the wash factors and the leach factors, respectively. In the baseline scenario, the wash factors reported by Hendrickson et al. (1998) were used. The leach factors for aluminum, bismuth, calcium, iron, sodium, phosphorous, silicon, sulfur, and uranium were taken from Hendrickson et al. (1998) and for chromium from Colton (1997). One of the sensitivities studied was the influence of the chromium leach factor on glass volume, which was performed because chromium concentration in the waste was found to have a substantial impact on glass volume for the standard melter-technology constraints with AABS glasses. Three chromium leach factors were used: $0.385,0.770$ (from Colton 1997), and 0.924.

After sludge washing, a significant fraction of sodium resides in the interstitials of washed solids. For the purposes of this study, the Study Team assumed that the interstitial sodium was sent to the HLW vitrification plant. However, the option of washing it to the LAW waste is possible and would likely occur in the plant on a case-by-case basis. Once a set of glass volume calculations was performed to determine the impact of this added sodium on the HLW glass volume, and it was found to be insignificant (less than 1\% reduction in HLW glass volume by removal of all excess sodium). The chemical products from separations (cesium, strontium, transuranics, and technetium) have been added to the HLW fraction assuming the baseline separations technologies.

Upon waste transfer, the baseline sequence generated 89 batches of waste, which is significantly below the number of waste tanks (177) even though no deliberate blending of tank waste was used. Only liquid waste came from some tanks and the wastes from others were combined during staging to the WTP. Wastes that are transferred can no longer be tracked by tank number, as is currently done in BBI. Therefore, batch numbers 1 through 89 are used to discern the specific wastes. The HLW batch compositions are listed in Appendix C. These waste compositions include the chemical products from separation of radionuclides from the LAW fraction.

\subsubsection{Waste Cluster Analyses}

Hanford HLW can be grouped in a number of ways: by tank or tank farm (location), by process (source), by safety concerns (risk), by planned retrieval date (time), and by composition (chemistry). For the purposes of this study, the appropriate grouping of wastes is grouped by composition. For the majority of sensitivity estimates made during this study, it was not practical, and as later discussed, not necessary, to perform calculations on each of $89 \mathrm{HLW}$ batch compositions. The batches were grouped with like chemical composition by cluster analysis. Ward's method (SAS 1995) of cluster analysis was performed 
on batch compositions normalized to the 16 major components ${ }^{1}-\mathrm{Al}_{2} \mathrm{O}_{3}, \mathrm{Bi}_{2} \mathrm{O}_{3}, \mathrm{CaO}, \mathrm{CdO}, \mathrm{Cr}_{2} \mathrm{O}_{3}, \mathrm{~F}$, $\mathrm{Fe}_{2} \mathrm{O}_{3}, \mathrm{MnO}, \mathrm{Na}_{2} \mathrm{O}, \mathrm{NiO}, \mathrm{P}_{2} \mathrm{O}_{5}, \mathrm{SiO}_{2}, \mathrm{SrO}, \mathrm{ThO}_{2}, \mathrm{U}_{3} \mathrm{O}_{8}$, and $\mathrm{ZrO}_{2}$. This resulted in 17 clusters of waste batches with like compositions. Summaries of the cluster compositions are given in Appendix C. A weighted average composition was calculated for each cluster. These average compositions, listed in Table 4.2, were used for a majority of sensitivity calculations and were the basis for waste-loading estimates of selected waste forms.

1 For the purposes of cluster analyses, this study defines a major component as one for which the concentration is at least 3 mass $\%$ in at least one waste feed. 
Table 4.2. Concentration of Major Waste Component (mass\%) and Total Mass (Mg) by Cluster

\begin{tabular}{|c|c|c|c|c|c|c|c|c|c|c|c|c|c|c|c|c|c|}
\hline \# & 1 & 2 & 3 & 4 & 5 & 6 & 7 & 8 & 9 & 10 & 11 & 12 & 13 & 14 & 15 & 16 & 17 \\
\hline $\mathrm{Al}_{2} \mathrm{O}_{3}$ & 19.55 & 12.73 & 19.59 & 18.48 & 17.74 & 27.23 & 18.07 & 23.03 & 6.61 & 6.66 & 7.45 & 7.31 & 2.23 & 14.97 & 8.32 & 3.34 & 2.63 \\
\hline $\mathrm{As}_{2} \mathrm{O}_{5}{ }^{(\mathrm{a})}$ & 0.02 & 0.03 & 0.19 & 0.05 & 0.02 & 0.13 & 0.03 & 1.30 & 0.41 & 0.09 & 0.81 & 1.52 & 0.02 & 0.54 & 0.02 & 0.02 & 0.04 \\
\hline $\mathrm{B}_{2} \mathrm{O}_{3}$ & 0.06 & 0.09 & 0.50 & 0.17 & 0.11 & 0.23 & 0.27 & 1.96 & 0.61 & 0.20 & 0.32 & 1.80 & 1.44 & 0.76 & 1.25 & 1.90 & 0.07 \\
\hline $\mathrm{Bi}_{2} \mathrm{O}_{3}{ }^{(\mathrm{a})}$ & 6.48 & 12.10 & 1.21 & 2.97 & 9.56 & 6.20 & 0.39 & 2.11 & 3.76 & 0.24 & 0.01 & 0.28 & 0.01 & 1.58 & 0.02 & 0.01 & 0.10 \\
\hline $\mathrm{CaO}$ & 2.82 & 3.15 & 2.26 & 5.52 & 3.37 & 2.23 & 1.97 & 1.45 & 0.69 & 0.98 & 2.90 & 0.87 & 1.41 & 0.78 & 0.93 & 1.86 & 0.39 \\
\hline $\mathrm{CdO}^{\text {(a) }}$ & 0.05 & 0.04 & 0.02 & 0.01 & 0.00 & 0.02 & 0.01 & 0.03 & 0.03 & 0.04 & 0.09 & 0.06 & 0.28 & 0.10 & 4.51 & 0.37 & 0.02 \\
\hline $\mathrm{Ce}_{2} \mathrm{O}_{3}{ }^{(\mathrm{a})}$ & 0.02 & 0.02 & 0.22 & \begin{tabular}{|l|}
0.07 \\
\end{tabular} & 0.02 & 0.10 & 0.04 & 1.02 & 0.36 & 0.07 & 0.33 & 1.18 & 0.02 & 0.45 & 0.26 & 0.03 & 0.03 \\
\hline $\mathrm{Cr}_{2} \mathrm{O}_{3}{ }^{(\mathrm{a})}$ & 0.55 & 0.77 & 1.69 & 1.31 & 0.89 & 1.36 & 2.02 & 2.51 & 0.17 & 1.32 & 0.20 & 0.47 & 0.16 & 4.25 & 0.11 & 0.21 & 0.54 \\
\hline$F$ & 0.42 & 1.02 & 2.76 & 2.21 & 3.65 & 1.20 & 1.04 & 1.21 & 2.33 & 0.12 & 0.04 & 3.77 & 0.10 & 1.39 & 0.33 & 0.14 & 0.06 \\
\hline $\mathrm{Fe}_{2} \mathrm{O}_{3}{ }^{(\mathrm{a})}$ & 15.68 & 21.50 & 7.27 & 13.46 & 17.27 & 12.06 & 8.38 & 7.25 & 14.13 & 5.19 & 45.66 & 1.44 & 11.84 & 10.96 & 47.83 & 15.65 & 2.20 \\
\hline $\mathrm{K}_{2} \mathrm{O}$ & 0.15 & 0.28 & 0.69 & 0.32 & 0.21 & 1.26 & 0.77 & 0.16 & 0.42 & 1.79 & 0.15 & 1.06 & 0.34 & 1.97 & 1.05 & 0.45 & 0.59 \\
\hline $\mathrm{La}_{2} \mathrm{O}_{3}$ & 0.33 & 1.21 & 0.12 & 0.08 & 0.28 & 0.60 & 0.06 & 0.06 & 0.19 & 0.08 & 0.90 & 0.30 & 0.28 & 0.21 & 1.59 & 0.38 & 0.03 \\
\hline $\mathrm{MgO}$ & 0.14 & 0.48 & 0.55 & 0.48 & 0.21 & 0.28 & 0.06 & 2.33 & 0.54 & 0.25 & 1.98 & 1.66 & 0.09 & 0.65 & 0.35 & 0.11 & 0.11 \\
\hline $\mathrm{MnO}^{(\mathrm{a})}$ & 1.73 & 2.81 & 1.50 & 1.53 & 1.36 & 2.28 & \begin{tabular}{ll|}
1.04 \\
\end{tabular} & 1.83 & 6.82 & 10.80 & 8.80 & 0.53 & 10.20 & 1.40 & 0.92 & 3.40 & 23.91 \\
\hline $\mathrm{Na}_{2} \mathrm{O}$ & 22.93 & 20.70 & 20.36 & 22.75 & 21.23 & 22.84 & 21.08 & 27.20 & 12.36 & 45.10 & 14.57 & 29.27 & 9.12 & 35.50 & 12.88 & 12.14 & 14.50 \\
\hline $\mathrm{Nd}_{2} \mathrm{O}_{3}$ & 0.03 & 0.02 & 0.14 & 0.03 & 0.01 & 0.10 & 0.02 & 0.99 & 0.31 & 0.08 & 0.56 & 1.16 & 0.03 & 0.42 & 0.74 & 0.04 & 0.03 \\
\hline $\mathrm{NiO}^{\text {(a) }}$ & 1.09 & 0.66 & 1.53 & 2.63 & 1.47 & 2.18 & 0.43 & 0.59 & 0.44 & 0.20 & 1.43 & 0.58 & 0.84 & 0.55 & 2.10 & 1.11 & 0.08 \\
\hline $\mathrm{P}_{2} \mathrm{O}_{5}{ }^{(\mathrm{a})}$ & 3.09 & 4.48 & 2.78 & 3.81 & 4.32 & 2.92 & 2.10 & 6.40 & 0.74 & 1.26 & 0.63 & 0.17 & 0.23 & 2.44 & 0.16 & 0.30 & 0.53 \\
\hline $\mathrm{PbO}^{\text {(a) }}$ & 0.63 & 0.84 & 0.52 & 0.56 & 0.69 & 0.44 & 0.50 & 0.44 & 0.75 & 0.29 & 1.44 & 0.41 & 0.25 & 0.52 & 0.22 & 0.33 & 0.12 \\
\hline $\mathrm{SiO}_{2}$ & 17.25 & 10.66 & 7.41 & 9.51 & 8.50 & 8.04 & 27.51 & 4.39 & 4.58 & 1.34 & 5.22 & 1.43 & 3.13 & 2.02 & 0.95 & 4.20 & 0.51 \\
\hline $\mathrm{SrO}$ & 0.34 & 0.30 & 0.40 & 1.02 & 0.57 & 0.38 & 0.14 & 0.32 & 13.75 & 21.12 & 0.16 & 0.06 & 17.13 & 0.09 & 0.08 & 0.04 & 52.31 \\
\hline $\mathrm{ThO}_{2}$ & 0.06 & 0.05 & 0.30 & 0.20 & 0.13 & 0.29 & 0.36 & 0.25 & 0.07 & 0.17 & 0.00 & 0.21 & 2.79 & 0.20 & 0.20 & 3.69 & 0.06 \\
\hline $\mathrm{Tl}_{2} \mathrm{O}^{(\mathrm{a})}$ & 0.03 & 0.03 & 0.27 & 0.07 & 0.01 & 0.20 & 0.04 & 1.71 & 0.58 & 0.18 & 1.11 & 2.15 & 0.03 & 0.74 & 0.00 & 0.03 & 0.05 \\
\hline $\mathrm{U}_{3} \mathrm{O}_{8}{ }^{(\mathrm{a})}$ & 5.98 & 4.84 & 10.77 & 10.06 & 7.76 & 6.37 & 10.66 & 6.87 & 6.07 & 1.78 & 1.42 & 9.85 & 15.82 & 5.15 & 3.63 & 20.90 & 0.74 \\
\hline$\overline{\mathrm{ZrO}_{2}}$ & 0.25 & 0.64 & 15.16 & 1.75 & 0.26 & 0.40 & 2.24 & 0.70 & 21.63 & 0.09 & 0.62 & 27.95 & 21.94 & 10.23 & 10.61 & 28.98 & 0.03 \\
\hline $\mathrm{SUM}^{(\mathrm{b})}$ & 99.68 & 99.47 & 98.18 & 99.04 & 99.64 & 99.30 & 99.24 & 96.10 & 98.38 & 99.40 & 96.78 & 95.49 & 99.73 & 97.88 & 99.05 & 99.64 & 99.65 \\
\hline mass $(\mathrm{Mg})$ & 2349 & 1749 & 1647 & 1395 & 1384 & 947 & 678 & 506 & 426 & 232 & 216 & 175 & 171 & 150 & 142 & 128 & 19 \\
\hline
\end{tabular}

(a) Multivalent components were grouped into a single oxidation state for reporting composition and waste-loading calculations.

(b) The sums of component mass percents are less than 100 because only a limited number of components are reported in this table. Full compositions, listed in Appendix C, were used in calculations based on AABS glasses. 


\subsection{Waste-Form Reviews}

This subsection describes the various waste forms, including glass, glass-ceramic, crystalline ceramic, calcine, cementitious, metallic alloy, and polymeric waste forms. Information on these waste forms was collected from literature reviews and previous evaluations of waste forms.

\subsubsection{Glass Waste Forms}

\subsubsection{Borosilicate}

Borosilicate glass is an amorphous material formed by melting silica and boric acid together with other constituents, such as soda. Virtually every major country processing HLW has selected borosilicate glass as the preferred waste form. The French have been immobilizing waste from reprocessing spent fuel for both themselves and other nations since 1978. The British are vitrifying their own HLW, as well as the waste from reprocessing spent nuclear fuel from Japan, at their Sellafield facility. In the United States, DWPF and WVDP are using borosilicate glasses to immobilize HLW. For each of these facilities, borosilicate glass was selected as the preferred waste form because of its excellent combination of reliable processing properties and acceptable product performance characteristics.

Borosilicate glass combines high-waste solubility and high tolerance to waste variation with excellent leach resistance; it also has high thermal and radiation stability and good mechanical integrity (Wicks 1985). These properties, coupled with the fact that it is a one-step processing operation (which is an attractive option for remote canyon operations), make this waste form a viable candidate for most HLW being considered. The baseline U.S. vitrification process feeds a slurry of waste sludge and glass frit (or chemicals) to a continuous Joule-heated, ceramic-lined, glass melter from which the waste glass is poured into its final form in canisters.

\subsubsection{High-Silica Glass}

The oldest glasses found in nature have high $\mathrm{SiO}_{2}$ content (50 to $60 \% \mathrm{SiO}_{2}$ ). A high-silica porous glass process was originally developed at Catholic University of America to immobilize highsodium HLW. In this process, a slurry of HLW sludge and porous glass frit is loaded into highsilica glass tubes, which are then sintered at 900 to $1100^{\circ} \mathrm{C}$. An Alternative Waste Form Peer Review Panel (DOE 1981) noted that the low vacuum and relatively high temperature needed to increase the density of the frit causes a substantial loss of cesium, which must be recovered by an off-gas treatment system. The panel ranked this process third in a group of eight waste forms it considered for SRS HLW.

\subsubsection{Sodium Phosphate Glasses}

Phosphate glasses were originally studied as a proposed waste form for HLW because of their low processing temperatures and increased solubility of sulfates (Lutze and Ewing 1988, DOE 1979, and LLNL 1996). In most cases, these early phosphate glasses were formed by adding phosphoric acid directly to a liquid waste stream, calcining the resulting phosphate composition, and then melting the resulting calcine to form a glass. The early liquid waste stream compositions used contained sodium ions in large concentrations and accordingly the properties of the resulting amorphous waste forms were essentially determined by the characteristics of sodium phosphate glass. However, the poor chemical durability, extreme corrosiveness, and tendency toward devitrification of these sodium phosphate-based glasses led to their exclusion from the pool of potential host matrices as a potential alternative waste form for immobilization of HLW. 


\subsubsection{Alumino-Phosphate Glasses}

The chemical stability of sodium phosphate can be considerably improved through small additions of $\mathrm{Al}_{2} \mathrm{O}_{3}$ (Scholze 1990). In fact, the Russians have been using an aluminum phosphate-based glass to immobilize HLW since the late 1980s (IAEA 1992, Aloy et al. 1989, Revenko et al. 1994, Aloy et al. 1994). The first melter was put into operation in 1987, operated for 1.5 years. It produced $998 \mathrm{~m}^{3}$ of HLW, with a total activity of $147 \mathrm{PBq}(3.97 \mathrm{MCi}$ ), which were vitrified, producing 366 canisters totaling over $162 \mathrm{Mg}$ of glass. The composition of the glass-formers (in mass \%) was reported as: 22 to $26 \% \mathrm{Na}_{2} \mathrm{O}, 21$ to $25 \% \mathrm{Al}_{2} \mathrm{O}_{3}, 47$ to $53 \% \mathrm{P}_{2} \mathrm{O}_{5}$, and up to $1.5 \%$ $\mathrm{Fe}_{2} \mathrm{O}_{3}$. (Aloy 1996) In 1988, failure of the power connection zone resulted in overheating, and the unit was shut down. After design changes, a second unit was constructed and placed into operation in 1991. Through 1995, $9160 \mathrm{~m}^{3}$ of HLW [12 PBq (320 MCi)] were vitrified, and 1770 $\mathrm{Mg}$ of glass were poured into 1372 canisters. Based on a personal communication with Dr. Albert Aloy, V.G. Khlopin Radium Institute, a new ceramic melter is currently under construction that will also process HLW with a similar aluminum phosphate glass waste form.

\subsubsection{Lead-Iron Phosphate Glasses}

While sodium phosphate glasses were eliminated from consideration, research continued in the area of other phosphate glass compositions, specifically lead-iron phosphate (LIP) glasses. Lead was added to decrease melt temperature and viscosity, and iron was added to increase durability and suppress the tendency towards crystallization. However, the low waste loading (typically $<20$ mass\%), low corrosion resistance of crystallized glasses, and limited experience in melting LIP glasses resulted in this glass type not being used or considered as a viable waste form matrix for immobilization of HLW (Marasinghe et al. 2000).

Jantzen (1986) found that there was a limited solubility for alumina, silica, and uranium in the LIP glasses. Also, there is limited solubility for zirconia, which forms a zirconium-rich crystalline phase in the glass. With respect to the SRS waste stream, the LIP glasses were not compatible with zeolite found in the waste (the zeolite did not dissolve in the melt and remained in the crucible after pouring). There were also issues with the melting-temperature range, flexibility of the LIP glasses to handle all of the components found in the waste, the durability of the glasses processed at lower temperatures or in a reducing atmosphere, and the inhomogeneity of the waste form. It was also determined that the LIP glasses would be incompatible with the Joule-heated melter because the interactions with the Inconel 690 electrodes and with the refractories would cause inhomogeneous melts.

Corrosion (e.g., durability or resistance to aqueous attack) testing of the LIP glasses indicated that these glasses performed well in solutions of distilled water and groundwaters with $\mathrm{pH}$ levels between 5 and 9 and temperatures less that $150^{\circ} \mathrm{C}$. Corrosion rates were significantly higher in saturated sodium-chloride solutions when compared to the same glass in distilled water. Another fundamental issue with the LIP glasses is the fact that lead is a Resource Conservation and Recovery Act (RCRA) metal and as such, the waste form must meet the TCLP, or it would unacceptable for repository storage (LLNL 1996).

\subsubsection{Iron Phosphate Glasses}

Within the last 10 years, numerous studies (Yu and Day 1995, Mogus-Milankovic et al. 1998, Day et al. 1998, Mesko et al. 1998, Chen and Day 1999, Ray et al. 1999, Mesko and Day 1999, Badyal 
et al. 1999) and Marasinghe et al. ${ }^{2}$ have focused on the use of iron phosphate (FeP) glasses as a viable waste form host for HLW. In contrast to the lead-iron phosphate glasses, FeP glasses have been produced (at laboratory scale) that contain in excess of 40 mass $\%$ of certain HLW components (Day et al. 1998). The atomic structure, specific structure-property relationships, redox equilibria, and crystallization characteristics of binary $\mathrm{FeP}$ glasses and those containing a single common waste component, such as $\mathrm{Na}_{2} \mathrm{O}, \mathrm{UO}_{2}, \mathrm{Cs}_{2} \mathrm{O}, \mathrm{SrO}$, or $\mathrm{Bi}_{2} \mathrm{O}_{3}$, have been reported (Marasinghe et al. 1997, 1998, and 1999).

Iron phosphate waste forms containing about nine different simulated nuclear wastes of complex composition have also been investigated (Mesko et al. 1998). Five of these simulated wastes are based on wastes at Hanford; one waste, Tank Farm B waste, was the mass average estimated composition of all the waste in Tank Farm B, while the other four had compositions corresponding to the waste in tanks B-110, C-106, C-112, and T-111. These wastes were selected because their composition was such (high content of $\mathrm{P}_{2} \mathrm{O}_{5}, \mathrm{Bi}_{2} \mathrm{O}_{3}, \mathrm{UO}_{2}$, etc.) that they were considered poorly suited for vitrification in borosilicate glass. Other simulated wastes vitrified to date in FeP glasses include aluminum-clad spent nuclear fuel (SNF), gunite waste from the Oak Ridge Reservation (ORR), a zirconia-rich calcine waste from the Idaho National Engineering and Environmental Laboratory (INEEL), and simulated plutonium wastes.

Thus, an extensive body of data exists for FeP waste forms at this time. This section briefly describes some of the major differences of FeP glasses relative to other phosphate-based glass systems, as well as those properties that make them attractive candidates for vitrifying nuclear waste (at least some waste compositions). Some of the characteristics of FeP glasses that are important to waste vitrification are

- $\quad$ their outstanding chemical durability (Day et al. 1997, Mesko et al. 1998, Day et al. 1998, Mesko et al. 2000, and Marasinghe et al. 2000)

- $\quad$ their tendency to buffer the $\mathrm{pH}$ of solutions in which they may come into contact, thereby preventing the accelerated chemical corrosion that usually occurs when an alkali-containing glass is in contact with a solution whose $\mathrm{pH}$ typically increases with time

- their inherently high solubility (Karabulut et al. 1999, Badyal et al. 1999, and Marasinghe et al. 2000) for many heavy metals (uranium, chromium, zirconium, cesium, molybdenum, etc.); noble metals; and rare earths commonly present in nuclear waste

- $\quad$ their low melting temperatures $\left(950^{\circ} \mathrm{C}\right.$ to $1100^{\circ} \mathrm{C}$ ), rapid melting rates (few hours), capability of tolerating a wide range in furnace atmospheres (oxidizing to reducing), and high melt fluidity (viscosity typically below one poise), which means that small furnaces can have reasonable throughput

- $\quad$ their unexpectedly low corrosion of oxide refractories (Chen and Day 1999) commonly used in glass melting furnaces, such as high alumina, zircon, and mullite

- their high waste loading, typically between 25 to 50 mass\%, depending on the waste, and higher density, typically 3.0 to $3.4 \mathrm{~g} / \mathrm{cm}^{3}$, which combine to minimize the volume of vitrified waste

- the influence of $\mathrm{PO}_{4}{ }^{2-}$ on solubility of actinides in repository-like environments.

\footnotetext{
${ }^{2}$ Currently in press: Marasinghe, GK, M Karabulut, X Fang, CS Ray, and DE Day. 2001. "Iron Phosphate Glasses: An Alternative to Borosilicate Glasses for Immobilizing Certain Nuclear Wastes," Environmental Issues and Waste Management Technologies IV; Ceramic Transactions.
} 


\subsubsection{Glass-Ceramic Waste Forms}

Glass-ceramics is a class of materials manufactured by controlling devitrification of a glass body. A portion of the glass is transformed to a crystalline structure with small amounts of the original glass matrix remaining between the crystals. The amount of residual glass remaining depends on the end-use of the product. In the case of nuclear waste encapsulation, the volume fraction of residual glass is approximately $50 \%$, resulting in a discrete crystalline phase within a glass matrix (Lutze and Ewing 1988).

Some of the advantages associated with this waste form are its higher mechanical and impact strengths; increased resistance to crack propagation; and the potential for better thermal shock resistance and durability, depending on the composition of the matrix and crystalline phase. Both phases can be tailored to meet the needs of the waste stream.

Following is a list of several types of glass-ceramics that have been proposed over recent years as candidate waste forms:

- $\quad$ Sphene $\left(\mathrm{Na}_{2} \mathrm{O}-\mathrm{Al}_{2} \mathrm{O}_{3}-\mathrm{CaO}-\mathrm{TiO}_{2}-\mathrm{SiO}_{2}\right.$ system $)$, proposed by Canada for their nuclear waste.

- Celsian glass-ceramics, proposed by researchers at the Hahn-Meitner Institute in Berlin.

- $\quad$ Fresnoite, which contains a boron-free glass phase, proposed by researchers at the Hahn-Meitner Institute and possessing greater chemical durability than the celsian composition.

- $\quad$ Basalt-based glass-ceramics, developed by researchers at the Rockwell Company at the Hanford Site.

- Iron-rich basalt composition, developed at INEEL.

- Vitreous Ceramic, developed at Argonne National Laboratory and the Pacific Northwest National Laboratory (PNNL) (Roth et al. 1995, for example)

- $\quad$ Diopside compositions, developed by the Japanese.

- Calcium aluminosilicates, developed by the Swedish Nuclear Fuel Safety Project.

- $\quad$ VCP-15 composition (a borosilicate glass with crystalline phases of $\mathrm{CaTiO}_{3}, \mathrm{CaMgSi}_{2} \mathrm{O}_{6}, \mathrm{CaTiSiO}_{5}$ and $\mathrm{CsAlSi}_{2} \mathrm{O}_{6}$ ), developed by researchers at Karlsruhe in Germany.

- $\quad$ Slag-sitalls, developed in the former Soviet Union; these are basalt-based glass-ceramics developed from blast furnace slags.

In general, glass-ceramics are believed to be an excellent candidate for encapsulation of HLW. Most compositions purport to have improved thermal stability, improved or similar chemical durability to that of borosilicate glasses, identifiable leaching mechanisms (it is believed that the glass matrix controls the overall dissolution rate), and lower processing temperatures. Major disadvantages appear to be controlling the final product because of numerous crystallization reactions that occur as the waste material is added, formation of metastable phases (Lutze and Ewing 1988), and the ability to reliably process at throughput rates that are appropriate for Hanford clean-up efforts. 


\subsubsection{Crystalline Ceramic Waste Forms}

\subsubsection{Ceramics}

The ceramic approach to immobilizing the radioactive elements present in nuclear waste is to incorporate the nuclides into a solid solution in an assemblage of mineral phases. The concept was originally promulgated by Hatch (1953), but was further developed by Pennsylvania State University (McCarthy and Davidson 1975; McCarthy 1976; McCarthy et al. 1979). The original philosophy for using crystalline host phases is that certain mineral phases containing radioactive elements have been known to be geologically stable for tens to hundreds of millions of years, some of them in contact with water for a considerable portion of that time. Thus, it is argued that analogously, synthetic mineral phases will also be stable over the required immobilization period. There are a number of potential advantages of ceramic waste forms for HLW immobilization. Hench et al. (1984) indicated that four of the most notable include 1) inherently low leach rates (particularly for titanates and phosphates), 2) demonstrated long-term resistance to leaching and radiation damage (via natural analogues), 3) capability of incorporating large volumes of waste types (high waste loadings), and 4) excellent thermal and mechanical stability. Potential drawbacks of the ceramic waste form include processing difficulties and low tolerance to large variations in waste-stream compositions.

\subsubsection{SYNROC}

Synthetic rock (SYNROC) is a ceramic material composed primarily of zirconolite $\left(\mathrm{CaZrTi}_{2} \mathrm{O}_{7}\right)$, hollandite $\left(\mathrm{Ba}_{1.2}(\mathrm{Al}, \mathrm{Ti})_{8} \mathrm{O}_{16}\right.$, perovskite $\left(\mathrm{CaTiO}_{3}\right)$, and various titanium oxides $\left(\mathrm{Ti}_{\mathrm{n}} \mathrm{O}_{2 \mathrm{n}-1}\right)$ (Lutze and Ewing 1988; Ringwood et al. 1979a; Ringwood et al. 1979b). This material has long been considered a serious candidate for immobilizing HLW because of the degree of waste loading possible, the belief that that the radionuclides would preferentially be incorporated into the phases with the highest thermodynamic stability, and its alleged insensitivity to radiation damage.

In past review panels, SYNROC was given an intermediate ranking in terms of scientific merit for least risk with respect to immobilization of HLW and was evaluated as a poor candidate in terms of engineering practicality (DOE 1979; LLNL 1996). However, SYNROC was given top ranking as a material worthy of further study. In later review studies, SYNROC was ranked second as a candidate for waste storage (DOE 1982b). This, together with new developments in processing, may increase the viability of SYNROC as a candidate waste form. A SYNROC-like waste form was recently chosen as the primary candidate for immobilization of excess plutonium due primarily to the difficulty in retrieving actinides for use in weapons (LLNL 1996).

\subsubsection{Monazite}

Monazite is a synthetic crystalline waste-candidate material modeled after the natural mineral monazite. The mineral monazite consists of lanthanide orthophosphates $\left(\mathrm{LnPO}_{4}\right.$, where $\mathrm{Ln}=\mathrm{La}$, $\mathrm{Ce}, \mathrm{Nd}$, etc.). Most natural monazites also contain uranium and thorium, and as such were considered as a host for other natural and man-made actinides. In addition, some monazites are believed to be over 2 billion years old, attesting to their suitability as a long-term storage matrix. The extensive chemical treatment required to extract thorium from the mineral is an indication of the chemical durability of the material.

The primary advantages of monazite as a waste-form material are as follows:

- $\quad$ High waste loadings are possible. 
- It has good chemical durability (corrosion rate of $<2 \times 10^{-3} \mathrm{~g} / \mathrm{m}^{2} / \mathrm{d}$ at $90^{\circ} \mathrm{C}$ in water).

- It is capable of accepting a wide range of waste materials.

- $\quad$ Cold pressing and sintering are sufficient to produce an acceptable waste form.

- Radiation damage does not appear to affect the chemical durability.

- $\quad$ Natural analogues are available to demonstrate long-term storage capabilities (Lutze and Ewing 1988; LLNL 1996).

The disadvantages associated with processing the waste form are that the urea precipitation process emits ammonia and water vapor, and the $1200^{\circ} \mathrm{C}$ sintering temperature volatilizes cesium, ruthenium, and molybdenum (Lutze and Ewing 1988; LLNL 1996).

\subsubsection{Tailored Ceramics}

This approach to HLW storage proposed by researchers at Rockwell International was to develop specific ceramic compositions that, when added to the waste along with necessary chemical additives, would upon consolidation form a dense ceramic material with known phases (Lutze and Ewing 1988). Two main types of ceramic waste forms were proposed. In the first type, the radionuclides were partitioned into all phases in a dilute solid solution (high waste loading, high fission product content). In the second type, the radionuclides were bound in individual phases dispersed throughout a ceramic matrix (high waste loading, low fission-product content or low waste loading, and high fission-product content). The advantages of this type of waste form include high waste loading, economic advantages associated with a waste-specific waste form, and good chemical durability with natural analogues available for comparison. This waste form failed to pass the first and second screening procedures for the plutonium disposition program, indicating that it failed to meet minimum requirements for a HLW form (LLNL 1996).

\subsubsection{Titanates}

Titanates are prepared by ion-exchanging radioactive species with alkali or alkaline earth titanates and zeolites (a silicate mineral with a high surface area). The resulting slurry is then dried and hot pressed to monolithic form. Advantages of this waste form include initial low processing temperatures, which reduce the amount of volatiles released, and homogeneous dispersion of the nuclides, which eliminate compositional gradients during densification of the final waste form. However, the same limitations discussed for the other polycrystalline waste materials remain. The titanate compositions are not fully understood, and the amorphous zeolite phase present after sintering may present problems with durability (Lutze and Ewing 1988).

\subsubsection{Calcine Waste Forms}

Calcination is a process where solutions are heated to a temperature below the point of fusion, resulting in the evaporation of water and oxidation of HLW metals. Calcination processes include the use of rotary drums, fluidized beds, sprayers, and a variety of simple or complex batch processes. Depending on the type of solution and calcination process, the resultant products called "calcines" can range from freeflowing powders to large agglomerates. In general, their large surface area and high potential for airborne release renders calcines and stabilized calcines unsuitable for use as a final waste form. 


\subsubsection{Pelletized Calcine}

Pelletized calcines are calcine waste material mixed with a predetermined amount of water and binders, with the mixture mechanically centrifuged to form pellets. This type of waste form offers little advantage over the calcine itself, as the pellets are weak and porous. It would be difficult to control the rheology of the mix when there is little control over particle size distribution and surface chemistry of the calcine. Also, if the pellets were crushed in transit, dispersion of airborne particles was likely. As such, pelletized calcines were ruled out as a final waste form. They were given further consideration as an intermediate step for SYNROC formation, or as a possible component of a multibarrier system with further sintering and densification. Overall, pelletized calcines were ranked low on the basis of scientific merit and research priority, but were ranked high for engineering practicality (DOE 1979; LLNL 1996).

\subsubsection{Stabilized Calcine}

Stabilized calcine is similar to pelletized calcine, with the exception that they are heat treated at higher temperatures, driving off additional moisture and nitrates. The higher temperatures result in a more compact pellet with somewhat greater durability and fewer tendencies to create dust particles. However, as with the pelletized calcine, while processing is relatively simple, the final product is unsuitable (primarily due to dusting potential) for long-term storage of HLW.

\subsubsection{Supercalcine}

Supercalcine is a polycrystalline material similar to that of SYNROC, except that it is based on the silicate mineral system rather than titanates. In general, supercalcines are a mixture of $\mathrm{Ca}_{3} \mathrm{Re}_{7}\left[\mathrm{SiO}_{4}\right]_{5}\left[\mathrm{PO}_{4}\right] \mathrm{O}_{2} ; \mathrm{CsAlSi}_{2} \mathrm{O}_{6} ; \mathrm{SrMoO}_{4} ; \mathrm{ZrO}_{2} ; \mathrm{Ni}(\mathrm{Fe}, \mathrm{Cr})_{2} \mathrm{O}_{4}$, and $(\mathrm{Fe}, \mathrm{Cr})_{2} \mathrm{O}_{3}(\mathrm{DOE} 1979 ;$ Rusin et al. 1978; Lutze and Ewing 1988). To accommodate a variable waste stream, the amounts of aluminum and silicon can be varied. High waste loadings on the order of 50 to 60 mass\% were believed to be possible with this material. High waste loadings were deemed both an advantage and disadvantage, depending on the point of reference. As a component of a multibarrier waste package, higher waste loadings are a significant advantage. In terms of radiation damage to this type of material, the higher waste loadings are less appealing. As with SYNROC, supercalcines would require additional processing, such as cold pressing and sintering, or hot pressing. The main detractants from this type of waste form include difficulty in assessing the leaching mechanisms associated with a complex polycrystalline waste form, the presence of pollucite to stabilize cesium (pollucite is soluble and easily weathered), and the lack of capability to consistently reproduce the waste form (DOE 1979).

\subsubsection{Cementitious Material Waste Forms}

Cementitious materials consist of cements and concrete. Cements consist mainly of silicates and aluminates of lime, and they react with water to yield hydroxides which, when dried, produce a monolithic form. Concretes consist of cements mixed with aggregates. Cementitious waste forms have been proposed and used for wastes categorized as hazardous (Conner 1990), low level (IAEA 1968 and 1970; Kibbey and Godbee 1977; Lokken 1978), intermediate (Gilmore 1977; Lokken 1978) and high level (Gilmore 1977; Schulz et al. 1980; Moore et al. 1981; Graham 1990). Cementitious materials work to immobilize the waste by a combination of encapsulation, redox control, and chemical reaction. The cement physically surrounds the waste and separates it from the environment. The types of cementitious forms evaluated for HLW immobilization include hot-press concrete, normal concrete, formed under elevated temperature and pressure (FUETAP) concrete, super grout, and sludge in concrete (Hench et al. 1984; Bernadzikowski 1982; DOE 1979, 1980, 1981, and 1982a; Dunson et al. 1982; E. R. Johnson 
Associates 1980; Bernadzikowski et al. 1987; Stone et al. 1979; Lutze and Ewing 1988; and Dole et al. 1983).

\subsubsection{Hot-Pressed Concrete}

In this waste form, the waste is mixed with cement and additives and poured into a heated press die. The concrete is pressed to 170 to $340 \mathrm{MPa}(25000$ to $50000 \mathrm{psi})$ and heated to 150 to $400^{\circ} \mathrm{C}$. The minimum amount of water is added, and the resulting product has very little free or unbound water.

\subsubsection{Cements}

Cements have been considered a method for long-term storage of HLW. While cement is relatively easy to manufacture, making it attractive from an engineering aspect, some of its inherent properties make it less viable as a long-term storage matrix. The primary reasons for disqualification included porosity, susceptibility to radiation damage, variability in composition, and the fact that the chemical reactions required to make a cement are complex as are the multiple phases produced. Determining, controlling, and predicting the outcome of cement in a radioactive environment was not warranted, given the expected durability performance (DOE 1979).

\subsubsection{FUETAP Concrete}

FUETAP is a concrete that is formed in an autoclave at temperatures of 100 to $300^{\circ} \mathrm{C}$ and pressures of 0.1 to $2 \mathrm{MPa}$ (16 to $600 \mathrm{psi}$ ). After the initial curing stage, the concrete is dewatered at $250^{\circ} \mathrm{C}$ for 24 hours. Other processing schedules are also possible, depending on composition and waste materials. In general, FUETAP concrete is a mixture of Portland cement, hydraulic cement, fly ash, sand, clays, and waste products. This waste form was considered an intermediate candidate for encapsulation of defense wastes (LLNL 1996). It can be processed at low temperatures and has good compressive strength, excellent thermal conductivity, and waste loadings in the range of 15 to 25 mass\%. In addition, chemical durability of FUETAP concrete appears to be good with low cesium and plutonium leach rates, and the process is economical (Lutze and Ewing 1988 and LLNL 1996).

\subsubsection{Super Concrete}

This waste form is similar to waste in concrete, with the exception of special additives added to decrease radionuclide leachability and improve other properties of the final concrete. Additives have been evaluated, such as zeolitic clays and minerals to sorb cesium, sodium titanate to sorb strontium, and precipitants or scavengers for technetium and iodine.

\subsubsection{Metallic Alloy Waste Forms}

Several types of metallic alloys have been proposed as media for radioactive waste disposal, including cermets, stabilized calcine in a metal matrix, multibarrier waste forms, glass beads dispersed in a metallic matrix, copper alloys, and iron-zirconium alloys (plutonium wastes). Some of these are discussed in the following paragraphs.

\subsubsection{Cermets}

Cermet waste forms consist of fine oxide and silicate species $(\sim 1 \mu \mathrm{m})$ dispersed throughout a metallic matrix. The advantages of this waste material include the very fine scale of dispersion of 
radionuclides, the use of metallic species already found in the waste stream, the ability to modify the waste form to meet the needs of the waste stream, high-thermal conductivity, and low leach rates (Lutze and Ewing 1988). With this waste form, waste loadings of $\sim 28$ mass $\%$ were achieved with simulated waste materials. Associated disadvantages were severe enough to warrant a negative response from early review panels. These included the potential for dispersion of the radionuclide fine particles upon corrosion of the metal when exposed to water. It was believed that dissolution rates would be high, and physical transport of the particles would be very rapid. In addition, it was speculated that local corrosion cells would occur due to compositional variations within the matrix, causing accelerated leaching. In addition, the available data were limited with respect to leaching behavior, making it difficult to extrapolate to long-term performance. Finally, it was believed that with this waste form, processing a consistently uniform waste material would prove very challenging (DOE 1979).

\subsubsection{Multibarrier Approach}

The multibarrier approach is somewhat similar to that of cermets. However, in this case, the encapsulants consist of either glass or stuffed glass pellets or coated polycrystalline ceramic pellets in preferably a lead matrix. In this novel approach, the radionuclides are encapsulated within the glass or ceramic pellets, and the pellets are in turn encapsulated within the metallic matrix. The advantages of this system include high-corrosion resistance of lead; low probability of mechanical fracture due to the impact resistance of lead; predictable heat transfer away from the pellets, which would limit or eliminate devitrification of glass pellets; limited exposure of the pellets to the environment should fracture occur (larger pellets $[\sim 1.3 \mathrm{~cm}]$ ); increased quality assurance by random sampling of the pellets during either melting or pelletizing procedures; and the extra layer of protection during the first 300 to 500 years of burial. While this approach apparently offers a number of advantages, several important disadvantages include 1) the requirement of two hot-cell processing steps; 2) low final waste loading; and 3) requirement of a greater number of heavy canisters (increased transportation costs and repository space and costs). While weighing the advantages and disadvantages, one review panel gave the multibarrier approach top ranking for scientific merit and research priority, but a low ranking for engineering practicality (DOE 1979). Later review panels ranked this waste form low in terms of durability and waste loading, but intermediate in terms of processability (DOE 1982b).

\subsubsection{Polymeric Waste Forms}

\subsubsection{Resins}

Epoxy, polyester, polyethylene, and urea-formaldehyde resins have been studied for immobilization of radioactive waste. Epoxy resin is capable of immobilizing wastes that contain large amounts of water and can attain a waste loading of 50 to 56 mass $\%$. Polyester resins can be formulated to a variety of physical states (hard, brittle, soft, flexible), and chemicals can be added to improve durability. Polyethylene resins were considered when volatility or decomposition of the waste was a problem. In general, polymeric waste forms are not suitable matrix material for HLW, but may be useful for low- or intermediate-level wastes (LLNL 1996).

\subsubsection{Other Waste Forms}

Many other materials have been proposed as candidates for encapsulating radioactive waste. Most were eliminated early in the down-selection process for future investigation for HLW. The following is a noninclusive listing of other waste forms that have been considered and are believed suitable for low- or intermediate-level radioactive waste, but not HLW immobilization. 
- Bitumin

- Pyrolytic carbon and silicon-carbon-coated particles

- Aqueous silicate

- Clay-ceramic monoliths, marbles

- Lotes Process

- Talc-silicon glass-ceramic

- Supergrout

- Various concretes

- Plasma spray coatings

- Thermite-type processes

- Ceramic sponge

- Coated sol-gel particles

- Ceramic in concrete

- Metal compounds

- Nitrate to Alumina and Ceramics

- Sulfur-polymer cement

- Sintered glass calcine

\subsection{Waste Form Reviews and Down Selections}

Research on HLW forms began in the 1950s with investigations of borosilicate glass (Mendel 1977; Lutze 1982), phosphate glass (Grambow and Lutze 1980), nepheline-syenite glass (Watson et al. 1960), and a variety of polyphase ceramic (McCarthy and Davidson 1975; Ringwood et al. 1980) and concrete (Moore et al. 1981) forms. As many as 17 various waste forms (see Table 4.3, from Hench et al. 1984) were considered as potential media for the geological disposal of HLW (Bernadzikowski 1982). During 1980 , research and development activities were terminated for 10 of the forms based on extensive reviews (DOE 1979; DOE 1980) that raised technical concerns about the viability of these forms as potential candidates for geological disposal of wastes. Research and development activities continued on the remaining seven forms for another year, after which another down-selection was made based on four different assessments by a DOE assessment team. The assessments or reviews included 1) evaluations at DOE defense waste sites (Bernadzikowski 1982); 2) peer review evaluation (DOE 1981); 3) a product performance evaluation (DOE 1982a); and 4) a processability analysis (Dunson et al. 1982). Based on these reviews, two of the seven forms - borosilicate glass and titanate-based polyphase ceramics-were selected as the reference and alternative, respectively, for the U.S. Defense HLW Program. A description of the evaluation process, performance indices, weighting factors, processability factors, and selection criteria are briefly summarized below. Bernadzikowski (1982) provides a more thorough review. 
Table 4.3. Candidate Waste Forms Considered for Geologic Disposal of HLW

\begin{tabular}{|l|l|}
\hline \multicolumn{1}{|c|}{ Waste Form } & \multicolumn{1}{c|}{ Comment } \\
\hline Borosilicate Glass & $\begin{array}{l}\text { Primary International Waste Form, } \\
\text { U.S. Reference Waste Form }\end{array}$ \\
\hline SYNROC - C, D & Alternative U.S. Waste Form \\
\hline & \\
\hline Tailored Ceramic & Semi-Finalist U.S. Alternative Waste Form \\
\hline High Silica Glass & Semi-Finalist U.S. Alternative Waste Form \\
\hline FUETAP Concrete & Semi-Finalist U.S. Alternative Waste Form \\
\hline Coated Sol-Gel Particles & Semi-Finalist U.S. Alternative Waste Form \\
\hline Glass Marbles in a Pb Matrix & Finalist U.S. Alternative Waste Form \\
\hline & \\
\hline Phosphate Glass & Eliminated from U.S. Development in 1979-80 \\
\hline Clay-Ceramic & Eliminated from U.S. Development in 1979-80 \\
\hline Titanate Ion Exchanger & Eliminated from U.S. Development in 1979-80 \\
\hline Stabilized Calcine & Eliminated from U.S. Development in 1979-80 \\
\hline Pelletized Calcine & Eliminated from U.S. Development in 1979-80 \\
\hline Normal Concrete & Eliminated from U.S. Development in 1979-80 \\
\hline Hot-Pressed Concrete & Eliminated from U.S. Development in 1979-80 \\
\hline Matrix Forms & Eliminated from U.S. Development in 1979-80 \\
\hline Cermet & Eliminated from U.S. Development in 1979-80 \\
\hline $\begin{array}{l}\text { Disc-Pelletized Coated } \\
\text { Particles }\end{array}$ & Eliminated from U.S. Development in 1979-80 \\
\hline
\end{tabular}

In 1981, the French Commissariate A L' Energie Atomique (French Atomic Energy Commission) (CEA) also selected borosilicate glass to solidify fission product solutions at the commercial waste reprocessing facility at La Hague (CEA 1982). The French decision was based in part on the successful operation of the PIVER (Pilote Verre) hot HLW vitrification pilot facility and the $\mathrm{AVM}^{3}$ prototype HLW vitrification plant at Marcoule (Bonniaud et al. 1978).

The performance indices, weighting factors, processability factors, and selection criteria for the downselection process are provided by Bernadzikowski (1982) and Bernadzikowski et al. (1983). To provide a quantitative comparison of product performance, waste loading, mechanical stability, and leaching properties were evaluated. The rating method was based on a procedure developed by a panel of scientists from organizations involved with the repository, transportation, and defense and commercial waste programs. The three properties were quantified, weighted by relative importance, and organized within three time periods that were deemed important for waste disposal:

- the operational period includes interim storage, transportation, and handling (100 to 500 years)

- the thermal pulse period, which begins after repository closure and spans the period when the fission products ${ }^{137} \mathrm{Cs}$ and ${ }^{90} \mathrm{Sr}$ generate most of the heat (assumed to last about 1000 years after the waste is placed in the repository)

- the geologic period, which begins after 1000 years when the hazards of waste are dominated by longlived fission products.

The figure of merit for the product-performance properties and their relative weightings are shown in Table 4.4 (from Bernadzikowski et al. 1983). Leaching, the primary mechanism for the release of

\footnotetext{
${ }^{3}$ French process to solidify HLW.
} 
radionuclides, was weighted the heaviest (73\%). When the rating scheme was applied to the performance data, a "figure of merit" rating was generated for each form.

Table 4.4. Hierarchy for Evaluating Properties of Waste Forms

\begin{tabular}{|c|c|c|c|c|}
\hline \multicolumn{5}{|c|}{ Figure of Merit } \\
\hline $\begin{array}{c}\text { Operational Period (32\%) } \\
(21.3 \%)\end{array}$ & $\begin{array}{c}\text { Thermal Pulse } \\
\text { Period (28\%) }\end{array}$ & $\begin{array}{c}\text { Geologic Period } \\
\text { (40\%) }\end{array}$ \\
\hline Curie content & Impact Resistance & Leach Rate & Leach Rate & Leaching \\
\hline
\end{tabular}

In support of a selection process to immobilize surplus and weapons-usable plutonium for ultimate disposal in a geologic repository, more than 70 waste forms were reviewed (LLNL 1996). The individual waste forms were grouped into families that share common chemical and physical characteristics, and their properties were reviewed. An approach was selected to screen the potential plutonium immobilization forms. This approach provided a formal, structured mechanism for selecting a set of candidates for further analysis and development. A two-stage screening approach was adopted with both pass-fail and multi-attribute type analysis techniques. The two-stage approach was based on formal decision-analysis techniques, which allowed the use of rigorous selection techniques as the number of options decreased and limited the data collection required in the early stages.

The first stage (Stage 1), which applied a small set of pass-fail screening criteria to the full list of immobilization forms, was aimed at quickly removing those forms that were clearly inappropriate for immobilizing plutonium. This process was performed while ensuring that no viable alternatives were eliminated from further consideration. The first-stage criteria included 1) no free water; 2) solidification and consolidation; 3) stability; 4) criticality control; 5) RCRA metal content; 6) readiness or technical viability/maturity; and 7) loading (or waste loading).

The second stage (Stage 2) evaluated more closely the remaining forms, with the goal of selecting a small set of potential plutonium immobilization forms for final consideration. This stage used a multi-attribute analysis technique (in an effort to maintain consistency) for a more formal treatment of the chosen attributes. Attributes and weighed factors were developed against which the waste forms (from Stage 1) were evaluated. Attributes included 1) technical viability/maturity; 2) environmental, safety, and health issues; 3) waste minimization; 4) cost effectiveness; 5) timeliness; 6) public and institutional acceptance; and 7) resistance to theft or diversion.

The screening process resulted in a ranking of 16 waste forms. As with the previous reviews for HLW, borosilicate glass ranked the highest of all the immobilization forms, with titanate-based ceramics (SYNROC) ranking second highest and phosphate glasses ranking third. Table 4.5 summarizes the 16 waste forms evaluated in Stage 2 and the utility (figure of merit) factors determined. The sensitivity analysis performed indicated that the form family rankings are very insensitive to changes in both the attribute weights generated and the technical scores assigned. 
Table 4.5 Final ranking of Waste Forms in Plutonium Immobilization Program

\begin{tabular}{|l|c|}
\hline \multicolumn{1}{|c|}{ Waste Form } & Utility \\
\hline Borosilicate Glass & 0.89 \\
\hline SYNROC & 0.66 \\
\hline Phosphate Glass & 0.55 \\
\hline Monazite & 0.49 \\
\hline Metallic Alloy & 0.47 \\
\hline High Silica Glass & 0.44 \\
\hline FUETAP concrete & 0.40 \\
\hline Hot-Pressed Concrete & 0.24 \\
\hline Phosphate based Ceramic & 0.17 \\
\hline Silicon-Zirconium Phosphate Ceramic & 0.17 \\
\hline Ceramics in Concrete & 0.14 \\
\hline Iron-Enriched Basalt & 0.13 \\
\hline Ceramic Pellet in Metal Matrix & 0.13 \\
\hline Supercalcine & 0.08 \\
\hline Glass-Ceramic Monolith & 0.03 \\
\hline Cermet & 0.00 \\
\hline
\end{tabular}

Although the waste-form selection process was aimed at immobilizing surplus plutonium (and not HLW), the authors felt it beneficial to include it in this assessment as the selection of primary waste forms continues to include borosilicate and titanate-based ceramics.

\subsection{Method of Selection/Non-Selection of Waste Forms}

Given the time and budget constraints of this task, it was not feasible to evaluate every possible immobilization alternative waste form (listed in the previous sections) with the care or detail one would like for the specific 17 Hanford clusters. Efforts were made to select a limited number of waste forms that had the potential to meet programmatic objectives (e.g., increased waste loadings relative to the current Joule-heated melter technology and/or the baseline borosilicate glass systems). Given these limitations, the down-selection process for this program was primarily based on specific constraints, information from previous waste form reviews, and a literature survey to highlight recent waste form developments. More specifically, the down-selection process was based on the following:

- Processing Constraint: The waste form must be processed through a waste glass melter. This constraint is restrictive in that it obviously eliminates a large number of the waste forms discussed above. However, it does not preclude using a ceramic-based waste form, given the recent advances in cold-wall crucible melter technology that have demonstrated processing of SYNROC-type waste forms. Waste forms produced through in-can melting processes were not assessed as part of the waste form review.

- Previous Reviews: Of those waste forms that "passed" the restrictive processing criteria, the downselection process then leveraged and used the knowledge developed during the initial down-selection process (DOE 1979, 1980, 1981, 1982a, and 1982b) for the U.S. HLW program as well as the more recent down-selection process for the surplus plutonium immobilization program (LLNL 1996). Although separate programs are from different eras, each review and down-selection process was conducted using formal decision-analysis techniques (as previously discussed). Not to use or consider this documented knowledge base would be inappropriate for the current study (particularly 
given the previous experimental and theoretical work that was performed in support of the U.S. HLW down-selection and the direct applicability to this program).

- Literature Review: Although the previous reviews are well documented, one must temper the data and waste-form descriptions with the current state of technology and/or waste-form development. That is, even though a particular waste form failed to meet specifications in previous reviews, the development (either from a compositional shift in the waste form and/or new technology that may benefit programmatic objectives) may have progressed to the point where it should be considered a viable candidate. Bearing this in mind, the Study Team performed a literature review to bring to light any new developments in alternative waste forms that may prove advantageous (but also passed the melter-processing criteria). The Study Team also sought technical experts to assess various waste forms in their capability to meet programmatic criteria in an effort to see whether the waste form should be assessed against the 17 Hanford clusters. Frankly, the literature reviewed shed little additional light on bringing a new waste form to the forefront. This is due largely because the Study Team members have stayed abreast of waste form developments and their publication through their participation in DOE and industrial programs involving waste form and processing development activities, professional society involvement, and professional peer relationships.

The review and assessment process (albeit limited due to schedule and budget constraints) downselected to the following waste forms:

- AABS glass

- alkali-aluminosilicate (AAS) glass

- FeP glass

- titanate-based ceramics.

These waste forms are consistent with those that surfaced as leading candidates in previous reviews. The down-selection included those waste forms that have a reasonable chance of successfully treating the waste while meeting the program objectives and/or constraints. The inclusion of silicate-based glasses was the most obvious, given that it is the U.S. current waste form of choice for HLW. The titanate-based ceramics are included because the French and the Russians have demonstrated the processing of titanatebased ceramics through a cold-walled crucible using induction technology. Iron-phosphate glasses were included because of the potential to handle the high $\mathrm{Cr}_{2} \mathrm{O}_{3}, \mathrm{P}_{2} \mathrm{O}_{5}$, and/or $\mathrm{Fe}_{2} \mathrm{O}_{3}$ streams identified via the cluster analysis, the research and development activities over the past 15 years for immobilization of HLW, and the fact that the Russians have been operating a melter using a phosphate-based glass to immobilize their HLW.

An assessment of these waste forms with respect to their advantages and disadvantages for immobilizing the 17 Hanford clusters is discussed below. For those waste forms where sufficient data exist and the technology is fairly well understood, waste loadings/glass volumes have been estimated for specific scenarios. The impact of producing a single-phased glass as well as a "glass-ceramic" on waste loading was assessed. The formation of a "glass-ceramic" product must not impede or compromise processability [i.e., either the crystals must form in the canister upon cooling (referred to as "canister centerline cooling"), or the melter technology must be capable of handling a limited amount of devitrification]. The effect of relaxing various constraints (e.g., durability and/or liquidus temperature) on waste loading was also evaluated where applicable and data allowed. The effect of relaxing liquidus temperature essentially translates into high-temperature processing $\left(>1150^{\circ} \mathrm{C}\right)$ and/or allowing a certain percentage of crystallization within the melt pool.

Where experimental data did not exist or models were not available and/or applicable, best estimates were provided based on the technical expertise for a given waste form. Where expert judgment was used, data 
gaps exist and may need to be filled if the waste form is found to be a potential candidate for all (or a select number) of the 17 clusters.

\subsection{Alkali-Alumino-Borosilicate Glass}

\subsubsection{Glass Property Models and Assumptions on Solubilities}

A wealth of data is available for key properties of AABS glasses. Hrma et al. (2001) recently compiled an expansive database of key properties of AABS glasses. First-order expansions of PCT response, viscosity temperature data, and liquidus temperature were fitted to this database. These expansions or first-order mixture models are given by:

$$
\begin{gathered}
\ln \left[r_{\alpha}\right]=\sum_{i=1}^{N} r_{\alpha, i} x_{i} \\
\ln [\eta]=\sum_{i=1}^{N}\left(a_{i}+\frac{b_{i}}{T}\right) x_{i} \\
T_{L, \beta}=\sum_{i=1}^{N} T_{\beta, i} x_{i}
\end{gathered}
$$

where $\mathrm{x}_{\mathrm{i}}$ is the $\mathrm{i}^{\text {th }}$ component normalized mole fraction in glass, $\mathrm{N}$ is the number of components for which the model was fit, $r_{\alpha}$ is the normalized release of $\alpha$ (boron, sodium, and lithium) from a PCT, $\mathrm{T}_{\mathrm{L}, \beta}$ is the liquidus temperature in the $\beta$ primary phase field (spinel and zircon), $\mathrm{T}$ is absolute temperature, and $\mathrm{r}_{\alpha, \mathrm{i}}, \mathrm{a}_{\mathrm{i}}$, $\mathrm{b}_{\mathrm{i}}$, and $\mathrm{T}_{\beta, \mathrm{i}}$ are the fitted model coefficients for the $\mathrm{i}^{\mathrm{th}}$ component. Similar models for electrical conductivity $(\varepsilon)$ and density $(\rho)$ from Hrma et al. (1994) were also used in the AABS glass-property calculations. The property models, as empirical functions, are only valid over fixed component concentration ranges. Model validity constraints were added to some calculations to ensure that the glass composition did not significantly deviate from the ranges of model validity.

For some properties of interest, there are either insufficient data to fit models of the form in Equations (1) through (3), or their behavior is not well described by such a model form. One example is the $T_{L}$ of glasses in the eskolaite primary phase field. When the concentration of chromium in glass exceeds its solubility, it precipitates as either spinel, $[\mathrm{Fe}, \mathrm{Ni}, \mathrm{Mn}][\mathrm{Fe}, \mathrm{Cr}]_{2} \mathrm{O}_{4}$, or eskolaite, $\mathrm{Cr}_{2} \mathrm{O}_{3}{ }^{4}$. The liquidus temperature in both primary phase fields is a function of glass composition. Therefore, chromium solubility is a function of both glass composition and temperature. The effect of composition on $\mathrm{T}_{\mathrm{L}}$ is known within a reasonable large fraction of the spinel primary phase field. However, there is a scarcity of data on $T_{L}$ in the eskolaite primary phase field. We have therefore taken the approach of using the $T_{L}$ model for spinel combined with a concentration limit for chromium in glass.

\subsubsection{Reference Property Constraint Set}

The method chosen to determine the sensitivity of glass volume to variation in property constraints was to first define a reference case, then vary constraints one-at-a-time and many-at-a-time from that reference. To determine the reference set of constraints, the Study Team considered the ranges of acceptable glass properties reported by WVDP and DWPF, and those planned for the WTP and previously considered for the HWVP. The Study Team also used a set of composition constraints to ensure model validity. The constraint set is summarized in Table 4.6.

\footnotetext{
${ }^{4}$ Alkali-chromates can also form if the melt is sufficiently oxidized; however, it is rare in the absence of other oxyanionic salts such as phosphate or sulfate.
} 
The nominal operating temperature, $\mathrm{T}_{\mathrm{M}}$, of the baseline melter technology is $1150^{\circ} \mathrm{C}$, as is that of the DWPF and WVDP. To avoid crystalline material in the melter, the Study Team imposed a limit of $\mathrm{T}_{\mathrm{L}} \leq \mathrm{T}_{\mathrm{M}}-100^{\circ} \mathrm{C}$. The $100^{\circ} \mathrm{C}$ allows for temperature variations within the melter and adds a margin of safety. Due to the uncertainty of model prediction and waste compositions, the Study Team added an additional $50^{\circ} \mathrm{C}$. The viscosity at $\mathrm{T}_{\mathrm{M}}$ is limited to the range from 2 to $10 \mathrm{~Pa} \cdot \mathrm{s}$. The electrical conductivity is restricted to between 10 and $100 \mathrm{~S} / \mathrm{m}$ at $\mathrm{T}_{\mathrm{M}}$. The WAPS requires that normalized releases of boron, lithium, and sodium $\left(\mathrm{r}_{\mathrm{B}}, \mathrm{r}_{\mathrm{Li}}\right.$, and $\mathrm{r}_{\mathrm{Na}}$ ) are less than those of the DWPF EA glass by the PCT-A (ASTM 1998). The Study Team chose to normalize the releases by the glass surface area to solution volume to account for differences in waste form densities (since the PCT is performed with fixed glass mass, not glass surface area). The EA glass release values are $8.35,4.78$, and $6.67 \mathrm{~g} / \mathrm{m}^{2}$ for $\mathrm{r}_{\mathrm{B}}, \mathrm{r}_{\mathrm{Li}}$, and $\mathrm{r}_{\mathrm{Na}}$, respectively. We have used a limit of $2 \mathrm{~g} / \mathrm{m}^{2}$ for $\mathrm{r}_{\mathrm{B}}, \mathrm{r}_{\mathrm{Li}}$, and $\mathrm{r}_{\mathrm{Na}}$ to account for model and glass composition uncertainty. To ensure model validity, limits were placed on the concentrations of (with mass\% limits) $\mathrm{B}_{2} \mathrm{O}_{3}(5-15), \mathrm{Fe}_{2} \mathrm{O}_{3}(\leq 20), \mathrm{MnO}(\leq 4), \mathrm{Li}_{2} \mathrm{O}(\leq 4), \mathrm{Na}_{2} \mathrm{O}(\leq 20), \mathrm{SiO}_{2}(\geq 35)$, and $\mathrm{Na}_{2} \mathrm{O}+\mathrm{Li}_{2} \mathrm{O}+\mathrm{K}_{2} \mathrm{O}(\leq 22)$.

A number of components are likely to limit the loading of waste in glass by their strong influence on amorphous or crystalline phase separation. For example, Jantzen et al. (2000) showed that generally, AABS waste glass melts with higher than 2.5 mass $\%$ of $\mathrm{P}_{2} \mathrm{O}_{5}$ tended to separate into two or more immiscible liquid phases. The Study Team therefore adopted that concentration as a limit to help ensure single-phase glass. Likewise, a number of studies found that immiscible salt phases form and segregate from melts with $\mathrm{SO}_{3}$ concentrations higher than roughly 0.6 to 1.2 mass \%. The Study Team adopted a limit of 0.8 mass $\% \mathrm{SO}_{3}$ to avoid salt segregation in the melter. The tendency to form $\mathrm{CaF}_{2}$ or other fluorine-containing minerals is highly influenced by fluoride concentration in the melt. The solubility of fluoride, or more accurately, the concentration of fluoride that a melt can contain without the formation of a fluorine-containing phase (such as $\mathrm{CaF}_{2}$ ) at melt temperature or during quenching, can vary from roughly 2 to 8 mass \%. As most of the Hanford wastes are relatively low in fluoride, the Study Team adopted the conservative limit of 2 mass\% fluorine. However, if they were found to influence the glass volume, then the Study Team would adjust that limit. There is a limit on the combined concentrations of $\mathrm{RuO}_{2}$ and $\mathrm{Rh}_{2} \mathrm{O}_{3}$ of 0.10 mass \% to avoid noble metal accumulation in the melter. Other noble metals $\left(\mathrm{Ag}_{2} \mathrm{O}, \mathrm{PdO}, \mathrm{Au}_{2} \mathrm{O}\right.$, etc.) are not expected to be a problem. 
Table 4.6. Reference Set of Constraints for AABS Glasses

\begin{tabular}{|c|c|c|c|}
\hline Constraint & Value & Unit & Purpose \\
\hline $\mathrm{T}_{\mathrm{M}}$ & 1150 & ${ }^{\circ} \mathrm{C}$ & processability \\
\hline $\mathrm{T}_{\mathrm{L}}(\mathrm{sp})$ & $\leq 1000$ & ${ }^{\circ} \mathrm{C}$ & processability \\
\hline $\mathrm{T}_{\mathrm{L}}(\mathrm{zr})$ & $\leq 1000$ & ${ }^{\circ} \mathrm{C}$ & processability \\
\hline$\eta$ & $2-10$ & $\mathrm{~Pa} \cdot \mathrm{s}$ & processability \\
\hline$\varepsilon$ & $10-100$ & $\mathrm{~S} / \mathrm{m}$ & processability \\
\hline$r_{B}$ & $\leq 2$ & $\mathrm{~g} / \mathrm{m}^{2}$ & WAPS \\
\hline$r_{L i}$ & $\leq 2$ & $\mathrm{~g} / \mathrm{m}^{2}$ & WAPS \\
\hline $\mathrm{r}_{\mathrm{Na}}$ & $\leq 2$ & $\mathrm{~g} / \mathrm{m}^{2}$ & WAPS \\
\hline$\left[\mathrm{B}_{2} \mathrm{O}_{3}\right]$ & $5-15$ & Mass $\%$ & model validity \\
\hline$\left[\mathrm{Fe}_{2} \mathrm{O}_{3}\right]$ & $\leq 20$ & Mass $\%$ & model validity/crystal formation \\
\hline$[\mathrm{MnO}]$ & $\leq 4$ & Mass $\%$ & model validity \\
\hline$\left[\mathrm{Li}_{2} \mathrm{O}\right]$ & $\leq 4$ & Mass\% & model validity \\
\hline$\left[\mathrm{Na}_{2} \mathrm{O}\right]$ & $\leq 20$ & Mass $\%$ & model validity/durability \\
\hline$\left[\mathrm{SiO}_{2}\right]$ & $\geq 35$ & Mass $\%$ & model validity $/ \mathrm{T}_{\mathrm{L}}$ and durability \\
\hline$\left[\mathrm{Na}_{2} \mathrm{O}\right]+\left[\mathrm{Li}_{2} \mathrm{O}\right]+\left[\mathrm{K}_{2} \mathrm{O}\right]=[\mathrm{Alk}]$ & $\leq 22$ & Mass \% & model validity/durability \\
\hline$\left[\mathrm{Cr}_{2} \mathrm{O}_{3}\right]$ & $\leq 1$ & Mass $\%$ & eskolaite $\mathrm{T}_{\mathrm{L}} / \mathrm{Cr}_{2} \mathrm{O}_{3}$ solubility \\
\hline$\left[\mathrm{P}_{2} \mathrm{O}_{5}\right]$ & $\leq 2.5$ & Mass $\%$ & immiscibility $/ \mathrm{P}_{2} \mathrm{O}_{5}$ solubility \\
\hline$[\mathrm{F}]$ & $\leq 2$ & Mass \% & immiscibility/opalescence \\
\hline$\left[\mathrm{SO}_{3}\right]$ & $\leq 0.8$ & Mass $\%$ & immiscibility/salt formation \\
\hline$\left[\mathrm{RuO}_{2}\right]+\left[\mathrm{Rh}_{2} \mathrm{O}_{3}\right]$ & $\leq 0.10$ & Mass $\%$ & noble metal solubility/settling \\
\hline$\left[\mathrm{SiO}_{2}\right] /\left(\left[\mathrm{SiO}_{2}\right]+\left[\mathrm{Na}_{2} \mathrm{O}\right]+\left[\mathrm{Al}_{2} \mathrm{O}_{3}\right]\right)$ & $\geq 0.62$ & & nepheline formation on cooling \\
\hline$[\mathrm{Alk}] /\left([\mathrm{Alk}]+\left[\mathrm{SiO}_{2}\right]+\left[\mathrm{B}_{2} \mathrm{O}_{3}\right]\right)$ & $\geq 0.12$ & & immiscibility \\
\hline
\end{tabular}

As stated earlier, the solubility of chromium in an AABS glass is a function of both composition and temperature. Since the effect of composition on $\mathrm{T}_{\mathrm{L}}$ in the eskolaite primary phase field is unknown, the Study Team estimated the solubility of $\mathrm{Cr}_{2} \mathrm{O}_{3}$ at 1 mass\%. The solubility of $\mathrm{Cr}_{2} \mathrm{O}_{3}$ was measured in at least four simulated waste glasses. The first two were low-level waste glasses studied by Feng et al. (1996): L6-5412 (0.5 mass\%) and L4-9012 (1.0 mass\%); the second set of glasses fabricated with a simulated Hanford HLW and 1.0 mass $\%$ and 0.8 mass $\% \mathrm{Cr}_{2} \mathrm{O}_{3}$; these glasses had a $\mathrm{T}_{\mathrm{L}}$ values of $1036^{\circ} \mathrm{C}$ and $974^{\circ} \mathrm{C}$, respectively, with eskolaite as the primary phase. These data suggest that glass compositions optimized for $\mathrm{Cr}_{2} \mathrm{O}_{3}$ solubility should be capable of achieving 1 mass $\%$.

Two composition rules were added to help avoid the formation of nepheline $\left[\mathrm{NaAlSiO}_{4}\right]$ and a silica-rich immiscible melt on cooling of the glass. Li et al. (1996) showed that AABS glasses with $\mathrm{Na}_{2} \mathrm{O} \cdot \mathrm{Al}_{2} \mathrm{O}_{3} \cdot \mathrm{SiO}_{2}$ sub-mixtures within the nepheline primary phase field in that ternary mixture are susceptible to nepheline formation. For practical purposes, glasses with $\left[\mathrm{SiO}_{2}\right] /\left(\left[\mathrm{Na}_{2} \mathrm{O}\right]+\left[\mathrm{Al}_{2} \mathrm{O}_{3}\right]+\right.$ 
$\left.\left[\mathrm{SiO}_{2}\right]\right) \geq 0.62$ are less susceptible to nepheline formation. Likewise, glasses with $\left(\left[\mathrm{Na}_{2} \mathrm{O}\right]+\right.$ $\left.\left[\mathrm{Li}_{2} \mathrm{O}\right]\right) /\left(\left[\mathrm{Na}_{2} \mathrm{O}\right]+\left[\mathrm{Li}_{2} \mathrm{O}\right]+\left[\mathrm{B}_{2} \mathrm{O}_{3}\right]+\left[\mathrm{SiO}_{2}\right]\right) \geq 0.12$ are less susceptible to silica rich immiscible liquid formation (Peeler et al. 1998).

This set of constraints is expected to yield reasonable, if a bit conservative, estimates of Hanford HLW loadings in glass. The glass will be processable in Hanford's baseline melter technology and will meet the current waste-form acceptability criteria. Section 4.6.3 discusses the glass volumes that would be produced assuming these reference constraints and which constraints limit waste loading. The impacts of changing one or more of these constraints on the volume of glass produced are discussed in Sections 4.6.4 and 4.6.5.

\subsubsection{Reference Glass Calculations}

A glass mass of $26539 \mathrm{Mg}$ is expected from vitrification of the 17 Hanford waste clusters. With 12314 $\mathrm{Mg}$ of waste, this represents a weighted average waste loading of 45.9 mass $\%$, and assuming $1.15 \mathrm{~m}^{3}$ glass/canister would yield 8542 canisters. This is roughly a third lower glass than the ORP baseline assumption that $38930 \mathrm{Mg}$ or 12700 canisters of glass would be produced (Kirkbride 2000). The difference in glass volume between the ORP baseline and the Study Team's reference case is primarily due to the difference in $\mathrm{Cr}_{2} \mathrm{O}_{3}$ constraint. The Study Team assumes a 1.0 mass\% solubility of $\mathrm{Cr}_{2} \mathrm{O}_{3}$, while Kirkbride (2000) assumes a 0.5 mass \% solubility of $\mathrm{Cr}_{2} \mathrm{O}_{3}$. In addition, there is a slightly higher waste loading due to the blending inherent in cluster analyses, and the Study Team didn't account for plant inefficiencies and waste composition variation. Table 4.7 summarizes the waste loading and limiting constraints for the 17 Hanford waste clusters.

Table 4.7. Summary of Waste Loading by Cluster for Reference Constraints

\begin{tabular}{crcrrrc}
\hline cluster & $\begin{array}{r}\text { waste } \\
\text { mass } \\
(\mathrm{Mg})\end{array}$ & $\begin{array}{c}\text { Waste } \\
\text { loading } \\
(\text { mass } \%)\end{array}$ & $\begin{array}{r}\text { glass } \\
\text { mass } \\
(\mathrm{Mg})\end{array}$ & $\begin{array}{r}\text { glass } \\
\text { (ensity } \\
\left(\mathrm{g} / \mathrm{cm}^{3}\right)\end{array}$ & $\begin{array}{r}\text { glass } \\
\text { volume } \\
\left(\mathrm{m}^{3}\right)\end{array}$ & $\begin{array}{r}\text { canisters limiting } \\
\text { constraints }\end{array}$ \\
\hline 1 & 2349 & 54.1 & 4342 & 2.69 & 1612 & $1402 \mathrm{sp}, \mathrm{np}, \mathrm{li}$ \\
2 & 1749 & 54.6 & 3202 & 2.85 & 1123 & $977 \mathrm{sp}, \mathrm{np}, \mathrm{v}, \mathrm{b}$ \\
3 & 1647 & 43.2 & 3815 & 2.73 & 1396 & $1214 \mathrm{sp}, \mathrm{np}, \mathrm{v}, \mathrm{li}$ \\
4 & 1395 & 44.6 & 3125 & 2.73 & 1146 & $997 \mathrm{sp}, \mathrm{np}, \mathrm{v}, \mathrm{li}$ \\
5 & 1384 & 48.0 & 2886 & 2.78 & 1040 & $904 \mathrm{sp}, \mathrm{np}, \mathrm{v}, \mathrm{li}$ \\
6 & 947 & 41.4 & 2288 & 2.63 & 869 & $756 \mathrm{sp}, \mathrm{np}, \mathrm{b}, \mathrm{li}$ \\
7 & 678 & 49.5 & 1369 & 2.62 & 523 & $454 \mathrm{cr}$ \\
8 & 506 & 39.0 & 1297 & 2.63 & 493 & $429 \mathrm{p}$ \\
9 & 426 & 49.9 & 853 & 2.97 & 287 & $250 \mathrm{zr}, \mathrm{np}, \mathrm{si}, \mathrm{b}$ \\
10 & 232 & 37.0 & 626 & 2.65 & 236 & $205 \mathrm{mn}$ \\
11 & 216 & 28.1 & 769 & 2.58 & 298 & $259 \mathrm{v}, \mathrm{pct}, \mathrm{b}$ \\
12 & 175 & 43.6 & 402 & 2.79 & 144 & $125 \mathrm{zr}, \mathrm{pct}, \mathrm{alk}, \mathrm{b}$ \\
13 & 171 & 39.2 & 437 & 2.94 & 148 & $129 \mathrm{mn}$ \\
14 & 150 & 23.5 & 637 & 2.51 & 253 & $220 \mathrm{cr}$ \\
15 & 142 & 35.8 & 396 & 2.75 & 144 & $125 \mathrm{sp}, \mathrm{pct}, \mathrm{b}$ \\
16 & 128 & 50.2 & 256 & 2.98 & 86 & $75 \mathrm{zr}, \mathrm{v}, \mathrm{si}, \mathrm{b}$ \\
17 & 19 & 16.7 & 115 & 2.59 & 44 & $39 \mathrm{mn}$ \\
\hline
\end{tabular}

The glass compositions for each cluster were numerically optimized. If a property, which is modeled as a function of composition, constrained the loading of a particular waste in glass, the additive composition would be adjusted until at least one additional constraint was met. Therefore, waste loading was limited by more than one property constraint, unless a single component concentration constraint (e.g., $\left[\mathrm{Cr}_{2} \mathrm{O}_{3}\right]$ or $\left.\left[\mathrm{P}_{2} \mathrm{O}_{5}\right]\right)$ was encountered. Those glasses with waste loading limited by a single component concentration 
do not have unique optimum glass compositions. Of the $26539 \mathrm{Mg}$ of glass, $75 \%$ was limited by the $\mathrm{T}_{\mathrm{L}}(\mathrm{sp}) \leq 1000^{\circ} \mathrm{C}$ constraint, $8 \%$ was limited by $\left[\mathrm{Cr}_{2} \mathrm{O}_{3}\right] \leq 1.0 \%$ criteria (cr), $6 \%$ was limited by the $\mathrm{T}_{\mathrm{L}}(\mathrm{zr}) \leq 1000^{\circ} \mathrm{C}$ constraint, with the remaining $11 \%$ limited by a range of other constraints.

The key sources of uncertainty in the glass volumes for the reference case are related to the amount of chromium in the waste and the allowable amount in the glass. The combination of uncertainties in the waste inventory, the partitioning of chromium to the HLW fraction (leach factors), and solubility in glass in the absence of sufficient nickel and iron to be in the spinel primary phase fields can change the glass volume estimates by several tens or even hundreds of percents. This impact on glass volume suggests that further testing is required to

1. more accurately estimate chromium inventories in the tanks

2. reduce the uncertainty on chromium leach factors

3. improve the understanding of chromium solubility in glass or composition effects on $T_{L}$ in the eskolaite primary phase field.

In addition, this result suggests that a melter technology that can tolerate crystalline phases (e.g., insoluble chromium in the form of eskolaite and spinel) would allow not only increased waste loading in glass, but also would reduce the sensitivity of glass volume projections to these uncertainties.

\subsubsection{Influence of Constraint Changes on Glass Volumes}

This section addresses the effects of varying the property constraints on the waste loading and glass volume compared to the reference case discussed in Section 4.6.3. Table 4.8 shows how these constraints were varied in a total of 21 cases with the summary of corresponding results on the estimated waste loadings and glass volumes. The total glass volume for each case is the sum of glass volumes calculated for each cluster, by dividing glass mass by estimated density values. More detailed results of these calculations on each cluster for each case are given in Appendix D.

Table 4.8 also summarizes primary constraints that limit waste loadings, showing how many clusters are limited by each constraint. When multiple constraints were met, the following order of priority as primary constraint was used: single component constraints and noble metals, liquidus temperatures, PCT releases, viscosity and electrical conductivity, nepheline formation, and model validity. The $\left[\mathrm{Fe}_{2} \mathrm{O}_{3}\right] \leq 20$ mass $\%$ and $[\mathrm{MnO}] \leq 4$ mass $\%$ constraints are included as part of model-validity constraints, but actually serves as a single component constraint because $\mathrm{Fe}_{2} \mathrm{O}_{3}$ and $\mathrm{MnO}$ are not additive components. The $\mathrm{SO}_{3}$ and immiscibility (expressed by normalized alkali content) constraints were never met in any clusters from any cases. The model-validity constraint was met only together with other constraints as a secondary. Further, the model-validity constraints were always encountered whenever single-component constraints were not met. 
Table 4.8. Effect of Constraint Changes on Estimated Glass Volume

\begin{tabular}{|c|c|c|c|c|c|c|c|c|c|c|c|}
\hline Case & & 1 & 2 & 3 & 4 & 5 & 6 & 7 & 8 & 9 & 10 \\
\hline $\begin{array}{c}\text { Constraint } \\
\text { (concentrations in } \\
\text { mass\%, } \\
\text { temperatures in } \\
\left.{ }^{\circ} \mathrm{C}\right)\end{array}$ & & Ref. & $\underset{1150}{T_{L}}$ & $\underset{1350}{T_{L}}$ & PCT 6 & $\begin{array}{l}\text { Multi } \\
\text { Phase }\end{array}$ & No $\mathrm{mv}$ & $\begin{array}{l}\text { HTM } \\
\text { Base }\end{array}$ & $\underset{\mathbf{1 3 5 0}}{\mathbf{H T M}}$ & $\underset{\mathbf{1 5 5 0}}{\mathbf{H T M}}$ & $\begin{array}{c}0.5 \\
\mathrm{Cr}_{2} \mathrm{O}_{3}\end{array}$ \\
\hline $\mathrm{T}_{\mathrm{M}}\left({ }^{\circ} \mathrm{C}\right)$ & & 1150 & & & & & & 1350 & 1350 & 1350 & \\
\hline $\mathrm{Cr}_{2} \mathrm{O}_{3}$ & $\mathrm{cr}$ & $<<$ & & & & & & & & & $<0.5$ \\
\hline $\mathrm{P}_{2} \mathrm{O}_{5}$ & $\mathrm{p}$ & $<2.5$ & & & & $<8$ & & & & & \\
\hline $\mathrm{F}$ & $\mathrm{f}$ & $<2$ & & & & $<4$ & & & & & \\
\hline $\mathrm{SO}_{3}$ & - & $<0.8$ & & & & & & & & & \\
\hline $\mathrm{RuO}_{2}+\mathrm{Rh}_{2} \mathrm{O}_{3}$ & $\mathrm{~nm}$ & $<0.1$ & & & & & & & & & \\
\hline $\mathrm{Fe}_{2} \mathrm{O}_{3}$ & $\mathrm{fe}$ & $<20$ & & & & & none & & & & \\
\hline $\mathrm{MnO}$ & $\mathrm{mn}$ & $<4$ & & & & & none & & & & \\
\hline $\mathrm{B}_{2} \mathrm{O}_{3}$ & & $5-15$ & & & & & none & & & & \\
\hline $\mathrm{Li}_{2} \mathrm{O}$ & & $<4$ & & & & & none & & & & \\
\hline $\mathrm{Na}_{2} \mathrm{O}$ & $\mathrm{mv}$ & $<20$ & & & & & none & & & & \\
\hline $\mathrm{SiO}_{2}$ & & $>35$ & & & & & none & & & & \\
\hline $\mathrm{Na}_{2} \mathrm{O}+\mathrm{Li}_{2} \mathrm{O}+\mathrm{K}_{2} \mathrm{O}$ & & $<22$ & & & & & none & & & & \\
\hline Norm. Si (np) & $\mathrm{np}$ & $>0.62$ & & & & None & & & & & \\
\hline Norm. Alk (imm) & - & $>0.12$ & & & & None & & & & & \\
\hline PCT B $\left(\mathrm{g} / \mathrm{m}^{2}\right)$ & & $<2$ & & & $<6$ & & & & & & \\
\hline PCT Li $\left(\mathrm{g} / \mathrm{m}^{2}\right)$ & pet & $<2$ & & & $<6$ & & & & & & \\
\hline PCT Na $\left(\mathrm{g} / \mathrm{m}^{2}\right)$ & & $<2$ & & & $<6$ & & & & & & \\
\hline $\mathrm{n}\left(\mathrm{T}_{\mathrm{M}}\right)(\mathrm{Pa} \cdot \mathrm{s})$ & $\mathrm{V}$ & $2-10$ & & & & & & & & & \\
\hline$\varepsilon\left(\mathrm{T}_{\mathrm{M}}\right)(\mathrm{S} / \mathrm{m})$ & $\mathrm{e}$ & $10-100$ & & & & & & & & & \\
\hline spinel $\mathrm{T}_{\mathrm{I}}\left({ }^{\circ} \mathrm{C}\right)$ & $\mathrm{sp}$ & $<1000$ & $<1150$ & $<1350$ & & & & $<1200$ & $<1350$ & $<1550$ & \\
\hline zircon $\mathrm{T}_{\mathrm{I}}\left({ }^{\circ} \mathrm{C}\right)$ & $\mathrm{zr}$ & $<1000$ & $<1150$ & $<1350$ & & & & $<1200$ & $<1350$ & $<1550$ & \\
\hline Waste Loading & & $46.4 \%$ & $51.0 \%$ & $52.8 \%$ & $46.5 \%$ & $49.3 \%$ & $47.8 \%$ & $49.9 \%$ & $52.7 \%$ & $53.6 \%$ & $38.1 \%$ \\
\hline Glass Mass (Mg) & & 26,539 & 24,166 & 23,317 & 26,476 & 24,961 & 25,779 & 24,682 & 23,350 & 22,963 & 32,335 \\
\hline Glass Volume $\left(\mathrm{m}^{3}\right)$ & & 9.720 & 8,808 & 8,462 & 9,700 & 9,029 & 9.295 & 9,089 & 8,532 & 8,370 & 12,110 \\
\hline Number of & & 8,452 & 7,660 & 7,358 & 8,435 & 7,851 & 8,083 & 7,904 & 7,419 & 7,278 & 10,531 \\
\hline Number of clusters & $\mathrm{cr}$ & 2 & 2 & 2 & 2 & 3 & 2 & 2 & 2 & 3 & 6 \\
\hline limited by & $\mathrm{sp}$ & 7 & 4 & 1 & 7 & 7 & 9 & 5 & 3 & & 4 \\
\hline each primary & $\mathrm{zr}$ & 3 & 2 & 2 & 3 & 3 & 2 & 3 & 2 & 1 & 3 \\
\hline constraint & $\mathrm{fe}$ & 1 & 2 & 2 & 1 & 1 & & 2 & 2 & 2 & 1 \\
\hline & $\mathrm{mn}$ & 3 & 3 & 3 & 3 & 3 & & 3 & 3 & 4 & 3 \\
\hline & $\mathrm{p}$ & 1 & 2 & 2 & 1 & & 1 & 2 & 2 & 2 & \\
\hline & $\mathrm{f}$ & & 1 & 1 & & & & & 1 & 1 & \\
\hline & $\mathrm{nm}$ & & 1 & 1 & & & 1 & & 1 & 1 & \\
\hline & pct & & & & & & 1 & & & & \\
\hline & \begin{tabular}{|c|}
$\mathrm{v}$ \\
\end{tabular} & & & 2 & & & & & & 2 & \\
\hline & $\mathrm{e}$ & & & & & & 1 & & & & \\
\hline & $\mathrm{np}$ & & & 1 & & & & & 1 & 1 & \\
\hline
\end{tabular}


Table 4.8. Effect of Constraint Changes on Estimated Glass Volume (cont'd)

\begin{tabular}{|c|c|c|c|c|c|c|c|c|c|c|c|c|}
\hline & & 11 & 12 & 13 & 14 & 15 & 16 & 17 & 18 & 19 & 20 & 21 \\
\hline $\begin{array}{c}\text { Constraint } \\
\text { (concentration in } \\
\text { mass\%, } \\
\text { temperatures in } \\
\left.{ }^{\circ} \mathrm{C}\right) \\
\end{array}$ & & $\begin{array}{c}1.5 \\
\mathrm{Cr}_{2} \mathrm{O}_{3}\end{array}$ & $\begin{array}{c}1.5 \\
\mathrm{Cr}_{2} \mathrm{O}_{3} \\
\mathbf{T}_{\mathrm{L}} \\
\mathbf{1 1 5 0}\end{array}$ & \begin{tabular}{|c|}
$\mathbf{H T M}$ \\
1.5 \\
$\mathrm{Cr}_{2} \mathrm{O}_{3}$ \\
$\mathrm{~T}_{\mathrm{L}}$ \\
$\mathbf{1 3 5 0}$ \\
\end{tabular} & $\begin{array}{c}\mathrm{HTM} \\
0.5 \\
\mathrm{Cr}_{2} \mathrm{O}_{3}\end{array}$ & $\begin{array}{c}\text { Multi } \\
\text { Phase } \\
\text { \& } \\
\text { PCT 6 }\end{array}$ & $\begin{array}{c}T_{L} \\
1150 \\
\text { No mv }\end{array}$ & $\begin{array}{c}T_{L} \\
1350 \\
\text { No } \mathbf{~ m v}\end{array}$ & \begin{tabular}{|c|}
$\mathbf{H T M}$ \\
1.5 \\
$\mathrm{Cr}_{2} \mathrm{O}_{3}$ \\
$\mathrm{~T}_{\mathrm{L}}$ \\
$\mathbf{1 5 5 0}$ \\
\end{tabular} & $\begin{array}{l}\text { HTM } \\
1.5 \mathrm{cr}\end{array}$ & $\begin{array}{l}\text { HTM } \\
\text { v,e } \\
\text { expan } \\
\text { d }\end{array}$ & $\begin{array}{l}\text { HTM } \\
\text { No mv }\end{array}$ \\
\hline $\mathrm{T}_{\mathrm{M}}\left({ }^{\circ} \mathrm{C}\right)$ & & & & 1350 & 1350 & & & & 1350 & 1350 & 1350 & 1350 \\
\hline $\mathrm{r}_{2} \mathrm{O}_{3}$ & $\mathrm{cr}$ & $<1.5$ & $<1.5$ & $<1.5$ & $<0.5$ & & & & $<1.5$ & $<1.5$ & & \\
\hline$\overline{{ }_{2} \mathrm{O}_{5}}$ & $\mathrm{p}$ & & & & & $<8$ & & & & & & \\
\hline $\mathrm{F}$ & $\mathrm{f}$ & & & & & $<4$ & & & & & & \\
\hline $\mathrm{SO}_{3}$ & - & & & & & & & & & & & \\
\hline $\mathrm{RuO}_{2}+\mathrm{Rh}_{2} \mathrm{O}_{3}$ & $\mathrm{~nm}$ & & & & & & & & & & & \\
\hline $\mathrm{Fe}_{2} \mathrm{O}_{3}$ & $\mathrm{fe}$ & & & & & & none & none & & & & none \\
\hline $\mathrm{MnO}$ & $\mathrm{mn}$ & & & & & & none & none & & & & none \\
\hline $\mathrm{B}_{2} \mathrm{O}_{3}$ & & & & & & & none & none & & & & none \\
\hline $\mathrm{Li}_{2} \mathrm{O}$ & & & & & & & none & none & & & & none \\
\hline $\mathrm{Na}_{2} \mathrm{O}$ & $\mathrm{mv}$ & & & & & & none & none & & & & none \\
\hline $\mathrm{SiO}_{2}$ & & & & & & & none & none & & & & none \\
\hline $\mathrm{Na}_{2} \mathrm{O}+\mathrm{Li}_{2} \mathrm{O}+\mathrm{K}_{2} \mathrm{O}$ & & & & & & & none & none & & & & none \\
\hline Norm. Si (np) & $\mathrm{np}$ & & & & & None & & & & & & \\
\hline Norm. Alk (imm) & - & & & & & None & & & & & & \\
\hline PCT B $\left(\mathrm{g} / \mathrm{m}^{2}\right)$ & & & & & & $<6$ & & & & & & \\
\hline PCT Li $\left(\mathrm{g} / \mathrm{m}^{2}\right)$ & pet & & & & & $<6$ & & & & & & \\
\hline PCT Na $\left(\mathrm{g} / \mathrm{m}^{2}\right)$ & & & & & & $<6$ & & & & & & \\
\hline $\mathrm{n}\left(\mathrm{T}_{\mathrm{M}}\right)(\mathrm{Pa} \cdot \mathrm{s})$ & $\mathrm{V}$ & & & & & & & & & & $0.1-10$ & \\
\hline$\varepsilon\left(\mathrm{T}_{M}\right)(\mathrm{S} / \mathrm{m})$ & $\mathrm{e}$ & & & & & & & & & & $10-150$ & \\
\hline spinel $\mathrm{T}_{\mathrm{I}}\left({ }^{\circ} \mathrm{C}\right)$ & $\mathrm{sp}$ & & $<1150$ & $<1350$ & $<1200$ & & $<1150$ & $<1350$ & $<1550$ & $<1200$ & $<1200$ & $<1200$ \\
\hline zircon $\mathrm{T}_{\mathrm{I}}\left({ }^{\circ} \mathrm{C}\right)$ & $\mathrm{zr}$ & & $<1150$ & $<1350$ & $<1200$ & & $<1150$ & $<1350$ & $<1550$ & $<1200$ & $<1200$ & $<1200$ \\
\hline Waste Loading & & $46.9 \%$ & $52.0 \%$ & $54.1 \%$ & $39.0 \%$ & $49.6 \%$ & $52.5 \%$ & $55.9 \%$ & $55.4 \%$ & $50.9 \%$ & $51.8 \%$ & $51.6 \%$ \\
\hline Glass Mass (Mg) & & 26,265 & 23,679 & 22,757 & 31,546 & 24,834 & 23,465 & 22,039 & 22,243 & 24,200 & 23,776 & 23,870 \\
\hline Glass Volume & & 9,600 & 8,592 & 8,331 & 11,854 & 8,975 & 8,383 & 7,833 & 8,130 & 8,875 & 8,647 & 8,697 \\
\hline Number of & & 8,348 & 7,471 & 7,244 & 10,308 & 7,805 & 7,289 & 6,812 & 7,069 & 7,717 & 7,519 & 7,562 \\
\hline Number of & $\mathrm{cr}$ & & 1 & 1 & 6 & 3 & 2 & 3 & 1 & 1 & 2 & 2 \\
\hline limited by & $\mathrm{sp}$ & 9 & 5 & 4 & 2 & 7 & 7 & 4 & & & 4 & 7 \\
\hline each primary & $\mathrm{zr}$ & 3 & 2 & 2 & 3 & 3 & 2 & 1 & 1 & 1 & 2 & 3 \\
\hline \multirow[t]{9}{*}{ constraint } & $\mathrm{fe}$ & 1 & 2 & 2 & 2 & 1 & & & 2 & 2 & 2 & \\
\hline & $\mathrm{mn}$ & 3 & 3 & 3 & 3 & 3 & & & 4 & 4 & 3 & \\
\hline & $p$ & 1 & 2 & 2 & 1 & & 2 & 2 & 2 & 2 & 2 & 2 \\
\hline & $\mathrm{f}$ & & 1 & 1 & & & 1 & 1 & 1 & 1 & 1 & \\
\hline & $\mathrm{nm}$ & & 1 & 1 & & & 1 & 2 & 1 & 1 & 1 & 1 \\
\hline & pct & & & & & & 1 & 1 & & & & 1 \\
\hline & $\mathrm{V}$ & & & & & & & 2 & 3 & 4 & & 1 \\
\hline & $\mathrm{e}$ & & & & & & 1 & 1 & & & & \\
\hline & $\mathrm{np}$ & & & 1 & & & & & 2 & 1 & & \\
\hline
\end{tabular}


The present analyses are based on calculations using 17 clusters instead of 89 full batches. As discussed previously, the waste cluster compositions are mass averages of those waste feeds within each cluster (equivalent to blending of wastes within each cluster). This composition averaging is expected to reduce glass volume estimates over those truly expected. To determine the impacts of this composition averaging on glass volume estimates, the same calculations based on 89 batches were performed using HTWOS tools for selected cases. The results are compared with those based on 17 clusters in Table 4.9 and plotted in Figure 4.1. Calculations based on 17 clusters resulted in roughly 0.9 mass $\%$ higher waste loading estimates or roughly $2.5 \%$ lower glass volume. These differences should be accounted for (e.g., increasing glass volume estimates from cluster analyses by $2.5 \%$ ) in accurate estimates of glass volumes along with estimates of process inefficiencies and waste composition variation impacts. However, these adjustments were not made in this study because relative glass volumes are sufficient to determine the impacts of property constraints and insufficient data are available to estimate the impacts of process inefficiencies and waste composition variation impacts.

Compared to the reference case (Case 1), increasing the melting temperature from 1150 to $1350^{\circ} \mathrm{C}$ decreases the volume of glass by $631 \mathrm{~m}^{3}$ or $6.5 \%$. Here it should be noted that a possible increase of $\mathrm{Cr}_{2} \mathrm{O}_{3}$ solubility by increasing melting temperature is not included. If the $\mathrm{T}_{\mathrm{L}}$ constraints are relieved to allow the crystals (spinel and/or zircon) to be present in the melter, the volume of glass decreases considerably: $1258 \mathrm{~m}^{3}$ or $12.9 \%$ decrease for $\mathrm{T}_{\mathrm{M}}=1150^{\circ} \mathrm{C}$ and $\mathrm{T}_{\mathrm{L}}=1350^{\circ} \mathrm{C}$ (Case 3 compared to Case 1) and $719 \mathrm{~m}^{3}$ or $7.9 \%$ decrease for $\mathrm{T}_{\mathrm{M}}=1350^{\circ} \mathrm{C}$ and $\mathrm{T}_{\mathrm{L}}=1550^{\circ} \mathrm{C}$ (Case 9 compared to Case 7 ). Case 3 and Case 9 both are represented by the constraint, $\mathrm{T}_{\mathrm{L}}<\left(\mathrm{T}_{\mathrm{M}}+200^{\circ} \mathrm{C}\right)$ or $350^{\circ} \mathrm{C}$ increase from the reference constraint, $\mathrm{T}_{\mathrm{L}}<\left(\mathrm{T}_{\mathrm{M}}-150^{\circ} \mathrm{C}\right)$. The number of clusters in which waste loading is limited by the $T_{L}$ constraints also decreases when $T_{L}$ constraint is relieved by $350^{\circ} \mathrm{C}$; from 10 to 3 clusters for $T_{M}=$ $1150^{\circ} \mathrm{C}$ and from 8 clusters to 1 cluster for $T_{M}=1350^{\circ} \mathrm{C}$. Therefore, relieving the $T_{L}$ constraint further has only minor effect on total glass volume.

The allowance of the $T_{L}$ constraint to be increased is in effect allowing crystals in the melter. These crystals will primarily be spinel, which has been shown to have little effect on PCT release of the final waste form (Jantzen et al. 1984, Kim et al. 1995, and Riley et al. 2001). However, the allowance of crystals in the reference case melter may be detrimental to melter operation if sufficiently large or in large fraction (Schill et al. ${ }^{5}$ and Matyáš et al. ${ }^{6}$ ). The technical issues associated with advanced melter technologies are discussed later in this report.

\footnotetext{
${ }^{5}$ Schill, P, M Trochta, J Matyáš, L. Nemec, and PR Hrma. 2001. Mathematical Model of Spinel Settling in a Real Waste Glass Melter. To be published in Waste Management ' 01 .

${ }^{6}$ Matyáš, J, J Kloužek, L Němec, and M Trochta. 2001. Spinel Settling in HLW Melters. To be published in the $8^{\text {th }}$ International Conference Proceedings (ICEM’01), September 30 - October 4, 2001, Bruges, Belgium.
} 
Table 4.9. Comparison of Estimated Waste Loadings and Glass Volumes Between Calculations with 17 Clusters and 89 Batches

\begin{tabular}{|c|c|c|c|c|c|c|c|c|}
\hline \multirow[b]{2}{*}{ Case Number } & \multicolumn{4}{|c|}{ Calculated with 17 Clusters } & \multicolumn{4}{|c|}{ Calculated with 89 Batches } \\
\hline & 1 & 7 & 13 & 15 & 1 & 7 & 13 & 15 \\
\hline Total Mass of Glass (Mg) & 26539 & 24682 & 22757 & 24834 & 27100 & 25306 & 23261 & 24916 \\
\hline $\begin{array}{l}\text { Mass Average Waste Loading } \\
(\mathrm{mass} \%)\end{array}$ & 46.4 & 49.9 & 54.1 & 49.6 & 45.4 & 48.7 & 52.7 & 49.6 \\
\hline Mass Average Density $\left(\mathrm{g} / \mathrm{cm}^{3}\right)$ & 2.73 & 2.72 & 2.73 & 2.77 & 2.72 & 2.70 & 2.72 & 2.76 \\
\hline Total Glass Volume $\left(\mathrm{m}^{3}\right)$ & 9720 & 9098 & 8331 & 8975 & 9966 & 9357 & 8544 & 9019 \\
\hline No. of Canisters at $1.15 \mathrm{~m}^{3} /$ can. & 8452 & 7904 & 7244 & 7805 & 8666 & 8137 & 7429 & 7843 \\
\hline
\end{tabular}

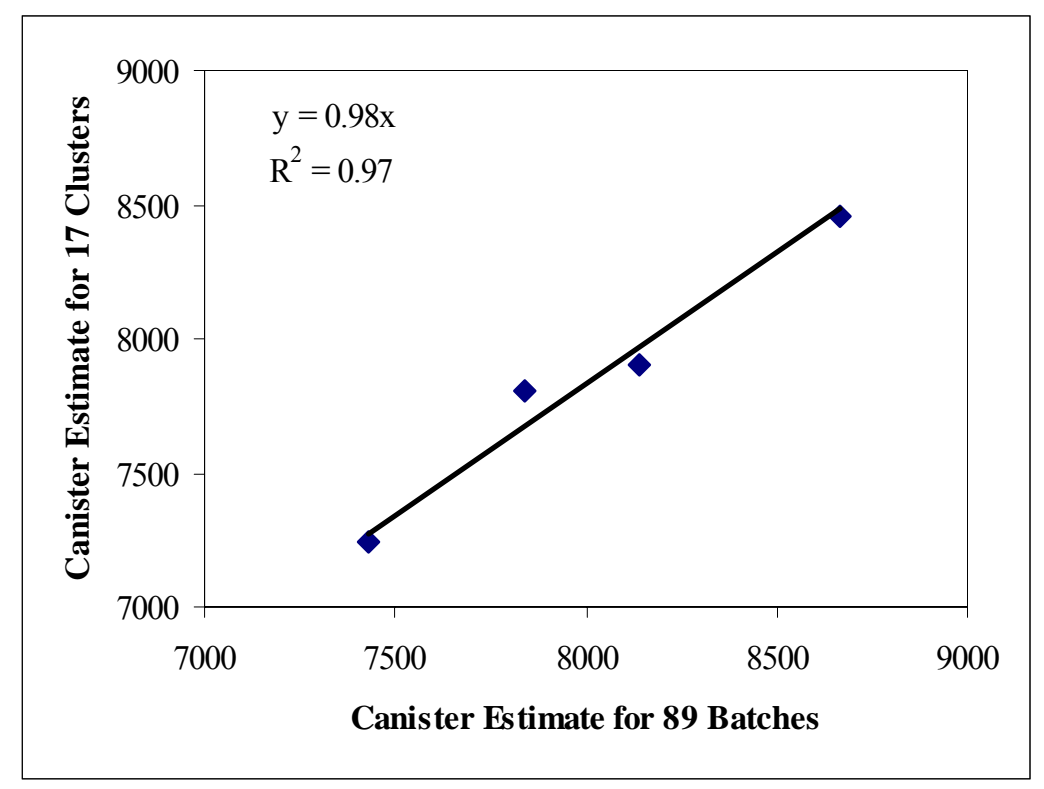

Figure 4.1. Comparison of Estimated Number of Canisters
From 89 Waste Batches and 17 Waste Clusters

The volume of glass decreases significantly when the limit of the $\mathrm{Cr}_{2} \mathrm{O}_{3}$ concentration is varied from 0.5 to $1.0 \mathrm{mass} \%$ : $2390 \mathrm{~m}^{3}$ or $19.7 \%$ decrease for $\mathrm{T}_{\mathrm{M}}=1150^{\circ} \mathrm{C}$ (Case $10 \mathrm{vs}$. Case 1 ) and $2765 \mathrm{~m}^{3}$ or $23.3 \%$ decrease for $\mathrm{T}_{\mathrm{M}}=1350^{\circ} \mathrm{C}$ (Case 14 vs. Case 7). However, further change of the $\mathrm{Cr}_{2} \mathrm{O}_{3}$ concentration limit from 1.0 to 1.5 mass $\%$ has smaller effect on estimated glass volume: $120 \mathrm{~m}^{3}$ or $1.2 \%$ decrease of glass volume for $\mathrm{T}_{\mathrm{M}}=1150^{\circ} \mathrm{C}$ (Case 11$)$ and $214 \mathrm{~m}^{3}$ or $2.4 \%$ decrease for $\mathrm{T}_{\mathrm{M}}=1350^{\circ} \mathrm{C}$ (Case 19). The number of clusters of which loading is limited by the $\mathrm{Cr}_{2} \mathrm{O}_{3}$ constraint decreases from 6 to 2 clusters when the $\mathrm{Cr}_{2} \mathrm{O}_{3}$ limit is varied from 0.5 to 1.0 mass $\%$ and becomes zero at 1.5 mass $\%$. Case 18 shows that increasing the $\mathrm{T}_{\mathrm{M}}$ to $1350^{\circ} \mathrm{C}$ along with relieving the $\mathrm{T}_{\mathrm{L}}$ constraint by $350^{\circ} \mathrm{C}$ and increasing the $\mathrm{Cr}_{2} \mathrm{O}_{3}$ constraint to 1.5 mass $\%$ results in a decrease of glass volume by $1383 \mathrm{~m}^{3}$ or $16.4 \%$.

The solubility of $\mathrm{Cr}_{2} \mathrm{O}_{3}$ depends on melt composition and temperature. When the $\mathrm{Cr}_{2} \mathrm{O}_{3}$ solubility limit is exceeded, the chromium will likely precipitate as either spinel or eskolaite. It is expected that current $\mathrm{T}_{\mathrm{L}}$ models can adequately estimate the solubility of $\mathrm{Cr}_{2} \mathrm{O}_{3}$ in melts within the spinel primary phase field. In 
Case 1, the average $\mathrm{Cr}_{2} \mathrm{O}_{3}$ concentration is roughly $0.5 \%$ for glasses in the spinel primary phase field. However, for melts in the eskolaite primary phase field, there are insufficient data to estimate either composition or temperature effects on $\mathrm{Cr}_{2} \mathrm{O}_{3}$ solubility. It is assumed based on limited data that the solubility of $\mathrm{Cr}_{2} \mathrm{O}_{3}$ in eskolaite primary phase field will range from 0.5 and 1.5 mass $\%$ at temperatures between 1000 and $1150^{\circ} \mathrm{C}$. That fraction of $\mathrm{Cr}_{2} \mathrm{O}_{3}$ above the solubility limit will form eskolaite, which may hinder operation of the reference melter design. Further study is required to more accurately assess the temperature and composition impacts on $\mathrm{Cr}_{2} \mathrm{O}_{3}$ solubility. However, based on currently available data, the Study Team's best assessment of the mean $\mathrm{Cr}_{2} \mathrm{O}_{3}$ solubility in glasses in the eskolaite primary phase field is roughly 1.0 mass $\%$.

The constraints on the PCT releases have little impact on the glass volume: the decrease of volume achieved by changing the constraint from 2 to $6 \mathrm{~g} / \mathrm{m}^{2}$ is negligibly small $\left(20 \mathrm{~m}^{3}\right.$ or $0.2 \%$, Case 4$)$. A moderate decrease of glass volume is achieved by relieving the constraints on multiphase formations (691 $\mathrm{m}^{3}$ or $7.1 \%$, Case 5). Case 15 shows the effects of relieving the constraints on the multiphase formation and PCT releases at the same time, which results in the decrease of glass volume by $745 \mathrm{~m}^{3}$ or $7.7 \%$. This decrease of glass volume is only slightly larger than the effect of relieving the constraint on the multiphase formation alone (7.1\%), which also shows that the PCT constraint has very small effect. However, current models are not able to predict the impact of multi-phase formation on the glass durability. The PCT releases from glasses in which nepheline and immiscible glass phases form may be significantly higher than those predicted with current models. Further study is required to more accurately estimate the impacts of allowing multiple phase formation on glass volume while maintaining adequate waste form durability. This research would be required before the plant would operate with melt compositions that have a reasonable chance of forming immiscible liquid phases or precipitate nepheline or other phases that strongly influence PCT releases. Hrma et al. (2001) summarizes the current understanding of the influence of crystalline phase formation on PCT releases.

Moderate decrease of glass volume is achieved by relieving the constraints on model-validity composition ranges $\left(461 \mathrm{~m}^{3}\right.$ or $4.7 \%$ for $\mathrm{T}_{\mathrm{M}}=1150^{\circ} \mathrm{C}-$ - Case 6 compared to Case $1 ; 392 \mathrm{~m}^{3}$ or $4.3 \%$ for $\mathrm{T}_{\mathrm{M}}=1350^{\circ} \mathrm{C}$ -- Case 21 compared to Case 7). The model validity constraints are not the actual limitations imposed by any processing or product performance requirements. Therefore, expanding the model validity range through testing of more glasses has the potential to decrease glass volume. Relieving the $\mathrm{T}_{\mathrm{L}}$ constraint by $150^{\circ} \mathrm{C}$ and $350^{\circ} \mathrm{C}$ together with removing the model validity constraint result in the decrease of glass volume by $1163 \mathrm{~m}^{3}$ or $13.8 \%$ (Case 16) and $1640 \mathrm{~m}^{3}$ or $19.4 \%$ (Case 17), which is the greatest decrease observed in the current study. However, the prediction of glass properties and therefore the estimation of glass volumes for compositions outside the ranges of model validity is subject to high uncertainties. Further testing would be required to better estimate glass volume if compositions are allowed to deviate significantly from current model validity ranges.

Relieving the constraints on the viscosity and electrical conductivity at $\mathrm{T}_{\mathrm{M}}$ resulted in a moderate decrease of glass volume, by $442 \mathrm{~m}^{3}$ or $4.9 \%$ (Case 20 compared to Case 7).

Figures 4.2 through 4.5 show the effect of certain constraint change (x-axis) for given constraint conditions (legend) on the number of canisters (y-axis) at $1.15 \mathrm{~m}^{3} /$ canister. Figure 3.2 shows the great effect of changing the $\mathrm{Cr}_{2} \mathrm{O}_{3}$ limit from 0.5 to $1.0 \mathrm{mass} \%$ for both baseline and high-temperature melter and small impact of changing the $\mathrm{Cr}_{2} \mathrm{O}_{3}$ limit from 1.0 to 1.5 mass\%. The effect of changing the $\mathrm{T}_{\mathrm{L}}$ constraint for both $1150^{\circ} \mathrm{C}$ and $1350^{\circ} \mathrm{C} \mathrm{T}_{\mathrm{M}}$ melters is shown in Figure 4.3. It can be seen that the advantage of high-temperature melter observed at the reference $T_{L}$ constraint $\left(T_{M}-T_{L}<150^{\circ} C\right)$ fades as the $T_{L}$ constraint is relieved allowing crystals in the melter. Figure 4.4 shows the effect of changing the $\mathrm{T}_{\mathrm{L}}$ constraint for $1150^{\circ} \mathrm{C}$ melter at the conditions with and without model validity constraint. The effect of removing model validity constraint becomes greater as the $T_{L}$ constraint is relieved. The moderate 
effect of removing the constraint on the multiphase formation is shown in Figure 4.5, which also clearly shows the very small effect of PCT constraint.

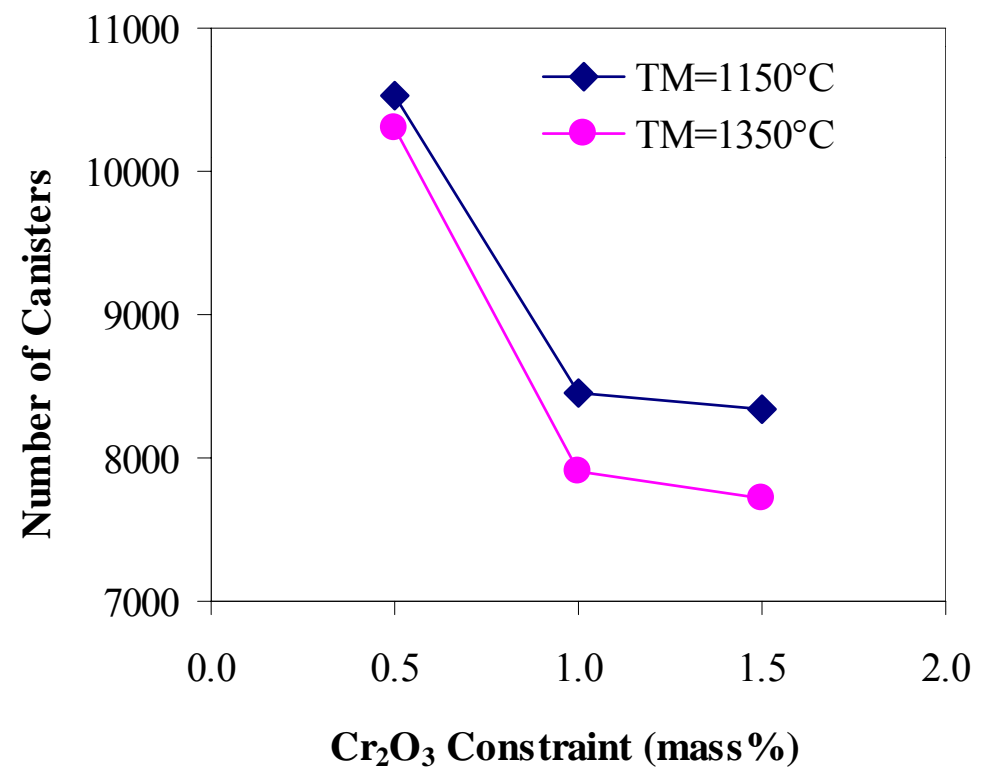

Figure 4.2. Effect of $\mathrm{Cr}_{2} \mathrm{O}_{3}$ Constraint on the Estimated Number of Canisters in Different $\mathbf{T}_{M}$ Melters

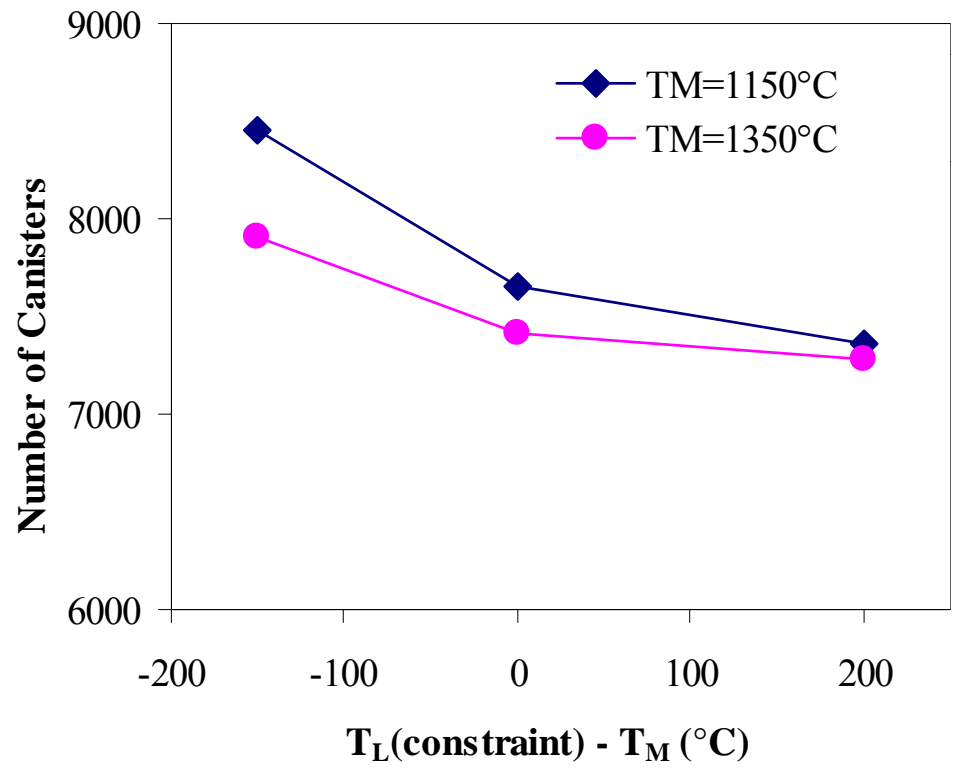

Figure 4.3. Effect of $T_{L}$ Constraint on the Estimated Number of Canisters in Different $\mathbf{T}_{M}$ Melters 


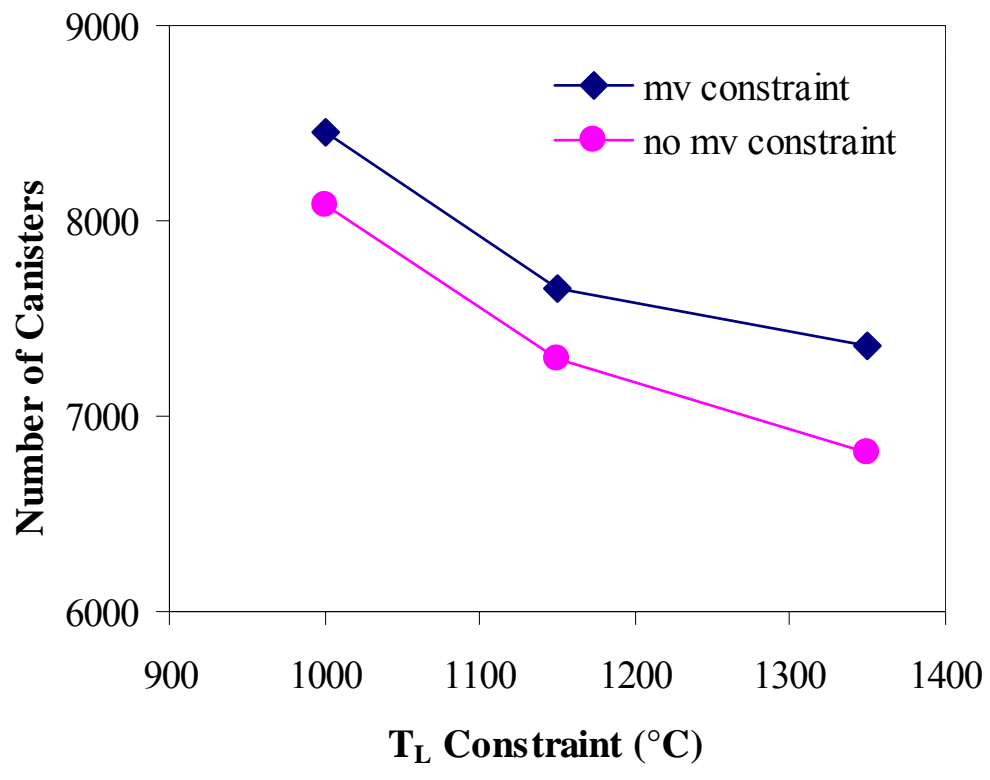

Figure 4.4. Effect of $T_{L}$ Constraint on the Estimated Number of Canisters With and Without Model Validity Constraints

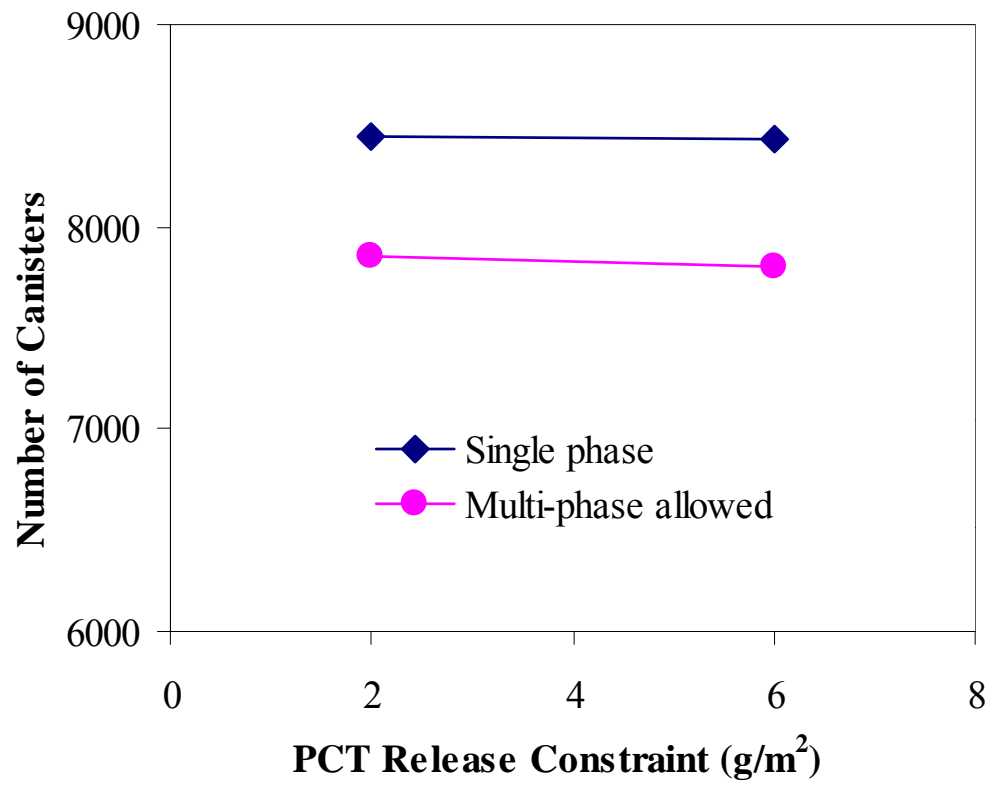

Figure 4.5. Effect of PCT Release Constraint on the Estimated Number of Canisters With and Without Restrictions on Multiple Phase Formation

Figure 4.6 shows the range of glass volume in each cluster resulting from different constraints set in this study. For every cluster, Case 10 gives the maximum volume, which is the same as given by the reference case for those clusters that are not affected by the $\mathrm{Cr}_{2} \mathrm{O}_{3}$ constraint. The minimum volume is 
achieved from Case 17 for most of clusters. The exceptions are Clusters 2, 7, and 17, of which the primary constraint is either $\mathrm{P}_{2} \mathrm{O}_{5}$ or $\mathrm{Cr}_{2} \mathrm{O}_{3}$ solubility. In these clusters, minimum volume is obtained when the $\mathrm{P}_{2} \mathrm{O}_{5}$ or $\mathrm{Cr}_{2} \mathrm{O}_{3}$ constraints are relieved. It can be seen from Figure 4.6 that the glass volume from some waste clusters (like 9 to 17) are insensitive to the variation of the glass property constraints. Figure 4.6 in general gives us information on which are the major clusters that contribute to the total glass volume most and so should be the focus on studies aimed at decreasing glass volume.

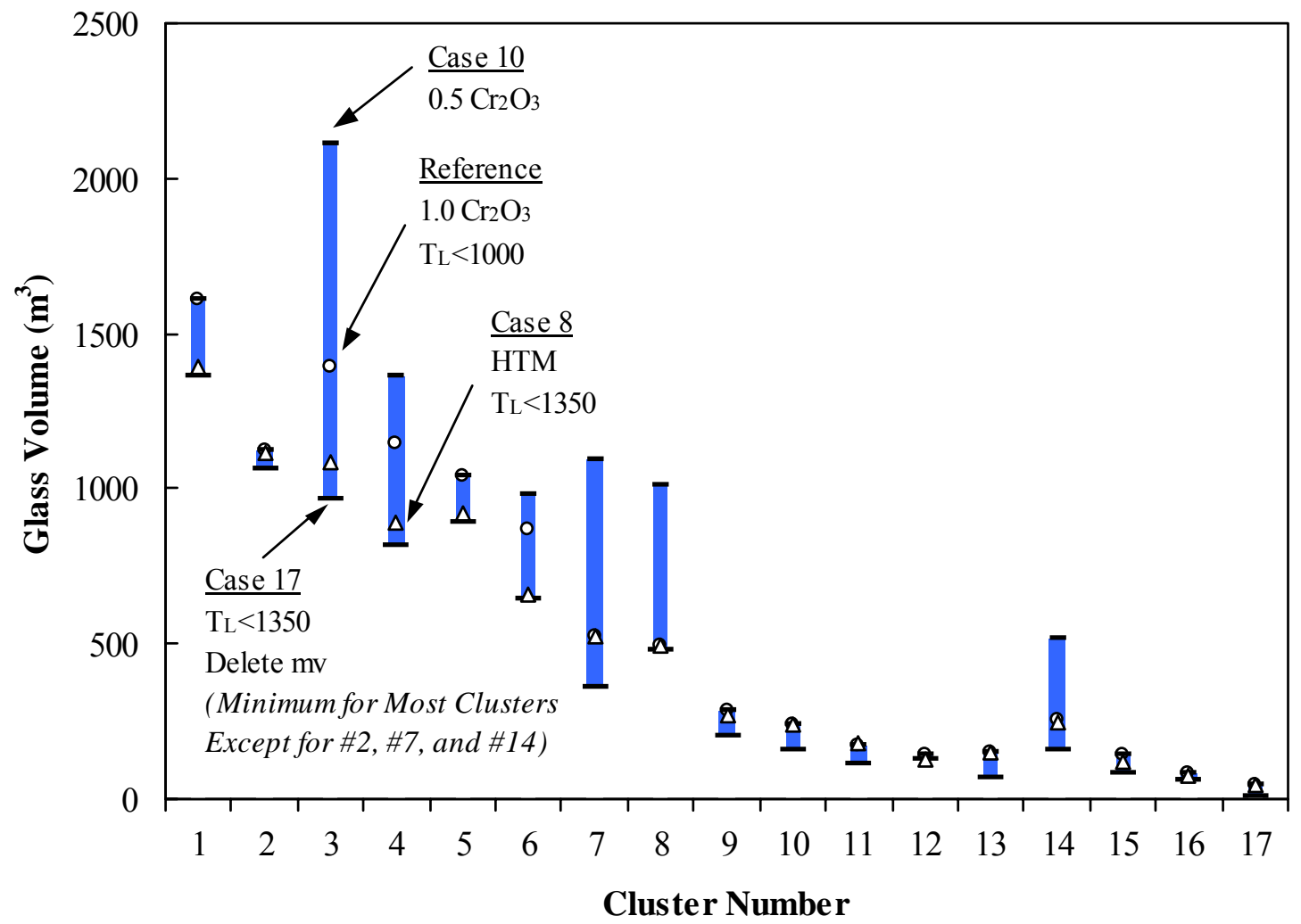

Figure 4.6. Range of Estimated Glass Volumes For Each Cluster with Selected Cases Highlighted

\subsubsection{Glass Volume Changes from Different Constraint Set Changes}

The constraints for glass properties applied in this study stem from the two basic requirements for waste glasses in general: product acceptability and processability. The model-validity constraint (mv) is an exception. The constraints related to the product acceptability are PCT releases (pct) and multi-phase formations ( $\mathrm{p}, \mathrm{f}, \mathrm{np}$ ), and those related to the processability are $\mathrm{Cr}_{2} \mathrm{O}_{3}$ concentration limit (cr), noble metals concentration limit ( $\mathrm{nm}), \mathrm{T}_{\mathrm{L}} \mathrm{s}(\mathrm{sp}, \mathrm{zr})$, viscosity (v), and electrical conductivity (e).

The most important constraints that have significant impacts on the glass volume such as the $\mathrm{Cr}_{2} \mathrm{O}_{3}$ concentration limit (cr) and liquidus temperature constraints ( $\mathrm{sp}, \mathrm{zr}$ ) are all related to crystal formation in the melter. For example, in the reference case (Case 1), the constraints related to crystallization limited waste loading in 12 clusters out of 17 , which accounts for $89 \%$ in terms of glass volume. Considering that the constraints on the $\mathrm{Fe}_{2} \mathrm{O}_{3}$ and $\mathrm{MnO}$ within model validity constraints are also related to the crystallization of spinel, the numbers are even higher. Table 4.10 summarizes the effect of changing the $\mathrm{Cr}_{2} \mathrm{O}_{3}$ limit and $\mathrm{T}_{\mathrm{L}}$ constraints on the glass volume. 
The group of constraints that have noticeable effects includes the model validity (mv) and multiphase constraints ( $\mathrm{p}, \mathrm{f}, \mathrm{np})$. Other constraints either limited the waste loading only in a small number of clusters and/or had relatively small impacts on the glass volume (pct, nm, v, e), as discussed previously.

Table 4.10. Change of Estimated Glass Volume (in $\mathrm{m}^{3}$ ) as Functions of $\mathrm{T}_{\mathrm{L}}$ and $\mathrm{Cr}_{2} \mathrm{O}_{3}$ Constraints

\begin{tabular}{|c|c|c|c|c|c|c|}
\hline & \multicolumn{2}{|c|}{$T_{L}<\left(T_{M}-150^{\circ} C\right)$} & \multicolumn{2}{|c|}{$\mathbf{T}_{\mathrm{L}}<\mathbf{T}_{\mathrm{M}}$} & \multicolumn{2}{|c|}{ No $T_{L}$ limit } \\
\hline $\mathrm{Cr}_{2} \mathrm{O}_{3}(\operatorname{mass} \%)$ & $\mathrm{T}_{\mathrm{M}}=1150^{\circ} \mathrm{C}$ & $T_{M}=1350^{\circ} \mathrm{C}$ & $T_{M}=1150^{\circ} \mathrm{C}$ & $T_{M}=1350^{\circ} \mathrm{C}$ & $T_{M}=1150^{\circ} \mathrm{C}$ & $T_{M}=1350^{\circ} \mathrm{C}$ \\
\hline$<0.5$ & $\begin{array}{c}12110 \\
(+24.6 \%)\end{array}$ & $\begin{array}{c}11854 \\
(+22.0 \%)\end{array}$ & & & & \\
\hline$<1.0$ & $\begin{array}{c}9720^{(\mathrm{a})} \\
\text { (Reference) }\end{array}$ & $\begin{array}{c}9089 \\
(-6.5 \%)\end{array}$ & $\begin{array}{c}8808 \\
(-9.4 \%)\end{array}$ & $\begin{array}{c}8532 \\
(-12.2 \%)\end{array}$ & $\begin{array}{c}8462 \\
(-12.9 \%)\end{array}$ & $\begin{array}{c}8370 \\
(-13.9 \%)\end{array}$ \\
\hline$<1.5$ & $\begin{array}{c}9600 \\
(-1.2 \%)\end{array}$ & & $\begin{array}{c}8592^{\text {(b) }} \\
(-11.6 \%)\end{array}$ & $\begin{array}{c}8331 \\
(-14.3 \%)\end{array}$ & & $\begin{array}{c}8130 \\
(-16.4 \%)\end{array}$ \\
\hline
\end{tabular}

\subsubsection{Effect of Chromium Leach Factor}

A study of the effect of chromium leach factor on glass volume was performed with the HTWOS tools for a reference property constraint set $\left(1.0\right.$ mass $\left.\% \mathrm{Cr}_{2} \mathrm{O}_{3}\right)$ and for a case with the $\mathrm{Cr}_{2} \mathrm{O}_{3}$ constraint of 0.5 mass $\%$. The resulting estimates of glass canisters are shown in Figure 4.7. The chromium leach factor used in the baseline scenario, which resulted in 89 waste batches, was 0.770 . The chromium leach factor has an enormous impact on estimated glass volume as is evident in Figure 4.7. The impact is much greater if the 0.5 mass $\% \mathrm{Cr}_{2} \mathrm{O}_{3}$ limit is assumed ${ }^{7}$. This result provides strong evidence that development of a high confidence in chromium concentrations in the waste, chromium leach factors, and chromium solubility in glass melts is important for Hanford to reduce uncertainty in glass volume estimates and more importantly to minimize glass volumes.

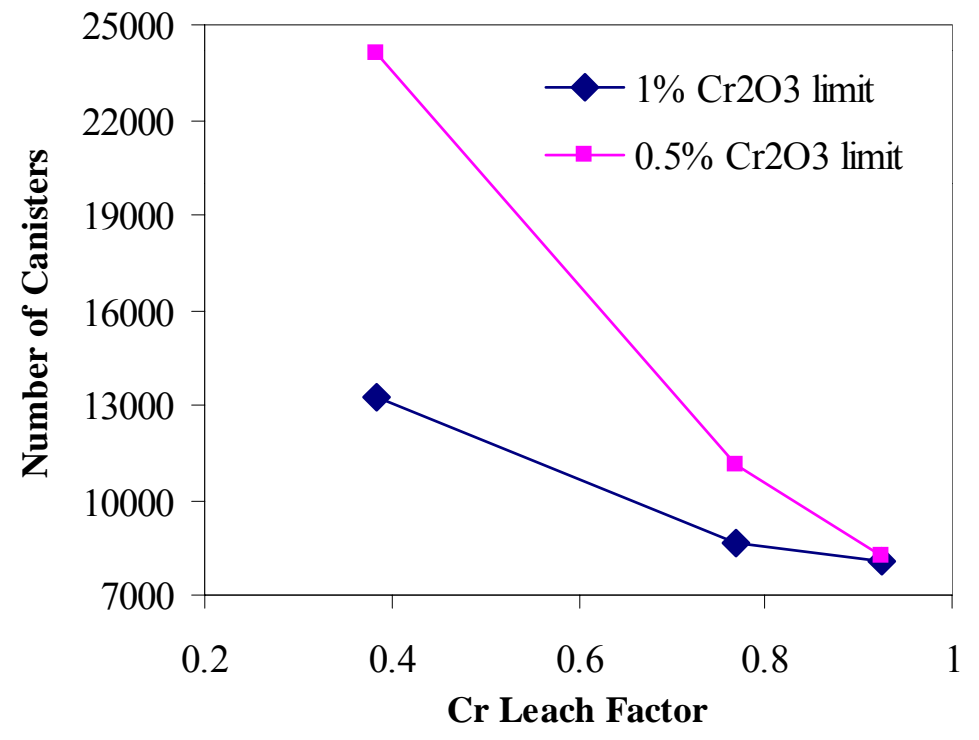

Figure 4.7. Effect of Chromium Leach Factor on the Estimated Number of Canisters at Different $\mathrm{Cr}_{2} \mathrm{O}_{3}$ Constraints

\footnotetext{
${ }^{7}$ Recall that the current ORP baseline assumes a 0.5 mass $\% \mathrm{Cr}_{2} \mathrm{O}_{3}$ limit.
} 


\subsubsection{Effect of Blending}

It was beyond the scope of this study to determine a retrieval sequence and blending scenario optimized for glass volume. However, the Study Team has calculated an all-blend composition (weighted average composition of all 89 waste feeds) in an effort to estimate the optimum. Using the constraint sets for Case 1 and Case 10, the all-blend waste generates 7863 and 8646 canisters, respectively. Completely blending all wastes would reduce the glass volume by $7 \%$ or $18 \%$ for Case 1 and Case 10 , respectively. This blending, although not economically feasible, may represent the best improvement that can occur over the assumed incidental blending that is performed during normal retrieval operations.

\subsection{Alkali-Aluminosilicate and Other Silicate Glasses}

The AABS glasses discussed in Section 3.6 were limited to a minimum of 5 mass $\% \mathrm{~B}_{2} \mathrm{O}_{3}$ except for constraint sets in cases $6,16,17$, and 21 . The limit of $\mathrm{B}_{2} \mathrm{O}_{3}$ concentration was added to ensure model applicability. A literature search turned up several articles on the testing of AAS glasses and AAS-based glass ceramics for immobilization of waste (Vienna et al. 1996a and b; Leturcq et al. 1997; Kipka et al. 1993; Vance et al. 1986; Brown and MacKenzie 1982; Arneson et al. 1986; Darab et al. 1998; Sundaram et al. 1999; Tait and Mandolesa 1983; Kim et al. 1995; Raju 1986; and Schreiber and Balazs 1982). However, there were insufficient data to develop glass property models for precise estimation of waste loadings. The Study Team therefore considered the results from AABS glasses and used the available literature data to estimate the impacts of boron removal.

The frit compositions in the glasses optimized according to cases $6,16,17$, and 21 all contained greater than $1 \% \mathrm{~B}_{2} \mathrm{O}_{3}$ by the normal optimization process, with the exception of those clusters limited by the nepheline rule (and cluster 9 for case 16, cluster 15 for case 6, and cluster 5 for case 21). The nepheline rule is too simplistic to be extrapolated to zero boron. Li et al. (1996) clearly showed that the addition of $\mathrm{B}_{2} \mathrm{O}_{3}$ suppressed the formation of nepheline in simulated HLW glasses. Therefore, extrapolation of the glass property models to glasses with low boron suggest that adding $\mathrm{B}_{2} \mathrm{O}_{3}$ may improve glass properties and waste loading in most glasses. However, it should be noted that model uncertainty is high for low or no boron glasses and that glasses with waste loading limited by single component concentrations (such as $\mathrm{Cr}_{2} \mathrm{O}_{3}$ ), the glass composition is not unique.

Figure 4.8 shows the impact of small additions of $\mathrm{B}_{2} \mathrm{O}_{3}$ on the $\mathrm{T}_{\mathrm{L}}$ of two glasses (SP-1 after Mika et al. 1996 and CVS3-1 after Vienna et al. 1996) in the spinel primary phase field. For the SP-1 glass composition, a small addition of $\mathrm{B}_{2} \mathrm{O}_{3}$ decreases $\mathrm{T}_{\mathrm{L}}$ to a much greater extent than larger additions. Spinel $\mathrm{T}_{\mathrm{L}}$ models used to calculate waste loading in AABS glasses confirm that $\mathrm{B}_{2} \mathrm{O}_{3}$ decreases $\mathrm{T}_{L}$ with an effect similar to that seen for both the CVS3-1 and SP-1 glass with $\mathrm{B}_{2} \mathrm{O}_{3}$ concentrations greater than 4 mass $\%$. Two conclusions can be drawn from this: 1) adding $\mathrm{B}_{2} \mathrm{O}_{3}$ will decrease the $\mathrm{T}_{\mathrm{L}}$ in the spinel primary phase field, even in very low concentrations, and 2) the $\mathrm{T}_{\mathrm{L}}$ 's of glasses with no $\mathrm{B}_{2} \mathrm{O}_{3}$ are likely to be higher than predicted with the AABS $T_{L}$ models.

The effect of small $\mathrm{B}_{2} \mathrm{O}_{3}$ additions on the viscosity of CVS3-1 glass at $1150^{\circ} \mathrm{C}$ is shown in Figure 4.9. Small $\mathrm{B}_{2} \mathrm{O}_{3}$ additions decrease glass viscosity at $1150^{\circ} \mathrm{C}$ (or any temperature with viscosities below 103 $\mathrm{Pa} \cdot \mathrm{s}$ ). Adding $\mathrm{B}_{2} \mathrm{O}_{3}$ to a glass will allow for a lower melting temperature at constant viscosity (lowering volatility) or decreasing viscosity at constant temperature (increasing the melt rate). The melting temperatures of AAS waste glasses reported in literature ranged from $1200^{\circ} \mathrm{C}$ to $1700^{\circ} \mathrm{C}$.

Since temperature affects viscosity so strongly and we also consider higher melting temperatures than $1150^{\circ} \mathrm{C}$, the effect of $\mathrm{B}_{2} \mathrm{O}_{3}$ additions on $\mathrm{T}_{\mathrm{M}^{-}} \mathrm{T}_{\mathrm{L}}(\Delta \mathrm{T})$ is a more appropriate criteria to consider. Vienna et al. (1996) and Hrma et al. (1995) showed that the addition of $\mathrm{B}_{2} \mathrm{O}_{3}$ to glass slightly decreases $\Delta \mathrm{T}$. 
Therefore, for higher temperature melters, there may be advantage to the use low or no boron glasses for $\mathrm{T}_{\mathrm{L}}$ limited wastes (assuming other properties don't strongly influence glass volume).

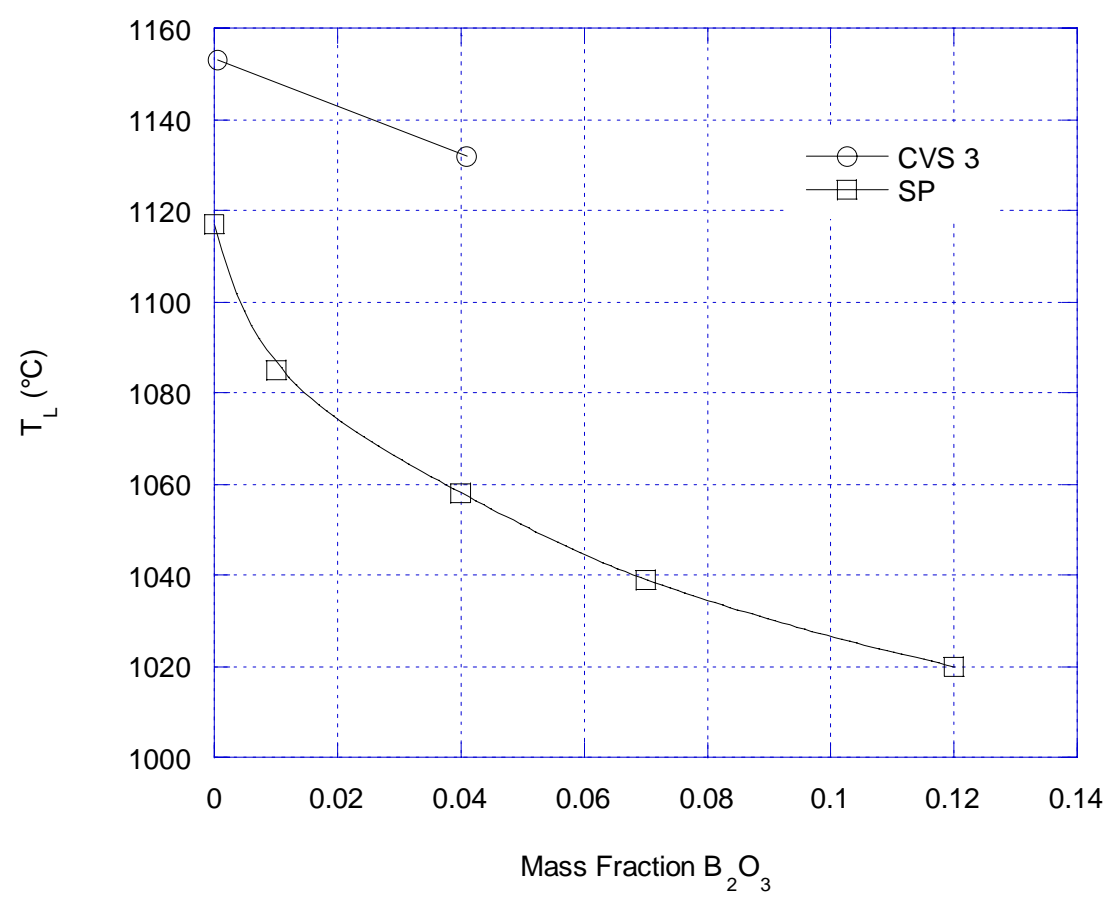

Figure 4.8. Effect of Boron Addition on the $T_{L}$ of CVS3-1 Glass (after Vienna et al. 1996b) and SP-1 Glass (after Mika et al. 1996).

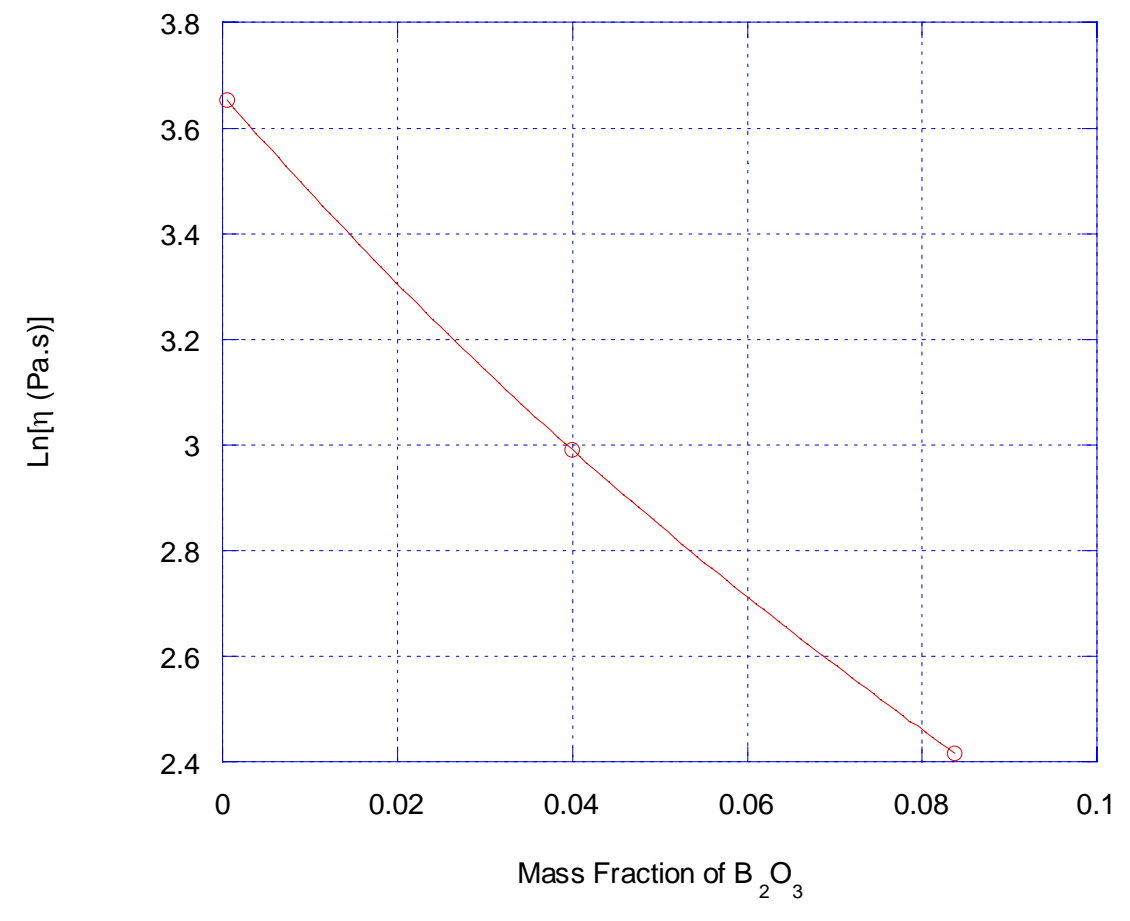

Figure 4.9. Viscosity at $1150^{\circ} \mathrm{C}$ as a Function of $\mathrm{B}_{2} \mathrm{O}_{3}$ Concentration for CVS3-1 (after Vienna et al. 1996b) 
Figure 4.10 shows the influence of increasing boron concentrations on the normalized element releases of glasses with different $\mathrm{Al}_{2} \mathrm{O}_{3}$ concentrations. Figure 4.11 shows the effect of small $\mathrm{B}_{2} \mathrm{O}_{3}$ additions on the normalized sodium release of CVS3-1 glass by PCT. However, glass-property models suggest that adding $\mathrm{B}_{2} \mathrm{O}_{3}$ will increase PCT releases (reduce glass durability). Small additions of $\mathrm{B}_{2} \mathrm{O}_{3}$ in AAS glasses or soda-lime-silicate glasses increase the durability of the glass. After roughly 5 mass $\%$ of $\mathrm{B}_{2} \mathrm{O}_{3}$ (concentration depends upon glass composition), further additions of $\mathrm{B}_{2} \mathrm{O}_{3}$ to a glass begin to increase the normalized releases from that glass in a PCT. The Study Team therefore expects that adding small amounts of $\mathrm{B}_{2} \mathrm{O}_{3}$ to a glass will increase glass durability. The releases from glasses free of $\mathrm{B}_{2} \mathrm{O}_{3}$ will be higher than those calculated with current models the.

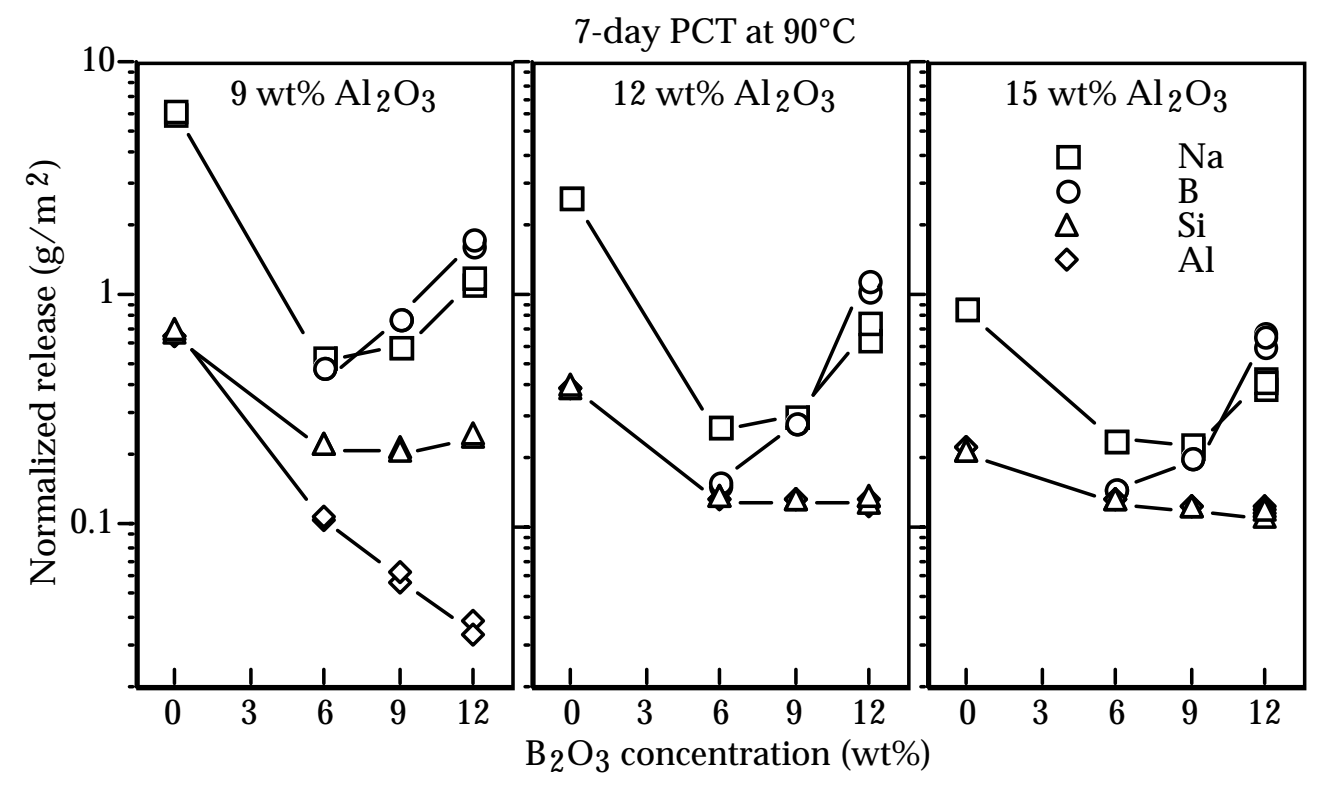

Figure 4.10. Normalized Element Releases in PCT as a Function of $\mathrm{B}_{2} \mathrm{O}_{3}$ Concentration at Various $\mathrm{Al}_{2} \mathrm{O}_{3}$ Concentrations (from Kim et al. 1996) 


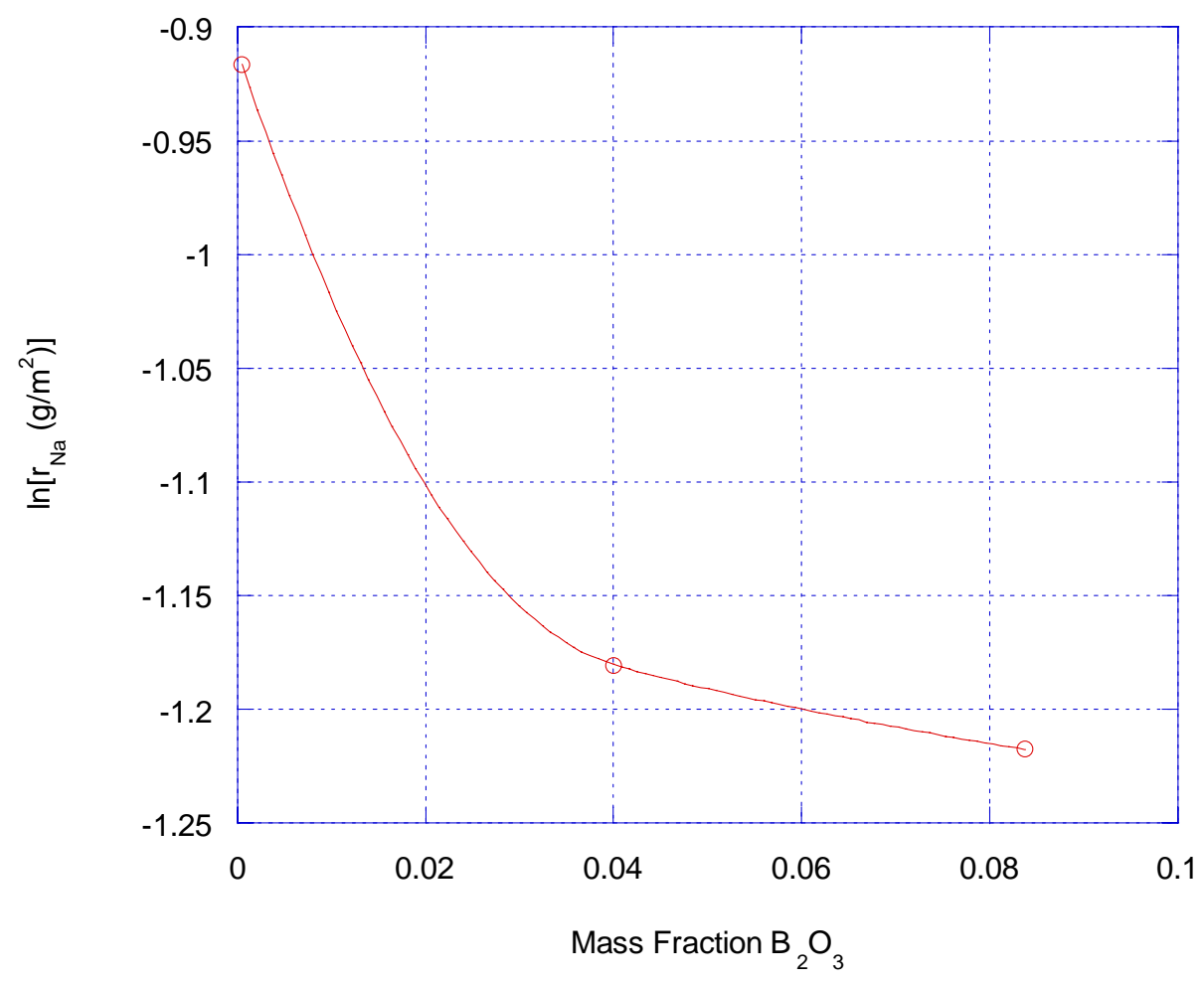

Figure 4.11. Normalized Sodium Release in PCT as a Function of $\mathrm{B}_{2} \mathrm{O}_{3}$ Concentration in CVS3-1 Glass (after Vienna et al. 1996a)

Schreiber and Balazs (1982) showed that uranium solubility in AAS glasses was roughly half that in AABS waste glasses. They concluded that the average valence state of uranium was responsible for the difference. The Study Team did not actively limit the amount of $\mathrm{U}_{3} \mathrm{O}_{8}$ in glass during their study, but the concentration ranged from 0.6 to $14 \mathrm{mass} \%$ ( $>10 \mathrm{mass} \%$ for all but cluster \#16), within the limit of concentrations demonstrated on laboratory scale for AABS glasses. However, it was above the range typically seen in AAS glasses ( 4.5 mass $\%)$.

Adding small concentrations of $\mathrm{B}_{2} \mathrm{O}_{3}$ was shown to improve many of the important properties for waste glasses. Although the Study Team has no direct method for estimating the volume of AAS glass to be produced from Hanford HLW, it is clear that the addition of small amounts of $\mathrm{B}_{2} \mathrm{O}_{3}$ to glass will generally be advantageous for reference melters and may be advantageous for high temperature melters.

To successfully apply AAS glass formulations to Hanford HLW immobilization, additional development would be required. Before AAS glass formulations could be used, glass testing and model development similar to what has already been done for AABS glasses would be needed including composition-models for

- $\mathrm{T}_{\mathrm{L}}$ within all appropriate primary phase fields

- PCT releases

- component solubility/temperature relationships

- electrical conductivity/temperature relationship

- viscosity/temperature relationship

- density. 
Adequate assessments of glass volumes can only be completed once these models are available. Many of these data would be required before plant design could be completed.

AAS glasses containing crystals were studied by Hrma and Bailey (1995). They showed that loadings of blended Hanford HLW up to $80 \%$ could be achieved while maintaining adequate PCT response if crystalline material was allowed to form during processing. Their approach was to add only $\mathrm{SiO}_{2}$ to the simulated waste, melt the material at temperatures ranging from $1215^{\circ} \mathrm{C}$ to $1350^{\circ} \mathrm{C}$, and quench to form a glass ceramic type waste form. This waste form contains significant fraction of crystallinity ( 1 to 45 vol $\%$ on quenching and 5 to $60 \mathrm{vol} \%$ on CCC) including baddeleyite, parakeldyshite, zircon, spinel, nepheline, and rare earth-zirconium oxides. Significant processing issues would need to be worked out to fabricate and qualify such a waste form for all of Hanford HLW. However, it does give an indication of how high waste loading could be for a material if processing concerns were not limiting.

\subsection{Phosphate-Based Glasses}

\subsubsection{Basis for Waste-Loading Estimates}

The Study Team assessed the use of FeP glasses to vitrify nuclear wastes (grouped into 17 clusters based on chemical compositions - see Table 4.11). The estimated waste loadings, estimated chemical durability, and expert judgments expressed in this section are based on data obtained from nearly 500 laboratory glass melts that have been studied in depth over a nearly 10-year period. Iron-phosphate waste forms containing up to nine different simulated nuclear wastes components have been investigated. However, the majority of glasses were relatively simple, containing only one or a combination of two or three waste components commonly present in nuclear waste (such as uranium, bismuth, sodium, cesium, and protactinium).

Five of these simulated wastes were based on wastes at Hanford whose nominal composition is given in Table 4.12. One waste, Tank Farm B Waste, was the estimated average composition of all the waste in Tank Farm B, while the other four had compositions corresponding to the waste in Tanks B-110, C-106, $\mathrm{C}-112$, and $\mathrm{T}-111$. These wastes were selected because their composition was such (high content of $\mathrm{P}_{2} \mathrm{O}_{5}$, $\mathrm{Bi}_{2} \mathrm{O}_{3}, \mathrm{UO}_{2}$, etc.) that they were considered poorly suited for vitrification in borosilicate glass (Mesko et al. 1998).

Other simulated wastes vitrified to date in FeP glasses include aluminum-clad SNF, gunite waste from ORR, a zirconia-rich calcine waste (see Table 4.12) from INEEL, and simulated plutonium wastes.

Thus, an extensive body of data exists for FeP waste forms at this time. As mentioned later, some of these FeP waste forms contain simulated wastes whose chemical composition, in terms of the types and amounts of major components, is fairly close to some of those in the 17 clusters. In these cases, therefore, a fairly high degree of confidence exists in the estimated waste loadings and other opinions regarding the vitrification of these wastes in $\mathrm{FeP}$ glasses. 
Table 4.11. Compositions of Hanford Wastes Used to Estimate Waste Loading for the FeP Glasses (mass\%)

\begin{tabular}{|c|c|c|c|c|c|c|c|c|c|c|c|c|c|c|c|c|}
\hline \# & Mass (Mg) & $\mathbf{A l}_{2} \mathbf{O}_{3}$ & $\mathrm{As}_{2} \mathrm{O}_{5}$ & $\mathbf{B}_{2} \mathbf{O}_{3}$ & $\mathrm{BaO}$ & $\mathbf{B i}_{2} \mathbf{O}_{3}$ & $\mathrm{CaO}$ & $\mathrm{CdO}$ & $\mathrm{Ce}_{2} \mathrm{O}_{3}$ & $\mathrm{Cr}_{2} \mathrm{O}_{3}$ & $\mathbf{F}$ & $\mathrm{Fe}_{2} \mathbf{O}_{3}$ & $\mathrm{~K}_{2} \mathrm{O}$ & $\mathrm{La}_{2} \mathrm{O}_{3}$ & $\mathrm{MgO}$ & MnO \\
\hline 1 & 2349 & 19.55 & 0.02 & 0.06 & 0.04 & 6.48 & 2.82 & 0.05 & 0.02 & 0.55 & 0.42 & 15.68 & 0.15 & 0.33 & 0.14 & 1.73 \\
\hline 2 & 1749 & 12.73 & 0.03 & 0.09 & 0.22 & 12.10 & 3.15 & 0.04 & 0.02 & 0.77 & 1.02 & 21.50 & 0.28 & 1.21 & 0.48 & 2.81 \\
\hline 3 & 1647 & 19.59 & 0.19 & 0.50 & 0.22 & 1.21 & 2.26 & 0.02 & 0.22 & 1.69 & 2.76 & 7.27 & 0.69 & 0.12 & 0.55 & 1.50 \\
\hline 4 & 1395 & 18.48 & 0.05 & 0.17 & 0.20 & 2.97 & 5.52 & 0.01 & 0.07 & 1.31 & 2.21 & 13.46 & 0.32 & 0.08 & 0.48 & 1.53 \\
\hline 5 & 1384 & 17.74 & 0.02 & 0.11 & 0.02 & 9.56 & 3.37 & 0.00 & 0.02 & 0.89 & 3.65 & 17.27 & 0.21 & 0.28 & 0.21 & 1.36 \\
\hline 6 & 947 & 27.23 & 0.13 & 0.23 & 0.08 & 6.20 & 2.23 & 0.02 & 0.10 & 1.36 & 1.20 & 12.06 & 1.26 & 0.60 & 0.28 & 2.28 \\
\hline 7 & 678 & 18.07 & 0.03 & 0.27 & 0.03 & 0.39 & 1.97 & 0.01 & 0.04 & 2.02 & 1.04 & 8.38 & 0.77 & 0.06 & 0.06 & 1.04 \\
\hline 8 & 506 & 23.03 & 1.30 & 1.96 & 0.49 & 2.11 & 1.45 & 0.03 & 1.02 & 2.51 & 1.21 & 7.25 & 0.16 & 0.06 & 2.33 & 1.83 \\
\hline 9 & 426 & 6.61 & 0.41 & 0.61 & 0.23 & 3.76 & 0.69 & 0.03 & 0.36 & 0.17 & 2.33 & 14.13 & 0.42 & 0.19 & 0.54 & 6.82 \\
\hline 10 & 232 & 6.66 & 0.09 & 0.20 & 0.06 & 0.24 & 0.98 & 0.04 & 0.07 & 1.32 & 0.12 & 5.19 & 1.79 & 0.08 & 0.25 & 10.80 \\
\hline 11 & 216 & 7.45 & 0.81 & 0.32 & 0.40 & 0.01 & 2.90 & 0.09 & 0.33 & 0.20 & 0.04 & 45.66 & 0.15 & 0.90 & 1.98 & 8.80 \\
\hline 12 & 175 & 7.31 & 1.52 & 1.80 & 0.56 & 0.28 & 0.87 & 0.06 & 1.18 & 0.47 & 3.77 & 1.44 & 1.06 & 0.30 & 1.66 & 0.53 \\
\hline 13 & 171 & 2.23 & 0.02 & 1.44 & 0.04 & 0.01 & 1.41 & 0.28 & 0.02 & 0.16 & 0.10 & 11.84 & 0.34 & 0.28 & 0.09 & 10.20 \\
\hline 14 & 150 & 14.97 & 0.54 & 0.76 & 0.24 & 1.58 & 0.78 & 0.10 & 0.45 & 4.25 & 1.39 & 10.96 & 1.97 & 0.21 & 0.65 & 1.40 \\
\hline 15 & 142 & 8.32 & 0.02 & 1.25 & 0.19 & 0.02 & 0.93 & 4.51 & 0.26 & 0.11 & 0.33 & 47.83 & 1.05 & $\begin{array}{ll}1.59 \\
\end{array}$ & 0.35 & 0.92 \\
\hline 16 & 128 & 3.34 & 0.02 & 1.90 & 0.05 & 0.01 & 1.86 & 0.37 & 0.03 & 0.21 & 0.14 & 15.65 & 0.45 & 0.38 & 0.11 & 3.40 \\
\hline 17 & 19 & 2.63 & 0.04 & 0.07 & 0.02 & 0.10 & 0.39 & 0.02 & 0.03 & 0.54 & 0.06 & 2.20 & 0.59 & 0.03 & 0.11 & 23.91 \\
\hline
\end{tabular}


Table 4.11. Compositions of Hanford Wastes Used to Estimate Waste Loading for the FeP Glasses (mass\%) (cont'd)

\begin{tabular}{|c|c|c|c|c|c|c|c|c|c|c|c|c|c|c|c|c|c|}
\hline$\#$ & $\mathrm{MoO}_{3}$ & $\mathrm{Na}_{2} \mathbf{O}$ & $\mathrm{Nd}_{2} \mathrm{O}_{3}$ & $\mathrm{NiO}$ & $\mathbf{P}_{2} \mathbf{O}_{5}$ & $\mathbf{P b O}$ & $\mathrm{Sb}_{2} \mathbf{O}_{3}$ & $\mathrm{SiO}_{2}$ & $\mathrm{SO}_{3}$ & SrO & $\mathrm{ThO}_{2}$ & $\mathbf{T l}_{2} \mathrm{O}$ & $\mathrm{U}_{3} \mathbf{O}_{8}$ & $\mathrm{ZnO}$ & $\mathrm{ZrO}_{2}$ & Total & $\begin{array}{l}\mathrm{Fe}_{2} \mathrm{O}_{3} \\
+\mathrm{P}_{2} \mathrm{O}_{5}\end{array}$ \\
\hline 1 & 0.01 & 22.93 & 0.03 & 1.09 & 3.09 & 0.63 & 0.01 & 17.25 & 0.19 & 0.34 & 0.06 & 0.03 & 5.98 & 0.01 & 0.25 & 99.93 & 18.8 \\
\hline 2 & 0.01 & 20.70 & 0.02 & 0.66 & 4.48 & 0.84 & 0.01 & 10.66 & 0.13 & 0.30 & 0.05 & 0.03 & 4.84 & 0.03 & 0.64 & 99.88 & 26.0 \\
\hline 3 & 0.14 & 20.36 & 0.14 & 1.53 & 2.78 & 0.52 & 0.09 & 7.41 & 0.12 & 0.40 & 0.30 & 0.27 & 10.77 & 0.83 & 15.16 & 99.56 & 10.1 \\
\hline 4 & 0.04 & 22.75 & 0.03 & 2.63 & 3.81 & 0.56 & 0.02 & 9.51 & 0.12 & 1.02 & 0.20 & 0.07 & 10.06 & 0.41 & 1.75 & 99.84 & 17.3 \\
\hline 5 & 0.01 & 21.23 & 0.01 & 1.47 & 4.32 & 0.69 & 0.01 & 8.50 & 0.21 & 0.57 & 0.13 & 0.01 & 7.76 & 0.03 & 0.26 & 99.92 & 21.6 \\
\hline 6 & 0.07 & 22.84 & 0.10 & 2.18 & 2.92 & 0.44 & 0.07 & 8.04 & 0.22 & 0.38 & 0.29 & 0.20 & 6.37 & 0.03 & 0.40 & 99.76 & 15.0 \\
\hline 7 & 0.03 & 21.08 & 0.02 & 0.43 & 2.10 & 0.50 & 0.01 & 27.51 & 0.14 & 0.14 & 0.36 & 0.04 & 10.66 & 0.02 & 2.24 & 99.47 & 10.5 \\
\hline 8 & 0.64 & 27.20 & 0.99 & 0.59 & 6.40 & 0.44 & 0.54 & 4.39 & 0.15 & 0.32 & 0.25 & 1.71 & 6.87 & 0.23 & 0.70 & 98.14 & 9.4 \\
\hline 9 & 0.21 & 12.36 & 0.31 & 0.44 & 0.74 & 0.75 & 0.23 & 4.58 & 0.03 & 13.75 & 0.07 & 0.58 & 6.07 & 0.07 & 21.63 & 99.14 & 14.8 \\
\hline 10 & 0.04 & 45.10 & 0.08 & 0.20 & 1.26 & 0.29 & 0.04 & 1.34 & 0.04 & 21.12 & 0.17 & 0.18 & 1.78 & 0.07 & 0.09 & 99.65 & 6.5 \\
\hline 11 & 0.03 & 14.57 & 0.56 & 1.43 & 0.63 & 1.44 & 0.38 & 5.22 & 0.03 & 0.16 & 0.00 & 1.11 & 1.42 & 0.09 & 0.62 & 97.71 & 46.3 \\
\hline 12 & 0.75 & 29.27 & 1.16 & 0.58 & 0.17 & 0.41 & 0.78 & 1.43 & 0.09 & 0.06 & 0.21 & 2.15 & 9.85 & 0.16 & 27.95 & 97.82 & 1.6 \\
\hline 13 & 0.01 & 9.12 & 0.03 & 0.84 & 0.23 & 0.25 & 0.01 & 3.13 & 0.02 & 17.13 & 2.79 & 0.03 & 15.82 & 0.03 & 21.94 & 99.83 & 12.0 \\
\hline 14 & 0.28 & 35.50 & 0.42 & 0.55 & 2.44 & 0.52 & 0.27 & 2.02 & 0.05 & 0.09 & 0.20 & 0.74 & 5.15 & 0.08 & 10.23 & 98.81 & 13.4 \\
\hline 15 & 0.03 & 12.88 & 0.74 & 2.10 & 0.16 & 0.22 & 0.00 & 0.95 & 0.19 & 0.08 & 0.20 & 0.00 & 3.63 & 0.04 & 10.61 & 99.51 & 48.0 \\
\hline 16 & 0.01 & 12.14 & 0.04 & 1.11 & 0.30 & 0.33 & 0.01 & 4.20 & 0.02 & 0.04 & 3.69 & 0.03 & 20.90 & 0.04 & 28.98 & 99.78 & 15.9 \\
\hline 17 & 0.01 & 14.50 & 0.03 & 0.08 & 0.53 & 0.12 & 0.02 & 0.51 & 0.02 & 52.31 & 0.06 & 0.05 & 0.74 & 0.03 & 0.03 & 99.76 & 2.7 \\
\hline
\end{tabular}


Table 4.12. Compositions of Various Simulated HLW Streams Used to Assess FeP Glass as a Potential Waste Form

\begin{tabular}{|c|c|c|c|c|c|c|c|c|c|c|c|c|c|c|c|c|c|c|}
\hline $\begin{array}{c}\text { HANFORD } \\
\text { WASTES }\end{array}$ & $\mathrm{Al}_{2} \mathrm{O}_{3}$ & $\mathbf{B i}_{2} \mathbf{O}_{3}$ & $\mathrm{CaO}$ & $\mathrm{CeO}_{2}$ & $\mathrm{CdO}$ & $\mathrm{Cr}_{2} \mathrm{O}_{3}$ & $\mathbf{F}$ & $\mathrm{Fe}_{2} \mathrm{O}_{3}$ & $\mathrm{~K}_{2} \mathrm{O}$ & $\mathbf{L a}_{2} \mathbf{O}_{3}$ & $\mathrm{MnO}_{2}$ & $\mathrm{Na}_{2} \mathrm{O}$ & $\mathrm{NiO}$ & $\mathbf{P}_{2} \mathbf{O}_{5}$ & $\mathrm{SiO}_{2}$ & $\mathrm{U}_{3} \mathrm{O}_{8}$ & $\mathrm{ZrO}_{2}$ & $\begin{array}{c}\mathrm{Fe}_{2} \mathbf{O}_{3}+ \\
\mathbf{P}_{2} \mathbf{O}_{5} \\
\end{array}$ \\
\hline Tank Farm B & 1.3 & 6.7 & - & 4.4 & - & - & 0.8 & 8.3 & - & - & 0.5 & 54.6 & 0.2 & 14.9 & 0.8 & - & 0.2 & 23.2 \\
\hline B-110 Tank & 2.7 & 25.8 & 1.5 & - & - & - & - & 30.6 & - & - & - & 14.4 & - & 1.7 & 23.4 & - & - & 32.3 \\
\hline C-106 Tank & 17.7 & - & - & - & - & - & - & 16.8 & - & - & - & 22.1 & - & 1.3 & 34.7 & - & - & 18.1 \\
\hline C-112 Tank & 4.2 & - & 16.1 & - & - & - & - & 15.0 & - & - & & 7.1 & 9.5 & 14.1 & 2.5 & 30.5 & - & 29.1 \\
\hline T-111 Tank & 1.1 & 29.8 & 3.4 & - & - & - & - & 26.3 & - & 5.1 & 10.4 & 5.6 & - & 3.6 & 11.3 & 3.8 & - & 29.9 \\
\hline
\end{tabular}

\begin{tabular}{|c|c|c|c|c|c|c|c|c|c|c|c|c|c|c|c|c|c|}
\hline INEEL WASTE & $\mathrm{Al}_{2} \mathrm{O}_{3}$ & $\mathbf{B i}_{2} \mathbf{O}_{3}$ & $\mathrm{CaF}_{2}$ & $\mathrm{CaO}$ & $\mathrm{CdO}$ & $\mathrm{Cr}_{2} \mathrm{O}_{3}$ & $\mathbf{F}$ & $\mathrm{Fe}_{2} \mathbf{O}_{3}$ & $\mathbf{K}_{2} \mathbf{O}$ & $\mathrm{La}_{2} \mathrm{O}_{3}$ & $\mathrm{MnO}_{2}$ & $\mathrm{Na}_{2} \mathrm{O}$ & $\mathrm{NiO}$ & $\mathbf{P}_{2} \mathbf{O}_{5}$ & $\mathrm{SiO}_{2}$ & $\mathrm{U}_{3} \mathrm{O}_{8}$ & $\mathrm{ZrO}_{2}$ \\
\hline Modified Calcine & 14.4 & & 34.1 & 25.9 & & - & & - & - & - & - & 1.4 & - & & - & & 22.8 \\
\hline
\end{tabular}


To objectively assess the practicality and performance of $\mathrm{FeP}$ glasses for waste vitrification, it is absolutely necessary to treat them differently from "ordinary" phosphate glasses. Iron phosphate glasses tend to be more like silica-based glasses than generic phosphate glasses. Some of the major unique characteristics of FeP glasses that are important to consider include the following:

(1) Their chemical durability, which often exceeds that of window glass and many borosilicate glasses (Yu and Day 1995, Mesko et al. 1998, Day et al. 1998, Mesko et al. 2000, and Marasinghe et al. 2000)

(2) Their inherently high solubility (Mesko et al. 1998, Day et al. 1998, Karabulut et al. 1999, Badyal et al. 1999, and Marasinghe et al. 2000) for many heavy metals (e.g., uranium, chromium, zirconium, cesium, and molybdenum), noble metals, and rare earths commonly present in nuclear waste

(3) Their low melting temperatures $\left(950^{\circ} \mathrm{C}\right.$ to $\left.1100^{\circ} \mathrm{C}\right)$, rapid melting rates, ability to tolerate a wide range of furnace atmospheres (oxidizing to reducing), and high melt fluidity (viscosity typically $<1$ Poise).

(4) Their unexpectedly low corrosion of refractories (Chen and Day 1999) commonly used in glass melting furnaces such as high alumina, zircon, and mullite.

(5) High waste loading, typically between 25 and 50 mass \% depending upon the waste, and higher density (typically 3.0 to $3.4 \mathrm{~g} / \mathrm{cm}^{3}$ ), which combine to minimize the volume of vitrified waste compared to waste forms of lower density.

An example of the outstanding chemical durability for iron phosphate waste forms containing various amounts of simulated Hanford waste is shown in Figure 4.12. All five of the iron phosphate waste forms have a dissolution rate (DR), measured in water at $90^{\circ} \mathrm{C}$, which is considerably lower than the EA glass. The low dissolution rate for Sample E, which contains 70 mass\% of the Hanford T-111 waste, demonstrates the excellent chemical durability of iron phosphate waste forms that are partially crystallized. A variety of crystalline phases (e.g., $\mathrm{Fe}_{3}\left(\mathrm{P}_{2} \mathrm{O}_{7}\right)_{2}, \mathrm{Fe}_{4}\left(\mathrm{P}_{2} \mathrm{O}_{7}\right)_{3}, \mathrm{BiPO}_{4}, \mathrm{Na}_{3} \mathrm{Fe}_{2}\left(\mathrm{PO}_{4}\right)_{3}$, $\mathrm{Ca}_{5} \mathrm{~F}\left(\mathrm{PO}_{4}\right)_{3}$ and $\mathrm{Al}(\mathrm{PO})_{4}$ and $\mathrm{Al}_{2} \mathrm{O}_{3}$ ) have been observed in partially devitrified $\mathrm{FeP}$ glasses. 


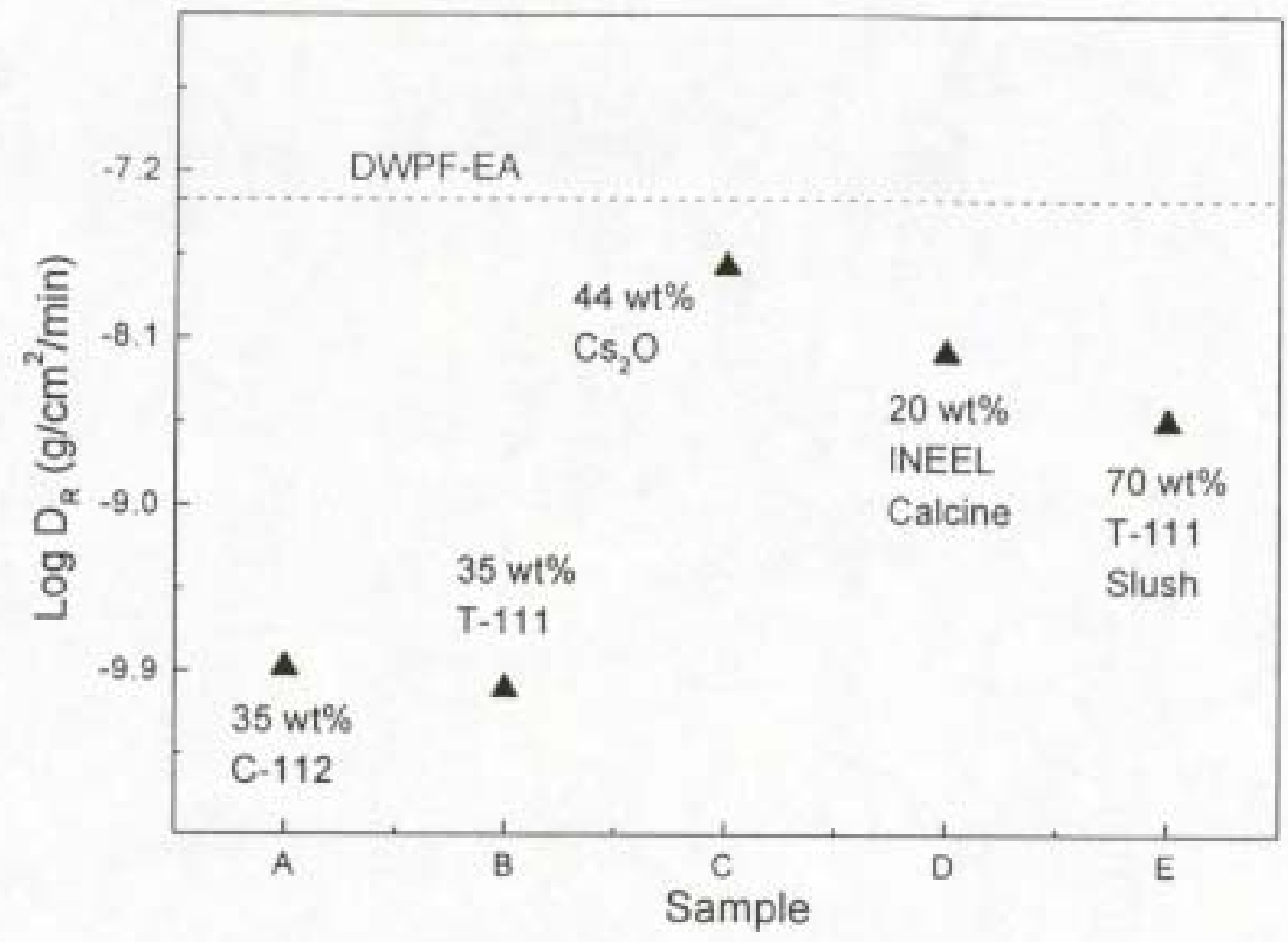

Figure 4.12. Dissolution Rate of Five Iron Phosphate Waste Forms Measured in Distilled Water at $90^{\circ} \mathrm{C}$.

(Note: Samples A - D are single-phase glasses while Sample E is partially devitrified. Data for samples $\mathrm{A}$ and $\mathrm{B}$ are from PCT while other data are from mass loss measurements.)

Figure 4.13 shows the concentration of ions found in solution after performing the PCT on FeP waste forms that contained 35 mass $\%$ of the simulated Hanford wastes. The data indicate that the FeP glasses compare very favorably with a borosilicate-based simulated nuclear waste glass. This could be a result of the tendency of iron phosphate glasses to buffer the $\mathrm{pH}$ of solutions in which they may come into contact with. 


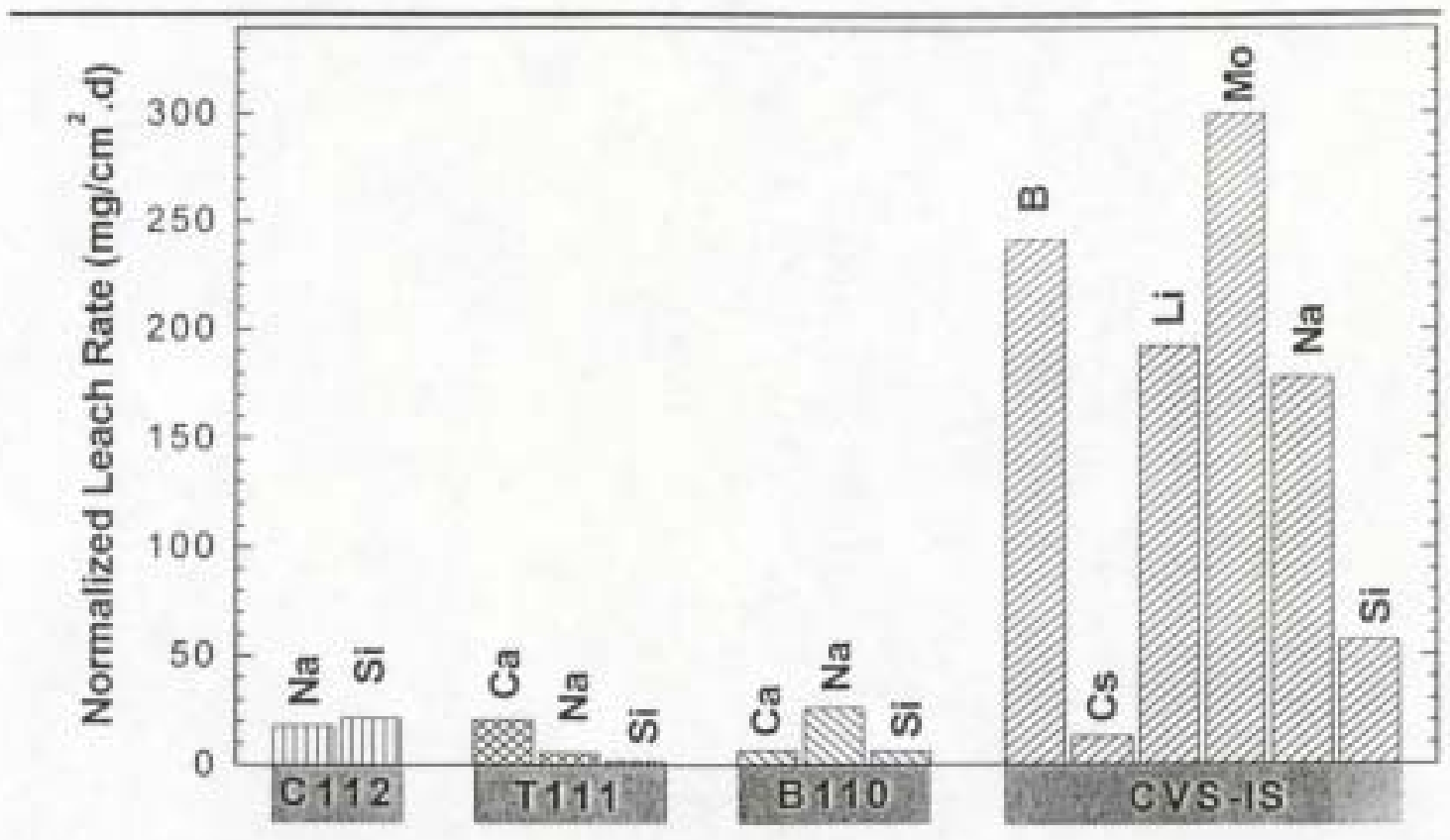

Figure 4.13. Normalized Elemental Mass Release (via PCT) for Three FeP Waste Forms which Contain 35 mass\% of Simulated Wastes from Hanford Tanks C-112, T-111, and B-110.

(Note: Only elements where the mass release was greater than $20 \mathrm{~g} /\left(\mathrm{m}^{2} \cdot \mathrm{d}\right)\left(2 \mathrm{mg} / \mathrm{cm}^{2} /\right.$ day $)$ are shown.)

A final example of chemical durability of iron phosphate glasses is shown in Figure 4.14. The DR at $90^{\circ} \mathrm{C}$ is shown for both glassy (single phase) and crystallized iron phosphate waste forms containing from 20 to 50 mass\% of the Hanford wastes. Crystallization had no detrimental effect on the DR, in fact, the DR actually decreased significantly with crystallization. 


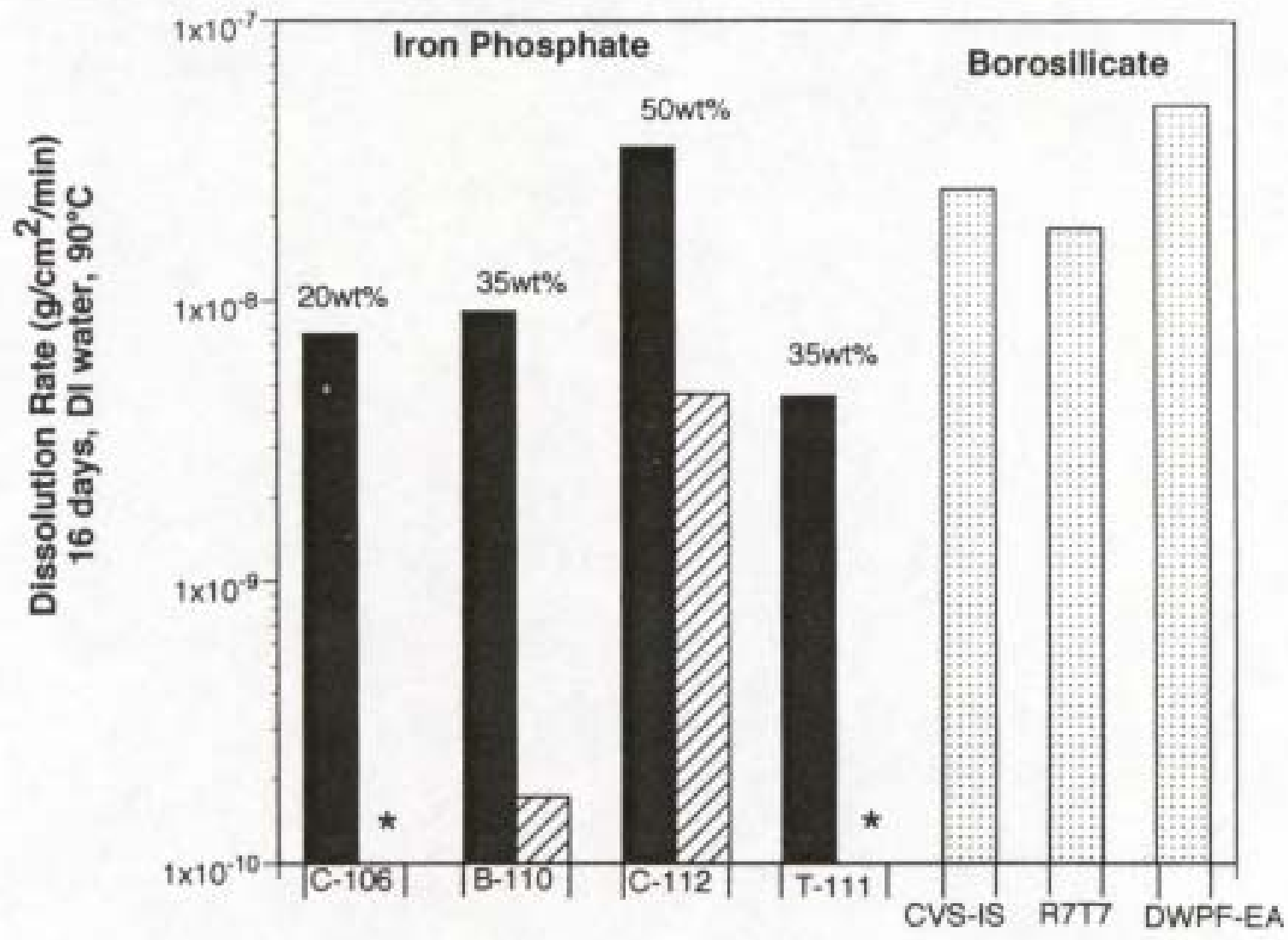

Figure 4.14. Dissolution Rate of Single Phase Glasses (solid bars) and Crystallized (hashed bars) Iron Phosphate Waste Forms Containing Simulated Hanford Wastes.

(Note: The number at the top of the bar denotes the waste content (mass\%) in the waste form. The asterisks denote waste forms that gained mass up to 0.36 mass $\%$ during immersion. The dissolution rates for three borosilicate glasses (right-hand side) are shown for comparison.)

The nuclear waste most suited for FeP melts are those that contain significant concentrations of $\mathrm{Fe}_{2} \mathrm{O}_{3}$, phosphates, as well as heavy metals. Typically, the only external materials added to simulated Hanford and other wastes are $\mathrm{Fe}_{2} \mathrm{O}_{3}$ and phosphate so that the overall iron and phosphate content is adequate to from a chemically durable glass. These two materials could be added as a glass frit or as individual components. Considerable research has been devoted to gaining an understanding of the compositional and structural parameters that control chemical durability in iron phosphate glasses [Marasinghe et al. (1997) and Day et al. (1998)]. A critical criterion for producing a durable iron phosphate waste form is the molar ratio of oxygen to phosphorus; which should be close to 3.6.

When FeP melts are melted in air or neutral atmospheres such as nitrogen or argon, between 950 and $1200^{\circ} \mathrm{C}$, about $20 \%$ of the iron is present in the ferrous state (see Sample A in Figure 4.15). Only in strongly reducing atmospheres does the ferrous ion concentration exceed about $50 \%$. The concentration 
of the ferrous iron varies very little with changes in the other components present in a melt but gradually increases with increasing melting temperature (see Samples A - D in Figure 4.15) from about 20\% at $1150^{\circ} \mathrm{C}$ to above $50 \%$ at $1450^{\circ} \mathrm{C}$, which is a much higher temperature than would be used in practice.

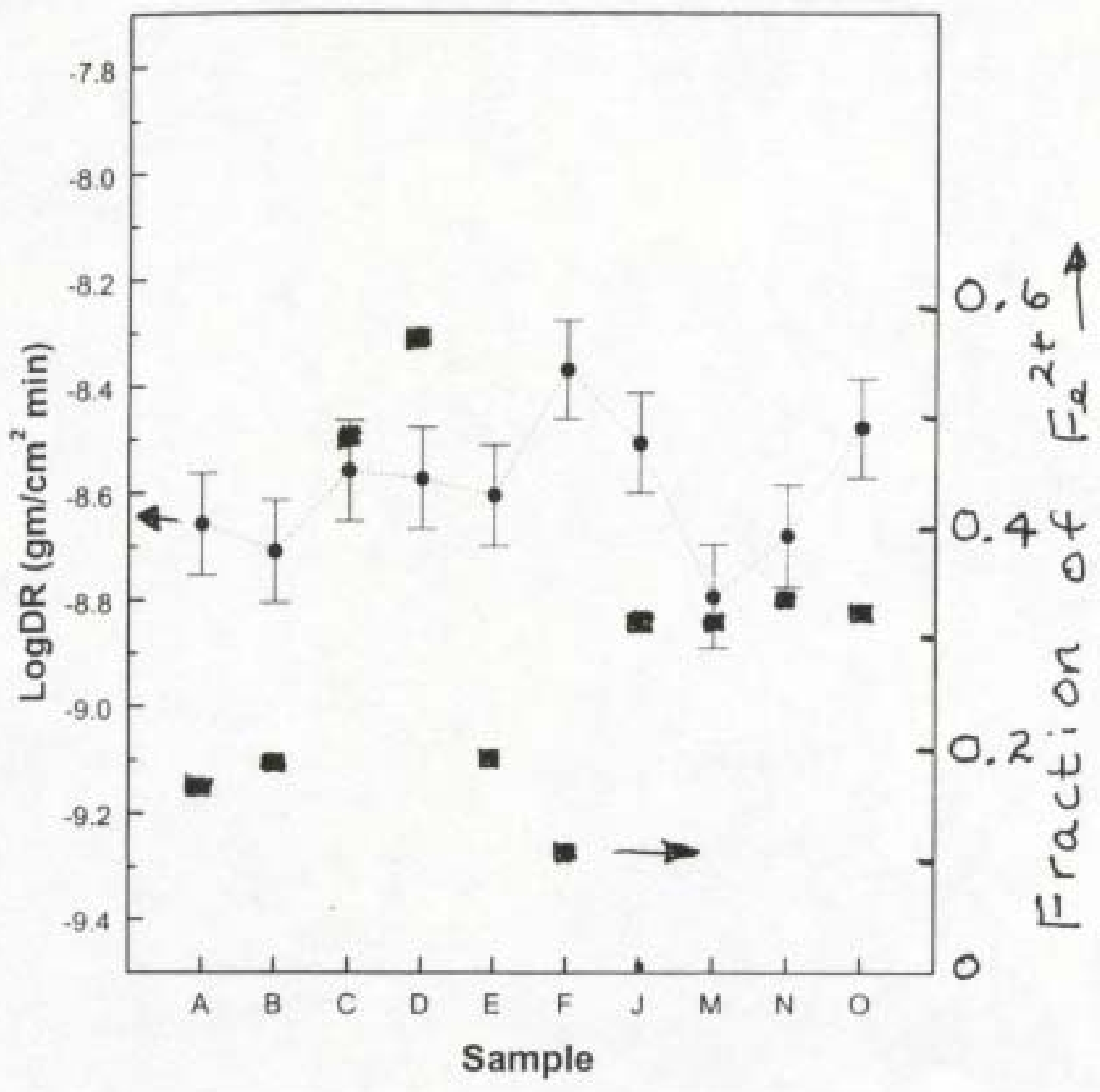

Figure 4.15. Chemical Durability (dissolution rate, solid dots) and Fraction of Ferrous Iron (solid rectangles) for Iron Phosphate Glasses Containing Varying Amounts of $\mathrm{UO}_{2}, \mathrm{Cs}_{2} \mathrm{O}$, and $\mathrm{Bi}_{2} \mathrm{O}_{3}$.

(Note: Samples A, B, C, and D are for a $43 \% \mathrm{Fe}_{2} \mathrm{O}_{3}-57 \% \mathrm{P}_{2} \mathrm{O}_{5}$ glass melted at $1150^{\circ}, 1200^{\circ}, 1350^{\circ}$, and $1450^{\circ} \mathrm{C}$, respectively)

Fortunately, chemical durability is independent of the ferrous/ferric concentration [Yu and Day (1995), Marasinghe et al. (1998), and Ray et al. (1999)] as shown in Figure 4.15. Although the chemical durability is not diminished with increasing ferrous concentration, the tendency for glass formation becomes less, and when the ferrous concentration is above approximately $60 \%$, crystallization becomes more prevalent during cooling. As long as durability and waste form compliance issues are meet, crystallization of $\mathrm{FeP}$ waste forms need not be a problem. 
In spite of their low viscosity, iron phosphate melts are not particularly corrosive toward common refractories (Chen and Day (1999). Figure 4.16 shows the corrosion rate for three commercial refractories (rotated at $9 \mathrm{rpm}$ for at least 24 hours) in four FeP melts, three of which contain Hanford waste. While there are some differences in the corrosion rate for the three refractories in the different melts, the data indicate that $\mathrm{FeP}$ melts did not corrode these refractories much differently that the borosilicate glass.

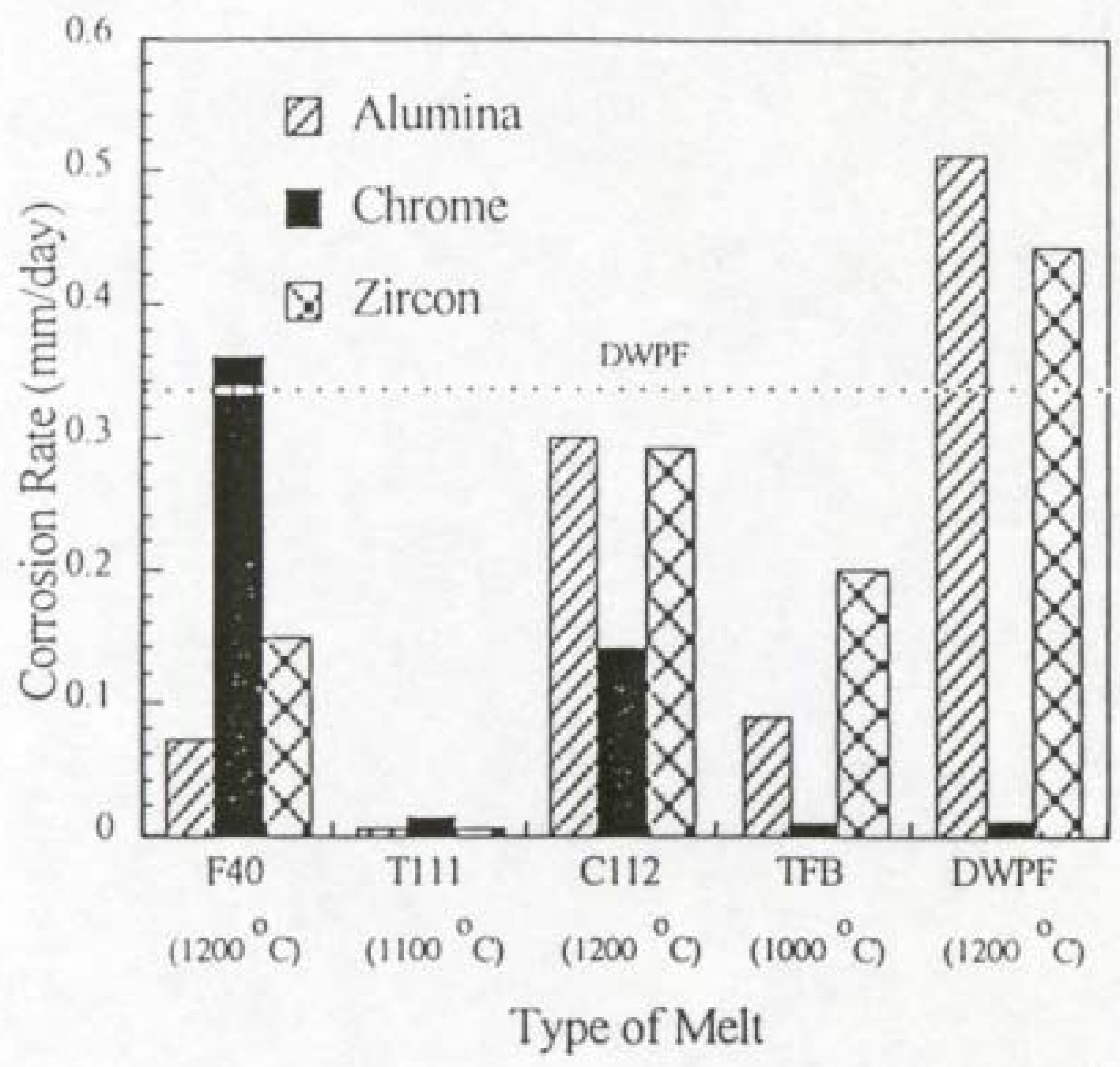

Figure 4.16. Dynamic Corrosion Rate of Refractories Rotated (at 9 RPM) in Different Iron Phosphate (F40, T111, C112, and TFB) and Borosilicate (DWPF) Melts

(Note: The temperatures at which tests were run are also indicated.)

Although an extensive database exists for FeP glasses, property-compositional models do not exist to provide a parallel analysis as was performed for the AABS glasses. For purposes of estimating the maximum waste loading in this report, compositional parameters (important to the glass-formation 
tendency and chemical durability for an FeP waste form) solubility guidelines, and processing considerations (e.g., viscosity, melt temperature, and corrosion) were used. The compositional parameters and solubility guidelines used were

- $\quad \mathrm{P}_{2} \mathrm{O}_{5}$ content between 42 and 50 mass $\%$

- $\quad \mathrm{Fe}_{2} \mathrm{O}_{3}$ content of at least 20 mass\%, although smaller amounts are permissible when $\mathrm{Al}_{2} \mathrm{O}_{3}, \mathrm{Bi}_{2} \mathrm{O}_{3}$, $\mathrm{La}_{2} \mathrm{O}_{3}, \mathrm{U}_{3} \mathrm{O}_{8}$, and other similar oxides are present

- the percentage of other components should not normally exceed that given as the typical range in Table 4.13

- $\quad$ the $\mathrm{O} / \mathrm{P}$ mole ratio of the final waste form should be in the range 3.4 to 3.8 .

Given that the other compositional parameters are met, when the percentage of a component falls in the typical range in the final waste form, it is considered acceptable.

Table 4.13. General Compositional and Solubility Guidelines for Designing FeP Waste Forms

\begin{tabular}{|c|c|c|}
\hline \multicolumn{3}{|c|}{ Overall O/P Mole Ratio of Waste Form Should Be 3.4 to 3.8} \\
\hline Component / Major & Mass Percent & Comments \\
\hline $\mathrm{Fe}_{2} \mathrm{O}_{3}$ & $20-38^{(\mathrm{a})}$ & Can be below $20 \%$ if alumina is present \\
\hline $\mathrm{P}_{2} \mathrm{O}_{5}$ & $42-50^{(a)}$ & $32-55$ in some cases \\
\hline & & Mass Percent \\
\hline Component / Other & Typical \% & Max \% \\
\hline $\mathrm{Al}_{2} \mathrm{O}_{3}$ & 5 & 10 \\
\hline $\mathrm{Bi}_{2} \mathrm{O}_{3}$ & $3-13$ & 49 \\
\hline $\mathrm{CaF}_{2}$ & 5 & 10 \\
\hline $\mathrm{CaO}$ & $7-10$ & 18 \\
\hline $\mathrm{Cr}_{2} \mathrm{O}_{3}{ }^{(\mathrm{b})}$ & 3 & $?$ \\
\hline $\mathrm{Cs}_{2} \mathrm{O}$ & 20 & 44 \\
\hline $\mathrm{K}_{2} \mathrm{O}$ & $5-10$ & 26 \\
\hline $\mathrm{La}_{2} \mathrm{O}_{3}$ & 3 & $?$ \\
\hline $\mathrm{Mn}_{2} \mathrm{O}_{3}$ & 5 & $?$ \\
\hline $\mathrm{MoO}_{3}$ & $4-8$ & 12 \\
\hline $\mathrm{Na}_{2} \mathrm{O}$ & 10 & 22 \\
\hline $\mathrm{NiO}$ & 6 & $?$ \\
\hline $\mathrm{SiO}_{2}$ & 10 & 20 \\
\hline $\mathrm{U}_{3} \mathrm{O}_{8} / \mathrm{UO}_{2}$ & 12 & 24 \\
\hline $\mathrm{ZrO}_{2}$ & 6 & 13 \\
\hline
\end{tabular}

It is important to understand that the percentages in Table 4.13 were arrived at, not by mathematical modeling, but by reviewing the results for several hundred laboratory-size melts and making a judgment for the "typical" and "maximum" contents that would yield FeP waste forms of acceptable chemical durability. Consequently, the process of arriving at these contents was subjective and was intended to yield conservative values as opposed to overtly optimistic values. In short, the glass compositions shown 
in Table 4.13 are intended to be a guide to what are acceptable contents based upon a fairly extensive amount of data on small, laboratory melts and should not be used as limits.

When used as a general guide, these contents should not be expected to always total $100 \%$. For example, the 44 mass\% maximum for $\mathrm{Cs}_{2} \mathrm{O}$ in Table 4.13 or the 49 mass\% for $\mathrm{Bi}_{2} \mathrm{O}_{3}$ seem inconsistent with the "typical" values for $\mathrm{Fe}_{2} \mathrm{O}_{3}$ and $\mathrm{P}_{2} \mathrm{O}_{5}$ contents at the top of the middle column in Table 4.13. If one takes the values literally, the sum of the three components exceeds $100 \%$. However, as indicated in the comment section (right-hand column), the percentage of $\mathrm{Fe}_{2} \mathrm{O}_{3}$ and phosphate can be outside the "typical" ranges given in Table 4.13. This is true in the case of $\mathrm{Cs}_{2} \mathrm{O}$, where the waste form had an actual composition of $44.5 \mathrm{Cs}_{2} \mathrm{O}, 23.8 \mathrm{Fe}_{2} \mathrm{O}_{3}$ and $31.7 \mathrm{P}_{2} \mathrm{O}_{5}$, mass\%.

The maximum waste loading attainable for each waste cluster has been estimate $\mathrm{d}$, assuming that the final waste form is either completely vitreous or partially crystallized, what is hereafter referred to as glassy or glass-ceramic waste forms (resulting from either a quenched or CCC thermal history), respectively. The terms homogeneous and heterogeneous, respectively, are sometimes used to describe these two types of waste forms. The compositional parameters and the solubility guidelines (see Table 4.13) were used to estimate the maximum waste loading for a glass waste form. Some exceptions, as stated later in this report, have been made in estimating the maximum waste loading for partially crystallized or glassceramic waste forms.

The following factors were assumed in estimating the maximum waste loadings:

- The compositional parameters given in Table 4.13 were satisfied, especially the $\mathrm{O} / \mathrm{P}$ ratio (between 3.4 and 3.8) and the iron and phosphorus oxide contents.

- The waste form would form a glass at normal cooling rates and have an acceptable chemical durability (its dissolution rate in distilled water at $90^{\circ} \mathrm{C}$ would not exceed $7 \cdot 10^{-4} \mathrm{~g} /\left(\mathrm{m}^{2} \cdot \mathrm{d}\right)\left(5 \times 10^{-8}\right.$ $\mathrm{g} / \mathrm{cm}^{2} / \mathrm{min}$ ).

- The typical melting temperature would be $1150^{\circ} \mathrm{C}$ or below, but would not exceed $1200^{\circ} \mathrm{C}$.

- The viscosity of the melt would be low enough that the melt could be poured from a crucible (i.e., less than $10 \mathrm{~Pa} \cdot \mathrm{s})$.

- The melts would not be expected to chemically corrode or attack common glass-melting refractories in an excessive manner.

In many cases, there is a reasonable amount of data that can be used to support the estimates, but in other cases, the data are limited. Furthermore, not all of these assumptions are considered necessarily realistic for FeP waste forms. For example, FeP glasses would likely be processed differently from the way borosilicate glasses are now being processed, so the restrictions on melting temperature and viscosity could change considerably. Nevertheless, the five factors shown above were used to obtain the estimated waste loadings reported in this document.

\subsection{Estimated Waste Loadings}

In this section, we discuss the estimated maximum waste loading for each of the 17 wastes the chemical compositions of which are listed in Table 4.11, the details of waste loading limitations are given in Appendix E. The chemical compositions in Table 4.11 are slightly different from those used to estimate waste loadings for the borosilicate glasses. Most minor components (those below 0.5 mass \%) were omitted for purposes of simplification. None of these simplifications is expected to change the waste loading estimated for each cluster. Because of the uncertainty in waste composition and the 
simplifications made in ignoring minor components, the maximum waste loadings given herein are only estimated to the nearest $\pm 2 \%$.

The nuclear wastes that are best suited for vitrification in FeP melts are those that contain either (a) a high combined $\mathrm{Fe}_{2} \mathrm{O}_{3}$ and phosphate content since these components are needed for high chemical durability $\left(\mathrm{Fe}_{2} \mathrm{O}_{3}\right)$ and for good glass forming tendency (phosphate) or (b) significant amounts of components such as heavy metals (chromium, bismuth, molybdenum, manganese, uranium, zirconium, zinc), noble metals, or other components that are poorly soluble or cause liquid immiscibility in borosilicate glasses.

The extreme right-hand column in Table 4.11 lists the combined percentage of $\mathrm{Fe}_{2} \mathrm{O}_{3}$ and phosphate in each waste. Those wastes containing large percentages of these two components, such as clusters \#15, $\# 11$, \#2, and \#5 (listed in decreasing percentage), are well suited for FeP waste forms since the waste itself supplies all or a large fraction of the components that are required to produce a chemically durable, glass waste form. In other words, the amount of these components that must be added to the waste from external sources is greatly reduced, if not eliminated.

Conversely, those wastes in Table 4.11 that contain only small percentages of these two components, such as \#12 and \#17, are less suitable for FeP glasses since significant amounts of these oxides must be supplied from external sources, thereby, limiting the maximum waste loading. However, there can be other components in these wastes that contain little $\mathrm{Fe}_{2} \mathrm{O}_{3}$ and phosphate that cannot be completely ignored since some of these components could limit the waste loading in other types of glass to such a point that $\mathrm{FeP}$ glasses might have the larger waste loading. For example, silver oxide is so highly soluble in phosphate glasses (up to 40 mass\% silver oxide) that it should never limit the waste loading in phosphate glasses. The amount of silver that can be allowed in AABS glasses without processing problems is currently unknown but expected to be $1 \%$ or less.

The three components in the wastes in Table 4.11 that are considered most important to limiting the waste loading in $\mathrm{FeP}$ waste forms are

- alumina, particularly the high amounts in clusters 2,6 , and 8 ,

- zirconia, particularly the high amounts in clusters 12,13 , and 16

- $\quad$ soda, particularly the high amounts in clusters 10 and 14 .

Alumina and zirconia, while contributing to good chemical durability, tend to increase the melting temperature and promote crystallization. This may not be a detriment if chemically durable, glassceramic waste forms are acceptable. With increasing soda concentration, the chemical durability of the waste form decreases to the point that it eventually becomes a concern, although chemically durable FeP glasses containing 15 to 20 mass $\% \mathrm{Na}_{2} \mathrm{O}$ have been prepared (Day et al. 1998).

As mentioned above, another compositional factor affecting the maximum waste loading in FeP glasses is the combined percentage of $\mathrm{Fe}_{2} \mathrm{O}_{3}$ and phosphate. A low combined percentage of these two oxides in the waste will usually result in a lower maximum waste loading, while a high combined percentage will yield higher maximum waste loading.

None of the other waste components in Table 4.11, such as the oxides of bismuth, calcium, chromium, manganese, rare earths, noble metals, silicon, strontium, thorium, or uranium, are considered critical to the maximum waste loading. Various simulated wastes containing nearly all of these components, either individually or combined, have been vitrified previously in FeP glasses. In many cases, such as for calcium, bismuth, silicon, and uranium oxides, the quantity of these oxides that have been dissolved in FeP glasses (see Table 4.12) is much greater than the amounts shown in Table 4.11. As an example, 
liquid immiscibility is known to form in simple systems containing $\mathrm{SiO}_{2}$ and $\mathrm{P}_{2} \mathrm{O}_{5}$ and may be of concern. Iron phosphate glasses have been used to immobilize simulated wastes that contain relatively high $\mathrm{SiO}_{2}$ concentrations (up to $\sim 35$ mass \% in Tank C-106 waste) without amorphous phase separation on a scale that is detectable under the SEM. Therefore, $\mathrm{SiO}_{2}$ was not considered to be a limiting component for Clusters \#1, \#2, or \#7. However, as the $\mathrm{SiO}_{2}$ concentration increases in a FeP glass, increases in melt temperature can also be expected.

The high solubility of $\mathrm{Cr}_{2} \mathrm{O}_{3}$, relative to the AABS glasses suggests that iron-phosphate glass is insensitive to the chromium leach factor. We saw in Figure 4.7 that as the leach factor is decreased, the AABS glass volume can more than double because the waste loading must decrease to avoid spinel formation. No changes in FeP glass volume estimates are expected from a reduction in leach factor.

Estimated waste loadings for the glassy and glass-ceramic FeP waste forms are presented in Tables 4.14 and 4.16, respectively. For glassy waste forms, the estimated waste loadings in Table 4.14 range from a low of 30 mass $\%$ for the waste in clusters \#12, \#16, and \#17 to a high of 50 mass \% for the waste in clusters \#11 and \#15. The waste form compositions Table 4.14 are expressed in the amounts of $\mathrm{Fe}_{2} \mathrm{O}_{3}$ and $\mathrm{P}_{2} \mathrm{O}_{5}$ that would be added to each waste, in mass\%. These are the only materials to be added to each waste.

Table 4.14. Estimated Maximum Waste Loading for Hanford Nuclear Wastes Assuming Glassy FeP Waste Form

\begin{tabular}{|c|c|c|c|c|}
\hline \multirow{2}{*}{ Cluster \# } & \multicolumn{3}{|c|}{ Nominal Batch Composition } \\
\cline { 2 - 4 } & \multicolumn{2}{|c|}{ Components, mass\% } & \multirow{2}{*}{$\begin{array}{c}\text { O/P } \\
\text { Ratio }\end{array}$} \\
\hline 1 & 35 & 18 & 47 & 3.73 \\
\hline 2 & 40 & 15 & 45 & 3.70 \\
\hline 3 & 35 & 20 & 45 & 3.77 \\
\hline 4 & 40 & 18 & 42 & 3.86 \\
\hline 5 & 43 & 15 & 42 & 3.78 \\
\hline 6 & 40 & 15 & 45 & 3.76 \\
\hline 7 & 35 & 18 & 47 & 3.74 \\
\hline 8 & 35 & 20 & 45 & 3.76 \\
\hline 9 & 35 & 20 & 45 & 3.75 \\
\hline 10 & 40 & 23 & 37 & 3.78 \\
\hline 11 & 50 & 5 & 45 & 3.71 \\
\hline 12 & 30 & 23 & 47 & 3.66 \\
\hline 13 & 32 & 20 & 40 & 3.68 \\
\hline 14 & 35 & 20 & 45 & 3.75 \\
\hline 15 & 50 & 5 & 45 & 3.69 \\
\hline 16 & 30 & 20 & 50 & 3.69 \\
\hline 17 & 30 & 25 & 45 & 3.69 \\
\hline
\end{tabular}

The estimated maximum waste loading for glass-ceramic (crystallized) waste forms are listed in Table 4.15. The maximum waste loading for glass-ceramic waste forms has been estimated based on the experience with other partially crystallized FeP waste forms containing simulated wastes whose compositions are generally similar to some of the wastes listed in Table 4.11. However, there is less certainty in the maximum percentages given for the glass-ceramic waste forms in Table 4.15. These percentages are considered conservative and higher waste loadings are possible, at least in some cases, 
depending upon the nature (durability) of the crystallized phases in the waste form as well as the maximum allowable melting temperature.

The waste loadings in Table 4.15 are for an assumed maximum melting temperature of $1200^{\circ} \mathrm{C}$, but an additional 10 to $15 \%$ waste loading could be accommodated (if a higher melter temperature, up to $1350^{\circ} \mathrm{C}$, was used.

Table 4.15. Estimated Maximum Waste Loading for Hanford Nuclear Wastes, Assuming a Glass-Ceramic FeP Waste Form

\begin{tabular}{|c|c|}
\hline Cluster \# & $\begin{array}{c}\text { Waste } \\
\text { (mass\%) }\end{array}$ \\
\hline 1 & $50-55$ \\
\hline 2 & $55-60$ \\
\hline 3 & 50 \\
\hline 4 & 60 \\
\hline 5 & 65 \\
\hline 6 & $55-60$ \\
\hline 7 & 60 \\
\hline 8 & 55 \\
\hline 9 & 60 \\
\hline 10 & 50 \\
\hline 11 & 70 \\
\hline 12 & 45 \\
\hline 13 & $55-60$ \\
\hline 14 & $50-55$ \\
\hline 15 & $65-70$ \\
\hline 16 & 60 \\
\hline 17 & $50-55$ \\
\hline
\end{tabular}

\subsection{Technical Issues}

Although sound technical research and development was performed over the past decade that addresses FeP glasses for HLW immobilization, technical issues still exist. It should be mentioned that these issues will not stop the proceeding or selection of FeP glasses for immobilizing all or select Hanford clusters. The issues may, however, be used to identify areas where technical risk could be high, resulting in the development of subsequent research and development activities. A brief summary of the technical issues appears below. Additional technical issues of concern include the effect of radiation on durability of FeP glasses, development of surface layers during corrosion and their impact on corrosion, and the lack of field or burial test data. These issues are not specifically called out for the borosilicate glass system since they have been thoroughly addressed by numerous researchers.

\section{(1) Impact of Crystallization on Durability and Radionuclide Partitioning}

Although waste loadings have been estimated for the glass-ceramic waste form, the data appear to be limited to the impacts of the type and extent of crystallization on the performance of the final product. The waste-compliance issues associated with glasses versus glass-ceramics are very different:

- In glass-ceramics, the radionuclide partitioning between the matrix and the crystal must be known and understood given that the repository will require knowledge of which elements are released 
from which phases and at what rates (e.g., which phase or phases govern which radionuclide releases from the final waste package).

- Is the amount of crystallization constant, or can it be controlled so that radionuclide release can be calculated or estimated in a consistent fashion? The final product needs to be consistent so that radionuclide release is "constant" for repository radionuclide migration calculations to be performed.

- Do the radionuclides migrate to the grain boundaries where selective grain boundary dissolution can occur?

Regardless of the base system (e.g., borosilicate, FeP, etc.), the degree of crystallinity and the potential impacts on radiation damage, metamictization, and accelerated grain boundary dissolution associated with glass-ceramic waste forms must be understood. Also, devitrification of the glass in the canister may impact glass cracking, which, in turn, can affect the release from the glass through a change is exposed surface area.

\section{(2) Technical Maturity (i.e., development of integrated flowsheet)}

The United States has essentially no "pilot-scale" data on processing a phosphate-based glass with an integrated flowsheet. However, as discussed previously, the Russians have been using an aluminum phosphate-based glass to immobilize HLW since the late 1980s. Over $10000 \mathrm{~m}^{3}$ of HLW with an approximate total activity of $12 \mathrm{PBq}(325 \mathrm{MCi})$ were vitrified, producing roughly 1740 canisters through 1995 (Aloy et al. 1996). Based on a personal communication with Dr. Albert Aloy, V.G. Khlopin Radium Institute, a new ceramic melter is currently under construction that will also process HLW using a similar aluminum phosphate glass waste form and over $12000 \mathrm{~m}^{3}$ of HLW glass has now been processed at Mayak.

\section{(3) Waste Form Qualification Issues}

If FeP glasses are deemed appropriate to immobilize HLW, to what degree can the waste qualification documentation for borosilicate glasses be used to support qualification of a new glass system? What will be the impacts on cost and schedule?

Other secondary issues that should be considered when assessing FeP as a potential waste form for HLW include the following:

\section{(4) Refractory/Electrode Corrosion}

While K-3 dense zircon (K-3) and high alumina refractories do not appear to corrode in FeP melts (Chen and Day 1999), limited data exist to assess corrosion of electrode materials. However, alternative processing technologies, such as cold-wall induction melting, could eliminate or minimize this issue.

\section{(5) Interactive Effects of Minor Components on Waste Loading}

There are few data on multicomponent interactions and their effect on component solubilities in FeP glasses, i.e. estimates of waste loading are primarily based on individual oxides reaching guideline limits. For example, in the glass-ceramic waste forms, $\mathrm{Cr}_{2} \mathrm{O}_{3}$ levels in glass exceed 5.0 mass $\%$ at the estimated waste loadings. The capability to achieve these high $\mathrm{Cr}_{2} \mathrm{O}_{3}$ solubilities in the presence of other components needs to be determined. 


\subsection{SYNROC-Type Waste Forms}

Distinct titanate-based ceramic formulations have been developed for a range of radioactive wastes; however; for HLW immobilization, the principal formulation is SYNROC. , Designed to contain about 20 mass\% HLW calcine (Lutze and Ewing 1988), SYNROC is a polyphase, fine-grained $(\leq 1 \mu \mathrm{m})$ titanate-based ceramic compromising the following major phases: zirconolite $\mathrm{CaZrTi}_{2} \mathrm{O}_{7}$ (ca. 30 mass\%), perovskite $\mathrm{CaTiO}_{3}$ (ca. 20 mass\%), hollandite $\mathrm{Ba}\left(\mathrm{Al}, \mathrm{Ti}_{2}\right)_{2} \mathrm{Ti}_{6} \mathrm{O}_{16}$ (ca. 30 mass\%), and titanium oxides $\mathrm{Ti}_{\mathrm{n}} \mathrm{O}_{2 \mathrm{n}-1}$ (ca. 15 mass\%). Additional minor phases are also present mainly as complex oxides, aluminates, and metallic alloys (ruthenium, molybdenum, technetium, palladium, iron, nickel, chromium, and phosphorus). The conventional fabrication process consists of mixing the high-level waste solution with ceramic precursors, drying, calcining $\left(750^{\circ} \mathrm{C}\right.$ for 1 to 2 hours), and hot-pressing/sintering (between 1150 and $1200^{\circ} \mathrm{C}$ at 14 to $20 \mathrm{MPa}$ ). The process was initially developed to condition fission product solutions generated from the reprocessing spent fuel from commercial reactors (Ringwood et al. 1979a); however, this type of nuclear waste is now being incorporated into borosilicate glasses (Cheron et al. 1995). Several laboratories are now investigating the feasibility of using the titanate-based ceramic waste forms (primarily pyrochlore and zirconolite) to incorporate substantial quantities of actinides.

Recent advances in melter technology (e.g., cold crucible melters) make it possible to produce SYNROC from a melt. Recent demonstrations by the French (Advocat et al. 1997, 1998, and 2000 ${ }^{8}$ ) and the Russians (Lifanov et al. 1995) provide insight into the use of induction melters to process titanate-based ceramic waste forms. This alternative fabrication process is based on high-temperature melting of oxide mixtures at 1450 to $1700^{\circ} \mathrm{C}$ for several hours, usually in a cold crucible melter, followed by controlled cooling to obtain either a ceramic or glass-ceramic waste form. This is not a new idea (Ringwood 1978; Pentinghaus ${ }^{9}$ ). However, it was not until the recent development of melting processes capable of withstanding these high temperatures, e.g. cold crucible melters or induction-heated cold crucible melters (ICCM) that the first real demonstration of a controlled melting process producing these types of waste forms was realized (Lifanov et al. 1995; Advocat et al. 1997).

Lifanov et al. (1995) performed some of the initial tests with this advanced melter technology. A SYNROC composition (shown in Table 4.16) was melted with oxides and nitrates under oxidizing and reducing conditions at temperatures between 1320 and $1700^{\circ} \mathrm{C}$, depending on the operating frequency and crucible dimensions. Products were formed via quenching and slow controlled cooling from the melt. A more dense waste form was obtained by quenching from the melt and the crystal size was smaller, on the order of a few micrometers. Based on x-ray diffraction (XRD) analysis, the waste forms produced under oxidizing conditions consisted of zirconolite, hollandite, perovskite, rutile (minor) and powellite (minor). The formation of powellite (a calcium molybdate containing both strontium and cesium) is undesirable because of its low chemical durability. The waste forms produced under reducing conditions contained the same mineral assemblage absent the powellite. It was noted that although the waste form produced was undoubtedly related to a SYNROC-type waste form, there were some differences, primarily associated with the mineral assemblage (e.g., a distribution of crystal sizes throughout the waste form as a result of differential cooling; formation of cavities due to differential thermal expansion/shrinkage).

\footnotetext{
${ }^{8}$ Currently in press. Advocat, T, PJ McGlinn, C Fillet, G Leturcq, S Schuller, A Bonnetier, and K Hart. 2000.

"Melted Synthetic Zirconolite-Based Matrices: Effect of Cooling Rate and Heat Treatment on Ceramic Microstructure and Chemical Durability." In Proceedings of the Materials Research Society Symposium, Scientific Basis for Nuclear Waste Management, pp. 55-62. Materials Research Society, Pittsburgh, Pennsylvania.

${ }^{9}$ Presentation by H. Pentinghaus, entitled "To SYNROC Through Melting," at the International Seminar on HighLevel Liquid Waste Solidification in Julich, Germany, dated June 1981.
} 
Table 4.16. Composition of SYNROC Type Waste Form

\begin{tabular}{|l|l|}
\hline Oxide & Mass\% \\
\hline $\mathrm{Cs}_{2} \mathrm{O}$ & 0.8 \\
\hline $\mathrm{SrO}$ & 0.6 \\
\hline $\mathrm{CaO}$ & 13.5 \\
\hline $\mathrm{BaO}$ & 6.1 \\
\hline $\mathrm{FeO}$ & 1.0 \\
\hline $\mathrm{NiO}$ & 0.3 \\
\hline $\mathrm{Al}_{2} \mathrm{O}_{3}$ & 6.1 \\
\hline $\mathrm{Nd}_{2} \mathrm{O}_{3}$ & 2.8 \\
\hline $\mathrm{Eu}_{2} \mathrm{O}_{3}$ & 0.4 \\
\hline $\mathrm{CeO}_{2}$ & 1.0 \\
\hline $\mathrm{MoO}_{2}$ & 1.6 \\
\hline $\mathrm{TiO}_{2}$ & 54.6 \\
\hline $\mathrm{ZrO}_{2}$ & 11.1 \\
\hline
\end{tabular}

Advocat et al. (1998) assessed the potential to produce neodymium-doped zirconolite materials by two high-temperature melting processes. The initial process involved devitrification of an aluminosilicate parent glass containing titanium, zirconium, and neodymium oxides, yielding a glass-ceramic compromising submicrometer zirconolite needles embedded in a silica-rich matrix. This glass-ceramic waste form was fabricated by melting a mixture of $\mathrm{SiO}_{2}, \mathrm{Al}_{2} \mathrm{O}_{3}, \mathrm{CaO}, \mathrm{ZrO}_{2}, \mathrm{TiO}_{2}$, and $\mathrm{Nd}_{2} \mathrm{O}_{3}($ see Table 4.17 ) at $1450^{\circ} \mathrm{C}$ in an alumina crucible for 2 hours, followed by quenching in air. Devitrification of the parent glass was obtained by isothermal treatment for 2 hours at $1050^{\circ} \mathrm{C}$. Scanning electron microscopy and XRD analyses indicated that zirconolite precipitated in the form of fine needles. The residual glass phase was enriched in silicon and aluminum, while titanium and zirconium were primarily found in the crystalline phases. Calcium was distributed throughout the crystalline and residual glass phases, with neodymium (simulating the actinide waste form) appearing to be incorporated mainly in the crystalline phase. The use of a glass-ceramic material for radionuclide disposal is based on a double containment principle. The primary containment is within a stable crystalline phase (zirconolite) with good resistance to leaching and radiation damage, and the secondary containment being an inherently durable glass phase containing few or no radioactive elements.

Table 4.17. Target Composition (mass\%) of Zirconolite Glass-Ceramic and Ceramic

\begin{tabular}{|c|c|c|}
\hline Oxide & Glass-Ceramic & Ceramic \\
\hline $\mathrm{SiO}_{2}$ & 40.75 & - \\
\hline $\mathrm{Al}_{2} \mathrm{O}_{3}$ & 12.00 & 7.86 \\
\hline $\mathrm{CaO}$ & 19.72 & 5.77 \\
\hline $\mathrm{ZrO}_{2}$ & 8.50 & 31.67 \\
\hline $\mathrm{TiO}_{2}$ & 12.51 & 28.75 \\
\hline $\mathrm{Nd}_{2} \mathrm{O}_{3}$ & 6.52 & 25.95 \\
\hline
\end{tabular}

The second process consisted of melting an oxide mixture with the stoichiometry of a highly neodymiumenriched zirconolite $\left(\mathrm{Ca}_{0.4} \mathrm{Nd}_{0.6} \mathrm{ZrTi}_{1.4} \mathrm{Al}_{0.6} \mathrm{O}_{7}\right)$, then quickly cooling the melt to produce a ceramic rich in zirconolite crystals several hundred micrometers long containing a large fraction of the initial neodymium. The oxide mixture (see Table 4.17 for target composition) was melted in an ICCM with an inside diameter of $80 \mathrm{~mm}$, coupled to a $3.7-\mathrm{MHz}$ generator. The mixture was melted at approximately $1600^{\circ} \mathrm{C}$ for 1 hour. The melt was poured and quickly cooled to produce a light pink ingot $80 \mathrm{~mm}$ in 
diameter and $60 \mathrm{~mm}$ high. Analyses with XRD and SEM indicated the presence of three crystalline phases: zirconolite (the primary phase), perovskite, and a mixed titanium-aluminum oxide $\left(\mathrm{Al}_{2} \mathrm{TiO}_{5}\right)$. A number of small low-intensity peaks could not be assigned to any phase.

Advocat et al. (1998) demonstrated that neodymium-enriched zirconolite could be synthesized by two different processes initially involving high-temperature melting in air. The presence of a single phase (zirconolite) in the glass-ceramic was a major difference with respect to traditional zirconium-based titanate ceramics. Although zirconolite was the major phase in the ceramic, perovskite and the mixed titanium-aluminum oxide were also present. Another significant difference between the two materials was the crystal size. In the glass-ceramic, zirconolite was found as fine, submicrometer needles, whereas in the ceramic, massive strips of zirconolite several hundred micrometers long were found. Heat treatment of the aluminosilicate melt to produced the glass-ceramic at $1050^{\circ} \mathrm{C}$ and allowed for controlled crystal growth through solid-state diffusion. In the zirconium titanate-based ceramic, zirconolite crystallization occurred more quickly but from a higher temperature melt and one that more closely approximated the desired composition. The third major difference in the zirconium titanate ceramic was the presence of microcracksthat were pervasive and primarily related to crystal size and thermal history.

Advocat et. al (2000) ${ }^{10}$ also indicated that heat treatment conditions (in particular the controlled cooling) are key factors in fabricating zirconolite ceramics and glass-ceramics following high-temperature melting. Similar to the work performed in 1998, both glass-ceramic and ceramic waste forms were produced. The major difference between the two studies was the heat treatment temperature used for the glass-ceramics. Previously, tests with only neodymium-based zirconolite glass-ceramics were processed at $1450^{\circ} \mathrm{C}$ and heat treated at $1050^{\circ} \mathrm{C}$ to precipitate zirconolite from the parent glass. This produced fine-grained zirconolite crystals with minor phases such as sphene. Advocat et al (2000) used a heat treatment temperature of $1200^{\circ} \mathrm{C}$ for 12 hours that was determined to be "the optimum conditions for obtaining the desired crystalline phase on cooling of the melt."

Table 4.18 compares the target compositions (mass\%) of the glass-ceramics and ceramic waste forms processing with high-temperature melting with that of the traditional sintered ceramic. Two zirconolite glass-ceramics containing either neodymium or cerium as the surrogate for actinides were produced. These waste forms were processed at $1450^{\circ} \mathrm{C}$ and were subsequently heat treated at $1200^{\circ} \mathrm{C}$ for 12 hours to precipitate zirconolite from the parent glass. This resulted in zirconolite needles 10 to 100 micrometers in length. Table 4.19 summarizes the compositions of the residual glass and zirconolite crystals from the $\mathrm{Nd}_{2} \mathrm{O}_{3}$ - and $\mathrm{Ce}_{2} \mathrm{O}_{3}$-based waste forms. The residual glass matrix is rich in $\mathrm{SiO}_{2}$ and $\mathrm{Al}_{2} \mathrm{O}_{3}$, while the zirconolite crystals contained $\mathrm{TiO}_{2}$ and $\mathrm{ZrO}_{2}$. Note that $\mathrm{Nd}_{2} \mathrm{O}_{3}$ and $\mathrm{Ce}_{2} \mathrm{O}_{3}$ were essentially evenly distributed between the residual glass matrix and the zirconolite crystals.

\footnotetext{
${ }^{10}$ Currently in press. Advocat, T, PJ McGlinn, C Fillet, G Leturcq, S Schuller, A Bonnetier, and K Hart. 2000.

"Melted Synthetic Zirconolite-Based Matrices: Effect of Cooling Rate and Heat Treatment on Ceramic Microstructure and Chemical Durability." In Proceedings of the Materials Research Society Symposium, Scientific Basis for Nuclear Waste Management, pp. 55-62. Materials Research Society, Pittsburgh, Pennsylvania.
} 
Table 4.18. Chemical Compositions (mass\%) of Glass-Ceramics and Zirconolite Ceramics Fabricated by Melting and by Sintering.

\begin{tabular}{|c|c|c|c|c|c|c|c|c|c|}
\hline \multirow[t]{2}{*}{ Oxide } & \multicolumn{2}{|c|}{$\begin{array}{l}\text { Melted Glass- } \\
\text { Ceramic }\end{array}$} & \multicolumn{6}{|c|}{ Melted Zirconolite Ceramic } & \multirow{2}{*}{$\begin{array}{c}\text { Sintered } \\
\text { Ceramic }\end{array}$} \\
\hline & GC1 & GC2 & Z1 & $\mathrm{Z} 2$ & Z3 & $\mathrm{Z4}$ & Z5 & Z6 & \\
\hline $\mathrm{SiO}_{2}$ & 40.8 & 40.8 & - & - & - & - & - & - & - \\
\hline $\mathrm{TiO}_{2}$ & 12.5 & 12.5 & 28.8 & 41.3 & 43.1 & 41.2 & 43.3 & 46.3 & 41.3 \\
\hline $\mathrm{ZrO}_{2}$ & 8.5 & 8.5 & 31.7 & 32.2 & 29.3 & 32.1 & 29.3 & 34.3 & 32.2 \\
\hline $\mathrm{CaO}$ & 19.7 & 19.7 & 5.8 & 12.5 & 13.0 & 12.4 & 13.1 & 16.3 & 12.5 \\
\hline $\mathrm{Al}_{2} \mathrm{O}_{3}$ & 12.0 & 12.0 & 7.9 & 2.0 & 2.1 & 2.0 & 1.7 & - & 2.0 \\
\hline $\mathrm{Nd}_{2} \mathrm{O}_{3}$ & 6.5 & - & 26.0 & 4.7 & - & 10.7 & 4.9 & - & 4.7 \\
\hline $\mathrm{Ce}_{2} \mathrm{O}_{3}$ & - & 6.5 & - & 4.6 & 11.0 & - & 4.8 & - & 4.6 \\
\hline $\mathrm{Gd}_{2} \mathrm{O}_{3}$ & - & - & - & 1.5 & 1.6 & 1.5 & 1.6 & - & 1.5 \\
\hline $\mathrm{La}_{2} \mathrm{O}_{3}$ & - & - & - & 1.4 & - & - & 1.4 & - & 1.4 \\
\hline $\mathrm{ThO}_{2}$ & - & - & - & - & - & - & - & 3.3 & - \\
\hline Total & 100.00 & 100.00 & 100.00 & 100.00 & 100.00 & 100.00 & 100.00 & 100.00 & 100.00 \\
\hline
\end{tabular}

Table 4.19. Chemical Compositions (mass\%) of the Zirconolite Crystalline Phase and the Residual Glass Phase of Zirconolite Glass-Ceramics.

\begin{tabular}{|c|c|c|c|c|}
\hline Oxide & $\begin{array}{c}\mathbf{G C}_{\mathbf{1}} \text { residual } \\
\text { glass }\end{array}$ & $\begin{array}{c}\mathbf{G C}_{\mathbf{1}} \text { zirconolite } \\
\text { needles }\end{array}$ & $\begin{array}{c}\mathbf{G C}_{2} \text { residual } \\
\text { glass }\end{array}$ & $\begin{array}{c}\mathbf{G C}_{2} \text { zirconolite } \\
\text { needles }\end{array}$ \\
\hline $\mathrm{SiO}_{2}$ & 47.2 & 0.8 & 47.0 & 0.9 \\
\hline $\mathrm{TiO}_{2}$ & 7.7 & 39.8 & 9.8 & 43.3 \\
\hline $\mathrm{ZrO}_{2}$ & 4.0 & 36.1 & 3.2 & 34.3 \\
\hline $\mathrm{CaO}$ & 21.0 & 12.7 & 19.9 & 14.0 \\
\hline $\mathrm{Al}_{2} \mathrm{O}_{3}$ & 13.7 & 2.1 & 11.5 & 1.8 \\
\hline $\mathrm{Nd}_{2} \mathrm{O}_{3}$ & 6.4 & 8.6 & - & - \\
\hline $\mathrm{Ce}_{2} \mathrm{O}_{3}$ & - & - & 8.6 & 5.8 \\
\hline
\end{tabular}

The ceramic waste forms were processed in the ICCM at temperatures between $1600^{\circ}$ and $1700^{\circ} \mathrm{C}$. After a 2-hour residence time, an initial series of melts $\left(Z_{2}, Z_{4}\right.$, and $Z_{6}$ in Table 4.18) were cooled at a high rate $\left(>100^{\circ} \mathrm{C} / \mathrm{min}\right)$, while the second series of melts $\left(Z_{1}, Z_{3}\right.$, and $Z_{5}$ in Table 4.18$)$ were cooled at a slower rate $\left(<25^{\circ} \mathrm{C} / \mathrm{min}\right)$. Five major phases were systematically observed in the melted and cooled ceramics with $\mathrm{XRD}$ and SEM analyses: zirconolite-enriched kernels (tazheranite, $\left.(\mathrm{Zr}, \mathrm{Ca}, \mathrm{Ti}) \mathrm{O}_{2}\right)$; calzirtite $\left(\mathrm{Ca}_{2} \mathrm{Zr}_{5} \mathrm{Ti}_{2} \mathrm{O}_{16}\right)$; zirconolite; perovskite; and titanium-aluminum oxide. The zirconia-enriched kernels were located in the zirconolite crystals and mainly formed after high-cooling rates. The aqueous leaching behavior, considered in terms of the evolution of the alteration kinetics with the reaction progress, was comparable to that observed with sintered zirconolite ceramics fabricated with traditional processes.

In summary, recent advances in melter technology (e.g., cold crucible melters) make melters viable equipment for the production of SYNROC. Recent work by the French (Advocat et al. 1997, 1998, and $2000^{11}$ ) and the Russians (Lifanov et al. 1995) provide insight into the use of the induction melters to

\footnotetext{
${ }^{11}$ Currently in press. Advocat, T, PJ McGlinn, C Fillet, G Leturcq, S Schuller, A Bonnetier, and K Hart. 2000. "Melted Synthetic Zirconolite-Based Matrices: Effect of Cooling Rate and Heat Treatment on Ceramic Microstructure and Chemical Durability." In Proceedings of the Materials Research Society Symposium, Scientific Basis for Nuclear Waste Management, pp. 55-62. Materials Research Society, Pittsburgh, Pennsylvania.
} 
process titanate-based ceramic waste forms. This alternative fabrication process of titanate-based ceramics is based on high-temperature melting of oxide mixtures at 1450 to $1700^{\circ} \mathrm{C}$ for several hours followed by controlled cooling to obtain either a ceramic or glass-ceramic waste form.

Although a brief review of the literature is provided, waste-loading estimates for the 17 clusters with this particular waste form were not attempted. The restriction that the waste form must be processed through a melter does limit the available data from which estimates could be made. That is, review of the literature indicates that limited research has been performed with the advanced melter technologies to process titanate-based ceramics but the focus has been on compositions suited for immobilization of actinide-bearing waste streams. This is understandable given the relatively high solubility of actinide and lanthanide oxides in the titanate-based ceramics. Given the compositional complexity of the 17 Hanford waste clusters, projecting waste loadings for the titanate-based ceramics is meaningless.

\subsection{Comparison of Waste Forms}

An evaluation of four waste forms (AABS glasses, AAS glasses, FeP glasses, and crystalline titanates) was performed to differing extents. The knowledge base differed significantly for these four selected waste forms, and glass volume estimates were made for only two of them (AABS and FeP glasses). A comparison between the glass volumes is made in Section 4.12.1, followed by a comparison of the state of knowledge and recommendations in Section 4.12.2.

\subsubsection{Comparative Table of Glass Volumes from Different Waste Types}

The mass average waste loadings for AABS and FeP glasses are summarized in Table 4.20. Figure 4.17 shows a plot of these waste loadings. Since each cluster contains a different mass of waste, and the density between AABS and FeP glasses are so different $\left(2.73 \mathrm{~g} / \mathrm{cm}^{3}\right.$ for the reference case AABS versus $\sim 3.1 \mathrm{~g} / \mathrm{cm}^{3}$ for FeP glasses), it is more useful to consider the volume of waste form or number of waste form canisters for each cluster. Table 4.21 summarizes the estimated canister counts for calcined waste (assuming a density of $3.16 \mathrm{~g} / \mathrm{cm}^{3}$ and $78 \%$ packing efficiency) ${ }^{12}$ and AABS and FeP glasses, while Figure 4.18 shows a plot of these glass volumes.

Although the total volume of FeP glass is higher than that of the reference AABS glass, there are a number of clusters for which FeP has lower glass volume (shown in Table 4.22 as positive values). One could conceive of a hybrid case in which the waste form could vary between FeP and AABS glass so that the lowest glass volume would be produced for each cluster. This would result in 8077 canisters, compared to 9090 and 8452 for FeP and AABS glasses alone (assuming the reference case AABS constraints). It isn't clear if such a hybrid case can actually be implemented at Hanford since there would be a heel of either glass in the melter at the end of a campaign, $\mathrm{P}_{2} \mathrm{O}_{5}$ is sparsely soluble in AABS glass, and $\mathrm{SiO}_{2}$ is sparsely soluble in $\mathrm{FeP}$ glass. Therefore, either the melter volume would need to be largely empty upon switching between the two forms, or a multiphase waste form would be produced as the two forms are mixed in the melter during each transition.

The total waste volume is listed in Table 4.21 as an indication of the minimum volume that could be produced by any waste form without further separations. The actual calcined wastes will neither be processable without additives to reduce gumming nor functional as a significant barrier to the release of

\footnotetext{
${ }^{12}$ A simulated Hanford HLW was heat-treated at $1450^{\circ} \mathrm{C}$ for 45 minutes with no change to batch powder, so the temperature was increased to $1600^{\circ} \mathrm{C}$ for 1 hour. The resulting material was found to be granular with an apparent density (measured with gas pycnometry) of $3.16 \mathrm{~g} / \mathrm{cm}^{3}$. The form was leached in deionized water at $90^{\circ} \mathrm{C}$. This resulted in $\sim 40 \%$ of all alkali in solution after 1 day. For the purposes of this study, the Study Team assumes that Hanford waste on average will have the same sintered density.
} 
hazardous and radioactive constituents. Nevertheless, it does point to a waste form volume that likely cannot be improved upon with any technology.

Table 4.20. Waste Mass and Mass\% Waste Loading for Selected Waste Forms by Cluster

\begin{tabular}{|c|c|c|c|c|c|c|}
\hline & & & \multicolumn{5}{|c|}{ Waste Loading (mass\%) } \\
\cline { 5 - 8 } & Waste & & \multicolumn{5}{|c|}{$\begin{array}{c}\text { AABS } \\
\text { Cass } \\
\text { Cluster }\end{array}$} & $\begin{array}{c}\text { FeP } \\
\text { Glass }\end{array}$ & $\begin{array}{c}\text { FeP Glass } \\
\text { Ceramic }\end{array}$ & $\begin{array}{c}\text { AABS Glass } \\
\text { Minimum }\end{array}$ & $\begin{array}{c}\text { AABS Glass } \\
\text { Max }\end{array}$ & $\begin{array}{c}\text { Glass } \\
\text { Reference }\end{array}$ \\
\hline 1 & 2349 & 35 & $50-55$ & 54.1 & 62.9 & 54.1 \\
\hline 2 & 1749 & 40 & $55-60$ & 54.6 & 57.3 & 54.6 \\
\hline 3 & 1647 & 35 & 50 & 29.6 & 59.6 & 43.2 \\
\hline 4 & 1395 & 40 & 60 & 38.2 & 60.5 & 44.6 \\
\hline 5 & 1384 & 43 & 65 & 48.0 & 54.8 & 48.0 \\
\hline 6 & 947 & 40 & $55-60$ & 36.8 & 54.6 & 41.4 \\
\hline 7 & 678 & 35 & 60 & 24.7 & 69.8 & 49.5 \\
\hline 8 & 506 & 35 & 55 & 20.0 & 39.9 & 39.0 \\
\hline 9 & 426 & 35 & 60 & 47.9 & 65.8 & 49.9 \\
\hline 10 & 232 & 40 & 50 & 37.0 & 52.2 & 37.0 \\
\hline 11 & 216 & 50 & 70 & 43.8 & 63.5 & 43.8 \\
\hline 12 & 175 & 30 & 45 & 43.6 & 48.3 & 43.6 \\
\hline 13 & 171 & 32 & $55-60$ & 39.2 & 73.2 & 39.2 \\
\hline 14 & 150 & 35 & $50-55$ & 11.8 & 35.3 & 23.5 \\
\hline 15 & 142 & 50 & $65-70$ & 35.8 & 56.1 & 35.8 \\
\hline 16 & 128 & 30 & 60 & 50.2 & 67.5 & 50.2 \\
\hline 17 & 19 & 30 & $50-55$ & 16.7 & 76.9 & 16.7 \\
\hline Total & 12314 & 38 & 58 & 38.1 & 55.9 & 46.4 \\
\hline & & & & & & \\
\hline
\end{tabular}




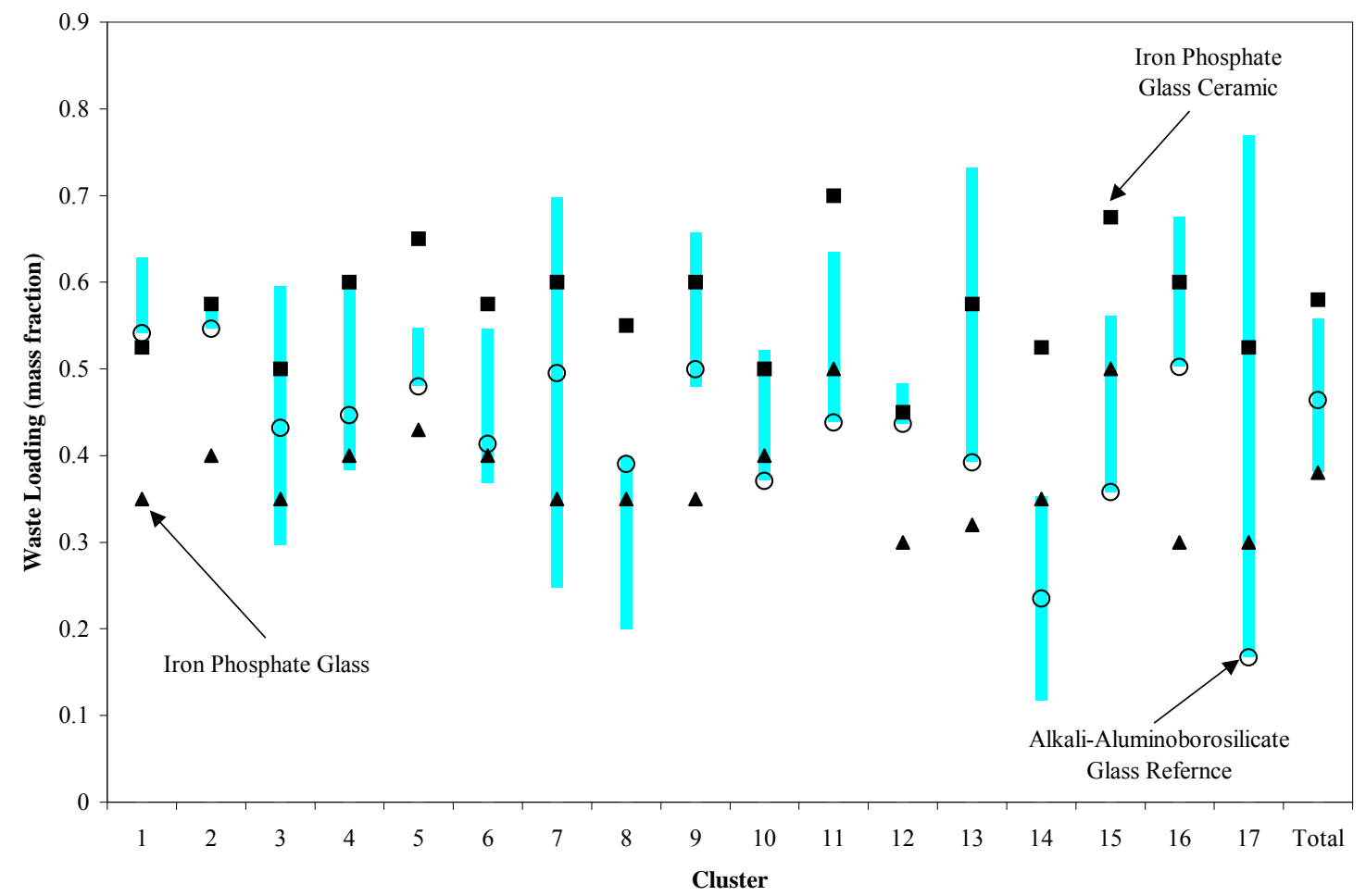

Figure 4.17. Comparison of Waste Loading for Selected Waste Forms by Cluster (Bars Represent the Range of Waste Loadings for AABS Glasses from the 21 Cases, Circles Represent the AABS Reference Case, Squares Represent FeP Glass Ceramics, and Triangles Represent FeP Glass)

Table 4.21 Estimated Volumes of Waste and Waste Forms by Cluster in Canisters $\left(1.15 \mathrm{~m}^{3}\right.$ each)

\begin{tabular}{|c|c|c|c|c|c|c|}
\hline & \multicolumn{7}{|c|}{ Canisters of Waste Form } \\
\hline $\begin{array}{c}\text { Cluster } \\
\#\end{array}$ & $\begin{array}{c}\text { Calcined } \\
\text { Waste }\end{array}$ & $\begin{array}{c}\text { FeP } \\
\text { Glass }\end{array}$ & $\begin{array}{c}\text { CeP Glass } \\
\text { Ceramic }\end{array}$ & $\begin{array}{c}\text { Minimum } \\
\text { Minims }\end{array}$ & $\begin{array}{c}\text { Max Glass } \\
\text { AaBS Glass }\end{array}$ & Reference \\
\hline 1 & 829 & 1883 & 1255 & 1181 & 1402 & 1402 \\
\hline 2 & 617 & 1226 & 853 & 922 & 983 & 977 \\
\hline 3 & 581 & 1320 & 924 & 841 & 1836 & 1214 \\
\hline 4 & 492 & 978 & 652 & 708 & 1184 & 997 \\
\hline 5 & 488 & 903 & 597 & 773 & 904 & 904 \\
\hline 6 & 334 & 664 & 462 & 558 & 853 & 756 \\
\hline 7 & 239 & 543 & 317 & 315 & 949 & 454 \\
\hline 8 & 179 & 406 & 258 & 415 & 877 & 429 \\
\hline 9 & 150 & 341 & 199 & 177 & 261 & 250 \\
\hline 10 & 82 & 163 & 130 & 138 & 207 & 205 \\
\hline 11 & 76 & 121 & 87 & 98 & 158 & 152 \\
\hline 12 & 62 & 164 & 109 & 109 & 125 & 125 \\
\hline 13 & 60 & 150 & 84 & 60 & 135 & 129 \\
\hline 14 & 53 & 120 & 80 & 140 & 450 & 220 \\
\hline 15 & 50 & 80 & 59 & 73 & 125 & 125 \\
\hline 16 & 45 & 120 & 60 & 51 & 75 & 75 \\
\hline 17 & 7 & 18 & 10 & 6 & 39 & 39 \\
\hline Total & 4344 & 9090 & 5956 & 6812 & 10531 & 8452 \\
\hline
\end{tabular}




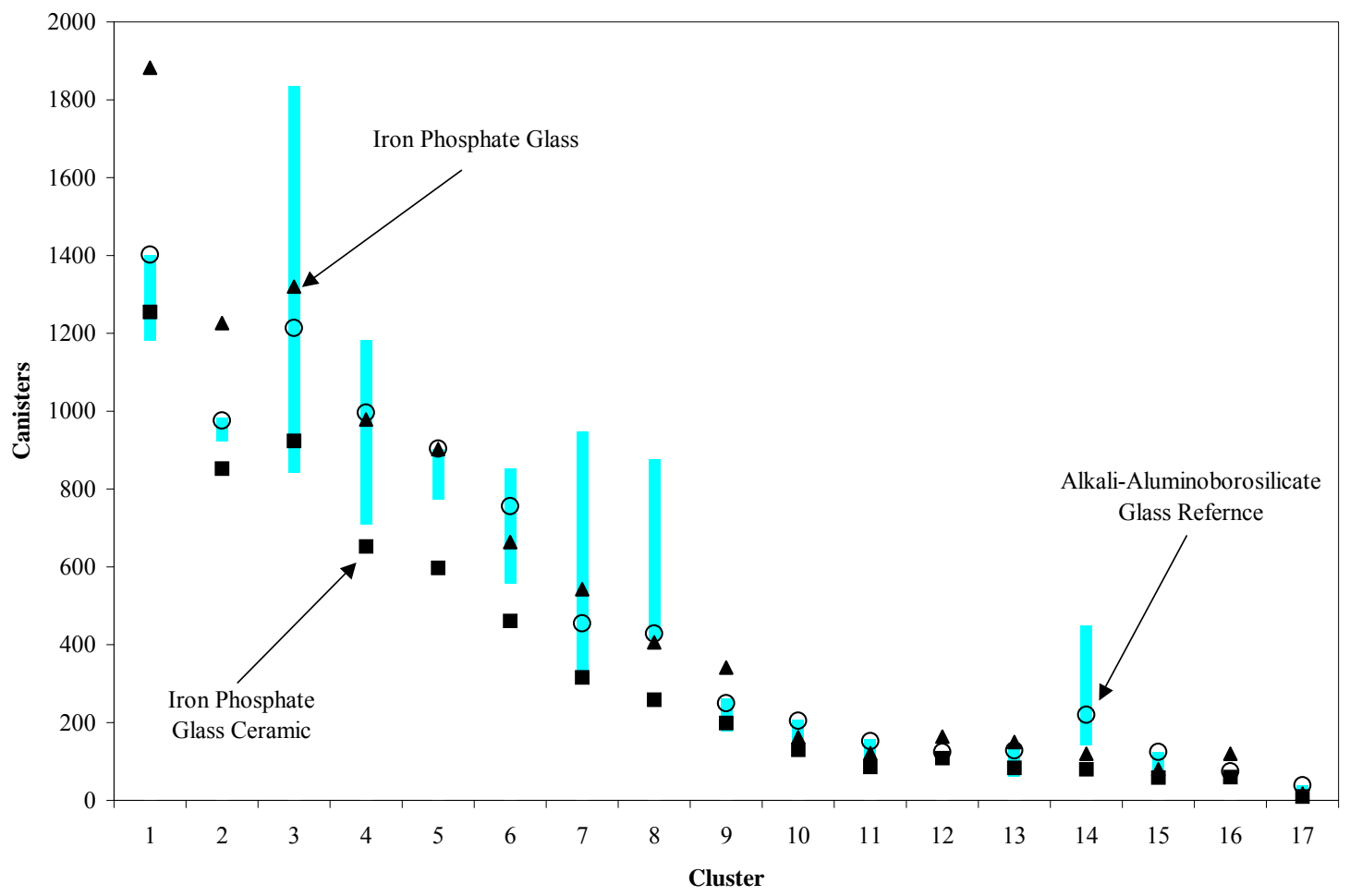

Figure 4.18. Comparison of Estimated Waste Form Volume (in Canisters at $1.1 \mathrm{~m}^{3}$ each) Selected by Cluster (Bars Represent the Range of Waste Loadings for AABS Glasses from the 21 Cases, Circles Represent the AABS Reference Case, Squares Represent FeP Glass Ceramics, and Triangles Represent FeP Glass)

Table 4.22 shows the current schedule for waste feeds to be delivered by cluster, along with the range of estimated AABS glass canister and differences between AABS and FeP estimated canisters. For the first 18 feeds (listed in bold), it will be difficult to develop new technologies in time to be implemented, while later feeds have a better chance of taking advantage of technology development efforts. For the total range of AABS glass canisters of nearly 4000 canisters, only about 300 are within the first 18 feed batches. These clusters are primarily limited by model validity constraints and $T_{L}$. 
Table 4.22. Comparison of Range of AABS Glass Canisters, Differences Between AABS and FeP Glass Canisters and Schedule for Feed Delivery by Cluster (the $1^{\text {st }} 18$ Feeds in Bold)

\begin{tabular}{|c|c|c|c|}
\hline Cluster & Waste Feed Schedule & Max-Min (AABS) & AABS-FeP \\
\hline 1 & $69-78,84,85$ & 221 & -481 \\
\hline 2 & $56-58,79-83,88$ & 61 & -250 \\
\hline 3 & $35-37,39-45,89$ & 994 & -106 \\
\hline 4 & $38,46,47,54,55,63,64,68$ & 475 & 19 \\
\hline 5 & $51-53,61,62,66,67$ & 131 & 1 \\
\hline 6 & $59,60,65,86,87$ & 295 & 92 \\
\hline 7 & $31-34$ & 634 & -89 \\
\hline 8 & $48-50$ & 462 & 23 \\
\hline 9 & $19-24$ & 84 & -92 \\
\hline $\mathbf{1 0}$ & $\mathbf{1 3 - 1 7}$ & $\mathbf{6 9}$ & $\mathbf{4 3}$ \\
\hline $\mathbf{1 1}$ & $\mathbf{3 - 6}$ & $\mathbf{6 0}$ & $\mathbf{3 1}$ \\
\hline 12 & $26-29$ & 16 & -39 \\
\hline $\mathbf{1 3}$ & $\mathbf{1 0 - 1 2}$ & $\mathbf{7 5}$ & $\mathbf{- 2 1}$ \\
\hline 14 & 25,30 & 310 & 100 \\
\hline $\mathbf{1 5}$ & $\mathbf{1 , 2}$ & $\mathbf{5 2}$ & $\mathbf{4 6}$ \\
\hline $\mathbf{1 6}$ & $\mathbf{7 - 9}$ & $\mathbf{2 3}$ & $\mathbf{- 4 6}$ \\
\hline $\mathbf{1 7}$ & $\mathbf{1 8}$ & $\mathbf{3 3}$ & $\mathbf{2 1}$ \\
\hline
\end{tabular}

\subsection{Comparison of the Certainty of Waste Loading Assessment/Knowledge Base}

\subsubsection{Alkali-Alumino-Borosilicate Glass Reference Case}

The knowledge base for the reference case AABS glass is clearly the greatest of any waste form evaluated in this study. Accurate assessments of glass volume were calculated for this reference case. It is the expectation of the Study Team that the baseline plant could successfully operate with this reference case AABS glass with no development past that in the current WTP technology development plan. However, significant increases in waste loading (or reduction in glass volume) can likely be achieved with further glass testing and model development as estimated by the removal of model validity constraints in Section 4.6.4. These improvements could be made in time for the first 18 wastes feeds that are primarily limited by model validity and $T_{L}$ constraints.

\subsubsection{Alkali-Alumino-Borosilicate Glass with Crystals in the Melter}

The knowledge base for AABS glasses with crystals is slightly less developed than the reference case and the melter technology will likely require development. It is the opinion of the Study Team that an AABS glass with crystals has the best chance of making a large impact on glass volume and, therefore, cleanup costs at Hanford. There are two possible avenues to pursue with these glasses: 1) obtaining a better understanding of the formation of crystals, their settling behavior, and their impacts on melter 
processability (see Schill et al. ${ }^{13}$ or Matyáš et al. ${ }^{14}$ for more detailed discussion on the related technical issues) and 2) development of advanced melter systems with higher tolerance for crystals.

\subsubsection{Alkali-Alumino-Borosilicate Glass with Multiple Phases in the Canister}

The knowledge base for AABS glasses with crystalline or amorphous phase separation upon canister cooling is strongly dependent on the phases that forms. The different possible phases can be divided into two general classes: 1) those phases for which there is little impact, and 2) those phases for which there is a significant impact.

The presence of silica rich immiscible phases in the glass does not appear to result any reduction in waste volume and these phases are not discussed further in this document. The formation of a phosphate rich immiscible phase, likely to occur with $\mathrm{P}_{2} \mathrm{O}_{5}$ concentrations greater than 2.5 mass $\%$, was predicted for some clusters under some conditions. However, those clusters that were limited by the $\mathrm{P}_{2} \mathrm{O}_{5}$ constraint met other constraints at only slightly higher waste loadings (see cluster \#2, for an example).

Nevertheless, Jantzen et al. (2000) discusses the influence of phosphate phase separation on PCT releases from a number of test glasses from Hanford, SRS, and INEEL. They suggest that significant phosphate phase separation may be and acceptable from a PCT response. The formation of fluorine-containing phases does not have very significant impact on glass volume. Crum et al. (2001) show that the formation of $\mathrm{CaF}_{2}$, the most likely phase to form during cooling, actually decreases PCT release. Finally, the precipitation of spinel and acmite during canister cooling were not used to limit waste loading. These phases regularly form in DWPF and WVDP melts and have been shown to have no significant impact on PCT releases. Ultimately, these phases have little impact on glass volume and the impact could be addressed with laboratory studies in a short time.

Nepheline is the phase with the highest impact on glass volume. The nepheline constraint is nearly entirely responsible for the difference in estimated glass volumes produced with and without the multiple phase constraints being used. It crystallizes in relatively high fractions during normal canister cooling and can strongly impact PCT release. To process glasses that precipitate nepheline, studies will be needed to determine the amount of nepheline to form during canister cooling as a function of melt composition. It is already known how to predict whether nepheline is likely to form (Li et al. 1996) and the influence on PCT releases. Kim et al. (1995) and Riley et al. (2001) showed that the influence of nepheline on PCT release is primarily due to its influence on the residual glass composition. The obtainable waste loadings for glasses with acceptable PCT release cannot be accurately assessed.

\subsubsection{Alkali-Alumino-Borosilicate Glass for High-Temperature Melters}

Due to the relatively high alkali content of the Hanford HLW glasses, little gain is expected from hightemperature melting of glass other than the commiserate increase in $T_{L}$ constraints. If the melter processing temperature is increased by $100^{\circ} \mathrm{C}$, the $\mathrm{T}_{\mathrm{L}}$ constraint will likewise increase by $100^{\circ} \mathrm{C}$. This increase in $\mathrm{T}_{\mathrm{L}}$ constraint and likely increase in $\mathrm{Cr}_{2} \mathrm{O}_{3}$ concentration limit would allow for significantly lower glass volume, as discussed in Section 4.6.4. There are a number of technical issues associated with higher-temperature melting of waste glass, such as electrode corrosion and volatilization. The Study Team expects a slightly higher uncertainty in waste loading estimates as compared to the reference case

\footnotetext{
${ }^{13}$ Schill, P, M Trochta, J Matyáš, L Nemec, and PR Hrma. 2001. Mathematical Model of Spinel Settling in a Real Waste Glass Melter. To be published in Waste Management ' 01 .

${ }^{14}$ Matyáš, J, J Kloužek, L Němec, and M Trochta. 2001. Spinel Settling in HLW Melters. To be published in the $8^{\text {th }}$ International Conference Proceedings (ICEM’01), September 30 - October 4, 2001, Bruges, Belgium.
} 
AABS glass. However, sufficient high-temperature glass data were represented in all the models used in glass volume estimates to suggest that the calculations are still valid up to $1350^{\circ} \mathrm{C}$. Calculations for higher-temperature glass (higher than $1350^{\circ} \mathrm{C}$ ) would be much more uncertain and therefore were not estimated.

\subsubsection{Boron-Free Silicate Glasses}

No waste loading estimates were made for boron-free silicate glasses (AAS glasses) since sufficient data were not available. However, based the available data it is unlikely that glass volumes will be lower for low-temperature (e.g., $\leq 1200^{\circ} \mathrm{C}$ ) boron-free glasses relative to their AABS counterparts. Slight increases in waste loadings may be possible for high-temperature AAS glasses as compared to their AABS counterparts. To change to AAS glasses at high-temperature, significant glass development would be required in addition to high-temperature melter development.

Alkali aluminosilicate glasses with crystals were shown to allow waste loadings up to $80 \%$ with adequate PCT response (Hrma and Bailey 1995). However, these materials were fabricated by mixing waste with the minimum amount of silica required to meet PCT constraints. Processing and repository qualification constraints may be difficult to overcome.

\subsubsection{Phosphate Glasses}

The knowledge base for phosphate glasses is significantly less developed than that for the AABS glass systems. As described in Section 4.8, waste-loading estimates were made based on the knowledge of the durable glass-forming region and the ranges of components typically found in test glasses. Further development work is required to give more detailed estimates of the waste loadings for glasses that meet all the appropriate property constraints. Technical issues associated with the FeP glasses are primarily related to the lack of experience in processing of these glasses at large scale and some proposed sensitivities to crystallization on slow cooling, impact on product quality, electrode corrosion, and other processing-related properties. See Section 4.10 for more detailed discussion.

\subsubsection{Crystallized Phosphate Glasses}

Less information is known on crystallizing phosphate waste glasses than on the fully amorphous version. The waste loading estimates for this waste form should be considered more uncertain than the homogeneous FeP glasses. Technical issues related to crystallizing phosphate glasses can be found in Section 4.10.

\subsubsection{Titanate Ceramics}

Less is known about processing titanate ceramics through a cold crucible melter than any other waste form reviewed in this study. No waste loading estimates could be made, and significant technical shortcomings would need to be overcome before this form could be seriously considered.

\subsection{Wastes From Other Sites}

\subsubsection{INEEL HLW}

As a result of four decades of nuclear fuels reprocessing at the Idaho Nuclear Technology and Engineering Center (INTEC), large amounts of radioactive wastes have been collected. At INTEC, formerly known as the Idaho Chemical Processing Plant, SNF was reprocessed to recover fissionable uranium. Since 1963, these wastes have been converted to a solid granular form through fluidized bed 
calcination. This calcine is considered a mixed hazardous waste under current RCRA regulations. Approximately $4400 \mathrm{~m}^{3}$ of calcine are presently stored in stainless-steel bins at INTEC. These bins are stored temporarily in concrete vaults to isolate them from the environment. The bins are designed to remove the heat generated from the radioactive decay of fission products (1 mass \%) in the calcine. Several calcined solids storage facilities (CSSF) have been constructed over the years. To date, six CSSFs are being used to store the calcine. Each CSSF design is different in that each CSSF includes a range of three to seven composite bins and sub-bins. In addition to the design differences, each bin includes the following internal obstructions that may hinder the retrieval process: multiple thermowells, wall stiffeners, braces, and corrosion coupons. The calcine compositions in these CSSFs vary as a result of variations in the feed composition to the calcine process. Therefore, the calcine types are layered in the binsets and the compositions defined by CSSF are reported as composite.

During the span of INTEC operations, secondary radioactive liquid wastes high in alkali oxide were also collected and stored. These wastes originate from decontamination, laboratory, and fuels storage activities. Collectively, these liquid wastes are known as "sodium bearing wastes (SBW)." They cannot be directly calcined because of their high alkali content. Historically they have been blended with reprocessing wastes or non-radioactive aluminum nitrate prior to calcination. Because fuel reprocessing is no longer being performed at INTEC, the option of waste blending to deplete SBW inventory is eliminated. Consequently, about 5.7 million liters of these wastes are temporarily stored in the stainlesssteel tanks at INTEC.

The Batt Settlement Agreement was established in August 1995 among the U.S. Navy, the State of Idaho, and DOE (DOE 1995). Per this agreement, both calcine and SBW [including newly generated liquid waste (NGLW)] at INEEL will be processed into final waste forms ready for disposal. The start and completion dates for each depend on the specific treatment process used.

Vitrification is considered the "Best Demonstrated Available Technology" for immobilizing HLW. Precedents for vitrifying HLW into borosilicate glass have been established by the production-scale operation of the DWPF at SRS, WVDP at the West Valley Site in New York, and certain European facilities.

Efforts are in progress at INEEL to develop integrated flowsheets and identify glass composition regions for vitrifying both calcine and SBW. The compositions of INTEC calcine differ significantly from the INEEL SBW as well as those wastes being vitrified at DWPF, WVDP and those planned for vitrification at Hanford. The INEEL High-Level Waste Technology Development program has the goal of defining integrated flowsheets that are capable of immobilizing INTEC HLWs to a qualified waste form that will meet regulatory milestones. Regardless of the flowsheet selection, the chemical composition of the highactivity waste (HAWs) resulting from either separations and/or direct vitrification will be unique because they contain high concentrations of aluminum, phosphate, potassium, zirconium, calcium, sulfate, and/or fluoride. The concentrations of these components make INTEC HAWs significantly different from those wastes being vitrified at DWPF, WVDP, and those planned for vitrification at Hanford.

\subsubsection{Calcine}

Two vitrification flowsheets for calcine are currently being evaluated at INEEL: 1) direct vitrification of calcines (i.e., no or minimal pretreatment), and 2) vitrification of feeds resulting from a separations flowsheet (i.e., pretreatment to partition or separate the HAW and LAW fractions). 


\section{Full Separations Flowsheet}

The INEEL Spent Nuclear Fuel and Environmental Restoration and Waste Management Program's EIS identifies radionuclide partitioning (separations) as a treatment option for HLW (DOE 1995). This option is attractive because it has the potential to significantly reduce the volume of HLW to be sent from INTEC to a federal repository. Thus, separating and vitrifying the radioactive HAW fraction of the dissolved calcine is being investigated.

Table 4.23 summarizes the HAW waste fraction compositions (in mass fraction) resulting from full separations of aluminum-calcine and zirconium-calcine (including undissolved solids). For the aluminum-HAW, $\mathrm{K}_{2} \mathrm{O}\left(50.2\right.$ mass \%) and $\mathrm{P}_{2} \mathrm{O}_{5}(25.2$ mass\%) dominate the final waste stream composition. Based on initial estimates, the aluminum-solids (undissolved solids) will be totally $\mathrm{Al}_{2} \mathrm{O}_{3}$. Zirconium oxide ( 92.6 mass $\%$ ) dominates the zirconium-HAW waste stream resulting from full separations of zirconium-calcine. The zirconium-solids contain $\mathrm{ZrO}_{2}, \mathrm{Al}_{2} \mathrm{O}_{3}$, and $\mathrm{CaO}$ at 52.7, 38.0, and 9.3 mass \%, respectively. It should be noted that the zirconium-HAW waste stream dominates the total volume of $\mathrm{HAW}$ waste resulting from full separations (approximately $93 \%$ of the total). Therefore, the solubility of $\mathrm{ZrO}_{2}$ in a low-temperature (nominal $1150^{\circ} \mathrm{C}$ processing temperature) borosilicate glass was expected to dictate the loading of zirconium-HAW.

Table 4.23. Waste Compositions (mass fraction) of Al-HAW and Zr-HAW Resulting from Full Separations.

\begin{tabular}{|c|c|c|c|c|}
\hline Oxide & Al HAW & Al solids & $\mathrm{Zr} \mathrm{HAW}$ & Zr solids \\
\hline $\mathrm{Al}_{2} \mathrm{O}_{3}$ & 0.011 & 1.00 & 0.021 & 0.38 \\
\hline $\mathrm{BaO}$ & 0.000 & 0.00 & 0.000 & 0.00 \\
\hline $\mathrm{CaO}$ & 0.000 & 0.00 & 0.005 & 0.09 \\
\hline $\mathrm{Cs}_{2} \mathrm{O}$ & 0.155 & 0.00 & 0.003 & 0.00 \\
\hline $\mathrm{CuO}$ & 0.000 & 0.00 & 0.000 & 0.00 \\
\hline $\mathrm{Fe}_{2} \mathrm{O}_{3}$ & 0.002 & 0.00 & 0.000 & 0.00 \\
\hline$\overline{\mathrm{Gd}_{2} \mathrm{O}_{3}}$ & 0.000 & 0.00 & 0.004 & 0.00 \\
\hline $\mathrm{K}_{2} \mathrm{O}$ & 0.502 & 0.00 & 0.026 & 0.00 \\
\hline$\overline{\mathrm{MoO}_{3}}$ & 0.000 & 0.00 & 0.000 & 0.00 \\
\hline $\mathrm{Na}_{2} \mathrm{O}$ & 0.000 & 0.00 & 0.000 & 0.00 \\
\hline $\mathrm{P}_{2} \mathrm{O}_{5}$ & 0.252 & 0.00 & 0.013 & 0.00 \\
\hline $\mathrm{PbO}$ & 0.000 & 0.00 & 0.000 & 0.00 \\
\hline $\mathrm{SiO}_{2}$ & 0.000 & 0.00 & 0.000 & 0.00 \\
\hline $\mathrm{SrO}$ & 0.025 & 0.00 & 0.000 & 0.00 \\
\hline $\mathrm{TruO}_{2}$ & 0.053 & 0.00 & 0.001 & 0.00 \\
\hline $\mathrm{ZrO}_{2}$ & 0.000 & 0.00 & 0.926 & 0.53 \\
\hline $\begin{array}{l}\text { Mass of HAW } \\
\text { (Metric Ton) }\end{array}$ & 2.97 & 0.001 & 146.82 & 8.48 \\
\hline $\begin{array}{l}\text { Mass\% of } \\
\text { INEEL HAW } \\
\text { oxides }\end{array}$ & 1.88 & 0.0006 & 92.76 & 5.36 \\
\hline
\end{tabular}


Peeler et al. (1998) and Vienna et al. (1999a) developed a series of glasses to assess $\mathrm{ZrO}_{2}$ solubility. The results of those studies provided a 16.2 mass $\%$ zirconium-HAW waste loaded glass (or 15 mass $\% \mathrm{ZrO}_{2}$ ) which meet both process (e.g., liquidus and viscosity) and product performance (e.g., durability) specifications.

Although no specific glass formulations were developed for aluminum-HAW, Piepel et al. (1999) developed statistically designed matrices to evaluate glass property - composition relationships within a region compatible with the resulting waste streams from full separations as shown in Table 4.23. As expected, Staples et al. (1999) indicated that the phosphate $\left(\mathrm{P}_{2} \mathrm{O}_{5}\right)$ content had an impact on the tendency of the resulting glasses to phase separate (i.e., immiscible liquid separation) and had a major influence on the crystallization behavior upon thermal heat treatment. Most likely, amorphous phase separation acted as a precursor to crystallization. With approximately 25 mass $\% \mathrm{P}_{2} \mathrm{O}_{5}$ in the aluminum-HAW fraction, and given $\mathrm{P}_{2} \mathrm{O}_{5}$ solubility limits in borosilicate glass to be approximately 2 to $2.5 \mathrm{mass} \%$, waste loadings for this particular stream will be limited to 5 to 10 mass $\%$. With $\mathrm{P}_{2} \mathrm{O}_{5}$ being introduced primarily from the separations processes, flowsheet adjustments are being evaluated to minimize the addition of $\mathrm{P}_{2} \mathrm{O}_{5}$ and other components that potentially could have a negative impact on waste loading, processability, and/or product performance.

For the full separations flowsheet, technical issues revolve around the solubility of $\mathrm{ZrO}_{2}$ and $\mathrm{P}_{2} \mathrm{O}_{5}$. The use of high temperature processes or advanced melter technologies (e.g., ICCM) may prove beneficial in terms of waste loadings for the zirconium-HAW fraction as $\mathrm{ZrO}_{2}$ solubility should increase with increasing temperature. This latter statement assumes that the use of hightemperature processes does not result in excessive volatilization of radionuclides or corrosion/erosion of the materials of construction. To address the $\mathrm{P}_{2} \mathrm{O}_{5}$ issues in the aluminumHAW fraction, one could potentially use a phosphate-based glass system (e.g., FeP glasses) to increase waste loadings relative to the borosilicate-based glasses, assuming the development of amorphous phase separation and/or devitrification in the borosilicate systems was detrimental. If the impact of amorphous phase separation or crystallization within the borosilicate could be predicted and demonstrated to have minimal impact on durability then increased waste loadings may result. The use of a borosilicate glass may minimize any additional effort on qualification of a new glass system although additional work would be required to address the impacts of phase separation on durability and partitioning of radionuclides.

\section{Direct Vitrification}

Due to unresolved issues with either changing waste form glass systems and/or development of an alternative pretreatment flowsheet that have minimal impact on downstream processing, assessments to use a direct vitrification (i.e., no or minimal separations or pretreatment) flowsheet for the INTEC calcines have been made. Although a larger volume of glass may potentially result from direct vitrification relative to vitrification of feeds resulting from separations, direct vitrification may offer some advantages, e.g. pretreatment facilities would be minimal; if required at all. The decision may ultimately become an economic balance among the number of canisters produced for each option, which is dictated by waste loading, the facility construction and operating costs, and/or disposal costs.

These calcines are layered within a specific binset and the compositions vary among binsets, but contain predominantly high concentrations of zirconia, aluminum, calcium, and/or fluoride.

Table 4.24 provides the averages of the available composition estimates from the calcine bin sets. Binset \#1 (referred to as aluminum-calcine) is primarily $\mathrm{Al}_{2} \mathrm{O}_{3}$ ( 93.27 mass $\%$ on average). Assuming an $1150^{\circ} \mathrm{C}$ processing constraint, direct vitrification of Binset \#1 (referred to as 
aluminum-calcine) without blending with other binsets could drastically limit the waste loading. Higher $\mathrm{Al}_{2} \mathrm{O}_{3}$ concentrations in glass typically increase the required melt temperature to ensure solubility, increase viscosity that could impact pouring, and increase liquidus temperature.

Table 4.24. Average Compositional Estimates for Six Calcine Binsets (mass fraction)

\begin{tabular}{|c|c|c|c|c|c|c|}
\hline \multirow[b]{2}{*}{ Oxide } & \multicolumn{6}{|c|}{ Mass Fraction of Oxides } \\
\hline & Binset \#1 & Binset \#2 & Binset \#3 & Binset \#4 & Binset \#5 & Binset \#6 \\
\hline $\mathrm{Al}_{2} \mathrm{O}_{3}$ & 0.9327 & 0.4469 & 0.2021 & 0.1755 & 0.2043 & 0.6059 \\
\hline $\mathrm{B}_{2} \mathrm{O}_{3}$ & 0.0083 & 0.0172 & 0.0252 & 0.0276 & 0.0281 & 0.0184 \\
\hline $\mathrm{BaO}$ & 0.0004 & 0.0001 & 0.0001 & 0.0001 & 0.0001 & 0.0001 \\
\hline $\mathrm{CaO}$ & 0.0000 & 0.2300 & 0.3375 & 0.3757 & 0.3384 & 0.1376 \\
\hline $\mathrm{CeO}_{2}$ & 0.0005 & 0.0002 & 0.0001 & 0.0001 & 0.0002 & 0.0001 \\
\hline $\mathrm{Cl}$ & 0.0000 & 0.0000 & 0.0004 & 0.0010 & 0.0013 & 0.0018 \\
\hline $\mathrm{Cr}_{2} \mathrm{O}_{3}$ & 0.0000 & 0.0019 & 0.0029 & 0.0034 & 0.0018 & 0.0024 \\
\hline $\mathrm{Cs}_{2} \mathrm{O}$ & 0.0003 & 0.0001 & 0.0001 & 0.0001 & 0.0001 & 0.0001 \\
\hline $\mathrm{F}$ & 0.0000 & 0.1431 & 0.1970 & 0.1894 & 0.1601 & 0.0461 \\
\hline $\mathrm{Fe}_{2} \mathrm{O}_{3}$ & 0.0125 & 0.0017 & 0.0031 & 0.0072 & 0.0073 & 0.0116 \\
\hline I & 0.0000 & 0.0000 & 0.0000 & 0.0000 & 0.0000 & 0.0001 \\
\hline $\mathrm{K}_{2} \mathrm{O}$ & 0.0000 & 0.0015 & 0.0023 & 0.0050 & 0.0079 & 0.0187 \\
\hline $\mathrm{La}_{2} \mathrm{O}_{3}$ & 0.0002 & 0.0001 & 0.0001 & 0.0001 & 0.0001 & 0.0000 \\
\hline $\mathrm{MgO}$ & 0.0000 & 0.0079 & 0.0101 & 0.0042 & 0.0075 & 0.0115 \\
\hline $\mathrm{MnO}$ & 0.0000 & 0.0000 & 0.0003 & 0.0000 & 0.0003 & 0.0008 \\
\hline $\mathrm{MoO}_{3}$ & & & 0.0001 & & 0.0002 & 0.0001 \\
\hline $\mathrm{Na}_{2} \mathrm{O}$ & 0.0184 & 0.0078 & 0.0126 & 0.0227 & 0.0439 & 0.0798 \\
\hline $\mathrm{Nb}_{2} \mathrm{O}_{3}$ & 0.0000 & 0.0003 & 0.0001 & 0.0001 & 0.0024 & 0.0001 \\
\hline $\mathrm{Nd}_{2} \mathrm{O}_{3}$ & 0.0008 & 0.0000 & 0.0002 & 0.0002 & 0.0002 & 0.0002 \\
\hline $\mathrm{NiO}$ & 0.0000 & 0.0005 & 0.0007 & 0.0010 & 0.0371 & 0.0138 \\
\hline $\mathrm{PdO}$ & 0.0001 & 0.0000 & 0.0000 & 0.0000 & 0.0000 & 0.0000 \\
\hline $\mathrm{P}_{2} \mathrm{O}_{5}$ & 0.0083 & 0.0022 & 0.0069 & 0.0005 & 0.0013 & 0.0025 \\
\hline $\mathrm{PrO}_{2}$ & 0.0002 & 0.0001 & 0.0001 & 0.0001 & 0.0001 & 0.0000 \\
\hline $\mathrm{Rb}_{2} \mathrm{O}$ & 0.0001 & 0.0000 & 0.0000 & 0.0000 & 0.0000 & 0.0000 \\
\hline $\mathrm{Rh}_{2} \mathrm{O}_{3}$ & 0.0001 & 0.0000 & 0.0000 & 0.0000 & 0.0000 & 0.0000 \\
\hline $\mathrm{RuO}_{2}$ & 0.0004 & 0.0001 & 0.0000 & 0.0000 & 0.0001 & 0.0001 \\
\hline $\mathrm{Sm}_{2} \mathrm{O}_{3}$ & 0.0002 & 0.0000 & 0.0000 & 0.0000 & 0.0000 & 0.0000 \\
\hline $\mathrm{SnO}_{2}$ & 0.0000 & 0.0018 & 0.0025 & 0.0024 & 0.0018 & 0.0005 \\
\hline $\mathrm{SO}_{3}$ & 0.0139 & 0.0038 & 0.0040 & 0.0009 & 0.0165 & 0.0113 \\
\hline $\mathrm{SrO}$ & 0.0003 & 0.0021 & 0.0029 & 0.0033 & 0.0030 & 0.0010 \\
\hline $\mathrm{TcO}_{2}$ & 0.0002 & 0.0001 & 0.0000 & 0.0000 & 0.0000 & 0.0000 \\
\hline $\mathrm{TeO}_{3}$ & 0.0001 & 0.0000 & 0.0000 & 0.0000 & 0.0000 & 0.0000 \\
\hline $\mathrm{UO}_{2}$ & 0.0001 & 0.0001 & 0.0001 & 0.0001 & 0.0001 & 0.0012 \\
\hline $\mathrm{Y}_{2} \mathrm{O}_{3}$ & 0.0000 & 0.0000 & 0.0001 & 0.0001 & 0.0001 & 0.0000 \\
\hline $\mathrm{ZrO}_{2}$ & 0.0011 & 0.1303 & 0.1887 & 0.1792 & 0.1357 & 0.0344 \\
\hline Total & 1.0000 & 1.0000 & 1.0000 & 1.0000 & 1.0000 & 1.0000 \\
\hline
\end{tabular}

For Binsets \#2 - \#5 (referred to as zirconium-calcine), the major components of interest include: $\mathrm{Al}_{2} \mathrm{O}_{3}, \mathrm{CaO}$, fluorine, and $\mathrm{ZrO}_{2}$. Expectations are that the $\mathrm{CaO}$ and fluorine concentrations will dictate waste loadings for these particular binsets. Binset \#6 also contains high concentrations of 
$\mathrm{Al}_{2} \mathrm{O}_{3}$ but appears to be some type of blend between the aluminum- and zirconium-calcine as $\mathrm{CaO}$ and fluorine levels are relatively high.

From previous glass formulation efforts (Musick et al. 2000; Crum et al. 2001; Vienna et al. 1999a), the lack of understanding regarding the effect of crystallization (type and extent of crystalline phases) on the durability has been the primary driver for limited waste loadings. In these studies, devitrification of fluorine-based crystals occurred as the concentrations of $\mathrm{CaO}$ and fluorine (or waste loadings) were increased. More specifically, these initial studies have used a self-imposed constraint on the volume percent crystalline phases $(<2 \mathrm{vol} \%)$ after centerline cooling as a guideline for glass formulations. This constraint was imposed because the potential negative impacts of crystallization on durability were not known or predictable for these glasses. However, devitrification need not be viewed as a negative characteristic as long as it occurs upon cooling (i.e., single phase at melt temperature) and does not affect product performance. If these conditions are met, crystallinity itself should not restrict waste loading, assuming standard Jouleheated melter constraints. Through these studies, glass formulations exceeding 35 mass $\%$ waste loadings have been developed and subsequently processed through a pilot-scale melter. Again, these studies imposed the 2 vol\% crystallization limit after CCC, which ultimately limited waste loading.

For example, Crum et al. (2001) developed a 40 mass \% waste-loading glass based on a blended calcine composition that was subsequently recommended and processed in a pilot-scale melter. During development efforts, it was observed that higher waste loadings could be achieved if the self-imposed constraint $(<2 \mathrm{vol} \%$ crystallization after CCC $)$ was relaxed or eliminated. The quenched sample of this glass at 40 mass $\%$ waste loading had no crystals while the CCC-treated sample showed $\sim 2$ mass $\%$ total crystals of $\mathrm{CaF}_{2}$ and $\mathrm{ZrO}_{2}$. Pittman et al. (2001) also evaluated the effects of crystallization on durability over a broad compositional range for glasses that may be produced from a direct vitrification flowsheet.

Figure 4.19 is a plot of normalized boron release versus crystallization (in mass $\%$ ) for a high fluorine-based borosilicate glass that was heat treated at $800^{\circ} \mathrm{C}$ for times of $1,9,72,144$, and 432 hours. The quenched and CCC versions of this glass are also shown. Fluorapatite was observed in the isothermal heat treatments that had been carried out for up to 9 hours. Based on normalized boron release values, as the percent of fluorapatite increases, durability increases. Between the 9- and 72-hour heat treatments, the devitrification phase transitioned from fluorapatite to hiortdahlite. As the heat treatment times increased from 72 to 432 hours, the mass $\%$ of hiortdahlite increased from approximately $11 \%$ to $15 \%$. Based on normalized boron release, the data indicate that the formation of hiortdahlite in this particular glass reduced durability as defined in the PCT. However, it should be noted that the durability of all glasses (quenched and all heat-treated glasses, including CCC) is well below the current acceptability criteria relative to EA regardless of the mass \% crystallization. These data provide the necessary basis to address the development of multiphase glasses to increase the loading of INEEL calcine. 


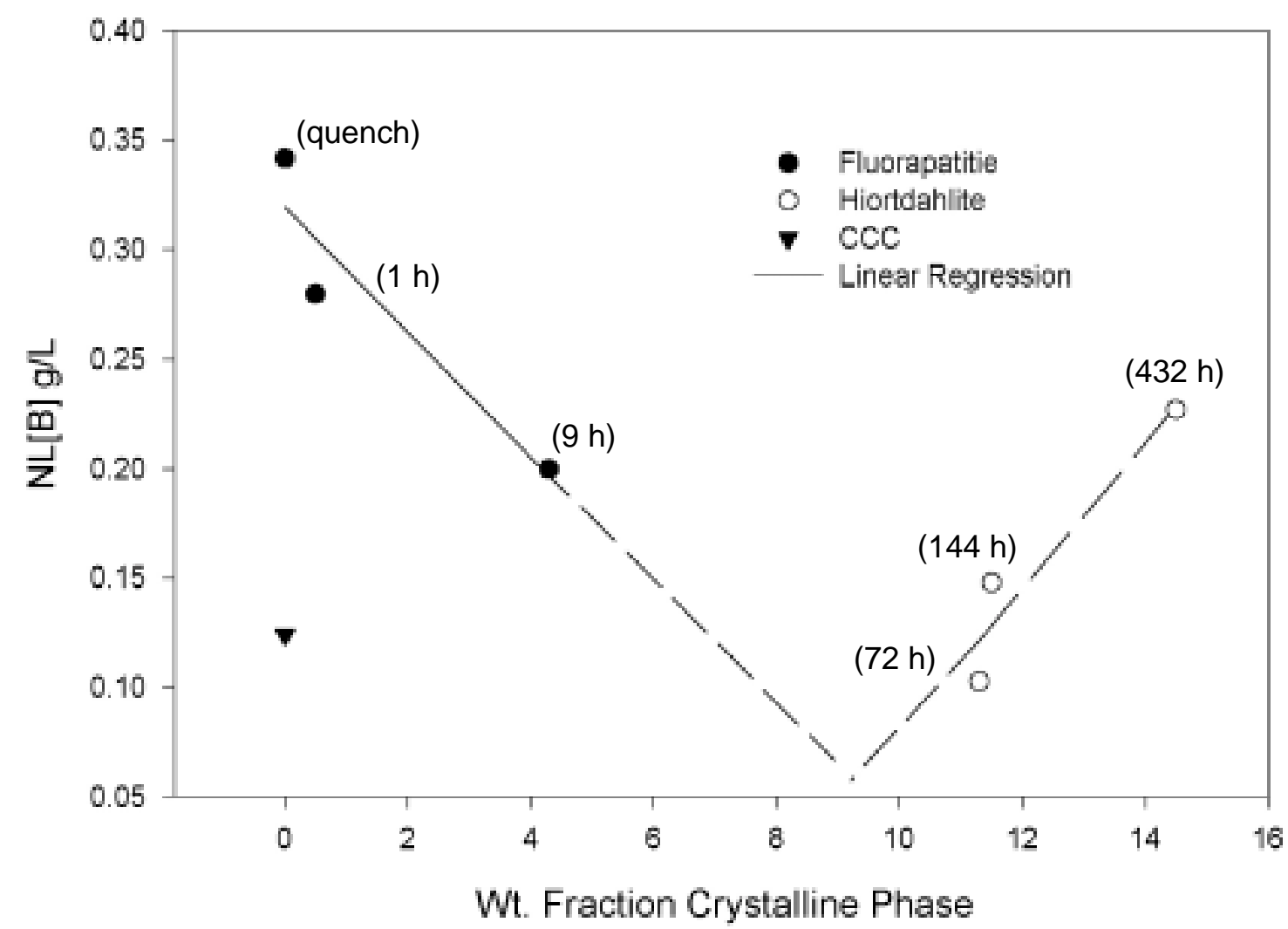

Figure 4.19. Effect of Crystallization on Durability of High F-Based Borosilicate Glass

As more data become available, this limit may be relaxed, allowing increases in waste loading without compromising processing constraints. More specifically, as waste loadings are increased, the tolerance for crystals within the melt pool as dictated by liquidus temperature will not be relaxed and only the formation of crystals after pouring, which does not negatively affect performance, will be acceptable.

The use of alternative processing techniques may allow for increased waste loadings if crystallization within the melt pool is deemed acceptable. However, the use of higher melt temperatures to increase waste loadings for direct vitrification of zirconium-calcine is not viewed as an advantage for the borosilicate system. Previous work to assess compositional effects on increased fluorine solubility indicated that those components that did increase fluorine solubility also lowered melt temperature. As stated above, the use of high temperature or advanced melters to increase waste loading for aluminum-calcine may be feasible given the high concentration of $\mathrm{Al}_{2} \mathrm{O}_{3}(\sim 93$ mass $\%)$ and assuming the aluminum-calcine is not blended. This latter statement assumes that the use of high-temperature processes does not result in excessive volatilization of radionuclides or corrosion/erosion of the materials of construction.

\subsubsection{Sodium Bearing Wastes}

The current path forward for immobilizing liquid SBW is direct vitrification. Vienna et al. (1999b) discussed a systematic study that was undertaken to develop a glass composition to demonstrate direct vitrification of INEEL's SBW. The objective of this study was to demonstrate feasibility of SBW vitrification, and not to develop an optimum formulation. The SBW waste composition was relatively high in sodium, aluminum, and sulfur. Calculations based on first- 
order expansions of selected glass properties in composition and some general tenets of glass chemistry led to an additive (frit) composition (68.69 mass $\% \mathrm{SiO}_{2}, 14.26$ mass $\% \mathrm{~B}_{2} \mathrm{O}_{3}, 11.31$ mass $\% \mathrm{Fe}_{2} \mathrm{O}_{3}, 3.08$ mass $\% \mathrm{TiO}_{2}$, and 2.67 mass $\% \mathrm{Li}_{2} \mathrm{O}$ ) that met all property restrictions when melted with 35 mass \% of SBW on an oxide basis. Given the 1999 composition estimates, waste loading was limited by $\mathrm{SO}_{3}$ solubility. This glass was ultimately recommended to INEEL and successfully processed in a pilot-scale melter at Clemson University. Although a glass was developed and processed that met specifications and demonstrated that direct vitrification of SBW is feasible, this glass was not optimized.

Barnes 2000 and a report currently being prepared by Barnes and Marshall ${ }^{15}$ provided revised estimates of expected SBW feed compositions and the sources, methods, and assumptions used in obtaining those estimates. These estimates are being used not only to support design efforts at INEEL, but also the glass formulation development activities defined by TFA and the INEEL HLW program. Feed streams to the SBW treatment facility are expected to come from existing tanks at the INTEC Tank Farm and from additional surge capacity that will be in use prior to facility start-up. The direct vitrification treatment process for SBW would process all existing and new tank farm waste, including liquids, liquids with small concentrations of solids, and heel sludges. Current INEEL Tank Farm management plans ${ }^{16}$ (also see Palmer et al. 2000) show that the treatment facility would be required to treat six feed streams. Three of these feed streams are SBW - acidic, radioactive, and hazardous liquid wastes containing small amount of undissolved solids (UDS) from three tanks, WM-180, WM-188, and WM-189. Table 4.25 summarizes the compositions presented for these three tanks and a fourth tank containing mostly concentrated NGLW.

Table 4.25. Comparison of SBW Tank Compositions - Major Chemical Species (mass\%)

\begin{tabular}{|c|c|c|c|c|c|}
\hline & WM-180 & WM-188 & WM-189 & $\begin{array}{c}\text { NT- } \\
\text { NGLW }\end{array}$ & Average \\
\hline $\mathrm{Al}_{203}$ & 29.54 & 32.41 & 28.87 & 29.72 & 30.10 \\
\hline $\mathrm{Sb}_{2 \mathrm{O} 5}$ & 0.009 & 0.003 & 0.003 & 0.004 & 0.005 \\
\hline $\mathrm{As}_{2 \mathrm{O} 5}$ & 0.05 & 0.03 & 0.01 & 0.04 & 0.03 \\
\hline $\mathrm{BaO}$ & 0.01 & 0.01 & 0.01 & 0.02 & 0.01 \\
\hline $\mathrm{BeO}$ & 0.000 & 0.000 & 0.000 & 0.000 & 0.000 \\
\hline $\mathrm{B} 2 \mathrm{O}_{3}$ & 0.37 & 1.04 & 1.06 & 1.63 & 0.94 \\
\hline $\mathrm{CdO}$ & 0.09 & 0.86 & 1.02 & 0.79 & 0.69 \\
\hline $\mathrm{CaO}$ & 2.40 & 4.76 & 3.70 & 6.60 & 4.03 \\
\hline $\mathrm{CeO} 2$ & 0.007 & 0.008 & 0.015 & 0.007 & 0.010 \\
\hline $\mathrm{Cs}_{2} \mathrm{O}$ & 0.001 & 0.008 & 0.015 & 0.009 & 0.008 \\
\hline $\mathrm{Cr}_{2} \mathrm{O}_{3}$ & 0.22 & 0.49 & 0.43 & 0.55 & 0.41 \\
\hline $\mathrm{CoO}$ & 0.001 & 0.005 & 0.003 & 0.006 & 0.004 \\
\hline $\mathrm{CuO}$ & 0.05 & 0.05 & 0.04 & 0.09 & 0.05 \\
\hline $\mathrm{Gd}_{2} \mathrm{O}_{3}$ & 0.03 & 0.07 & 0.26 & 0.13 & 0.13 \\
\hline $\mathrm{GeO}_{2}$ & 0.000 & 0.000 & 0.000 & 0.000 & 0.000 \\
\hline $\mathrm{Fe}_{2} \mathrm{O}_{3}$ & 1.53 & 2.37 & 1.92 & 2.94 & 2.07 \\
\hline
\end{tabular}

\footnotetext{
${ }^{15}$ From CM Barnes and DR Marshall, INEEL, to CA Musick, INEEL, "Draft Calculation of Projected SodiumBearing Waste Compositions for Use in Development of a Surrogate for Melter Tests," dated April 11, 2001. ${ }^{16}$ Interoffice memorandum by TG Garn, entitled "Sampling and Characterization of WM-180," TGG-01-01, dated January 11, 2001.
} 


\begin{tabular}{|c|c|c|c|c|c|}
\hline $\mathrm{PbO}$ & 0.25 & 0.23 & 0.21 & 0.19 & 0.22 \\
\hline $\mathrm{Li}_{2} \mathrm{O}$ & 0.004 & 0.004 & 0.008 & 0.004 & 0.005 \\
\hline $\mathrm{MgO}$ & 0.42 & 0.20 & 0.67 & 0.40 & 0.43 \\
\hline $\mathrm{MnO}_{2}$ & 1.07 & 1.69 & 1.90 & 1.84 & 1.61 \\
\hline $\mathrm{MoO}_{3}$ & 0.03 & 0.14 & 0.19 & 0.42 & 0.16 \\
\hline $\mathrm{NiO}$ & 0.10 & 0.19 & 0.16 & 0.32 & 0.17 \\
\hline $\mathrm{Nb}_{2} \mathrm{O}_{5}$ & 0.002 & 0.008 & 0.014 & 0.007 & 0.008 \\
\hline $\mathrm{Pd}_{2} \mathrm{O}_{3}$ & 0.003 & 0.002 & 0.003 & 0.001 & 0.002 \\
\hline $\mathrm{P}_{2} \mathrm{O}_{5}$ & 0.86 & 0.13 & 0.38 & 0.42 & 0.44 \\
\hline $\mathrm{PuO}_{2}$ & 0.00 & 0.00 & 0.00 & 0.00 & 0.00 \\
\hline $\mathrm{K}_{2} \mathrm{O}$ & 7.96 & 7.95 & 8.45 & 6.07 & 7.84 \\
\hline $\mathrm{Ru}_{2} \mathrm{O}_{3}$ & 0.01 & 0.02 & 0.03 & 0.03 & 0.02 \\
\hline $\mathrm{SeO}_{2}$ & 0.01 & 0.03 & 0.03 & 0.30 & 0.06 \\
\hline $\mathrm{SiO}_{2}$ & 0.02 & 0.15 & 0.39 & 0.34 & 0.22 \\
\hline $\mathrm{Ag}_{2} \mathrm{O}$ & 0.001 & 0.007 & 0.007 & 0.011 & 0.006 \\
\hline $\mathrm{Na}_{2} \mathrm{O}$ & 54.68 & 44.75 & 47.93 & 41.36 & 47.85 \\
\hline $\mathrm{SrO}$ & 0.01 & 0.01 & 0.02 & 0.01 & 0.01 \\
\hline $\mathrm{TeO}_{3}$ & 0.000 & 0.000 & 0.000 & 0.34 & 0.26 \\
\hline $\mathrm{Tl}_{2} \mathrm{O}_{3}$ & 0.008 & 0.002 & 0.002 & 0.001 & 0.003 \\
\hline $\mathrm{SnO}_{2}$ & 0.005 & 0.002 & 0.003 & 0.002 & 0.003 \\
\hline $\mathrm{TiO}_{2}$ & 0.004 & 0.003 & 0.008 & 0.004 & 0.005 \\
\hline $\mathrm{UO}_{2}$ & 0.08 & 0.19 & 0.30 & 0.81 & 0.28 \\
\hline $\mathrm{V}_{2} \mathrm{O}_{5}$ & 0.07 & 0.01 & 0.00 & 0.02 & 0.03 \\
\hline $\mathrm{ZnO}$ & 0.08 & 0.07 & 0.06 & 0.08 & 0.07 \\
\hline $\mathrm{ZrO}_{2}$ & 0.01 & 2.10 & 1.88 & 4.47 & 1.78 \\
\hline $\mathrm{Br}$ & 0.00 & 0.00 & 0.01 & 0.03 & 0.01 \\
\hline $\mathrm{Cl}$ & 0.94 & 0.88 & 0.98 & 0.69 & 0.90 \\
\hline $\mathrm{F}$ & 0.82 & 2.85 & 1.92 & 3.75 & 2.13 \\
\hline $\mathrm{I}$ & 0.000 & 0.001 & 0.002 & 0.004 & 0.002 \\
\hline $\mathrm{Hg}$ & 0.34 & 0.59 & 0.33 & 0.47 & 0.42 \\
\hline $\mathrm{SO}_{4}^{-2}$ & 5.85 & 4.38 & 4.65 & 6.66 & 5.16 \\
\hline
\end{tabular}

Barnes (2000) indicated that liquid samples from some tanks contained small amounts of UDS. The UDS may be present as suspended solids, or they may include heel solids entrained during the jetting process as liquid is transferred from the tanks. Table 4.26 shows the estimated UDS composition converted to an oxide basis. Based on the values reported by Barnes (2000), the UDS compositions have relatively high concentrations of $\mathrm{B}_{2} \mathrm{O}_{3}, \mathrm{SiO}_{2}, \mathrm{ZrO}_{2}, \mathrm{P}_{2} \mathrm{O}_{5}$, and $\mathrm{SO}_{4}$. 
Table 4.26. Estimated Average Composition of UDS

\begin{tabular}{|l|l|}
\hline Oxide/Anion & Mass\% \\
\hline $\mathrm{Al}_{2} \mathrm{O}_{3}$ & 5.17 \\
\hline $\mathrm{B}_{2} \mathrm{O}_{3}$ & 14.64 \\
\hline $\mathrm{CaO}$ & 1.94 \\
\hline $\mathrm{Cr}_{2} \mathrm{O}_{3}$ & 0.51 \\
\hline $\mathrm{Fe}_{2} \mathrm{O}_{3}$ & 5.43 \\
\hline $\mathrm{K}_{2} \mathrm{O}$ & 2.94 \\
\hline $\mathrm{MnO}_{2}$ & 0.94 \\
\hline $\mathrm{Na}_{2} \mathrm{O}$ & 8.94 \\
\hline $\mathrm{Nb}_{2} \mathrm{O}_{5}$ & 0.34 \\
\hline $\mathrm{NiO}$ & 2.83 \\
\hline $\mathrm{SiO}_{2}$ & 13.32 \\
\hline $\mathrm{ZrO}$ & 28.70 \\
\hline $\mathrm{P}_{2} \mathrm{O}_{5}$ & 14.30 \\
\hline & \\
\hline $\mathrm{Anions}$ & \\
\hline $\mathrm{Cl}$ & 4.14 \\
\hline $\mathrm{F}$ & 4.05 \\
\hline $\mathrm{SO}_{4}$ & 22.37 \\
\hline $\mathrm{Hg}$ & 0.90 \\
\hline
\end{tabular}

Based on these compositions, glass formulations will still be $\mathrm{SO}_{3}$-limited unless an integrated flowsheet can be developed that increases $\mathrm{SO}_{3}$ solubility to over 1 mass\% in glass or sulfur partitioning to the off-gas is increased by the use of an effective reductant or melter design. The use of high-temperature or advanced melters may be beneficial, as partitioning of sulfur to the off-gas system could be increased and thus minimize the potential impacts of a salt layer forming on the glass surface in the melter. If successful, this may allow for waste-loading increases for SBW.

If the $\mathrm{SO}_{3}$ issue could be resolved, durability may limit waste loadings for SBW. That is, as waste loadings increase, the concentration of $\mathrm{Na}_{2} \mathrm{O}$ increases. Glasses with $\sim 20$ mass $\% \mathrm{Na}_{2} \mathrm{O}$ can be fabricated, meeting current product specifications; however, concentrations over this limit tend to decrease durability (as defined by the PCT) dramatically. Although not necessarily a wasteloading limitation, the high levels of $\mathrm{NO}_{3}$ in the waste may have a significant impact on melt rate and, ultimately, throughput.

\subsubsection{Savannah River Site HLW}

The Savannah River Site, located in South Carolina, is a 300-square-mile DOE complex that has produced nuclear materials for national defense, research, and medical programs since it began operating in 1951. As a waste by-product of this production, there are currently approximately 130 million liters of liquid, high-level radioactive waste stored on an interim basis in 49 underground waste storage tanks. Continued, long-term storage of this liquid HLW in underground tanks poses an environmental risk, as nine of the SRS tanks have a waste leakage history. 
The DWPF at SRS is currently processing this high-level liquid waste into a durable borosilicate waste glass. A ceramic, slurry-fed, Joule-heated electric melter is being used to reliably melt the borosilicate glass at approximately $1150^{\circ} \mathrm{C}$.

The defense high-level liquid wastes were initially acidic and were neutralized with $\mathrm{NaOH}$ to be safely stored in carbon-steel tanks. Aging of the waste and reaction with the $\mathrm{NaOH}$ have caused the waste to stratify into a sludge, salt cake, and salt solution. The sludge consists primarily of precipitates of the hydroxides of iron and alumina and contains most of the radioactivity, with the exception of radioactive cesium. The waste compositions vary from a high-alumina-containing waste to a high-iron-containing (Purex) waste. The salt cake and salt solution are mainly composed of sodium salts or common anions, such as nitrate, nitrite, aluminate, and hydroxide. The salt fraction of the waste contains most of the radioactive cesium and only traces of other radioactive species.

The radioactive waste in the SRS Tank Farms is separated into a water-soluble salt solution and salt cake, and an insoluble sludge of metal hydroxides and oxides. The salt solution and salt cake are decontaminated for disposal as low-level radioactive waste by removing the radionuclides by precipitation and sorption. The glass produced to date has contained sludge waste. Salt waste processing was suspended in Fiscal Year 1998 (FY98) because the facility could not cost effectively meet both the safety and production requirements of the HLW system. The selection by DOE of an alternative salt processing technology is expected in FY01, with construction of a salt processing facility scheduled to be completed by FY10, depending on available funding.

Within the DWPF, the sludge is transferred directly to the Sludge Receipt and Adjustment Tank (SRAT) for processing. When the alkaline sludge is transferred to the SRAT, it is neutralized with nitric acid and formic acid. The excess formic acid reduces the mercuric oxide in the sludge to elemental mercury, which is then steam-stripped from the SRAT into a holding tank from which it is later pumped and decontaminated. After processing in the SRAT, the slurry is transferred to the Slurry Mix Evaporator (SME), where a borosilicate glass frit is added and the slurry is concentrated to produce melter feed. The amount of SRAT material and frit to be blended in the SME is determined by the desired glass composition. Any point within the acceptable glass-processing region can be selected as the target for a particular batch. The SME is the hold point in the process where feed acceptability is determined. The analyses of samples from the SME are used by DWPF engineers to determine acceptability of the melter feed (determined with glass property models and statistical algorithms, which take into account analytical uncertainty to ensure that the glass product will be acceptable and that processing constraints, such as viscosity and liquidus, are met). In order for the glass to be acceptable, it must be more durable than the EA glass as measured by the PCT.

Once the melter feed material in the SME is determined to be acceptable, it is transferred to the Melter Feed Tank and then fed to the Joule-heated melter. The DWPF melter has two pairs of electrodes. The feed slurry is introduced from the top of the melter and forms a crust, or cold cap, on the surface of the melt pool as the water is evaporated and removed via the off-gas system. The cold cap melts from the bottom and forms the borosilicate glass matrix. The nominal glass melt pool temperature is $1150^{\circ} \mathrm{C}$. The glass is removed from the melter near the bottom through a riser and pour spout, and a vacuum is drawn on the pour spout to pour the glass.

With the suspension of the salt waste processing operations in FY98, DWPF radioactive operations have processed what is referred to a "sludge-only flowsheet." To date, over $3.6 \times 10^{6} \mathrm{~m}^{3}\left(9 \times 10^{11}\right.$ gallons) of radioactive waste have been processed through the DWPF, producing over 4 million pounds of glass in approximately 1100 canisters. DWPF is currently processing Sludge Batch 1B (MB2), which is sludge from Tank 42. In addition, vitrification of Sludge Batch 2 (an equal blend of Tanks 8 and Tank 40) is currently scheduled to begin in January 2002. 
According to the HLW Systems Plan, Revision 11 (WSRC 2000), sludge-only processing will continue for the next three sludge batches. Table 4.27 summarizes compositional bounds of the major components for those individual tanks projected to be associated with sludge-only processing. The bounds account for different washing scenarios (nominal and underwashed cases) and historical measurement and sampling uncertainties. It should be noted that based on current plans, Sludge Batch 3 will process Tank 7 alone; Sludge Batch 4 will consist of a blend of Tanks 26 and 11; and Sludge Batch 5 will consist of a blend of Tanks 5, 12 and 15. Tanks 18 and 19 may also be blended into either Sludge Batch 3 or Sludge Batch 4. Given the uncertainties of future blending strategies for these two tanks coupled with the fact that the volumes of these two tanks are extremely small, they are not shown or discussed in this report.

Table 4.27. Compositional Bounds of Major Components of Sludge-Only Processing.

\begin{tabular}{|c|c|c|c|c|c|c|c|c|c|c|c|c|}
\hline & \multirow{2}{*}{\multicolumn{2}{|c|}{$\begin{array}{c}\text { SB3 } \\
\text { Tank } 7\end{array}$}} & \multicolumn{4}{|c|}{ SB4 } & \multicolumn{6}{|c|}{ SB5 } \\
\hline & & & \multicolumn{2}{|c|}{ Tank 26} & \multicolumn{2}{|c|}{\begin{tabular}{|l|} 
Tank 11 \\
\end{tabular}} & \multicolumn{2}{|c|}{ Tank 5} & \multicolumn{2}{|c|}{ Tank 12} & \multicolumn{2}{|c|}{ Tank 15} \\
\hline Oxide & Min & Max & Min & Max & Min & Max & Min & Max & Min & Max & Min & Max \\
\hline $\mathrm{Al}_{2} \mathrm{O}_{3}$ & 14.593 & 19.740 & 18.53 & 26.98 & 21.16 & 44.59 & 3.98 & 5.60 & 25.70 & 36.74 & 23.98 & 49.59 \\
\hline $\mathrm{BaO}$ & 0.237 & 0.237 & 0.23 & \begin{tabular}{|l|}
0.23 \\
\end{tabular} & 0.22 & 0.22 & 0.40 & 0.40 & 0.16 & \begin{tabular}{|l|}
0.16 \\
\end{tabular} & \begin{tabular}{|l|}
0.16 \\
\end{tabular} & 0.16 \\
\hline $\mathrm{CaO}$ & 2.661 & 4.047 & 2.86 & 4.68 & 2.57 & 4.77 & 2.04 & 3.23 & 1.64 & 2.64 & 1.84 & 3.47 \\
\hline $\mathrm{Ce}_{2} \mathrm{O}_{3}$ & 312 & 0.312 & 0.34 & 0.34 & 0.00 & 0.00 & 0.29 & 0.29 & 0.10 & 0.10 & 0.30 & 0.30 \\
\hline $\mathrm{Cr}_{2} \mathrm{O}_{3}$ & 0.349 & 0.349 & 0.36 & 0.36 & 0.35 & 0.35 & 0.45 & 0.45 & 0.27 & 0.27 & 0.27 & 0.27 \\
\hline $\mathrm{Fe}_{2} \mathrm{O}_{3}$ & 32.265 & 43.027 & 33.24 & 47.70 & 22.18 & 36.02 & 33.10 & 45.87 & 12.27 & 17.29 & 14.45 & 23.92 \\
\hline $\mathrm{K}_{2} \mathrm{O}$ & 405 & 0.405 & 0.46 & 0.46 & 0.22 & 0.22 & 0.28 & 0.28 & 0.17 & 0.17 & 0.17 & 0.17 \\
\hline $\mathrm{La}_{2} \mathrm{O}_{3}$ & 0.185 & 0.185 & 0.20 & 0.20 & 0.20 & 0.20 & 0.15 & 0.15 & 0.07 & 0.07 & 0.12 & 0.12 \\
\hline $\mathrm{MgO}$ & 0.170 & 0.170 & 0.16 & 0.16 & 0.00 & 0.00 & 0.30 & 0.30 & 0.27 & 0.27 & 0.37 & 0.37 \\
\hline $\mathrm{MnO}$ & 6.150 & 8.738 & 2.76 & 4.22 & 2.78 & 4.81 & 7.85 & 11.58 & 9.45 & 14.18 & 3.50 & 6.17 \\
\hline $\mathrm{Na}_{2} \mathrm{O}$ & 9.300 & 27.467 & 7.95 & 32.56 & 6.12 & 19.29 & 3.90 & 18.63 & 6.81 & 27.74 & 6.20 & 21.18 \\
\hline $\mathrm{NiO}$ & 1.364 & 2.092 & 0.00 & 0.00 & 0.33 & 0.61 & 7.45 & 11.88 & 1.56 & 2.52 & 0.00 & 0.00 \\
\hline $\mathrm{PbO}$ & 0.276 & 0.276 & 0.31 & 0.31 & 0.20 & 0.20 & 0.19 & 0.19 & 0.04 & 0.04 & 0.11 & 0.11 \\
\hline $\mathrm{SiO}_{2}$ & 0.280 & \begin{tabular}{|l|}
3.565 \\
\end{tabular} & 0.30 & 4.11 & 1.12 & 17.33 & 0.22 & 2.93 & 0.88 & 11.81 & 0.90 & 14.24 \\
\hline $\mathrm{ThO}_{2}$ & 0.00 & 0.00 & 0.00 & 0.00 & 0.00 & 0.00 & 0.00 & 0.00 & 7.60 & 10.08 & 8.16 & 12.71 \\
\hline $\mathrm{U}_{3} \mathrm{O}_{8}$ & 4.308 & 14.808 & 2.49 & 9.20 & 0.00 & 0.00 & 8.47 & 30.25 & 0.67 & 2.43 & 0.00 & 0.00 \\
\hline $\mathrm{ZnO}$ & 0.390 & 0.390 & 0.43 & 0.43 & 0.07 & 0.07 & 0.31 & 0.31 & 0.10 & 0.10 & 0.06 & 0.06 \\
\hline $\mathrm{ZrO}_{2}$ & 0.638 & 0.801 & 0.67 & 0.91 & 0.48 & 0.74 & 0.58 & 0.75 & 0.00 & 0.00 & 0.00 & 0.00 \\
\hline
\end{tabular}

These wastes are relatively high in both $\mathrm{Al}_{2} \mathrm{O}_{3}$ and $\mathrm{Fe}_{2} \mathrm{O}_{3}$, which could limit waste loading for these streams. Other components that may impact waste loadings in these projected sludge-only macrobatches include $\mathrm{NiO}, \mathrm{MnO}, \mathrm{ThO}_{2}$, and $\mathrm{U}_{3} \mathrm{O}_{8}$ for the baseline melter technology currently being used. The use of high-temperature or advanced melter technology may prove beneficial for increasing waste loadings for these particular streams. This latter statement assumes that issues associated radionuclide volatility and/or excessive corrosion/erosion of the melter/off-gas materials of construction are not an issue. The use of high temperatures could result in relaxed constraints on liquidus temperature that most likely limit waste loading for these wastes.

Another potential advantage of high-temperature melters with respect to DWPF projected wastes involves the uncertainties associated with sludge washing and aluminum dissolution for some streams. For example, assuming aluminum dissolution is ineffective due to the formation of beohmite in selected waste tanks, waste streams containing high concentrations of $\mathrm{Al}_{2} \mathrm{O}_{3}$ and $/$ or $\mathrm{Fe}_{2} \mathrm{O}_{3}$ could result. Given the $1150^{\circ} \mathrm{C}$ nominal melter operating temperature, waste loadings may have to be reduced to meet other processing constraints such as viscosity. The increase in waste loading one may achieve with high-temperature 
melters must be balanced against other processing issues such as volatility and/or corrosion of melter construction materials.

Given the uncertainty of the salt waste processing operations on projected couple flowsheet waste compositions, no attempt was made to address this issue in this study. However, it is anticipated that $\mathrm{Al}_{2} \mathrm{O}_{3}, \mathrm{Fe}_{2} \mathrm{O}_{3}$, and $\mathrm{Cr}_{2} \mathrm{O}_{3}$ will continue to have significant impacts on waste loading and other such components (e.g., $\mathrm{SrO}, \mathrm{MnO}, \mathrm{TiO}_{2}$ and $\mathrm{ZrO}_{2}$ ) may come into play as they are introduced from the alternative salt program. 


\subsection{Design and Operational Requirements for Immobilization Technologies for Hanford High-Level Waste}

This section identifies the important design and operating parameters required for vitrification systems capable of producing the desired waste forms and loadings. To solicit additional input for this assessment, a list of questions (see Appendix F) was developed and posed to personnel from DWPF and WVDP.

\subsection{Prior Experience}

A significant amount of experience exists in the United States and abroad in the area of HLW vitrification. In this country, DWPF and WVDP have been processing radioactive feed since 1996. Thus, a strong technical basis has been built regarding parameters and requirements that are important to HLW vitrification. Based on past development and operations experience, the key parameters that impact overall efficiency and optimization of vitrification are known to include the following relationships or properties: viscosity vs. temperature; electrical conductivity vs. temperature; magnetic permeability (induction heating only) vs. temperature; liquidus temperature; durability (of quenched and slowly-cooled waste forms); spinel formation and growth kinetics; phase stability (of quenched and slowly-cooled waste forms); and corrosivity. Melter technology considerations have historically included operating temperature; size; refractory materials of construction; electrode materials of construction (Joule-heating only); glass mixing; glass discharge; removal of settled phases; process control stability; operational life; maintainability; state of development; and operability under remote radioactive facility conditions.

\subsubsection{DWPF Experience}

The DWPF melter design produces $103 \mathrm{~kg} / \mathrm{h}(228 \mathrm{lbs} / \mathrm{h})$ of glass. DWPF is currently processing the second batch of radioactive sludge. Typical production rates for the first sludge batch were 77 to $82 \mathrm{~kg} / \mathrm{h}$ $(170$ to $180 \mathrm{lbs} / \mathrm{h})$, while the production rate with the second sludge batch is lower at 68 to $73 \mathrm{~kg} / \mathrm{h}(150$ to $160 \mathrm{lbs} / \mathrm{h}$ ). The series of questions listed in Appendix F was developed to solicit input from DWPF on production rate and other melter technology issues, and the results of the survey are summarized below.

As noted above, DWPF is currently operating at a lower production rate than the facility's design basis. In addition, different production rates are observed from processing the first to second sludge batch. It is believed that several parameters affect production rate:

- Melter feed slurry concentration: The target mass\% solids in the melter feed going to the melter is 48 to 59 mass\%; however, in several cases DWPF has operated in the 40 to 42 mass \% solids range. Low mass \% solids has been caused by excessive water addition to the melter feed tank due to extensive pump priming (pump problems led to several starts and stops of feeding) and flushes of the melter feed sampling system.

- $\quad$ Melter plenum temperature constraints: DWPF currently has a vapor space temperature limit below which feeding must be terminated. Thus, feed rates are often limited by this temperature. Work is under way to lower this limit so feed rates can be increased.

- Melt rate improvements: The development of a foam layer on the surface of the melt pool may be more of a factor in limiting melt rates of the second sludge batch than plenum temperatures. An extensive program is under way to understand and improve DWPF melt rates and minimize glass foaming in the melter. 
- $\quad$ Melter temperature limitations: Due to melter design and materials of construction, melter temperature cannot be significantly raised. However, the power input to the upper and lower electrodes and where temperatures are monitored can be modified. Optimization of the melter temperatures may allow better melting.

- $\quad$ Glass properties: The current sludge batch produces a higher viscosity glass than the first batch. Glass viscosity can impact the melt rate of the feed. The constraints on glass processing (e.g., liquidus) don't necessarily limit glass production rate but can significantly impact waste loading. Liquidus temperature is the current limiting factor for waste loading for DWPF.

- Analytical time: The time required to produce and analyze a melter feed batch can limit production rate due to lack of available feed. Although this problem has not routinely occurred in DWPF, as other parameters are improved this aspect will become the rate-limiting step for production.

- Visibility of cold cap: DWPF cannot currently view the melter cold cap. DWPF personnel believe that with the ability to view the cap, other modifications could be made to melter operation to improve production rate.

Handling of HLW-contaminated equipment has not been a problem for DWPF to this point. Reliability of the equipment has been excellent and, as a result, has not been a factor in defining DWPF's total operating efficiency (TOE). DWPF has not yet replaced a melter; however, current estimates indicate that it would take five to six months to replace a melter and resume operation. Thus, future equipment, including melters, that can be received, commissioned, and installed in an efficient manner is an important attribute for DWPF.

DWPF materials of construction are not overly conservative. Several melter top head Inconel $690^{\circledR}$ components have shown significant oxidation, and limited work is under way to evaluate improved materials.

\subsubsection{WVDP Experience}

A listing of questions (see Appendix F) to obtain information about WVDP's operational experience was sent to WVDP staff with a request for completion and return. In addition, follow-up telephone calls were made to solicit support for the effort. However, no responses were provided to the Study Team by the end of the study period. Based on cognizance of the Study Team members related to WVDP operations, the Joule-heated ceramic melter operation has been largely very successful. Melter TOE has exceeded design basis and is believed to have been in the 80 to $85 \%$ range. All primary components have operated without failure. The one major issue known to have occurred is the gradual reduction in melter glass tank resistance with time, which is believed to be caused by the deposit of noble metals accumulations on the tank floor. The WVDP melter floor slopes from the electrodes down to a bottom electrode.

Accumulations of ruthenium oxide and rhodium and palladium metal are believed to have occurred over time along the corners of the walls. However, WVDP has been able to complete its HLW processing mission despite these accumulations. Lessons learned from the WVDP experience include the following:

- $\quad$ Noble metals fractional accumulations, although lower than anticipated, had a marked impact on operations. Melter technologies that are designed to prevent, accommodate, or are insensitive to accumulations should be considered.

- $\quad$ WVDP increased their glass production rate over time, progressively increasing their melter feed solids concentration. Feed preparation, feeding, sampling, and melters should be designed to handle a broad range of slurry properties as is reasonable. 
- $\quad$ Routine steam and air cleaning of the off-gas film cooler highlight the need to emphasize in the design stage a functional and flexible facility that can be readily maintained with the ability to incrementally modify operations.

- Analytical support for feed analyses was found to be a major factor in achieving overall time-cycle and TOE targets. Analytical facilities should be carefully sized, and redundant analytical equipment should be planned in situations where extended repair times could occur.

\subsection{Design and Operational Requirements to be Evaluated}

Based on the DWPF and WVDP experiences, the primary requirements that should be considered when evaluating melter technologies are summarized as follows:

- $\quad$ Throughput rate/melt rate: The system must deliver the quantity of glass required to meet production goals and should not be the rate-limiting step in the process. This attribute could include parameters such as mixing, high temperature, volatility, etc.

- Glass properties and processing limits: The requirements for the final glass product must be met and the glass must be able to be processed through the melter system. Liquidus temperature, including the ability to handle crystalline material, is a primary requirement that must be considered. Glass solubility limits, glass viscosity, glass redox, durability, phase stability, electrical conductivity, magnetic permeability, etc. are other parameters that must also be considered.

- Materials issues: The melter glass contact materials (refractory and electrode) must be compatible with the glass being processed and must not significantly impact melter life. Vapor space components must also be able to withstand the off-gas environment such that changeout of these components impacts will not seriously affect production rate.

- $\quad$ Production issues: The melter system must be able to be operated and maintained in a remote environment. Melter size must be compatible with facility design, and operational life must also be considered.

Appendix $\mathrm{G}$ provides a detailed list of identified waste form process and technology design requirements compiled by the Study Team based on their experience and from discussions with WVDP and DWPF personnel. The basis for each requirement is given, followed by potential modifications that can be perceived as beneficially impacting the requirement. Potential impacts to facility operations, both positive and negative, have also been captured in Appendix G.

The requirements are grouped into three categories: 1) waste form considerations, 2) operational and processing considerations, and 3) design considerations. Within each category, the requirements are listed in order of importance for evaluating and comparing vitrification technology options. Of the 17 requirements, three are based on waste form considerations, five are based on operational and processing considerations, and nine are based on design considerations. It can be argued that each of the operational and processing considerations are largely fixed by the specific melter design. However, these were separated from the other design requirements to highlight the importance of having as much flexibility as possible to make changes in these parameters during operations. 
This page intentionally left blank 


\subsection{Status of HLW Processing World-Wide}

\subsection{Hanford Waste Treatment Plant}

In 1990 the Tri-Party Agreement (TPA) was signed among DOE, the U.S. Environmental Protection Agency, and the Washington State Department of Ecology (Ecology et al. 1990). The TPA established treatment goals and schedules for treatment of double-shell tanks (DSTs) and single-shell tanks (SSTs). The addition of SST wastes into the HLW and low-activity waste (LAW) treatment strategies significantly increased the projected treatment volumes and final waste form volumes. As a result, in 1991 a TWRS program redefinition effort was performed to re-evaluate the current plans (Grygiel et al.1991). An integrated systems approach was used to evaluate facility and process alternatives. The redefinition, besides being driven by the need to address SST wastes, also recognized that many of the existing Hanford facilities, such as B-Plant, could not be renovated to meet current environmental and safety requirements. In 1992, DOE decided to prepare a TWRS EIS, rather than the supplemental EIS originally planned. In 1992 and 1993, Westinghouse Hanford Company conducted an extensive systems engineering study to identify technical options for treatment and disposal of DST and SST wastes (Boomer et al. 1993). Based on the recommendations of this work, the TWRS project performed engineering and research activities supporting the TWRS mission "to store, treat, and immobilize highly radioactive Hanford waste (current and future tank waste and cesium/strontium capsules) in an environmentally sound, safe, and cost effective manner" (DOE 1994). This work included the assessment and testing of commercially available vitrification technologies. During this period, private industry representatives began to approach DOE with proposals for privatization concepts for TWRS pretreatment and immobilization operations. In 1997, privatization activities were initiated that eventually led to the selection of a team headed by British Nuclear Fuels, Limited (BNFL). From 1998 through 2000, the BNFL team developed conceptual process and facility designs and conducted research and technology testing activities. However, in 2000 ORP made the decision to replace the BNFL team. Through a competitive procurement process, a two-contractor team led by Bechtel National, Inc. (BNI) was selected to complete the design, construction, and commissioning of the WTP facilities. The following sections describe in greater detail the WTP.

\subsubsection{Waste Treatment Plant}

In the following sections, the mission and current conceptual design of the Hanford WTP are generally described. This information was taken from documentation prepared primarily by the previous privatization contractor, BNFL, during the Part B-1 contract period (Arm et al. 2001). The current WTP technical requirements, conceptual design, and specifications are based on the Part B-1 work. Additional specific technical requirements for the HLW vitrification technology are presented in Section 6.1.3.

The WTP will be comprised of several buildings to be located in the 200 East Area near the center of the Hanford Site on a relatively flat terrace known as the 200 Area Plateau. Primary WTP operations will include pretreatment, LAW vitrification, and HLW vitrification. Adjacent facilities will include the administration building, chemical storage building, new melter assembly building, and the failed melter packaging building. Figure 6.1 shows an isometric view of the WTP facilities. A schematic diagram of the overall WTP waste treatment process appears in Figure 6.2. 


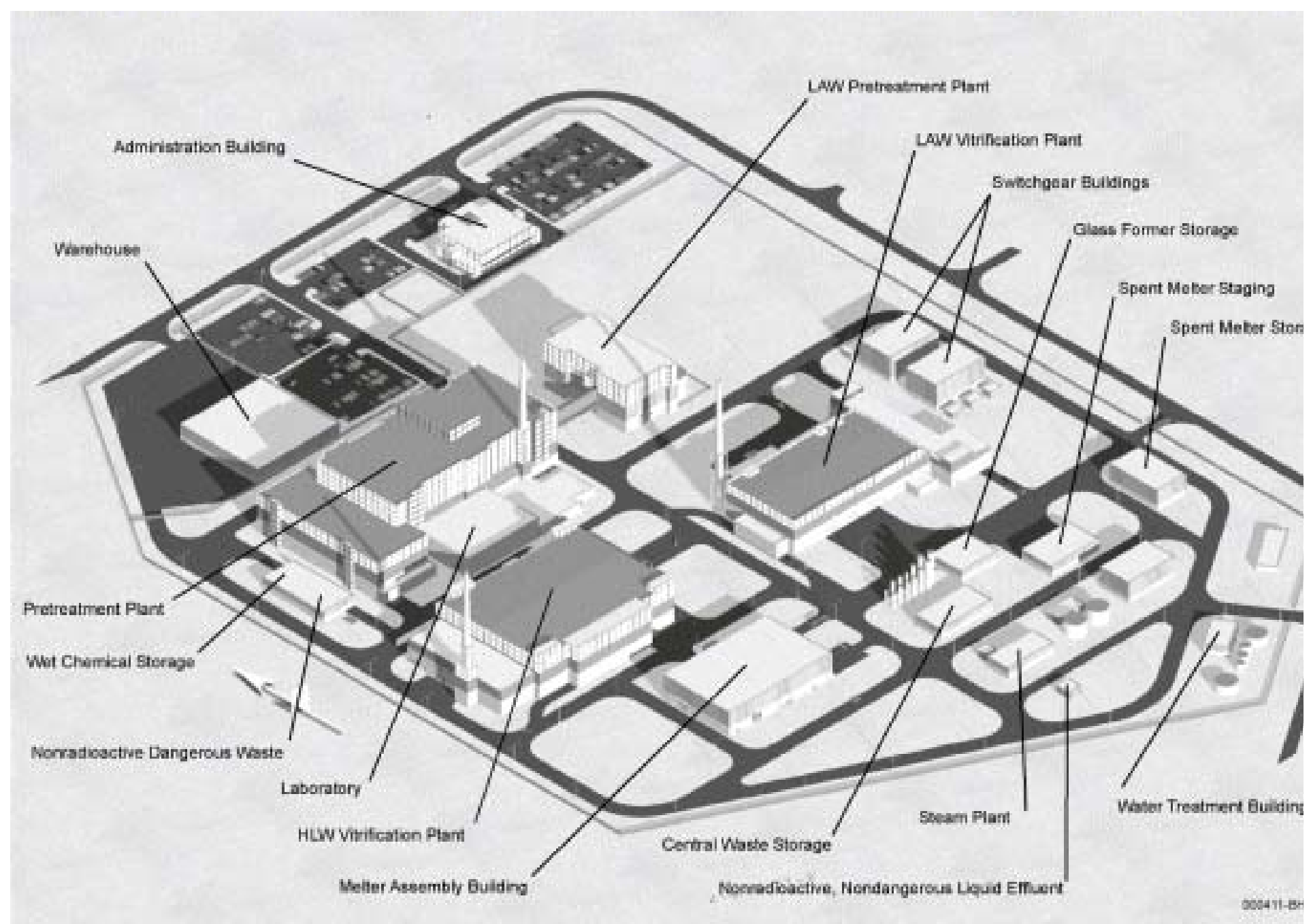

Figure 6.1 Location of Facilities at the WTP 


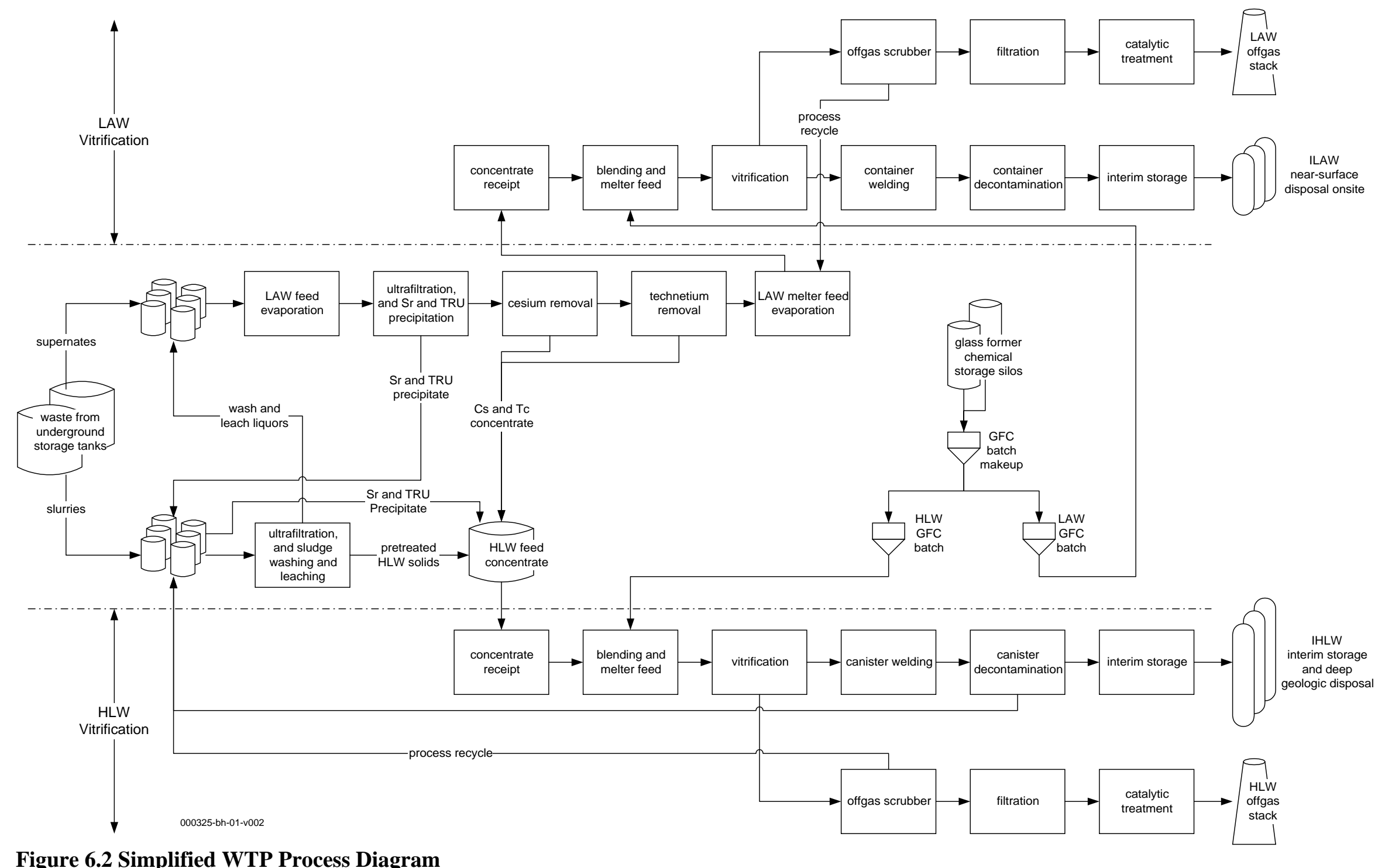




\subsubsection{Pretreatment Facility}

Waste feeds will be received at the WTP pretreatment building by way of pipeline transfer from underground storage tanks. Waste feeds are defined as envelopes. Envelopes A, B, and C are LAW supernatants, and Envelope D consists of the HLW solids. Envelopes A, B, and C contain primarily sodium salts (for example, nitrate, nitrite, aluminate, sulfate, phosphate, hydroxide) and soluble radionuclides such as cesium-137 $\left({ }^{137} \mathrm{Cs}\right)$ and technetium-99 $\left({ }^{99} \mathrm{Tc}\right)$. Most of the LAW to be treated in the WTP will be from Envelope A. Envelope B has higher ${ }^{137} \mathrm{Cs}$ levels and higher concentrations of glass limiting constituents such as sulfate $\left(\mathrm{SO}_{4}\right)$. Envelope $\mathrm{C}$ contains organically complexed strontium-90

$\left({ }^{90} \mathrm{Sr}\right)$ and TRU elements that will have to be removed to ensure that immobilized LAW product specifications will be met. Envelopes A, B, and C will be transferred to the WTP as solutions that contain up to $2 \mathrm{wt} \%$ entrained solids. Envelope D is made up primarily of a slurry of insoluble metal hydroxides (for example, iron, aluminum, zirconium) and contains most of the long-lived radionuclides (for example, plutonium, americium, curium, uranium). The Envelope D solids will be received at the WTP combined with Envelope A, B, or C supernates.

The initial step in the LAW pretreatment process will be the evaporation of dilute feeds, or dilution of concentrated feeds, to approximately 5- to 7-Molar (M) sodium concentration to prepare the feeds for subsequent processing. Envelope A feeds will then be ultrafiltered to remove entrained solids. A very limited number of Envelope $C$ waste tanks will undergo precipitation and ultrafiltration to remove the strontium and TRU precipitate and any entrained solids present. This process involves isotopic dilution with non-radioactive strontium to de-complex radioactive ${ }^{90} \mathrm{Sr}$ and carrier precipitation of TRU with $\mathrm{MnO}_{2}$ by addition of permanganate. Envelope $\mathrm{B}$ solids will be removed at the pretreatment building as part of the HLW pretreatment process (because the waste will be received at the WTP with the initial batches of Envelope D HLW solids). The Envelope A entrained solids will be washed and either stored prior to HLW vitrification or transferred to the DST system for storage.

Following ultrafiltration, LAW feeds will undergo ion-exchange to remove ${ }^{137} \mathrm{Cs}$ and ${ }^{99} \mathrm{Tc}$. The cesium and technetium eluates will be stored in the pretreatment building and blended with pretreated HLW solids prior to transfer to the HLW vitrification process. The final step in LAW pretreatment process, at the LAW pretreatment plant, will be melter feed evaporation. Optimum LAW feed concentrations are expected to range from 8- to 10-M sodium for Envelope A, 3- to 5-M sodium for Envelope B, and 5- to 6$\mathrm{M}$ sodium for Envelope $\mathrm{C}$ waste feeds.

The initial step in pretreatment of the Envelope D HLW solids will be ultrafiltration to separate the LAW supernate and concentrate the HLW solids. The solids will then be washed with water and leached with sodium hydroxide solution as required to remove soluble chemical constituents. Chemical constituents such as aluminum, chromium, sulfate, and phosphate can greatly affect the volume and quality of the HLW glass produced; therefore, they will be removed to the extent practical before HLW vitrification. The solutions generated from water washing and caustic leaching of the HLW solids will be routed to the front end of the LAW pretreatment process. Radioactive and dangerous waste liquid effluents will either be recycled or sent to the Hanford Site Liquid Effluent Retention Facility or the Effluent Treatment Facility.

After pretreatment, the HLW solids will be transferred to one of two collection vessels, where they will be blended with strontium and TRU precipitates, combined with cesium and technetium concentrate, and sampled prior to transfer to HLW vitrification. 


\subsubsection{High-Level Waste Vitrification Facility}

HLW feed concentrate (pretreated HLW solids with pretreatment intermediate waste products added) will be transferred from the pretreatment building to concentrate receipt vessels in the HLW vitrification building. Batches of HLW feed concentrate from these vessels will then be transferred to the melter feed preparation vessel. The feed concentrate will be blended with glass former chemicals and other additives, and mixed to ensure uniformity. The melter feed slurry will then be transferred to the melter feed vessel, from which it will then be fed continuously to the HLW melter.

The HLW melter will be a large-capacity Joule-heated ceramic melter designed to be operated at a nominal temperature of $1150^{\circ} \mathrm{C}\left(2100^{\circ} \mathrm{F}\right)$. The melter feed slurry will be introduced from the top of the melter and will form a cold cap above the surface of the melt pool. Water and volatiles will evaporate or decompose and will be drawn off through the off-gas system. Non-volatiles will react to form oxides and melt into the glass pool. The melt pool is heated by passing an electric current through the molten glass. The nominal inventory of the HLW melter will be about $9 \mathrm{t}$ of glass -- equivalent to about three canisters of immobilized high-level waste (IHLW) product. At a nominal production rate of $1.5 \mathrm{t}$ per day, the average residence time in the melter will be about six days.

HLW glass will be poured periodically into stainless-steel canisters measuring $0.6 \mathrm{~m}$ diameter by $4.5 \mathrm{~m}$ long ( $2 \mathrm{ft}$ diameter by $14.8 \mathrm{ft}$ long) by means of an airlift system located inside the melter. The glass will be poured in a series of lifts over a period of about two days for each canister. An infrared-level detection system, similar to that used at WVDP, will be used to monitor the fill height of glass in the canister.

After filling, the canister will remain connected to the melter pour spout for approximately eight hours to allow volatile components to off-gas during initial cooling. The canister will then be disconnected from the melter, and a temporary lid will be placed over the opening. The IHLW canister will then be allowed to cool sufficiently to allow subsequent canister-handling activities.

The filled canister will be transferred to a station within the canister-handling cell, where the contents will be inspected, sampled as necessary, and prepared for sealing. A lid will be welded over the opening of the canister using an automated welding process operated remotely from the cell's operating gallery. The canister will be weighed after sealing and prior to decontamination.

Next, the canister will be decontaminated using a nitric acid and cerium (IV) chemical milling process. In this process, a thin layer of the canister outer-wall material will be removed by dissolution. The process will remove the heat scale that will form on the outer surface of the canister during filling, leaving a bright finish characteristic of freshly etched stainless steel.

In order to inspect for removable contamination, the decontaminated canister will be swabbed remotely over an area representing the full length of the canister and in areas that are difficult to decontaminate, such as the neck flange and canister base. If surface contamination is found within specification limits, the filled canister will be transferred to the interim storage area, weighed, and stored prior to transfer to the Hanford Site's Canister Storage Building (CSB).

The HLW melter off-gas stream will be treated to remove particulates and radionuclides. Scrubber solution will be recycled to an HLW feed receipt tank in the pretreatment building. Spent canister decontamination solution will be combined with the scrubber solution and recycled to the pretreatment building as well. 


\subsection{Technology Review}

\subsubsection{Review Approach}

This section describes the sources of information and the methods used to obtain, assess, and evaluate the various technology options and technology features.

\subsubsection{Technology Review Approach}

The technology review activities were conducted in parallel with other project activities. Under an optimum scenario, the Task 4 activities would have started after Tasks 1, 2, and 3 had been completed. However, due to the short duration of this project, it was necessary to conduct this task concurrently with the other tasks. As a result, early in the review the criteria and parameters by which to assess technologies and technology features were established based on preliminary information from the other tasks and the experience of the Study Team. Through frequent interactions, the status and progress of the other tasks were monitored and information was updated or revised as necessary so that the technology options were being assessed by the appropriate criteria and parameters.

DOE performed a comprehensive vitrification technology review in 1994 (Calmus 1995). Since that time, DOE has continued to support vitrification technology development and demonstration activities, primarily as part of HLW and mixed waste DOE-EM development programs. Private industry and other domestic and foreign government programs and agencies have also continued to make technology development investments. The intent of the current review was to assemble information on new, novel, or emerging technologies not previously evaluated. Technologies that were previously recommended for development and demonstration but had since not been adequately evaluated were also given a fresh look. In evaluating and screening the information, the Study Team relied heavily on its understanding of previous and ongoing technology development efforts in the U.S. and internationally. The vitrification area encompasses quite a small and specific "community" and the type of environment where everyone knows what everyone else is doing. From this perspective, the Study Team emphasized and brought forward for review and presentation to the Review Team new information and developments. A comprehensive re-review of all technologies and documentation was not intended.

The review approach was to obtain technology information from a variety of sources. These included literature searches, patent searches, review of previous DOE technology assessments, and a formal Request for Information (RFI). The guidance for the review by the Review Team was to be as broad and open to new technological solutions as possible. As a result, the initial data gathering effort used broad and general criteria. Criteria important to the specific application to HLW vitrification were used to examine and differentiate the technologies and technology features. Using key recommendations from the waste form and facility reviews, as well as criteria developed under this task, the optimal technologies and technology features were assessed by the Study Team experts and provided input from others using a workshop forum. The preliminary results were assembled and presented to the Review Team during two-day meetings held in February and April 2001. Guidance from the Review Team was incorporated into the assessment documented in this Study Team report. 


\subsubsection{Waste Form and Operational Results Incorporated into Technology Review}

The key information and recommendations developed by preceding project Tasks 1, 2, and 3 and used to guide or support the technology reviews have been extracted from the task letter reports and summarized here.

Task 1 - Waste Form Requirements: As described in Section 2, the HLW repository requirements are described in the WASRD (U. S. DOE 1996a). EM has responsibility for the DOE sites that produce or will be producing immobilized HLW. EM has passed the WASRD requirements to the producer sites via the WAPS Form Product Specifications (U.S. DOE 1996b). The WAPS also established requirements intended to assure with high confidence that the waste form would meet the repository requirements at the time of production. The waste form properties that directly or indirectly could affect one or more WAPS requirements and are important when evaluating technologies were identified by Task 1 as

- waste loading as it impacts PCT performance

- liquidus temperature

- glass viscosity

- solubility limits in glass

- materials of construction limitations

- volatility of components from the melter.

Additionally, the requirement also exists that the producer be able to describe to the DOE-RW the characteristics of the waste form after production. This requires that the effects of production and subsequent cooling and storage be understood. Therefore, it is necessary that the performance and operation of the technology be well understood, predictable, and repeatable.

Task 2 - Waste Form Evaluations: The waste form assessment produced two significant findings. First, three types of waste forms were feasible: glass waste forms, glass and crystalline waste forms, and vitreous ceramic waste forms. The degree to which each could beneficially reduce the volume of IHLW is still not clear. As a result, technologies should be considered that could produce each or all of them. Second, a lot of uncertainty still exists regarding the true composition of Hanford HLW. The Hanford HLW composition projections are based on limited tank characterizations and laboratory studies. Key partitioning assumptions for chromium, sulfur, phosphorus, and other chemicals that affect waste loading are also based on limited data and theoretical assumptions. Therefore, technologies that can process a wide range of compositions and respond to unanticipated ranges of properties (e.g., viscosity, liquidus temperature, process temperature, etc.) would be of highest impact.

Task 3 - Design and Operational Requirements: Vitrification technology design and operational requirements were identified with input from operating staff at WVDP and DWPF. Requirements based on waste form considerations, operational and processing considerations, and design considerations were documented. Significant issues identified based on process development and facility-operating experiences are summarized in the following statements or recommendations:

- Although feed preparation equipment may be able to achieve concentration goals, actual plant operations can lead to unplanned water additions to the melter feed from pumps and line flushes. For the WTP, there is a possibility that batches of feed may be delivered to the vitrification facility more dilute than expected. Therefore, feed handling and vitrification technologies that can accommodate higher water loadings while still achieving glass production rate goals should be emphasized. 
- It is not possible nor realistic to expect that pilot-plant testing will evaluate all the possible waste composition variations and chemistry conditions that might impact melting rate and steady state melting conditions. Properties that can negatively impact production rate include variations in gas generation beneath the cold cap from redox reactions, cold cap melting kinetics, cold cap heat transfer properties, and viscosity effects on production rate. Therefore, vitrification technologies that can tolerate and overcome variable melting conditions should be emphasized.

- Facility and remote equipment design and layout should emphasize a functional and flexible facility that can be readily maintained with the ability to incrementally modify operations as necessary.

- Process monitoring capabilities should support real-time diagnostics and evaluation of process conditions. Technologies and designs should permit instrumentation and monitoring of critical functions, including visual observations of processing conditions.

Additionally, key factors in assessing technologies, based on the Task 3 matrix, are as follows:

- Waste form considerations: Technologies that can process and discharge glasses with crystal phases present (mixing and/or draining capabilities) or increase the solubility of waste constituents (increased temperature) are advantageous.

- Operational and processing considerations: Technologies that provide a relatively broad temperature-operating range offer the most ability during operation to respond to varying feed compositions (i.e., are able to counter changes in viscosity and cold cap melting characteristics). Secondarily are those with relatively broad power input capabilities to respond to changes in glass electrical conductivity.

- Design considerations: Of paramount importance is to assure the production capacity exceeds the plant requirements by a sufficient margin to respond to varying waste compositions, water content, and the ability to recover TOE after prolonged outages. The simplicity of design to assure good maintainability and operability are also very important. Initial design and selection of construction materials are important to assure that design operational life will be met and preferably exceeded.

Based on the information brought forward from Tasks 1, 2 and 3, seven general criteria can be formulated that capture the major recommendations. Ultimately the technologies should

1. allow the projection of the waste form composition, characteristics (phases), and therefore its physical and chemical properties

2. allow operation at elevated temperatures above the normal range, if necessary

3. maintain crystalline phases in the melt during processing and transport them into the canister

4. force mixing to overcome poor melting kinetics or poor heat transfer condition

5. provide excess production capacity

6. be designed for high operability and maintainability

7. be designed to allow high levels of monitoring and diagnostic capability.

\subsubsection{Assessment of 1995 Technology Review}

In 1995 a HLW vitrification technology review was conducted in support of the Hanford HLW vitrification mission (Calmus 1995). Significant efforts were made to identify and obtain 
information about commercial technologies that could be applied to HLW vitrification. Through a series of information requests, literature searches, and reviews, a set of promising technologies were identified and recommended to DOE for follow-on demonstration and evaluation. Before the recommendations could be taken forward, the Hanford HLW, pretreatment, and LAW vitrification activities were combined into the TWRS-Privatization Project. As a result, no significant DOEfunded development and demonstration activities occurred. The results of the 1995 review are being revisited under this review to serve as an initial starting point. The review criteria and recommendations are reassessed and a determination made whether the technologies or technology features recommended for future development are appropriate for this study. Conversely, technologies not recommended for future development in 1995 are being reassessed to determine whether the bases for their elimination were still valid or if they should be considered today given the WTP's mission and technology criteria.

\subsubsection{Request for Information Review}

To supplement the literature review, an RFI was determined to be another valuable method for soliciting directly from technology developers updates on advancements or new approaches to vitrification. The RFI was prepared and submitted to DOE for issuance through the National Environmental Technology Laboratory (NETL). The technical information requirements in the RFI were developed based on the study objectives. The 1995 technology assessment criteria were also reviewed and adopted as appropriate. The RFI that was published on the NETL electronic solicitation site (http://www.netl.doe.gov/business/solicit/index-b.html) is documented in Appendix H.

\subsubsection{Expert Judgment Reviews}

Study Team members were selected for their breadth of vitrification experience and long-term activity in vitrification technology development. Their knowledge of past and recent developments were relied on heavily to efficiently review information sources and make judgments as to the appropriateness of technologies and technology features. The Study Team also received oversight and guidance from Review Team members through two multi-day meetings in which task progress was presented and discussed. On months when face-to-face meetings did not occur, teleconference calls occurred. Finally, as part of the task's activities, information was reviewed and discussed during a two-day review held at PNNL on March 19 and 20, 2001. Additional PNNL staff augmented the reviewers based on their knowledge in the field of vitrification, one or more of the technology types under consideration, WTP requirements, and remote design and operation. The workshop agenda and list of participants are provided in Appendix I.

\subsection{Technology and Facility Requirements}

\subsubsection{Hanford WTP Baseline and Schedule Descriptions}

In January 2001, a contract was signed between ORP and BNI to complete the design, construction, and commissioning of the WTP. Hot commissioning is scheduled to start in 2007 and be completed by 2011. The plan to treat and immobilize all Hanford tank waste is divided into two phases. A phased implementation was chosen in accordance with the EIS because it meets all regulatory requirements, addresses technical uncertainties, and provides flexibility to accommodate future changes in response to new information and technology development. In Phase 1, 10 percent of the waste by mass and 25 percent by radioactivity will be treated and immobilized by 2018. Phase 2, referred to as the Balance of Mission, treats and immobilizes the remainder of the waste by about 2040. 
The nominal WTP capacity during Phase 1 will be 1.5 metric tons glass/day (MTG/day) of IHLW. The WTP will have a second vitrification cell into which a second HLW melter can be installed and operated. The HLW vitrification system will be sized such that the capacity can be increased to 6 MTG/day through enhancements to the melters. Retrieval and feed staging capabilities and the WTP pretreatment operations are being designed to support the $6 \mathrm{MTG} / \mathrm{d}$ production rate. The WTP is being designed for a 40-year life.

\subsubsection{Technology Requirements}

Plan and elevation views of the conceptual design of the WTP HLW vitrification cell are shown in Figures 6.3 and 6.4, respectively. The cell is approximately $10 \mathrm{~m}$ wide by $23 \mathrm{~m}$ long by $10 \mathrm{~m}$ high ( $33 \mathrm{ft}$ wide by $75 \mathrm{ft}$ long by $33 \mathrm{ft}$ high). As currently laid out, the 4.6-m-tall (15-ft-tall) canisters will be coupled to the melter through two access ports in the floor of the cell. In the current layout, HLW melters are transported into the cell on a rail system through an airlock door approximately $3.8 \mathrm{~m}(12.5 \mathrm{ft})$ tall. Failed melters will be drawn into a shielded box and transported to the WTP spent melter storage building for temporary storage.

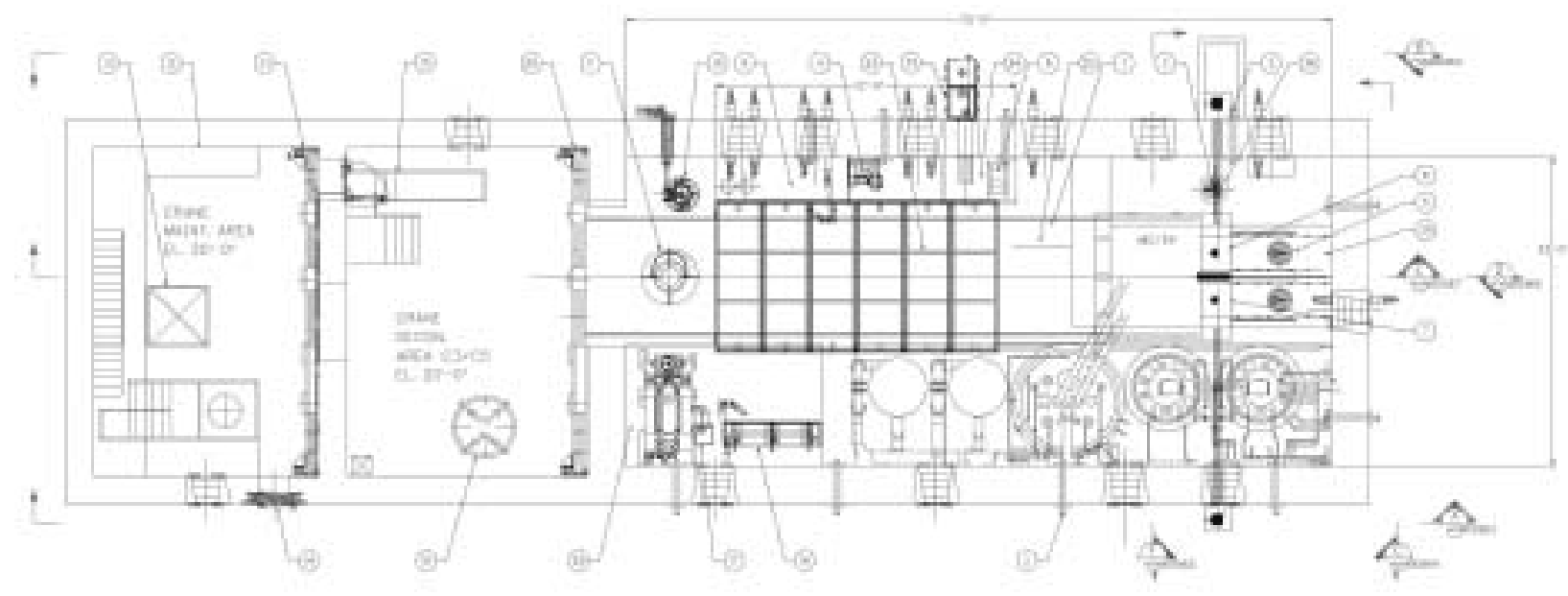

Figure 6.3. WTP HLW Vitrification Cell Plan View 


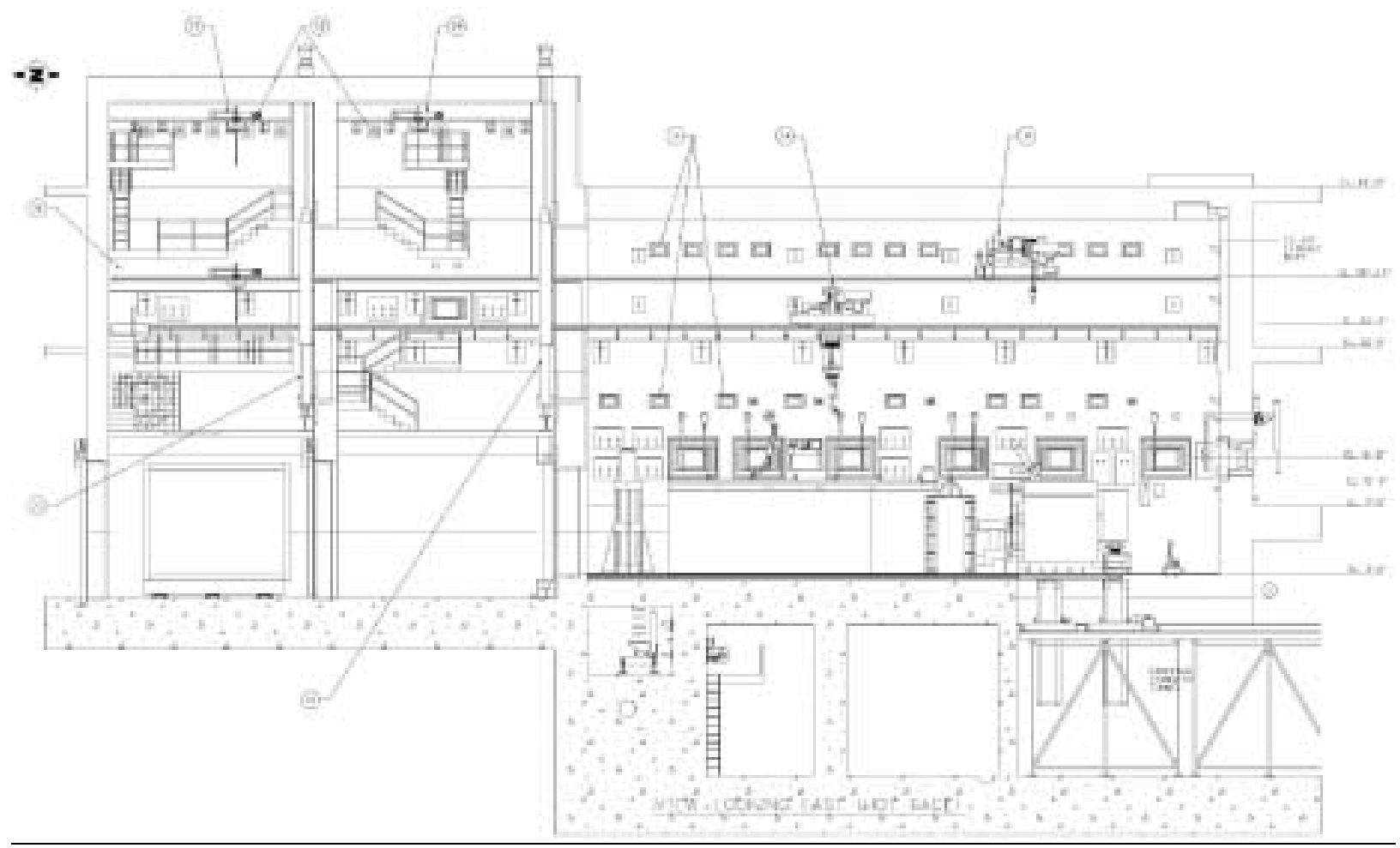

Figure 6.4. WTP HLW Vitrification Cell Elevation View

Feed tanks, off-gas treatment equipment, and maintenance and work areas used to size-reduce melter consumable equipment (overflow section heaters, bubblers, thermowells, etc.) occupy a large fraction of the cell floor space. As a result, the floor space available for the vitrification technology is limited to a footprint of about $6.1 \mathrm{~m}$ by $6.1 \mathrm{~m}(20 \mathrm{ft}$ by $20 \mathrm{ft})$. Gallery windows and manipulators are located approximately $3.7 \mathrm{~m}(12 \mathrm{ft})$ above the floor. Manipulators, a 7.5-ton crane and telerobotic arm are available to perform in-cell operations.

In Phase 1, the HLW vitrification technology must be capable of producing $1.5 \mathrm{MTG}$ /day of a borosilicate waste form at a TOE of $60 \%$. Following plant expansion, daily production rates of $6.0 \mathrm{MTG} /$ day at a TOE of $60 \%$ will be required. Non-volatile waste oxide loadings in the glass are assumed to be in the range of 25 to $35 \mathrm{wt} . \%$. The current melter design is a Joule-heated ceramic melter design with a nominal operating temperature of $1150^{\circ} \mathrm{C}$ and an assumed operating life of four years.

\subsubsection{Methods and Criteria Used in Assessment Activities}

Assessment activities were conducted in two phases, the initial period of information gathering and assessment, and the period of detailed technical assessment. In the initial period of information gathering and assessment, very broad criteria were used to limit the possibility that a promising technology or technology feature would be prematurely eliminated. The criteria included

- the technology or technology feature must be applicable to HLW immobilization

- $\quad$ the candidate technology must be able to produce vitreous, vitreous and crystalline, or fully crystalline waste forms in a molten state 
- $\quad$ the process melt and homogenize the HLW and glass former chemicals prior to transfer into the canister. One exception to this criterion were approaches that vitrified the HLW directly in the disposal canister.

- information about the technology must be available for review and study by the Study Team. Cases where technologies were being proposed or promoted but no information was supplied could not be considered in this review.

To perform the detailed assessments, it was first necessary to develop a list of the important parameters that provide a basis to compare and assess candidate technologies and technology features. The following list was created and used to capture and record information from the various literature and RFI sources. Where information was not explicitly available, knowledge of the technologies and expert judgment were used.

\section{Number of Operating Lines and Cell Impacts:}

- $\quad$ Number of lines required at $1.5 \mathrm{MTG} / \mathrm{d}$

- $\quad$ Number of lines required at $6 \mathrm{MTG} / \mathrm{d}$

- $\quad$ Dimensions $\mathrm{L} \cdot \mathrm{W} \cdot \mathrm{H}$ in $\mathrm{ft}$. at $1.5 \mathrm{MTG} / \mathrm{d}$

- $\quad$ Dimensions $\mathrm{L} \cdot \mathrm{W} \cdot \mathrm{H}$ in $\mathrm{ft}$. at $6 \mathrm{MTG} / \mathrm{d}$

- $\quad$ Required height below melter

- $\quad$ Required height above melter

- Effect on current import/export area

\section{Impacts on Process and Support Equipment}

- $\quad$ Feed preparation

- Off-gas treatment

- $\quad$ Power supplies

- $\quad$ Canister filling

- Secondary wastes

- $\quad$ Safety and permitting

- Secondary waste volume impacts

Implementation Considerations

- Development time and costs

- Demonstration time and costs

- Remote design time and costs

- Total time to deployment

\section{Technical Considerations}

- $\quad$ Limitations of technology relative to key failure modes or constraints (e.g., noble metals, crystal formation, waste form quality)

- Operating temperature

- Waste forms produced 
- $\quad$ Restraints on glass characteristics

- Restraints on materials of construction

- Years between replacement

- $\quad$ Restraints on off-gas process capabilities

- Restraints on glass removal

- Restraints on routine maintenance

- Restraints on remote radioactive facility operability

- $\quad$ Possible impacts on WTP operations (e.g., TOE)

The compiled information were used to assess and compare the technical options. The criteria that were used are listed and described below.

- Ability to tolerate or remove spinels and crystals: The largest gains in waste loading are estimated to be achieved by producing waste forms in which crystalline phases are allowed to form. Plant throughput capacity will also be supported by having this additional flexibility if needed; even though it may not be initially anticipated.

- Ability to operate within a broad temperature region: Technologies that operate across a wide temperature range versus a narrow temperature range enhance operational capacity and the ability to respond to unexpected composition effects (e.g., high viscosity and slow melt rate).

- Ability to control and predict process conditions: The level to which the operation of the technology and the product characteristics can be predicted is important for waste form qualification and process control.

- High reliability and maintainability: Technologies and technology features should first be reliable but also have a high degree of maintainability compatible with a remote facility operating philosophy.

- $\quad$ Ability to monitor process: Technologies should have adequate instrumentation and monitoring capabilities to allow diagnosis of process upsets, abnormal conditions, and equipment status.

- Ability to operate at increased rates above the design basis: The ability to increase feeding rate to respond to high water content, or to "catch up" after an unplanned outage is desirable.

- $\quad$ Facility impacts: Changes that may be required in the WTP design or impacts to WTP operations (e.g., TOE, should be understandable).

- Development and deployment requirements: The effort required to develop the technology or technology feature, the issues to be addressed, and an estimate of the cost and time required should be understandable.

- Viability and likelihood of success: The barriers that exist, both technical and institutional should be understandable. 


\subsection{Vitrification at Forschungszentrum Karlsruhe}

\subsubsection{Background}

At the Forschungszentrum Karlsruhe (FZK), there has been a long history of melter technology development in the Institut für Nukleare Entsorgungstechnik. Construction and operation of a radioactive vitrification plant on the FZK site is within the scope of the Karlsruhe Vitrification Facility (VEK) project. The melter designed for VEK is for low production capacity because the amount of waste to be treated is low and it represents the most advanced system with all the improvements from previous test operations and from experience with processing radioactive wastes. The inactive demonstration of the core process technology of VEK was carried out in a 1:1 scale prototype, remote test facility [Prototype Vitrificatons Test facility (PVA)] operated from 1998 to 2000. Besides the small-scale VEK melter design, a large-scale melter type is being operated in an inactive mock-up test facility in China. This facility was designed and constructed by FZK-INE staff. Two long-term operations with the Chinese melter were started in 2000 and 2001 with the vitrification of $30 \mathrm{~m}^{3}$ of HLW simulant. In the course of both tests, 54 glass canisters were produced.

\subsubsection{Melter Design}

Recent development work has been performed to optimize the melter design with emphasis on the key items listed below. Besides experimental work and theoretical considerations, the system was optimized through three-dimension thermohydraulic modeling. These key items are

- noble metals compatibility (melt tank configuration, power electrode arrangement, noble metals sludge discharge)

- bottom-drain pouring system

- off-gas pipe cleaning by blaster technique

- glass-level measurement in the melter by another independent system

- extension of service life (exchangeable components, electrodes by air-cooling)

- operational safety.

\subsubsection{VEK Waste Glass Test Melter}

The VEK melter type represents a new generation of melter that incorporates the key items identified in the previous section. The cross-section of the VEK test melter is shown in Figure 6.5. It is a liquid-fed Joule-heated ceramic glass melter with a throughput capacity of about 10 liters of liquid waste per hour and a glass production rate of $7 \mathrm{~kg} / \mathrm{h}$. The melter has a cylindrical outside shape formed by a stainlesssteel casing. The outer diameter measures $1.5 \mathrm{~m}$, and the height measures $1.7 \mathrm{~m}$. The dimensions, along with some other characteristic data, are compiled in Table 6.1 . The melt pool surface is $0.44 \mathrm{~m}^{2}$, and it is heated with a pair of Inconel- $690^{\circledR}$ power electrodes, placed on opposite sides in the upper part of the melting tank. Two opposing auxiliary electrodes are located near the bottom and staggered by 30 degrees relative to the main electrodes. These electrodes are used in case additional power is needed for glass pouring. The operational experience, however, showed that the temperature in the lower part of the glass pool, as determined with the thermocouples inside of these electrodes, is always high enough ( 950 to $1050^{\circ} \mathrm{C}$ ) to ensure an easy pouring. Glass is poured through a bottom drain, the design of which is quite mature from many years of experience and testing. During operation, it functions as a thermal valve with an induction heating of the thick-walled Inconel- $690^{\circledR}$ tube during glass discharge. The glass flow is halted within a few minutes through natural heat loss by gradually reducing the induction power input. 


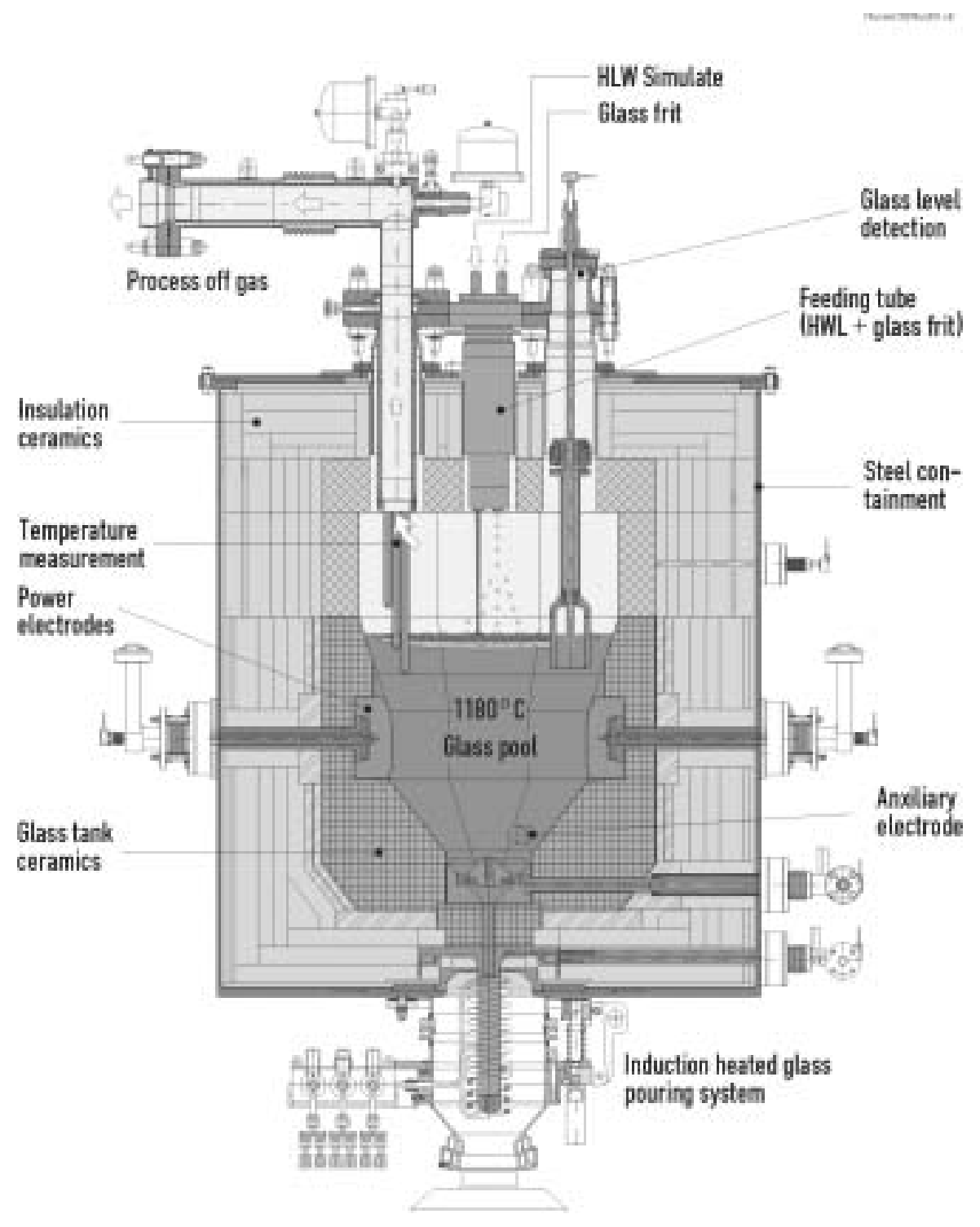

Figure 6.5. Cross-Section View of the VEK Ceramic Test Melter

The noble metals compatibility of the melting system is achieved by a combination of the special shape of the melt tank and ease with which the viscous noble metals sludge can enter the bottom-drain pouring system. The slope of the melt tank walls in the lower area causes the segregating and settling noble metals particles to flow towards the discharge area where they are concentrated and drained preferably during the initial phase of each routine glass pour. The round-shaped metallic (Inconel-690 ${ }^{\circledR}$ ) compartment that forms the entrance of the glass discharge channel assures the inflow of the noble metals sludge while keeping any large solid pieces, possibly originating from melter structure materials, from clogging the discharge tube. Twelve openings along the circumference and one central opening in this compartment provide an unimpeded flow of the noble metals sediments.

The capacity of the melt tank is about $400 \mathrm{~kg}$ of glass, corresponding to the capacity of the European standard canister. Thus, if needed, the melter can be emptied in one pour into one canister. Due to the limited melt inventory, only $100 \mathrm{~kg}$ of glass are poured each batch or four batches per canister. With the reference waste composition, it takes about 2.5 days or a batch every 15 hours to fill a canister. 
Liquid HLW and glass frit are fed to the melter through separate inlet pipes in the melter ceiling. Liquid feeding ( $90 \%$ of HLW simulate $+10 \%$ of recycled scrub solution from the dust scrubber) is performed continuously whereas the glass frit is added batch-wise in form of beads. The process off-gas exits the melter through a vertical pipe in the ceiling, then flows through a horizontal pipe to the first off-gas cleaning component. Two independent cleaning devices (blasters) are installed for keeping the horizontal and vertical pipe free of deposits. The principle is based on shock-wave cleaning. A millisecond release of a few liters of pressurized air generates an extremely effective ultrasonic wave. During the cleaning operation, the melter pressure is lowered from 2 mbar to 10 mbar below ambient pressure. This keeps the plenum from being pressurized during cleaning. The cleaning operation is performed every eight hours during routine operation.

Table 6.1. Main Features of the VEK Test Melter

\begin{tabular}{|c|c|}
\hline Parameter & Data \\
\hline \multicolumn{2}{|l|}{ Design data } \\
\hline Throughput capacity & $10 \mathrm{~L} / \mathrm{h}$ (HLW simulate) \\
\hline Glass production rate & $7 \mathrm{~kg} / \mathrm{h}$ \\
\hline \multicolumn{2}{|l|}{ Geometrical data } \\
\hline Outside dimensions & $\varnothing 1.5 \mathrm{~m}$, height $1.7 \mathrm{~m}$ \\
\hline Weight & 8 metric tons \\
\hline Melt tank capacity & $150 \mathrm{~L}$ \\
\hline Glass pool surface & $0.44 \mathrm{~m}^{2}$ \\
\hline \multicolumn{2}{|l|}{ Materials } \\
\hline Melt tank refractory & ER $2161\left(\mathrm{Al}_{2} \mathrm{O}_{3}-\mathrm{Cr}_{2} \mathrm{O}_{3}-\mathrm{ZrO}_{2}\right)$ \\
\hline $\begin{array}{l}\text { Power electrodes, bottom electrode, } \\
\text { pouring channel }\end{array}$ & Inconel-690 ${ }^{\circledR}$ \\
\hline \multicolumn{2}{|l|}{ Heating system } \\
\hline Glass pool heating & 1 pair of air-cooled electrodes \\
\hline Installed electrical power & $80 \mathrm{kVA}$ \\
\hline $\begin{array}{l}\text { Auxiliary heating (in lower section } \\
\text { of the glass tank) }\end{array}$ & $\begin{array}{l}1 \text { pair of small Inconel- } 690^{\circledR} \text { electrodes, } \\
\text { cylindrical shape }\end{array}$ \\
\hline Start-up heating & $\begin{array}{l}5 \text { external } \mathrm{SiC} \text { heating elements encased } \\
\text { in Inconel- } 690^{\circledR} \text { tubes }\end{array}$ \\
\hline Glass pouring system & $\begin{array}{l}\text { Bottom drain system, induction heated } \\
(10 \mathrm{kHz})\end{array}$ \\
\hline
\end{tabular}




\subsubsection{Melting Process Control}

Process control mainly refers to the control of melt level, extent, and consistency of the process area on top of the glass pool (cold cap), melt temperatures, and correctness of the mass streams of HLW and glass frit. Process control is accomplished though four thermocouples that are arranged vertically in different heights in the upper part of the melter interior. The one placed in the lowest position indicates the melt temperature, as this position is always in the melt. The upper thermocouple is positioned in the melter plenum and supplies the operator with information about the extent of the cold cap on top of the glass pool. To minimize volatilization, a high degree of cold cap coverage (80 to 90\%) is needed. This corresponds to a plenum temperature of 500 to $650^{\circ} \mathrm{C}$. The pool coverage is adjusted by control of the feeding rate. The two intervening thermocouple positions mark the minimum and maximum melt level. Another independent-level detection system is located just below the maximum level. Voltage readings from this position indicate the start of the glass pouring procedure. When contacting the electrically conductive glass melt, an electrical circuit is closed, generating a distinctive voltage signal. When the glass melt level falls below this point, the voltage drops. Mass balances on the entering and exiting streams serve as a third independent method for calculating the melt level. In the future, a radiationresistant camera system will be used.

\subsubsection{Operational Experience}

The recent experience has been mainly with the nonradioactive testing of the VEK process technology. The overall goal of the prototype PVA facility has been the complete, nonradioactive demonstration of the vitrification technology and especially the proof that the new noble metals system is functional. Other goals with respect to VEK have been

- confirmation of the VEK design basis (i.e., HLW throughput capacity and decontamination efficiency)

- collection of operational experience and creation of an operational database

- clarification of the effect of varying waste compositions on process behavior

- investigation of the impact of and the ability to recover from process upsets

- verification of the remote-handling concept

- proof of the ability to produce waste glass with specified composition

- licensing support (participation of the licensing authority's experts in test runs)

- pretraining of VEK operating staff.

In a period of 20 months, five long-term vitrification tests were performed with different objectives. The respective four-week tests were carried out in simulation of continuous hot operations. Table 6.2 gives an overview of the PVA production data.

\subsubsection{Overall Results}

During almost 3000 hours of net feeding time, about $26 \mathrm{~m}^{3}$ of HLW simulant containing 2.9 metric tons of waste oxides were converted to 18 metric tons of glass product in 44 canisters. The simulant volume corresponds to almost $40 \%$ of the real waste. This intense operation period ensures a sufficiently hard performance test for the vitrification technology to be applied in VEK. This test provided proof of the reliable and safe operation of the technology. Other than intentional process disruptions, there were no equipment failures or missed operations. 
Results from the analysis of 930 glass samples showed that the process is well suited to the production a glass with a specified composition. The average waste loading obtained during the five test runs varied between 16.1 and 16.4 mass \%, compared to the acceptable range of 13 to 19 mass $\%$. To investigate the effect of filling a canister in four batches, glass samples were taken from the interfaces between the batches after cutting a canister in half. The result did not reveal any effect on the glass properties (i.e., crystallization). In addition, results from the analysis of the canister with computer tomography showed insignificant changes in properties of the glass batches.

Table 6.2. Overall Production Data of PVA Operation

\begin{tabular}{|l|l|}
\hline \multicolumn{1}{|c|}{ Parameter } & \multicolumn{1}{c|}{ Data } \\
\hline Melter feeding rate & $8-12 \mathrm{~L} / \mathrm{h}$ \\
Glass production rate & $5-7 \mathrm{~kg} / \mathrm{h}$ \\
Feeding time & $3000 \mathrm{~h}$ \\
HLW simulate (feed) volume & $26000 \mathrm{~L}(28800 \mathrm{~L})$ \\
Waste glass production & $18 \mathrm{metric}$ tons \\
Total amount of noble metals & $165 \mathrm{~kg}$ (in terms of oxides) \\
Simulated waste oxides & $2900 \mathrm{~kg}$ \\
Number of pours/canisters & $187 / 44$ \\
Waste glass loading (target $16 \pm 3 \mathrm{wt} . \%)$ & $16.1-16.4$ mass $\%$ \\
Number of glass/liquid samples & $930 / 940$ (for tests only) \\
Plant availability & $100 \%$ \\
\hline
\end{tabular}

\subsubsection{Melter Performance and Noble Metals Compatibility}

The new melter provided good performance with regard to processing behavior, process control, glass pouring, and throughput capacity. Depending on the composition of the waste simulant, a melter feed capacity of 8 to $12 \mathrm{~L} / \mathrm{h}$ could be achieved. The corresponding range of glass production rate was 5 to 7 $\mathrm{kg} / \mathrm{h}$. The reliability of the bottom drain system and the simple, safe glass-pouring procedure were demonstrated during 187 pouring operations. The actual mass of glass poured during the demonstration test was equal to the target value within $\pm 1.5 \mathrm{~kg}$. During the test, the effect of an operator's error was simulated. In this simulation, an operator failed to terminate the glass-pouring operation when there was less than $4 \mathrm{~kg}$ of glass remaining to achieve a full canister. This automatically triggered the weightcontrol signal when canister mass was equal to the target mass.

One of the primary requirements for the VEK test melter was the ability to process waste solutions with high concentrations of noble metals, since the HLW from the Reprocessing Plant Karlsruhe (WAK) contains noble metals. Depending on the simulant, the total concentration of noble metals ranged between 3.7 and $9 \mathrm{~g} / \mathrm{L}$ in the feed and from 0.7 to almost 1 mass $\%$ in the glass. In the course of the experiments, a total of about $165 \mathrm{~kg}$ of noble metals (as oxides) was fed to the melter. The discharge 
efficiency was controlled by analysis of glass samples taken from the pour stream. Figure 6.6 shows results from the second test run (PVA-2), which is considered the reference test.

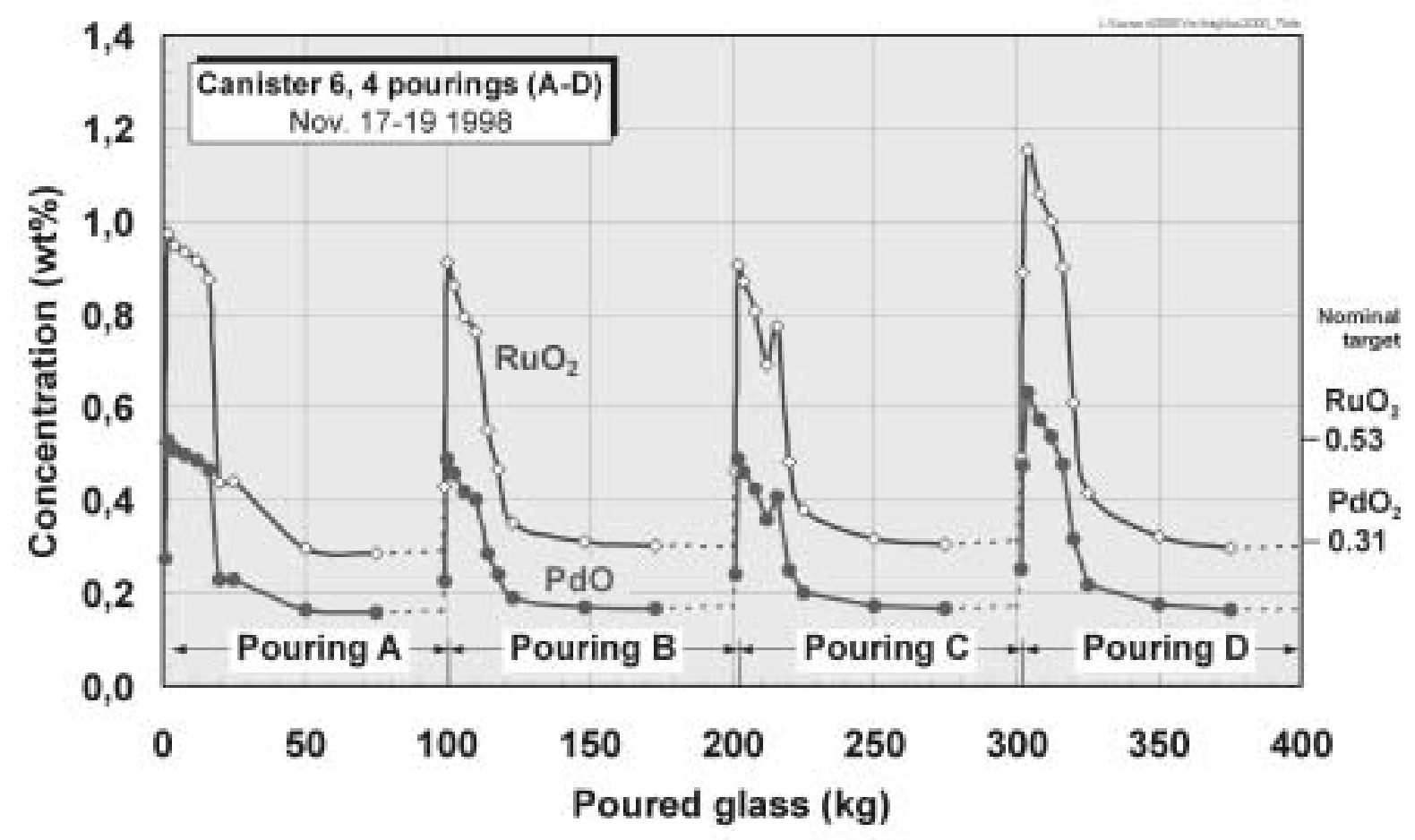

Figure 6.6. Concentration of Noble Metals in the Glass as it Exited the Melter During Run PVA-2

The diagram contains the concentrations of ruthenium dioxide and palladium oxide as a function of the quantity of glass poured into the canister. The data are given for a complete canister filling (four batches). Additionally, the nominal target values are shown. The shape of the plots in Figure 6.6 was expected based on the design of the noble metals collection area in the melter. Mass balances based on the sample analyses showed $100 \%$ discharge efficiency. These findings were confirmed by inspection of the melter interior after emptying the melter at the end of the test.

An additional test of melter maintenance was required by the licensing authorities. In this part of the test, the melter functions, especially the pouring abilities, had to be demonstrated after a "two months of idling" period with the melter full, including noble metals. The test was successful, and the melter could be emptied completely. However, high concentrations of noble metals up to 20 mass $\%$ were found in a small residual glass layer next to the bottom electrode.

\subsubsection{Decontamination Efficiency}

The decontamination efficiency of the melter and of the off-gas line was evaluated from mass balances. The mass balance is based on the analytical results from liquid samples that were taken daily from the scrub solutions of all components in the off-gas treatment and from the receiving tanks. The results for the melter decontamination efficiency were crosschecked with the glass product analyses. Good agreement for both methods was found. Table 6.3 contains the calculated decontamination factors (DF) for the elements cesium and strontium, which together amount to more than $95 \%$ of the radioactivity in the WAK HLW, and for ruthenium. In this table, the experimental DF values for the melter only and for the melter-to- $\mathrm{NO}_{\mathrm{x}}$-absorber are compared with the design values. The DF values are obtained from the 
second test run (PVA-2). The DF values found for the melter indicate high-retention efficiency for each of the three elements; each of them exceeds the design value.

Table 6.3. DF Obtained from the PVA-2 Test Run with Reference Simulant

\begin{tabular}{|c|c|c|c|c|}
\hline \multirow[t]{2}{*}{ Element } & \multicolumn{2}{|c|}{ Melter } & \multicolumn{2}{|c|}{ Melter to $\mathrm{NO}_{\mathrm{x}}$-Absorber } \\
\hline & PVA-2 test & Design & PVA-2 test & Design \\
\hline Cs & 42 & 30 & 16300 & 9000 \\
\hline $\mathrm{Sr}$ & 133 & 60 & 273000 & 45000 \\
\hline $\mathrm{Ru}$ & 12.5 & 5 & 12400 & 12500 \\
\hline
\end{tabular}

\subsubsection{Off-Gas Pipe Cleaning}

The use of the blaster equipment for routine cleaning of the off-gas pipe proved to be very effective. The routine application of the blaster operation of every eight hours helped to prevent deposit layers in the offgas pipe. This was confirmed during the test runs, as the formation of deposits is usually indicated by an increase of the differential pressure along the pipe, and by visual inspection of the pipe after the tests. The induced short-term pressure increase did not lead to higher-than-acceptable pressures in the melter plenum.

\subsubsection{Level Detection Probe}

The use of an additional level determination method was introduced to obtain an independent measure of the glass level in the melter through a distinct signal to the operator when to start the pouring procedure. The suitability of the level detection probe, which gives an electrical signal as long as contacting the glass melt, was confirmed. Under normal process conditions a clear signal can be expected. However, when strong non-normal process conditions like overfeeding occur, the signal output can lead to difficulties in interpretation.

\subsubsection{Melter Restart}

During long-term loss of power to the melter, the glass cools. This is one of the most important process upsets from which recovery must be possible. In a separate experiment, the restart of a cold melter had to be shown. With a full melt inventory, the melter was powered off until the glass exhibited temperatures below $100^{\circ} \mathrm{C}$. To restart the melter, external SiC heating elements were placed above the melt pool. After about two week of heating the glass with the resistance heaters, the glass was hot enough that Joule heating could be used to heat the glass to operating temperature.

\subsubsection{Radiation-Resistant Camera}

For easier operation of the melter and to supplement the data used for process control, visual information about the condition/coverage of the larger part of the melt surface would be very helpful. In the last two decades, camera systems have been tested and used without much success, mainly because of deposition of material on the lens system; it was not possible to keep them clean enough even with air to flush the area around the objective.

In collaboration with a company from the United Kingdom, FZK plans to test a new camera. The camera's main feature is the very small objective of only $2 \mathrm{~mm}$ in diameter. It is expected that an airflow rate of about $10 \mathrm{~m}^{3} / \mathrm{h}$ can keep the camera objective continuously and completely free of deposits, 
regardless of their nature (small particles, volatiles). A representative test of the new camera during melter operation will be carried out in the near future (Fall 2001). The camera is radiation resistant up to 2 MGy and temperature resistant up to $1200^{\circ} \mathrm{C}$.

\subsection{Experience from Europe (other than Germany) and Asia}

\subsubsection{ENEA EUREX Plant, Saluggia, Italy}

At the ENEA Enriched Uranium Extaction (EUREX) Plant in Saluggia, Italy, $225 \mathrm{~m}^{3}$ of waste (five different types) are stored. It is foreseen to use existing cells within the former EUREX reprocessing building to install a cold crucible for vitrification about $180 \mathrm{~m}^{3}$ of waste solution. The remaining $45 \mathrm{~m}^{3}$ will be converted to cement, mainly because it is very high in sulfate. Even if the sulfate waste was blended with other wastes, it could not be vitrified because the solubility limit of sulfate in borosilicate glass is too low. Currently, the project is undergoing a revision in order to optimize the mission. No glass composition has been found yet that could incorporate more sulfate than about 1 mass $\%$.

\subsubsection{France}

The experience in France is well documented and needs not be discussed here. The reader is referred to Bonniaud et al. (1978); Lutze and Ewing (1988); and DOE (1994).

\subsubsection{Japan, Tokai-mura}

The ceramic melter-based radioactive plant Tokai Vitrification Facility (TVF) at Tokai-mura has been in hot operation since 1996. The glass in this melter is poured through a bottom drain system consisting mainly of a thick-walled induction-heated pouring pipe made of Inconel $690^{\circledR}$. Experience indicated the need for a new glass-sampling system that is located between the pour pipe and the canister. After a few glass batches, the original glass sampling system caused the formation of glass filaments when the glass was first poured. At each successive batch that was poured, additional glass would accumulate, eventually clogging the space between the pour tube and the canister. As a result, the TVF was shut down for a year, and the glass melter maintained in the idling mode. The original glass sampling system was removed, and the new one installed under remote conditions. Since installation of the new glass sampling system, no glass sampling problems have been experienced.

Another item under consideration and development at the Tokai-mura TVF is the off-gas pipe between melter and submerged bed scrubber. The problem is the substantial amount of deposition of airborne material on the inner pipe wall. Current development activities are directed to minimize such deposition with off-gas flow modeling and the development of an optimized pipe cleaning method and equipment.

\subsubsection{Japan, Rokkasho-mura}

A liquid-fed ceramic melter will be used at the Rokkasho-mura spent fuel reprocessing plant in northern Japan. A large-scale melter with a design production capacity of $52 \mathrm{~kg} / \mathrm{h}$ waste glass has been under design and construction. The testing program includes tests with HLW simulant that contains high concentrations of noble metals. The prototype melter has a glass pool surface area of $2.2 \mathrm{~m}^{2}$. The bottom slope is between approximately 45 and 50 degrees. Glass is poured through an induction-heated bottom drain freeze valve. The noble metal sludge that should form near the bottom walls should be removed easily. The details of the sludge entrainment area were optimized with respect to easy discharge of noble metals sludge into the major channel and for protection of the major channel from blockage by smaller pieces that may originate from the melter structure.

Several long-term test runs revealed that the design throughput capacity could be achieved with HLW simulant without noble metals, but was $25 \%$ lower when the HLW-simulant contained the nominal concentration of noble metals (more than 7 to $8 \mathrm{~g} / \mathrm{L}$ ). At this time, it is uncertain if the decrease in 
throughput is due to process kinetics or to the changes in melt temperature profile that result from the changes to the power distribution in the melt because of noble metals accumulation. The waste glass contains a nominal 1.5 mass $\%$ noble metals. Other work with this melter includes glass melting and glass product composition optimization.

\subsubsection{China, SNFP}

At a former irradiated fuel reprocessing site in the province of Sichuan, China, an industrial-scaled prototype remote nonradioactive pilot vitrification facility was constructed. Several long-term tests were carried out at this facility, and a liquid-fed ceramic melter will be used to vitrify the HLW stored at the site. The large-scale melter has a $1.4-\mathrm{m}^{2}$ glass pool surface area and a demonstrated feed throughput capacity of approximately $55 \mathrm{~L} / \mathrm{h}$. This feed rate corresponds to a glass production rate of $26 \mathrm{~kg} / \mathrm{h}$. Two long-term tests were carried out with the production of 26 glass canisters containing $400 \mathrm{~kg}$ each in April/May 2000 and 29 canisters in May 2001. The glass has been poured through the bottom drain of the melter. The melter has also an airlift-supported overflow drain that was tested previously. It was originally designed as a back-up drain, but has never been used.

For the active plant, only a bottom drain will be used. The mature design no longer requires the overflow as a backup. This measure allows a more optimized arrangement of the melter in the hot cell and easier remote operation and maintenance. The melter is fully noble metals compatible. This was demonstrated previously in a test run during which $70 \mathrm{~kg}$ of ruthenium as $\mathrm{RuNO}\left(\mathrm{NO}_{3}\right)$ were fed to the melter in the HLW simulant and which were completely removed with the glass batches and at the end of the run when the melter was drained. The upper section of the melter is mainly for waste processing and melting. It is powered with two sets of air-cooled Inconel- $690^{\circledR}$ electrodes. The lower part of the melt pool is powered with one set of air-cooled Inconel- $690^{\circledR}$ electrodes and has a wall inclination between 60 and 75 degrees. In this section, the glass is maintained at an optimized temperature range for glass pouring between 950 and $1050^{\circ} \mathrm{C}$.

\subsection{Technology Review Revisited}

In June and September 1994, two workshops were held to evaluate and select commercial vitrification technologies with the high potential for successfully supporting the tank waste remediation mission. Capacities of up to $20 \mathrm{MTG} / \mathrm{d}$ production were sought either by a single process unit or multiple process units. The evaluation criteria that were established by which to assess technologies are reproduced in Appendix J. These criteria were reviewed and, where applicable, were incorporated into the RFI used in this current review to obtain updated information from technology suppliers.

A Technical Advisory Committee (TAC) was formed composed of Hanford Site experts; TWRS Project staff; and external experts from industry, academia, and other DOE sites. Melter technology categories considered at that time included Joule-heated melters, combustion melters, induction melters, plasma/arc furnaces, microwave melters, and hot isostatic presses.

\subsubsection{Phase 1 Initial Technology Elimination}

During the June, 1994 workshop, the TAC reviewed background information on melter system selection process; defined selection criteria; established methods for weighting and scoring; and outlined a schedule for remaining work. The following minimum criteria for the melter technology viability were established. The use of criteria here is more definitive since these were the basis for excluding a number of candidate technologies from further consideration as a result of the phase 1 review.

- The technology must have the ability to incorporate HLW into borosilicate glass or equivalent. 
- The technology must have the technical maturity to allow development within schedule and cost constraints.

- The technology must have a reasonable total program cost (development, capital, operating, and repository).

Table 6.4 summarizes the technology review results from the preliminary assessment. The key advantages and disadvantages are summarized in the table. The TAC recommendations for technologies warranting more detailed review in the second phase (September 1994 workshop) of the review are also indicated. Four basic technology types, gas-fired, plasma arc, microwave, and hot isostatic pressing (HIP), were determined to be unsuitable for further consideration. The following paragraphs discuss the primary bases for their elimination and whether renewed consideration is warranted under this study as documented in Calmus (1995).

Gas-fired Technology: This classification included cyclone, industrial, and rotary kiln technologies. The primary concerns raised were 1) a lack of industrial experience (with the exception of the industrial glass melter technology); 2) high volatility losses during melting; 3 ) significantly increased volumes of noncondensable off-gas products; 4) a short residence time, possibly requiring a secondary melter hold tank (with the exception of the industrial glass melter technology); and 5) safety issues associated with large quantities of fossil fuel use within the remote facility. 
Table 6.4. Summary of Technology Assessment and Phase 1 Recommendations

\begin{tabular}{|c|c|c|c|c|c|c|c|c|c|}
\hline \multicolumn{3}{|c|}{ Technology } & \multicolumn{3}{|c|}{ Key Advantages } & \multicolumn{3}{|c|}{ Key Disadvantages } & \multirow{2}{*}{$\begin{array}{l}\text { Recommendations } \\
\text { Include in Phase } 2 \text { of } \\
\text { study }\end{array}$} \\
\hline $\begin{array}{l}\text { Joule- } \\
\text { heated }\end{array}$ & Low temperature & $\begin{array}{l}\text { Ceramic } \\
\text { lined }\end{array}$ & $\begin{array}{l}\text { Well } \\
\text { developed }\end{array}$ & $\begin{array}{l}\text { Reliable and } \\
\text { passive }\end{array}$ & $\begin{array}{l}\text { Remote } \\
\text { experience }\end{array}$ & $\begin{array}{l}\text { Low production } \\
\text { rate }\end{array}$ & $\begin{array}{l}\text { Low temp. limits } \\
\text { waste loading }\end{array}$ & $\begin{array}{l}\text { High disposal } \\
\text { cost }\end{array}$ & \\
\hline & & $\begin{array}{l}\text { Metal } \\
\text { lined }\end{array}$ & $\begin{array}{l}\text { High process } \\
\text { rate }\end{array}$ & $\begin{array}{l}\text { Suspends } \\
\text { insolubles }\end{array}$ & Compact & Materials concerns & $\begin{array}{l}\text { Low temp. limits } \\
\text { waste loading }\end{array}$ & $\begin{array}{l}\text { Increased } \\
\text { volatility loses }\end{array}$ & $\begin{array}{l}\text { Evaluate stirred melter } \\
\text { option Phase } 2\end{array}$ \\
\hline & High temperature & $\begin{array}{l}\text { Ceramic } \\
\text { lined }\end{array}$ & $\begin{array}{l}\text { Large base of } \\
\text { industrial } \\
\text { experience }\end{array}$ & $\begin{array}{l}\text { Increased waste } \\
\text { loading }\end{array}$ & Passive & $\begin{array}{l}\text { Electrode } \\
\text { materials concerns }\end{array}$ & $\begin{array}{l}\text { Large size vs } \\
\text { production rate }\end{array}$ & $\begin{array}{l}\text { High disposal } \\
\text { cost }\end{array}$ & Evaluate in Phase 2 \\
\hline & & $\begin{array}{l}\text { Metal } \\
\text { lined }\end{array}$ & Passive & $\begin{array}{l}\text { Increased waste } \\
\text { loading }\end{array}$ & Simple design & $\begin{array}{l}\text { Liner life \& } \\
\text { materials concerns }\end{array}$ & $\begin{array}{l}\text { High disposal cost } \\
\text { if liner is not } \\
\text { replaceable }\end{array}$ & $\begin{array}{l}\text { No remote } \\
\text { experience }\end{array}$ & Evaluate in Phase 2 \\
\hline \multirow[t]{2}{*}{ Induction } & Low frequency & & $\begin{array}{l}\text { Well } \\
\text { developed }\end{array}$ & $\begin{array}{l}\text { Tolerant of } \\
\text { insolubles }\end{array}$ & $\begin{array}{l}\text { Remote } \\
\text { experience }\end{array}$ & $\begin{array}{l}\text { Limited operating } \\
\text { life }\end{array}$ & $\begin{array}{l}\text { Low temp. limits } \\
\text { waste loading }\end{array}$ & $\begin{array}{l}\text { Limited scale- } \\
\text { up ability }\end{array}$ & $\begin{array}{l}\text { Consider as a basis for } \\
\text { comparison in Phase } 2\end{array}$ \\
\hline & High frequency & & $\begin{array}{l}\text { Increased } \\
\text { waste loading }\end{array}$ & Passive & $\begin{array}{l}\text { Tolerant of } \\
\text { insolubles }\end{array}$ & $\begin{array}{l}\text { Liquid feeding not } \\
\text { demonstrated }\end{array}$ & $\begin{array}{l}\text { No remote } \\
\text { experience }\end{array}$ & $\begin{array}{l}\text { Limited scale- } \\
\text { up ability }\end{array}$ & Evaluate in Phase 2 \\
\hline \multirow[t]{3}{*}{ Gas-fired } & Cyclone & & $\begin{array}{l}\text { Compact with } \\
\text { high } \\
\text { production } \\
\text { rate }\end{array}$ & $\begin{array}{l}\text { Increased waste } \\
\text { loading }\end{array}$ & & $\begin{array}{l}\text { No remote or } \\
\text { industrial } \\
\text { experience }\end{array}$ & $\begin{array}{l}\text { High volatility with } \\
\text { increased off gas } \\
\text { equipment sizes }\end{array}$ & $\begin{array}{l}\text { Short residence } \\
\text { time requires } \\
\text { secondary } \\
\text { melter hold } \\
\text { tank }\end{array}$ & $\begin{array}{l}\text { Do not consider in } \\
\text { Phase } 2\end{array}$ \\
\hline & Industrial & & $\begin{array}{l}\text { Large base of } \\
\text { industrial } \\
\text { experience }\end{array}$ & $\begin{array}{l}\text { Increased waste } \\
\text { loading }\end{array}$ & & $\begin{array}{l}\text { Large size vs } \\
\text { production rate }\end{array}$ & $\begin{array}{l}\text { Limited radiant heat } \\
\text { transfer to dark } \\
\text { HLW glasses }\end{array}$ & $\begin{array}{l}\text { Safety issues } \\
\text { with fuel } \\
\text { sources }\end{array}$ & $\begin{array}{l}\text { Do not consider in } \\
\text { Phase } 2\end{array}$ \\
\hline & Rotary kiln & & $\begin{array}{l}\text { High } \\
\text { throughput }\end{array}$ & & & High volatility & $\begin{array}{l}\text { Safety issues w/ } \\
\text { fuel sources }\end{array}$ & $\begin{array}{l}\text { Short residence } \\
\text { time requires } \\
\text { secondary } \\
\text { melter hold } \\
\text { tank }\end{array}$ & $\begin{array}{l}\text { Do not consider in } \\
\text { Phase } 2\end{array}$ \\
\hline Plasma Arc & $\begin{array}{l}\text { Plasma torch, } \\
\text { transferred arc and } \\
\text { arc furnaces }\end{array}$ & & $\begin{array}{l}\text { Increased } \\
\text { process rate }\end{array}$ & $\begin{array}{l}\text { Increased waste } \\
\text { loading }\end{array}$ & & Volatility issues & $\begin{array}{l}\text { Increase in short- } \\
\text { life components, } \\
\text { mechanically more } \\
\text { complex }\end{array}$ & $\begin{array}{l}\text { Short residence } \\
\text { time requires } \\
\text { secondary } \\
\text { melter hold } \\
\text { tank }\end{array}$ & $\begin{array}{l}\text { Do not consider in } \\
\text { Phase } 2\end{array}$ \\
\hline \multicolumn{2}{|l|}{ Microwave } & & $\begin{array}{l}\text { Increased } \\
\text { waste loading }\end{array}$ & $\begin{array}{l}\text { Some } \\
\text { radioactive } \\
\text { experience }\end{array}$ & & Batch process & $\begin{array}{l}\text { Waste form quality } \\
\text { concerns }\end{array}$ & $\begin{array}{l}\text { Scale-up } \\
\text { limitations }\end{array}$ & $\begin{array}{l}\text { Do not consider in } \\
\text { Phase } 2\end{array}$ \\
\hline \multicolumn{2}{|l|}{ HIP } & & $\begin{array}{l}\text { High glass } \\
\text { durability }\end{array}$ & $\begin{array}{l}\text { Some } \\
\text { radioactive } \\
\text { experience }\end{array}$ & & $\begin{array}{l}\text { Low waste } \\
\text { loadings }\end{array}$ & $\begin{array}{l}\text { Complex waste } \\
\text { formulation }\end{array}$ & $\begin{array}{l}\text { Low production } \\
\text { rate }\end{array}$ & $\begin{array}{l}\text { Do not consider in } \\
\text { Phase } 2\end{array}$ \\
\hline
\end{tabular}


Cyclone gas-fired melter: Limited development, demonstration, and application of gas-fired technology, most notably the Vortec Corporation's cyclone combustion system shown in Figure 6.7, has occurred since the 1995 review. A production unit was constructed and operated in Ohio to process aluminum pot liner waste. A demonstration unit was also planned to be constructed and operated at the DOE Paducah Gaseous Diffusion Plan to demonstrate contaminated soil remediation. However, for non-technical reasons, the Paducah demonstration was redefined to include only the waste sorting and packaging "pretreatment" activities. The vitrification portion of the project was cancelled. ${ }^{17}$ Significant volatility of alkali metals, heavy metals, borates, and semivolatile isotopes (cesium) is still a major drawback of this technology requiring additional recycle handling and glass qualification actions. Due to the short residence time in the combustion melting chamber, a second melter tank would be required; albeit it would be smaller than a Joule-heated ceramic melter that is directly fed. Safety concerns with fossil fuel use in the HLW facility also persists. Finally, the reliability, availability, and maintainability of the technology under remote operational requirements cannot be estimated due to the lack of significant demonstration to date.

Feedstocks/Fuel
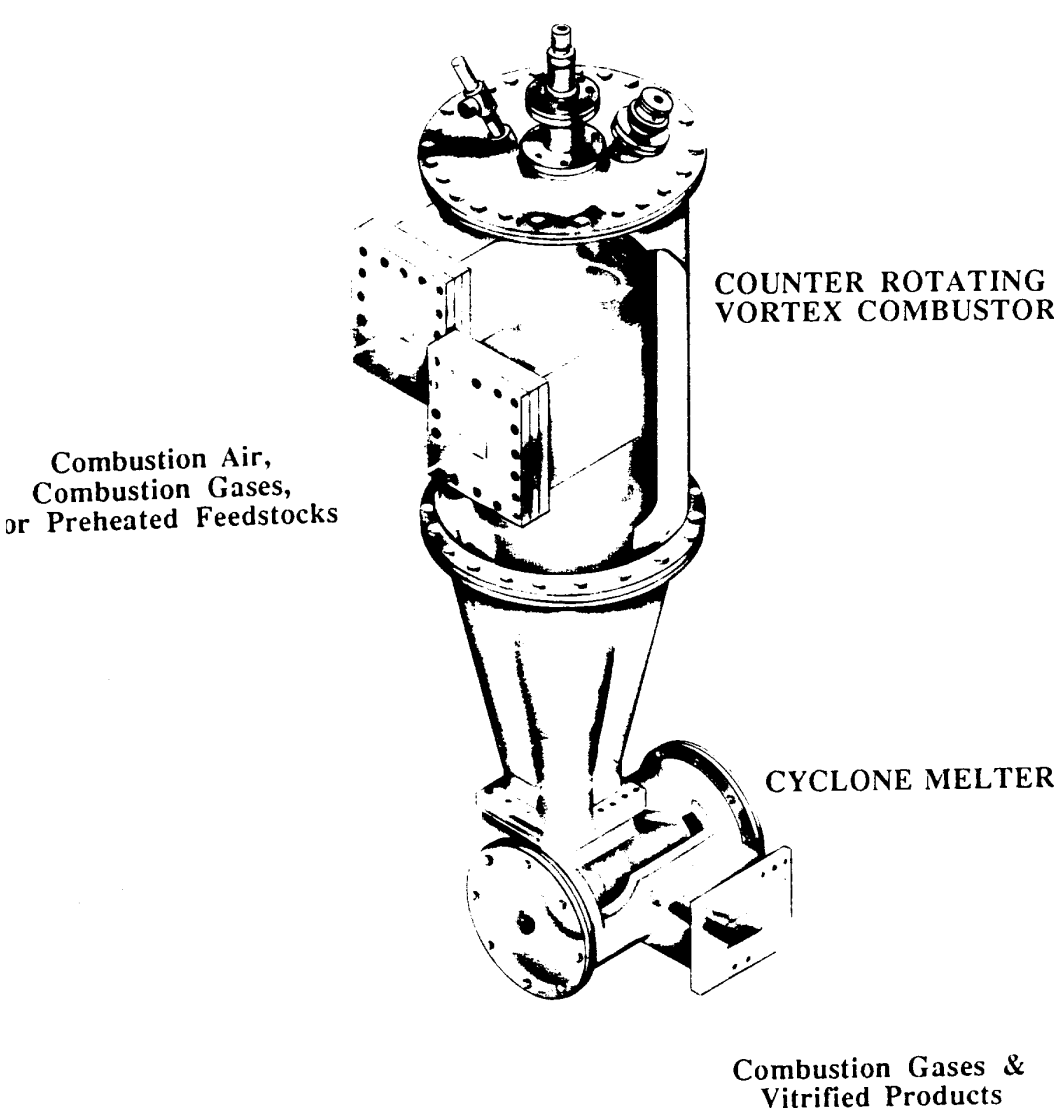

Figure 6.7. Vortec Cyclone Combustion Melting System (Myles et al. 1992)

\footnotetext{
${ }^{17}$ This data presented by J. Hnat, M Pineda, D Detwiler, and M Schaffer on October 17-19, 2000, at the "Industry Partnership for Environmental Science and Technology Conference." Presentation entitledm "Innovative Pretreatment and Vitrification Technology for Waste Remediation."
} 
Little new information was uncovered in the literature search that was not already generally known. The RFI response submitted by Vortec Corp. contained proprietary markings. As a result, a Review Team member completed the necessary non-disclosure agreement and reviewed the information. Therefore, this information is not available to the Study Team for discussion in this report. However, based on the Review Team member's review, it is concluded that this gas-fired technology is not applicable to WTP HLW vitrification.

Industrial gas-fired melter: No development or application of this technology to HLW or similar waste has occurred since 1995. As a result, extensive development is believed to still be required. Technically, radiant heat transfer is very poor for dark glasses of the type that would be produced. Therefore, the efficacy of this technology remains in question. While volatility losses would not be amplified to the same degree as the cyclone gas-fired melter, higher gross entrainment losses would result from the high velocities created in the plenum spaced from the combustion gas volumes. Industrial glasses with more than normal volatility are typically melted in Joule-heated ceramic melter furnaces; rather than the gas-fired reverberatory furnaces that are described here. Safety concerns with fossil fuel use in the HLW facility also persists as a concern. Finally, this technology is not believed to provide any clear advantage over the baseline Joule-heated ceramic melter technology. Therefore, industrial gas-fired melter technologies are still appropriately defined as not applicable to WTP HLW vitrification.

Rotary kiln gas-fired melter: No development, demonstration, or application of this technology to HLW treatment has occurred since the TWRS HLW and LAW vitrification demonstration programs in 1994 and 1995. Significant volatility of alkalis, alkaline earths, heavy metals, and semivolatile isotopes (cesium) is still a major drawback of this technology requiring additional recycle handling and glass qualification actions. Due to the short residence time in the kiln chamber, a second melter tank may be required -- albeit it would be smaller than a Joule-heated ceramic melter that is directly fed. Safety concerns with fossil fuel use in the HLW facility also persist. Finally, the reliability, availability, and maintainability of the technology under remote operational requirements cannot be estimated due to the lack of significant demonstration to date. Therefore, rotary kiln gas-fired melter technologies are still appropriately defined as not applicable to WTP HLW vitrification.

Plasma Arc Technology: This classification included plasma torch, transferred arc, and arc furnaces. The primary concerns raised in 1995 were 1) high volatility losses during melting; 2) an increase in short-lived components that are mechanically more complex; and 3) a short residence time, possibly requiring a secondary melter hold tank. Development and demonstration of plasma arc technologies have continued under various government and industrial sponsorship. Exposed plasma and arc torches possess some of the same technical deficiencies and concerns as the gas-fired melter technologies. Submerged arc applications have a better application to HLW processing because they are able to introduce significantly more thermal energy into the melt locally than Joule-heating electrodes. However, this ability also creates concerns due to the high local temperatures, electrode positioning control and electrode feeding requirements, and electrode material consumption. DC and carbon electrodes in general also create the potential affect of electrode-glass reduction reactions and the formation of reduced secondary phases, such as reduced metals and sulfides. The possible production of a metal or slag phase and its effect on the glass phase composition and properties has not been evaluated for HLW glasses. Therefore, with the exception of its possible use as a secondary boosting technique and pending the results of the RFI and literature submissions, the plasma arc technology is not believed to provide any clear 
advantage over the baseline Joule-heated ceramic melter technology. Therefore, these melter technologies are still appropriately defined as not applicable to WTP HLW vitrification.

Microwave Technology: This technology was included in the 1995 review to be comprehensive and recognize that DOE has conducted considerable microwave melting development and demonstration activities, particularly at the Oak Ridge and Rocky Flats sites. The primary concerns raised in 1995 and that are still considered valid today are that microwave melting has been developed as a batch process in which drums of waste are loaded into a microwave furnace. Uneven heating within the volume of the drum was also cited as a primary technical issue. The third major issue is that process scale-up has not been done to the scale necessary to meet WTP requirements. Therefore, a large number of operating lines would be required. Microwave technology has been investigated by DOE and internationally as a boosting technique. It is quite effective in this regard, but it does place added design constraints on the melter design. The Japanese HLW program developed and demonstrated microwave heating to the greatest degree as secondary heating and startup techniques. However, based on a 1995 paper describing plans to build the commercial fuel reprocessing plant at Rokkasyo by the Japan Nuclear Fuel Limited, microwave boosting is not planned (Kitamura et al. 1995). Within the scope of this review, microwave melting would be more appropriately considered as a possible energy input technique for in-can melting technologies. As a stand-alone melter technology; however, this technology is not believed to provide any clear advantage over the baseline Joule-heated ceramic melter technology. Therefore, microwave melter technologies are still appropriately defined as not applicable to WTP HLW vitrification.

HIP: This technology was included in the 1995 review to be comprehensive and recognize that DOE had conducted a considerable development and demonstration effort at INEEL in the 1980s and early 1990s. Ceramic waste forms that are produced using a HIP process were attractive to INEEL because of the composition of the calcined HLW (high calcium, fluorine, aluminum, and zirconium). When applied to the alkaline type wastes common to the Hanford and Savannah River Sites, low waste loadings and high waste form volumes result. Additional technical issues include 1) complex formulation requirements necessary to achieve the desired ceramic and glass phases; 2) the ability to accurately project the partitioning of the radionuclides between the phases; 3 ) durability performance as a function of waste variability; and 4) low production rates make this technology unsuitable for a majority of DOE HLW. As a stand-alone technology, HIP does not provide any clear advantage over the baseline Joule-heated ceramic melter technology. Therefore, HIP technologies are still appropriately defined as not applicable to WTP HLW vitrification.

\subsubsection{Phase 2 Final Technology Selection}

The following six candidate technologies were recommended for further in-depth evaluation by the review panel:

Low-temperature, ceramic-lined, Joule-heated melter: This melter technology can be liquidor dry-fed, is electrically heated, and operates at a nominal temperature of $1150^{\circ} \mathrm{C}$. The melter possesses bottom drain or overflow glass discharge capabilities and optional agitation.

Advantages of this technology include its experience with processing HLW, it has passive and simple features, a well-developed technical maturity, and its availability at several testing facilities. However, this technology is associated with relatively low temperature and low production rates, a larger size, and high disposal costs. 
Low-temperature, metal-lined, stirred, Joule-heated melter: This melter technology can be liquid- or dry-fed, is electrically heated, and reaches an operating temperature of $1100^{\circ} \mathrm{C}$. This melter possesses a super-heater chamber and the ability for agitation with a metal impeller. Advantages of this technology include a high-processing rate, a compact build, availability at testing facilities, and its ability to handle undissolved solids and high-viscosity glasses. However, this technology is associated with low temperature, materials concerns, dynamic operation, and increased volatility.

High-temperature, ceramic-lined, Joule-heated melter: This melter technology can be liquidor dry-fed, is electrically heated, and reaches an operating temperature of $1500^{\circ} \mathrm{C}$. This melter possesses optional agitators, bottom drain or overflow glass discharge capabilities, and hightemperature metal or metal-oxide electrodes. Advantages of this technology include passive and flexible features, high-temperature capabilities, and a technical maturity well developed for commercial glasses. However, this technology is associated with electrode corrosion concerns, a larger size, and high disposal costs.

High-temperature, metal-lined, Joule-heated melter (cold wall): This melter technology features molybdenum glass contact material, can be liquid- or dry-fed, and is electrically heated. Advantages of this technology include its ability to reach an operating temperature of up to $1700^{\circ} \mathrm{C}$ and its passive, simple, and flexible features. However, materials concerns are associated with this technology.

Low-frequency, metal can, induction-heated melter (low temperature): This melter technology consists of a metal body, is usually dry-fed and inductively heated, features batch operation and bottom drain capabilities, and reaches an operating temperature of up to $1100^{\circ} \mathrm{C}$. Advantages of this technology include simple features, the capacity for easy melter replacement, compatibility with insoluble compounds, and a technical maturity well developed for remote applications. However, low temperature, limited scale-up ability, and shorter life span are limitations of this melter.

High-frequency, cold-wall, induction-heated melter (high temperature): This melter technology consists of a glass-lined, metal body; is dry-fed and inductively heated; features batch or continuous operation capabilities; and reaches an operating temperature of up to $2000^{\circ} \mathrm{C}$. Advantages of this technology include smaller melter size (constituting a higher processing rate), high-temperature capabilities, flexible features, and its availability in testing facilities. However, this technology is associated with limited scale-up ability and its need to be dry-fed (resulting in the need for a large calciner).

In preparation for the September 1994 workshop, each member of the evaluation committee received technology data packages and facility impact study summaries and results containing information specific to each of the six melter technologies. This information coupled with the committee members' expertise provided a basis for evaluating the technologies. The committee evaluated strengths and weaknesses of each technology related to the following criteria (see Appendix $\mathrm{J}$ for additional criteria details):

- melter feed processability

- $\quad$ product/process control

- $\quad$ state of technology development

- facility/system integration

- design life 
- $\quad$ melter system scaleup

- product sampling and recycle

- $\quad$ operability

- factors affecting total cost

- $\quad$ features creating special or unusual safety or environmental problems.

The strengths and weaknesses were listed for each technology relative to the above criteria, and the committee then compared all six technologies to each criterion sequentially. The technologies were numerically scored using a scoring system, then ranked by the committee. Individual scoring results for each technology were then used to promote further detailed discussion. Once the evaluation, scoring, and rankings were completed, the committee identified general trends and performed an overall assessment of the scoring results, and final recommendations were adopted by a decision-making body from Westinghouse Hanford Company. The recommendations are described below along with an assessment of their application to this current study.

Two of the technologies, the high-temperature, metal-lined, Joule-heated melters (cold wall) and the low-frequency, metal can, induction-heated melters scored well below the other options in a majority of the criteria. The Joule-heated technology concerns included high electrode corrosion, therefore, requiring the ability to remotely advance, replace and/or add electrode sections during operation. There were also no compelling advantages over other options being considered. Since 1995, there has been no known development or demonstration of a cold-wall Joule-heated melter. Just as importantly, electrode material development for high-temperature applications has not advanced since 1995 . Therefore, this technology is still appropriately defined as not applicable to WTP HLW vitrification.

Concerns over the low-frequency, metal can, induction-heated melter technology included 1) the limited operating life of the nickel-alloy vessels ( $<1,000$ hours); 2 ) reduced maximum melting temperature $\left(<1,100^{\circ} \mathrm{C}\right)$, the limited scale-up of the system requiring a significant number of processing lines; and 3 ) the recommendation that the alkaline waste be acidified and calcined prior to introduction into the melter. Since 1995, there have been improvements in the service life of the Inconel ${ }^{\circledR}$ vessels and mixers have been added to increase production rate and product quality. However, the number of vitrification lines is still large, especially if calcination is not used as a pre-melter operation. Combined with the use of calcination, the limited service life of the Inconel ${ }^{\circledR}$ vessels, and temperature limitations, this technology has no compelling advantages over other options being considered.

The technologies or enhancements recommended for future development that are also applicable to the current study are:

- $\quad$ low- and high-temperature Joule-heated ceramic melter

- $\quad$ cold-crucible, induction-heated melter

- technology enhancements, such as agitations, drying or calcinations, and sloped-bottom designs with bottom drains.

Based on Review Team discussions, a consensus was reached to include these technologies as candidates for use in the current study. For the high-temperature Joule-heated ceramic melter, the emphasis was placed on determining whether electrode designs would permit improved cooling capabilities that would permit the nickel alloy electrode material to be operated above the current nominal temperature of $1,150^{\circ} \mathrm{C}$. Operating ranges of 1,200 to $1,250^{\circ} \mathrm{C}$ were targeted for investigation. 


\subsection{RFI Technology Response Evaluation}

This section reports on the results of information obtained through a formal RFI. To assure that technology developers and suppliers were aware of the RFI notice and had the opportunity to respond, the Study Team prepared a list of potential respondents and directly contacted them. The list was composed from a vendor list constructed during the 1995 technology review, vendors that participated in the TWRS Low-Level Waste vitrification demonstrations in 1994 and 1995, and vendors that Study Team staff knew to still be active in technology development and deployment. The list of contacts that were notified is provided in Table 6.5. As the table shows, some technology vendors could not be located, presumably because they were no longer active in this "market." RFI responses to NETL are summarized in Table 6.6. Information provided by the respondents towards each of the RFI technical areas were summarized by the Study Team and are provided as Appendix K.

Based on an initial review, several of the technology submittals were judged to be either nonresponsive or the technology did not meet the basic requirements of this review (i.e., the technology should produce a molten waste form that could be transferred into a canister where it would solidify into glass and or crystalline phases). These submittals were as follows:

- Chemical bonding HLW immobilization by Clean Technologies International Corp., essentially an aluminum smelting technology. It does not produce a glass/crystalline waste form but rather an aluminum metals phase and a slag phase rich in the alkali and alkaline earth metals. The technology would require a pre-calcination step of all waste to prohibit water being introduced into the aluminum bath.

- Resonant shock compaction by RSC, LLC, at the University of Denver. This technology is a batch solids compaction process that can be followed by a furnace step to sinter or melt the monolith. Technology would require pre-calcination step of all wastes and is quite immature.

- $\quad$ Simplified Integrated Immobilization Process by Hanford Nuclear Services, Inc. This technology is vaguely described as a comprehensive waste pretreatment process without elaboration. No immobilization technology is offered.

- Penberthy Melter by Penberthy Vitrification Associates. This vendor did not complete the RFI information template. Copies of information previously supplied by Mr. Penberthy in response to the 1995 technology review and copies of subsequent literature indicate that the Joule-heated ceramic melter technology is identical to previous information available to the Study Team.

- Hemispheric Center for Environmental Technology at Florida International University provided a description of a small glass-melting furnace used to support DOE's TFA projects. They did not provide any new technology information.

- Duratek Inc. provided two responses describing existing DOE-owned Joule-heated ceramic melter pilot melter systems. They did not provide any new technology information.

- University of North Dakota Energy and Environmental Research Center proposed pretreatment technologies for sulfate and chlorine removal from HLW. 
- $\quad \mathrm{dmc2}$, Degussa Metals Cerdec Corp. proposed to supply frits for the WTP.

Table 6.5. RFI Vendor Contact List

\begin{tabular}{|l|l|l|}
\hline \multicolumn{1}{|c|}{ Technology Supplier } & \multicolumn{1}{|c|}{ Notified? } & \multicolumn{1}{c|}{ Technology Type } \\
\hline B\&W (info several years old) & $\begin{array}{l}\text { No - telephone information no } \\
\text { longer valid }\end{array}$ & Gas fired \\
\hline EPI & Yes & Arc plasma \\
\hline $\begin{array}{l}\text { Svedala Industries, Inc. Pyro } \\
\text { Systems (busy signals will try } \\
\text { again) }\end{array}$ & $\begin{array}{l}\text { Not able to leave message - } \\
\text { affiliated with EPI, however }\end{array}$ & EPI arc plasma \\
\hline $\begin{array}{l}\text { Univ. of Mississippi DIAL - } \\
\text { Russian technology }\end{array}$ & Yes & $\begin{array}{l}\text { Plasma torch w/ } \\
\text { induction melting }\end{array}$ \\
\hline GTS Duratek & Yes & JHCM \\
\hline $\begin{array}{l}\text { Integrated Environmental } \\
\text { Technologies }\end{array}$ & Yes & Joule + DC arc melter \\
\hline Numatec/Cogema & Yes & $\begin{array}{l}\text { Adv. cold crucible } \\
\text { melter (CCM) }\end{array}$ \\
\hline Penberthy Vitrification Associates & Yes & JHCM \\
\hline Phoenix Solutions Co. & Yes & Plasma torch \\
\hline $\begin{array}{l}\text { Plasma Energy Applied } \\
\text { Technology, Inc. (PEAT) }\end{array}$ & Yes & Plasma \\
\hline $\begin{array}{l}\text { Radioactive Isolation Consortium, } \\
\text { LLC }\end{array}$ & Yes & In-can melting \\
\hline Ray Robinson (RKR Inc.) & Yes & Undisclosed \\
\hline Retech/MSE & Yes & Plasma torch \\
\hline Seiler Pollution Control Systems & $\begin{array}{l}\text { No - previous number and } \\
\text { office number on internet no } \\
\text { valid }\end{array}$ & $\begin{array}{l}\text { JHCM w/ preheating } \\
\text { zone }\end{array}$ \\
\hline YlassTech/Stir-Melter, Inc. & Yes & $\begin{array}{l}\text { Metal-wall, Joule- } \\
\text { heated stirred melter } \\
\text { electric glass furnace }\end{array}$ \\
\hline TECO & Yes & Gas fired \\
\hline Vortec Corp. & & \\
\hline
\end{tabular}

The RFI submissions were reviewed and discussed during the two-day review held at PNNL March 19 and 20, 2001. The RFI and prepared summary sheets were used as part of the technology evaluation. The RFI materials were evaluated and discussed relative to their ability to meet a list of technical parameters related to the waste form, process requirements, and facility requirements.

Stir Melter, Inc. Stir Melter ${ }^{\circledR}:$ Stir-Melter is a compact system that would fit within the existing footprint of the WTP melter. A schematic of the melter is shown in Figure 6.8. Because of its high production rate relative to its size, a single unit could be used to achieve the $6 \mathrm{MTG} / \mathrm{d}$ production rate ultimately required. This potentially could free up the second vitrification cell for other uses. However, feed, off-gas, and canister-handling requirements for the first cell would need to be expanded. The "low-temperature" version comprised of an Inconel ${ }^{\circledR}$ liner and watercooled Inconel impeller were the focus of this evaluation. The company also describes a hightemperature version. However, it was felt that the high-temperature system development had not 
progressed sufficiently since 1995 to be seriously considered. Requirements for being able to routinely add electrode segments and advance the electrode into the melter placed significant incell requirements on the facility. The lack of suitable electrode materials for the high-temperature Joule-heated ceramic melter technology also factors against the high-temperature variant of this technology. 
Table 6.6. Melter Review RFI Responses

\begin{tabular}{|c|c|c|c|c|c|}
\hline Responder Name & POC & Address & Phone/Fax & $\begin{array}{l}\text { Date } \\
\text { Received }\end{array}$ & Comments \\
\hline $\begin{array}{l}\text { Technology Trade Name: DC Graphite arc Company } \\
\text { Name: Electro-Pyrolysis, Inc. }\end{array}$ & $\begin{array}{l}\text { J. Kenneth Wittle, } \\
\text { Ph.D. }\end{array}$ & $\begin{array}{l}996 \text { Old Eagle School Rd. Wayne, PA } \\
19087\end{array}$ & $\begin{array}{l}\text { (610) 687-9070 - Phone } \\
\text { (610) 964-8570-Fax }\end{array}$ & $2 / 15 / 2001$ & $\begin{array}{l}\text { Internet Address: } \\
\text { electropyrolysis.com }\end{array}$ \\
\hline Company Name: Retech Systems LLC & David W. Keaney & & (707) 467-1764 - Phone & $2 / 16 / 01$ & Declined to propose \\
\hline Company Name: $\quad$ COGEMA, Inc. & V.K. Sazawal & & (301) 941-8377 & $2 / 20 / 01$ & $\begin{array}{l}\text { Alt. POC: Arvid Jensen } \\
(208) 785-4363\end{array}$ \\
\hline Company Name: $\quad$ PHOENIX Solutions Co & Gary J. Hanus & $\begin{array}{l}5900 \text { Olson Memorial Highway } \\
\text { Minneapolis, MN 55422-4999 }\end{array}$ & $\begin{array}{l}\text { (763) 544-2721-Phone } \\
\text { (763) 546-5617-Fax } \\
\text { garyhanus@phoenixsolutions } \\
\text { co.com }\end{array}$ & $2 / 20 / 01$ & \\
\hline Company Name: Radioactive Isolation Consortium LLC & James Jordan & $\begin{array}{l}708 \text { East Broad Street } \\
\text { Church, VA 22046-3610 }\end{array}$ & $\begin{array}{l}\text { (703) 241-8711 - Phone } \\
\text { (703) 241-8714 - Fax } \\
\text { james.jordan@ricllc.com }\end{array}$ & $2 / 21 / 01$ & $\begin{array}{l}\text { Internet Address: } \\
\frac{\text { www.ricllc.com }}{\text { ROM included }} \quad \mathrm{CD}\end{array}$ \\
\hline $\begin{array}{l}\text { Company Name: Florida International University } \\
\text { Hemispheric Center for Environmental Technology (HCET) }\end{array}$ & $\begin{array}{l}\text { M.A. Ebadian, } \\
\text { Ph.D. }\end{array}$ & $\begin{array}{l}\text { Center for Engineering \& Applied } \\
\text { Science, } 10555 \text { West Flagler St., EAS- } \\
2100, \text { Miami, FL } 33174\end{array}$ & $\begin{array}{l}\text { (305) 348-3585 - Phone } \\
\text { (305) 348-1697 - Fax } \\
\text { ebadian@hcet.fiu.edu }\end{array}$ & $2 / 21 / 01$ & \\
\hline Penberthy Vitrification Associates & $\begin{array}{l}\text { H. Larry } \\
\text { Penberthy }\end{array}$ & 7141 Fauntleroy Way, Seattle, WA 98136 & (206) 937-8221 - Phone/Fax & $2 / 21 / 01$ & \\
\hline $\begin{array}{l}\text { Company Name: Clean Technologies International } \\
\text { Corporation }\end{array}$ & Tony Wagner, & $\begin{array}{l}713 \text { Mariner } \quad \text { Lakeway, TX } \\
78734\end{array}$ & $\begin{array}{l}\text { (512) 658-9618- Phone ; tony } \\
\text { @ cleantechinternational.org }\end{array}$ & $2 / 2 / 01$ & \\
\hline $\begin{array}{l}\text { Company Name: University of North Dakota Energy and } \\
\text { Environmental Research Center }\end{array}$ & $\begin{array}{l}\text { Christina B. Behr- } \\
\text { Andres, Ph.D, P.E. }\end{array}$ & $\begin{array}{l}15 \text { North } 23^{\text {rd }} \text { St., P.O. Box } 9018 \text { Grand } \\
\text { Forks, ND 58202-9018 }\end{array}$ & $\begin{array}{l}\text { (701) 777-5000-Phone } \\
\text { (701) 777-5000- Fax } \\
\text { cbandres@undeerc.org }\end{array}$ & $2 / 23 / 01$ & www.undeerc.org \\
\hline $\begin{array}{lc}\text { Company Name: DURATEK } & \text { Technology } \\
\text { Trade Name: RPP Reference High Level Waste DuraMelter }\end{array}$ & Brad Bowan & $\begin{array}{l}10100 \text { Old Columbia Rd. Columbia, MD } \\
21046\end{array}$ & $\begin{array}{l}\text { (410) 312- 5100- Phone } \\
\text { (410) 290-9070- Fax } \\
\text { bbowan@duratekinc.com }\end{array}$ & $2 / 23 / 01$ & \\
\hline $\begin{array}{l}\text { Company Name: RSC, LLC at the University of Denver } \\
\text { Technology Trade Name: Resonant Shock Compaction }\end{array}$ & Robert C. Amme & $\begin{array}{l}2112 \text { East Wesley Ave. Physics } \\
\text { Department, } \quad \text { Denver, CO } 80208\end{array}$ & $\begin{array}{l}\text { (303) 871-3852- Phone } \\
\text { (303) 871-4405- Fax } \\
\text { ramme@du.edu }\end{array}$ & $2 / 23 / 01$ & \\
\hline Company Name: Stir Melter Inc. & $\begin{array}{l}\text { Kenneth } \mathrm{H} \text {. } \\
\text { Wetmore }\end{array}$ & $\begin{array}{lr}\text { Ampoint Industrial Park } & 995 \\
\text { Fourth Street } & \text { Perrysburg, OH } \\
43522 & \end{array}$ & $\begin{array}{l}\text { (419) 661-0814 - Phone } \\
\text { (419) 661-9616-Fax } \\
\text { kwetmoe@glasstech.com }\end{array}$ & $2 / 23 / 01$ & 2 video cassettes attached \\
\hline Company Name: Westinghouse Plasma Corporation & Daniel E, Lazzara & $\begin{array}{l}\text { Waltz_Mill Site P.O. Box } 410 \text { Madison, } \\
\text { PA } 15663\end{array}$ & $\begin{array}{l}\text { (724) } 722-7052 \text { - Phone } \\
\text { (724) } 7227057 \text { - Fax } \\
\text { Lazzarade@westinghouse- } \\
\text { plasma.com }\end{array}$ & $3 / 5 / 01$ & $\begin{array}{l}\text { 1/02/01 Fax of letter dated } \\
\text { Sept, } 18,2000 \\
\text { www.westinghouse- } \\
\text { plasma.com }\end{array}$ \\
\hline Company Name: dmc2, Degussa metals Cerdec Corp. & $\begin{array}{l}\text { Simon K. } \\
\text { Boocock, Ph.D. }\end{array}$ & $\begin{array}{l}\text { Cerdec Division, PO Box } 519 \text { West } \\
\text { Wylie Ave, } \quad \text { Washington, PA } 15301\end{array}$ & $\begin{array}{l}\text { (724) 229-5606 - Phone } \\
\text { (724) 229-5388 - Fax }\end{array}$ & $2 / 26 / 01$ & www.dmc-2.com \\
\hline Company Name: $\quad$ RKRI, Ray K. Robinson, Inc. & $\begin{array}{l}\text { Ray K. Robinson, } \\
\text { Sc.D. }\end{array}$ & $\begin{array}{l}200 \text { Hillview Drive-Suite } 100 \text { Richland, } \\
\text { WA } 99352\end{array}$ & $\begin{array}{l}\text { (509) 627-6235 - Phone } \\
\text { (509) 627-6141 - Fax }\end{array}$ & $2 / 26 / 01$ & \\
\hline
\end{tabular}




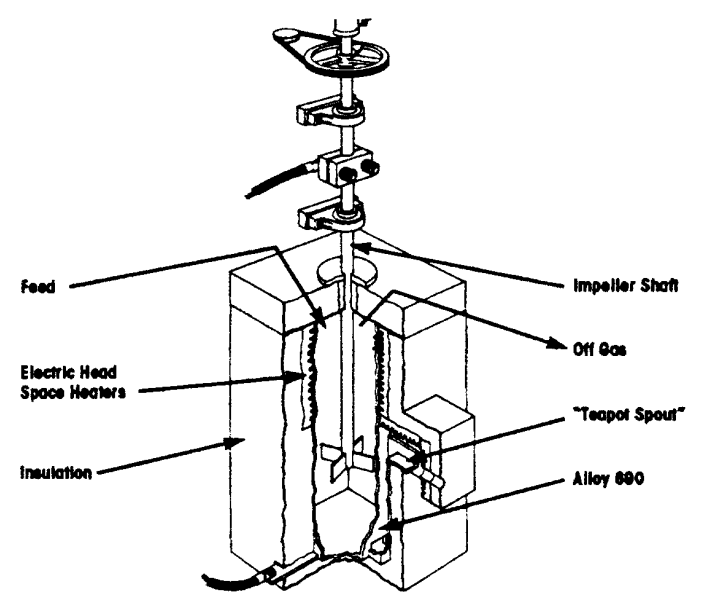

Figure 6.8. Stir-Melter ${ }^{\circledR}$ Schematic

The metal lining of the melter will require periodic replacement. However, simplified glass removal from the liner and the small volume of solid waste requiring disposal relative to the baseline are considered attractive features. The use of an adjustable mixing system can be used to maintain crystalline phases in suspension and can resuspend settled sludges.

Technology issues include lower-temperature constraints on operating temperature because of the metal liner and potentially higher volatility. The temperature constraint prohibits this technology from being considered to produce high-temperature waste forms (e.g., SYNROC).

Cogema Advanced Cold Crucible Melter (ACCM): The advanced ACCM differs from the $\mathrm{CCM}$ (see Figures 6.9a and 6.9b) in that the induction coils are placed under the floor of the melter; rather then around the cylindrical side-wall. This permits larger diameter melters to be designed. However, it is believed that this results in the requirement that the glass melt be agitated to distribute the heat throughout the glass melt and up to the cold cap. The use of water-cooled mixers is typical of the Cogema system. Because refractories are not used, the footprint of the melter is smaller than the baseline. Slurry and dry feeding have been demonstrated. However, experience with direct slurry feeding is much more limited than French and Russian experience with dry or calcine feeding. Based on current designs and estimated throughput rates, two redundant systems may be required to meet the $6 \mathrm{MTG} / \mathrm{d}$ production rate goal. Both systems could possibly fit into a single process cell. However, this will have to be verified with more detailed engineering. The high temperatures that can be achieved by the ACCM allow it to produce all of the waste forms being considered. The water-cooled walls provide glass containment by freezing a thin layer of glass against the stainless steel. This prevents corrosion and supports a long operating life. The water-cooled lid is also constructed of stainless steel. The effects of long-term liquid feeding on the operating life of the metal above the melt line is expected to be a technical issue requiring evaluation. Solid waste volumes should be very small since the melter inventory is not that large, and upon draining the thin skull of glass should spall and release from the metal. The small glass inventory does raise the issue of glass quality control during canister filling that will need to be evaluated. 


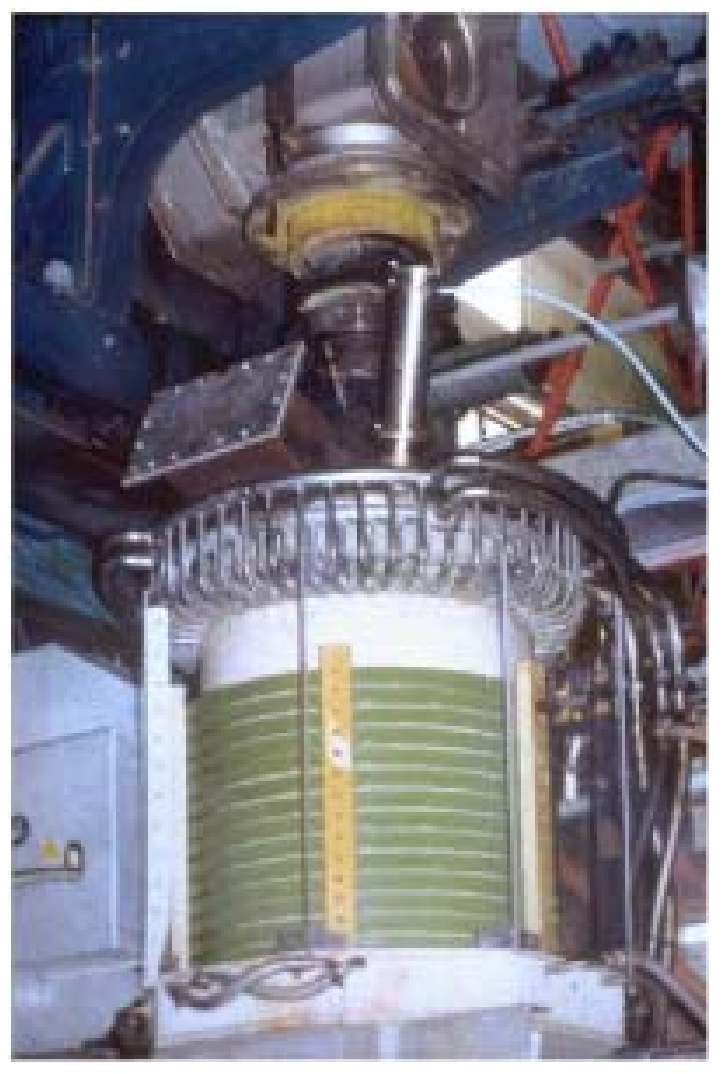

Figure 6.9a. 500-m-dia. CCM at Marcoule Pilot Plant Facilities

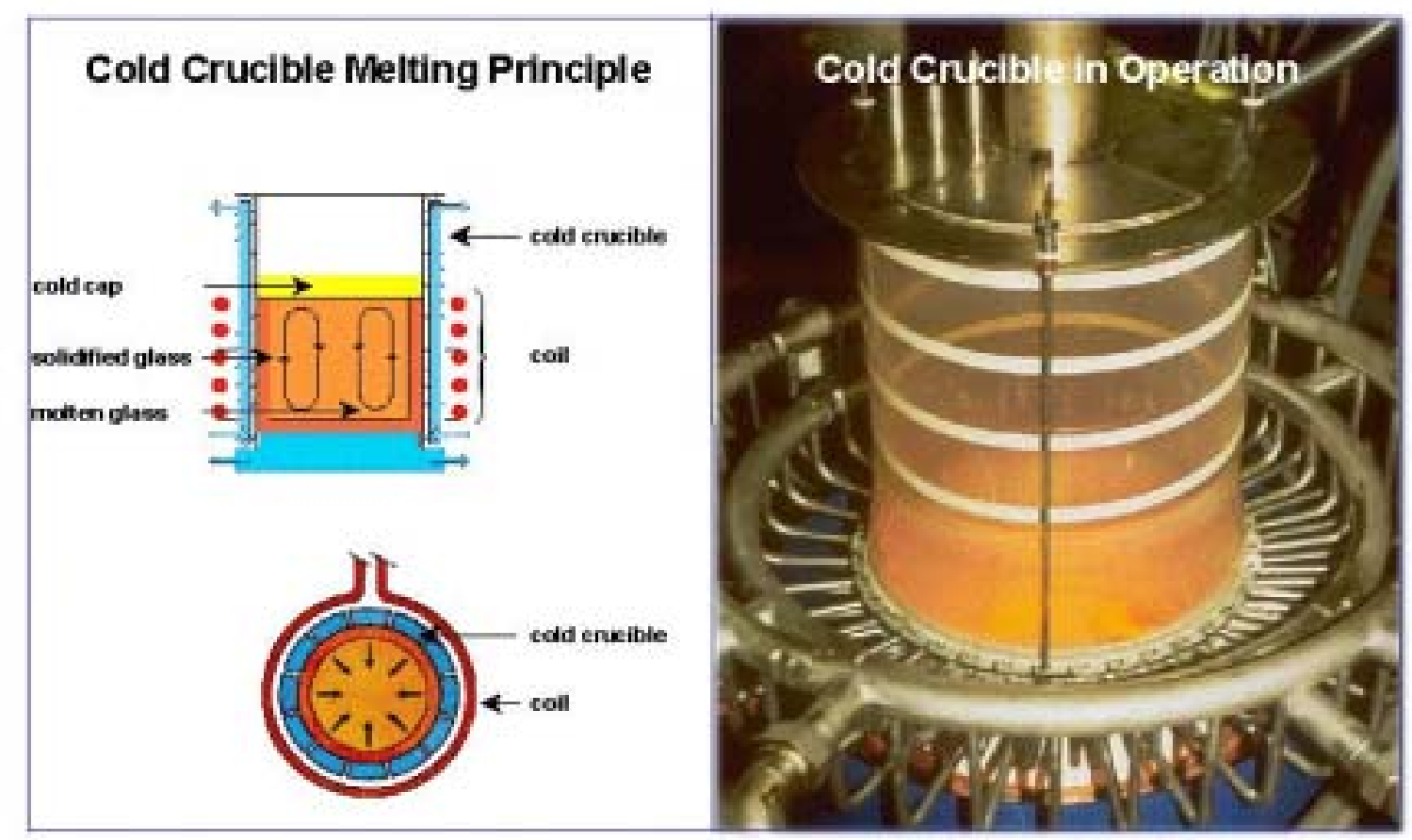

Figure 6.9b. French Cold Crucible Melter 
Radioactive Isolation Consortium, LLC, Advanced Vitrification System: This system is a type of in-can melting technology that uses extremely low-frequency induction heating to heat the canister components. The batch process requires pre-drying of the feed that is fed sequentially with glass former material into the sealed canister. The heat generated within the graphite crucible is conducted into the pre-dried HLW and glass formers charged into the canister. The process eliminates the use of a continuous melter, relying instead on a series of in-can melting lines to achieve the necessary plant production capacity of $6 \mathrm{MTG} / \mathrm{d}$. The technology is just in the beginnings of the development and demonstration phase. A number of technical uncertainties were identified by the workshop panel that needs to be addressed in order to consider the Advanced Vitrification System technology as an attractive option. Primary among these are the characteristics of the waste form and ability of the approach to be successfully scaled given the complex assembly and materials within the canister system. A major facility impact is the need for increased cell height to permit loading and unloading the canisters into the induction furnaces. Potential benefits include the elimination of a melter system and its associated disposal costs.

Phoenix Solutions Plasma Torch Technology: As discussed previously, the use of plasma torch technology is not considered directly applicable to HLW treatment. Based on the information provided, this assessment remains unchanged. Little new work has been reported to expand the technology past contaminated materials treatment (e.g., asbestos, organic wastes and soils). Limited torch life, significant off-gas losses, high maintenance requirements, and more complex melter control requirements make this technology unattractive compared to the baseline technology. Melter size is expected to be less than or equal to the Joule-heated ceramic melter technology with similar end-of-life refractory treatment requirements.

Electro-Pyrolysis Inc. DC Arc Melter Technology: As discussed previously, the use of DC arc furnaces is not considered directly applicable to HLW treatment. Based on the information provided, this assessment remains unchanged. Little new work has been reported to expand the technology past previous knowledge and understanding. Graphite electrodes promote strongly reducing conditions and intense localized temperatures that lead to metals reduction and higher volatility, respectively. Electrode replacement requirements and more complex melter control requirements make this technology unattractive compared to the baseline technology. Melter size is expected to be less than or equal to the Joule-heated ceramic melter technology with similar end-of-life refractory treatment requirements.

Duratek Duramelter Technology: Although the Duratek response mainly described testing capabilities, a significant amount is known about the technology based on Study Team involvement in the WTP project. As the baseline technology under the Part B-1 privatization contract, the Duratek design is being used as a basis for comparison to other technologies.

The Joule-heated ceramic melter-based technology was designed to be operated both with and without a mixing system using a system of gas bubblers. The melter design is based on DOE Joule-heated ceramic melter technology development conducted in the 1980s and early 1990s with modifications and incremental advancements developed by Duratek.

Westinghouse Plasma Torch System: As discussed previously, the use of plasma torch technology is not considered directly applicable to HLW treatment. Based on the information provided this assessment remains unchanged. Little new work has been reported to expand the technology. Limited torch life, significant off-gas losses, high maintenance requirements, and more complex melter control requirements make this technology unattractive compared to the baseline technology. Melter size is expected to be less than or equal to the Joule-heated ceramic melter technology with similar end-of-life refractory treatment requirements. 


\subsection{Literature and Patent Reviews}

This section describes the results of literature and patent reviews that were performed as part of this study. U. S. and international literature sources were included in the review. As will be discussed in Section 6.8.2, the patent search was limited to the U.S. patent database. The objective of the searches was to identify and review literature and patents describing advancements in processes or equipment not already known to the Study Team. The searches were performed using the resources and staff at the Consolidated Information Center's Hanford Technical Library (CIC). Additional international literature sources were also identified and provided to the Study Team as part of the scope of work performed by the German institute, FZK. The details of the literature search are described in Section 6.8.1, and summary abstracts are found in Appendix L.

\subsubsection{Literature Search Results}

Four main electronic databases were used to conduct a comprehensive search of the available literature:

- DIALOG accessed two main databases:

○ Energy Science and Technology 1974-2001/Dec - A multidisciplinary database from DOE and other non-U.S. contributing agencies

o NTIS--National Technical Information Service 1964-2001/Jan - Summaries of U.S. government-sponsored research, development, and engineering, plus analyses prepared by federal agencies, their contractors, or grantees. Some summaries of reports from state and local government agencies are also included.

- INSPEC: 1969-2001/Jan - Institution of Electrical Engineers - Information of the global literature of physics, electronics and electrical engineering, computers, and information technology. A total of 4100 journals and serials are included in this database.

- Compendex: 1970-2001/Dec - 2001 Engineering Info. Inc. - Provides abstracted information from the world's significant engineering and technological literature. Approximately 4500 journals and selected government reports and books are included in this database.

- CA SEARCH: Chemical Abstracts - 1967-2001 - American Chemical Society (including patent titles). Thirteen million citations of the worldwide literature of chemistry and its applications are included in the Chemical Abstracts database.

The search was carried out through the following steps:

- The following key search words were provided to the CIC staff: "high level waste," "radioactive waste," "vitrification," "melt," "melting," "glass," "process," "technology," and "technique."

- Key words were used individually, in combinations, and as word fragments (e.g., vitrif-).

- Searches were conducted over two time periods: 1990 to 1995, and 1995 to present. 
As a means of winnowing down the literature, title searches were conducted first. After reviewing the titles, abstracts were requested for those titles that were most appropriate. Finally, based on the abstract reviews, full papers were ordered for review. Full papers were not requested for articles describing processes or equipment that were either not applicable to the review or for which the Study Team was already aware. Also, several papers were judged to be of a programmatic overview nature. In these cases, the most recent and up-to-date paper was ordered if judged to be of value. For a majority of cases, the full papers were available at the CIC or electronically for a nominal charge. Papers that were not available in English (there were several Japanese and Korean publications) were not ordered. Exceptions to this case were those that could be obtained through FZK directly or through their summary compilation of applicable and available European and Asian technical information.

A total of 532 title citations were obtained from the initial key word search. Citations were obtained from literature in the United States, Europe, and Asia. Based on the large number of titles obtained from the first search, it was concluded that the key words selected were adequate and that a second search with additional key words was not necessary. Following a title review, 103 abstracts were requested to review the literature source more closely.

Thirty-five full papers were either ordered or obtained directly from available copies of conference or symposium proceedings. Abstract citations of these papers are documented in Appendix L. A limited number of articles could not be obtained in the time permitted to perform the reviews. Topics included information on waste form development (including noble metals behavior), materials testing, technology testing, and programmatic reviews of international or U. S. operations. Information on waste form development of SYNROC and alumino-silicate waste forms was forwarded to the Task 2 waste form activity Study Team members. Process and technology papers were reviewed to identify any new advancements or technologies that were previously unknown. The literature was predominated by DOE and international literature including literature on the French cold crucible; Russian cold crucible; WVDP and DWPF activities; Japanese and Chinese waste treatment activities; and DOE HLW, mixed waste, and low-level waste technology development. Despite the broad key word field and coverage of pertinent journals, no new inventions, processes, or modifications to technologies were described.

\subsubsection{Patent Search Results}

The patent search was conducted similarly to the literature search. Key words were selected with which to conduct title and abstract key word matches. Patents awards were limited to between 1995 and the present; again to focus on recent developments. The U. S. patent database was the only database searched for several reasons. The decision to search international sources was deferred until the magnitude of matches made from the U. S. patent field was determined. Secondly, foreign patent sources are not necessarily available in English and are not centralized. Therefore, significant time and resources would be required. Lastly, if a significant portion of U.S. patents is from foreign origin, a good fraction of the significant foreign developments will be identified.

Beginning with the same list of keywords used in the literature search, the patent search was conducted using the words, "GLASS? OR MELTER OR MELTING OR VITRIF." This search returned 3899 matches -- much too broad and in need of reduction. It was then decided to search patent titles and full text abstracts with only "VITRIF." This resulted in 162 matches to review. From a review of the titles and abstracts, it was concluded that approximately 60 
dealt with topics of interest. Fourteen of the patents were assigned to non-U. S. companies or individuals. However, the vast majority of these were related to developers or technologies already known to the Study Team. Interestingly, the patents tend to be bunched over a short period of time for specific technologies. This indicates periods of significant development or at least efforts by the developers to distinguish and protect their technologies from other developers. Examples of these included Electro-Pyrolysis Inc.; RIC; Integrated Environmental Technologies, LLC; the Archimedes Technology Group, Inc.; Vortec Corp.; Stir Melter, Inc.; Retech Corp.; VECTRA Technologies, Inc.; and Oak Ridge National Laboratory's GEMODS process. The largest portions of inventions were related to technologies based on plasma arc, DC arc, combustion furnace technologies, and high-energy plasma and light techniques. None of the patent titles and abstracts indicated any novel inventions or ideas that warranted obtaining and reviewing the full patents.

A second patent title and abstract search was conducted using the keywords, "melt?" and "waste." This search returned 241 patents, of which 209 were not identified in the first patent search. Of the 209 patents, 32 dealt with topics of interest. Seventeen of these were assigned to foreign companies or individuals. Combined with the first search, foreign patent holders were from Canada, Russia, Germany, France, Japan, Switzerland, and the United Kingdom. Five patents were identified from this group that appeared to be novel and have potential applications to HLW melters. The full patents were obtained and reviewed. The following is a short summary of the five.

\section{Plasma Arc Furnace with Improved Replaceable Electrodes}

Inventors: U.S.: Flannery Philip A.; McClafferty Jason; Orne Donald A

Assignee: Unassigned or assigned to inventors

Patent No.: U.S. 6015963 (January 2000)

Patent abstract described the invention of a refractory electrode with long-life properties. Based on a review of the full patent it was determined that the "novel" aspect of the invention are methods to replace, protect, and construct the electrodes made of non-metallic materials. Materials identified included conductive ceramic, graphite, molybdenum disilicide, silicon carbide, tungsten and hafnium. No new materials for HLW processing were identified. The developers appear to be associated with the DOE Western Environmental Technology Office's facility operating the Retech centrifugal plasma torch furnace technology.

\section{Reducing Melt Borosilicate Glass Having Improved UV Transmission Properties and Water Resistance and Methods of Use}

Inventors: Germany: Brix Peter; Kloss Thomas; Ott Franz; Watzke Eckhart

Assignee: Germany: Schott Glaswerke

Patent No.: U.S. 5610108 (March 1997)

This patent looked to be marginally applicable. It was obtained and forwarded to the Study Team members performing the waste form assessments for their use, if applicable.

\section{Recycle of Glass Furnace Waste Materials; from Refractory Brick}

Inventors: U.S.: Edwards George H.

Assignee: Corning Inc.

Patent No.: U.S. 5538526 (July 1996)

This patent describes the idea of using spent refractory materials (e.g., firebrick and zirconia). along with consumer glass and ceramics housewares (e.g., bowls, television tubes, etc.) and/or 
industrial wastes (e.g., furnace dusts) as feedstock materials for glass production. The concept of vitrifying wastes and creating useful products is not new. However, the explicit use of glass tank refractory brick as feedstock apparently had not yet been covered by a patent.

\section{Waste Gas Piping for a Filter Dust Melting Furnace}

Inventors: Switzerland: Ammon Hans; Balg Jurgen; Pfister Markus

Assignee: Japan: ABB Gadelius KK JP

Patent No.: U.S. 5489085 (February 1996)

This patent was obtained to evaluate whether the design offered superior advantages over the current film cooler design. This design uses water cooling of an outer annulus and air cooling and injection into the process stream from an inner annulus. The off-gas line is tapered slightly as the line progresses out of the melter ("in the manner of a diffuser") to prevent radiant heating of the wall from the furnace that could support solids accumulation.

\section{Refractory for Containment of Fluoride-rich Salt Melts; Destroying Fluorine- containing Waste in Refractory with Liner of Beta-Alumina Inventors: U. S.: Morgan Peter E D; Schnittgrund Gary D \\ Assignee: Rockwell International Corp \\ Patent No.: U.S. 5476991 (December 1995)}

This patent describes a method of fabricating phase change resistant beta-alumina refractory bricks that are resistant to fluoride salt attack. Developed for molten salt oxidation furnaces, the refractory may offer superior plenum refractory performance for vitrification technologies as well. The method of production of the beta-alumina $\left(\mathrm{Na}_{2} \mathrm{O} \cdot 11 \mathrm{Al}_{2} \mathrm{O}_{3}\right)$ is to heat a mixture of alpha-alumina refractory and sodium carbonate in the presence of a few percent, e.g. 5\% sodium fluoride at about $900^{\circ} \mathrm{C}$. The resulting material can then be pressed, dried, fired, or sintered to product the refractory. Operational temperatures appear to be in the same range as the HLW vitrification systems being considered in this study.

\subsection{Comparison of Technology Feature Options}

It is possible that a combination of vitrification technology features may provide a design that overall has superior characteristics when compared to current system options. As part of the technology review March 19 and 20, 2001, the subcomponents of potential vitrification technologies were considered individually. Subcomponents here are defined as the major features that may comprise a technology (e.g., tank construction, method of heating, agitation, etc.). The purpose of this exercise was to develop a consensus as to the benefits and issues of the subcomponent options. It was expected that major benefits or deficiencies might be identified that would be taken into consideration when drawing final conclusions and recommendations relative to future technology investments. The results of the discussions are documented in Table 6.7. There was good agreement among the participants that the level of comparison in Table 6.7 was balanced among the options. In general, it tended to illustrate the following major conclusions:

- Tank design: Refractories were valued for their durability and reliability, while metallined designs were valued for their ease of construction and could be replaced readily.

- Heating methods: Joule-heating with improved electrode cooling presented the potential for greater operational flexibility by increasing the nominal tank temperature as much as $100^{\circ} \mathrm{C}$. Induction heating provided even greater flexibility. However, based on the waste 
form assessment, the estimated benefit of significantly higher operating temperature $\left(\geq 200^{\circ} \mathrm{C}\right)$ is not very large. Submerged DC and AC arc heating were considered inappropriate as the primary heating method.

- Secondary boosting: While not evaluated to the same level as other subcomponents, boosting by resistance heating is considered a leading option because of the level of development that has occurred.

- Pre-calcination and pre-drying: A significant potential to provide significant reductions in melter size requirements. However, U. S. experience is limited, and alkaline flowsheets are more difficult to dry and calcine compared to acid flowsheets, effectively limiting the options available.

- Agitation: Provides the potential to both increase production rate and maintain crystalline and reduced metal phases in suspension. This supports both of the key drivers for reducing glass volume and operating duration. Mechanical mixing and bubble agitation have been demonstrated, however, only to a limited extent with Hanford alkaline flowsheets.

- Glass discharge methods have proven largely successful for all options: A bottom drain capability minimizes settling of conductive phases, particularly if forced agitation is not used. Methods to assure reliability and remote maintainability are warranted here to provided added confidence. 
Table 6.7. Comparison of Technology Attribute Benefits and Issues

\begin{tabular}{|c|c|c|}
\hline Technology Attribute & Benefits & Issues \\
\hline \multicolumn{3}{|l|}{ Tank Design } \\
\hline Refractory Lined & $\begin{array}{ll}\text { - } & \text { Reliable - proven design with DWPF and WVDP } \\
\text { - } & \text { Large experience base } \\
\text { - } & \text { Corrosion resistant } \\
\text { - } & \text { High-temperature duty } \\
\text { - } & \text { Good scalability } \\
\text { - } & \text { Rugged and robust }>3-5 y r \text { operating life } \\
\text { - } & \text { Advanced state of design available for HLW }\end{array}$ & $\begin{array}{ll}- & \text { Large solid waste volume } \\
\text { - } & \text { HLW segregation may be required for melter disposal } \\
\text { - } & \text { Long procurement/construction/post-commissioning } \\
& \text { time } \\
\text { - } & \text { Slow design change cycle } \\
\text { - } & \text { Higher risk of structural effects of moving large } \\
& \text { melters (loosening of refractory blocks) }\end{array}$ \\
\hline Metal Lined (hot wall) & $\begin{array}{ll}\text { - } & \text { Reduced solid waste at time of melter disposal and } \\
& \text { easier to meet HSSWAC } \\
\text { - } & \text { Modular design allows specific component } \\
& \text { replacement } \\
\text { - } & \text { Reduced melter capital costs } \\
\text { - } & \text { Rapid design evolution } \\
\text { - } & \text { Compact footprint } \\
\text { - } & \text { Ease of attaching components below the melt line } \\
\text { - } & \text { Flexible for thermal cycling }\end{array}$ & $\begin{array}{ll} & \text { Long-term reliability (corrosion, weld failure) } \\
\text { - } & \text { Lower temperature operating limit } \\
\text { - } & \text { Creep rupture potential } \\
\text { - } & \text { Thermatibility with iron phosphate glasses (TBD) } \\
\text { - } & \text { Corrosion of metal salts in the headspace } \\
\text { - } & \text { Liquid feeding experience not extensive } \\
& \text { For use with induction melting - small dimensional } \\
\text { - } & \text { Forances to mitigate hot spots } \\
\end{array}$ \\
\hline Metal Lined (cold wall) & 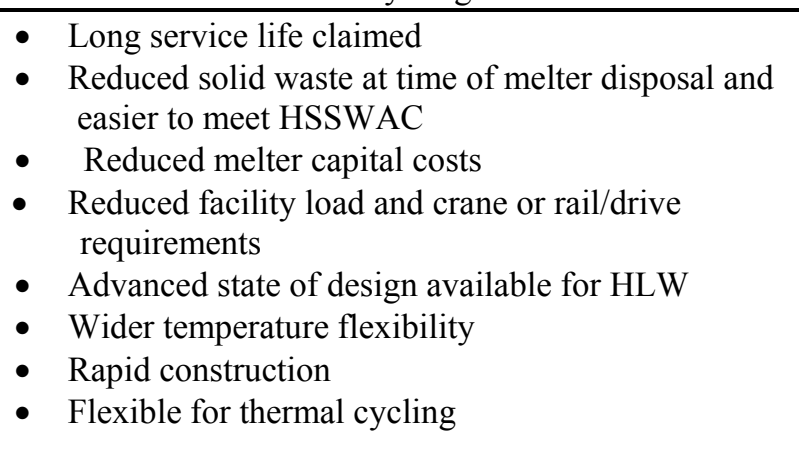 & $\begin{array}{l}\text { - } \begin{array}{l}\text { Effect on waste form product "quality" requires active } \\
\text { mixing and temperature cycling }\end{array} \\
\text { - } \quad \text { Requirements to satisfy safety concern for possible } \\
\text { catastrophic failure } \\
\text { - Increased facility power and cooling flow } \\
\text { requirements compare to current WTP baseline } \\
\text { - Corrosion of cooled metal lining in the headspace } \\
\text { TBD } \\
\text { - Liquid feeding experience not extensive } \\
\text { - Specific melt rate with liquid feeding not clearly } \\
\text { established }\end{array}$ \\
\hline
\end{tabular}




\begin{tabular}{|c|c|c|}
\hline Technology Attribute & Benefits & Issues \\
\hline $\begin{array}{l}\text { In Can Melting - } \\
\text { LT-ICM based on resistance } \\
\text { heating } \\
\text { HT-ICM based on induction } \\
\text { heating }\end{array}$ & $\begin{array}{l}\text { - Simple method with a large body of past } \\
\text { development } \\
\text { - Accepts wastes insolubles } \\
\text { - Applicable to limited volumes requiring special or } \\
\text { unique treatment } \\
\text { - Relaxes waste form processing constraints, e.g., } \\
\text { electrical conductivity, viscosity, liquidus } \\
\text { temperature. }\end{array}$ & $\begin{array}{l}\text { - Limited scale-up potential/ multiple lines required to } \\
\text { meet capacity requirements } \\
\text { - } \quad \text { Uncertainty of glass quality } \\
\text { - } \text { restrictions. } \\
\text { - High-temperature ICM has greater waste loading } \\
\text { liner and other in-can components } \\
\text { - Requires drying/calcination step to optimize melt rate } \\
\text { - Canister undergoes extreme thermal cycling and } \\
\text { possible distortion } \\
\text { - Contamination control/decon more difficult } \\
\text { - Waste qualification strategy and verification need to } \\
\text { be developed } \\
\text { Engineered canister systems (RIC-AVS) have not } \\
\text { been demonstrated at large scale }\end{array}$ \\
\hline \multicolumn{3}{|c|}{ Energy Input (Heating) Method } \\
\hline $\begin{array}{l}\text { Joule-heated } \\
\text { (standard electrode design) }\end{array}$ & $\begin{array}{ll} & \text { Reliable } \\
- & \text { Large experience base } \\
- & \text { Flexible with respect to melter size } \\
- & \text { Energy is delivered directly into the glass } \\
- & \text { High electrical to thermal efficiency } \\
- & \text { Standard electrical components } \\
- & \text { Uniform heating with no extreme temperatures } \\
\text { - } & \text { Simple electrical connections in cell } \\
\text { Advanced state of design available for HLW }\end{array}$ & $\begin{array}{ll}\text { - } & \text { Temperature operating limit }\left(1150-1250^{\circ} \mathrm{C}\right) \\
\text { - } & \text { Places constraint on waste form composition with } \\
& \text { respect to resistivity } \\
\text { - } & \text { Corrosion resistance varies with waste form } \\
\text { - } & \text { Alternative startup method required } \\
\text { - } & \text { Susceptible to electrical shorting by conductive } \\
\text { sludges } \\
\text { - Susceptible to creep and overheating of components in } \\
\text { mal-operation event } \\
\text { - Critical components not replaceable in remote melter } \\
\text { design }\end{array}$ \\
\hline $\begin{array}{l}\text { Joule-heated } \\
\text { (improved electrode cooling) }\end{array}$ & $\begin{array}{ll} & \text { Reliable } \\
- & \text { Large experience base } \\
\text { - } & \text { Flexible WRT melter size } \\
\text { - } & \text { Higher operating temperature limit }-\left(1250^{\circ} \mathrm{C} \text { at }\right. \\
& \text { FZK }) \\
\text { - } & \text { Simple electrical hookup }\end{array}$ & $\begin{array}{l}\text { - Water vs air cooling vs design are TBD } \\
\text { - } \quad \text { Effect on thermal efficiency is TBD } \\
\text { - } \text { Maximum waste from processing temperature } \\
\text { achievable is TBD } \\
\text { - } \quad \text { Design limitations are TBD } \\
\text { - } \text { sesistivity requirements may reduce waste loading in } \\
\text { - Susceptible to shorting by conductive sludges } \\
\text { - } \quad \text { masceptible to creep and overheating of components in } \\
\text { - Critical components not replaceable }\end{array}$ \\
\hline
\end{tabular}




\begin{tabular}{|c|c|c|}
\hline Technology Attribute & Benefits & Issues \\
\hline $\begin{array}{l}\text { Induction-heated } \\
\text { (cold-wall melter assumed) }\end{array}$ & $\begin{array}{l}\text { - Reliable } \\
\text { - Advanced state of design available for HLW } \\
\text { - "High" temperatures are achievable } \\
\text { - Capable of processing molten ceramic waste form } \\
\text { - No electrodes in contact with glass }\end{array}$ & $\begin{array}{l}\text { - } \begin{array}{l}\text { Resistivity requirements may reduce waste loading in } \\
\text { some cases }\end{array} \\
\text { - } \\
\text { - } \\
\text { Requirect on maximum melter size achievable is TBD } \\
\text { heat } \\
\text { Melter location close to cell wall required so melter } \\
\text { and high-frequency capacitor bank on the gallery side } \\
\text { of the cell wall } \\
\text { - Susceptible to developing hot spots where conductive } \\
\text { sludges occur } \\
\text { - Melter floor clearance required in cell is TBD } \\
\text { Tank design may not be optimized for glass pouring } \\
\text { during feeding } \\
\text { Glass discharge remote design has not been fully } \\
\text { developed }\end{array}$ \\
\hline Submerged DC or AC arc & $\begin{array}{l}\text { - High thermal input capability } \\
\text { - "High" temperatures achievable } \\
\text { - Capable of processing molten ceramic waste form } \\
\text { - Large non-remote industrial experience base }\end{array}$ & $\begin{array}{l}\text { - } \begin{array}{l}\text { Requires mechanical electrode positioning and } \\
\text { feeding system }\end{array} \\
\text { - Requires ability to add electrode segments remotely } \\
\text { due to high electrode consumption rate } \\
\text { - Impacts on waste form characteristics, (large fraction } \\
\text { of reduced metal phases, carbon inclusions, etc.) are } \\
\text { TBD } \\
\text { - High localized temperature may significantly increase } \\
\text { DF's of semi-volatile species } \\
\text { - Routine product pouring methods claimed but } \\
\text { unsubstantiated for remote operability requirements } \\
\text { - Scalability vs number of electrodes and placement is } \\
\text { TBD } \\
\text { - Requires more restrictive operating conditions, e.g. } \\
\text { water removal and/or protection of electrode }\end{array}$ \\
\hline
\end{tabular}




\begin{tabular}{|c|c|c|}
\hline Technology Attribute & Benefits & Issues \\
\hline Resistance heating & $\begin{array}{l}\text { - } \\
\text { Reliable designs demonstrated remotely for } \\
\text { permanently installed equipment } \\
\text { - } \quad \text { No by-products or additions to off-gas stream } \\
\text { Effective in partial destruction of organics }\end{array}$ & $\begin{array}{l}\text { - Off-gas temperature significantly increased } \\
\text { - } \\
\text { - Offect mainly on slurry evaporation rate } \\
\text { restricting access for other equipment } \\
\text { - Feed rate increase is not equally effective for all } \\
\text { flowsheets } \\
\text { - Replaceable components not demonstrated } \\
\text { Maximum power input limited by melter head space, } \\
\text { materials of construction, and designs }\end{array}$ \\
\hline Plasma torch heating & $\begin{array}{ll} & \text { High thermal input locally } \\
- & \text { More compact - higher power input possible }\end{array}$ & $\begin{array}{l}\text { - } \\
\text { - } \quad \text { Opfect on volatilitity DFs is TBfe of electrode tips limited to } \sim 1,000 \\
\text { hours - requiring remote maintenance } \\
\text { - } \quad \text { Increased off-gas (non-transferred arc) flow } \\
\text { - Position close to glass surface and cold cap required } \\
\text { for optimal performance } \\
\text { - Formation of radical offgas species and NOx due to } \\
\text { high localized temperature possible }\end{array}$ \\
\hline Submerged arc heating & $\begin{array}{l}\text { - High thermal input locally } \\
\text { - } \quad \text { "High" temperatures achievable } \\
\text { - Capable of processing molten ceramic waste forms } \\
\text { - Large non-remote industrial experience base }\end{array}$ & $\begin{array}{l}\text { - } \\
\text { Requires mechanical electrode positioning and } \\
\text { feeding system } \\
\text { Requires ability to add electrode segments remotely } \\
\text { due to high electrode consumption rate } \\
\text { - Impacts on waste form characteristics, (large fraction } \\
\text { of reduced metal phases, carbon inclusions, etc.) are } \\
\text { TBD } \\
\text { - High localized temperature may significantly increase } \\
\text { DF's of semi-volatile species } \\
\text { - Routine product pouring methods claimed but } \\
\text { unsubstantiated for remote operability requirements } \\
\text { - Scalability vs number of electrodes and placement is } \\
\text { TBD } \\
\text { Requires more restrictive operating conditions, e.g. } \\
\text { water removal and/or protection of electrode }\end{array}$ \\
\hline
\end{tabular}




\begin{tabular}{|c|c|c|}
\hline Technology Attribute & Benefits & Issues \\
\hline Chemical additives & $\begin{array}{l}\text { - Demonstrated with reducing agents (sugar) and to a } \\
\text { lesser extent reactive metals (most recent } \\
\text { experience reported by Russia institutes) } \\
\text { - Eliminates need for addition in-cell equipment } \\
\text { - "Adjustable" to flowsheet conditions } \\
\text { - Places thermal load where it is most needed (the } \\
\text { cold cap solids) }\end{array}$ & $\begin{array}{l}\text { - Affect on glass redox control strategy and oxidant } \\
\text { load is TBD } \\
\text { - Effect on melting characterisitics, cold cap behavior is } \\
\text { complex and little understood } \\
\text { - } \\
\text { - Sffectiveness and efficiency are TBD } \\
\text { Safety concerns relative to reactive metals are TBD }\end{array}$ \\
\hline Pre-calcination of HLW & $\begin{array}{l}\text { - Significantly reduce melter size requirements } \\
\text { - } \quad \text { Large industrial and remote experience base } \\
\text { - } \text { Good scalability } \\
\text { - Rugged and robust } \\
\text { Advanced state of design available for HLW for } \\
\text { acid flowsheets }\end{array}$ & $\begin{array}{ll}\text { - } & \text { Calcination of alkaline slurry w/o additives difficult } \\
\text { - } & \text { Calciner equipment reliability and size must be } \\
\text { - } & \text { Effored into melter cell requirements } \\
\text { - } & \text { Impacts on TOE and cell contamination control are } \\
\text { TBD }\end{array}$ \\
\hline Pre-drying of HLW & 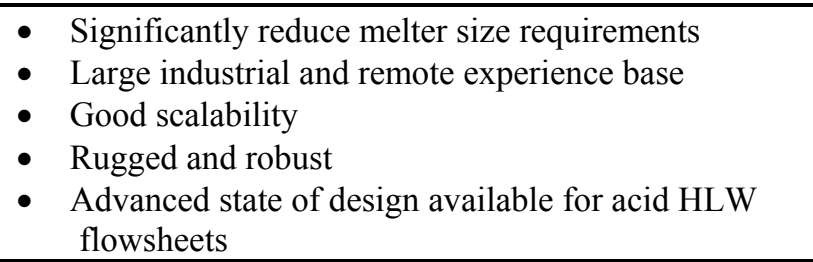 & $\begin{array}{ll}\text { - } & \text { Drying of alkaline slurry w/o additives difficult } \\
\text { - } & \text { Drying equipment reliability and size must be factored } \\
\text { into melter cell requirements } \\
\text { - } \\
\text { - } \\
\text { Imffect on waste form qualification strategy TBD } \\
\text { TBD }\end{array}$ \\
\hline \multicolumn{3}{|l|}{ Agitation } \\
\hline Gas bubbling & $\begin{array}{l}\text { - } \begin{array}{l}\text { Demonstrated in non-remote environment in DOE } \\
\text { melter programs }\end{array} \\
\text { - Increase in production rate } 2 \mathrm{X} \text { to } 4 \mathrm{X} \text { above standard } \\
\mathrm{JHCM} \text { rate of } 0.4 \mathrm{MTG} / \mathrm{m}^{2} \bullet \mathrm{d} \text { resulting in } \\
\text { proportionally smaller melter sizes } \\
\text { - }\end{array}$ & $\begin{array}{ll}\text { - } & \text { Materials service life and designs sufficient to meet } \\
& \text { plant requirements are TBD } \\
\text { - } & \text { Effect of catastrophic failures on melter life is TBD } \\
\text { - } & \text { Occupy significant fraction of melter lid } \\
\text { - } & \text { Increased secondary solid waste and cell space to } \\
& \text { handle disposal requirements } \\
\text { - } \quad \text { Decrease in TOE due to replacement frequency } \\
\text { - }\end{array}$ \\
\hline $\begin{array}{l}\text { Stirred with water-cooled } \\
\text { stainless steel impeller }\end{array}$ & $\begin{array}{l}\text { - } \\
\text { - } \\
\text { Increase in production rate due to elimination of hot } \\
\text { spots and forced convection beneath cold cap } \\
\text { - Reliability stated by French to be excellent } \\
\text { - Possible benefit by suspending or resuspension of } \\
\text { insolubles }\end{array}$ & $\begin{array}{l}\text { - Sealing from cell environment could fail resulting in } \\
\text { increased cell contamination } \\
\text { - Adds mechanical complexity into remote cell } \\
\text { - Effect of liquid feeding on corrosion of exposed shaft } \\
\text { is TBD (French experience primarily with calcine } \\
\text { feeding operation) } \\
\text { - Number and size and operating requirements (turbine } \\
\text { design, rpm's, depth, angle, etc.) required to be } \\
\text { effective are TBD }\end{array}$ \\
\hline
\end{tabular}




\begin{tabular}{|c|c|c|}
\hline Technology Attribute & Benefits & Issues \\
\hline $\begin{array}{l}\text { High-speed mixing } \\
\text { (Stir Melt巴) }\end{array}$ & $\begin{array}{l}\text { - Significantly reduce melter size requirements } \\
\text { - } \quad \text { Demonstrated in non-remote environment } \\
\text { - } \text { Increase in production rate } 12 \mathrm{X} \text { (hot top) above } \\
\text { standard Joule-heated ceramic melter rate of } 0.4 \\
\mathrm{MTG} / \mathrm{m}^{2} \bullet \mathrm{d} \\
\text { - } \quad \text { Reliability stated to be excellent } \\
\text { - Suspends crystals and insolubles } \\
\text { - Can produce BSi and FeP and glass + crystalline } \\
\quad \text { forms }\end{array}$ & $\begin{array}{l}\text { - Seal from cell environment could fail } \\
\text { - } \\
\text { - } \quad \text { Edded mechanical of liquid feeding on corrosion of shaft } \\
\text { unresolved } \\
\text { - Limitation of waste forms it can produce due to temp } \\
\text { of operation } \\
\text { - Temperature limitation precludes ceramic waste forms } \\
\text { - Single supplier of technology }\end{array}$ \\
\hline Hot-point heating (TECO) & $\begin{array}{l}\text { - Increase convective mixing and production rates up } \\
\text { to } 2 X(?)\end{array}$ & $\begin{array}{l}\text { - } \\
\text { - } \\
\text { - } \\
\text { - } \text { Requirect on volatility DFs is TBD } \\
\text { feeding system } \\
\text { - Capability requl electrode positioning and } \\
\text { remotely } \\
\text { - Affects on waste form characteristics (reduced phases, } \\
\text { carbon inclusion, etc.) are TBD }\end{array}$ \\
\hline \multicolumn{3}{|l|}{ Discharge Method } \\
\hline \multicolumn{3}{|l|}{ Riser/Overflow } \\
\hline $\begin{array}{l}\text { Gravity overflow with } \\
\text { mechanical valve }\end{array}$ & $\begin{array}{l}\text { Adapted from French designs and combined with } \\
\text { U.S. discharge design concepts } \\
\text { - Provides positive control over glass discharge into } \\
\text { canister }\end{array}$ & $\begin{array}{l}\text { - Not demonstrated to be superior to other, already } \\
\text { developed and demonstrated systems } \\
\text { - Failure of mechanical valve could lead to over-filling } \\
\text { consequence } \\
\text { Potentially require overflow section to be heated to a } \\
\text { higher temperature to maintain stationary glass at } \\
\text { nominal glass tank processing temperature }\end{array}$ \\
\hline Airlift & $\begin{array}{l}\text { - } \\
\text { - Proven remotely at PNNL and WVDP } \\
\text { - } \quad \text { Does not require the glass discharge area to be } \\
\text { sealed against cell inleakage to the degree required } \\
\text { by other methods } \\
\text { - } \quad \text { Pour rate easily controllable } \\
\end{array}$ & $\begin{array}{l}\text { - Requires periodic replacement of airlift lance } \\
\text { Rate control/repeatability dependant on glass } \\
\text { properties and glass tank level }\end{array}$ \\
\hline Differential pressure pour & $\begin{array}{l}-\quad \text { Proven remotely at DWPF } \\
-\quad \text { Proven reliable at DWPF }\end{array}$ & $\begin{array}{l}\text { - Control sensitive to melter plenum pressure stability } \\
\text { and setpoint control approach } \\
\text { - More sensitive to inleakage and deficiencies in } \\
\text { overflow and canister-to-overflow section seals }\end{array}$ \\
\hline
\end{tabular}




\begin{tabular}{|c|c|c|}
\hline Technology Attribute & Benefits & Issues \\
\hline \multicolumn{3}{|l|}{ Bottom Drain } \\
\hline Mechanical valve & $\begin{array}{ll}- & \text { Proven remotely and industrially Russia and } \\
& \text { France } \\
\text { - } & \text { No electrical systems required } \\
\text { - } & \text { Proven compatible with cold wall melter design } \\
\text { - } & \text { Compatible with high-temperature applications } \\
\end{array}$ & $\begin{array}{l}\text { Estimated by French to require annual } \\
\text { replacement/maintenance } \\
\text { - Pour rate dictated by glass properties and tank glass } \\
\text { hydraulic head } \\
\text { - Fit up to overflow section and control of glass flow } \\
\text { into canister are TBD }\end{array}$ \\
\hline $\begin{array}{l}\text { Induction-heated freeze } \\
\text { valve }\end{array}$ & $\begin{array}{ll}- & \text { Proven remotely at UK (Selafield), France } \\
\text { (LaHague), PAMELA and Tokai } \\
\text { - } & \text { Demonstrated to be remotely maintainable } \\
\text { - } & \text { Proven reliable at PAMELA and Tokai } \\
\text { - } & \text { High-temperature systems recently demonstrated } \\
\text { industrially by Integrated Environmental } \\
\text { Technologies, LLC (Personal communication JM } \\
\text { Perez to ML Elliott) }\end{array}$ & $\begin{array}{l}\text { Available materials could dictate or constrain } \\
\text { maximum glass temperature operating range } \\
\text { Drain size engineering critical to starting and stopping } \\
\text { glass flow }\end{array}$ \\
\hline
\end{tabular}




\subsection{Discussion of Results}

\subsubsection{Potential Technologies and Technology Features}

A review of the literature, U. S. patents, and RFI responses identified no new concepts or ideas not previously known by the Study Team participants. This is not entirely surprising considering that DOE is a major developer and "investor" in waste treatment technologies. Therefore, it only stands to reason that DOE and DOE contractors responsible for technology deployments will be very cognizant of emerging technologies. The technologies and technology features that were identified in this study that are believed to potentially meet or not meet WTP requirements are discussed in the following paragraphs.

Joule-heated ceramic melter: The Joule-heated ceramic melter is the WTP HLW vitrification baseline technology. The technology is robust, reliable, and simple to operate. Previous remoteoperating experiences using this technology in the U.S. and worldwide provides a strong argument for its continued use. At present, it is reasonable to expect that the nominal operating temperature can be raised to $1250^{\circ} \mathrm{C}$ when the electrode design incorporates forced air-cooling channels in the electrode body and not just the bus bar. Operation at higher temperatures will require alternative electrode materials that have not yet been demonstrated. Therefore, waste forms that can be produced by this technology would include borosilicate glasses, low-melting alkali-sodium-alumino-silicate glasses, and potentially phosphate glasses. The corrosivity of phosphate glasses on nickel alloy electrodes requires study to verify compatibility. With forced mixing and/or bottom drain features, glasses with crystalline phases present should have the ability to be accommodated as well. Two melters, one in each cell, will be needed to meet the 6MTG/d requirement within the current WTP cell design. Considerations that would negatively affect this technology are its large size and significant requirements to disassemble and dispose of the melter. To meet disposal requirements, some segregation of glass from the refractory should be expected, especially when a significant fraction of glass will remain in the melter at shutdown. To prevent significant impacts to plant TOE, a separate melter disassembly and disposal preparation cell will be required. This additional cell is not currently reflected in the WTP conceptual design.

Induction-heated, cold-wall melter: This technology has been under development in France and Russia for over 20 years, although, its application to HLW treatment has only been seriously pursued since about 1995 . The technology is reported to be robust, reliable, and simple to operate. There is no remote experience as of yet, but plans are to install it in France's La Hague facility to process high-molybdenum waste and in Russia's Mayak facility to process HLW within the next few years. The maximum operating temperature can exceed $1700^{\circ} \mathrm{C}$, providing the highest temperature capability of any vitrification technology. All of the waste forms considered in this study can be produced by this technology. Like the Joule-heated ceramic melter, forced mixing and/or bottom drain features are required to process glasses with crystalline phases present. The French ACCM concept appears to require water-cooled mechanical mixers to assure adequate processing efficiency by mixing the heated glass from near the bottom of the melter with the rest of the glass tank inventory. The ACCM design approach of placing the induction field along the bottom of the melter rather than the walls permits larger-diameter melters to be designed. Two melters will be needed to meet the 6-MTG/d requirement within the current WTP cell design. Given their relatively compact size, it is possible that both melters could fit in a single cell. However, this would require additional feed preparation and off-gas and canister-handling capability to be combined into a single cell. The lack of refractory materials in its construction makes end-of-life disposal and replacement very modest in comparison to the 
Joule-heated ceramic melter. No separate melter disassembly and disposal preparation cell are envisioned for this technology. One technical issue that must be considered is the lack of experience in application of this technology to processing liquid, alkaline slurries. The effects on materials life, especially in the plenum space, are not well understood.

Stir Melter ${ }^{\circledR}$ : The stirred melter technology, along with the CCM technology, were recommended for development and evaluation in the 1995 evaluation. Its application to HLW treatment has been proposed for several years; however, very little testing and demonstration has occurred. The technology is not considered to be as robust, reliable, and simple to operate as the Joule-heated ceramic melter and CCM technologies. However, the main metal components should be able to be replaced quickly. No remote experience exists with this technology. The maximum operating temperature is about $1100^{\circ} \mathrm{C}$, providing the lowest temperature capability of any vitrification technology. Because of its high shear mixing action, glass formulations designed for processing at 1150 to $1200^{\circ} \mathrm{C}$ in a Joule-heated ceramic melter or CCM melter can be processed at $1100^{\circ} \mathrm{C}$ in a stirred melter. Also, because of the high level of mixing, high concentrations of crystalline phases in the glass can be processed. A single small melter will be capable of meeting the 6-MTG/d requirement within the current WTP cell design. However, this would require additional feed preparation and off-gas and canister-handling capability to be combined into a single cell. The lack of refractory materials in its construction makes end-of-life disposal and replacement very modest in comparison to the Joule-heated ceramic melter. No separate melter disassembly and disposal preparation cell are envisioned for this technology. One technical issue that must be considered is the lack of experience processing liquid, alkaline slurries. The effects on materials life, operational stability, and glass quality are not well understood. A deep, two-zone tank design or a second melter tank will be required to assure unmelted feed material and excessive bubble concentrations are not discharged into the canister.

In-can melting technology: In-can melting technologies were extensively researched and demonstrated in the 1970s for HLW immobilization. Both dry-fed and liquid-fed approaches were investigated. Several technical reasons exist for halting in-can melting development and focusing on a melter-based technology. The furnace and canister design was limited by both the maximum temperature at which it could be operated and the rate heat that could be transferred into the canister. Concern for canister integrity and being able to project the waste form properties and product quality were also major issues. In addition, from an operating perspective, it was projected that higher incidences of cell contamination would occur, TOE would be low due to high maintenance requirements, and low processing rates would require a significant number of operating lines. The current proposed approach by RIC overcomes the low temperature constraint by employing induction heating and multi-component canister approaches. However, many significant technical issues were identified during this review that must be overcome before the technology can be seriously considered.

- The HLW must be dried prior to introduction into the canister. No clear definition of the technology to be used, or the method of feeding, was defined. Pre-drying the feed has been identified in this study as a potential option for increasing production rate. However, it is also acknowledged as a technical issue that equipment to reliably dry and transfer alkaline slurries requires development. This technology places an added requirement on drying in that the material must be completely dry. In other applications, a paste or semi-dry feed is acceptable. Again, the high alkalinity of the feed will make this difficult to achieve.

- Independent frit or glass former addition and how it will be controlled to assure that the waste form specified is actually produced has not been described. 
- The waste form will consist of a complex composite of glass, crystals, and metal inclusions. To date, research has been inadequate to describe the waste form composition as a function of waste composition and processing conditions. Therefore, review for possible repository acceptance or even evaluation cannot be performed.

- Waste form repository acceptance activities have not been described and are expected to be significant considering what has been required to date to qualify borosilicate glass.

- Feed dryer and the in-can furnace are not sufficiently defined or demonstrated to determine their reliability, maintainability, operability, and facility requirements. For instance, the RFI information describes significant air-cooling requirements to maintain the metal canister wall at ambient temperatures. Given that at least $67 \%$ of the energy will be dissipated in the metal canister material, and that air is a poor heat transfer fluid, significant and undefined volumes of air will be required at significant flow rates and pressures. Guaranteeing a positive seal between the furnace and the cell environment will be difficult but has not been discussed.

- The WTP facility and cell designs will require the RIC process to occur in the vitrification cell. The maximum crane lifting height (about $10 \mathrm{~m}$, or $33 \mathrm{ft}$ ) is not high enough to allow the canisters to be raised and lowered into the furnace. Therefore, redesign of the cell would be required immediately to provide the option to consider this technology.

- Many technical issues were raised regarding the basic design of the canister and assembly: 1 ) the availability of alumina liner material and ability to manufacture it for a 4.6-m (15-ft) canister; 2) the integrity of alumina liner during extended full-scale operation has not been sufficiently researched; 3 ) it has not been sufficiently demonstrated that isolation of the graphite materials from the feed, moisture, and sulfur in the feed (which can produce $\mathrm{H}_{2} \mathrm{SO}_{4}$ ) can be guaranteed; 4) fabrication, shipping, and handling effects on container quality and integrity have not been demonstrated; 5) zone melting effects on components have not been demonstrated; 6) uncertainty that operation at $1,500^{\circ} \mathrm{C}$ is feasible at full scale; 7) the stated $2: 1$ ratio in thermal heating of the outer metal canister and graphite line at full-scale diameters is expected to increase; 8) the three-day cycle time is based on small-scale testing and appears too short for full-scale operation; 9) contamination spread into the cell from removal and attachment of the furnace headpiece will be significant; 10) the off-gas treatment system must be coupled between multiple dryer and in-can melter units; and 11) operating limits on graphite and alumina components are not well defined.

A significant amount of development and demonstration work is required to allow this technology to be adequately judged. Even assuming that the technology can be shown to meet the claims of the developers, there is still the question of whether or not this technology should be considered for HLW immobilization. Arguments for this technology include that the higher waste loading will significantly reduce the number of canisters that will be produced. The waste form review conducted as part of this study estimates that waste loadings of 46 (Case 1) to 56 (Case 17) \% may be achievable. The RIC canister has an internal volume that is $76.5 \%$ of the WTP reference canister. Therefore, just to achieve the same number of canisters, the RIC process must achieve waste loadings of 60 to $73 \%$. A DOE review of the RIC process and results obtained in 1999 indicated that waste loadings of up to $61 \%$ could be substantiated. ${ }^{18}$ Test results provided by RIC as part of the RFI request reported successful small-scale melting tests at waste

18 "Technical Review Panel - Gate 3 Evaluation of the Advanced Vitrification System of the Radioactive Isolation Consortium, LLC - Final Report," November 5, 1999, Prepared by Concurrent Technologies Corporation, Pittsburgh, PA under Task No. FT50503, DOE Contract No. DE-AM26-99FT40465. 
loadings up to $70 \%$. Therefore, based on results reported to date and estimations of waste loadings that may be achieved using current technology, significant reductions in glass volume and the number of canisters produced do not appear to have the ability to be realized.

Mixing: Agitation of the glass tank inventory can suspend crystalline phases that would otherwise settle in the melter in substantial proportions. This will allow glasses to be processed with concentrations of crystals present. Forced mixing should provide improved processing rate and capabilities by transferring heat to the cold cap and diminishing impediments to heat transfer. Foam or bubbles in the boundary layer between the cold cap and the bulk glass may also be diminished because the hotter glass will have a low viscosity. Mechanical agitation has been demonstrated by French and Russian organizations in small melter tank volumes. The use of sparging with bubblers has been demonstrated in large melters by Duratek in their M-area melter and pilot-testing in support of the WTP project. To maintain crystals in suspension will require that the entire glass volume be mixed. Melter tank zones not mixed will be stagnant and eventually be filled by crystal deposits. The number and design of mechanical mixers to do this in a large melter tank has not been demonstrated. The ability of bubblers to prevent settling also requires modeling and demonstration. The design of a reliable mixing system must include remotely maintainable and replaceable functions that do not cause significant cell contamination. When applied to the Joule-heated ceramic melter and CCM technologies, both options must also take into consideration that they not interfere with the melter's electrical field.

Bottom drain use: Bottom drain designs for glass discharge have been demonstrated by German, French, and Japanese HLW management projects. Most recently, the melter design for the Verglasungseinrichtung Karlsruhe (VEK) project in Germany incorporates the most recent bottom drain design ideas (Weisenburger 1999). They have been shown to be effective in preventing noble metal phases (crystalline and metallic) from accumulating in the melter over time. However, use of bottom drains requires that the melter walls be sloped at a significant angle in order to assure that settled phases do not accumulate. This results in Joule-heated ceramic melter designs that are taller relative to standard Joule-heated ceramic melter designs. To assure reliability, the bottom drain components must be remotely maintainable.

High-temperature operation: The waste form evaluation shows only a modest increase in waste loading when processing temperature is increased from $1150^{\circ} \mathrm{C}$ to $1350^{\circ} \mathrm{C}$ for alkali-aluminoborosilicate glasses. Insufficient information is available in the literature to judge the potential gains in waste loading by producing crystalline waste forms or boron-free alkali-alumino-silicate glasses. There is an acknowledged benefit in being able to react to poor processing condition by having the ability to increase melter-operating temperature above its intended nominal temperature. In cases where processing rates are hindered by higher viscosity glasses, slow melting cold caps, or bubble formation beneath the cold cap, increasing the temperature by $50^{\circ} \mathrm{C}$ to $100^{\circ} \mathrm{C}$ above normal can make a notable improvement. Current Joule-heated ceramic melter technology will not support sustained operation above $1200^{\circ} \mathrm{C}$. Wiesenburger (1999) reports modeling results for the VEK Joule-heated ceramic melter in which air cooling is shown to reduce the electrode face temperature by $100^{\circ} \mathrm{C}$. Electrode material development is required or the use of consumable electrode material must be considered. Cold crucible melter technology is capable of operating at elevated temperatures.

Pre-drying and calcinations: It is well known that melter size and production rate are significantly affected by the water content in a melter feed. The use of dryers or calciners prior to the melter should permit at least a doubling of production rate with the condition that the material is effectively distributed over the glass surface. Significant development and demonstration will be necessary because of the alkaline chemistry of Hanford HLW. Pre-acidification of the feed 
would eliminate many drying and calciner technology issues. However, this would create a sizable unit operation in the pretreatment facility and significant $\mathrm{NO}_{\mathrm{x}}$ treatment requirements in the off-gas treatment systems. Finally, additional in-cell equipment would be required that would need to be maintained and operated. The incremental decrease in melter size and subsequent solid waste disposal volumes, principally for the Joule-heated ceramic melter, may not be worth the additional complexity and uncertainty of reliability and maintainability.

Secondary heat-boosting: Additional power input could be obtained by resistance, plasma, or DC arc systems. Resistance heating is limited by the amount of melter headspace available for heat insertion. Resistance and plasma torch heating have the negative aspect of excessively heating the off-gas. Designing replaceable resistance heater components will eliminate the potential for early failure, leading to early melter replacement. However, continued operation of the melter without lid heaters is certainly possible (unless they are required for permitting reasons). DC arc electrodes submerged beneath the cold cap will deliver the thermal energy without heating the plenum gases. However, electrode position control requirements, electrode wear, and the formation of reduced metal phases make DC arc heating unattractive.

\subsection{Optimizing Melting Processes}

Based on the information previously presented, considerations for optimizing melting processes are discussed in this section. The key criteria used in selecting melter systems were discussed in Section 6.3.3. These criteria are used in summary fashion in Table 6.8 to compare the technology and technology features considered applicable to the WTP. What should be generally apparent is that versatility, high production rate, and the ability to process a wide range of waste form properties can be achieved with increased complexity and potential risk to maintainability and reliability. The range of options vary from the baseline Joule-heated ceramic melter, which is reliable and easily maintained (but has the most narrow capability), to the stirred melter and ACCM options, which provide the maximum capability to produce glass and crystalline waste forms, and are compact, easily replaced, and generate a relatively small volume of solid waste. Figure 6.10 attempts to portray the relationship of complexity to capability for the different technologies in a relative fashion. Increasing complexity can indicate the combination of more features, a lack of previous deployment experience, increased development and demonstration requirements, and potentially reduced TOE due to maintainability and operability issues. Increasing capability includes increased production capacity as a function of size, larger temperature operating range, capability to produce a larger number of waste forms, increased TOE resulting from compact size, ease of replacement, and ease of disposal. What the figure attempts to relate is the Study Team's conclusion that significant gains in capability should be achieved with JHCM technologies employing bottom drains and/or mixing systems. To judge the feasibility of using a JHCM with bottom drain and mixing capabilities, FZK prepared a conceptual elevation drawing of a typical FZK melter. The melter, shown in Figure 6.11, has been modified to include dual bottom drains, rather than the single bottom drain typically seen. The location and number of mixers and feed nozzles has not been optimized. However, it provides a first view of what may be possible. 


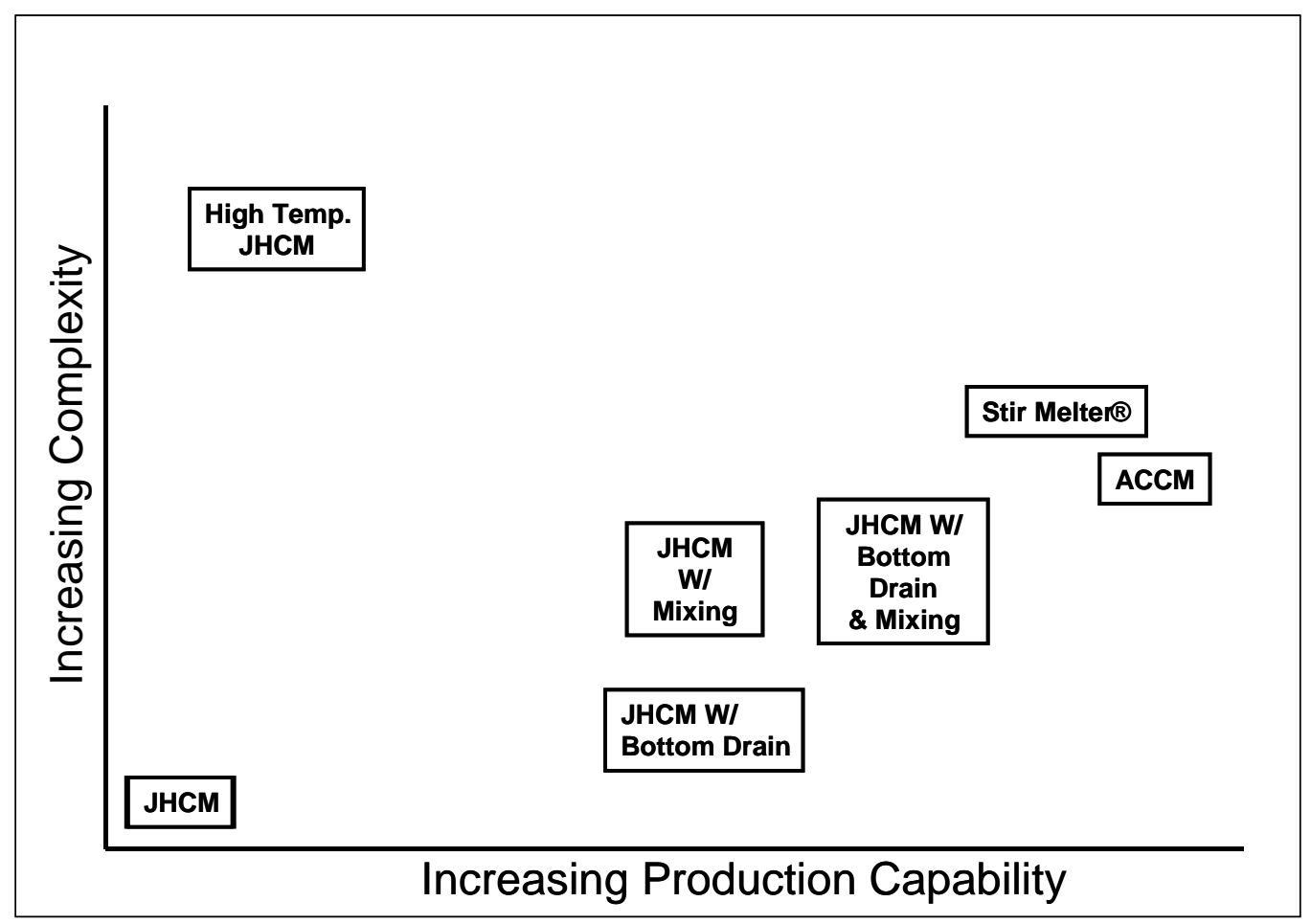

Figure 6.10. Representation of Technologies Based on Complexity and Capability

Figure 6.11. JHCM Concept with Dual Bottom Drain Design and Mechanical Agitation 
Further increases in capability should be realized through the use of ACCM and Stir Melter technologies, but with some incremental increase in complexity. The degree of gain versus the degree of complexity cannot be quantified until testing and evaluation have occurred.

Secondary heat-boosting techniques are another feature that could be overlaid on the technology options. They are not appropriate for the Stir Melter technology. Advanced Cold Crucible Melter technologies may be difficult to augment with secondary heat boosting given the melter's limited size. They are appropriate for Joule-heated ceramic melter technologies. However, they add complexity, uncertainty about the extent of potential benefits, and intrusiveness in the melter. Therefore, it would be preferable to assure WTP objectives by increasing the base capacity of the immobilization technology and use the features discussed earlier.

Drying or calcination furnaces placed upstream of the melter, if demonstrated to be reliable and maintainable, will certainly reduce the size requirements for the base vitrification technology. Only the Joule-heated ceramic melter technologies are projected to be of sufficient size such that reducing their footprint may be an incentive. The Stir Melter technology is already of modest size. Pre-drying or calcining the feed would be of benefit if processing slurry feeds were determined to be impractical. However, testing with slurries has been demonstrated in the past and so should not be assumed to be a requirement. The French and Russian HLW operations utilize calciners as a matter of course. However, the cell dimensions can support larger ACCM units. Most important, however, is the fact that alkaline feeds have been difficult to process through dryers and calcination furnaces. Melter feed dried to a paste consistency will be difficult to spread across the glass surface. Calcined feed may require significant quantities of refractory additives, such as alumina, to make the material flow from a calciner. Finally, system off-gas pressures for the furnaces the melter must be coordinated and the gas streams combined at some point. International experience is to pass the melter off-gas through the calciner. Whether this is feasible with alkaline flowsheets is to be determined.

Based on Hanford waste projections, waste form analyses, and review of potential technologies, it is apparent that vitrification technologies that can process waste forms with levels of spinels and other crystalline phases will provide the best potential to achieve the maximum waste loading and subsequent reduction in the numbers of canisters produced. These technologies also provide an important level of insurance against the uncertainties in Hanford waste characterization and the level of efficiencies that will be achieved during sludge washing and leaching. Chief among these are technologies with strong agitation and melters with bottom drain designs. Secondarily, melters with wide operating temperature capability provide additional insurance in processing glass compositions with varying viscosity and melting characteristics. 
Table 6.8. Comparisons of Technologies and Technology Features to Evaluation Criteria

\begin{tabular}{|c|c|c|c|c|c|c|c|c|c|c|}
\hline \multirow{2}{*}{$\begin{array}{l}\text { Technology or } \\
\text { Technology } \\
\text { Feature }\end{array}$} & \multirow{2}{*}{$\begin{array}{l}\text { Ability to tolerate } \\
\text { or remove spinels } \\
\text { and crystals }\end{array}$} & \multirow{2}{*}{\begin{tabular}{|l|} 
Ability to operate \\
within a broad \\
temperature region
\end{tabular}} & \multirow{2}{*}{$\begin{array}{l}\text { Ability to control and } \\
\text { predict process } \\
\text { conditions }\end{array}$} & \multirow{2}{*}{$\begin{array}{l}\text { High reliability and } \\
\text { maintainability }\end{array}$} & \multirow{2}{*}{$\begin{array}{l}\text { Ability to } \\
\text { monitor } \\
\text { process }\end{array}$} & \multirow{2}{*}{$\begin{array}{l}\text { Ability to operate at } \\
\text { increased rates above } \\
\text { the design basis }\end{array}$} & \multicolumn{2}{|c|}{ WTP impacts } & \multirow{2}{*}{$\begin{array}{l}\text { Development and deployment } \\
\text { requirements }\end{array}$} & \multirow{2}{*}{$\begin{array}{l}\text { Potential major } \\
\text { problems }\end{array}$} \\
\hline & & & & & & & Facility & Operational & & \\
\hline $\begin{array}{l}\text { High-temperature } \\
\mathrm{JHCM}^{*}\end{array}$ & $\begin{array}{l}\text { No unique capability, } \\
\text { mixing is by natural } \\
\text { convection. }\end{array}$ & $\begin{array}{l}\text { Operation over a range } \\
\text { from } 1000^{\circ} \mathrm{C} \text { in excess } \\
\text { of } 15000^{\circ} \mathrm{C} \text { possible. }\end{array}$ & $\begin{array}{l}\text { JHCM operation is well } \\
\text { documented and } \\
\text { understood. } \\
\text { Relatively large size } \\
\text { permitg good access for } \\
\text { monitoring and control. } \\
\text { Mixing within the tank is } \\
\text { very slow (crmsec rates } \\
\text { convection rates). } \\
\text { However, due to long } \\
\text { residence time well-mixed } \\
\text { behavior occurs }\end{array}$ & $\begin{array}{l}\text { Basic JHCM technology has } \\
\text { been shown to be very } \\
\text { reliable. } \\
\text { Maintainability can be } \\
\text { dependant on degree of } \\
\text { replaceable components } \\
\text { desinged into system. Can be } \\
\text { assumed that only refractory } \\
\text { and electrodes are not } \\
\text { replaceable. } \\
\text { Reliability of electrode } \\
\text { materials is currently low. }\end{array}$ & \begin{tabular}{|l} 
Relatively large \\
size permits \\
good access for \\
monitoring and \\
control.
\end{tabular} & $\begin{array}{l}\text { JHCM can be } \\
\text { oversized. However, } \\
\text { large penalty is paid in } \\
\text { size, weight, and the } \\
\text { fact that the majority } \\
\text { of the time the melter } \\
\text { would be operating } \\
\text { with a reduced cold } \\
\text { cap, causing higher } \\
\text { volatility and higher } \\
\text { plenum temperatures. }\end{array}$ & \begin{tabular}{|l} 
Remote electrode \\
maintenance to feed \\
electrodes and attach \\
new sections. \\
Changes to cell \\
include electrode \\
segment transfer \\
capability into cell \\
from gallery glove box \\
or similar; assume \\
electrode services are \\
on top of melter lid.
\end{tabular} & $\begin{array}{l}\text { Assume electrodes must } \\
\text { be maintained w/o } \\
\text { feeding and no power - } \\
\text { add } 2 \text { days of melter } \\
\text { outage per month. } \\
\text { Increased volatility of } \\
\text { seni-volatite Cs and Tc } \\
\text { anticipated. } \\
25 \% \text { higher replacement } \\
\text { rate of overflow heaters, } \\
\text { thermowells, etc. } \\
\text { Melter disposal volumes } \\
\text { comparable to baseline. } \\
\end{array}$ & \begin{tabular}{|l} 
No suitable electrode material has \\
been demonstrated. \\
Refractory life impacts needs to be \\
determined. \\
Canister materials requirements \\
need to be assessed. \\
Effect on volatility on recycle waste \\
management needs to be assessed. \\
Estimate 5 years \& $\$ 25 \mathrm{M}$ \\
\\
\end{tabular} & 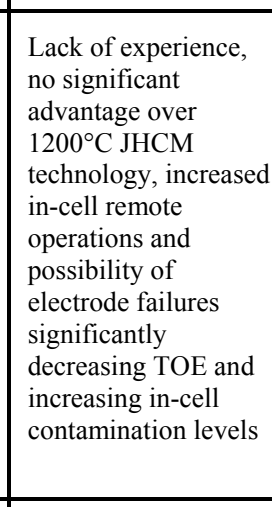 \\
\hline JHCM w/ mixing & $\begin{array}{l}\text { Forced mixing, e.g., } \\
\text { mechanical mixers or } \\
\text { bubblers. }\end{array}$ & \begin{tabular}{|l} 
Electrode cooling \\
permits operation over \\
a range from $1000^{\circ} \mathrm{C}$ \\
up to $1250^{\circ} \mathrm{C}$.
\end{tabular} & $\begin{array}{l}\text { JHCM operation is well } \\
\text { documented and } \\
\text { understood. } \\
\text { Relatively large size } \\
\text { permitg good access for } \\
\text { monitoring and control. } \\
\text { Added mixing should only } \\
\text { reinforce well-mixed } \\
\text { characteristics. Reduced } \\
\text { tank volumes could be } \\
\text { considered in the case } \\
\text { where mixing is used. }\end{array}$ & $\begin{array}{l}\text { Basic JHCM technology has } \\
\text { been shown to be very } \\
\text { reliable. } \\
\text { Maintainability can be } \\
\text { dependant on degree of } \\
\text { replaceable conponents } \\
\text { desinged into system. Can be } \\
\text { assumed that only refractories } \\
\text { and electrodes are not } \\
\text { replaceable. } \\
\text { Mixer reliability and } \\
\text { maintainability are TBD. } \\
\text { France CEA has stated } \\
\text { excellent reliabilitity and mixer } \\
\text { is designed to be replaceable. }\end{array}$ & \begin{tabular}{|l} 
Relatively large \\
size permits \\
good access for \\
monitoring and \\
control.
\end{tabular} & \begin{tabular}{|l} 
Dependant on the \\
number and type of \\
mixers used. Possible \\
to operate with \\
nominal mixing and \\
more vigorous mixing \\
to "catch up". \\
However, the degree to \\
which this will be \\
successful must be \\
demonstrated.
\end{tabular} & \begin{tabular}{|l} 
Remote service and \\
maintenance of mixing \\
systems do not change \\
WTP design. \\
Smaller melter \\
footprint $25 \%$ ( 6 \\
MT//) to $50 \%(1.5$ \\
MT/d) provides more \\
area for other cell \\
activities \& smaller \\
failed melter transfer \\
boxes. \\
For mechanical mixers \\
addede electrical and \\
water cooling required \\
(considered minor).
\end{tabular} & 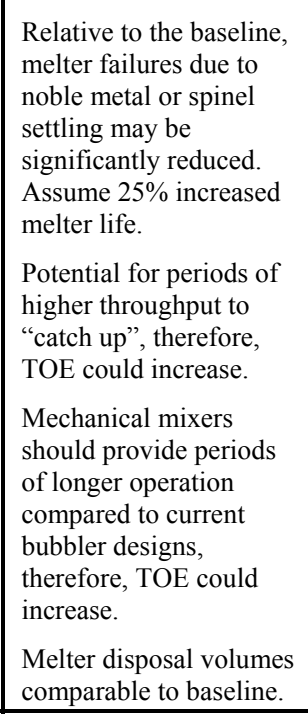 & 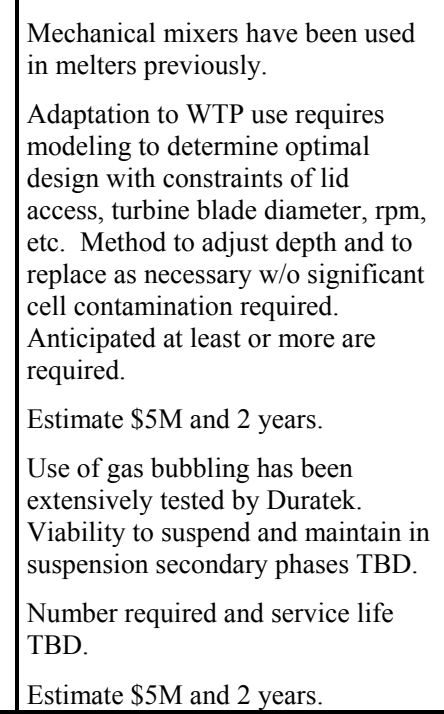 & \begin{tabular}{|l} 
Poor reliability, \\
inability to provide \\
substantially \\
improved glass \\
convection.
\end{tabular} \\
\hline $\begin{array}{l}\text { JHCM w/ bottom } \\
\text { drain }\end{array}$ & $\begin{array}{l}\text { Routine use of a } \\
\text { bottom drain } \\
\text { combined with a } \\
\text { stseeply sloped wall } \\
\text { melter design. }\end{array}$ & $\begin{array}{l}\text { Electrode cooling } \\
\text { permits operation over } \\
\text { a range from } 1000^{\circ} \mathrm{C} \\
\text { up to } 1250^{\circ} \mathrm{C} .\end{array}$ & $\begin{array}{l}\text { JHCM operation is well } \\
\text { documented and } \\
\text { understood. } \\
\text { Relatively large size } \\
\text { permitg good access for } \\
\text { monitoring and control. } \\
\text { Mixing within the tank is } \\
\text { very slow (crmsec rates } \\
\text { convection rates). } \\
\text { However, due to long } \\
\text { residence time well-mixed } \\
\text { behavior occurs. }\end{array}$ & $\begin{array}{l}\text { Basic JHCM technology has } \\
\text { been shown to be very } \\
\text { reliable. } \\
\text { Maintainability can be } \\
\text { dependant on degree of } \\
\text { replaceable components } \\
\text { designed into system. Can be } \\
\text { assumed that only } \\
\text { refractories, olectrodes and } \\
\text { imbedded drain tube are not } \\
\text { replaceable. } \\
\text { FZK-INE/ and Belgo Process } \\
\text { PAMELA have designed a } \\
\text { bottom drain tube and heating }\end{array}$ & $\begin{array}{l}\text { Relatively large } \\
\text { size permits } \\
\text { good access for } \\
\text { monitoring and } \\
\text { control. }\end{array}$ & $\begin{array}{l}\text { JHCM can be } \\
\text { oversized. However, } \\
\text { large penalty is paid in } \\
\text { size, weight, and the } \\
\text { fact that the majority } \\
\text { of the time the melter } \\
\text { would be operating } \\
\text { with a reduced cold } \\
\text { cap, causing higher } \\
\text { volatility and higher } \\
\text { plenum temperatures. }\end{array}$ & $\begin{array}{l}\text { Melter with dual } \\
\text { bottom drains } \\
\text { estimated to be } 3.5 \mathrm{~m} \\
\text { long by } 2 \mathrm{~m} \text { wide by } \\
3.1 \mathrm{~m} \text { tall. } \\
\text { Assume bottom drain } \\
\text { maintenance includes } \\
\text { cell and canister tunnel } \\
\text { access. } \\
\text { Height of melter } \\
\text { exceeds shield door } \\
\text { height. Require partial } \\
\text { assembly/disassembly } \\
\text { in cell to be viable. }\end{array}$ & 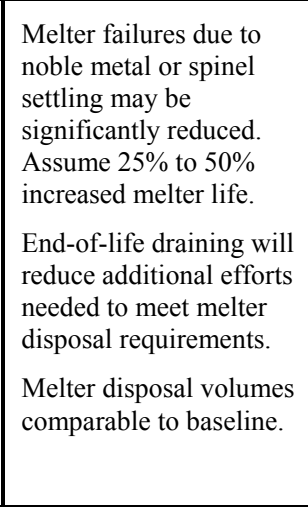 & \begin{tabular}{|l} 
Dual bottom drain design required. \\
Modeling to verify nominally $60^{\circ}$ \\
slope is adequate required. \\
Contract with bottom drain supplier \\
with experience required. \\
Design and demonstrate remote \\
maintenance tools required. \\
Test prototype design. \\
Estimate $\$ 25 \mathrm{M}$ and 3 years. \\
Cell and facility impacts related to \\
melter transport are not significicant \\
if partial disassembly and assembly
\end{tabular} & $\begin{array}{l}\text { Reliability and } \\
\text { maintainability of } \\
\text { mixers and bottom } \\
\text { drains. }\end{array}$ \\
\hline
\end{tabular}




\begin{tabular}{|c|c|c|c|c|c|c|c|c|c|c|}
\hline \multirow{2}{*}{$\begin{array}{l}\text { Technology or } \\
\text { Technology } \\
\text { Feature }\end{array}$} & \multirow{2}{*}{$\begin{array}{l}\text { Ability to tolerate } \\
\text { or remeve spinels } \\
\text { and crystals }\end{array}$} & \multirow{2}{*}{$\begin{array}{l}\text { Ability to operate } \\
\text { within a broad } \\
\text { temperature region }\end{array}$} & \multirow{2}{*}{$\begin{array}{l}\text { Ability to control and } \\
\text { predict process } \\
\text { conditions }\end{array}$} & \multirow{2}{*}{$\begin{array}{l}\text { High reliability and } \\
\text { maintainability }\end{array}$} & \multirow{2}{*}{$\begin{array}{l}\text { Ability to } \\
\text { monitor } \\
\text { process }\end{array}$} & \multirow{2}{*}{$\begin{array}{l}\text { Ability to operate at } \\
\text { increased rates above } \\
\text { the design basis }\end{array}$} & \multicolumn{2}{|c|}{ WTP impacts } & \multirow{2}{*}{$\begin{array}{l}\text { Development and deployment } \\
\text { requirements }\end{array}$} & \multirow{2}{*}{$\begin{array}{l}\text { Potential major } \\
\text { problems }\end{array}$} \\
\hline & & & & & & & Facility & Operational & & \\
\hline & & & & $\begin{array}{l}\text { system that can be replaced } \\
\text { remontely. Testing and } \\
\text { demonstration are required to } \\
\text { verify and adapt to } \mathrm{d} \text { U.S. } \\
\text { remote operations. }\end{array}$ & & & & & $\begin{array}{l}\text { are assumed. If not assumed it is } \\
\text { not expected to be acceptablet to } \\
\text { require larger cell doors, and } \\
\text { impacts on work areas above melter } \\
\text { transport areas }\end{array}$ & \\
\hline $\begin{array}{l}\text { Stir Melter囚 } \\
\text { technology }\end{array}$ & $\begin{array}{l}\text { Vigorous mechanical } \\
\text { mixing. }\end{array}$ & $\begin{array}{l}\text { Temperature limited } \\
\text { by metal components. } \\
\text { Operation up to } \\
1100^{\circ} \mathrm{C} \text { is acceptable } \\
\text { without significantly } \\
\text { reducing operating } \\
\text { life. Note that } \\
\text { vigorous stirring } \\
\text { action allows } \\
\text { production at a } \\
\text { temperature } 50 \text { to } \\
100^{\circ} \mathrm{C} \text { below typical } \\
\text { JHCM and CCM } \\
\text { melters. }\end{array}$ & $\begin{array}{l}\text { Compact size limits access } \\
\text { for monitioring and } \\
\text { instrumentatation. } \\
\text { To prevent unreacted } \\
\text { material and excess bubbles } \\
\text { from entering the canister } \\
\text { this technology will require } \\
\text { a two-zone tank design ir a } \\
\text { second “fining" tank to } \\
\text { assure product } \\
\text { predictability. The two- } \\
\text { zone tank design has been } \\
\text { proposed by the vendor but } \\
\text { requires evaluation and } \\
\text { demonstration. }\end{array}$ & $\begin{array}{l}\text { Long-term reliability and } \\
\text { maintainability are TBD. } \\
\text { Replacement of metal tank } \\
\text { and mixer//impeller unit } \\
\text { should be a straightforward } \\
\text { operation. }\end{array}$ & $\begin{array}{l}\text { Compact size } \\
\text { limits access for } \\
\text { monitoring and } \\
\text { instrumentation }\end{array}$ & $\begin{array}{l}\text { Expect that system } \\
\text { could be oversized } \\
\text { slightly and still permit } \\
\text { operation within } \\
\text { specified conditions, } \\
\text { i.e., limit carryover, } \\
\text { limit volatility, prevent } \\
\text { entrainment of bubbles } \\
\text { and unmelted feed } \\
\text { material from entering } \\
\text { canister. }\end{array}$ & 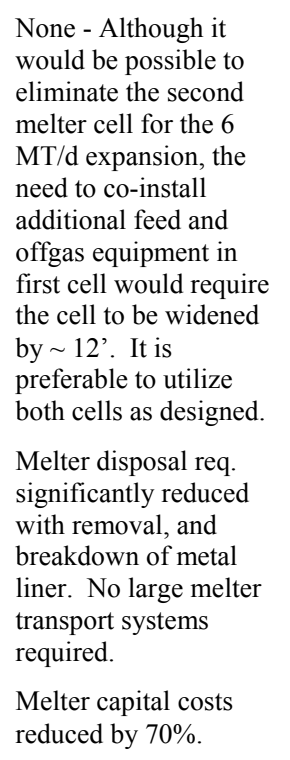 & $\begin{array}{l}\text { Melter replacement } \\
\text { reduced from } 3 \text { months } \\
\text { to } 1 \text { month. } \\
\text { Melter replacement } \\
\text { frequency increased by } \\
\text { factor of } 3 \text {. } \\
\text { Potential for periods of } \\
\text { higher throughput to } \\
\text { "cath up", therefore, } \\
\text { TOE could increase. } \\
\text { Mechanical mixers } \\
\text { should provide periods } \\
\text { of longer operation } \\
\text { compared to current } \\
\text { bubbler designs, } \\
\text { therefore, TOE could } \\
\text { increase. } \\
\text { Melter disposal volumes } \\
\text { significantly less than } \\
\text { baseline. }\end{array}$ & $\begin{array}{l}\text { Develop with deeper chamber to } \\
\text { eliminate need for post-melter glass } \\
\text { holdup tank. } \\
\text { Demonstrate remote replacement } \\
\text { features. } \\
\text { Demonstrate long-term operation } \\
\text { and reliability. } \\
\text { Demonstrate acceptable offgas flow } \\
\text { characteristics \& DFs. } \\
\begin{array}{l}\text { Demonsstrate whether glass REDOX } \\
\text { chemical control is required. } \\
\text { Estimate \$15M and } 3 \text { years. }\end{array} \\
\end{array}$ & $\begin{array}{l}\text { Technical viability } \\
\text { needs to be } \\
\text { demonstrated. }\end{array}$ \\
\hline $\begin{array}{l}J \mathrm{JCM} \mathrm{w} / \text { bottom } \\
\text { drain \& mixing }\end{array}$ & $\begin{array}{l}\text { Forced mixing, e.g., } \\
\text { mechanical mixers or } \\
\text { bubblers combined } \\
\text { with routine use of a } \\
\text { bottom drain } \\
\text { combined with a } \\
\text { steeply sloped wall } \\
\text { melter design. }\end{array}$ & $\begin{array}{l}\text { Electrode cooling } \\
\text { permits operation over } \\
\text { a range from } 1000^{\circ} \mathrm{C} \\
\text { up to } 1250^{\circ} \mathrm{C}\end{array}$ & $\begin{array}{l}\text { JHCM operation is well } \\
\text { documented and } \\
\text { understood. } \\
\text { Relatively large size } \\
\text { permitt good access for } \\
\text { monitoring and control. } \\
\text { Added mixing should only } \\
\text { reinforce well-mixed } \\
\text { characteristictic. Reduced } \\
\text { tank oulumes could be } \\
\text { considered in the case } \\
\text { where mixing is used. }\end{array}$ & 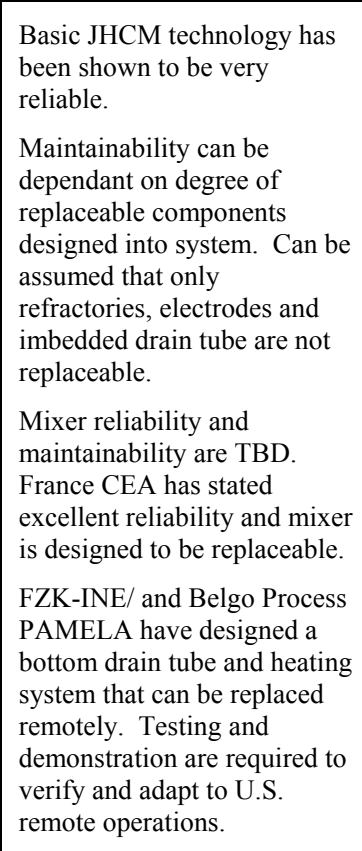 & $\begin{array}{l}\text { Relatively large } \\
\text { size permits } \\
\text { good access for } \\
\text { monitoring and } \\
\text { control. }\end{array}$ & $\begin{array}{l}\text { Dependant on the } \\
\text { number and type of } \\
\text { mixers used. Possible } \\
\text { to operate with } \\
\text { nominal mixing and } \\
\text { more vigorous mixing } \\
\text { to "catch up". } \\
\text { However, the degree to } \\
\text { which this will be } \\
\text { successful must be } \\
\text { demonstrated. }\end{array}$ & $\begin{array}{l}\text { Remote service and } \\
\text { maintenance of mixing } \\
\text { systems do not change } \\
\text { WTP design. } \\
50 \% \text { smaller melter } \\
\text { footprint provides } \\
\text { more area for other } \\
\text { cell activities \& } \\
\text { smaller failed melter } \\
\text { transfer boxes. } \\
\text { For mechanical mixers } \\
\text { added electrical and } \\
\text { water cooling required } \\
\text { (considered minor). } \\
\text { Melter height will be } \\
\sim 11 \text { and could pass } \\
\text { through existing cell } \\
\text { passageways. }\end{array}$ & 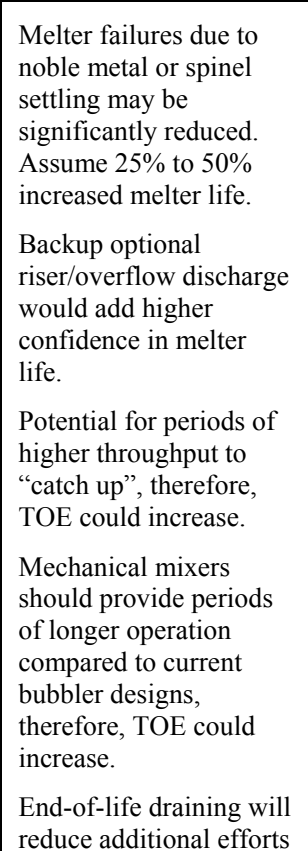 & 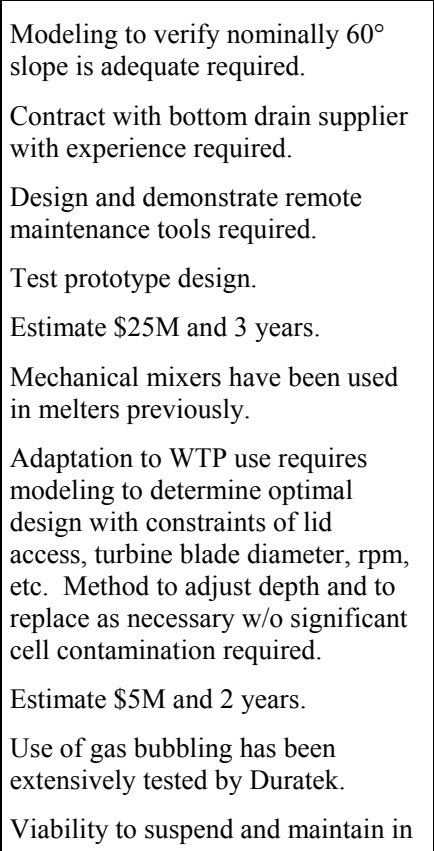 & $\begin{array}{l}\text { Mixer reliability and } \\
\text { inability to provide } \\
\text { substantially } \\
\text { improved glass } \\
\text { convection. }\end{array}$ \\
\hline
\end{tabular}




\begin{tabular}{|c|c|c|c|c|c|c|c|c|c|c|}
\hline \multirow{2}{*}{$\begin{array}{l}\text { Technology or } \\
\text { Technology } \\
\text { Feature }\end{array}$} & \multirow{2}{*}{$\begin{array}{l}\text { Ability to tolerate } \\
\text { or remove spinels } \\
\text { and crystals }\end{array}$} & \multirow{2}{*}{$\begin{array}{l}\text { Ability to operate } \\
\text { within a broad } \\
\text { temperature region }\end{array}$} & \multirow{2}{*}{$\begin{array}{l}\text { Ability to control and } \\
\text { predict process } \\
\text { conditions }\end{array}$} & \multirow{2}{*}{$\begin{array}{l}\text { High reliability and } \\
\text { maintainability }\end{array}$} & \multirow{2}{*}{$\begin{array}{l}\text { Ability to } \\
\text { monitor } \\
\text { process }\end{array}$} & \multirow{2}{*}{$\begin{array}{l}\text { Ability to operate at } \\
\text { increased rates above } \\
\text { the design basis }\end{array}$} & \multicolumn{2}{|c|}{ WTP impacts } & \multirow{2}{*}{$\begin{array}{l}\text { Development and deployment } \\
\text { requirements }\end{array}$} & \multirow{2}{*}{$\begin{array}{l}\text { Potential major } \\
\text { problems }\end{array}$} \\
\hline & & & & & & & Facility & Operational & & \\
\hline & & & & & & & & $\begin{array}{l}\text { needed to meet melter } \\
\text { disposal requirements. } \\
\text { Melter disposal volumes } \\
\text { comparable to baseline }\end{array}$ & $\begin{array}{l}\text { suspension secondary phases TBD. } \\
\text { Number required and service life } \\
\text { TBD. } \\
\text { Estimate } \$ \text { M and } 2 \text { years. }\end{array}$ & \\
\hline $\begin{array}{l}\text { Advanced Cold } \\
\text { Crucible Melter (w/ } \\
\text { mixing) }\end{array}$ & $\begin{array}{l}\text { Mechanical mixers } \\
\text { combined with small } \\
\text { melter holdup } \\
\text { volume and routine } \\
\text { use of adrain located } \\
\text { in the side wall near } \\
\text { the floor. }\end{array}$ & $\begin{array}{l}\text { Operation over a range } \\
\text { from } 1000^{\circ} \mathrm{C} \text { in excess } \\
\text { of } 1500^{\circ} \mathrm{C} \text { possible. } \\
\text { However, service life } \\
\text { of mixing systems at } \\
\text { elevated temperatures } \\
\text { requires evaluation } \\
\text { and demonstration. }\end{array}$ & 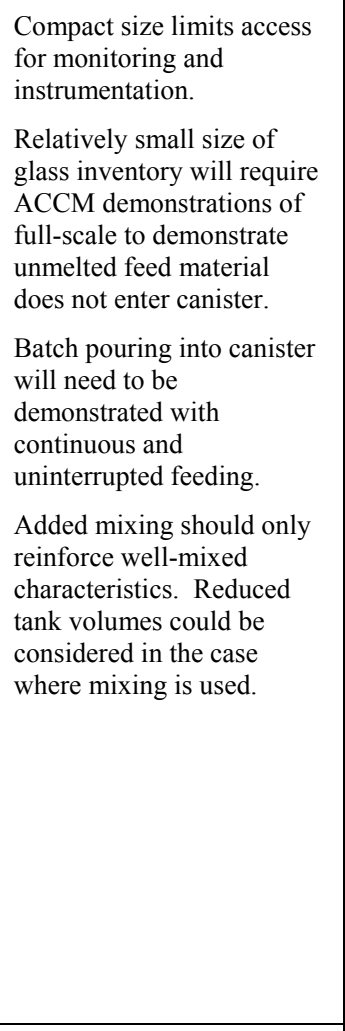 & \begin{tabular}{|l|} 
Mixer reliability and \\
maintainability are TBD. \\
France CEA has stated \\
excellent reliability and mixer \\
is designed to be replaceable. \\
Melter reliability feeding \\
alkaline slurry and \\
maintainability are TBD. \\
Remote replacement of metal \\
melter component should be a \\
straightforward operation.
\end{tabular} & $\begin{array}{l}\text { Compact size } \\
\text { limits access for } \\
\text { monitoring and } \\
\text { instrumentation }\end{array}$ & $\begin{array}{l}\text { Dependant on the } \\
\text { number and type of } \\
\text { mixers used. Possible } \\
\text { to operate with } \\
\text { nominal mixing and } \\
\text { more vigorous mixing } \\
\text { to "catch hup". } \\
\text { However, the degree to } \\
\text { which this will be } \\
\text { successful must be } \\
\text { demonstrated. }\end{array}$ & 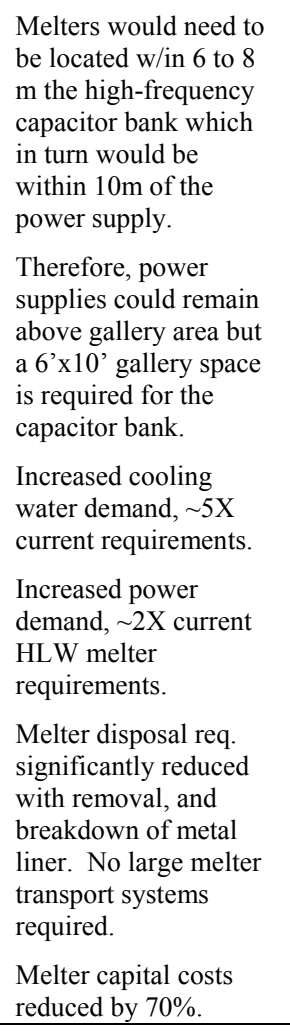 & $\begin{array}{l}\text { Melter replacement } \\
\text { frequency decreased at } \\
\text { least by } 2 \text { X factor. } \\
\text { Melter replacement } \\
\text { reduced from } 3 \text { months } \\
\text { to } 1 \text { month. } \\
\text { Annual } 1 \text { wk outage to } \\
\text { replace mechanical pour } \\
\text { device. } \\
\text { Effectively no solid } \\
\text { waste from melter } \\
\text { disposal. } \\
\text { End-of-life draining and } \\
\text { removal ol loose glass } \\
\text { released from cooled } \\
\text { walls hhould be } \\
\text { sufficient to receive a } \\
\text { non-HLW ruling (WIR) } \\
\text { without further efforts. } \\
\text { Melter risposal volumes } \\
\text { significantly less than } \\
\text { baseline. }\end{array}$ & \begin{tabular}{|l} 
Demonstration of long term \\
operations reliability, abilitit to pour \\
glass w/ feed interruptions, \\
mechanical mixer reliability, \\
corrosion resistance of mixers and \\
head space required. \\
Estimate $\$ 25 \mathrm{M}$ and 3 years. \\
\end{tabular} & $\begin{array}{l}\text { Skull design may } \\
\text { requiresecondary } \\
\text { enclosure as a } \\
\text { consideration of } \\
\text { safety concerns for } \\
\text { loss of glass accident } \\
\text { (however, this was } \\
\text { not judged a } \\
\text { significant outcome } \\
\text { event for the current } \\
\text { melter design with } \\
\text { significantly larger } \\
\text { glass volumes. }\end{array}$ \\
\hline $\begin{array}{l}\text { High-temperature } \\
\mathrm{JHCM} \text { w/mixing }\end{array}$ & $\begin{array}{l}\text { Forced mixing, e.g., } \\
\text { mechanical mixers or } \\
\text { bubblers. }\end{array}$ & $\begin{array}{l}\text { Operation over a range } \\
\text { from } 10000^{\circ} \mathrm{C} \text { in excess } \\
\text { of } 1500^{\circ} \mathrm{C} \text { possible. } \\
\text { However, service life } \\
\text { of mixing systems at } \\
\text { elevated temperatures } \\
\text { requires evaluation } \\
\text { and demonstration. }\end{array}$ & $\begin{array}{l}\text { JHCM operation is well } \\
\text { documented and } \\
\text { understood. } \\
\text { Relatively large size } \\
\text { permits good access for } \\
\text { monitoring and control. } \\
\text { Added mixing should only } \\
\text { reinforce well-mixed } \\
\text { characteristicics. Reduced } \\
\text { tank volumes could be } \\
\text { considered in the case } \\
\text { where mixing is used. }\end{array}$ & $\begin{array}{l}\text { Basic JHCM components are } \\
\text { reliable. However, reliability } \\
\text { and maintainabilily of } \\
\text { electrode materials are TBD } \\
\text { given lack of suitable } \\
\text { candidate materials and } \\
\text { development to date. Also, } \\
\text { revfactory life at elevatated } \\
\text { temperatures should be } \\
\text { determined to support design. } \\
\text { Mixer reliability and } \\
\text { maintainability are TBD. } \\
\text { France CCA has stated } \\
\text { excellent reliability and mixer } \\
\text { is designed to be replaceable. }\end{array}$ & $\begin{array}{l}\text { Relatively large } \\
\text { size permits } \\
\text { good access for } \\
\text { monitoring and } \\
\text { control. }\end{array}$ & $\begin{array}{l}\text { Dependant on the } \\
\text { number and type of } \\
\text { mixers used. Possible } \\
\text { to operate with } \\
\text { nominal mixing and } \\
\text { more vigorous mixing } \\
\text { to "catch up". } \\
\text { However, the degree to } \\
\text { which this will be } \\
\text { successful must be } \\
\text { demonstrated. }\end{array}$ & $\begin{array}{l}\text { Remote electrode } \\
\text { maintenance to feed } \\
\text { electrodes and attach } \\
\text { new sections. } \\
\text { Changes to cell } \\
\text { include electrode } \\
\text { segment transfer } \\
\text { capabililyt into cell } \\
\text { from gallery glove box } \\
\text { or similar, assume } \\
\text { electrode services are } \\
\text { on top of melter lid. } \\
\text { Remote service and } \\
\text { maintenance of mixing } \\
\text { systems do not change } \\
\text { WTP design. }\end{array}$ & $\begin{array}{l}\text { Assume electrodes must } \\
\text { be maintained w/o } \\
\text { feeding and no power - } \\
\text { add } 2 \text { days of melter } \\
\text { outage per month. } \\
25 \% \text { increased volatility } \\
\text { of Cs and Tc } \\
25 \% \text { higher replacement } \\
\text { rate of overflow heaters, } \\
\text { thermowells, etc. } \\
\text { Melter failures due to } \\
\text { noble metal or spinel } \\
\text { settling may be be } \\
\text { significantly reduced. } \\
\text { Assume } 25 \% \text { increased }\end{array}$ & 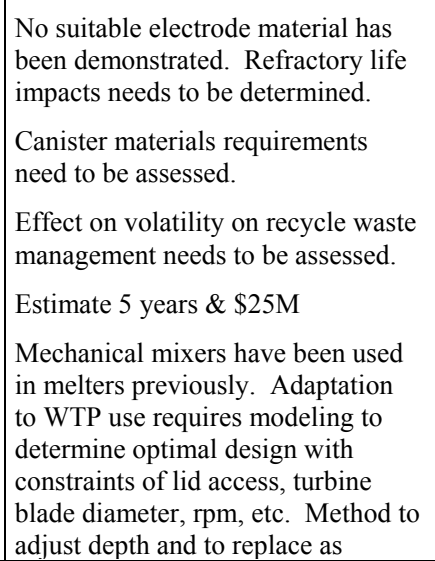 & 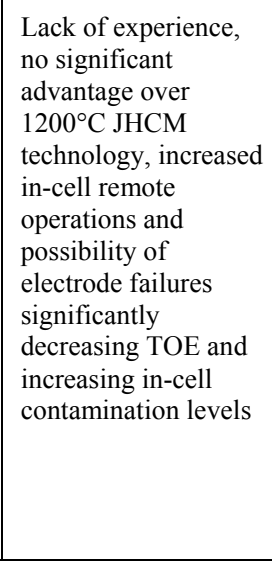 \\
\hline
\end{tabular}




\begin{tabular}{|c|c|c|c|c|c|c|c|c|c|c|}
\hline \multirow{2}{*}{$\begin{array}{l}\text { Technology or } \\
\text { Technology } \\
\text { Feature }\end{array}$} & \multirow{2}{*}{$\begin{array}{l}\text { Ability to tolerate } \\
\text { or remove spinels } \\
\text { and crystals }\end{array}$} & \multirow{2}{*}{$\begin{array}{l}\text { Ability to operate } \\
\text { within a broad } \\
\text { temperature region }\end{array}$} & \multirow{2}{*}{$\begin{array}{l}\text { Ability to control and } \\
\text { predict process } \\
\text { conditions }\end{array}$} & \multirow{2}{*}{$\begin{array}{l}\text { High reliability and } \\
\text { maintainability }\end{array}$} & \multirow{2}{*}{$\begin{array}{l}\text { Ability to } \\
\text { monitor } \\
\text { process }\end{array}$} & \multirow{2}{*}{$\begin{array}{l}\text { Ability to operate at } \\
\text { increased ratesabovove } \\
\text { the design basis }\end{array}$} & \multicolumn{2}{|c|}{ WTP impacts } & \multirow{2}{*}{$\begin{array}{l}\text { Development and deployment } \\
\text { requirements }\end{array}$} & \multirow{2}{*}{$\begin{array}{l}\text { Potential major } \\
\text { problems }\end{array}$} \\
\hline & & & & & & & Facility & Operational & & \\
\hline & & & & & & & $\begin{array}{l}\text { Smaller melter } \\
\text { footprint } 25 \%(6 \\
\text { MT/d) to } 50 \%(1.5 \\
\text { MT/d) provides more } \\
\text { area for other cell } \\
\text { activities \& smaller } \\
\text { failed melter transfer } \\
\text { boxes. } \\
\text { For mechanical mixers } \\
\text { addede electrical and } \\
\text { water cooling required } \\
\text { (considered minor). }\end{array}$ & $\begin{array}{l}\text { melter life. } \\
\text { Potential for periods of } \\
\text { higher throughput to } \\
\text { "cath up", therefore, } \\
\text { TOE could increase. } \\
\text { Mechanical mixers } \\
\text { should provide eriods } \\
\text { of longer operation } \\
\text { compared to current } \\
\text { bubbler designs, } \\
\text { therefore, TOE could } \\
\text { increase. } \\
\text { Melter disposal volumes } \\
\text { comparable to baseline. }\end{array}$ & $\begin{array}{l}\text { necessary w/o significiant cell } \\
\text { contamination required. } \\
\text { Estimate } \$ 5 \mathrm{M} \text { and } 2 \text { years. } \\
\text { Use of gas bubbling has been } \\
\text { extensively tested by Duratek. } \\
\text { Viability to suspend and maintain in } \\
\text { suspension secondary phases TBD. } \\
\text { Number required and service life } \\
\text { TBD. } \\
\text { Estimate } \$ 5 \mathrm{M} \text { and } 2 \text { years. }\end{array}$ & \\
\hline $\begin{array}{l}\text { Add pre-drying } \\
\text { operation }\end{array}$ & N/A & $\mathrm{N} / \mathrm{A}$ & $\begin{array}{l}\text { Process has no hold up so } \\
\text { operation should be } \\
\text { acceptable pending } \\
\text { sufficieint demonstration. } \\
\text { DOE evaluation of drying } \\
\text { technologies in the 1970's } \\
\text { with alkaline HLW } \\
\text { surrogates was not } \\
\text { conclusively successful. } \\
\text { Therefore, significant } \\
\text { development and } \\
\text { demonstration should be } \\
\text { assumed. }\end{array}$ & $\begin{array}{l}\text { Reliability and } \\
\text { maintainability of drying } \\
\text { systems that produce a paste- } \\
\text { like substance requires } \\
\text { significant develoment, } \\
\text { adaptation and demonstration. } \\
\text { Method to reliably distribute } \\
\text { feed over majoirity of the } \\
\text { melter glass surface is also } \\
\text { required. }\end{array}$ & $\begin{array}{l}\text { Simple process } \\
\text { should provide } \\
\text { adequate } \\
\text { monitoring } \\
\text { capabilities. }\end{array}$ & $\begin{array}{l}\text { Equipment can be } \\
\text { sized with a turndown } \\
\text { capability and operate } \\
\text { at less than maximum } \\
\text { without impacting } \\
\text { performance. }\end{array}$ & $\begin{array}{l}\text { Some added in-cell } \\
\text { equipment but } 30 \% \text { to } \\
50 \% \text { reduction in } \\
\text { melter size or number } \\
\text { of units. Current cell } \\
\text { design appears } \\
\text { adequate. } \\
\text { Assume capital costs } \\
\text { for pre-dryer are off- } \\
\text { set by reduced melter } \\
\text { capital costs. }\end{array}$ & $\begin{array}{l}\text { Added complexity and } \\
\text { unit operations. } \\
\text { However, catch-up } \\
\text { capability increased if } \\
\text { feed preparation can } \\
\text { support increased } \\
\text { operations. } \\
\text { Assume this is the case. } \\
\text { Therefore, assume no } \\
\text { impact on TOE. }\end{array}$ & $\begin{array}{l}\text { Develop and demonstrate dryer } \\
\text { technology that is compatible with } \\
\text { alkaline slurries. } \\
\text { Determine best glass additive } \\
\text { blending/addition method. } \\
\text { Demonstrate integrated operations } \\
\text { with melter. } \\
\text { Demonstrate melter feeding } \\
\text { adequate to cover glass surface. } \\
\text { Estimate } \$ 15 \mathrm{M} \text { and three years. } \\
\text { Estimate } 2 \text { year delay in HL vit. cell } \\
\text { process equipment and services } \\
\text { design. }\end{array}$ & $\begin{array}{l}\text { Ability to adjust WTP } \\
\text { design \& construction } \\
\text { schedules to prevent } \\
\text { impacts unlikely. } \\
\text { Therefore, ORP and } \\
\text { other stakeholder } \\
\text { concurrence on } \\
\text { slippage required. }\end{array}$ \\
\hline $\begin{array}{l}\text { Add pre-calciner } \\
\text { operation }\end{array}$ & $\mathrm{N} / \mathrm{A}$ & $\mathrm{N} / \mathrm{A}$ & $\begin{array}{l}\text { Process has no hold up so } \\
\text { operation should be } \\
\text { acceptable pending } \\
\text { sufficient demonstration. } \\
\text { DOE evaluation of } \\
\text { calcination technologies in } \\
\text { the } 1970 \text { 's with alkaline } \\
\text { HLW surrogates } \\
\text { detererined that signifificant } \\
\text { additions of "bulking" } \\
\text { materials was required to } \\
\text { help assure material would } \\
\text { flow from reactors. In } \\
\text { addition, testing as not } \\
\text { conclusively successfull. } \\
\text { Therefore, significicant } \\
\text { development and } \\
\text { demonstration is assumed. }\end{array}$ & $\begin{array}{l}\text { Reliability and } \\
\text { maintainability of calciner } \\
\text { systems requires significant } \\
\text { development, adaptation and } \\
\text { demonststation. } \\
\text { Method to reliably distribute } \\
\text { calcine over majority of the } \\
\text { melter glass surface is also } \\
\text { required. }\end{array}$ & $\begin{array}{l}\text { Simple process } \\
\text { should provide } \\
\text { adequate } \\
\text { monitoring } \\
\text { capabilities. }\end{array}$ & $\begin{array}{l}\text { Equipment can be } \\
\text { sized with a turndown } \\
\text { capability and operate } \\
\text { at less than maximum } \\
\text { without impacting } \\
\text { performance. }\end{array}$ & $\begin{array}{l}\text { Some added in-cell } \\
\text { equipment but } 30 \% \text { to } \\
50 \% \text { reduction in } \\
\text { melter size or number } \\
\text { of units. Current cell } \\
\text { design appears } \\
\text { adequate. } \\
\text { Assume capital costs } \\
\text { for pre-calciner are } \\
\text { off-set by reduced } \\
\text { melter capital costs. }\end{array}$ & $\begin{array}{l}\text { Added complexity and } \\
\text { unit operations. } \\
\text { However, catch-up } \\
\text { capability increased if } \\
\text { feed preparation can } \\
\text { support increased } \\
\text { operations. } \\
\text { Assume this is the case. } \\
\text { Therefore, assume no } \\
\text { impact on TOE. }\end{array}$ & $\begin{array}{l}\text { Develop and demonstrate calciner } \\
\text { technology that is compatible with } \\
\text { alkaline slurries. } \\
\text { Determine best glass additive } \\
\text { blending/addition method. } \\
\text { Demonstrate integrated operations } \\
\text { with melter. } \\
\text { Demonstrate melter feeding } \\
\text { adequate to cover glass surface. } \\
\text { Estimate } \$ 15 \mathrm{M} \text { and three years. } \\
\text { Estimate } 2 \text { year delay in HL vit. cell } \\
\text { process equipment and services } \\
\text { design. }\end{array}$ & $\begin{array}{l}\text { Ability to adjust WTP } \\
\text { design \& construction } \\
\text { schedules to prevent } \\
\text { impacts unlikely. } \\
\text { Therefore, ORP and } \\
\text { other stakeholder } \\
\text { concurrence on } \\
\text { slippage required. }\end{array}$ \\
\hline $\begin{array}{l}\text { Secondary heat } \\
\text { boosting }\end{array}$ & $\mathrm{N} / \mathrm{A}$ & $\begin{array}{l}\text { Maximum } \\
\text { temperature, } \\
\text { temperature range of } \\
\text { efficient operation, }\end{array}$ & $\begin{array}{l}\text { Control and monitoring of } \\
\text { boosting techniques should } \\
\text { present no technical issues; } \\
\text { with the exception that DC }\end{array}$ & $\begin{array}{l}\text { Reliability and } \\
\text { maintainability of boosting } \\
\text { systems will vary with type. } \\
\text { DC arc and plasma torch }\end{array}$ & $\begin{array}{l}\text { Secondary heat } \\
\text { boosting } \\
\text { systems should } \\
\text { provide }\end{array}$ & $\begin{array}{l}\text { Possible for DC arc } \\
\text { and plasma torch } \\
\text { systems. } \\
\text { The maximum amount }\end{array}$ & $\begin{array}{l}\text { Additional power } \\
\text { supplies and services } \\
\text { run into cell. Assume } \\
\text { \$1M added to design }\end{array}$ & $\begin{array}{l}\text { Assume no affect on } \\
\text { TOE based on DWPF } \\
\text { experience. }\end{array}$ & $\begin{array}{l}\text { For other than radiant heating } \\
\text { technology it is required to develop } \\
\text { and demonstrate the technology. } \\
\text { Estimate \$15M and three years. }\end{array}$ & $\begin{array}{l}\text { For other than radiant } \\
\text { heating technology; } \\
\text { abbilit to adjust WTP } \\
\text { design \& construction }\end{array}$ \\
\hline
\end{tabular}




\begin{tabular}{|c|c|c|c|c|c|c|c|c|c|c|}
\hline \multirow{2}{*}{$\begin{array}{l}\text { Technology or } \\
\text { Technology } \\
\text { Feature }\end{array}$} & \multirow{2}{*}{$\begin{array}{l}\text { Ability to tolerate } \\
\text { or remove spinels } \\
\text { and crystals }\end{array}$} & \multirow{2}{*}{$\begin{array}{l}\text { Ability to operate } \\
\text { within a broad } \\
\text { temperature region }\end{array}$} & \multirow{2}{*}{$\begin{array}{l}\text { Ability to control and } \\
\text { predict process } \\
\text { conditions }\end{array}$} & \multirow{2}{*}{$\begin{array}{l}\text { High reliability and } \\
\text { maintainability }\end{array}$} & \multirow{2}{*}{$\begin{array}{l}\text { Ability to } \\
\text { monitor } \\
\text { process }\end{array}$} & \multirow{2}{*}{$\begin{array}{l}\text { Ability to operate at } \\
\text { increased ratesabovove } \\
\text { the design basis }\end{array}$} & \multicolumn{2}{|c|}{ WTP impacts } & \multirow{2}{*}{$\begin{array}{l}\text { Development and deployment } \\
\text { requirements }\end{array}$} & \multirow{2}{*}{$\begin{array}{l}\text { Potential major } \\
\text { problems }\end{array}$} \\
\hline & & & & & & & Facility & Operational & & \\
\hline & & $\begin{array}{l}\text { and total power input } \\
\text { will vary with } \\
\text { boosting technique, } \\
\text { melter size and } \\
\text { materials of } \\
\text { construction. }\end{array}$ & $\begin{array}{l}\text { arc electrodes. Operated in } \\
\text { the submerged mode } \\
\text { requires constant } \\
\text { monitoring and adjustment } \\
\text { of electrode position. }\end{array}$ & $\begin{array}{l}\text { systems must be designed to } \\
\text { be replaceable. } \\
\text { Radiant heater systems have } \\
\text { been demonstrated to be } \\
\text { reliable. Maintainable } \\
\text { designs are possible if } \\
\text { sufficient access is available } \\
\text { and maintenance equipment is } \\
\text { developed. }\end{array}$ & $\begin{array}{l}\text { adequate } \\
\text { monitoring } \\
\text { capabilities. } \\
\text { Uncertainty } \\
\text { about ability to } \\
\text { monitor out of } \\
\text { normal } \\
\text { conditions and } \\
\text { predict when } \\
\text { failure is } \\
\text { imminent. }\end{array}$ & $\begin{array}{l}\text { of power input from } \\
\text { radiant heater systems } \\
\text { typically is limitited by } \\
\text { melter plenum space } \\
\text { availability. } \\
\text { Therefore, it is not } \\
\text { expected that this is } \\
\text { relevant for this } \\
\text { technique. Limited } \\
\text { turndown would be } \\
\text { possible in any case, } \\
\text { however, sheath } \\
\text { material temperature } \\
\text { must be kept above a } \\
\text { minimum temperature } \\
\text { to prevent excessive } \\
\text { corrosion. }\end{array}$ & $\begin{array}{l}\text { and equipment costs. } \\
\text { Reduction in melter } \\
\text { size for IHCM (no- } \\
\text { mixing) technology } \\
\text { assume } 20 \% \text { cost } \\
\text { reduction. } \\
\text { Increase in off-gas } \\
\text { temperature from } \\
\text { melter will require } \\
\text { increased cooling, } \\
\text { including steam } \\
\text { service not currently } \\
\text { available. }\end{array}$ & & $\begin{array}{l}\text { Estimate } 2 \text { year delay in } \mathrm{HL} \text { vit. cell } \\
\text { process equipment and services } \\
\text { design. }\end{array}$ & $\begin{array}{l}\text { schedules to prevent } \\
\text { impacts unlikely. } \\
\text { Therefore, ORP and } \\
\text { other stakeholder } \\
\text { concurrence on } \\
\text { slippage required. }\end{array}$ \\
\hline
\end{tabular}




\subsection{Recommendations}

Assessments were made of immobilization technologies with the potential of exceeding Hanford WTP objectives of $6 \mathrm{MTG} / \mathrm{d}$. Literature, patent, and vendor sources were investigated to attempt to identify promising new technologies capable of significantly reducing glass volume and total plant operating time. This review covered the period from 1995, when a similar but much more detailed review was performed, to the present. No new and compelling technologies were identified as emerging technologies. The focus of this study was therefore focused on previously developed technologies and technology features that could be applied to best meet the WTP needs. Based on the results of this review, the following recommendations are made.

- Vitrification technologies that can process waste forms with levels of spinels and other crystalline phases will provide the best potential to achieve the maximum waste loading and subsequent reduction in the numbers of canisters produced.

- Considering the large variation in Hanford HLW tank contents and that retrieval and pretreatment activities will affect the ultimate composition of the HLW feed, the vitrification technology and facility capabilities should be as robust and flexible as possible. Therefore, melters and melter features that provide the largest range of temperature, mixing, and draining should be developed.

- The two technologies considered as having the highest potential capability, the induction-heated, cold-wall melter and the high-shear, low-temperature Stir Melter ${ }^{\circledR}$, were recommended in the 1995 study for DOE development and demonstration. They are still considered to have high probabilities for success and should be evaluated.

- The standard U.S. Joule-heated ceramic melter technology, combined with actively cooled electrodes, glass tank mixing, and bottom draining features, is considered to be a strong technical solution to WTP needs.

- The use of secondary heat boosting is not recommended as a strong option equivalent to mixing, bottom draining and increased glass temperature features.

- Effects of melter replacement on facility requirements, costs, and impacts to the HLW vitrification facility operating efficiency are not considered well defined or quantified. Therefore, strong consideration has been given in the study to technologies that generate minimal waste and can be replaced quickly. 
This page left blank intentionally. 


\subsection{Cost Benefit Analysis}

\subsection{Introduction}

\subsubsection{Task Scope}

The purpose of this section is to provide insight into the cost sensitivity of DOE's HLW vitrification programs to the future use of alternate waste forms and melter technologies. Hanford's HLW Vitrification Program provides the context for assessing the potential costs and benefits of the alternatives examined in this study. Hanford's tank waste constitutes a significant fraction of the total governmentmanaged nuclear waste destined for disposal in the geologic repository. Hanford's program also provides an appropriate focus because cost sensitivity analyses can be performed on the current baseline cost estimate, which is based on approximately $\$ 300 \mathrm{M}$ of design work carried out over the past three years. Hanford's plans also call for start of construction within two years and future expansion of the HLW vitrification facility in about 2017. Many of the alternatives under consideration in this study would be potential candidates for the expanded facility.

Two other DOE sites are, or will become, generators of HLW glass for repository disposal, but are not included explicitly in this analysis. SRS has operated the DWPF since 1996 and is producing vitrified HLW for repository disposal. Enhancements to DWPF are likely to be relatively small, incremental changes that are not likely to have significant impacts on total glass volume or cost. INEEL also has HLW destined for the repository. The assessment of the costs and benefits of the alternatives was not extended to INEEL waste at this time because there was insufficient time to complete the analysis and INEEL does not yet have a baseline plan or cost estimate that is sufficiently well developed to support the sensitivity analyses performed in this section.

This task uses the results of each of the other tasks to develop estimates of the cost impacts from the full range of alternatives that have been examined in this study. No new estimates for storage or repository disposal costs have been generated. Rather prior estimates are used to bound sensitivity analyses.

\subsubsection{Summary of Approach}

The approach consists of the following steps:

- Assemble prior estimates of the costs related to vitrification, storage, and disposal of HLW, especially the sensitivity of such costs to changes in the volume of HLW and/or the number of canisters produced.

- Characterize the range of uncertainties and technology alternatives resulting from other tasks and develop a parametric cost model for estimating the potential cost impact of those alternatives for Hanford's WTP.

- Evaluate operational cost impacts of key uncertainties and technology performance assumptions.

- Analyze potential cost impacts of melter and waste form alternatives. 


\subsubsection{Overview of Prior Cost Analyses}

This section summarizes estimates from prior studies of the incremental cost of producing one more, or one fewer, HLW canister. Three components of cost are considered: 1) HLW vitrification operations at the Hanford Site; 2) interim costs for storing HLW canisters at the Hanford Site; and 3) disposal costs at the geologic repository (Yucca Mountain, Nevada). Table 7.1 shows the cost estimates from several recent studies. The remainder of this section discusses those estimates, their underlying assumptions, and the relevance to the current study.

Table 7.1 Previous Differential Cost Estimates for HLW Glass (Incremental Cost per Canister)

\begin{tabular}{|c|c|c|c|c|c|c|c|}
\hline \multirow{2}{*}{\multicolumn{2}{|c|}{ Function }} & \multicolumn{2}{|c|}{$\begin{array}{c}\text { SAIC }^{19} \\
(1999 \$)\end{array}$} & \multicolumn{2}{|c|}{$\begin{array}{c}\text { ORP }^{20} \\
(1999 \$)\end{array}$} & \multicolumn{2}{|c|}{$\begin{array}{c}\text { TWRS EIS } \\
\text { (1994 \$) }\end{array}$} \\
\hline & & Low & High & Low & High & Low & High \\
\hline \multicolumn{2}{|r|}{ Vitrification Operations } & $\$ 0^{1}$ & $\$ 476 \mathrm{~K}^{2}$ & $\$ 0^{1}$ & $\$ 321 \mathrm{~K}^{3}$ & & \\
\hline & Interim Storage & $\$ 76 \mathrm{~K}^{4}$ & $\$ 151 \mathrm{~K}^{5}$ & $\$ 21 \mathrm{~K}^{6}$ & $\$ 151 \mathrm{~K}^{5}$ & & \\
\hline \multicolumn{2}{|r|}{ Repository Disposal } & $\$ 380 \mathrm{~K}^{7}$ & $\$ 420 \mathrm{~K}^{7}$ & $\$ 103 K^{8}$ & $\$ 120 \mathrm{~K}^{8}$ & $\begin{array}{l}\$ 196 K^{9} \\
\$ 100 K^{10}\end{array}$ & $\begin{array}{l}\$ 394 K^{9} \\
\$ 150 K^{10}\end{array}$ \\
\hline \multicolumn{8}{|c|}{ Notes: } \\
\hline 1 & \multicolumn{7}{|c|}{$\begin{array}{l}\text { Assumes length of production mission is independent of the amount of glass; therefore, no incremental savings from } \\
\text { making fewer canisters. }\end{array}$} \\
\hline 2 & \multicolumn{7}{|c|}{ Based on DWPF average annual operations cost $(\$ 119 \mathrm{M})$ and production rate (250 canisters/year). } \\
\hline 3 & \multicolumn{7}{|c|}{ Same as (2) except higher nominal throughput assumed. } \\
\hline 4 & \multicolumn{7}{|c|}{ Based on average cost to store Hanford IHLW with an early shipping period from 2010 to 2033 . } \\
\hline 5 & \multicolumn{7}{|c|}{ Based on average cost to store all Hanford IHLW in CSB (expanded) with a late shipping scenario. } \\
\hline 6 & \multicolumn{7}{|c|}{$\begin{array}{l}\text { Assumes early shipments to repository eliminate need for additional modules. Incremental savings results from shortened } \\
\text { storage life ( } \$ 15.9 \mathrm{M} / \mathrm{yr} / 750 \text { canisters/yr shipped to repository). }\end{array}$} \\
\hline 7 & \multicolumn{7}{|c|}{ Based on current repository cost allocation scheme. } \\
\hline 8 & \multicolumn{7}{|c|}{$\begin{array}{l}\text { Based on incremental cost to repository of more/fewer HLW canisters, not the cost allocation formula. (Change in } \\
\text { repository cost/\# of canisters.) }\end{array}$} \\
\hline 9 & \multirow{2}{*}{\multicolumn{7}{|c|}{$\begin{array}{l}\text { Based on cost allocation formula (except } \$ 394 \mathrm{~K} \text { ), case was outside the range of the allocation model's validity. } \\
\text { Same as }(8) \text {, incremental cost to repository. }\end{array}$}} \\
\hline 10 & & & & & & & \\
\hline
\end{tabular}

\subsubsection{Vitrification Operations}

Two principal sources of savings in vitrification operations are considered in this study: (1) increased waste loading, which reduces the number of canisters and thus the required length of the vitrification mission, and (2) increased throughput or operating efficiency, which also shortens the length of the mission.

\footnotetext{
${ }^{19}$ Memorandum from A. Papadopoulos, H. Sutter, and A. Elliff, entitled "Estimated Per Canister, Differential Costs of Production, Storage, and Disposal of Hanford High Level Waste Glass,"dated June 22, 2000.

${ }^{20}$ Memorandum from N. Brown, Office of River Protection, to T. Pietrok, Tanks Focus Area, dated June 22, 2000.

${ }^{21}$ Memorandum from TRW Environmental Safety Systems, Inc., entitled "Cost Estimate Report on Disposal Costs for Tank Waste Remediation System Alternatives," dated June 28, 1996.
} 
Science Applications International Corporation (SAIC) developed estimates for incremental vitrification operations cost (per canister) based on average annual production rate and cost for DWPF. A baseline cost estimate for Hanford's WTP was not available at that time. The upper bound estimate is based on the assumption that fewer canisters correspond to shorter operating period and thus cost savings. The percanister cost is derived from DWFP's average annual production cost $(\$ 119 \mathrm{M})$ and its target production rate (250 canisters/year). By contrast, ORP used the same approach but assumed that at $75 \%$ operating efficiency, DWPF would have a higher nominal throughput rate (and thus a slightly lower incremental cost per canister).

The lower range of the estimate for incremental operations cost $(\$ 0 /$ canister) would result if production length is not a function of number of canisters (i.e., if some other factor, such as feed delivery or lack of funding constrains throughput). Then fewer canisters would have essentially no impact on cost (annual operations costs are roughly constant and independent of the number of canisters that are produced).

The ORP upper-bound estimate is updated through the analysis reported later in this section to reflect the current cost estimates and operating assumptions for the WTP. Because the WTP throughput during the Phase 2 portion of its mission is likely to be much higher than current DWPF throughput, it is anticipated that the upper-bound estimate for incremental cost savings will be lower than seen for DWPF.

Prior estimates of incremental production costs indicate that these costs are a function of the amount of glass produced (number of canisters), but real savings would only be realized if melter throughput is not constrained by other portions of the system (e.g., feed delivery or funding).

\subsubsection{Interim Storage}

The second row of Table 7.1 shows estimates for incremental interim storage costs for immobilized HLW canisters based on storage in Hanford's Canister Storage Building (CSB). Hanford's current plan is to use Vaults 2 and 3 of the existing CSB to store the first 880 canisters of HLW (the other two vaults will store $\mathrm{SNF}$ ). If more storage space is needed, then additional storage modules would be built. These are assumed to be similar to the CSB, holding 2640 canisters each and costing $\$ 343 \mathrm{M}$ to construct (average incremental cost of $\$ 130 \mathrm{~K} /$ canister). In addition, the CSB costs $\$ 15.9 \mathrm{M} /$ year to operate and the shipping rate to the repository is assumed to be 750 canisters per year. Therefore, the incremental savings to CSB operation of making one fewer canister would be $\$ 21 \mathrm{~K}$ ( $\$ 15.9 \mathrm{M} / 750$ canisters) (i.e., an incremental reduction in the operating period).

Figure 7.1 illustrates these two bounding cases. If shipments to the repository can be made on a schedule and at a rate to eliminate incremental additions to onsite storage facilities, then a total savings ranging from $\$ 1.5 \mathrm{~B}$ to $\$ 2.0 \mathrm{~B}$ could be achieved. Approximately 600 canisters are expected to be produced during Phase 1 operations (through 2017). All of these canisters could be stored in the existing CSB. If shipments to the repository begin about the end of Phase 1 and proceed at a rate of up to 750 canisters per year, there would be no need to add storage modules beyond the existing capacity. Production rates during the balance of the mission would be about 400 to 800 canisters per year, depending on the expansion scenario that is assumed.

A key finding from these studies is that the incremental cost of more/fewer HLW canisters is highly dependent on the timing and rate of shipments to the repository. If shipments are delayed indefinitely, then a maximum number of storage modules would be required. However, if shipments occur early and at sufficient rate, then additional storage modules can be avoided. In the latter situation, the incremental savings from producing one fewer canister is simply the avoided CSB operations cost that results from earlier shutdown of the facility. In the former case, however, additional incremental savings would occur 
only if sufficiently fewer canisters were produced to obviate the need to construct an additional CSB module.

\subsubsection{Repository Disposal}

Repository costs are allocated to both commercial and DOE defense waste generators using a cost allocation formula (Federal Register Notice, 52 FR 31508, August 20, 1987). The intent of this allocation formula is to ensure that the full costs of the repository program are covered by waste generators and to ensure that there is an equitable sharing of costs between commercial and defense users of the repository (i.e., neither group subsidizes the other). Three types of costs are considered: 1) assignable direct costs; 2) assignable common variable costs (largely driven by piece count and disposal area required); and 3) common unassigned costs. The latter costs are allocated in the same proportion as the assignable costs combined. Therefore, a reduction in the number of HLW packages would reduce the assignable costs and would also reduce the allocation of the unassigned costs, thus amplifying the direct effect of a reduction in piece count.

DOE-RW prepares an annual report of the repository program's expected costs (TRW ESS, Inc. 1999). This report is produced to ensure that overall repository program costs are fully recovered by civilian and defense waste generators. It also calculates the share of costs to be covered by both categories of generators for each of several scenarios for repository deployment. For planning purposes, it is assumed that Hanford will generate between 12000 and 14000 canisters of HLW (4.5-meter-long canisters). The total number of canisters of vitrified defense HLW is expected to be about 20000 . Defense waste generators are also expected to contribute 2570 metric tons heavy metal of defense spent nuclear fuel. The total share of repository costs to be borne by defense waste generators is $28.2 \%$ of $\$ 51.570 \mathrm{~B}$ (\$14.54B). The repository cost allocation formula can provide estimates of changes in the defense/civilian shares of costs for various scenarios.

For relatively small changes from the current numbers of canisters, the allocation formula can provide reasonable estimates of incremental savings/costs. However, for variations that are significantly different from the current set of assumptions, the formula may not be valid. For the results shown in Table 7.1, the high end of the range for SAIC and the TWRS EIS were established by the allocation formula. The low end of the ranges for ORP and TWRS EIS were calculated based on just the incremental cost to the repository (i.e., change in repository cost due to canister count change divided by change in number of canister). This latter approach yields a much smaller estimate of the incremental cost/savings from more/fewer canisters.

In summary, these prior studies clearly indicate that there would be a real savings to the repository from producing less glass (fewer canisters), but the magnitude of the savings is dependent on assumptions about how costs would be shared between defense and civilian waste generators. The magnitude of savings would also be dependent on other factors (that are far beyond the scope of this study), such as how relatively cooler HLW canisters would be mixed with relatively hotter SNF packages to achieve a more uniform heat loading within the repository. 


\section{Total Incremental Interim Storage Cost}

(Incremental to Current CSB; Late and Early Shipments to Repository)

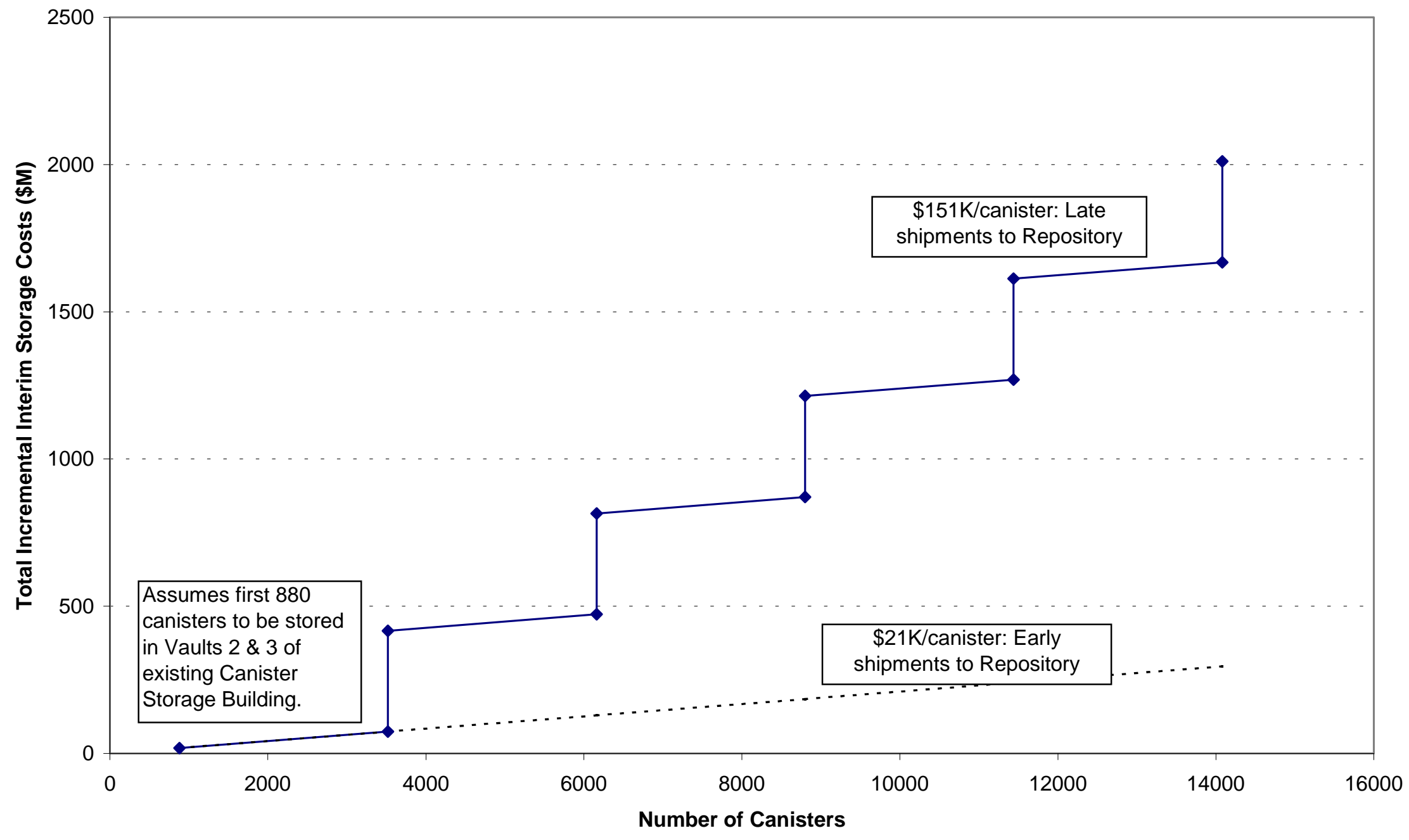

Figure 7.1 Increment HLW Storage Cost for Two Repository Shipment Scenarios 


\subsection{Hanford Waste Treatment Plant Cost and Performance Baseline}

This section describes the reference plans for treatment of Hanford's radioactive tank waste. Hanford's plans for vitrifying the HLW portion of the tank waste set the reference point for evaluating the potential costs and benefits of alternate waste forms and advanced melter technologies. This evaluation focuses on the impacts that could result during the operating period that follows an initial eight- to 10 -year period of operations, Phase 1. This latter phase of operations was called Phase 2 during ORP's effort to privatize the design, construction, and operation of the WTP, but this phase is now called "balance of mission." These terms may be used interchangeably in this section.

\subsubsection{Baseline Assumptions for Hanford's WTP}

In May 2000, ORP canceled its approach to privatize the design, construction, and operation of the WTP when it terminated its contract with BNFL. The contract with BNFL called for private investment to design and construct the WTP with a return on the private investment recovered during an initial 10-year operating period, Phase 1 . The intent was to treat $10 \%$ of the tank waste by mass and $25 \%$ of the tank waste by activity by 2018 , as required by the TPA. This remains the intent with ORP's current approach to acquiring the WTP.

Following the termination of the BNFL Contract, ORP held a competitive procurement to resume design activities for the WTP this time using a government-owned, contractor-operated framework. In December 2000, a contract was awarded to BNI. The current contract includes essentially the same technical specifications as the prior contract, but is limited to design, construction, and limited operations during a commissioning period. A subsequent contract will be developed for full-scale operation of the WTP. The current contract calls for start of hot operations (in support of commissioning) by December 2007 , and turnover of the fully operational facility to an operations contractor following a two- to threeyear commissioning period.

Figure 7.2 depicts the WTP's provisions for future expansion. The HLW vitrification facility will have two cells, only one of which will operate initially (1.5 MT Glass/day). Subsequently, a second melter can be added and both melters could be upgraded (to 3.0 MTG/day) through performance enhancements (e.g., mixing) to achieve a combined design capacity of $6.0 \mathrm{MTG} /$ day (termed the $1 \mathrm{X}$ to $4 \mathrm{X}$ expansion scenario). LAW vitrification would be expanded by adding a second facility with an additional 30 MTG/day capacity yielding a total of 60 MTG/day. Pretreatment would have sufficient initial capacity to feed both expanded versions of HLW and LAW vitrification. If these expansions occur by 2017, the full tank waste treatment mission could be completed by about 2044 .

The TPA also requires DOE to complete retrieval and treatment of all tank waste (assuming 99\% retrieval) by 2028. To meet this requirement, ORP would need to implement the HLW and LAW expansions as described above, and build a second fully expanded plant (i.e., a complete duplication of the capability shown in Figure 7.2). Under this expansion scenario (the $1 \mathrm{X}$ to $8 \mathrm{X}$ expansion scenario), the mission could be completed by about 2032, assuming that tank waste retrieval can keep pace with the expanded treatment capacity. Both expansion scenarios were examined for purposes of assessing the potential impact of alternate melter technologies and waste forms. 


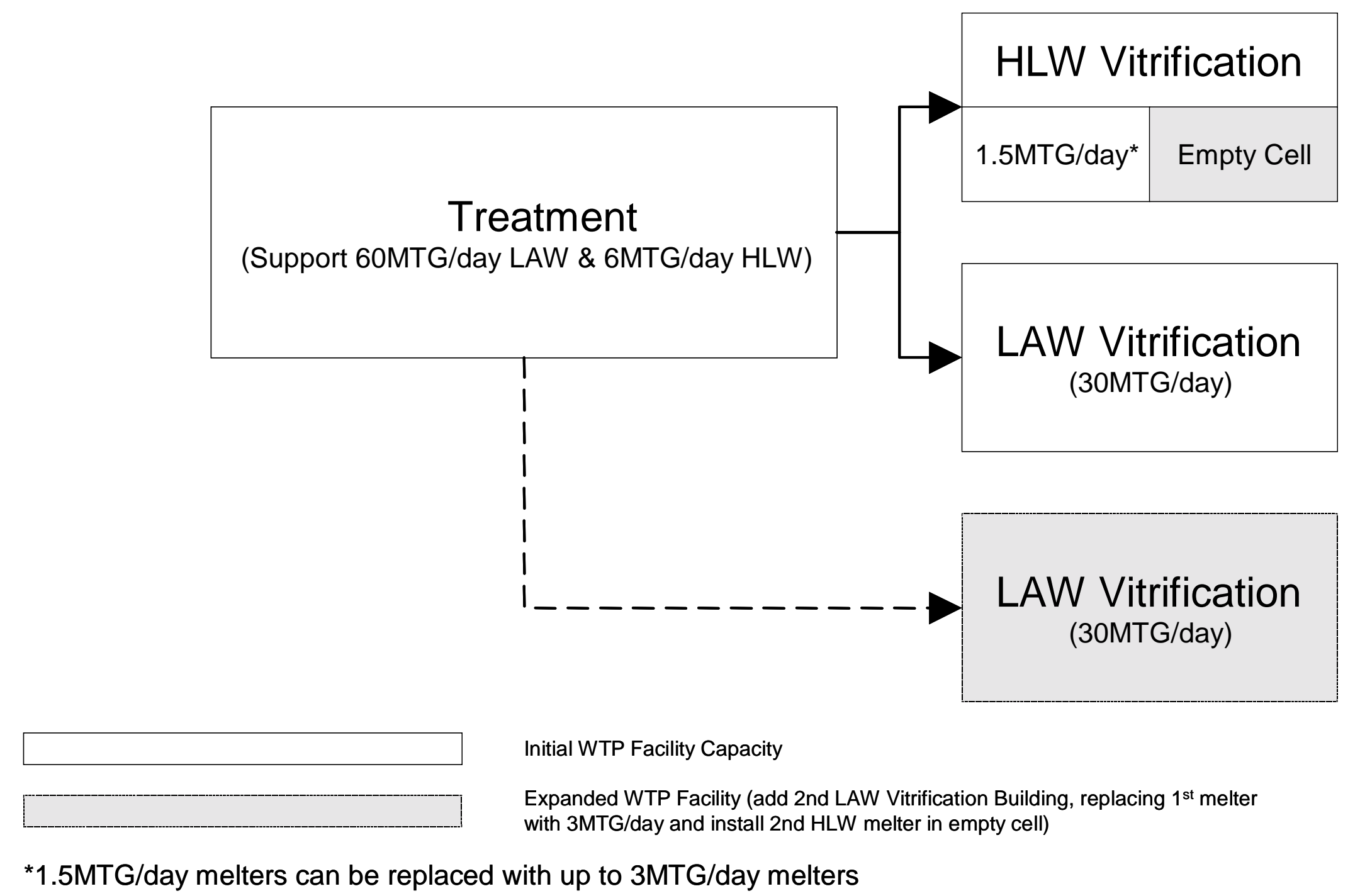

Figure 7.2 Waste Treatment Plant Expansion Options 


\subsubsection{Basis for Estimating WTP Cost and Performance}

Several sources of cost data exist for generating an estimate for Hanford's baseline tank waste treatment scenarios. For this study, these cost estimates are derived from the BNFL design that was prepared as part of the privatization contract (see ORP website for listing of design documentation and also see the Contract for technical specifications). An independent cost estimate was prepared for the government's use in evaluating BNFL's cost proposal. This independent estimate is known as the Government Fair Cost Estimate (GFCE). ${ }^{22}$ This estimate was also used to develop the Target Cost estimate for the recompetition of the WTP Contract.

The GFCE, however, only covers the Phase 1 period of operations. To provide a basis of estimate for post-Phase 1 processing, ORP has developed a Life-Cycle Model (LCM) that includes all tank wasterelated operations including tank waste storage, characterization, retrieval, treatment, product storage and disposal. For the treatment portion of the model, GFCE costs were extrapolated to provide a basis for the increased capacities of post-Phase 1 plants. In addition, the LCM apportions common costs including management and some engineering and support services to the primary constituent facilities of the WTP (i.e., pretreatment, LAW vitrification, and HLW vitrification). Thus, costs reported in this study for the HLW vitrification facility include both direct costs and a portion of these common costs. Therefore, when assessing the impact of a shortened operating period for HLW vitrification, there will also be a savings in these common costs.

\subsubsection{Description and Summary of Design, Operational, and Cost Parameters}

Figure 7.3 shows the relationships among the input parameters and the calculated parameters of a parametric model that was developed for estimating the operational cost impacts of variations in melter and waste form characteristics. Shaded items indicated input variables (variables that are changed to establish sensitivity cases) and unshaded items are calculated values that show the impact of changes in input parameters.

A set of sensitivity cases was constructed to provide a range of outcomes that are representative of the potential impacts of alternate waste forms and melter technologies. This work did not generate specific cost estimates for each waste form and melter technology. Rather, sensitivity cases were constructed to examine the cost impacts of variations in key parameters such as TOE, melter replacement cost, waste loading, melter life, etc. These variations were intended to span the range of likely performance from the alternatives included in this study. For example, some melter concepts are expected to have significantly longer lifetimes than the baseline Joule-heated ceramic melter. The impact of longer melter life was examined by varying the reference assumption. The result of these sensitivity studies, then, is an assessment of the operational cost variation (increase or decrease) due to a change in each key parameter. Table 7.3 summarizes the reference parameter values and the range of variation in those parameters that have been evaluated through sensitivity analysis.

As noted in Table 7.3, the ORP LCM was used to provide several key inputs to the analysis of operational cost variations. Table 7.4 contains a summary of relevant inputs to the LCM and its outputs for each of the two deployment scenarios. The primary output from the LCM was the steady-state operations cost during Phase 2. Two WTP expansion scenarios (1X to $4 \mathrm{X}$ and $1 \mathrm{X}$ to $8 \mathrm{X}$ ) were evaluated to provide bases from which sensitivity cases could be derived. For purposes of estimating Phase 2 operating cost impacts, these two scenarios yield nearly identical results. For the $8 \mathrm{X}$ case, the LCM contains two

\footnotetext{
${ }^{22}$ Report prepared by Informatics and Raytheon under subcontract to the Pacific Northwest National Laboratory: DeTienne, K.D. and Edmondson, A.D. (2000). "Government Fair Cost Estimate River Protection Project -Privatization Phase I, Part B." Not formally published.
} 
identical $6 \mathrm{MTG} /$ day HLW vitrification facilities and these are each identical to the single $6 \mathrm{MTG} /$ day facility in the $4 \mathrm{X}$ case. The $4 \mathrm{X}$ case runs twice as long as the $8 \mathrm{X}$ case but total (undiscounted) operations costs are identical in the two scenarios. Capital costs between the two scenarios will be quite different. 


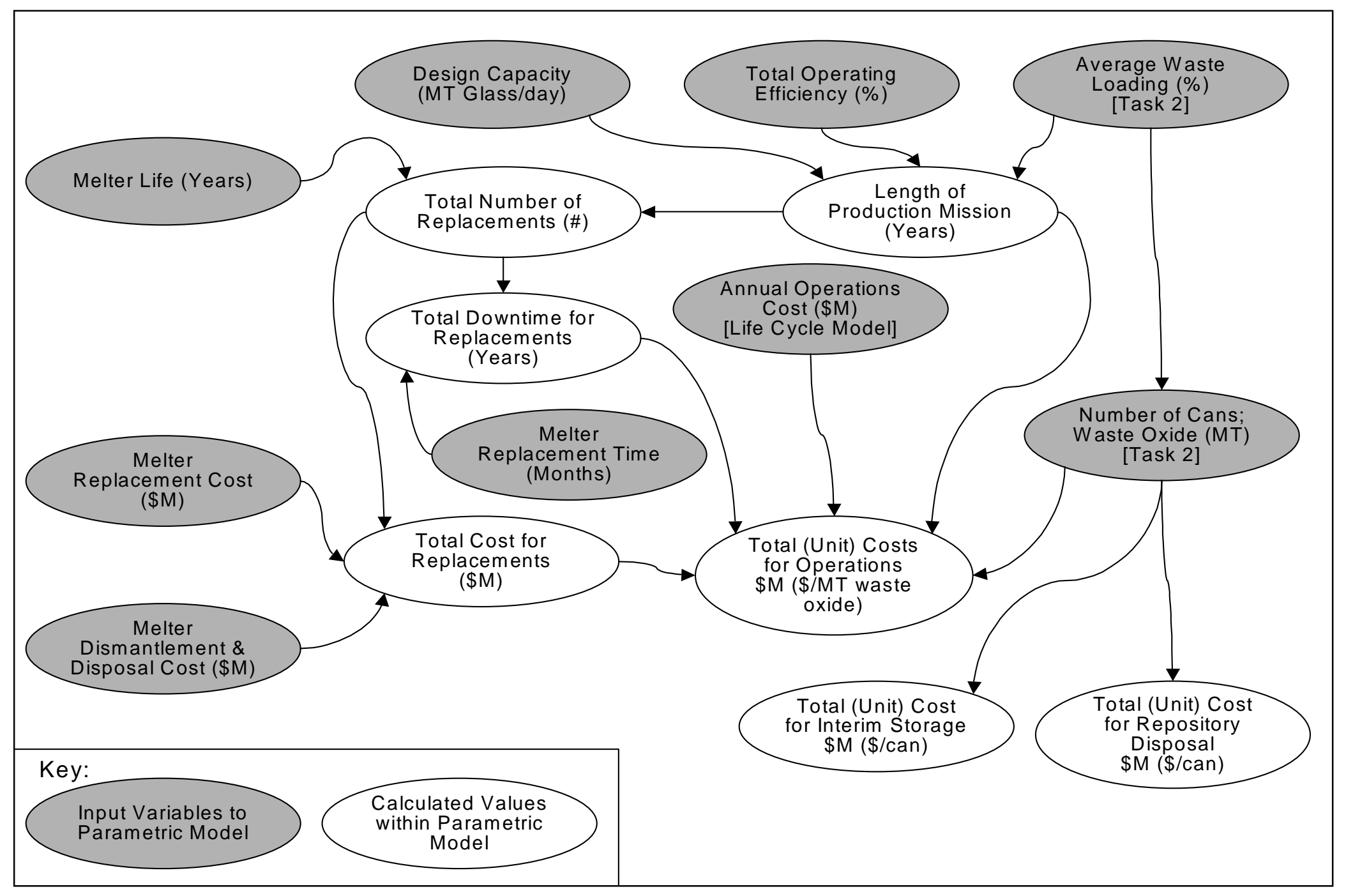

Figure 7.3. Relationships among Input and Calculated Parameters for the Operational Cost Parametric Model 
Table 7.3. Parameter Values for Operational Cost Sensitivity Analysis

\begin{tabular}{|c|c|c|c|}
\hline Parameter & Reference & Range of Values & Discussion \\
\hline $\begin{array}{l}\text { Melter Design } \\
\text { Capacity }\end{array}$ & 6.0 MTG/day & $\begin{array}{l}3.0 \mathrm{MTG} / \text { day to } \\
9.0 \mathrm{MTG} / \text { day }\end{array}$ & $\begin{array}{l}\text { Nominal Phase } 2 \text { capacity is assumed to be } 3.0 \mathrm{MTG} / \text { day } \\
\text { for each melter. This must be achieved in approximately } \\
\text { the same space as the initial } 1.5 \mathrm{MTG} / \text { day melter. The } \\
\text { current intent is to use mixing through the use of } \\
\text { bubblers. Past experience has shown variability in the } \\
\text { ability to achieve throughput rate compared to the design } \\
\text { capacity. }\end{array}$ \\
\hline TOE & $60 \%$ & $50 \%$ to $80 \%$ & $\begin{array}{l}\text { Includes downtime ( } 6.25 \%) \text { for melter replacement ( } 3 \\
\text { months every } 4 \text { years) }\end{array}$ \\
\hline $\begin{array}{l}\text { Waste Loading } \\
\text { (Glass Volume) }\end{array}$ & $31 \%$ & $\sim 26 \%$ to $\sim 56 \%$ & $\begin{array}{l}\text { Waste loading can be affected by melter characteristics } \\
\text { (e.g., temperature, crystal tolerance through bottom } \\
\text { draining, etc.) and by variations in pretreatment steps and } \\
\text { glass formulations. }\end{array}$ \\
\hline $\begin{array}{l}\text { Expected Melter } \\
\text { Life }\end{array}$ & 4 years & 2 to 16 years & $\begin{array}{l}\text { Melter life is dependent on many factors with some } \\
\text { concepts purported to be less susceptible to failure (e.g., } \\
\text { induction heated melters). DWPF, however, has operated } \\
\text { since March } 1996 \text { and has exceeded the expected life ( } 2 \\
\text { years) of the initial melter with no indication of } \\
\text { diminished performance. }\end{array}$ \\
\hline $\begin{array}{l}\text { Melter Replacement } \\
\text { Time }\end{array}$ & 3 months & 1 to 5 months & $\begin{array}{l}\text { This parameter indicates the amount of downtime } \\
\text { required to replace a melter in case of failure. }\end{array}$ \\
\hline $\begin{array}{l}\text { Melter Replacement } \\
\text { Cost }\end{array}$ & $\$ 6 \mathrm{M}$ & $\$ 6 \mathrm{M}$ to $\$ 12 \mathrm{M}$ & $\begin{array}{l}\text { The initial value for this parameter is estimated by the } \\
\text { GFCE based on Duratek design information. A factor of } \\
\text { two increase in cost is assumed to encompass possible } \\
\text { uncertainty in the true cost of the reference melter and to } \\
\text { reflect the potential cost of alternative melter concepts. }\end{array}$ \\
\hline $\begin{array}{l}\text { Melter } \\
\text { Dismantlement \& } \\
\text { Disposal Cost }\end{array}$ & $\$ 2 \mathrm{M}$ & $\$ 2 \mathrm{M}$ to $\$ 20 \mathrm{M}$ & $\begin{array}{l}\text { The reference value is a "placeholder" value contained in } \\
\text { ORP's baseline cost estimate. This estimate reflects the } \\
\text { assumption/requirement that the WTP operations } \\
\text { contractor must provide overpacked failed melters that } \\
\text { meet the Hanford Site Solid Waste Acceptance Criteria } \\
\text { for on-site burial as low-level waste. }\end{array}$ \\
\hline Canister Size & $\begin{array}{l}4.5 \text { meters by } \\
0.68 \text { meters }\end{array}$ & No alternatives & $\begin{array}{l}\text { This canister holds } 1.15 \mathrm{~m}^{3} \text { of glass, which weighs about } \\
3.1 \mathrm{MT} \text {. An alternative larger canister ( } 1.68 \mathrm{~m} \text { diameter) } \\
\text { was considered in a series of analytical questions posed to } \\
\text { DOE-RW, but no separate cost analysis was performed } \\
\text { for use of this canister at the vitrification facility. }\end{array}$ \\
\hline \multicolumn{4}{|c|}{$\begin{array}{l}\text { Notes: } \\
\text { (1) Discussions with ORP design staff indicate that it would be very difficult to accommodate this large canister at the WTP. } \\
\text { Significant changes would be required in the WTP handling systems. Moreover, the interim storage facility is not designed to } \\
\text { handle this system, nor are the repository-handling systems. Use of the large canister would also limit the repository's ability to } \\
\text { blend waste packages of varying heat load. }\end{array}$} \\
\hline
\end{tabular}


Table 7.4. Selected Inputs and Outputs from ORP LCM Cases

\begin{tabular}{|c|c|c|c|}
\hline Parameter & "1X - 4X" Case & "1X - 8X" Case & Discussion \\
\hline \multicolumn{4}{|c|}{ Inputs } \\
\hline $\begin{array}{l}\text { Phase } 2 \text { Plant Hot Start } \\
\text { Date }\end{array}$ & July 2016 & May 2017 & $\begin{array}{l}\text { Double capacity scenario requires } \\
\text { longer construction time, but does } \\
\text { not affect steady-state operating } \\
\text { cost. }\end{array}$ \\
\hline $\begin{array}{l}\text { Total Operating } \\
\text { Efficiency ( } \% \text { of Design } \\
\text { Capacity) }\end{array}$ & $60 \%$ & $60 \%$ & \\
\hline $\begin{array}{l}\text { Design Capacity } \\
\text { (MTG/day) }\end{array}$ & 6.0 & 12.0 & \\
\hline Operations End Date & January 2044 & September 2031 & $\begin{array}{l}\text { Operating period covers the end of } \\
\text { primary vitrification of HLW. If } \\
\text { LAW vitrification extends longer, } \\
\text { then some HLW vitrification } \\
\text { would be needed for a longer } \\
\text { period to handle separated } \\
\text { constituents from LAW } \\
\text { pretreatment. }\end{array}$ \\
\hline $\begin{array}{l}\text { Waste Loading in Glass } \\
\text { (Mass \% waste oxides) }\end{array}$ & 29.0 & 29.0 & $\begin{array}{l}\text { Nominal amount assumed by the } \\
\text { LCM }\end{array}$ \\
\hline \multicolumn{4}{|c|}{ Outputs } \\
\hline \# of HLW Canisters & 12,479 & 12,479 & $\begin{array}{l}\text { Total mission including Phase } 1 \\
(\sim 600)\end{array}$ \\
\hline $\begin{array}{l}\text { Years of HLW } \\
\text { Production }\end{array}$ & 27.5 years & 14.25 & $\begin{array}{l}\text { Does not include residual } \\
\text { processing of HLW as noted } \\
\text { above. }\end{array}$ \\
\hline $\begin{array}{l}\text { Total HLW Operations } \\
\text { Cost during Phase } 2 \\
\text { Production Period }(\$ M)\end{array}$ & $\$ 1,764 \mathrm{M}$ & $\$ 1,701 \mathrm{M}$ & $\begin{array}{l}\text { Only includes operating costs } \\
\text { during steady-state Phase } 2 \\
\text { operations. }\end{array}$ \\
\hline $\begin{array}{l}\text { Average Annual Cost } \\
\text { for Phase } 2 \text { Operations } \\
(\$ \mathrm{M} / \mathrm{yr})\end{array}$ & $\$ 54 \mathrm{M}$ & $\$ 118 \mathrm{M}$ & Key input to parametric analysis \\
\hline
\end{tabular}

\subsection{Analysis Results for WTP Operations}

This section summarizes potential cost impacts from variations in parameters that could be affected by alternate melter technologies and/or alternate waste forms. All results are reported relative to the current ORP baseline as modeled by the GFCE and the ORP LCM.

Figure 7.4 illustrates the relationships among key system parameters and their cost impacts. The primary attribute used in this study to compare the relative merits of alternatives is HLW glass volume. Glass volume (or mass) is a critical determinant of cost. Vitrification operations cost is largely a function of the mass of glass produced, while storage and disposal costs are principally driven by the number of HLW canisters produced. Other attributes include research and development issues and overall feasibility or likelihood of success. Some investment will be needed to make any of the alternatives viable. Even with research and development investment, however, some alternatives will face significant obstacles to successful adoption. 


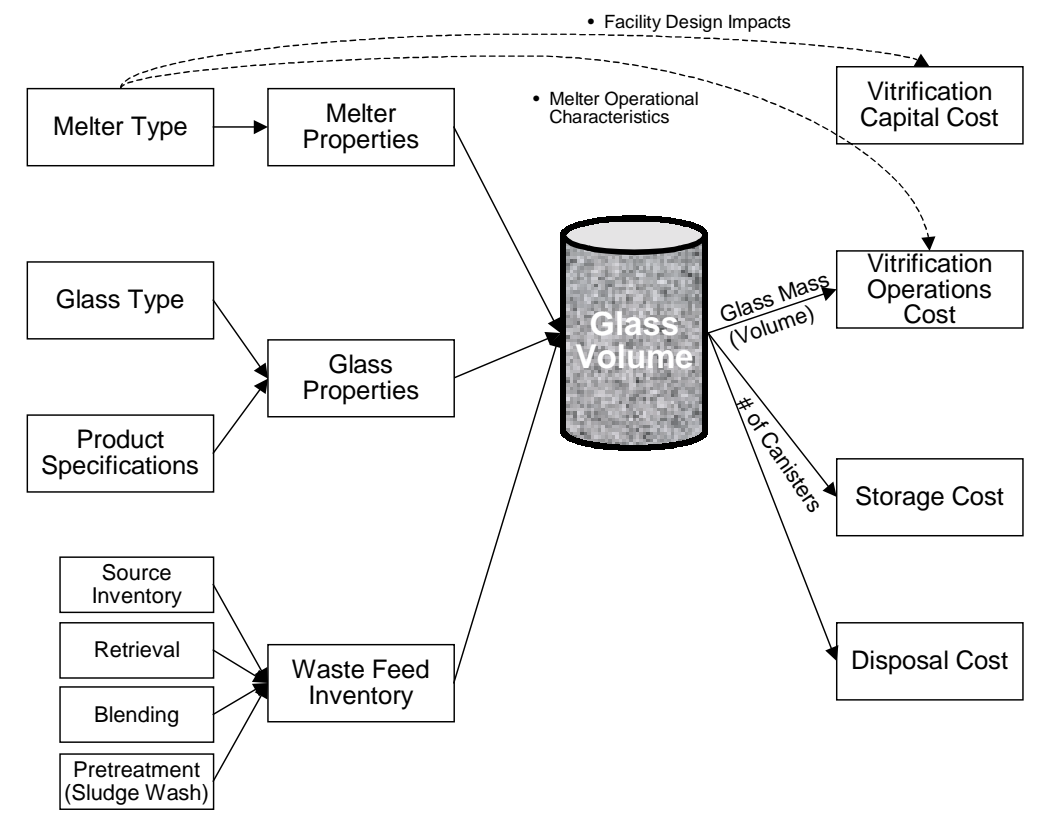

\section{Figure 7.4. System Parameters for HLW Melter Analysis}

Figure 7.5 shows the relationships among three key variables: design capacity, average waste loading, and years of operation required to complete the Balance of the Mission (Phase 2, 90\% mass). The WTP is being designed to have a total operating life of 40 years. Assuming Phase 1 lasts about ten years, there would 30 years of available plant life to complete the mission. As shown in this figure, the current baseline plan (1X - 4X scenario) would be able to finish the mission within the 30 -year time period assuming the reference $30 \%$ waste loading and $6 \mathrm{MTG} /$ day and $60 \%$ TOE. Higher waste loadings could provide a means to accomplish the mission earlier and greater installed capacity (or higher TOE) could also lead to earlier mission completion. The years of operation is the primary cost driver for vitrification operations. Total operating cost is essentially a linear function of the number of years of operation.

Figure 7.6 summarizes the glass volume projections from Task 2 and compares those projections to prior estimates for Hanford's expected quantity of immobilized HLW. All results from Task 2 have been increased by $10 \%$ to provide a more realistic basis for comparison to prior estimates. This adjustment results from two factors: 1) the effect of incidental blending within clusters (which understates the variability of some key constituents and would not occur with actual feed batches); and 2) possible suboptimization of glass formulations, which would likely occur during actual plant operation.

Figure 7.6 shows that there are two "reference cases" from which to evaluate cost. The first is the current "ORP Baseline" (the second bar), 12700 canisters. The second reference case is the "Study Reference" that is defined by Case 1 from Task 2, about 9300 canisters. The Study Reference produces a very substantial $(\sim 25 \%)$ reduction in the expected number of canisters, which results from higher waste loading that could be achieved primarily from enhanced chromium leaching during pretreatment. 


\section{Years of Operation as a Function of Plant Throughput and Waste Loading}

(Balance of Mission only)

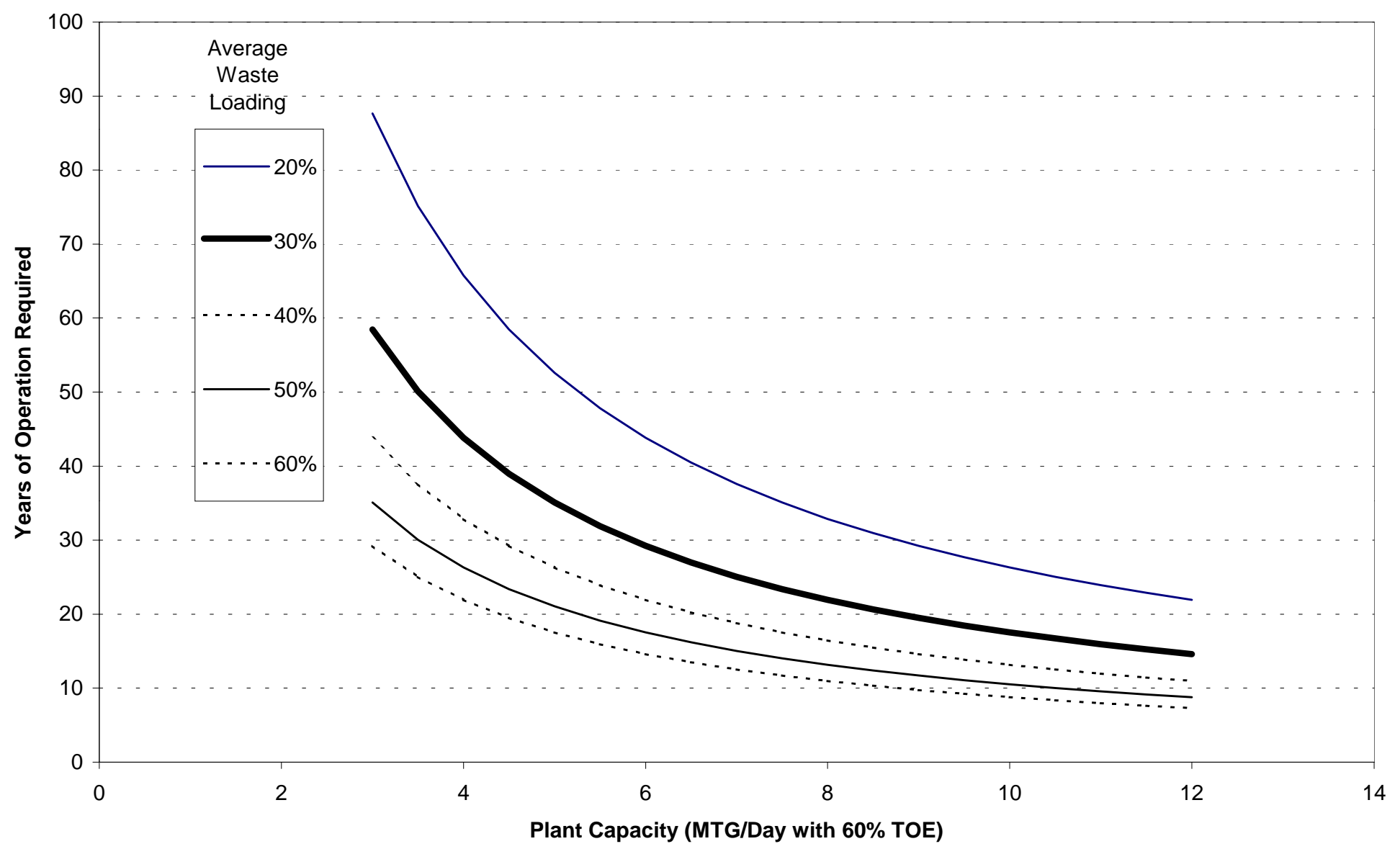

Figure 7.5. Years of Operation as a Function of Melter Capacity and Waste Loading 
Range of IHLW Canister and Mass Projections

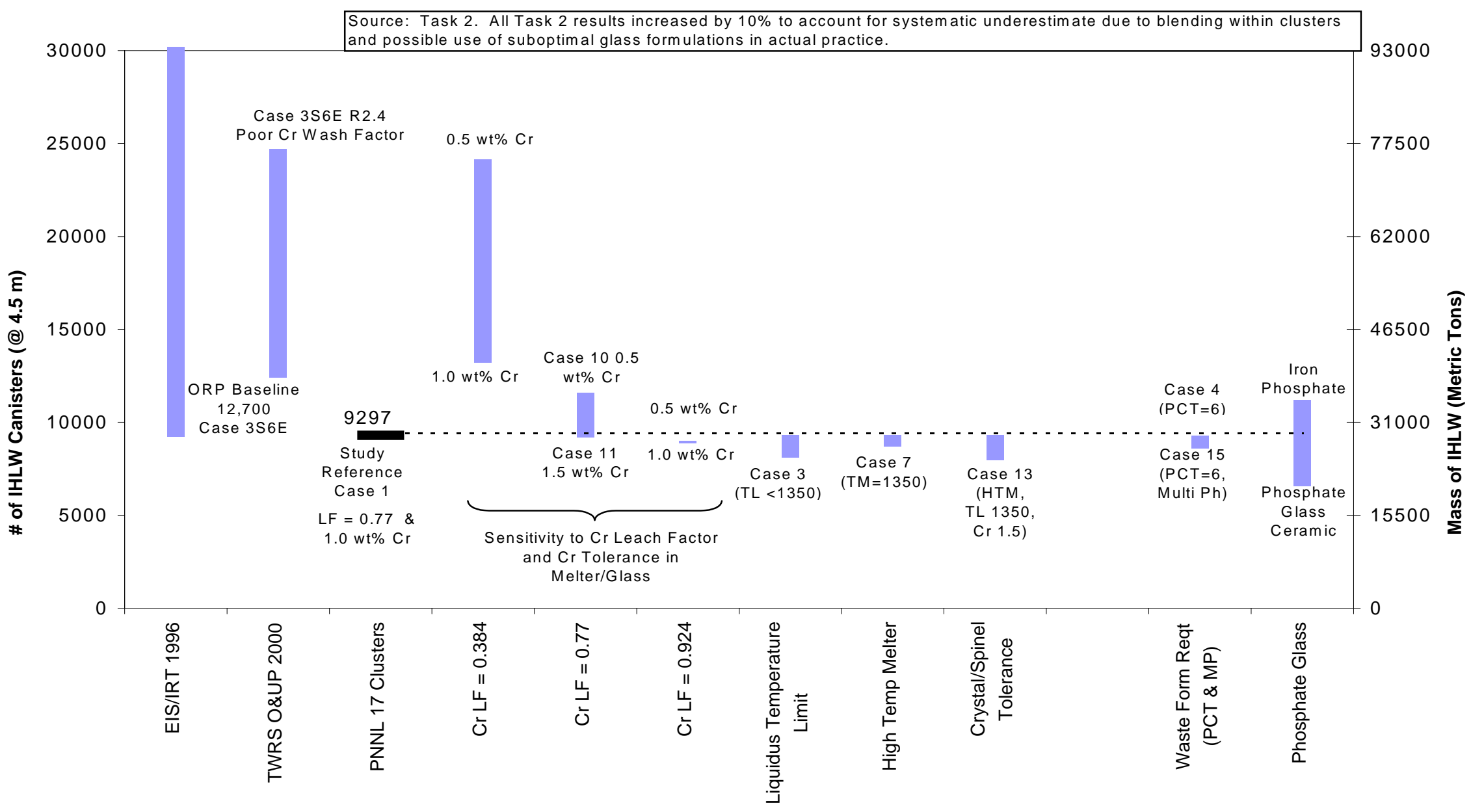

Figure 7.6. Variability of IHLW Canister Estimates 


\subsection{Impact of Uncertainties in Glass Volume Projections}

\subsubsection{Variability in Prior Glass Volume Estimates}

Prior glass volume estimates (TWRS EIS 1996 and Kirkbride 2000) included a wide range of estimates. For example, TWRS EIS considered pretreatment alternatives that varied from minimal to extensive separations and thus caused the observed range of variation. These estimates were refined and confirmed by an independent review team. The variation in cases produced by the most recent Tank Farm Contractor Operations and Utilization Plan (Kirkbride 2000) is due primarily to the assumptions regarding the nature and efficiency of sludge washing and its impact on removal of chromium. [As discussed in Task 2, the next update to the TFC O\&UP will use the same glass properties model that is used to support this study, and subsequent results are expected to be closer to those shown in the reference (Case 1) for this study.]

\subsubsection{Glass Volume Uncertainty due to Chromium Assumptions}

Figure 7.6 shows that glass volume is highly sensitive to the chromium content of the waste feed and the tolerance for chromium in either the melter itself or the final waste form. At this point in time, the chromium leach factor is quite uncertain. (See Section 4 of this report for a discussion of this issue.) The glass volume benefit that can result from chromium tolerant melters and/or waste forms is highly dependent on the leach factor. More information is needed to obtain an accurate prediction of the leach factor so that a more defensible estimate of the benefit of chromium tolerant melters can be determined.

\subsubsection{Variability of Glass Volume Estimates due to Melter Operational Assumptions}

The next three cases plotted in Figure 7.6 (Cases 3, 7, and 13) show the impact of melter operating parameters that can reflect the tolerance for crystal formation in the glass product. These parameters are the liquidus temperature, melter temperature, and allowed concentration of chromium in the product. The combined effect of relaxing these possible constraints, relative to the reference (Case 1) is to reduce the total number of canisters by $14.3 \%$.

\subsubsection{Variability Glass Volume Estimates due to Waste Form Assumptions}

Cases 4 and 15 shown in Figure 7.6 show the potential impact of relaxing two existing WASRD (1999) waste form requirements - PCT and the presence of multiphase glass (either crystalline or immiscible secondary glass phases, see the discussion in Section 4). The combined effect of relaxing these requirements is relatively small, a $7.7 \%$ reduction in the number of canisters produced.

\subsubsection{Variability Glass Volume Estimates due to Phosphate Waste Form Assumptions}

The final set of cases shown in Figure 7.6 illustrates the potential impact of the use of phosphate glass. A few waste clusters showed a reduction in glass volume with the use of phosphate glasses. Selective use of phosphate glasses would achieve a reduction from the study reference glass volume when applied to the most beneficial waste clusters only.

\subsection{Impact of Uncertainties in WTP Operational Costs}

Reduction in glass volume through higher waste loading is not the only way to gain cost savings in operations. Other possible means of achieving cost savings include increased melter throughput (e.g., 
through mixing or simply greater installed capacity), greater operating availability, longer lived melter and/or shorter replacement time, or reduced cost for replacement and disposal of failed melters. While none of these operational improvements will reduce canister production (and lead to storage and disposal cost savings), each of these factors can lead to significant cost savings in overall operations costs. This section examines the potential for operational savings and places those savings in comparison to savings due to increases in waste loading.

Figure 7.7 shows a set of sensitivity cases that vary a single parameter at a time. The parameters that are varied are shown along the $\mathrm{x}$-axis and the impact on operating cost is shown on the $\mathrm{y}$-axis. For all cases the operations cost includes only the cost of operations during the "balance of mission" or Phase 2 period. This is the period following initial treatment of the first $10 \%$ of the waste by mass. The two y-axis scales provide two distinct measures of the operations cost. The left-hand scale provides a normalized cost per metric ton of waste oxide ( $\sim 12200$ MT will remain to be processed following Phase 1). The right-hand axis shows the total cost for HLW vitrification operations during the balance of mission. The solid horizontal line indicates the ORP reference value as calculated by the ORP LCM for the scenario as defined (i.e., expansion of the initial plant in about 2017 to $6.0 \mathrm{MTG} /$ day and completion in about 2044). This scenario also assumes the current ORP baseline assumptions for retrieval, pretreatment, and glass formulation, which together result in about 12700 total HLW canisters.

\subsubsection{Impact of Waste Loading}

As noted earlier, the ORP reference case does not reflect the chromium leach factors, chromium solubility assumptions or the current Glass Properties Model that resulted in the Case 1 quantity of 8452 canisters (or 9297 when increased by 10\%). The potential reduction in operating cost due to Case 1 as shown in Figure 7.7 occurs because of the shortened time required to complete the HLW treatment mission. Case 1 results in an 8.25-year reduction in the mission length with a nominal savings of $\$ 54 \mathrm{M}$ per year in operating cost (as determined in the LCM). Additional savings would be incurred because the shorter operating period would require fewer melter replacements, less downtime for replacement, and reduced disposal cost. The second bar in Figure 7.7 represents direct results from the LCM for a \pm 5 percent variation in waste loading.

Phase 2 operations costs would be reduced by about $\$ 506 \mathrm{M}$ and the number of canisters reduced by 3703 (13 000 - 9297). Therefore, the incremental cost is about $\$ 140 \mathrm{~K} /$ canister. This estimate is lower than that derived from DWPF experience, but appears reasonable due to greater economies of scale with the larger throughput of the WTP during Phase 2 operations.

\subsubsection{Impact of Melter Design Capacity and Operating Efficiency}

The third and fourth bars shown on Figure 7.7 show the impact of variations in the achieved melter capacity during the balance of mission and TOE. The product of these two terms provides a measure of the average daily throughput for the HLW facility. Product of balance of mission capacity and TOE shows average daily throughput.

Achievable Phase 2 melter capacity is a very significant determinant of overall mission length and therefore total operating cost. As noted previously, Hanford's plan is to upgrade the $1.5 \mathrm{MTG} /$ day melter with a 3.0 MTG/day melter in the identical space. This upgrade will require some technology improvement to be accommodated within the existing melter cell space. As a point for comparison, if the two melters each only achieve the initial capacity of $1.5 \mathrm{MTG} /$ day, then the combined capacity of 3.0 MTG/day would necessitate a doubling of the Phase 2 mission length (from 27.5 years to 55 years), which would greatly exceed the planned life of the facility. This scenario would lead to a doubling of the operations cost even without constructing a replacement facility. 


\section{Sensitivity of HLW Operations Cost to Variation in Key Parameters}

(Balance of Mission Operations Cost Only; 4X Expansion Scenario)

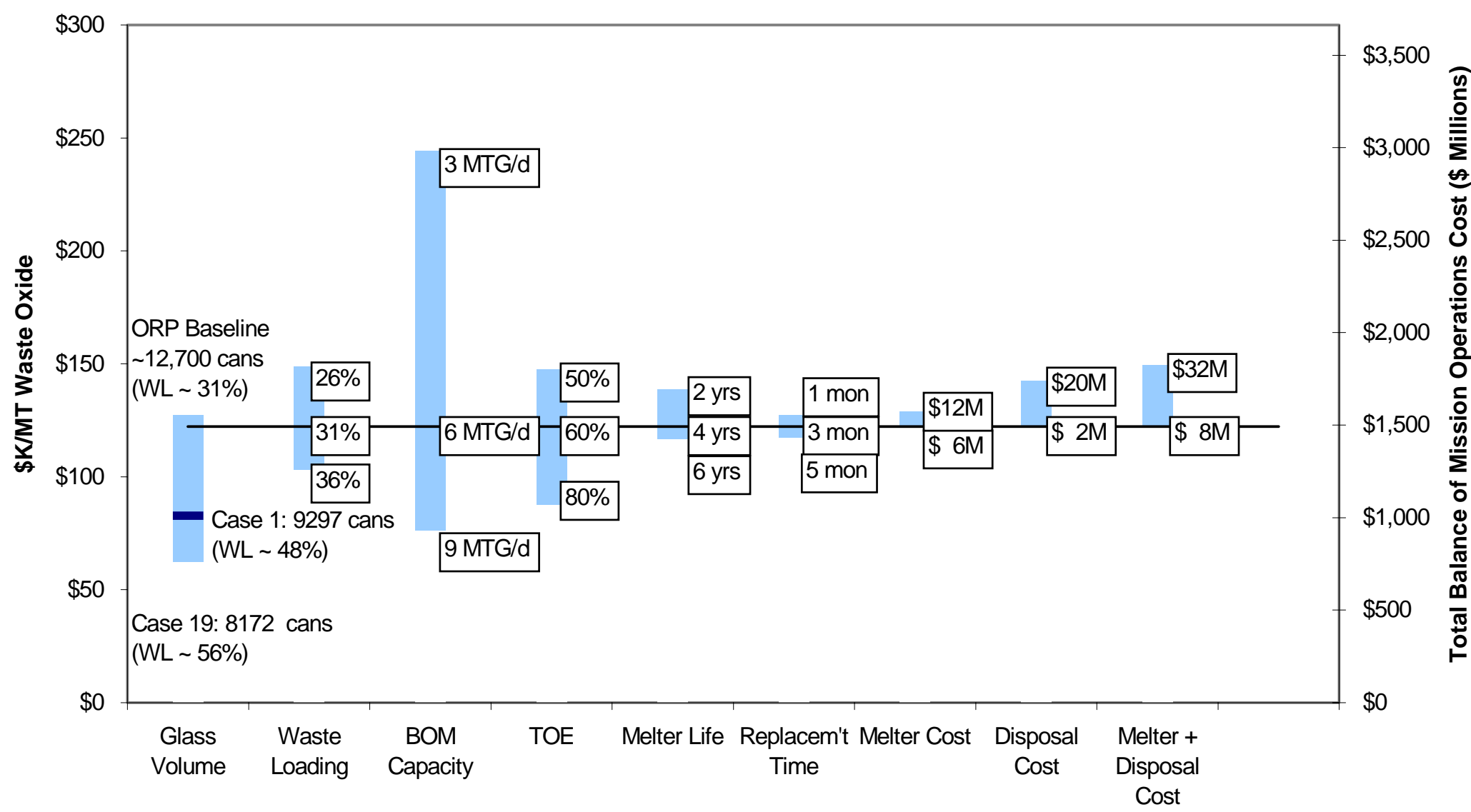

Figure 7.7. Sensitivity of HLW Operations Cost to Variation in Key Parameters 
TOE can have a very similar effect on the length of the mission and total operating cost. DWPF has achieved higher TOE but lower capacity than was expected with its design. Increasing Phase 2 TOE from the nominal $60 \%$ to $80 \%$ shortens the mission by almost seven years and saves about $\$ 420 \mathrm{M}$. This results from avoidance of seven years of operation at $\$ 54 \mathrm{M}$ per year and additional savings from fewer melter replacements.

\subsubsection{Impact of Melter Life, Replacement Cost, and Disposal Cost}

Melter life is another potentially important variable in determining overall operations cost. The longer the time between melter change out, the greater the cost avoided for melter replacement, dismantlement, and disposal and the less time that the plant is down for replacement. DWPF experience has been (five to six years of operation with little or no degradation of performance). For this analysis, melter life is allowed to vary between two years and 16 years with four years being the nominal amount. Melter technologies that are less prone to failure could experience significantly longer times between change out than the reference system.

Melter replacement time affects total downtime, which translates into a lengthened period for mission completion. The GFCE assumes that the replacement time is three months. Sensitivity cases are examined that range from one to five months.

Melter replacement cost within the GFCE is estimated to be about $\$ 6 \mathrm{M}$. For purpose of sensitivity analysis, an upper range of $\$ 12 \mathrm{M}$ was examined.

A significant unknown (or highly uncertain) cost element is the total cost to dismantle and dispose failed HLW melters. ORP assumes that actions will be taken by the WTP operations contractor to prepare failed melters for onsite disposal as low-level waste and will therefore meet the Hanford Site Solid Waste Acceptance Criteria (DOE 1998). As noted in Section 6, some melters can achieve low-level waste status more easily than others (e.g., non-refractory concepts that allow solidified glass to be easily removed). Because the actions required to achieve acceptable onsite disposal are uncertain at this time, a range of $\$ 2 \mathrm{M}$ to $\$ 20 \mathrm{M}$ is evaluated for purposes of sensitivity analysis. The current WTP design does not include a melter breakdown cell. If a particular melter technology requires a breakdown cell, this cost factor would be increased significantly.

Figure 7.8 shows a more detailed set of sensitivity cases that vary both melter replacement cost (including disposal cost) and expected melter life. Longer-lived melters are much less sensitive to the uncertainties in melter replacement and disposal costs. 


\section{Sensitivity of Total HLW Operations Cost to Melter Replacement Assumptions}

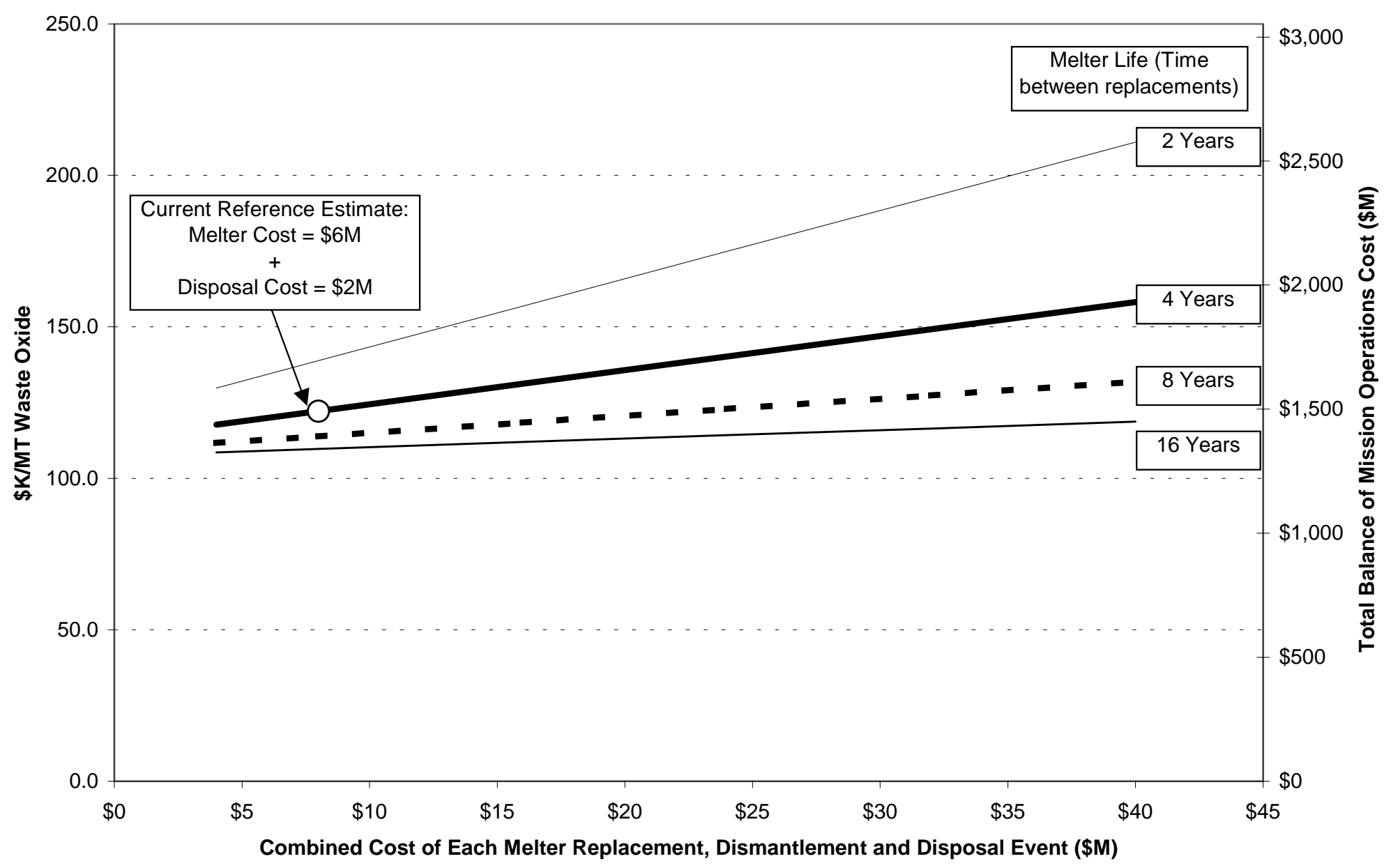

Figure 7.8. Sensitivity of Total HLW Operations Cost to Melter Replacement Assumptions 


\subsection{Impact of Future Technology and Glass Volume Uncertainties on WTP Expansion Decisions}

Current ORP plans call for expansion of the initial WTP HLW processing capability in about 2017 by adding a 3.0 MTG/day melter in the empty cell and upgrading the original $1.5 \mathrm{MTG} /$ day melter also to 3.0 MTG/day. Pretreatment capacity would not require expansion as it is intended to support the 6.0 $\mathrm{MTG}$ /day expansion scenario (shown as $1 \mathrm{X}$ to $4 \mathrm{X}$ in Figure 7.9). An additional expansion option would be considered that would in addition build a duplicate 6.0 MTG/day HLW plant (and corresponding pretreatment and LAW vitrification plants). Under this scenario (1X to 8X), the HLW processing mission could be completed on or before 2032. Even greater expansion could be required to meet the 2028 milestone date contained in the TPA. This decision has been examined on several previous occasions for purposes of determining what expansion flexibility should be included in the initial WTP (ORP 1999). In summary, these analyses have shown that it is most cost-effective for ORP to build an initial plant that can be readily expanded and that, if expanded, could complete the entire tank waste treatment mission within the 40 -year lifetime of the initial facility.

Figure 7.9 provides a simplified representation of capital and operating cost expenditures (all dollar figures are undiscounted, constant 2000 dollars). Costs are shown only for the HLW vitrification facility, not pretreatment or LAW vitrification. For the $1 \mathrm{X}$ to $4 \mathrm{X}$ scenario, there is an initial capital investment of about $\$ 1.1 \mathrm{~B}$ and then an expansion of about $\$ 60 \mathrm{M}$ in 2017, followed by annual operating costs of about \$54M until mission completion. Higher waste loading (or operating efficiency) can shorten the length of the mission significantly as shown in the figure, assuming that other factors do not constrain plant operations, such as waste retrieval rate, pretreatment capacity, or funding, etc. This figure shows the potential impact of the Case 1 waste loading and the highest waste loading evaluated in this study for borosilicate glass $(\sim 56 \%)$. The higher waste loading factors used in this study provide increased assurance that the initial WTP capital investment (in HLW vitrification) would be sufficient to complete the mission within that facility's expected lifetime.

\subsection{Potential Cost Impacts of Melter Technologies and Waste Forms}

This section analyzes those characteristics of the alternative melters and waste forms that would be most likely to affect future costs for vitrification operations, interim storage and repository disposal of Hanford's HLW. Section 7.7.1 integrates the results from Task 4 with the insights gained regarding the sensitivity of the WTP's operating cost to changes in melter performance attributes. Section 7.7.2 integrates the results from Task 4 with an assessment of the possible costs (or savings) of modifying the WTP to accommodate alternate melter technologies. Section 7.7.3 integrates the results of Task 1 with insights gained to provide estimates of potential operational, storage, and disposal cost savings from alternate waste forms.

\subsubsection{Summary Assessment of Operating Cost Impacts of Alternate Melter Technologies}

Table 7.5 restates the information from Section 6 that could affect operations cost for the WTP. Three principal factors were found to influence operating cost: waste loading; throughput capacity assurance (design capacity times total operating efficiency); and total cost for melter replacements and disposal actions (a function of melter life, replacement time, melter cost, and dismantlement and disposal ease/cost). Two columns are provided for waste-loading benefits. The first column retains the liquidus temperature limit at $150^{\circ} \mathrm{C}$ below the melter operating temperature. The second column relaxes this constraint. Glass volume reductions are expressed as percentage reduction in this study's base case (Case 1 -- 9297 canisters). As noted earlier, this case reflects a significant reduction ( 25\%) from the current ORP baseline due to assumptions about chromium leaching and chromium tolerance in the melter. 


\section{Cumulative Capital and Operating Cost}

HLW Plant Only: Two Expansion Scenarios (1X - 4X and 1X - 8X)

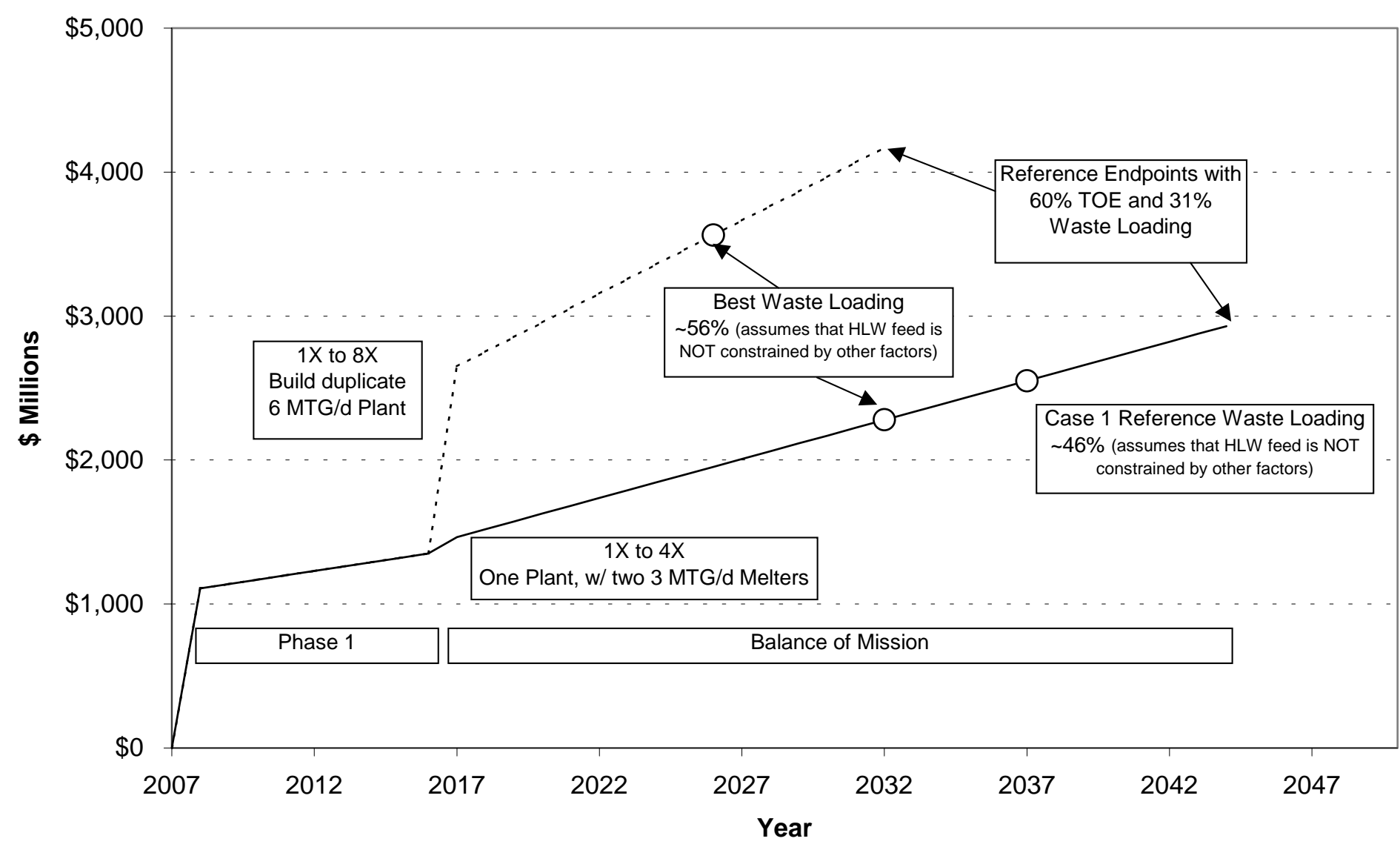

Figure 7.9. Cumulative Capital and Operating Cost 
These waste-loading estimates can also be applied to compute incremental savings in interim storage and repository disposal costs using the cost factors discussed previously.

In Figure 7.5, the column labeled "Capacity Assurance" indicates features of each melter concept that could affect its ability to achieve throughput goals. In general, melters with mixing capability tend to be able to achieve higher throughput, all other things being equal.

The final column in Figure 7.5 contains features of each melter concept that could affect the total cost of melter replacements. This information can be combined with the sensitivity analysis shown in Figure 6.8 to estimate potential incremental costs or savings due to melter replacement and disposal attributes. One area of difference relates to the ease with which a failed melter could be made ready for onsite disposal as low-level waste. (Note: Table 7.5 also contains estimates of incremental cost of the melters, which is relevant to assessment of the relative impact on replacement costs.) Melter life (time between replacements) and the cost to dismantle and dispose of the failed melters are the most important attributes related to this cost factor (see Figure 7.8).

\subsubsection{WTP Capital Cost Impacts of Alternate Melter Technologies}

Alternate melter concepts could require some modifications to the current WTP HLW facility design. Some concepts could be readily accommodated with little or no change, but others could require significant redesign of the current cell concept. Table 7.6 lists the design considerations for each melter concept that could drive changes to the current WTP design. The last column indicates the nature of changes to the WTP design that could be required. This analysis indicated that, in addition to direct cost for the melter, facility capital cost could be affected by: changes in the height of the cell was required to accommodate taller melters (e.g., bottom drain systems); changes in the width of the cell; changes in the cell shield door dimensions; or changes in dimensions of the melter overpack. The potential cost impacts of redesigning major internal systems, such as off-gas treatment, feed delivery, and power supplies, were not quantitatively examined in this study.

To provide rough estimates for several types of facility changes, ORP's cost estimators developed simple parametric models based on GFCE quantity and cost information. Figure 7.10 shows the results of these parametric estimates. These estimates are considered valid for relatively small changes in current dimensions and should not be extrapolated beyond a few feet. These results suggest that for the melter concepts considered in this study, relatively small incremental changes in the WTP capital cost would be expected. A more significant impact of these changes, however, would be the impact on the design and construction schedule for the WTP. Any significant redesign of the cell layout would have an adverse impact on project schedule. The magnitude of this potential impact would need to be identified by the design contractor and is beyond the scope of this study.

\subsubsection{Cost Impact of Alternate Waste Forms}

Table 7.7 summarizes the potential cost impacts of the alternate waste forms and waste form attributes considered in this study (Tasks 1 and 2). The primary impact of these alternatives results from higher waste loading. This impact shortens WTP operations period and produces fewer canisters requiring interim storage and repository disposal. The last column in Table 7.7 describes potential facility changes or impacts that could result of changes in waste form requirements. In general, these impacts are quite minor. The primary cost factor appears to be potential impacts on waste form qualification requirements. 
Figure 7.10 Potential Incremental Capital Cost Impacts from Accommodating Alternative Melter Concepts

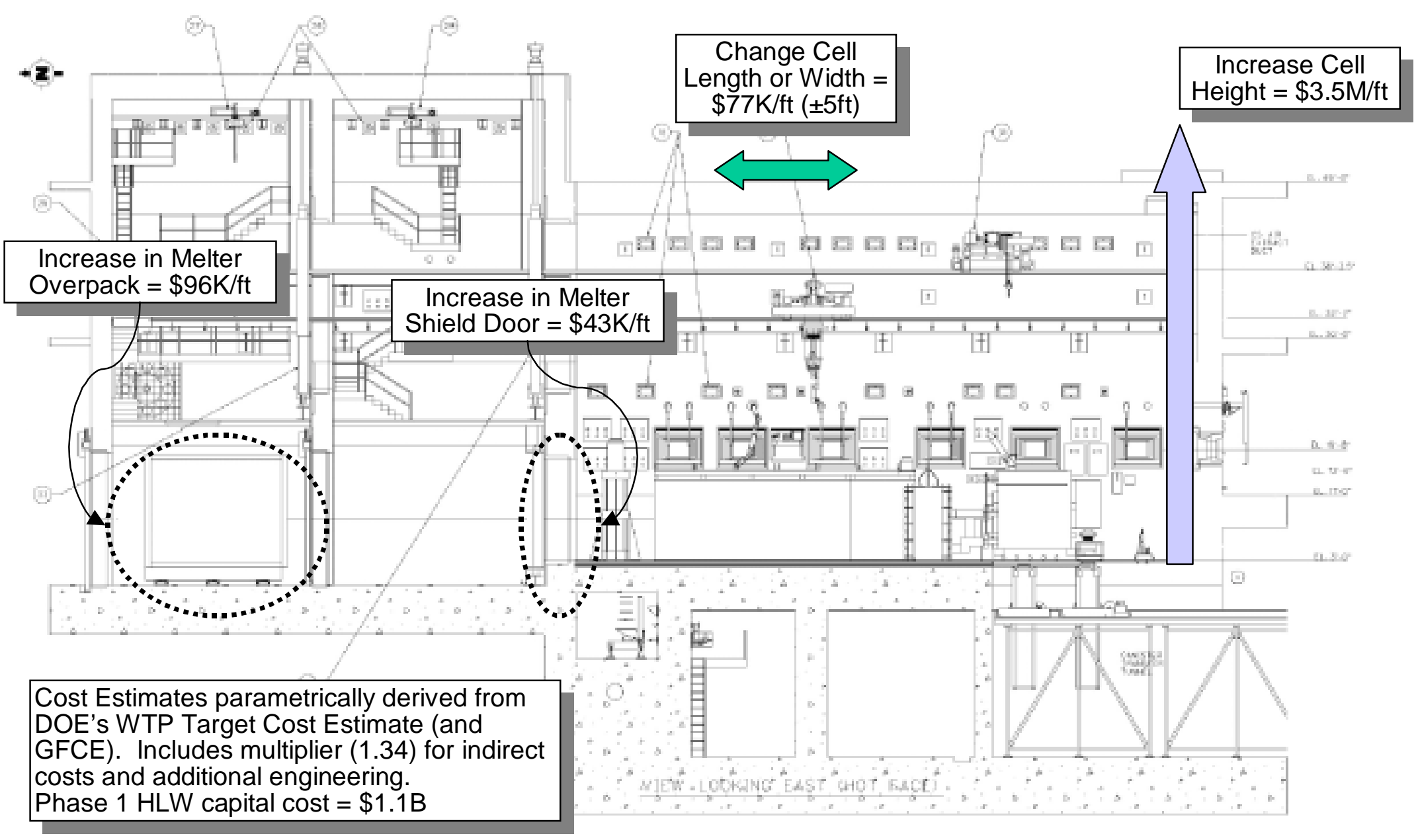


Table 7.5. Summary of Operational Cost Impacts of Alternate Melter Technologies

\begin{tabular}{|c|c|c|c|c|}
\hline \multirow[t]{2}{*}{ Alternative } & \multicolumn{2}{|c|}{ Potential Benefit for Waste Loading } & \multirow{2}{*}{$\begin{array}{c}\text { Capacity Assurance } \\
\text { (Design Capacity x TOE) }\end{array}$} & \multirow{2}{*}{$\begin{array}{c}\text { Replacement Cost } \\
\text { (Melter Life, Melter Cost, } \\
\text { Dismantlement \& Disposal) }\end{array}$} \\
\hline & $\begin{array}{c}\text { Maintain Liquidus } \\
\text { Temp. }<\mathbf{1 5 0}^{\circ} \text { C Melter } \\
\text { Temp. } \\
\end{array}$ & $\begin{array}{l}\text { No Liquidus Temp. } \\
\text { Constraints }\end{array}$ & & \\
\hline $\begin{array}{l}\text { Reference } \\
\text { JHCM }\end{array}$ & Baseline case & Baseline case & & \\
\hline $\begin{array}{l}\text { Hi-Temp } \\
\text { JHCM }\end{array}$ & $\begin{array}{l}6.5 \% \text { reduction in glass } \\
\text { volume (Case } 7)\end{array}$ & $\begin{array}{l}\text { Not practical } \mathrm{w} / \mathrm{o} \text { mixing } \\
\text { or bottom drain capability }\end{array}$ & $\begin{array}{l}\text { - Assume electrodes must be maintained w/o feeding } \\
\text { and no power - add } 2 \text { days of melter outage per } \\
\text { month. } \\
\text { - } 25 \% \text { increased volatility of semi-volatile Cs and Tc } \\
\text { - } 25 \% \text { higher replacement rate of overflow heaters, } \\
\text { thermowells, etc. }\end{array}$ & \\
\hline $\begin{array}{l}\text { JHCM w/ } \\
\text { mixing }\end{array}$ & $\begin{array}{l}1.2 \% \text { reduction in glass } \\
\text { volume (Case } 11)\end{array}$ & $\begin{array}{l}9.4 \% \text { to } 11.6 \% \text { reduction } \\
\text { in glass volume (Case } 2 \\
\& \text { Case } 12, \text { respectively) }\end{array}$ & $\begin{array}{l}\text { Potential for periods of higher throughput to "catch } \\
\text { up", therefore, TOE could increase. } \\
\text { - Mechanical mixers should provide periods of longer } \\
\text { operation compared to current bubbler designs, } \\
\text { therefore, TOE could increase. }\end{array}$ & $\begin{array}{l}\text { Melter failures due to noble metal or } \\
\text { spinel settling may be significantly } \\
\text { reduced. Assume } 25 \% \text { increased melter } \\
\text { life }\end{array}$ \\
\hline $\begin{array}{l}\text { JHCM w/ } \\
\text { bottom drain }\end{array}$ & $\begin{array}{l}1.2 \% \text { reduction in glass } \\
\text { volume (Case 11) }\end{array}$ & $\begin{array}{l}9.4 \% \text { to } 11.6 \% \text { reduction } \\
\text { in glass volume (Case } 2 \\
\& \text { Case } 12, \text { respectively) }\end{array}$ & & $\begin{array}{l}\text { - Melter failures due to noble metal or } \\
\text { spinel settling may be significantly } \\
\text { reduced. Assume } 25 \% \text { to } 50 \% \text { increased } \\
\text { melter life. } \\
\text { - However, requirement to partially } \\
\text { dismantle failed melter and assemble new } \\
\text { melter in cell will double or triple melter } \\
\text { change-out time. } \\
\text { - However, end-of-life draining may be } \\
\text { sufficient to receive a non-HLW ruling } \\
\text { (WIR) without further segregation. }\end{array}$ \\
\hline $\begin{array}{l}\text { Stir Melter } \AA \\
\text { technology }\end{array}$ & $\begin{array}{l}1.2 \% \text { reduction in glass } \\
\text { volume (Case } 11)\end{array}$ & $\begin{array}{l}9.4 \% \text { to } 11.6 \% \text { reduction } \\
\text { in glass volume (Case } 2 \\
\& \text { Case } 12, \text { respectively) }\end{array}$ & $\begin{array}{l}\text { Potential for periods of higher throughput to "catch } \\
\text { up", therefore, TOE could increase. } \\
\text { Mechanical mixers should provide periods of longer } \\
\text { operation compared to current bubbler designs, } \\
\text { therefore, TOE could increase. }\end{array}$ & $\begin{array}{l}\text { - Melter replacement reduced from } 3 \\
\text { months to } 1 \text { month. } \\
\text { - Melter replacement frequency increased } \\
\text { by factor of } 3 \text {. }\end{array}$ \\
\hline $\begin{array}{l}\text { JHCM w/ } \\
\text { bottom drain } \\
\& \text { mixing }\end{array}$ & $\begin{array}{l}1.2 \% \text { reduction in glass } \\
\text { volume (Case } 11)\end{array}$ & $\begin{array}{l}9.4 \% \text { to } 11.6 \% \text { reduction } \\
\text { in glass volume (Case } 2 \\
\& \text { Case } 12 \text {, respectively) }\end{array}$ & $\begin{array}{l}\text { Potential for periods of higher throughput to "catch } \\
\text { up", therefore, TOE could increase. } \\
\text { - Mechanical mixers should provide periods of longer } \\
\text { operation compared to current bubbler designs, } \\
\text { therefore, TOE could increase. }\end{array}$ & $\begin{array}{ll}\text { - } & \text { Melter failures due to noble metal or } \\
\text { spinel settling may be significantly } \\
\text { reduced. Assume } 25 \% \text { to } 50 \% \text { increased } \\
\text { melter life. } \\
\text { - } \\
\text { Backup optional riser/overflow discharge } \\
\text { would add higher confidence in melter } \\
\text { life. } \\
\text { - End-of-life draining may be sufficient to } \\
\text { receive a non-HLW ruling (WIR) without } \\
\text { further segregation. }\end{array}$ \\
\hline $\begin{array}{l}\text { Advanced } \\
\text { Cold Crucible } \\
\text { Melter (w/ } \\
\text { mixing) }\end{array}$ & $\begin{array}{l}6.5 \% \text { reduction in glass } \\
\text { volume (Case } 7)\end{array}$ & $\begin{array}{l}12.2 \% \text { to } 16.4 \% \\
\text { reduction in glass volume } \\
\text { (Case } 8 \text { \& Case } 18 \\
\text { respectively) }\end{array}$ & $\begin{array}{l}\text { - Annual } 1 \text { wk outage to replace mechanical pour } \\
\text { device. }\end{array}$ & $\begin{array}{l}\text { - Melter replacement frequency decreased } \\
\text { by factor of } 2 \text {. } \\
\text { - Melter replacement reduced from } 3 \\
\text { months to } 1 \text { month. } \\
\text { - Effectively no solid waste from melter } \\
\text { disposal. } \\
\text { - } \\
\text { End-of-life draining and removal of loose }\end{array}$ \\
\hline
\end{tabular}




\begin{tabular}{|c|c|c|c|c|}
\hline \multirow[t]{2}{*}{ Alternative } & \multicolumn{2}{|c|}{ Potential Benefit for Waste Loading } & \multirow{2}{*}{$\begin{array}{c}\text { Capacity Assurance } \\
\text { (Design Capacity x TOE) }\end{array}$} & \multirow{2}{*}{$\begin{array}{c}\text { Replacement Cost } \\
\text { (Melter Life, Melter Cost, } \\
\text { Dismantlement \& Disposal) }\end{array}$} \\
\hline & $\begin{array}{c}\text { Maintain Liquidus } \\
\text { Temp. }<\mathbf{1 5 0}^{\circ} \mathrm{C} \text { Melter } \\
\text { Temp. } \\
\end{array}$ & $\begin{array}{l}\text { No Liquidus Temp. } \\
\text { Constraints }\end{array}$ & & \\
\hline & & & & $\begin{array}{l}\text { glass released from cooled walls should } \\
\text { be sufficient to receive a non-HLW ruling } \\
\text { (WIR) without further efforts. }\end{array}$ \\
\hline $\begin{array}{l}\text { Hi-Temp } \\
\text { JHCM } \\
\text { w/ mixing }\end{array}$ & $\begin{array}{l}6.5 \% \text { reduction in glass } \\
\text { volume (Case } 7)\end{array}$ & $\begin{array}{l}12.2 \% \text { to } 16.4 \% \\
\text { reduction in glass volume } \\
\text { (Case } 8 \text { \& Case } 18, \\
\text { respectively) }\end{array}$ & $\begin{array}{l}\text { Assume electrodes must be maintained w/o feeding } \\
\text { and no power - add } 2 \text { days of melter outage per } \\
\text { month. } \\
\text { - } 25 \% \text { higher replacement rate of overflow heaters, } \\
\text { thermowells, etc. } \\
\text { - Potential for periods of higher throughput to "catch } \\
\text { up", therefore, TOE could increase. } \\
\text { Mechanical mixers should provide periods of longer } \\
\text { operation compared to current bubbler designs, } \\
\text { therefore, TOE could increase. }\end{array}$ & $\begin{array}{l}\text { - } 25 \% \text { increased volatility of semi-volatile } \\
\text { Cs and Tc } \\
\text { Melter failures due to noble metal or } \\
\text { spinel settling may be significantly } \\
\text { reduced. Assume } 25 \% \text { increased melter } \\
\text { life. }\end{array}$ \\
\hline $\begin{array}{l}\text { Add pre-dryer } \\
\text { to vitrification } \\
\text { technology }\end{array}$ & None & None & $\begin{array}{l}\text { - Added complexity and unit operations. } \\
\text { - However, catch-up capability increased if feed } \\
\text { preparation can support increased operations. } \\
\text { - Assume this is the case. Therefore, assume no impact } \\
\text { on TOE. }\end{array}$ & \\
\hline $\begin{array}{l}\text { Add pre- } \\
\text { calciner to } \\
\text { vitrification } \\
\text { technology }\end{array}$ & None & None & $\begin{array}{l}\text { - Added complexity and unit operations. } \\
\text { However, catch-up capability increased if feed } \\
\text { preparation can support increased operations. } \\
\text { Assume this is the case. Therefore, assume no impact } \\
\text { on TOE. }\end{array}$ & \\
\hline $\begin{array}{l}\text { Secondary } \\
\text { heat boosting }\end{array}$ & None & None & $\begin{array}{l}\text { Assume no affect on TOE based on DWPF } \\
\text { experience. }\end{array}$ & \\
\hline
\end{tabular}


Table 7.6 Summary of Facility and Capital Cost Impacts of Alternate Melter Technologies

\begin{tabular}{|c|c|}
\hline Alternatives & Facility Impact (Factors potentially affecting WTP capital cost) \\
\hline Reference JHCM & ( \\
\hline Hi-Temp JHCM & $\begin{array}{l}\text { - Remote electrode maintenance to feed electrodes and attach new sections. } \\
\text { - Changes to cell include electrode segment transfer capability into cell from gallery glove box or similar; assume electrode services } \\
\text { are on top of melter lid. }\end{array}$ \\
\hline $\mathrm{JHCM}$ w/ mixing & $\begin{array}{l}\text { - Remote service and maintenance of mixing systems do not change WTP design. } \\
\text { - Smaller melter footprint } 25 \% \text { (6 MT/d) to } 50 \%(1.5 \mathrm{MT} / \mathrm{d}) \text { provides more area for other cell activities \& smaller failed melter } \\
\text { transfer boxes. } \\
\text { - For mechanical mixers added electrical and water cooling required (considered minor). }\end{array}$ \\
\hline JHCM w/ bottom drain & $\begin{array}{l}\text { - Melter with dual bottom drains estimated to be } 3.5 \mathrm{~m} \text { long by } 2 \mathrm{~m} \text { wide by } 3.1 \mathrm{~m} \text { tall. } \\
\text { - Assume bottom drain maintenance includes cell and canister tunnel access. } \\
\text { - Height of melter exceeds shield door height. Require partial assembly/disassembly in cell to be viable. }\end{array}$ \\
\hline $\begin{array}{l}\text { Stir Melter }{ }^{\circledR} \\
\text { technology }\end{array}$ & $\begin{array}{l}\text { - None - Although it would be possible to eliminate the second melter cell for the } 6 \mathrm{MT} / \mathrm{d} \text { expansion, the need to co-install additional } \\
\text { feed and offgas equipment in first cell would require the cell to be widened by } \sim 12 \text { '. It is preferable to utilize both cells as } \\
\text { designed. } \\
\text { - Melter disposal req. significantly reduced with removal, and breakdown of metal liner. No large melter transport systems required. } \\
\text { - Melter capital costs reduced by } 70 \% \text {. }\end{array}$ \\
\hline $\begin{array}{l}\text { JHCM w/ bottom drain \& } \\
\text { mixing }\end{array}$ & $\begin{array}{l}\text { - Remote service and maintenance of mixing systems do not change WTP design. } \\
\text { - } 50 \% \text { smaller melter footprint provides more area for other cell activities \& smaller failed melter transfer boxes. } \\
\text { - For mechanical mixers added electrical and water cooling required (considered minor). } \\
\text { - Melter height will be } \sim 11 \text { ' and could pass through existing cell passageways. }\end{array}$ \\
\hline $\begin{array}{l}\text { Advanced Cold Crucible } \\
\text { Melter (w/ mixing) }\end{array}$ & $\begin{array}{l}\text { - Melters would need to be located w/in } 6 \text { to } 8 \mathrm{~m} \text { the high-frequency capacitor bank which in turn would be within } 10 \mathrm{~m} \text { of the power } \\
\text { supply. } \\
\text { - Therefore, power supplies could remain above gallery area but a } 6 \text { 'x10' gallery space is required for the capacitor bank. } \\
\text { - Increased cooling water demand, } \sim 5 \mathrm{X} \text { current requirements. } \\
\text { - Increased power demand, } \sim 2 \mathrm{X} \text { current } \mathrm{HLW} \text { melter requirements. } \\
\text { - Melter disposal req. significantly reduced with removal, and breakdown of metal liner. No large melter transport systems required. } \\
\text { Melter capital costs reduced by } 70 \% \text {. }\end{array}$ \\
\hline $\begin{array}{l}\text { Hi-Temp JHCM } \\
\text { w/ mixing }\end{array}$ & $\begin{array}{l}\text { - Remote electrode maintenance to feed electrodes and attach new sections. } \\
\text { - Changes to cell include electrode segment transfer capability into cell from gallery glove box or similar; assume electrode services } \\
\text { are on top of melter lid. } \\
\text { - Remote service and maintenance of mixing systems do not change WTP design. } \\
\text { - Smaller melter footprint } 25 \%(6 \mathrm{MT} / \mathrm{d}) \text { to } 50 \%(1.5 \mathrm{MT} / \mathrm{d}) \text { provides more area for other cell activities \& smaller failed melter } \\
\text { transfer boxes. } \\
\text { - For mechanical mixers added electrical and water cooling required (considered minor). }\end{array}$ \\
\hline $\begin{array}{l}\text { Add pre-dryer to } \\
\text { vitrification technology }\end{array}$ & $\begin{array}{l}\text { - Some added in-cell equipment but } 30 \% \text { to } 50 \% \text { reduction in melter size or number of units. Current cell design appears adequate. } \\
\text { - Assume capital costs for pre-dryer are off-set by reduced melter capital costs. }\end{array}$ \\
\hline $\begin{array}{l}\text { Add pre-calciner to } \\
\text { vitrification technology }\end{array}$ & $\begin{array}{l}\text { - Some added in-cell equipment but } 30 \% \text { to } 50 \% \text { reduction in melter size or number of units. Current cell design appears adequate. } \\
\text { - Assume capital costs for pre-calciner are off-set by reduced melter capital costs. }\end{array}$ \\
\hline Secondary heat boosting & $\begin{array}{l}\text { - Additional power supplies and services run into cell. Assume } \$ 1 \mathrm{M} \text { added to design and equipment costs. } \\
\text { - Reduction in melter size for JHCM (no-mixing) technology assume } 20 \% \text { cost reduction. } \\
\text { - Increase in off-gas temperature from melter will require increased cooling, including steam service not currently available. }\end{array}$ \\
\hline
\end{tabular}


Table 7.7. Facility and Cost Impacts of Waste Form Alternatives

\begin{tabular}{|c|c|c|}
\hline & Potential Benefits for Waste Volume & Facility Impacts \\
\hline Alternative & $\begin{array}{l}\text { If successful, what impact on waste product } \\
\text { volume would result? }\end{array}$ & $\begin{array}{c}\text { What changes would be required in WTP process } \\
\text { design? }\end{array}$ \\
\hline $\begin{array}{l}\text { Reference Borosilicate } \\
\text { Glass }\end{array}$ & $\begin{array}{l}\text { Baseline }-1.0 \% \text { Cr oxide solubility limit: } 8,452 \text { canisters } \\
\text { (Case 1) }\end{array}$ & Baseline case - None \\
\hline $\begin{array}{l}\mathrm{B}-\mathrm{Si} \text { with increased } \\
\text { spinel content (also allow } \\
\mathrm{Cr}_{2} \mathrm{O}_{3} \text { crystals to form) }\end{array}$ & $1.2 \%$ reduction in glass volume (Case 11$)$ & $\begin{array}{l}\text { No waste form specific impacts. Technology impacts } \\
\text { described above. }\end{array}$ \\
\hline $\begin{array}{l}\text { B-Si with relaxed PCT } \\
\text { requirement }\end{array}$ & $0.2 \%$ reduction in glass volume (Case 4 ) & $\begin{array}{l}\text { Reduction in qualification strategy requirements could } \\
\text { result in minor operational cost reduction. }\end{array}$ \\
\hline $\begin{array}{l}\mathrm{B}-\mathrm{Si} \text { with } \mathrm{T}_{\mathrm{L}} \text { requirement } \\
\text { relaxed }\end{array}$ & $9.4 \%$ reduction in volume (Case 2 ) & $\begin{array}{l}\text { No waste form specific impacts. Technology impacts } \\
\text { described above. }\end{array}$ \\
\hline $\begin{array}{l}\mathrm{B}-\mathrm{Si} \text { with } \mathrm{Cr}_{2} \mathrm{O}_{3}, \mathrm{~T}_{\mathrm{L}} \& \\
\text { Performance } \\
\text { requirements eliminated }\end{array}$ & $\begin{array}{l}13.8 \% \text { reduction in glass volume (Case } 16)(19.4 \% \\
\left.\left.\text { reduction if } \mathrm{T}_{\mathrm{L}} \text { is also raised to } 1,350^{\circ} \mathrm{C} \text { (Case } 17\right)\right)\end{array}$ & $\begin{array}{l}\text { No waste form specific impacts. Technology impacts } \\
\text { described above. } \\
\text { Reduction in qualification strategy requirements could } \\
\text { result in minor operational cost reduction. }\end{array}$ \\
\hline $\begin{array}{l}\text { B-Si with } \mathrm{T}_{\mathrm{M}} \text { increased to } \\
1,350^{\circ} \mathrm{C}\end{array}$ & $\begin{array}{l}6.5 \% \text { reduction in glass volume (Case } 7) \\
\left(13.9 \% \text { reduction in glass volume if } T_{L} \text { is also raised to }\right. \\
\left.1,550^{\circ} \mathrm{C} \text { (Case } 9\right)\end{array}$ & $\begin{array}{l}\text { Increase in canister wall thickness possible (TBD) could } \\
\text { result in a fractional increase in number of canisters } \\
\text { produced. For example, if canister wall thickness } \\
\text { changes from } 0.25 \text { " to } 0.375 \text { " a } 4 \% \text { in canister cross } \\
\text { sectional area results. }\end{array}$ \\
\hline FeP Glass & $\begin{array}{l}37 \% \text { increase in volume } \mathrm{w} / \text { best assumptions (assumes } \\
11,614 \text { canisters vs } 8,452 \text { canisters) }\end{array}$ & $\begin{array}{l}\text { If assume melter materials corrosion rates are not } \\
\text { increased - no waste form-specific impacts. Technology } \\
\text { impacts described above. }\end{array}$ \\
\hline Phosphate Glass Ceramic & $\begin{array}{l}24 \% \text { reduction in volume } \mathrm{w} / \text { best assumptions (assumes } \\
6,800 \text { canisters vs } 8,452 \text { canisters) }\end{array}$ & Same affect as increasing $\mathrm{T}_{\mathrm{M}}$ above. \\
\hline Other - Titanate ceramics & No data & Same affect as increasing $\mathrm{T}_{\mathrm{M}}$ above. \\
\hline Aluminosilicate Glass & TBD & \\
\hline
\end{tabular}




\subsection{Summary of Results}

Table 7.8 summarizes the plausible ranges of cost impacts from adoption of the melter alternatives considered in this study. This table indicates that the savings that could be realized by achieving the Case 1 waste loading (compared to the current ORP baseline) is roughly three times the savings that could be realized from making the next increment of improvement (Case 1 to Case 19). Also, there remains a very wide range of assumptions for the incremental cost savings that could result from production, storage and disposal of fewer HLW canisters. This table also shows that the savings from reasonable enhancements to "capacity assurance" (design capacity and/or TOE) are of a similar magnitude to the savings from the waste loading benefits considered in this study.

Key findings from this analysis include

- uncertainty in chromium leach factor and solubility/tolerance in glass are the dominant uncertainties in glass volume and total operating cost. There is a very high potential payoff from reducing this uncertainty.

- melters that are crystal tolerant can also reduce glass volume and cost, but the magnitude of this savings is highly dependent on the actual chromium leach factor that is achieved

- making fewer canisters is not the only approach to saving money. Melters that provide high assurance of throughput capacity ( $6 \mathrm{MTG} /$ day and TOE) can significantly reduce operating cost by shortening the overall mission length. Also, establishing a canister shipment schedule to the repository that eliminates the need for additional expansions to the CSB could save $\$ 1.5 \mathrm{~B}$ to $\$ 2.0 \mathrm{~B}$.

- optimized waste loading can significantly reduce the time required to complete the mission, but this is contingent on comparable improvements in the balance of the system (e.g., retrieval, pretreatment, LAW vitrification)

- capital cost impacts to accommodate broader range of next generation melters are relatively small in comparison to potential benefits. However, some concepts require significant R\&T and/or redesign of the cell concept/layout and would adversely affect near-term project schedule. 
Table 7.8. Summary of Plausible Incremental Cost Savings from Study Alternatives

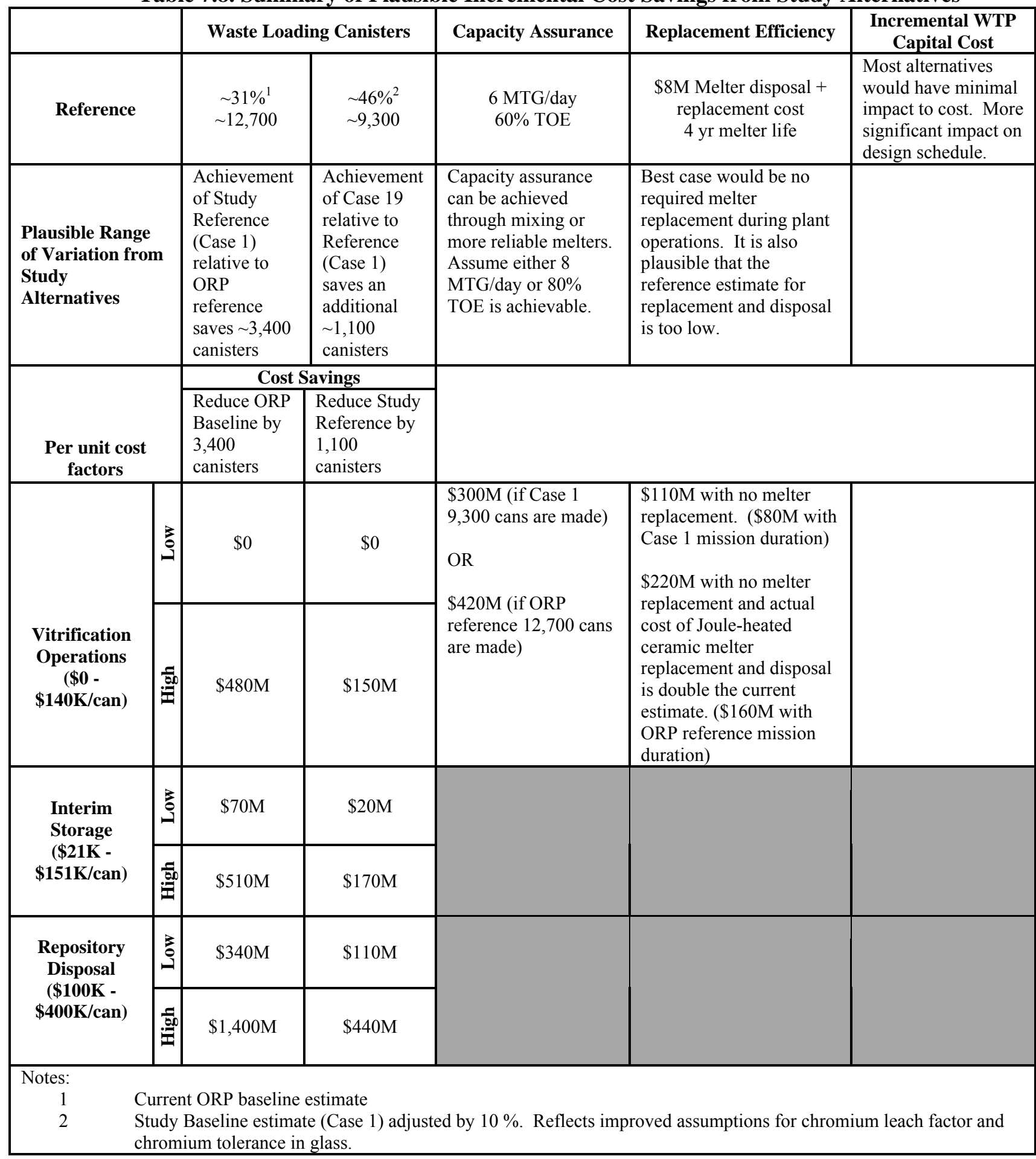




\subsection{References}

52 FR 31508. August 20, 1987. U.S. Department of Energy. "Civilian Radioactive Waste Management; Calculating Nuclear Waste Fund Disposal Fees for Department of Energy Defense Program Waste." Federal Register.

Advocat, T, C Fillet, J Marillet, G Leturcq, JM Boubals, and A Bonnetier. 1998. "Nd-Doped Zirconolite Ceramic and Glass Ceramic Synthesized by Melting and Controlled Cooling." In Scientific Basis for Nuclear Waste Management XXI, Vol. 506, pp. 55-62. Materials Research Society, Pittsburgh, Pennsylvania.

Advocat, T, G Leturcq, J Lacombe, G Berger, RA Day, K Hart, E Vernaz, and A Bonnetier. 1997. "Alteration of Cold Crucible Melter Titanate Based Ceramics: Comparison with Hot-Pressed Titanate-Based Ceramic." In Scientific Basis for Nuclear Waste Management XX, Vol. 465, pp. 355-362. Materials Research Society, Pittsburgh, Pennsylvania.

Aloy, AS, VA Bel'yukov, AV Demin, and YA Revenko. 1996. "Experiences with Vitrification of HLW and Development of New Approaches in Russia." In Glass as a Waste Form and Vitrification Technology: Summary of an International Workshop, pp. E.50-E.51. National Academy Press, Washington, DC.

Aloy, AS, BY Galkin, and BS Kuznetsov. 1989. "Fractioning of Liquid High-Radioactive Waste and Incorporation of Long-Lived Radionuclides into Ceramics and Vitreous Compositions." In Waste Management '89, Vol. 1, pp. 677-681. University of Arizona, Tucson, AZ.

Aloy, AS, AV Trofimenko, and OA Iskhakova. 1994. "The Development of a Glass Matrix for the Immobilization of Simulated Strontium and Cesium Concentrate after HLW Separation.” In International Topical Meeting on Nuclear and Hazardous Waste Management (SPECTRUM '94), Vol. 1, pp. 791 - 764. American Nuclear Society, Atlanta, Georgia.

American Society for Testing and Materials (ASTM). 1998. Standard Test Method for Determining Chemical Durability of Nuclear Waste Glasses, The Product Consistency Test (PCT). ASTM-C-1285-97, Philadelphia, Pennsylvania.

Arneson, MC, CA Boase, KW Chambers, EM Gardy, and KB Harvey. 1986. "Design and Use of a Sealed Radioactive Leach Test Apparatus." In Advances in Ceramics, Vol. 20, pp. 551-556. American Ceramic Society, Columbus, Ohio.

Barnes, CM. 2000. Feed Composition for Sodium-Bearing Waste Treatment Process. INEEL/EXT-2000-01378, Idaho Falls, Idaho.

Badyal, Y, M Karabulut, GK Marasinghe, ML Saboungi, D Haeffner, S Shastri, DE Day, and CS Ray. 1999. "The Effects of Uranium Oxide High-Level Waste on the Structure of Iron Phosphate Glasses." In Scientific Basis for Nuclear Waste Management XXII, Vol. 556, pp. 297-303. Materials Research Society, Pittsburgh, Pennsylvania.

Bernadzikowski, TA. 1982. The Evaluation and Selection of Candidate High Level Waste Forms. USDOE/TIC11611, National Technical Information Service, Springfield, Virginia.

Bernadzikowski, TA, JS Allender, DE Gordon, TH Gould, and JA Stone. 1987. "The Development, Evaluation, and Selection of Candidate High-Level Waste Forms.” Tech. High-Level Waste Disposal, 3:3. 
Bernadzikowski, TA, JS Allender, JA Stone, DE Gordon, TH Gould, and CF Westberry. 1983. "High-Level Nuclear Waste Form Performance Evaluation." Ceram. Bull 62(12): pp. 1364-1368 and 1390.

Bonniaud, R, C Sombret, C, A Jouan, LA Casey. 1978. "Large Scale Waste Glass Production.” In Proceedings of the Conference on High Level Radioactive Solid Waste. NUREG/CP-0005, U.S. Nuclear Regulatory Commission, Washington, DC.

Boomer, KD, SK Baker, AL Boldt, JD Galbraith, JS Garfield, CE Golberg, BA Higley, LF Johnson, MF Kupfer, RM Marusich, RJ Parazin, AN Praga, GW Reddick, JAReddick, EJ Slaathaug, LM Swanson, TL Waldo, and CE Worcester. 1993. Tank Waste Technical Options Report. WHC-EP-0616, Westinghouse Hanford Company, Richland, Washington.

Brown, IWM, and KJD MacKenzie. 1982. "Process Design for the Production of a Ceramic-like Body from Recycled Waste Glass.” Journal of Material Science 17(8): 2184-2193.

Calmus, RB. 1995. High-Level Waste Melter Alternatives Assessment Report. WHC-EP-0847, Westinghouse Hanford Company, Richland, Washington.

Commissariate a L'Energie Atomique. 1982. Radioactive Glasses: Research and Testing. Editions MSA, Paris, France.

Chen, F. and DE Day. 1999. "Corrosion of Selected Refractories by Iron Phosphate Melts." In Environmental Issues and Waste Management Technologies IV; Ceramic Transaction, Vol. 93, pp. 213-220. The American Ceramic Society, Westerville, Ohio.

Cheron, P, P Chevalier, RD Quang, G Tanguy, M Sourroulle, S Woignier, M Senoo, T Banba, K Kuramoto, T Yamaguchi, K Shimizu, C Fillet, N Jacquet-Francillon, J Godard, JL Dussossoy, F Pacaud, and JG Charbonnel. 1995. "Examination and Testing of an Active Glass Sample Produced by Cogema." Scientific Basis for Nuclear Waste Management XVIII, Vol. 353, pp.55-62. Materials Research Society, Pittsburgh, Pennsylvania.

Colton, NG. 1997. Status Report: Pretreatment Chemical Evaluation FY 1997- Wash and Leach Factors for the Single-Shell Tank Waste Inventory. PNNL-11646, Pacific Northwest National Laboratory, Richland, Washington.

Conner, JR. 1990. Chemical Fixation and Solidification of Hazardous Wastes. Van Nostrand Reinhold, New York.

Crum, JV, JD Vienna, DK Peeler, and IA Reamer. 2001. Formulation Efforts for Direct Vitrification of INEEL Blend Calcine Waste Simulant: Fiscal Year 2000. PNNL-13483, Pacific Northwest National Laboratory, Richland, Washington.

Darab, JG, JC Linehan, and BP McGrail. 1998. "NMR Characterization of Simulated Hanford Low-Activity Waste Glasses and its Use in Understanding Waste Form Chemical Durability." In Proceedings of the Materials Research Society Symposium, Scientific Basis for Nuclear Waste Management XXII, pp. 337-344. Materials Research Society, Pittsburgh, Pennsylvania.

Day, DE, Z Wu, CS Ray, and PR Hrma. 1998. "Chemically Durable Iron Phosphate Glass Wasteforms.” Journal of Non-Crystalline Solids 241(1): 1-12.

DE Day, X Yu, GJ Long, and RK Brow. 1997. "Properties and Structure of Sodium-Iron Phosphate Glasses." J. Non-Crystalline Solids, 215(1): $21-31$. 
Dole, LR, G Rogers, M Morgan, D Stinson, J Kessler, S Robinson, and J Moore. 1983. Cement-based Radioactive Waste Hosts Formed Under Elevated Temperatures and Pressures (FUETAP Concretes) for Savannah River Plant High-Level Defense Wastes. ORNL/TM-8579, Oak Ridge National Laboratory, Oak Ridge, Tennessee.

Dunson, JB, AM Eisenberg, RL Schyler, TH Gould, JL Butler, and JB Pickett. 1982. Assessment of Processes, Facilities, and Costs for Alternative Solid Forms for Immobilization of SRP Defense Waste. DP-1625, Savannah River Laboratory, Aiken, South Carolina.

E. R. Johnson Associates, Inc. 1980. Preliminary Evaluation of Alternative Waste Form Solidification Processes, Volume II: Evaluation of the Processes. PNL-3477, Pacific Northwest Laboratories, Richland, Washington.

Feng, X, PR Hrma, JH Westsik, Jr., NR Brown, MJ Schweiger, H Li, JD Vienna, G Chen, GF Piepel, DE Smith, BP McGrail, SE Palmer, D Kim, Y Peng, WK Hahn, AJ Bakel, WL Ebert, DK Peeler, and C. Chang. 1996. Glass Optimization for Vitrification of Hanford Site Low-Level Tank Waste. PNNL-10918, Pacific Northwest Laboratory, Richland, Washington.

Garfield, JS, RA Kirkbride, TM Hohl, and WJ Stokes. 2000. Single-Shell Tank Retrieval Sequence: Fiscal Year 2000 Update. RPP-7087, Rev. 0, Numatec Hanford Company, Richland, Washington.

Gilmore, WR. 1977. Radioactive Waste Disposal Low and High Level. Noyes Data Corporation, Park Ridge, New Jersey.

Graham, D. 1990. "Incorporation of Processing Raffinates and High-Level Solids in Cement." In High-Level Radioactive Waste Management, Vol. 2, p. 1381. American Nuclear Society, La Grange Park, Illinois.

Grambow, B, and W Lutze. 1980. "Chemical Stability of a Phosphate Glass Under Hydrothermal Conditions." In Scientific Basis for Nuclear Waste Management, Vol. 2, pp. 109-116. Materials Research Society, Plenum, New York.

Grygiel, ML, CA Augustine, MA Cahill, JS Garfield, ME Johnson, MJ Kupfer, GA Meyer, JH Roecker, LK Holton, VL Hunter, and MB Triplett. 1991. Tank Waste Disposal Program Redefinition. WHC-EP-0475, Westinghouse Hanford Company, Richland, Washington.

Hatch, LP. 1953. “Ultimate Disposal of Radioactive Waste.” Am. Sci. 41(3): 410-421.

Hench, LL, DE Clark, and J Campbell. 1984. "High Level Waste Immobilization Forms." Nucl. Chem. Waste Manage. 5(2): 149-173.

Hendrickson, DW, DE Place, GT MacLean, and SL Lambert. 1998. Best-Basis Wash and Leach Factor Analysis. HNF-3157, Rev. 0, COGEMA Engineering, Richland, Washington.

Hrma, PR, GF Piepel, MJ Schweiger, DE Smith, DS Kim, PE Redgate, JD Vienna, CA LoPresti, DB Simpson, DK Peeler, and MH Langowski. 1994. Property/Composition Relationships for Hanford High-Level Waste Glasses Melting at $1150^{\circ} \mathrm{C}$. PNL-10359, Vol. 1 and 2, Pacific Northwest Laboratory, Richland, Washington.

Hrma, PR, and AW Bailey. 1995. "High-Level Waste at Hanford: Potential for Waste Loading Maximization." In Proceedings of the 1995 International Conference of Nuclear Waste Management and Environmental Remediation (ICEM'95), Vol. 1, pp. 447-451. American Society for Mechanical Engineers, New York. 
Hrma, PR, GF Piepel, JD Vienna, SK Cooley, DS Kim, and RL Russell. 2001. Database and Interim Glass Property Models for Hanford HLW Glasses. PNNL-13573, Pacific Northwest National Laboratory, Richland, Washington.

International Atomic Energy Agency (IAEA). 1968. Treatment of Low- and Intermediate-Level Radioactive Waste. Technical Report Series No. 82, STI/DOC/10/82, IAEA, Vienna, Austria.

International Atomic Energy Agency (IAEA). 1970. Management of Low- and Intermediate-Level Radioactive Waste. STI/PUB/264, International Atomic Energy Agency, Vienna, Austria.

International Atomic Energy Agency (IAEA). 1992. Design and Operation of HLW Vitrification and Storage Facilities. TRS N339, IAEA, Vienna, Austria.

Jantzen, CM. 1986. Investigation of Lead-Iron-Phosphate Glass for SRP Waste. DP-1729, Savannah River Site, Aiken, South Carolina.

Jantzen, CM, DF Bickford, and DG Karraker. 1984. "Time-Temperature-Transformation Kinetics in SRL Waste Glass," In Advances in Ceramics, Volume 8. pp. 30-38. American Ceramic Society. Columbus, Ohio.

Jantzen, CM, KG Brown, JB Pickett, and GL Ritzhaupt. 2000. Crystalline Phase Separation in Phosphate Containing Waste Glasses: Relevancy to Vitrification of Idaho National Engineering and Environmental Laboratory (INEEL) High Activity Waste (U). WSRC-TR-2000-00339, Westinghouse Savannah River Company, Aiken, South Carolina.

Karabulut, M, GK Marasinghe, CS Ray, DE Day, O Ozturk, and GD Waddill. 1999. "X-ray Photoelectron and Mossbauer Spectroscopic Studies of Iron Phosphate Glasses Containing U, Cs, and Bi." J. Non-Crystalline Solids, 249(2-3): 106-116.

Kibbey, H, and HW Godbee. 1977. A Critical Review of Solid Radioactive Waste Practices at Nuclear Power Plants. ORNL-4924, Oak Ridge National Laboratory, Oak Ridge, Tennessee.

Kim, DS, PR Hrma, SE Palmer, DE Smith, and MJ Schweiger. 1995. "Effect of $\mathrm{B}_{2} \mathrm{O}_{3}, \mathrm{CaO}$, and $\mathrm{Al}_{2} \mathrm{O}_{3}$ on the Chemical Durability of Silicate Glasses for Hanford Low-Level Waste Glass Immobilization." In Ceramic Transactions, Vol. 61, pp. 531-538. American Ceramic Society, Westerville, Ohio.

Kipka, A, B Luckscheiter, and W Lutze. 1993. "Melting of Fly Ashes and Product Properties." Glastech. Ber. 66(9): 215-220.

Kirkbride, RA. 2000. Tank Farm Contractor Operation and Utilization Plan (TWRS-OUP). HNF-SD-WM-SP012, Rev. 2, CH2M Hill Hanford Group, Inc., Richland, Washington.

Kitamura, M, K Miwa, M Ayabe. 1995. "Vitrification Process Development and Design for Large Scale Plant." Presented at the 1995 ASME Radioactive Waste Management and Environmental Remediation Conference, Kyoto, Japan, pp. 385-388.

Lawrence Livermore National Laboratory (LLNL). 1996. Fissile Material Disposition Program - Screening of Alternate Immobilization Candidates for Disposition of Surplus Fissile Materials. UCRL-ID-118819, L-20790-1, LLNL, Livermore, California.

Leturcq, G, G Berger, T Advocat, C Fillet, O Halgand, and E Vernaz. 1997. "Chemical Durability of Aluminosilicate Glasses Containing Low Solubility Chemical Elements." In Scientific Basis for Nuclear Waste Management XXI, Vol. 506, pp. 199-206. Materials Research Society, Pittsburgh, Pennsylvania. 
Li, H, JD Vienna, PR Hrma, DE Smith, and MJ Schweiger. 1996. "Nepheline Precipitation in High-Level Waste Glasses: Compositional Effects and Impact on the Waste Form Acceptability." In Scientific Basis for Nuclear Waste Management XX, Vol. 465, pp. 261-268. Materials Research Society, Pittsburgh, Pennsylvania.

Lifanov, FA, IA Sobolev, and SV Stefanovsky. 1995. "Production of Synroc Through Melting in 'Cold Crucible'." In Radioactive Waste Management and Environmental Remediation, pp. 419 - 423. American Society of Mechanical Engineers, New York.

Lokken, RO. 1978. A Review of Radioactive Waste Immobilization in Concrete. PNL-2654, Pacific Northwest Laboratory, Richland, Washington.

Lutze, W. 1982. Scientific Basis for Nuclear Waste Management V. Vol. 11, Materials Research Society, NorthHolland, New York.

Lutze, W, and RE Ewing. 1988. Radioactive Waste Forms for the Future. North-Holland Publishing, New York.

Marasinghe, GK, M Karabulut, CS Ray, DE Day, MG Shumsky, WB Yelon, CH Booth, PG Allen, and DK Shuh. 1997. "Structural Features of Iron Phosphates Glasses.” J. Non-Crystalline Solids, 222: 144-152.

Marasinghe, GK, M Karabulut, CS Ray, DE Day, CH Booth, PG Allen, and DK Shuh. 1998. "Redox Characteristics and Structural Properties of Iron Phosphate Glasses: A Potential Host Matrix for Vitrifying High Level Nuclear Waste." In Environmental Issues and Waste Management Technologies IV; Ceramic Transactions, Vol. 87, pp. 261-270. American Ceramic Society, Westerville, Ohio.

Marasinghe, GK, M Karabulut, CS Ray, DE Day, PG Allen, JJ Bucher, DK Shuh, Y Bagyal, ML Saboungi, M Grimsditch, S Shastri, and D Heaffner. 1999. "Effects of Nuclear Waste Composition on Redox Equilibria, Structural Features, and Crystallization Characteristics of Iron Phosphate Glasses." In Environmental Issues and Waste Management Technologies IV; Ceramic Transactions, Vol. 93, pp. 195-202. American Ceramic Society, Westerville, Ohio.

Marasinghe, GK, M Karabulut, X Fang, CS Ray, DE Day. 2000. "Vitrified Iron Phosphate Nuclear Waste Forms Containing Multiple Waste Components." Environmental Issues and Waste Management Technologies IV; Ceramic Transactions, Vol. 107, pp.115-122. American Ceramic Society, Westerville, Ohio.

McCarthy, GJ. 1976. "High-Level Waste Ceramics.” Trans. Am. Nucl. Soc., 23: 168-169.

McCarthy, GJ, S Komarneni, BE Scheetz, and WB White. 1979. "Hydrothermal Reactivity of Simulated Nuclear Waste Forms and Water-Catalysed Waste-Rock Interactions." In Scientific Basis for Nuclear Waste Management, Vol. 1, pp. 329-340. Plenum, New York.

McCarthy, GJ, and MT Davidson. 1975. "Ceramic Nuclear Waste Forms: 1, Crystal Chemistry and Phase Formulation.” Ceram. Bull, 54:782-786.

Mendel, JE. 1977. "High-Level Waste Glass.” Nucl. Technol. 32:72.

Mesko, M, DE Day, and BC Bunker. 1998. "Immobilization of High-Level Radioactive Sludges in Iron Phosphates Glasses." In Science and Technology for Disposal of Radioactive Tank Waste, eds. WW Schulz and NJ Lombardo, pp. 379-390. Plenum Publishing Corp., New York.

Mesko, M, and DE Day. 1999. "Immobilization of Spent Nuclear Fuel in Iron Phosphate Glass." Journal of Nuclear Materials, 273(1): 27-36. 
Mesko, M, DE Day, and BC Bunker. 2000. "Immobilization of $\mathrm{CsCl}$ and $\mathrm{SrF}_{2}$ in Iron Phosphate Glass." Waste Management, 20(4): $271-278$.

Mika, M, MJ Schweiger, JD Vienna, and PR Hrma. 1996. "Liquidus Temperature of Spinel Precipitating HighLevel Waste Glasses." In Proceedings of the Materials Research Society Symposium, Scientific Basis for Nuclear Waste Management XX, pp. 71-78. Materials Research Society, Pittsburgh, Pennsylvania.

Mogus-Milankovic, A, M Fajiic, A Drasner, R Tojiko, and DE Day. 1998. "Crystallization of Iron Phosphate Glasses." Physics and Chemistry of Glasses, 39(2): 70-75.

Moore, JG, GC Rogers, S Katz, MT Morgan, and E Newman. 1981. "FUETAP Concretes-Tailored Autoclaved Concretes for the Fixation of Radioactive Wastes." In Waste Management '81, Vol. 1, p. 267. University of Arizona, Tucson, Arizona.

Musick, CA, BA Scholes, RD Tillotson, DM Bennert, JD Vienna, JV Crum, DK Peeler, IA Reamer, DF Bickford, JC Marra, and NL Waldo. 2000. Technical Status Report: Vitrification Technology Development Using INEEL Run 78 Pilot Plant Calcine. INEEL\EXT-2000-00110, Idaho National Engineering and Environmental Laboratory, Idaho Falls, Idaho.

Palmer, WB, WB McNaught, CB Millet, MD Staiger, MC Swenson, FS Ward. 2000. INTEC Waste Management Through 2070. INEEL/EXT-2000-01005, Idaho National Engineering and Environmental Laboratory, Idaho Falls, Idaho.

Peeler, DK, IA Reamer, JD Vienna, and JV Crum. 1998. Technical Status Report, Preliminary Glass Formulation Report for INEEL HAW. WSRC-TR-98-00132, Rev. 1, Westinghouse Savannah River Company, Aiken, South Carolina.

Piepel, GF, Vienna, JD, and Hrma PR. 1999. Phase 1 Experimental Design for the INEEL HLW Glass Composition Variation Study. PNNL-SA-29594, Rev. 2, Pacific Northwest National Laboratory, Richland, Washington.

Pittman, DJ, IA Reamer, DK Peeler, and TB Edwards. 2001. Property-Composition Relationships for the DP Glasses: Effect of Crystallization on Durability (U). WSRC-TR-2001-00166, Rev. 0, Westinghouse Savannah River Company, Aiken, South Carolina.

Raju, CB. 1986. "Development of Anti-Wear and Chemically Durable Tiles from Thermal Wastes." Trans. of Indian Ceramic Society, 45(4): 101-105.

Ray, CR, X Fang, M Karabulut, GK Marasinghe, and DE Day. 1999. "Iron Redox and Crystallization of Iron Phosphate Glass." In Environmental Issues and Waste Management Technologies; Ceramic Transactions, Vol. 43, pp.187-194. American Ceramic Society, Westerville, Ohio.

Revenko, YA, LN Lazarev, and VN Romanovsky. 1994. "Radioactive Waste Management of he Radiochemical Plant Under Construction near Krasnoyarsk." In International Topical Meeting on Nuclear and Hazardous Waste Management (SPECTRUM '94), Vol. 3 (1994), pp. 2015-2018. American Nuclear Society, Atlanta, Georgia.

Riley, BJ, JA Rosario, and PR Hrma. 2001. Impact of HLW Glass Crystallinity on the PCT Response. PNNL13491, Pacific Northwest National Laboratory, Richland, Washington.

Ringwood, AE. 1978. Safe Disposal of High-Level Nuclear Reactor Waste - A New Strategy. Canberra, ANU Press, Sydney, Australia. 
Ringwood, AE, SE Kesson, and NG Ware. 1980. "Immobilization of U.S. Defense Nuclear Wastes Using SYNROC Process.” In Scientific Basis for Nuclear Waste Management, Vol. 2, pp. 265-272. Plenum Press, New York.

Ringwood, AE, SE Kesson, NG Ware, W Hibberson, and A Major. 1979a. "The Synroc Process: A Geochemical Approach to Nuclear Waste Immobilization.” Geochem. J, 13(4): 141-165.

Ringwood, AE, SE Kesson, NG Ware, W Hibberson, and A Major. 1979b. "Immobilization of High Level Nuclear Reactor Wastes in SYNROC." Nature, 278: 219.

Roth, C, T Metzger, X Feng, DS Kim, WK Hahn, PR Hrma, L Wang, and W Gong. 1995. "Vitreous Ceramic Waste Form for Hanford Tank Waste." Ceram. Trans. 61: 356-380.

Rusin, JM, RO Lokken, JM Lukacs, KR Sump, MF Browning, and GJ McCarthy. 1978. Multibarrier Waste Forms. Part I: Development. PNL-2668-1, Pacific Northwest Laboratory, Richland, Washington.

SAS Institute. 1995. JMP® Statistics and Graphics Guide: Version 3 of JMP. SAS Institute, Inc., Cary, North Carolina.

Scholze, H. 1990. Glass: Nature, Structure, and Properties. Springer-Verlag, New York.

Schreiber, HD, and GB Balazs. 1982. "The Chemistry of Uranium in Borosilicate Glasses." Phys. Chem. Glasses, 23(5): 139-146.

Schulz, WW, MM Beary, SA Gallagher, BA Higley, RG Johnston, FM Jungfleisch, MJ Kupfer, RA Palmer, RA Watrous, and GA Wolf. 1980. Preliminary Evaluation of Alternative Forms of Immobilization of Hanford HighLevel Defense Wastes. RHO-ST-32/US-70, Rockwell Hanford Operations, Richland, Washington.

Staples, BA, Peeler, DK, Vienna, JD, Scholes, BA, and Musick, CA. 1999. The Preparation and Characterization of INTEC HAW Phase 1 Composition Variation Study Glasses. INEEL/EXT-98-00970, Rev. 1, Idaho National Engineering and Environmental Laboratory, Idaho Falls, Idaho.

Stone, JA, ST Goforth, Jr., and PK Smith. 1979. Preliminary Evaluation of Alternative Forms for Immobilization of Savannah River Plant High-Level Waste. DP-1545, Savannah River Site, Aiken, South Carolina.

Sundaram, SK, ML Elliott, and DF Bickford. 1999. Technical Exchange on Improved Design and Performance of High-Level Waste Melters - Final Report. PNNL-13030, Pacific Northwest National Laboratory, Richland, Washington.

Tait, JC, and DL Mandolesa. 1983. The Chemical Durability of Alkali-Aluminosilicate Glasses. AECL-7803, Atomic Energy of Canada, Ltd., Pinawa, Manitoba, Canada.

TRW Environmental Safety Systems, Inc. (1999). "Report to Update Total System Life Cycle Cost Estimate for Site Recommendation/License Application,” TDR-CRW-SE-000001, Rev. 01, December 1999.

Tank Waste Remediation System Environmental Impact Statement (TWRS EIS). 1996. Final Environmental Impact Statement, Tank Waste Remediation System. DOE/EIS-0189, U.S. Department of Energy, Richland, Washington. 
U.S. Department of Energy (DOE). 1979. The Evaluation and Review of Alternative Waste Forms for Immobilization of High-Level Radioactive Waste. Report Number 1, DOE/TIC-10288, United States Department of Energy, Alternative Waste Form Peer Review Panel, Washington, DC.

U.S. Department of Energy (DOE). 1980. The Evaluation and Review of Alternative Waste Forms for Immobilization of High-Level Radioactive Waste. Report Number 2, DOE/TIC-11219, United States Department of Energy, Alternative Waste Form Peer Review Panel, Washington, DC.

U.S. Department of Energy (DOE). 1981. The Evaluation and Review of Alternative Waste Forms for Immobilization of High-Level Radioactive Waste. Report Number 3, DOE/TIC-11472, United States Department of Energy, Alternative Waste Form Peer Review Panel, Washington, DC.

U.S. Department of Energy (DOE). 1982a. A Method for Product Performance Evaluation of Candidate Waste Forms for Immobilization of High-Level Radioactive Wastes. DOE-TIC-11612, United States Department of Energy, Interface Working Group on High-Level Waste Form Selection Factors, Washington, DC.

U.S. Department of Energy (DOE). 1982b. The Evaluation and Selection of Candidate High-Level Waste Forms. DOE/TIC 11611, United States Department of Energy, Washington DC.

U.S. Department of Energy (DOE). 1994. Tank Waste Remediation System Functions and Requirements. DOE/RL-92-60 Rev. 1, U.S. Department of Energy, Richland, Washington.

U.S. Department of Energy (DOE) 1995. The INEEL Spent Nuclear and Environmental Restoration and Waste Management Programs Environmental Impact Statement. DOElEIS-0202-F, U.S. Department of Energy, Washington, D.C.

U.S. Department of Energy (DOE). 1996a. Waste Acceptance System Requirements Document (WA-SRD). DOE/RW-0351P, U.S. Department of Energy, Office of Civilian Radioactive Waste Management, Washington D.C.

U.S. Department of Energy (DOE). 1996b. Waste Acceptance Product Specifications for Vitrified High-Level Waste (WAPS). DOE/EM-0093, U.S. Department of Energy, Office of Environmental Management, Washington, DC.

U.S. Department of Energy (DOE). 1998. Management on Non-Routine High-Level Wastes from the TWRS High Level Waste Plant." WDD-PRIV-98-002, U.S. Department of Energy, Washington, DC.

U.S. Department of Energy, Office of River Protection (ORP). 1999. Optimization of Treatment Systems and Facility Concepts - Phase II Expansion. ORPSAS 1b, U.S. Department of Energy, Richland, Washington.

Vance, ER, PJ Hayward, and IM George. 1986. "Crystallization of $\mathrm{Na}_{2} \mathrm{O}-\mathrm{Al}_{2} \mathrm{O}_{3}-\mathrm{CaO}-\mathrm{TiO} 2-\mathrm{SiO}_{2} \mathrm{Glasses}$ Containing Rare Earth Oxides.” Phys. Chem. Glasses, 27(2): 107-113.

Vienna, JD, PR Hrma, DS Kim, MJ Schweiger, and DE Smith. 1996a. "Compositional Dependence of Viscosity, Electrical Conductivity, and Liquidus Temperature of Multicomponent Borosilicate Waste Glasses." In Ceramic Transactions, Vol. 72, pp. 427-436. American Ceramic Society, Westerville, Ohio.

Vienna, JD, PR Hrma, MJ Schweiger, and MH Langowski. 1996b. "Compositional Dependence of Elemental Release from HLW Glasses by the Product Consistency Test: A One Component-at-a-Time Study.” In Ceramic Transactions, Vol. 72, pp. 307-316. American Ceramic Society, Westerville, Ohio. 
Vienna, JD, TJ Plaisted, RL Plaisted, DK Peeler, JV Crum, RD Tillotson, IA Reamer, CA Musick, and TL James. 1999a. Glass Formulations for Idaho National Engineering and Environmental Laboratory Zirconia Calcine High-Activity Waste. PNNL-12202, Pacific Northwest National Laboratory, Richland, Washington.

Vienna, JD, MJ Schweiger, DE Smith, HD Smith, JV Crum, DK Peeler, IA Reamer, CA Musick, RD Tillotson. 1999b. Glass Formulation Development for INEEL Sodium-Bearing Waste. PNNL-12234, Pacific Northwest National Laboratory, Richland, Washington.

Washington State Department of Ecology (Ecology), U.S. Department of Energy (DOE), and U.S. Environmental Protection Agency (EPA). 1990. Hanford Federal Facility Agreement and Consent Order, Volumes 1 and 2. Washington State Department of Ecology, Olympia, Washington.

Watson, LC, AM Aiken, and AR Bancroft. 1960. Disposal of Radioactive Wastes. STI/PUB/18, International Atomic Energy Agency, Vienna, Austria.

Westinghouse Savannah River Company (WSRC). 2000. SRS High Level Waste System Plan. HLW-2000-0017, Rev. 11, WSRC, Aiken, South Carolina.

Wicks, GG. 1985. "Nuclear Waste Glasses.” In Glass IV, Volume 26, eds. M Tomozawa and RH Doremus eds, pp. 57-118. Academic Press, Inc. New York.

$\mathrm{Yu}, \mathrm{X}$, and DE Day, 1995. "Effect of Raw Materials on the Redox State of Iron and Properties of Iron Phosphate Glasses." In Proceedings of the $17^{\text {th }}$ International Congress on Glass, Vol. 2, pp. 45-51. International Academic Publishers, Beijing, The People's Republic of China. 
This page left blank intentionally 


\section{Appendix A - Evaluation of Existing Product and Processing Requirements for Potential Impact}

\begin{tabular}{|c|c|c|c|}
\hline Requirement & Basis for Requirement & $\begin{array}{l}\text { Potential Impact of } \\
\text { Modification to Requirement }\end{array}$ & Basis for Potential Impact \\
\hline $\begin{array}{l}\text { This column lists the WASRD/WAPS } \\
\text { requirements that are currently imposed as } \\
\text { well as known process limitations that } \\
\text { limit waste loading. }\end{array}$ & $\begin{array}{l}\text { This column describes the basis for } \\
\text { the requirement whether it be from a } \\
\text { CFR, DOE imposed or a processing } \\
\text { limitation. }\end{array}$ & $\begin{array}{l}\text { This column describes the potential } \\
\text { impact of removing or relaxing the } \\
\text { constraint on reduction of number of } \\
\text { canisters } / \text { increase in waste loading. }\end{array}$ & $\begin{array}{l}\text { This column describes the reasons and } \\
\text { justification for making the impact assumption. } \\
\text { (Basis can include references to other work, } \\
\text { expert opinions, etc.) }\end{array}$ \\
\hline $\begin{array}{l}\text { WAPS } 1.1-\text { Waste form is } \\
\text { borosilicate waste glass. } \\
\text { WA-SRD } 4.2 .2 \text { and } 4.2 .3\end{array}$ & $\begin{array}{l}\text { Borosilicate glass was the } \\
\text { waste form of choice selected } \\
\text { for HLW after a thorough } \\
\text { review of waste forms and } \\
\text { technologies - Ref. DOE/TIC- } \\
11611 \text {, March, 1982. NEPA } \\
\text { documentation from each of } \\
\text { the sites (DWPF, WVDP, } \\
\text { Hanford) also confirm use of } \\
\text { borosilicate glass. }\end{array}$ & $\begin{array}{l}\text { Elimination/modification of } \\
\text { requirement would allow for } \\
\text { another type of glass or } \\
\text { crystalline material. Alternate } \\
\text { waste forms may allow } \\
\text { increased waste loading for } \\
\text { some waste types. However, an } \\
\text { understanding of the fate of the } \\
\text { radionuclides from the waste } \\
\text { form and the impact of radiation } \\
\text { damage must be understood. }\end{array}$ & $\begin{array}{l}\text { Other waste forms will potentially } \\
\text { allow increased waste loading and } \\
\text { also may involve alternate processing } \\
\text { technologies. (see Task } 2 \text { work). }\end{array}$ \\
\hline $\begin{array}{l}\text { WAPS 1.1.1 - Project chemical } \\
\text { compositions and crystalline } \\
\text { phases and report in Waste Form } \\
\text { Qualification Report (WQR). } \\
\text { WA-SRD 4.2.2 and 4.2.3 }\end{array}$ & $\begin{array}{l}\text { DOE requirement - Provide } \\
\text { information on the waste form } \\
\text { to the repository for } \\
\text { performance assessment and } \\
\text { other evaluations }\end{array}$ & $\begin{array}{l}\text { Elimination of projection } \\
\text { requirement would reduce } \\
\text { qualification task to be } \\
\text { completed and allow limited cost } \\
\text { savings but would have no } \\
\text { impact on the ability to increase } \\
\text { waste loading. The requirements } \\
\text { may need to be modified } \\
\text { depending on alternate waste } \\
\text { form. One of the baseline } \\
\text { assumptions in this study is to } \\
\text { know and predict the phases that } \\
\text { may be present in the waste } \\
\text { form. There is no crystallinity } \\
\text { limit, however, current } \\
\text { production glass formulations } \\
\text { have been developed to have low } \\
\text { crystallinity }(<2 \text { volume \%). } \\
\text { Allowing a waste form with } \\
\text { higher crystalline content may }\end{array}$ & $\begin{array}{l}\text { Task } 2 \text { work demonstrates higher } \\
\text { waste loading with more crystallinity } \\
\text { present for some waste forms. }\end{array}$ \\
\hline
\end{tabular}

$$
\text { A - } 1
$$




\begin{tabular}{|c|c|c|c|}
\hline Requirement & Basis for Requirement & $\begin{array}{l}\text { Potential Impact of } \\
\text { Modification to Requirement }\end{array}$ & Basis for Potential Impact \\
\hline \multirow[t]{2}{*}{$\begin{array}{l}\text { This column lists the WASRD/WAPS } \\
\text { requirements that are currently imposed as } \\
\text { well as known process limitations that } \\
\text { limit waste loading. }\end{array}$} & $\begin{array}{l}\text { This column describes the basis for } \\
\text { the requirement whether it be from a } \\
\text { CFR, DOE imposed or a processing } \\
\text { limitation. }\end{array}$ & $\begin{array}{l}\text { This column describes the potential } \\
\text { impact of removing or relaxing the } \\
\text { constraint on reduction of number of } \\
\text { canisters/increase in waste loading. }\end{array}$ & $\begin{array}{l}\text { This column describes the reasons and } \\
\text { justification for making the impact assumption. } \\
\text { (Basis can include references to other work, } \\
\text { expert opinions, etc.) }\end{array}$ \\
\hline & & $\begin{array}{l}\text { yield higher waste loading. This } \\
\text { requirement may limit some } \\
\text { waste forms whose phases can } \\
\text { not be predicted with confidence } \\
\text { as functions of composition and } \\
\text { process conditions. }\end{array}$ & \\
\hline $\begin{array}{l}\text { WAPS 1.1.2 - Report chemical } \\
\text { composition of waste form in } \\
\text { Production Records and estimated } \\
\text { error in reported composition in } \\
\text { the WQR. } \\
\text { WA-SRD 4.2.2 and } 4.2 .3\end{array}$ & $\begin{array}{l}\text { DOE requirement - Provide } \\
\text { characterization data of the } \\
\text { waste forms to be sent to the } \\
\text { repository. }\end{array}$ & $\begin{array}{l}\text { Elimination/modification of this } \\
\text { requirement would potentially } \\
\text { reduce Producer facility } \\
\text { analytical and control } \\
\text { requirements which may reduce } \\
\text { costs and allow faster } \\
\text { production. Since it is a } \\
\text { reporting requirement it alone } \\
\text { has little impact on waste } \\
\text { loading. However, one of the } \\
\text { baseline assumptions in this } \\
\text { study is to know and predict the } \\
\text { composition and phases that may } \\
\text { be present in the waste form. } \\
\text { Therefore, this requirement will } \\
\text { not be evaluated further for } \\
\text { elimination. Conversely, this } \\
\text { requirement may limit some } \\
\text { waste forms whose composition } \\
\text { can not be determined with } \\
\text { confidence. }\end{array}$ & $\begin{array}{l}\text { Measurement of melter feed/glass } \\
\text { composition impacts glass production } \\
\text { rate since the analysis of the feed is } \\
\text { required prior to transferring it to the } \\
\text { melter. Since there are no specific } \\
\text { limits in this specification, waste } \\
\text { loading is not limited by this } \\
\text { requirement alone. }\end{array}$ \\
\hline $\begin{array}{l}\text { WAPS } 1.2 .1 \text { - Project } \\
\text { radionuclide inventory per } \\
\text { canister and upper limit for all } \\
\text { canisters indexed to years } 2010 \\
\text { and } 3110 . \\
\text { WA-SRD 4.2.3 }\end{array}$ & $\begin{array}{l}\text { 10CFR } 60 \text { - Provide } \\
\text { information on the waste form } \\
\text { to the repository for } \\
\text { performance assessment and } \\
\text { other evaluations. A period of } \\
1100 \text { years for indexing has } \\
\text { been selected to account for } ~\end{array}$ & $\begin{array}{l}\text { Elimination of projection } \\
\text { requirement would reduce } \\
\text { qualification tasks (and to a } \\
\text { limited extent reduce costs) to be } \\
\text { completed but would have no } \\
\text { impact on the ability to increase } \\
\text { waste loading. This requirement }\end{array}$ & $\begin{array}{l}\text { Since there is no limit on radionuclide } \\
\text { inventory waste loading is not } \\
\text { impacted by this requirement. }\end{array}$ \\
\hline
\end{tabular}




\begin{tabular}{|c|c|c|c|}
\hline Requirement & Basis for Requirement & $\begin{array}{l}\text { Potential Impact of } \\
\text { Modification to Requirement }\end{array}$ & Basis for Potential Impact \\
\hline \multirow[t]{2}{*}{$\begin{array}{l}\text { This column lists the WASRD/WAPS } \\
\text { requirements that are currently imposed as } \\
\text { well as known process limitations that } \\
\text { limit waste loading. }\end{array}$} & $\begin{array}{l}\text { This column describes the basis for } \\
\text { the requirement whether it be from a } \\
\text { CFR, DOE imposed or a processing } \\
\text { limitation. }\end{array}$ & $\begin{array}{l}\text { This column describes the potential } \\
\text { impact of removing or relaxing the } \\
\text { constraint on reduction of number of } \\
\text { canisters/increase in waste loading. }\end{array}$ & $\begin{array}{l}\text { This column describes the reasons and } \\
\text { justification for making the impact assumption. } \\
\text { (Basis can include references to other work, } \\
\text { expert opinions, etc.) }\end{array}$ \\
\hline & $\begin{array}{l}100 \text { years of facility operation } \\
\text { and } 1000 \text { years of post-closure } \\
\text { performance. }\end{array}$ & will not be evaluated further. & \\
\hline $\begin{array}{l}\text { WAPS 1.2.2 - Report } \\
\text { radionuclide inventory for each } \\
\text { canister and waste type in } \\
\text { Production Records and estimated } \\
\text { error in reported inventory in the } \\
\text { WQR indexed to years } 2010 \text { and } \\
3110 . \\
\text { WA-SRD 4.2.3 }\end{array}$ & $\begin{array}{l}\text { 10CFR } 60 \text { - Provide } \\
\text { characterization data of the } \\
\text { waste forms to be sent to the } \\
\text { repository. A period of } 1100 \\
\text { years for indexing has been } \\
\text { selected to account for } \sim 100 \\
\text { years of facility operation and } \\
1000 \text { years of postclosure } \\
\text { performance (from } 10 \\
\text { CFR60). }\end{array}$ & $\begin{array}{l}\text { Elimination of this reporting } \\
\text { requirement would reduce } \\
\text { production tasks (and eliminate } \\
\text { some costs) but would have no } \\
\text { impact on the ability to increase } \\
\text { waste loading. This requirement } \\
\text { will not be evaluated further. }\end{array}$ & $\begin{array}{l}\text { Since there is no limit on radionuclide } \\
\text { inventory waste loading is not } \\
\text { impacted by this requirement. }\end{array}$ \\
\hline $\begin{array}{l}\text { WAPS } 1.3 \text { - Produce glass waste } \\
\text { form that is better than DWPF } \\
\text { Environmental Assessment glass } \\
\text { as determined by Product } \\
\text { Consistency Test. } \\
\text { WA-SRD } 4.2 .3\end{array}$ & $\begin{array}{l}\text { DOE requirement - To ensure } \\
\text { a consistent glass product by } \\
\text { control of the vitrification } \\
\text { process. Formally establishes } \\
\text { EA glass as benchmark. This } \\
\text { is a DOE imposed } \\
\text { requirement. }\end{array}$ & $\begin{array}{l}\text { Relaxation of this requirement } \\
\text { by removing the confidence } \\
\text { limit requirements could } \\
\text { potentially allow an increase in } \\
\text { waste loading. } \\
\text { Removal of this requirement } \\
\text { could allow highly soluble waste } \\
\text { forms. However, it is expected } \\
\text { that a test to demonstrate product } \\
\text { consistency of some type would } \\
\text { still be necessary and an } \\
\text { understanding of the fate of the } \\
\text { radionuclides would be needed. } \\
\text { A PCT test may not be an } \\
\text { accurate measure of product } \\
\text { consistency for alternative waste } \\
\text { forms, e.g. glass-ceramic. } \\
\text { Therefore, modification of this } \\
\text { requirement to include an }\end{array}$ & $\begin{array}{l}\text { Task } 2 \text { activities will identify the } \\
\text { degree to which this requirement } \\
\text { dictates waste loading and waste form } \\
\text { type. }\end{array}$ \\
\hline
\end{tabular}

$$
\text { A - } 3
$$




\begin{tabular}{|c|c|c|c|}
\hline Requirement & Basis for Requirement & $\begin{array}{l}\text { Potential Impact of } \\
\text { Modification to Requirement }\end{array}$ & Basis for Potential Impact \\
\hline \multirow[t]{2}{*}{$\begin{array}{l}\text { This column lists the WASRD/WAPS } \\
\text { requirements that are currently imposed as } \\
\text { well as known process limitations that } \\
\text { limit waste loading. }\end{array}$} & $\begin{array}{l}\text { This column describes the basis for } \\
\text { the requirement whether it be from a } \\
\text { CFR, DOE imposed or a processing } \\
\text { limitation. }\end{array}$ & $\begin{array}{l}\text { This column describes the potential } \\
\text { impact of removing or relaxing the } \\
\text { constraint on reduction of number of } \\
\text { canisters } / \text { increase in waste loading. }\end{array}$ & $\begin{array}{l}\text { This column describes the reasons and } \\
\text { justification for making the impact assumption. } \\
\text { (Basis can include references to other work, } \\
\text { expert opinions, etc.) }\end{array}$ \\
\hline & & alternate test may be necessary. & \\
\hline $\begin{array}{l}\text { WAPS 1.4 - Measure glass } \\
\text { transition temperatures and } \\
\text { develop TTT diagrams on } \\
\text { projected glass compositions (see } \\
\text { WAPS 1.1.1), document storage } \\
\text { conditions keep glass below } 400^{\circ} \\
\text { C. } \\
\text { WA-SRD 4.2.3 }\end{array}$ & $\begin{array}{l}\text { DOE requirement }-400^{\circ} \mathrm{C} \text { is } \\
\sim 40-100^{\circ} \mathrm{C} \text { below the glass } \\
\text { transition temperature and was } \\
\text { chosen to provide a } \\
\text { conservative, discrete, control } \\
\text { target. No changes in phase } \\
\text { structure will occur if glass is } \\
\text { maintained below the glass } \\
\text { transition temperature. This is } \\
\text { a DOE-imposed requirement } \\
\text { to ensure maintenance of a } \\
\text { consistent waste form. }\end{array}$ & $\begin{array}{l}\text { Elimination/modification of this } \\
\text { requirement would be necessary } \\
\text { if a non-glass waste form were } \\
\text { utilized. By itself } \\
\text { elimination/modification would } \\
\text { not impact waste loading and } \\
\text { have limited impact on reducing } \\
\text { costs. However, the relationship } \\
\text { to product consistency and } \\
\text { performance would need to be } \\
\text { determined. }\end{array}$ & $\begin{array}{l}\text { If a non-glass waste form or a glass } \\
\text { with a high level of crystallinity were } \\
\text { utilized an evaluation would be } \\
\text { needed to determine if there was any } \\
\text { impact on final product performance } \\
\text { (tie into WAPS 1.3). }\end{array}$ \\
\hline $\begin{array}{l}\text { WAPS } 1.5-\text { RCRA hazardous } \\
\text { waste is not to be sent to the } \\
\text { repository. The waste form shall } \\
\text { pass the TCLP. } \\
\text { WA-SRD 4.2.3 }\end{array}$ & $\begin{array}{l}\text { Requirement for non- } \\
\text { hazardous waste has been } \\
\text { generated from State of } \\
\text { Nevada regulations. }\end{array}$ & $\begin{array}{l}\text { Elimination/modification of the } \\
\text { requirement to pass the TCLP } \\
\text { could allow higher waste loading } \\
\text { in some cases. Additional work } \\
\text { in this area would be necessary. } \\
\text { If WAPS } 1.3 \text { were significantly } \\
\text { modified this requirement may } \\
\text { in some cases be the determinant } \\
\text { factor in maximum waste } \\
\text { loading. } \\
\text { Due to the strong political and } \\
\text { regulatory influence on this } \\
\text { requirement it is unlikely that } \\
\text { any progress could be made in } \\
\text { modifying this requirement. } \\
\text { However, it should be } \\
\text { recognized that there may be } \\
\text { some benefit to } \\
\text { eliminating/modifying this } \\
\text { requirement. However, }\end{array}$ & $\begin{array}{l}\text { Hanford waste is designated a listed } \\
\text { and characteristic waste by the State } \\
\text { of Washington. A waste can be } \\
\text { determined to be not characteristically } \\
\text { hazardous if it passes the TCLP. } \\
\text { However, the waste form must be } \\
\text { delisted to remove the listed } \\
\text { designation. In order to delist the } \\
\text { waste form and make it acceptable for } \\
\text { the repository a delisting petition must } \\
\text { be developed. This delisting petition } \\
\text { requires a thorough evaluation of the } \\
\text { process and waste form. It undergoes } \\
\text { an extensive review by regulatory } \\
\text { agencies. } \\
\text { Limited data is available regarding the } \\
\text { limitations of the TCLP, thus, Task } 2 \\
\text { will unlikely be able to draw any } \\
\text { specific conclusions regarding this } \\
\text { requirement. }\end{array}$ \\
\hline
\end{tabular}




\begin{tabular}{|c|c|c|c|}
\hline Requirement & Basis for Requirement & $\begin{array}{l}\text { Potential Impact of } \\
\text { Modification to Requirement }\end{array}$ & Basis for Potential Impact \\
\hline \multirow[t]{2}{*}{$\begin{array}{l}\text { This column lists the WASRD/WAPS } \\
\text { requirements that are currently imposed as } \\
\text { well as known process limitations that } \\
\text { limit waste loading. }\end{array}$} & $\begin{array}{l}\text { This column describes the basis for } \\
\text { the requirement whether it be from a } \\
\text { CFR, DOE imposed or a processing } \\
\text { limitation. }\end{array}$ & $\begin{array}{l}\text { This column describes the potential } \\
\text { impact of removing or relaxing the } \\
\text { constraint on reduction of number of } \\
\text { canisters } / \text { increase in waste loading. }\end{array}$ & $\begin{array}{l}\text { This column describes the reasons and } \\
\text { justification for making the impact assumption. } \\
\text { (Basis can include references to other work, } \\
\text { expert opinions, etc.) }\end{array}$ \\
\hline & & $\begin{array}{l}\text { additional data would need to be } \\
\text { collected to determine the extent } \\
\text { of the benefit. }\end{array}$ & \\
\hline $\begin{array}{l}\text { WAPS } 1.6-\text { Report } \mathrm{U} \text { and } \mathrm{Pu} \\
\text { isotopes. } \\
\text { WA-SRD } 4.2 .3\end{array}$ & IAEA requirement. & $\begin{array}{l}\text { Elimination of this reporting } \\
\text { requirement would reduce } \\
\text { production tasks and have } \\
\text { limited cost savings but would } \\
\text { have no impact on the ability to } \\
\text { increase waste loading. This } \\
\text { requirement will not be } \\
\text { evaluated further. }\end{array}$ & $\begin{array}{l}\text { Since there is no limit on radionuclide } \\
\text { inventory, waste loading is not } \\
\text { impacted by this requirement. In } \\
\text { addition, since this is an international } \\
\text { commitment modification would not } \\
\text { be appropriate. }\end{array}$ \\
\hline $\begin{array}{l}\text { WAPS } 2.1 \text { - The canister and } \\
\text { label shall be austenitic stainless } \\
\text { steel. } \\
\text { WA-SRD 4.2.3.1 }\end{array}$ & DOE requirement & $\begin{array}{l}\text { While other materials may be } \\
\text { cheaper the savings would be } \\
\text { minimal and, thus, it will not be } \\
\text { addressed further in this study. } \\
\text { However, if an alternate waste } \\
\text { form or alternate package size } \\
\text { are utilized, an evaluation as to } \\
\text { the appropriateness of this } \\
\text { material would be needed. }\end{array}$ & $\begin{array}{l}\text { The waste form must be compatible } \\
\text { with the canister material (WAPS } \\
\text { 3.6). If an alternate size or } \\
\text { configuration for the canister is } \\
\text { selected an evaluation as to the ability } \\
\text { to fabricate from stainless steel would } \\
\text { be necessary. Although this is an } \\
\text { unlikely concern. }\end{array}$ \\
\hline $\begin{array}{l}\text { WAPS } 2.2-\text { The outermost } \\
\text { canister closure shall be leaktight } \\
\text { to } 1 \times 10^{-4} \mathrm{~atm}-\mathrm{cc} / \mathrm{sec} \text { helium. } \\
\text { WA-SRD 4.2.3.A }\end{array}$ & $\begin{array}{l}\text { DOE requirement - However, } \\
\text { tied to requirement to exclude } \\
\text { free liquid which comes from } \\
\text { 10CFR60 - need to confirm. }\end{array}$ & $\begin{array}{l}\text { Less stringent or deletion of } \\
\text { leaktight requirements could } \\
\text { allow liquid to enter the canister } \\
\text { which would violate other } \\
\text { requirements (see WAPS } 3.1 \text { ). } \\
\text { There is no waste loading gain } \\
\text { and little cost savings, thus, this } \\
\text { requirement will not be } \\
\text { addressed further in this study. }\end{array}$ & NA \\
\hline $\begin{array}{l}\text { WAPS } 2.3-\text { The canister shall } \\
\text { have two visible labels with a } \\
\text { unique alphanumeric identifier. } \\
\text { WA-SRD 4.2.2 and } 4.2 .3\end{array}$ & $\begin{array}{l}\text { DOE requirement }- \text { Allows } \\
\text { tracking of canisters and } \\
\text { connection to Production } \\
\text { Records. }\end{array}$ & $\begin{array}{l}\text { Deletion of this requirement } \\
\text { would provide little cost } \\
\text { reduction and, thus, this } \\
\text { requirement will not be } \\
\text { addressed further in this study. }\end{array}$ & $\begin{array}{l}\text { Canister labels are not a significant } \\
\text { part of the total cost of the canister. }\end{array}$ \\
\hline
\end{tabular}

$$
\text { A - } 5
$$




\begin{tabular}{|c|c|c|c|}
\hline Requirement & Basis for Requirement & $\begin{array}{l}\text { Potential Impact of } \\
\text { Modification to Requirement }\end{array}$ & Basis for Potential Impact \\
\hline $\begin{array}{l}\text { This column lists the WASRD/WAPS } \\
\text { requirements that are currently imposed as } \\
\text { well as known process limitations that } \\
\text { limit waste loading. }\end{array}$ & $\begin{array}{l}\text { This column describes the basis for } \\
\text { the requirement whether it be from a } \\
\text { CFR, DOE imposed or a processing } \\
\text { limitation. }\end{array}$ & $\begin{array}{l}\text { This column describes the potential } \\
\text { impact of removing or relaxing the } \\
\text { constraint on reduction of number of } \\
\text { canisters/increase in waste loading. }\end{array}$ & $\begin{array}{l}\text { This column describes the reasons and } \\
\text { justification for making the impact assumption. } \\
\text { (Basis can include references to other work, } \\
\text { expert opinions, etc.) }\end{array}$ \\
\hline $\begin{array}{l}\text { WAPS } 2.4-\text { Canister length and } \\
\text { diameter must be within } \\
\text { specifications. } \\
\text { WA-SRD } 4.2 .3 .1\end{array}$ & $\begin{array}{l}\text { DOE requirement }- \text { The } \\
\text { canister must fit into the } \\
\text { transportation cask and the } \\
\text { disposal container. }\end{array}$ & $\begin{array}{l}\text { Significant changes to canister } \\
\text { dimensions could affect } \\
\text { repository design with little } \\
\text { potential benefit to the waste } \\
\text { form producer. If any benefits } \\
\text { for a change in canister size } \\
\text { develop from the cost analysis in } \\
\text { Task } 5 \text { this requirement will be } \\
\text { reevaluated. Relaxation of } \\
\text { tolerance requirements could } \\
\text { allow flexibility in facility and } \\
\text { transportation requirements. }\end{array}$ & $\begin{array}{l}\text { Reevaluate after full cost analysis } \\
\text { performed, if appropriate. }\end{array}$ \\
\hline $\begin{array}{l}\text { WAPS } 3.1 \text { - Canistered waste } \\
\text { form shall not contain detectable } \\
\text { free liquids. } \\
\text { WA-SRD 4.2.2.D }\end{array}$ & 10CFR60 & $\begin{array}{l}\text { Elimination/modification of this } \\
\text { requirement would reduce } \\
\text { processing constraints and } \\
\text { controls, however, there would } \\
\text { be no impact on waste loading. } \\
\text { Thus, it will not be considered } \\
\text { further. }\end{array}$ & NA \\
\hline $\begin{array}{l}\text { WAPS } 3.2 \text { - Canistered waste } \\
\text { form shall not contain detectable } \\
\text { amounts of free gas. The internal } \\
\text { gas pressure shall not exceed } 150 \\
\mathrm{kPa} \text { at } 25^{\circ} \mathrm{C} \text {. } \\
\text { WA-SRD 4.2.3.A }\end{array}$ & $\begin{array}{l}\text { DOE requirement - However } \\
\text { the limits are identified as "To } \\
\text { Be Verified" in the WA-SRD. }\end{array}$ & $\begin{array}{l}\text { Elimination/modification of this } \\
\text { requirement would reduce } \\
\text { processing constraints and } \\
\text { controls, however, there would } \\
\text { be no impact on waste loading. } \\
\text { Thus, it will not be considered } \\
\text { further. }\end{array}$ & NA \\
\hline $\begin{array}{l}\text { WAPS } 3.3 \text { - Canistered waste } \\
\text { form shall not contain detectable } \\
\text { amounts of explosives, } \\
\text { pyrophorics, or combustibles. } \\
\text { WA-SRD } 4.2 .2\end{array}$ & DOE requirement - & $\begin{array}{l}\text { Elimination/modification of this } \\
\text { requirement would reduce } \\
\text { processing constraints and } \\
\text { controls, however, there would } \\
\text { be no impact on waste loading. } \\
\text { Thus, it will not be considered } \\
\text { further. }\end{array}$ & NA \\
\hline WAPS 3.4 - Canistered waste & 10CFR60 - need to confirm & Elimination/modification of this & Reevaluate after completion of Task \\
\hline
\end{tabular}




\begin{tabular}{|c|c|c|c|}
\hline Requirement & Basis for Requirement & $\begin{array}{l}\text { Potential Impact of } \\
\text { Modification to Requirement }\end{array}$ & Basis for Potential Impact \\
\hline $\begin{array}{l}\text { This column lists the WASRD/WAPS } \\
\text { requirements that are currently imposed as } \\
\text { well as known process limitations that } \\
\text { limit waste loading. }\end{array}$ & $\begin{array}{l}\text { This column describes the basis for } \\
\text { the requirement whether it be from a } \\
\text { CRR, DOE imposed or a processing } \\
\text { limitation. }\end{array}$ & $\begin{array}{l}\text { This column describes the potential } \\
\text { impact of removing or relaxing the } \\
\text { constraint on reduction of number of } \\
\text { canisters } / \text { increase in waste loading. }\end{array}$ & $\begin{array}{l}\text { This column describes the reasons and } \\
\text { justification for making the impact assumption. } \\
\text { (Basis can include references to other work, } \\
\text { expert opinions, etc.) }\end{array}$ \\
\hline $\begin{array}{l}\text { form shall not contain organic } \\
\text { materials. } \\
\text { WA-SRD 4.2.3.A }\end{array}$ & & $\begin{array}{l}\text { requirement would reduce } \\
\text { processing constraints and } \\
\text { controls, however, there would } \\
\text { be no impact on waste loading } \\
\text { for existing waste forms. } \\
\text { However, if an alternate waste } \\
\text { form is identified that may } \\
\text { contain organic materials this } \\
\text { requirement will be revisited. }\end{array}$ & 2 , if appropriate. \\
\hline $\begin{array}{l}\text { WAPS } 3.5 \text { - Contents of } \\
\text { canistered waste form shall not } \\
\text { cause internal corrosion of the } \\
\text { canister which could adversely } \\
\text { affect normal handling. } \\
\text { WA-SRD 4.2.3 }\end{array}$ & $\begin{array}{l}\text { DOE requirement - Although } \\
\text { this is tied to WAPS 3.1. }\end{array}$ & $\begin{array}{l}\text { Elimination/modification of this } \\
\text { requirement would reduce } \\
\text { processing constraints and } \\
\text { controls, however, there would } \\
\text { be no impact on waste loading. } \\
\text { However, if an alternate waste } \\
\text { form is utilized an evaluation as } \\
\text { to the appropriateness of this } \\
\text { material would be needed. } \\
\text { Elimination of this requirement } \\
\text { could cause problems with } \\
\text { canister handling and } \\
\text { transportation. }\end{array}$ & $\begin{array}{l}\text { The waste form must be compatible } \\
\text { with the canister material in order for } \\
\text { it to be handled for transportation to } \\
\text { the repository. An alternate waste } \\
\text { form would require evaluation. }\end{array}$ \\
\hline $\begin{array}{l}\text { WAPS } 3.6-\text { Canister shall be } \\
\text { filled to height equivalent to at } \\
\text { least } 80 \% \text { of the volume of the } \\
\text { empty canister. } \\
\text { WA-SRD 4.2.3.1 }\end{array}$ & DOE requirement & $\begin{array}{l}\text { Since the producer facility will } \\
\text { require some fill height target } \\
\text { and method of determining, } \\
\text { elimination/modification of this } \\
\text { requirement would not } \\
\text { significantly reduce processing } \\
\text { constraints and controls. } \\
\text { However, there would be no } \\
\text { impact on waste loading in the } \\
\text { glass. DOE is considering } \\
\text { elimination of this requirement } \\
\text { and it will not be considered }\end{array}$ & NA \\
\hline
\end{tabular}




\begin{tabular}{|c|c|c|c|}
\hline Requirement & Basis for Requirement & $\begin{array}{l}\text { Potential Impact of } \\
\text { Modification to Requirement }\end{array}$ & Basis for Potential Impact \\
\hline \multirow[t]{2}{*}{$\begin{array}{l}\text { This column lists the WASRD/WAPS } \\
\text { requirements that are currently imposed as } \\
\text { well as known process limitations that } \\
\text { limit waste loading. }\end{array}$} & $\begin{array}{l}\text { This column describes the basis for } \\
\text { the requirement whether it be from a } \\
\text { CFR, DOE imposed or a processing } \\
\text { limitation. }\end{array}$ & $\begin{array}{l}\text { This column describes the potential } \\
\text { impact of removing or relaxing the } \\
\text { constraint on reduction of number of } \\
\text { canisters/increase in waste loading. }\end{array}$ & $\begin{array}{l}\text { This column describes the reasons and } \\
\text { justification for making the impact assumption. } \\
\text { (Basis can include references to other work, } \\
\text { expert opinions, etc.) }\end{array}$ \\
\hline & & further in this study. & \\
\hline $\begin{array}{l}\text { WAPS } 3.7 \text { - Level of removable } \\
\text { of radioactive contamination on } \\
\text { external surfaces shall not exceed } \\
200 \mathrm{dpm} / 100 \mathrm{~cm}^{2} \text { alpha and } 2200 \\
\mathrm{dpm} / 100 \mathrm{~cm}^{2} \text { beta/gamma. } \\
\text { WA-SRD } 4.2 .3\end{array}$ & $\begin{array}{l}\text { Basis is Department of } \\
\text { Transportation requirements } \\
\text { on shipping cask. }\end{array}$ & $\begin{array}{l}\text { Elimination/modification of this } \\
\text { requirement would reduce } \\
\text { processing constraints and } \\
\text { controls, however, there would } \\
\text { be no impact on waste loading. } \\
\text { Thus, it will not be considered } \\
\text { further. }\end{array}$ & NA \\
\hline $\begin{array}{l}\text { WAPS 3.8.1 - Project expected } \\
\text { thermal output and the range of } \\
\text { expected variation indexed to } \\
2015 . \\
\text { WA-SRD 4.2.3.1 }\end{array}$ & $\begin{array}{l}\text { DOE requirement - Provide } \\
\text { information on the waste form } \\
\text { to the repository for } \\
\text { performance assessment and } \\
\text { other evaluations. }\end{array}$ & $\begin{array}{l}\text { Elimination of projection } \\
\text { requirement would reduce } \\
\text { qualification task to be } \\
\text { completed but would have no } \\
\text { impact on the ability to increase } \\
\text { waste loading. This requirement } \\
\text { will not be evaluated further. }\end{array}$ & NA \\
\hline $\begin{array}{l}\text { WAPS } 3.8 .2 \text { - Heat generation } \\
\text { per canister shall not exceed } 1500 \\
\text { watts } / 3 \mathrm{~m} \text {-tall canister }(2540 \\
\text { watts } / 4.5 \mathrm{~m} \text {-tall canister will be } \\
\text { added in next revision of WAPS } \\
\text { and WA-SRD) at year of } \\
\text { shipment. The heat generation for } \\
\text { each canister shall be reported at } \\
\text { year of shipment. } \\
\text { WA-SRD 4.2.3.1 }\end{array}$ & $\begin{array}{l}\text { DOE requirement }- \text { Ensure } \\
\text { heat loading does not exceed } \\
\text { limit established during } \\
\text { repository design. }\end{array}$ & $\begin{array}{l}\text { Elimination of this reporting } \\
\text { requirement would reduce } \\
\text { production tasks but would have } \\
\text { no impact on the ability to } \\
\text { increase waste loading. This } \\
\text { requirement will not be } \\
\text { evaluated further. } \\
\text { A possible exception to this } \\
\text { assessment would be when } \\
\text { Hanford incorporates the Cs and } \\
\text { Sr capsule wastes into the HLW } \\
\text { plant for immobilization. To } \\
\text { avoid impacting waste loading } \\
\text { maximums the capsule waste } \\
\text { may have to be blended over a } \\
\text { longer period of time than would }\end{array}$ & $\begin{array}{l}\text { Even } 100 \% \text { waste loading would most } \\
\text { likely not cause a canister to exceed } \\
\text { this requirement. }\end{array}$ \\
\hline
\end{tabular}




\begin{tabular}{|c|c|c|c|}
\hline Requirement & Basis for Requirement & $\begin{array}{l}\text { Potential Impact of } \\
\text { Modification to Requirement }\end{array}$ & Basis for Potential Impact \\
\hline \multirow[t]{2}{*}{$\begin{array}{l}\text { This column lists the WASRD/WAPS } \\
\text { requirements that are currently imposed as } \\
\text { well as known process limitations that } \\
\text { limit waste loading. }\end{array}$} & $\begin{array}{l}\text { This column describes the basis for } \\
\text { the requirement whether it be from a } \\
\text { CFR, DOE imposed or a processing } \\
\text { limitation. }\end{array}$ & $\begin{array}{l}\text { This column describes the potential } \\
\text { impact of removing or relaxing the } \\
\text { constraint on reduction of number of } \\
\text { canisters/increase in waste loading. }\end{array}$ & $\begin{array}{l}\text { This column describes the reasons and } \\
\text { justification for making the impact assumption. } \\
\text { (Basis can include references to other work, } \\
\text { expert opinions, etc.) }\end{array}$ \\
\hline & & otherwise be necessary. & \\
\hline $\begin{array}{l}3.9 .1 \text { - Project gamma and } \\
\text { neutron dose rates per canister } \\
\text { indexed to the year } 2015 . \\
\text { WA-SRD 4.2.3.1 }\end{array}$ & $\begin{array}{l}\text { DOE requirement - Provide } \\
\text { information on the waste form } \\
\text { to the repository for } \\
\text { performance assessment and } \\
\text { other evaluations. }\end{array}$ & $\begin{array}{l}\text { Elimination of projection } \\
\text { requirement would reduce } \\
\text { qualification task to be } \\
\text { completed but would have no } \\
\text { impact on the ability to increase } \\
\text { waste loading. This requirement } \\
\text { will not be evaluated further. }\end{array}$ & NA \\
\hline $\begin{array}{l}3.9 .2-\text { Dose rates shall not } \\
\text { exceed } 10^{5} \mathrm{rem} / \mathrm{hr} \text { gamma and } 10 \\
\text { rem/hr neutron. The dose rate for } \\
\text { each canister shall be reported at } \\
\text { the time of shipment. } \\
\text { WA-SRD } 4.2 .3 .1\end{array}$ & $\begin{array}{l}\text { DOE requirement - Ensure } \\
\text { heat loading does not exceed } \\
\text { limit established during } \\
\text { repository design. }\end{array}$ & $\begin{array}{l}\text { Elimination of this reporting } \\
\text { requirement would reduce } \\
\text { production tasks but would have } \\
\text { no impact on the ability to } \\
\text { increase waste loading. This } \\
\text { requirement will not be } \\
\text { evaluated further. }\end{array}$ & $\begin{array}{l}\text { Even } 100 \% \text { waste loading would not } \\
\text { cause a canister to exceed this } \\
\text { requirement - need to confirm. }\end{array}$ \\
\hline $\begin{array}{l}3.10-\text { The waste form shall be } \\
\text { designed to ensure that a nuclear } \\
\text { criticality accident is not possible } \\
\text { under normal and accident } \\
\text { conditions. } \\
\text { WA-SRD 4.2.3.C }\end{array}$ & $\begin{array}{l}\text { 10CFR60 - Need to avoid } \\
\text { criticality concerns. }\end{array}$ & $\begin{array}{l}\text { Elimination of this requirement } \\
\text { would reduce qualification and } \\
\text { production tasks but would have } \\
\text { no impact on the ability to } \\
\text { increase waste loading. This } \\
\text { requirement is imperative from a } \\
\text { safety perspective and will not } \\
\text { be evaluated further. }\end{array}$ & $\begin{array}{l}\text { Requirement necessary for safety } \\
\text { reasons. }\end{array}$ \\
\hline $\begin{array}{l}3.11 \text { - Canistered waste form } \\
\text { weight shall be less than } 2500 \mathrm{~kg} \\
\text { (for } 3 \mathrm{~m} \text {-tall canister) (weight limit } \\
\text { for } 5 \mathrm{~m} \text { canister will be added in } \\
\text { next revision). The canistered } \\
\text { waste form dimensions shall be } \\
\text { such that it can stand upright } \\
\text { without support and fit into a right } \\
\text { circular cylinder of specified } \\
\text { dimensions. }\end{array}$ & DOE requirement & $\begin{array}{l}\text { Elimination of this requirement } \\
\text { would reduce qualification and } \\
\text { production tasks but would have } \\
\text { no impact on the ability to } \\
\text { increase waste loading. This } \\
\text { requirement will not be } \\
\text { evaluated further. }\end{array}$ & $\begin{array}{l}\text { Even if the canister was } 100 \% \text { filled } \\
\text { with the glass this requirement cannot } \\
\text { be exceeded. }\end{array}$ \\
\hline
\end{tabular}




\begin{tabular}{|c|c|c|c|}
\hline Requirement & Basis for Requirement & $\begin{array}{l}\text { Potential Impact of } \\
\text { Modification to Requirement }\end{array}$ & Basis for Potential Impact \\
\hline $\begin{array}{l}\text { This column lists the WASRD/WAPS } \\
\text { requirements that are currently imposed as } \\
\text { well as known process limitations that } \\
\text { limit waste loading. }\end{array}$ & $\begin{array}{l}\text { This column describes the basis for } \\
\text { the requirement whether it be from a } \\
\text { CFR, DOE imposed or a processing } \\
\text { limitation. }\end{array}$ & $\begin{array}{l}\text { This column describes the potential } \\
\text { impact of removing or relaxing the } \\
\text { constraint on reduction of number of } \\
\text { canisters } / \text { increase in waste loading. }\end{array}$ & $\begin{array}{l}\text { This column describes the reasons and } \\
\text { justification for making the impact assumption } \\
\text { (Basis can include references to other work, } \\
\text { expert opinions, etc.) }\end{array}$ \\
\hline \multicolumn{4}{|l|}{ WA-SRD 4.2.3.1 } \\
\hline $\begin{array}{l}3.12 \text { - Canistered waste form } \\
\text { shall withstand a } 7 \text { meter drop } \\
\text { without breaching. } \\
\text { WA-SRD 4.2.3.1 }\end{array}$ & $\begin{array}{l}\text { DOE requirement - This } \\
\text { requirement is based on the } \\
\text { maximum lift design height } \\
\text { during repository operation } \\
\text { and the consequences of a } \\
\text { canister breach. }\end{array}$ & $\begin{array}{l}\text { Elimination of this requirement } \\
\text { would reduce qualification tasks } \\
\text { and reduce controls on canister } \\
\text { but would have no impact on the } \\
\text { ability to increase waste loading. } \\
\text { This requirement will not be } \\
\text { evaluated further. }\end{array}$ & NA \\
\hline $\begin{array}{l}3.13 \text { - Canistered waste form } \\
\text { shall have concentric neck and } \\
\text { flange. The producer shall design } \\
\text { a grapple suitable for repository } \\
\text { use. } \\
\text { WA-SRD 4.2.3.1 }\end{array}$ & DOE requirement & $\begin{array}{l}\text { Elimination of this requirement } \\
\text { would reduce tasks but would } \\
\text { have no impact on the ability to } \\
\text { increase waste loading. Thus, } \\
\text { this requirement will not be } \\
\text { evaluated further. }\end{array}$ & NA \\
\hline $\begin{array}{l}3.14-\text { Concentration of Pu shall } \\
\text { be less than } 2500 \mathrm{~g} / \mathrm{m} 3 \text {. } \\
\text { WA-SRD } 4.2 .3\end{array}$ & $\begin{array}{l}\text { IAEA requirement }- \\
\text { Demonstrates that special } \\
\text { security actions are not } \\
\text { necessary. }\end{array}$ & $\begin{array}{l}\text { Elimination/modification of this } \\
\text { requirement would have little } \\
\text { impact on waste loading, thus, } \\
\text { this requirement will not be } \\
\text { addressed further in this study. }\end{array}$ & $\begin{array}{l}\text { Even } 100 \% \text { waste loading will not } \\
\text { cause the canisters to exceed this } \\
\text { limit. }\end{array}$ \\
\hline $\begin{array}{l}\text { Liquidus temperature requirement } \\
\text { - Liquidus temperature of glass } \\
\text { shall be less than } 1050^{\circ} \mathrm{C} \text {. }\end{array}$ & $\begin{array}{l}\text { Prevents large amounts of } \\
\text { crystalline material from } \\
\text { accumulating in the melter and } \\
\text { causing pouring problems. }\end{array}$ & $\begin{array}{l}\text { This liquidus temperature limit } \\
\text { currently limits waste loading at } \\
\text { DWPF and is expected to do the } \\
\text { same for Hanford wastes. } \\
\text { Relaxing this constraint through } \\
\text { the use of alternate melter } \\
\text { technologies has the potential to } \\
\text { significantly increase waste } \\
\text { loading for some wastes. } \\
\text { Collecting additional data to } \\
\text { better define a model may also } \\
\text { allow the safety factor of } 100^{\circ} \mathrm{C} \\
\text { (difference between limit and } \\
\text { typical joule-heated melter }\end{array}$ & See tasks 2-3. \\
\hline
\end{tabular}




\begin{tabular}{|c|c|c|c|}
\hline Requirement & Basis for Requirement & $\begin{array}{l}\text { Potential Impact of } \\
\text { Modification to Requirement }\end{array}$ & Basis for Potential Impact \\
\hline \multirow[t]{2}{*}{$\begin{array}{l}\text { This column lists the WASRD/WAPS } \\
\text { requirements that are currently imposed as } \\
\text { well as known process limitations that } \\
\text { limit waste loading. }\end{array}$} & $\begin{array}{l}\text { This column describes the basis for } \\
\text { the requirement whether it be from a } \\
\text { CFR, DOE imposed or a processing } \\
\text { limitation. }\end{array}$ & $\begin{array}{l}\text { This column describes the potential } \\
\text { impact of removing or relaxing the } \\
\text { constraint on reduction of number of } \\
\text { canisters } / \text { increase in waste loading. }\end{array}$ & $\begin{array}{l}\text { This column describes the reasons and } \\
\text { justification for making the impact assumption. } \\
\text { (Basis can include references to other work, } \\
\text { expert opinions, etc.) }\end{array}$ \\
\hline & & $\begin{array}{l}\text { operating temperature) to be } \\
\text { reduced, thus, allowing an } \\
\text { increase in waste loading. }\end{array}$ & \\
\hline $\begin{array}{l}\text { Glass Viscosity } \\
\text { - Current viscosity limits for } \\
\text { joule-heated melters similar to } \\
\text { DWPF's are defined as between } \\
20-100 \text { poise at } 1150^{\circ} \mathrm{C} \text {. }\end{array}$ & $\begin{array}{l}\text { Levels were developed based } \\
\text { on glass industry practice and } \\
\text { HLW JHCM development } \\
\text { experience. Minimum limit } \\
\text { imposed to prevent excessive } \\
\text { penetration into brick joints, } \\
\text { minimize erosion of } \\
\text { refractories and probes and } \\
\text { maximize convective mixing. } \\
\text { Maximum limit imposed to } \\
\text { ensure that glass can be } \\
\text { poured from melter into } \\
\text { canister. Although, significant } \\
\text { amounts of testing have not } \\
\text { been performed beyond these } \\
\text { ranges. These limits can be } \\
\text { quite dependent on the melter } \\
\text { technology. }\end{array}$ & $\begin{array}{l}\text { The glass or alternate waste form } \\
\text { has to be able to be "poured" } \\
\text { from the melter system, thus } \\
\text { some sort of maximum limit is } \\
\text { needed, however, additional } \\
\text { testing would be needed } \\
\text { Experience points to working in } \\
\text { the lower region of the } \\
\text { alternate melter technologies } \\
\text { may allow the current lower } \\
\text { limit to be expanded. Also, } \\
\text { additional research may allow } \\
\text { the definition of better models } \\
\text { and testing to better understand } \\
\text { and define these limits. Glass } \\
\text { viscosity can also have an } \\
\text { impact on glass production (or } \\
\text { melt) rate. }\end{array}$ & See tasks 2-3. \\
\hline Solubility limits & $\begin{array}{l}\text { Certain components have } \\
\text { limitations on how much can } \\
\text { be incorporated into the glass } \\
\text { matrix. If limitations are } \\
\text { exceeded separate phases in } \\
\text { the glass can occur or phases } \\
\text { can segregate in the melter and } \\
\text { compromise glass } \\
\text { performance. }\end{array}$ & $\begin{array}{l}\text { Solubility limits can limit waste } \\
\text { loading. Alternate melter } \\
\text { technologies (e.g. use of higher } \\
\text { temperatures) would increase } \\
\text { solubility limits for many critical } \\
\text { components, e.g., iron, chrome, } \\
\text { and nickel. In addition, the } \\
\text { bases for certain limits could be } \\
\text { better defined with additional } \\
\text { research which could allow } \\
\text { waste loading to be increased. }\end{array}$ & See tasks 2-3. \\
\hline Materials limitations & $\begin{array}{l}\text { Certain glass components } \\
\text { cause corrosion problems for }\end{array}$ & $\begin{array}{l}\text { The component limits for } \\
\text { materials reasons can limit waste }\end{array}$ & See Task 4. \\
\hline
\end{tabular}

$$
\text { A - } 11
$$




\begin{tabular}{|c|c|c|c|}
\hline Requirement & Basis for Requirement & $\begin{array}{l}\text { Potential Impact of } \\
\text { Modification to Requirement }\end{array}$ & Basis for Potential Impact \\
\hline \multirow[t]{2}{*}{$\begin{array}{l}\text { This column lists the WASRD/WAPS } \\
\text { requirements that are currently imposed as } \\
\text { well as known process limitations that } \\
\text { limit waste loading. }\end{array}$} & $\begin{array}{l}\text { This column describes the basis for } \\
\text { the requirement whether it be from a } \\
\text { CFR, DOE imposed or a processing } \\
\text { limitation. }\end{array}$ & $\begin{array}{l}\text { This column describes the potential } \\
\text { impact of removing or relaxing the } \\
\text { constraint on reduction of number of } \\
\text { canisters/increase in waste loading. }\end{array}$ & $\begin{array}{l}\text { This column describes the reasons and } \\
\text { justification for making the impact assumption. } \\
\text { (Basis can include references to other work, } \\
\text { expert opinions, etc.) }\end{array}$ \\
\hline & $\begin{array}{l}\text { typical melter materials (e.g. } \\
\text { sulfates, phosphates, etc.) }\end{array}$ & $\begin{array}{l}\text { loading. Alternate melter } \\
\text { technologies (e.g. use of non- } \\
\text { traditional materials) could raise } \\
\text { these limits and allow higher } \\
\text { waste loadings. Also, additional } \\
\text { research could be performed to } \\
\text { better define materials } \\
\text { limitations. }\end{array}$ & \\
\hline Volatility & $\begin{array}{l}\text { Some components are more } \\
\text { likely to volatilize from the } \\
\text { melter and be removed } \\
\text { through the off-gas system. } \\
\text { Volatility of certain } \\
\text { components is undesirable due } \\
\text { to environmental concerns and } \\
\text { efficiency in incorporation of } \\
\text { the waste components into the } \\
\text { waste form. }\end{array}$ & $\begin{array}{l}\text { Concerns related to volatility can } \\
\text { limit waste loading. } \\
\text { Significantly increasing waste } \\
\text { loading, especially in } \\
\text { conjunction with higher } \\
\text { temperature melter technologies, } \\
\text { volatility can also increase. } \\
\text { Alternate melter technologies } \\
\text { (perhaps those that maintain a } \\
\text { cold cap) could reduce volatility } \\
\text { concerns. This issue must be } \\
\text { addressed in conjunction with } \\
\text { alternate melter technologies. }\end{array}$ & See Task 4. \\
\hline
\end{tabular}




\section{Appendix B - Questions for HLW Vitrification Personnel}

1. What limits waste loading in glass for each of your major waste types?

- troublesome components?

- Glass property predictions (durability, liquidus, viscosity)? Associated uncertainties?

2. What Waste Acceptance Product Specifications are most limiting to production rate (including waste loading) and/or cost?

- glass form requirements (including reporting requirements)

- canister requirements

- canistered waste form requirements

3. What features of your waste compliance strategy (compliance with WAPS) are restrictive to waste loading?

4. What features of your processing strategies/limitations are restrictive to waste loading?

5. What features of your waste compliance strategy would you change to improve waste loading/production rate based on lessons learned to date or if requirements were interpreted differently?

6. What waste acceptance requirements (WAPS) would you changes (and how) to improve waste loading/production rate?

7. Have waste form materials other than borosilicate glass been considered/evaluated as an approach to increased loadings for your major waste types?

8. What alternative or advanced melter features might give you a basis to increase waste loading either independently or in conjunction with alterations in formulation or revisions to requirements? 
This page left blank intentionally

B - 2 


\section{Appendix C - Compositions of 89 Waste Batches in Mass Percent of Oxides and Summary of Cluster Compositions}




\begin{tabular}{|c|c|c|c|c|c|c|c|c|c|c|c|c|c|c|c|c|c|}
\hline Batch & 69 & 70 & 71 & 72 & 73 & 74 & 75 & 76 & 77 & 78 & 84 & 85 & Total Mass & Min & Max & Median & Mean \\
\hline Mass & 171 & 193 & 159 & 168 & 190 & 167 & 194 & 197 & 179 & 178 & 270 & 283 & 2349 & 159 & 283 & & \\
\hline $\mathrm{Ag}_{2} \mathrm{O}$ & 0.00 & 0.00 & 0.00 & 0.00 & 0.00 & 0.01 & 0.01 & 0.00 & 0.01 & 0.01 & 0.02 & 0.03 & 0.2 & 0.00 & 0.03 & 0.00 & 0.01 \\
\hline $\mathrm{Al}_{2} \mathrm{O}_{3}$ & 18.86 & 21.14 & 25.76 & 28.99 & 19.06 & 17.56 & 15.63 & 22.73 & 19.52 & 13.47 & 16.86 & 18.21 & 459.4 & 13.47 & 28.99 & 18.96 & 19.55 \\
\hline $\mathrm{Am}_{2} \mathrm{O}_{3}$ & 0.00 & 0.00 & 0.00 & 0.00 & 0.00 & 0.00 & 0.00 & 0.00 & 0.00 & 0.00 & 0.00 & 0.00 & 0.0 & 0.00 & 0.00 & 0.00 & 0.00 \\
\hline $\mathrm{As}_{2} \mathrm{O}_{5}$ & 0.01 & 0.00 & 0.00 & 0.02 & 0.01 & 0.02 & 0.02 & 0.01 & 0.04 & 0.04 & 0.02 & 0.05 & 0.5 & 0.00 & 0.05 & 0.02 & 0.02 \\
\hline $\mathrm{B}_{2} \mathrm{O}_{3}$ & 0.03 & 0.01 & 0.01 & 0.06 & 0.03 & 0.08 & 0.06 & 0.04 & 0.12 & 0.12 & 0.13 & 0.03 & 1.4 & 0.01 & 0.13 & 0.05 & 0.06 \\
\hline $\mathrm{BaO}$ & 0.00 & 0.00 & 0.00 & 0.01 & 0.02 & 0.09 & 0.10 & 0.00 & 0.02 & 0.15 & 0.03 & 0.03 & 0.9 & 0.00 & 0.15 & 0.02 & 0.04 \\
\hline $\mathrm{BeO}$ & 0.00 & 0.00 & 0.00 & 0.00 & 0.00 & 0.00 & 0.00 & 0.00 & 0.00 & 0.00 & 0.00 & 0.00 & 0.0 & 0.00 & 0.00 & 0.00 & 0.00 \\
\hline $\mathrm{Bi}_{2} \mathrm{O}_{3}$ & 4.80 & 6.59 & 7.43 & 6.03 & 7.99 & 7.28 & 7.99 & 7.06 & 8.00 & 6.67 & 5.15 & 4.38 & 152.2 & 4.38 & 8.00 & 6.87 & 6.48 \\
\hline $\mathrm{CaO}$ & 4.58 & 4.41 & 3.14 & 2.37 & 2.71 & 2.81 & 2.96 & 3.05 & 2.51 & 2.71 & 1.88 & 1.78 & 66.3 & 1.78 & 4.58 & 2.76 & 2.82 \\
\hline $\mathrm{CdO}$ & 0.00 & 0.00 & 0.00 & 0.00 & 0.00 & 0.01 & 0.01 & 0.00 & 0.00 & 0.01 & 0.36 & 0.04 & 1.1 & 0.00 & 0.36 & 0.00 & 0.05 \\
\hline $\mathrm{Ce}_{2} \mathrm{O}_{3}$ & 0.01 & 0.00 & 0.00 & 0.01 & 0.01 & 0.04 & 0.03 & 0.01 & 0.03 & 0.06 & 0.02 & 0.03 & 0.5 & 0.00 & 0.06 & 0.02 & 0.02 \\
\hline $\mathrm{Cl}-$ & 0.01 & 0.01 & 0.01 & 0.01 & 0.01 & 0.01 & 0.01 & 0.01 & 0.01 & 0.01 & 0.04 & 0.04 & 0.4 & 0.01 & 0.04 & 0.01 & 0.02 \\
\hline $\mathrm{Cm}_{2} \mathrm{O}_{3}$ & 0.00 & 0.00 & 0.00 & 0.00 & 0.00 & 0.00 & 0.00 & 0.00 & 0.00 & 0.00 & 0.00 & 0.00 & 0.0 & 0.00 & 0.00 & 0.00 & 0.00 \\
\hline $\mathrm{CoO}$ & 0.00 & 0.00 & 0.00 & 0.00 & 0.00 & 0.00 & 0.00 & 0.00 & 0.01 & 0.01 & 0.00 & 0.01 & 0.1 & 0.00 & 0.01 & 0.00 & 0.00 \\
\hline $\mathrm{Cr}_{2} \mathrm{O}_{3}$ & 0.54 & 0.72 & 0.85 & 0.62 & 0.51 & 0.49 & 0.45 & 0.53 & 0.60 & 0.39 & 0.55 & 0.48 & 13.0 & 0.39 & 0.85 & 0.54 & 0.55 \\
\hline $\mathrm{Cs}_{2} \mathrm{O}$ & 0.00 & 0.00 & 0.00 & 0.00 & 0.00 & 0.00 & 0.00 & 0.00 & 0.00 & 0.00 & 0.00 & 0.00 & 0.0 & 0.00 & 0.00 & 0.00 & 0.00 \\
\hline $\mathrm{CuO}$ & 0.00 & 0.00 & 0.00 & 0.00 & 0.00 & 0.01 & 0.01 & 0.00 & 0.00 & 0.02 & 0.01 & 0.01 & 0.1 & 0.00 & 0.02 & 0.00 & 0.01 \\
\hline $\mathrm{F}^{-}$ & 0.76 & 0.83 & 0.53 & 0.20 & 0.28 & 0.22 & 0.29 & 0.21 & 0.44 & 1.06 & 0.22 & 0.19 & 9.8 & 0.19 & 1.06 & 0.28 & 0.42 \\
\hline $\mathrm{Fe}_{2} \mathrm{O}_{3}$ & 10.48 & 11.29 & 12.01 & 11.89 & 15.32 & 15.27 & 16.50 & 15.33 & 15.11 & 21.06 & 19.58 & 19.60 & 368.4 & 10.48 & 21.06 & 15.29 & 15.68 \\
\hline $\mathrm{K} 2 \mathrm{O}$ & 0.12 & 0.15 & 0.16 & 0.09 & 0.11 & 0.08 & 0.10 & 0.08 & 0.09 & 0.10 & 0.35 & 0.25 & 3.6 & 0.08 & 0.35 & 0.10 & 0.15 \\
\hline $\mathrm{La}_{2} \mathrm{O}_{3}$ & 0.02 & 0.04 & 0.06 & 0.03 & 0.05 & 0.14 & 0.15 & 0.10 & 0.39 & 0.27 & 1.10 & 0.86 & 7.7 & 0.02 & 1.10 & 0.12 & 0.33 \\
\hline $\mathrm{Li}_{2} \mathrm{O}$ & 0.00 & 0.00 & 0.00 & 0.00 & 0.00 & 0.00 & 0.00 & 0.00 & 0.00 & 0.00 & 0.00 & 0.00 & 0.0 & 0.00 & 0.00 & 0.00 & 0.00 \\
\hline $\mathrm{MgO}$ & 0.10 & 0.05 & 0.03 & 0.02 & 0.07 & 0.28 & 0.29 & 0.02 & 0.07 & 0.45 & 0.10 & 0.16 & 3.2 & 0.02 & 0.45 & 0.08 & 0.14 \\
\hline $\mathrm{MnO}$ & 1.08 & 1.18 & 1.77 & 1.92 & 1.40 & 1.49 & 1.26 & 2.02 & 2.09 & 1.17 & 2.36 & 2.40 & 40.7 & 1.08 & 2.40 & 1.63 & 1.73 \\
\hline $\mathrm{MoO}_{3}$ & 0.00 & 0.00 & 0.00 & 0.01 & 0.00 & 0.01 & 0.01 & 0.01 & 0.02 & 0.02 & 0.00 & 0.00 & 0.2 & 0.00 & 0.02 & 0.01 & 0.01 \\
\hline $\mathrm{Na}_{2} \mathrm{O}$ & 23.36 & 24.78 & 23.93 & 23.53 & 22.96 & 24.02 & 23.03 & 22.43 & 24.40 & 22.90 & 21.16 & 20.86 & 538.6 & 20.86 & 24.78 & 23.19 & 22.93 \\
\hline $\mathrm{Nb}_{2} \mathrm{O}_{5}$ & 0.00 & 0.00 & 0.00 & 0.00 & 0.00 & 0.00 & 0.00 & 0.00 & 0.00 & 0.00 & 0.00 & 0.00 & 0.0 & 0.00 & 0.00 & 0.00 & 0.00 \\
\hline $\mathrm{Nd}_{2} \mathrm{O}_{3}$ & 0.01 & 0.00 & 0.00 & 0.01 & 0.01 & 0.04 & 0.03 & 0.01 & 0.03 & 0.06 & 0.06 & 0.04 & 0.6 & 0.00 & 0.06 & 0.02 & 0.03 \\
\hline $\mathrm{NiO}$ & 0.96 & 0.89 & 1.02 & 1.19 & 1.31 & 1.66 & 1.69 & 1.02 & 1.03 & 2.02 & 0.50 & 0.44 & 25.6 & 0.44 & 2.02 & 1.03 & 1.09 \\
\hline $\mathrm{NpO}_{2}$ & 0.00 & 0.00 & 0.00 & 0.00 & 0.00 & 0.00 & 0.00 & 0.00 & 0.00 & 0.00 & 0.00 & 0.00 & 0.0 & 0.00 & 0.00 & 0.00 & 0.00 \\
\hline $\mathrm{P}_{2} \mathrm{O}_{5}$ & 2.74 & 3.19 & 2.94 & 2.61 & 3.62 & 3.72 & 4.05 & 3.06 & 3.74 & 4.09 & 2.09 & 2.17 & 72.6 & 2.09 & 4.09 & 3.12 & 3.09 \\
\hline $\mathrm{PbO}$ & 0.32 & 0.37 & 0.38 & 0.32 & 0.40 & 0.52 & 0.55 & 0.37 & 0.55 & 2.21 & 0.78 & 0.67 & 14.7 & 0.32 & 2.21 & 0.46 & 0.63 \\
\hline $\mathrm{PuO}_{2}$ & 0.00 & 0.00 & 0.00 & 0.01 & 0.00 & 0.01 & 0.00 & 0.01 & 0.01 & 0.01 & 0.01 & 0.00 & 0.1 & 0.00 & 0.01 & 0.00 & 0.01 \\
\hline $\mathrm{Rb}_{2} \mathrm{O}$ & 0.00 & 0.00 & 0.00 & 0.00 & 0.00 & 0.00 & 0.00 & 0.00 & 0.00 & 0.00 & 0.00 & 0.00 & 0.0 & 0.00 & 0.00 & 0.00 & 0.00 \\
\hline $\mathrm{Rh}_{2} \mathrm{O}_{3}$ & 0.00 & 0.00 & 0.00 & 0.00 & 0.00 & 0.00 & 0.00 & 0.00 & 0.00 & 0.00 & 0.00 & 0.00 & 0.0 & 0.00 & 0.00 & 0.00 & 0.00 \\
\hline $\mathrm{RuO}_{2}$ & 0.00 & 0.00 & 0.00 & 0.00 & 0.00 & 0.00 & 0.00 & 0.00 & 0.00 & 0.00 & 0.00 & 0.00 & 0.0 & 0.00 & 0.00 & 0.00 & 0.00 \\
\hline $\mathrm{Sb}_{2} \mathrm{O}_{3}$ & 0.00 & 0.00 & 0.00 & 0.01 & 0.00 & 0.01 & 0.01 & 0.01 & 0.01 & 0.02 & 0.01 & 0.02 & 0.2 & 0.00 & 0.02 & 0.01 & 0.01 \\
\hline $\mathrm{SeO}_{2}$ & 0.00 & 0.00 & 0.00 & 0.00 & 0.00 & 0.00 & 0.00 & 0.00 & 0.00 & 0.00 & 0.02 & 0.04 & 0.2 & 0.00 & 0.04 & 0.00 & 0.01 \\
\hline
\end{tabular}

$$
\text { C - } 2
$$




\begin{tabular}{|c|c|c|c|c|c|c|c|c|c|c|c|c|c|c|c|c|c|}
\hline Batch & 69 & 70 & 71 & 72 & 73 & 74 & 75 & 76 & 77 & 78 & 84 & 85 & Total Mass & Min & Max & Median & Mean \\
\hline Mass & 171 & 193 & 159 & 168 & 190 & 167 & 194 & 197 & 179 & 178 & 270 & 283 & 2349 & 159 & 283 & & \\
\hline $\mathrm{SiO}_{2}$ & 23.26 & 16.81 & 12.85 & 12.25 & 16.13 & 16.77 & 17.53 & 13.03 & 14.11 & 12.04 & 22.42 & 23.49 & 405.3 & 12.04 & 23.49 & 16.45 & 17.25 \\
\hline $\mathrm{Sm}_{2} \mathrm{O}_{3}$ & 0.00 & 0.00 & 0.00 & 0.00 & 0.00 & 0.00 & 0.00 & 0.00 & 0.00 & 0.00 & 0.00 & 0.00 & 0.0 & 0.00 & 0.00 & 0.00 & 0.00 \\
\hline $\mathrm{SnO}_{2}$ & 0.00 & 0.00 & 0.00 & 0.00 & 0.00 & 0.00 & 0.00 & 0.00 & 0.00 & 0.00 & 0.00 & 0.00 & 0.0 & 0.00 & 0.00 & 0.00 & 0.00 \\
\hline $\mathrm{SO}_{3}$ & 0.12 & 0.15 & 0.06 & 0.08 & 0.12 & 0.12 & 0.16 & 0.13 & 0.17 & 0.15 & 0.38 & 0.38 & 4.4 & 0.06 & 0.38 & 0.14 & 0.19 \\
\hline $\mathrm{SrO}$ & 0.79 & 0.78 & 0.46 & 0.26 & 0.20 & 0.16 & 0.15 & 0.22 & 0.18 & 0.25 & 0.29 & 0.34 & 7.9 & 0.15 & 0.79 & 0.26 & 0.34 \\
\hline $\mathrm{TcO}_{2}$ & 0.00 & 0.00 & 0.01 & 0.00 & 0.00 & 0.00 & 0.00 & 0.00 & 0.00 & 0.00 & 0.00 & 0.00 & 0.1 & 0.00 & 0.01 & 0.00 & 0.00 \\
\hline $\mathrm{TeO}_{2}$ & 0.00 & 0.00 & 0.00 & 0.00 & 0.00 & 0.00 & 0.00 & 0.00 & 0.00 & 0.00 & 0.00 & 0.00 & 0.0 & 0.00 & 0.00 & 0.00 & 0.00 \\
\hline $\mathrm{ThO}_{2}$ & 0.05 & 0.08 & 0.08 & 0.04 & 0.04 & 0.03 & 0.04 & 0.03 & 0.04 & 0.04 & 0.14 & 0.10 & 1.5 & 0.03 & 0.14 & 0.04 & 0.06 \\
\hline $\mathrm{TiO}_{2}$ & 0.00 & 0.00 & 0.00 & 0.00 & 0.00 & 0.01 & 0.01 & 0.00 & 0.00 & 0.02 & 0.00 & 0.01 & 0.1 & 0.00 & 0.02 & 0.00 & 0.01 \\
\hline $\mathrm{Tl}_{2} \mathrm{O}$ & 0.01 & 0.01 & 0.00 & 0.02 & 0.01 & 0.03 & 0.03 & 0.02 & 0.05 & 0.05 & 0.02 & 0.06 & 0.7 & 0.00 & 0.06 & 0.02 & 0.03 \\
\hline $\mathrm{U}_{3} \mathrm{O}_{8}$ & 6.86 & 6.36 & 6.37 & 7.19 & 7.38 & 6.74 & 6.63 & 8.23 & 6.38 & 8.13 & 2.64 & 2.44 & 140.5 & 2.44 & 8.23 & 6.68 & 5.98 \\
\hline $\mathrm{V}_{2} \mathrm{O}_{5}$ & 0.00 & 0.00 & 0.00 & 0.01 & 0.01 & 0.01 & 0.01 & 0.01 & 0.02 & 0.02 & 0.01 & 0.03 & 0.3 & 0.00 & 0.03 & 0.01 & 0.01 \\
\hline $\mathrm{WO}_{3}$ & 0.00 & 0.00 & 0.00 & 0.00 & 0.00 & 0.00 & 0.00 & 0.00 & 0.00 & 0.00 & 0.00 & 0.00 & 0.0 & 0.00 & 0.00 & 0.00 & 0.00 \\
\hline $\mathrm{ZnO}$ & 0.00 & 0.00 & 0.00 & 0.00 & 0.00 & 0.01 & 0.01 & 0.00 & 0.00 & 0.02 & 0.01 & 0.01 & 0.2 & 0.00 & 0.02 & 0.00 & 0.01 \\
\hline $\mathrm{ZrO}_{2}$ & 0.11 & 0.11 & 0.14 & 0.17 & 0.20 & 0.21 & 0.21 & 0.20 & 0.21 & 0.19 & 0.69 & 0.29 & 5.8 & 0.11 & 0.69 & 0.20 & 0.25 \\
\hline
\end{tabular}

\begin{tabular}{|c|c|c|c|c|c|c|c|c|c|c|c|c|c|c|}
\hline Batch & 56 & 57 & 58 & 79 & 80 & 81 & $\mathbf{8 2}$ & 83 & 88 & Total Mass & Min & Max & Median & Mean \\
\hline Mass & 230 & 233 & 197 & 213 & 177 & 185 & 206 & 203 & 106 & 1749 & 106 & 233 & & \\
\hline $\mathrm{Ag}_{2} \mathrm{O}$ & 0.03 & 0.04 & 0.01 & 0.00 & 0.00 & 0.00 & 0.00 & 0.01 & 0.01 & 0.2 & 0.00 & 0.04 & 0.01 & 0.01 \\
\hline $\mathrm{Al}_{2} \mathrm{O}_{3}$ & 15.47 & 12.65 & 17.78 & 7.04 & 9.32 & 10.73 & 13.93 & 13.59 & 14.24 & 222.6 & 7.04 & 17.78 & 13.59 & 12.73 \\
\hline $\mathrm{Am}_{2} \mathrm{O}_{3}$ & 0.00 & 0.00 & 0.00 & 0.00 & 0.00 & 0.00 & 0.00 & 0.00 & 0.00 & 0.0 & 0.00 & 0.00 & 0.00 & 0.00 \\
\hline $\mathrm{As}_{2} \mathrm{O}_{5}$ & 0.06 & 0.02 & 0.03 & 0.02 & 0.02 & 0.01 & 0.01 & 0.02 & 0.04 & 0.4 & 0.01 & 0.06 & 0.02 & 0.03 \\
\hline $\mathrm{B}_{2} \mathrm{O}_{3}$ & 0.15 & 0.13 & 0.15 & 0.07 & 0.06 & 0.04 & 0.03 & 0.07 & 0.14 & 1.6 & 0.03 & 0.15 & 0.07 & 0.09 \\
\hline $\mathrm{BaO}$ & 0.65 & 0.73 & 0.13 & 0.05 & 0.09 & 0.03 & 0.03 & 0.04 & 0.02 & 3.9 & 0.02 & 0.73 & 0.05 & 0.22 \\
\hline $\mathrm{BeO}$ & 0.01 & 0.00 & 0.00 & 0.00 & 0.00 & 0.00 & 0.00 & 0.00 & 0.00 & 0.0 & 0.00 & 0.01 & 0.00 & 0.00 \\
\hline $\mathrm{Bi}_{2} \mathrm{O}_{3}$ & 9.03 & 12.77 & 13.63 & 14.49 & 13.33 & 15.80 & 11.19 & 9.96 & 7.05 & 211.6 & 7.05 & 15.80 & 12.77 & 12.10 \\
\hline $\mathrm{CaO}$ & 4.11 & 3.21 & 2.08 & 2.69 & 3.89 & 5.24 & 2.56 & 1.96 & 2.47 & 55.2 & 1.96 & 5.24 & 2.69 & 3.15 \\
\hline $\mathrm{CdO}$ & 0.06 & 0.08 & 0.01 & 0.00 & 0.01 & 0.00 & 0.00 & 0.15 & 0.00 & $\begin{array}{l}0.7 \\
\end{array}$ & 0.00 & 0.15 & 0.01 & 0.04 \\
\hline $\mathrm{Ce}_{2} \mathrm{O}_{3}$ & 0.05 & 0.01 & 0.02 & 0.02 & 0.03 & 0.02 & 0.01 & 0.01 & 0.03 & 0.4 & 0.01 & 0.05 & 0.02 & 0.02 \\
\hline $\mathrm{Cl}^{-}$ & 0.03 & 0.02 & 0.02 & 0.01 & 0.01 & 0.01 & 0.02 & 0.02 & 0.01 & 0.3 & 0.01 & 0.03 & 0.02 & 0.02 \\
\hline $\mathrm{Cm}_{2} \mathrm{O}_{3}$ & 0.00 & 0.00 & 0.00 & 0.00 & 0.00 & 0.00 & 0.00 & 0.00 & 0.00 & 0.0 & 0.00 & 0.00 & 0.00 & 0.00 \\
\hline $\mathrm{CoO}$ & 0.02 & 0.01 & 0.00 & 0.00 & 0.00 & 0.00 & 0.00 & 0.00 & 0.01 & 0.1 & 0.00 & 0.02 & 0.00 & 0.01 \\
\hline $\mathrm{Cr}_{2} \mathrm{O}_{3}$ & 1.26 & 0.82 & 1.20 & 0.50 & 0.51 & 0.81 & 0.60 & 0.54 & 0.51 & 13.5 & 0.50 & 1.26 & 0.60 & 0.77 \\
\hline $\mathrm{Cs}_{2} \mathrm{O}$ & 0.00 & 0.00 & 0.01 & 0.00 & 0.00 & 0.00 & 0.00 & 0.00 & 0.00 & 0.0 & 0.00 & 0.01 & 0.00 & 0.00 \\
\hline $\mathrm{CuO}$ & 0.11 & 0.14 & 0.03 & 0.01 & 0.01 & 0.00 & 0.00 & 0.00 & 0.00 & 0.7 & 0.00 & 0.14 & 0.01 & 0.04 \\
\hline $\mathrm{F}^{-}$ & 1.18 & 1.46 & 2.25 & 0.83 & 0.93 & 0.67 & 0.37 & 0.28 & 1.19 & 17.8 & 0.28 & 2.25 & 0.93 & 1.02 \\
\hline $\mathrm{Fe}_{2} \mathrm{O}_{3}$ & 21.88 & 24.66 & 16.14 & 25.42 & 22.63 & 17.79 & 20.73 & 22.05 & 20.81 & 376.0 & 16.14 & 25.42 & 21.88 & 21.50 \\
\hline
\end{tabular}

C - 3 


\begin{tabular}{|c|c|c|c|c|c|c|c|c|c|c|c|c|c|c|}
\hline Batch & 56 & 57 & 58 & 79 & 80 & 81 & 82 & 83 & 88 & Total Mass & Min & Max & Median & Mean \\
\hline Mass & 230 & 233 & 197 & 213 & 177 & 185 & 206 & 203 & 106 & 1749 & 106 & 233 & & \\
\hline $\mathrm{K}_{2} \mathrm{O}$ & 0.38 & 0.41 & 0.33 & 0.12 & 0.15 & 0.34 & 0.27 & 0.27 & 0.13 & 4.9 & 0.12 & 0.41 & 0.27 & 0.28 \\
\hline $\mathrm{La}_{2} \mathrm{O}_{3}$ & 1.03 & 1.46 & 1.01 & 0.31 & 0.69 & 2.04 & 1.84 & 1.71 & 0.46 & 21.2 & 0.31 & 2.04 & 1.03 & 1.21 \\
\hline $\mathrm{Li}_{2} \mathrm{O}$ & 0.02 & 0.01 & 0.01 & 0.00 & 0.00 & 0.00 & 0.00 & 0.00 & 0.00 & 0.1 & 0.00 & 0.02 & 0.00 & 0.01 \\
\hline $\mathrm{MgO}$ & 1.33 & 1.40 & 0.31 & 0.15 & 0.32 & 0.19 & 0.05 & 0.06 & 0.06 & 8.4 & 0.05 & 1.40 & 0.19 & 0.48 \\
\hline $\mathrm{MnO}$ & 2.76 & 3.23 & 2.75 & 1.04 & 1.90 & 4.32 & 3.71 & 3.49 & 1.51 & 49.2 & 1.04 & 4.32 & 2.76 & 2.81 \\
\hline $\mathrm{MoO}_{3}$ & 0.03 & 0.01 & 0.01 & 0.01 & 0.01 & 0.01 & 0.00 & 0.00 & 0.02 & 0.2 & 0.00 & 0.03 & 0.01 & 0.01 \\
\hline $\mathrm{Na}_{2} \mathrm{O}$ & 18.57 & 18.41 & 20.95 & 23.37 & 22.01 & 21.22 & 19.74 & 19.31 & 25.96 & 362.0 & 18.41 & 25.96 & 20.95 & 20.70 \\
\hline $\mathrm{Nb}_{2} \mathrm{O}_{5}$ & 0.00 & 0.00 & 0.00 & 0.00 & 0.00 & 0.00 & 0.00 & 0.00 & 0.00 & 0.0 & 0.00 & 0.00 & 0.00 & 0.00 \\
\hline $\mathrm{Nd}_{2} \mathrm{O}_{3}$ & 0.05 & 0.01 & 0.02 & 0.02 & 0.03 & 0.01 & 0.01 & 0.03 & 0.03 & 0.4 & 0.01 & 0.05 & 0.02 & 0.02 \\
\hline $\mathrm{NiO}$ & 1.18 & 0.75 & 1.10 & 0.55 & 1.07 & 0.36 & 0.18 & 0.27 & 0.28 & 11.6 & 0.18 & 1.18 & 0.55 & 0.66 \\
\hline $\mathrm{NpO}_{2}$ & 0.00 & 0.00 & 0.00 & 0.00 & 0.00 & 0.00 & 0.00 & 0.00 & 0.00 & 0.0 & 0.00 & 0.00 & 0.00 & 0.00 \\
\hline $\mathrm{P}_{2} \mathrm{O}_{5}$ & 3.85 & 4.35 & 4.99 & 5.81 & 4.15 & 3.48 & 4.40 & 3.90 & 6.05 & 78.3 & 3.48 & 6.05 & 4.35 & 4.48 \\
\hline $\mathrm{PbO}$ & 0.73 & 0.80 & 0.60 & 1.44 & 1.69 & 0.65 & 0.45 & 0.59 & 0.59 & 14.7 & 0.45 & 1.69 & 0.65 & 0.84 \\
\hline $\mathrm{PuO}_{2}$ & 0.02 & 0.02 & 0.01 & 0.00 & 0.01 & 0.01 & 0.00 & 0.00 & 0.00 & 0.2 & 0.00 & 0.02 & 0.01 & 0.01 \\
\hline $\mathrm{Rb}_{2} \mathrm{O}$ & 0.00 & 0.00 & 0.00 & 0.00 & 0.00 & 0.00 & 0.00 & 0.00 & 0.00 & 0.0 & 0.00 & 0.00 & 0.00 & 0.00 \\
\hline $\mathrm{Rh}_{2} \mathrm{O}_{3}$ & 0.00 & 0.00 & 0.00 & 0.00 & 0.00 & 0.00 & 0.00 & 0.00 & 0.00 & 0.0 & 0.00 & 0.00 & 0.00 & 0.00 \\
\hline $\mathrm{RuO}_{2}$ & 0.00 & 0.00 & 0.00 & 0.00 & 0.00 & 0.00 & 0.00 & 0.00 & 0.00 & 0.0 & 0.00 & 0.00 & 0.00 & 0.00 \\
\hline $\mathrm{Sb}_{2} \mathrm{O}_{3}$ & 0.02 & 0.01 & 0.01 & 0.01 & 0.01 & 0.00 & 0.00 & 0.01 & 0.02 & 0.2 & 0.00 & 0.02 & 0.01 & 0.01 \\
\hline $\mathrm{SeO}_{2}$ & 0.00 & 0.00 & 0.00 & 0.00 & 0.00 & 0.00 & 0.00 & 0.01 & 0.00 & 0.0 & 0.00 & 0.01 & 0.00 & 0.00 \\
\hline $\mathrm{SiO}_{2}$ & 8.75 & 7.09 & 7.87 & 10.96 & 9.77 & 8.89 & 15.47 & 17.93 & 8.58 & 186.5 & 7.09 & 17.93 & 8.89 & 10.66 \\
\hline $\mathrm{Sm}_{2} \mathrm{O}_{3}$ & 0.00 & 0.00 & 0.00 & 0.00 & 0.00 & 0.00 & 0.00 & 0.00 & 0.00 & 0.0 & 0.00 & 0.00 & 0.00 & 0.00 \\
\hline $\mathrm{SnO}_{2}$ & 0.00 & 0.00 & 0.00 & 0.00 & 0.00 & 0.00 & 0.00 & 0.00 & 0.00 & 0.0 & 0.00 & 0.00 & 0.00 & 0.00 \\
\hline $\mathrm{SO}_{3}$ & 0.11 & 0.11 & 0.13 & 0.17 & 0.08 & 0.05 & 0.14 & 0.21 & 0.13 & 2.2 & 0.05 & 0.21 & 0.13 & 0.13 \\
\hline $\mathrm{SrO}$ & 0.16 & 0.19 & 0.31 & 0.36 & 0.42 & 0.54 & 0.27 & 0.17 & 0.44 & 5.3 & 0.16 & 0.54 & 0.31 & 0.30 \\
\hline $\mathrm{TcO}_{2}$ & 0.01 & 0.00 & 0.02 & 0.00 & 0.00 & 0.00 & 0.00 & 0.01 & 0.00 & 0.1 & 0.00 & 0.02 & 0.00 & 0.01 \\
\hline $\mathrm{TeO}_{2}$ & 0.00 & 0.00 & 0.00 & 0.00 & 0.00 & 0.00 & 0.00 & 0.00 & 0.00 & 0.0 & 0.00 & 0.00 & 0.00 & 0.00 \\
\hline $\mathrm{ThO}_{2}$ & 0.05 & 0.05 & 0.13 & 0.04 & 0.03 & 0.02 & 0.04 & 0.07 & 0.06 & 0.9 & 0.02 & 0.13 & 0.05 & 0.05 \\
\hline $\mathrm{TiO}_{2}$ & 0.01 & 0.00 & 0.00 & 0.01 & 0.01 & 0.00 & 0.00 & 0.00 & 0.00 & 0.1 & 0.00 & 0.01 & 0.00 & 0.00 \\
\hline $\mathrm{Tl}_{2} \mathrm{O}$ & 0.08 & 0.02 & 0.03 & 0.03 & 0.02 & 0.02 & 0.01 & 0.02 & 0.06 & 0.5 & 0.01 & 0.08 & 0.02 & 0.03 \\
\hline $\mathrm{U}_{3} \mathrm{O}_{8}$ & 4.94 & 2.58 & 5.38 & 4.33 & 6.66 & 6.61 & 3.88 & 2.94 & 8.94 & 84.6 & 2.58 & 8.94 & 4.94 & 4.84 \\
\hline $\mathrm{V}_{2} \mathrm{O}_{5}$ & 0.03 & 0.01 & 0.01 & 0.01 & 0.01 & 0.01 & 0.01 & 0.01 & 0.02 & 0.2 & 0.01 & 0.03 & 0.01 & 0.01 \\
\hline $\mathrm{WO}_{3}$ & 0.00 & 0.00 & 0.00 & 0.00 & 0.00 & 0.00 & 0.00 & 0.00 & 0.00 & 0.0 & 0.00 & 0.00 & 0.00 & 0.00 \\
\hline $\mathrm{ZnO}$ & 0.07 & 0.08 & 0.07 & 0.01 & 0.01 & 0.00 & 0.00 & 0.00 & 0.00 & 0.5 & 0.00 & 0.08 & 0.01 & 0.03 \\
\hline $\mathrm{ZrO}_{2}$ & 1.73 & 2.22 & 0.47 & 0.07 & 0.10 & 0.07 & 0.04 & 0.26 & 0.09 & 11.2 & 0.04 & 2.22 & 0.10 & 0.64 \\
\hline
\end{tabular}




\begin{tabular}{|c|c|c|c|c|c|c|c|c|c|c|c|c|c|c|c|c|}
\hline batch & 35 & 36 & 37 & 39 & 40 & 41 & 42 & 43 & 44 & 45 & 89 & Total Mass & Min & Max & Median & Mean \\
\hline mass (Mg) & 136 & 204 & 222 & 182 & 174 & 139 & 122 & 155 & 125 & 137 & 49 & 1647 & 49 & 222 & & \\
\hline $\mathrm{Ag}_{2} \mathrm{O}$ & 0.01 & 0.05 & 0.08 & 0.07 & 0.07 & 0.03 & 0.01 & 0.04 & 0.03 & 0.03 & 0.09 & 0.8 & 0.01 & 0.09 & 0.04 & 0.05 \\
\hline $\mathrm{Al}_{2} \mathrm{O}_{3}$ & 27.66 & 18.52 & 13.85 & 16.70 & 13.56 & 19.04 & 23.04 & 19.31 & 29.59 & 25.00 & 13.05 & 322.7 & 13.05 & 29.59 & 19.04 & 19.59 \\
\hline $\mathrm{Am}_{2} \mathrm{O}_{3}$ & 0.00 & 0.00 & 0.00 & 0.00 & 0.00 & 0.00 & 0.00 & 0.00 & 0.00 & 0.00 & 0.00 & 0.0 & 0.00 & 0.00 & 0.00 & 0.00 \\
\hline $\mathrm{As}_{2} \mathrm{O}_{5}$ & 0.04 & 0.22 & 0.32 & 0.22 & 0.23 & 0.14 & 0.04 & 0.19 & 0.11 & 0.11 & 0.47 & 3.1 & 0.04 & 0.47 & 0.19 & 0.19 \\
\hline $\mathrm{B}_{2} \mathrm{O}_{3}$ & 0.71 & 0.58 & 0.59 & 0.51 & 0.47 & 0.31 & 0.16 & 0.47 & 0.57 & 0.48 & 0.67 & 8.3 & 0.16 & 0.71 & 0.51 & 0.50 \\
\hline $\mathrm{BaO}$ & 0.02 & 0.19 & 0.35 & 0.42 & 0.40 & 0.12 & 0.07 & 0.11 & 0.13 & 0.13 & 0.22 & 3.5 & 0.02 & 0.42 & 0.13 & 0.22 \\
\hline $\mathrm{BeO}$ & 0.00 & 0.02 & 0.03 & 0.02 & 0.02 & 0.01 & 0.00 & 0.02 & 0.01 & 0.01 & 0.05 & 0.3 & 0.00 & 0.05 & 0.02 & 0.02 \\
\hline $\mathrm{Bi}_{2} \mathrm{O}_{3}$ & 0.23 & 0.99 & 1.54 & 1.14 & 0.93 & 1.40 & 1.69 & 0.90 & 1.03 & 1.52 & 3.49 & 20.0 & 0.23 & 3.49 & 1.14 & 1.21 \\
\hline $\mathrm{CaO}$ & 1.49 & 2.01 & 2.81 & 2.76 & 2.15 & 2.28 & 2.66 & 1.87 & 1.78 & 2.82 & 1.32 & 37.2 & 1.32 & 2.82 & 2.15 & 2.26 \\
\hline $\mathrm{CdO}$ & 0.01 & 0.02 & 0.03 & 0.03 & 0.03 & 0.01 & 0.00 & 0.01 & 0.01 & 0.01 & 0.02 & 0.3 & 0.00 & 0.03 & 0.01 & 0.02 \\
\hline $\mathrm{Ce}_{2} \mathrm{O}_{3}$ & 0.03 & 0.22 & 0.36 & 0.35 & 0.35 & 0.15 & 0.06 & 0.17 & 0.13 & 0.13 & 0.38 & 3.6 & 0.03 & 0.38 & 0.17 & 0.22 \\
\hline $\mathrm{Cl}^{-}$ & 0.05 & 0.04 & 0.03 & 0.02 & 0.02 & 0.02 & 0.03 & 0.04 & 0.02 & 0.02 & 0.01 & 0.5 & 0.01 & 0.05 & 0.02 & 0.03 \\
\hline $\mathrm{Cm}_{2} \mathrm{O}_{3}$ & 0.00 & 0.00 & 0.00 & 0.00 & 0.00 & 0.00 & 0.00 & 0.00 & 0.00 & 0.00 & 0.00 & 0.0 & 0.00 & 0.00 & 0.00 & 0.00 \\
\hline $\mathrm{CoO}$ & 0.01 & 0.04 & 0.06 & 0.04 & 0.04 & 0.02 & 0.01 & 0.03 & 0.02 & 0.02 & 0.08 & 0.6 & 0.01 & 0.08 & 0.03 & 0.03 \\
\hline $\mathrm{Cr}_{2} \mathrm{O}_{3}$ & 2.42 & 1.42 & 1.07 & 1.19 & 0.92 & 1.91 & 2.54 & 2.41 & 2.41 & 2.02 & 0.30 & 27.8 & 0.30 & 2.54 & 1.91 & 1.69 \\
\hline $\mathrm{Cs}_{2} \mathrm{O}$ & 0.01 & 0.01 & 0.00 & 0.00 & 0.00 & 0.00 & 0.01 & 0.00 & 0.00 & 0.01 & 0.01 & 0.1 & 0.00 & 0.01 & 0.00 & 0.01 \\
\hline $\mathrm{CuO}$ & 0.01 & 0.03 & 0.06 & 0.06 & 0.06 & 0.02 & 0.01 & 0.02 & 0.02 & 0.02 & 0.04 & 0.6 & 0.01 & 0.06 & 0.02 & 0.03 \\
\hline $\mathrm{F}^{-}$ & 2.13 & 3.01 & 3.17 & 2.22 & 2.79 & 2.76 & 2.12 & 3.71 & 2.41 & 2.70 & 3.04 & 45.4 & 2.12 & 3.71 & 2.76 & 2.76 \\
\hline $\mathrm{Fe}_{2} \mathrm{O}_{3}$ & 5.66 & 5.80 & 7.35 & 7.13 & 6.10 & 8.07 & 10.27 & 7.48 & 7.22 & 8.51 & 8.49 & 119.8 & 5.66 & 10.27 & 7.35 & 7.27 \\
\hline $\mathrm{K}_{2} \mathrm{O}$ & 1.23 & 1.53 & 0.93 & 0.83 & 0.32 & 0.35 & 0.41 & 0.36 & 0.21 & 0.27 & 0.42 & 11.3 & 0.21 & 1.53 & 0.41 & 0.69 \\
\hline $\mathrm{La}_{2} \mathrm{O}_{3}$ & 0.07 & 0.14 & 0.17 & 0.14 & 0.15 & 0.08 & 0.03 & 0.11 & 0.10 & 0.07 & 0.26 & 1.9 & 0.03 & 0.26 & 0.11 & 0.12 \\
\hline $\mathrm{Li}_{2} \mathrm{O}$ & 0.22 & 0.11 & 0.08 & 0.07 & 0.06 & 0.04 & 0.02 & 0.07 & 0.11 & 0.07 & 0.06 & 1.4 & 0.02 & 0.22 & 0.07 & 0.08 \\
\hline $\mathrm{MgO}$ & 0.06 & 0.49 & 0.90 & 1.05 & 0.99 & 0.32 & 0.17 & 0.30 & 0.33 & 0.33 & 0.66 & 9.1 & 0.06 & 1.05 & 0.33 & 0.55 \\
\hline $\mathrm{MnO}$ & 1.29 & 0.94 & 0.79 & 1.25 & 1.56 & 2.10 & 2.75 & 2.12 & 1.56 & 1.78 & 0.50 & 24.6 & 0.50 & 2.75 & 1.56 & 1.50 \\
\hline $\mathrm{MoO}_{3}$ & 0.03 & 0.14 & 0.22 & 0.20 & 0.20 & 0.10 & 0.05 & 0.12 & 0.10 & 0.09 & 0.24 & 2.2 & 0.03 & 0.24 & 0.12 & 0.14 \\
\hline $\mathrm{Na}_{2} \mathrm{O}$ & 24.87 & 19.23 & 13.44 & 15.82 & 16.86 & 25.24 & 28.82 & 22.01 & 22.21 & 23.32 & 19.90 & 335.3 & 13.44 & 28.82 & 22.01 & 20.36 \\
\hline $\mathrm{Nb}_{2} \mathrm{O}_{5}$ & 0.00 & 0.00 & 0.00 & 0.00 & 0.00 & 0.00 & 0.00 & 0.00 & 0.00 & 0.00 & 0.00 & 0.0 & 0.00 & 0.00 & 0.00 & 0.00 \\
\hline $\mathrm{Nd}_{2} \mathrm{O}_{3}$ & 0.03 & 0.16 & 0.23 & 0.16 & 0.17 & 0.10 & 0.03 & 0.15 & 0.09 & 0.08 & 0.37 & 2.3 & 0.03 & 0.37 & 0.15 & 0.14 \\
\hline $\mathrm{NiO}$ & 0.91 & 1.12 & 1.84 & 2.19 & 1.88 & 1.50 & 1.70 & 1.06 & 1.32 & 1.84 & 0.65 & 25.2 & 0.65 & 2.19 & 1.50 & 1.53 \\
\hline $\mathrm{NpO}_{2}$ & 0.00 & 0.00 & 0.00 & 0.00 & 0.00 & 0.00 & 0.00 & 0.00 & 0.00 & 0.00 & 0.00 & 0.0 & 0.00 & 0.00 & 0.00 & 0.00 \\
\hline $\mathrm{P}_{2} \mathrm{O}_{5}$ & 1.48 & 2.06 & 2.68 & 2.32 & 1.89 & 4.45 & 5.39 & 2.81 & 2.54 & 3.51 & 1.99 & 45.8 & 1.48 & 5.39 & 2.54 & 2.78 \\
\hline $\mathrm{PbO}$ & 0.40 & 0.47 & 0.63 & 0.59 & 0.54 & 0.50 & 0.49 & 0.45 & 0.38 & 0.45 & 1.01 & 8.5 & 0.38 & 1.01 & 0.49 & 0.52 \\
\hline $\mathrm{PuO}_{2}$ & 0.01 & 0.01 & 0.01 & 0.02 & 0.02 & 0.01 & 0.01 & 0.01 & 0.01 & 0.01 & 0.00 & 0.2 & 0.00 & 0.02 & 0.01 & 0.01 \\
\hline $\mathrm{Rb}_{2} \mathrm{O}$ & 0.00 & 0.00 & 0.00 & 0.00 & 0.00 & 0.00 & 0.00 & 0.00 & 0.00 & 0.00 & 0.00 & 0.0 & 0.00 & 0.00 & 0.00 & 0.00 \\
\hline $\mathrm{Rh}_{2} \mathrm{O}_{3}$ & 0.00 & 0.06 & 0.09 & 0.06 & 0.07 & 0.04 & 0.01 & 0.05 & 0.02 & 0.02 & 0.15 & 0.8 & 0.00 & 0.15 & 0.05 & 0.05 \\
\hline $\mathrm{RuO}_{2}$ & 0.00 & 0.01 & 0.02 & 0.01 & 0.01 & 0.01 & 0.00 & 0.01 & 0.00 & 0.00 & 0.02 & 0.1 & 0.00 & 0.02 & 0.01 & 0.01 \\
\hline $\mathrm{Sb}_{2} \mathrm{O}_{3}$ & 0.02 & 0.11 & 0.16 & 0.10 & 0.12 & 0.07 & 0.01 & 0.10 & 0.05 & 0.05 & 0.26 & 1.5 & 0.01 & 0.26 & 0.10 & 0.09 \\
\hline
\end{tabular}




\begin{tabular}{|c|c|c|c|c|c|c|c|c|c|c|c|c|c|c|c|c|}
\hline batch & 35 & 36 & 37 & 39 & 40 & 41 & 42 & 43 & 44 & 45 & 89 & Total Mass & Min & Max & Median & Mean \\
\hline mass (Mg) & 136 & 204 & 222 & 182 & 174 & 139 & 122 & 155 & 125 & 137 & 49 & 1647 & \begin{tabular}{r|}
49 \\
\end{tabular} & 222 & & \\
\hline $\mathrm{SeO}_{2}$ & 0.01 & 0.03 & 0.04 & 0.03 & 0.04 & 0.02 & 0.01 & 0.03 & 0.01 & 0.01 & 0.07 & 0.4 & 0.01 & 0.07 & 0.03 & 0.03 \\
\hline $\mathrm{SiO}_{2}$ & 6.82 & 6.87 & 9.98 & 12.59 & 10.34 & 5.26 & 4.92 & 4.13 & 4.70 & 5.34 & 5.27 & 122.0 & 4.13 & 12.59 & 5.34 & 7.41 \\
\hline $\mathrm{Sm}_{2} \mathrm{O}_{3}$ & 0.00 & 0.00 & 0.00 & 0.00 & 0.00 & 0.00 & 0.00 & 0.00 & 0.00 & 0.00 & 0.00 & 0.0 & 0.00 & 0.00 & 0.00 & 0.00 \\
\hline $\mathrm{SnO}_{2}$ & 0.00 & 0.00 & 0.00 & 0.00 & 0.00 & 0.00 & 0.00 & 0.00 & 0.00 & 0.00 & 0.00 & 0.0 & 0.00 & 0.00 & 0.00 & 0.00 \\
\hline $\mathrm{SO}_{3}$ & 0.09 & 0.11 & 0.12 & 0.10 & 0.06 & 0.12 & 0.16 & 0.20 & 0.11 & 0.11 & 0.14 & 1.9 & 0.06 & 0.20 & 0.11 & 0.12 \\
\hline $\mathrm{SrO}$ & 0.19 & 0.13 & 0.14 & 0.11 & 0.18 & 0.78 & 1.04 & 0.66 & 0.59 & 0.80 & 0.14 & 6.6 & 0.11 & 1.04 & 0.19 & 0.40 \\
\hline $\mathrm{TcO}_{2}$ & 0.01 & 0.01 & 0.00 & 0.01 & 0.01 & 0.02 & 0.09 & 0.01 & 0.01 & 0.02 & 0.00 & 0.3 & 0.00 & 0.09 & 0.01 & 0.02 \\
\hline $\mathrm{TeO}_{2}$ & 0.00 & 0.02 & 0.04 & 0.02 & 0.03 & 0.02 & 0.00 & 0.02 & 0.01 & 0.01 & 0.07 & 0.3 & 0.00 & 0.07 & 0.02 & 0.02 \\
\hline $\mathrm{ThO}_{2}$ & 0.37 & 0.36 & 0.29 & 0.36 & 0.25 & 0.29 & 0.38 & 0.29 & 0.19 & 0.22 & 0.10 & 4.9 & 0.10 & 0.38 & 0.29 & 0.30 \\
\hline $\mathrm{TiO}_{2}$ & 0.01 & 0.03 & 0.04 & 0.03 & 0.03 & 0.02 & 0.00 & 0.02 & 0.01 & 0.01 & 0.05 & 0.4 & 0.00 & 0.05 & 0.02 & 0.02 \\
\hline $\mathrm{Tl}_{2} \mathrm{O}$ & 0.06 & 0.31 & 0.47 & 0.33 & 0.32 & 0.19 & 0.06 & 0.26 & 0.16 & 0.15 & 0.64 & 4.4 & 0.06 & 0.64 & 0.26 & 0.27 \\
\hline $\mathrm{U}_{3} \mathrm{O}_{8}$ & 10.07 & 11.76 & 12.13 & 10.59 & 11.76 & 9.84 & 7.88 & 11.09 & 10.52 & 10.64 & 9.32 & 177.3 & 7.88 & 12.13 & 10.59 & 10.77 \\
\hline $\mathrm{V}_{2} \mathrm{O}_{5}$ & 0.02 & 0.03 & 0.04 & 0.03 & 0.01 & 0.01 & 0.01 & 0.02 & 0.03 & 0.03 & 0.01 & 0.4 & 0.01 & 0.04 & 0.02 & 0.02 \\
\hline $\mathrm{WO}_{3}$ & 0.00 & 0.00 & 0.00 & 0.00 & 0.00 & 0.00 & 0.00 & 0.00 & 0.00 & 0.00 & 0.00 & 0.0 & 0.00 & 0.00 & 0.00 & 0.00 \\
\hline $\mathrm{ZnO}$ & 0.02 & 0.62 & 1.35 & 1.95 & 1.79 & 0.42 & 0.31 & 0.24 & 0.51 & 0.52 & 0.05 & 13.7 & 0.02 & 1.95 & 0.51 & 0.83 \\
\hline $\mathrm{ZrO}_{2}$ & 11.25 & 19.98 & 21.49 & 16.13 & 22.20 & 11.79 & 2.50 & 16.50 & 8.63 & 6.73 & 25.90 & 249.8 & 2.50 & 25.90 & 16.13 & 15.16 \\
\hline
\end{tabular}




\begin{tabular}{|c|c|c|c|c|c|c|c|c|c|c|c|c|c|}
\hline Batch & 38 & 46 & 47 & 54 & 55 & 63 & 64 & 68 & Total Mass & Min & Max & Median & Mean \\
\hline Mass & 169 & 147 & 162 & 216 & 207 & 150 & 145 & 199 & 1395 & 145 & 216 & & \\
\hline $\mathrm{Ag}_{2} \mathrm{O}$ & 0.06 & 0.02 & 0.02 & 0.02 & 0.02 & 0.00 & 0.00 & 0.00 & 0.3 & 0.00 & 0.06 & 0.02 & 0.02 \\
\hline $\mathrm{Al}_{2} \mathrm{O}_{3}$ & 20.06 & 18.11 & 12.25 & 16.03 & 15.59 & 25.96 & 21.45 & 20.34 & 257.8 & 12.25 & 25.96 & 19.09 & 18.48 \\
\hline $\mathrm{Am}_{2} \mathrm{O}_{3}$ & 0.00 & 0.00 & 0.00 & 0.00 & 0.00 & 0.00 & 0.00 & 0.00 & 0.0 & 0.00 & 0.00 & 0.00 & 0.00 \\
\hline $\mathrm{As}_{2} \mathrm{O}_{5}$ & 0.10 & 0.06 & 0.08 & 0.06 & 0.06 & 0.00 & 0.00 & 0.00 & 0.7 & 0.00 & 0.10 & 0.06 & 0.05 \\
\hline $\mathrm{B}_{2} \mathrm{O}_{3}$ & 0.47 & 0.28 & 0.37 & 0.12 & 0.12 & 0.01 & 0.01 & 0.00 & 2.3 & 0.00 & 0.47 & 0.12 & 0.17 \\
\hline $\mathrm{BaO}$ & 0.50 & 0.11 & 0.06 & 0.33 & 0.41 & 0.03 & 0.07 & 0.00 & 2.8 & 0.00 & 0.50 & 0.09 & 0.20 \\
\hline $\mathrm{BeO}$ & 0.01 & 0.01 & 0.01 & 0.01 & 0.01 & 0.00 & 0.00 & 0.00 & 0.1 & 0.00 & 0.01 & 0.01 & 0.00 \\
\hline $\mathrm{Bi}_{2} \mathrm{O}_{3}$ & 1.04 & 2.09 & 1.44 & 4.35 & 2.84 & 3.71 & 2.46 & 4.95 & 41.4 & 1.04 & 4.95 & 2.65 & 2.97 \\
\hline $\mathrm{CaO}$ & 3.60 & 5.07 & 4.98 & 6.26 & 6.84 & 5.86 & 3.71 & 6.83 & 77.0 & 3.60 & 6.84 & 5.46 & 5.52 \\
\hline $\mathrm{CdO}$ & 0.03 & 0.01 & 0.02 & 0.01 & 0.02 & 0.00 & 0.01 & 0.00 & 0.2 & 0.00 & 0.03 & 0.01 & 0.01 \\
\hline $\mathrm{Ce}_{2} \mathrm{O}_{3}$ & 0.31 & 0.09 & 0.08 & 0.05 & 0.05 & 0.00 & 0.00 & 0.00 & 1.0 & 0.00 & 0.31 & 0.05 & 0.07 \\
\hline $\mathrm{Cl}^{-}$ & 0.02 & 0.01 & 0.02 & 0.03 & 0.03 & 0.01 & 0.01 & 0.01 & 0.3 & 0.01 & 0.03 & 0.02 & 0.02 \\
\hline $\mathrm{Cm}_{2} \mathrm{O}_{3}$ & 0.00 & 0.00 & 0.00 & 0.00 & 0.00 & 0.00 & 0.00 & 0.00 & 0.0 & 0.00 & 0.00 & 0.00 & 0.00 \\
\hline $\mathrm{CoO}$ & 0.02 & 0.01 & 0.01 & 0.01 & 0.01 & 0.00 & 0.00 & 0.00 & 0.1 & 0.00 & 0.02 & 0.01 & 0.01 \\
\hline $\mathrm{Cr}_{2} \mathrm{O}_{3}$ & 1.05 & 1.29 & 1.68 & 1.21 & 1.23 & 1.47 & 2.40 & 0.52 & 18.2 & 0.52 & 2.40 & 1.26 & 1.31 \\
\hline $\mathrm{Cs}_{2} \mathrm{O}$ & 0.01 & 0.00 & 0.01 & 0.00 & 0.00 & 0.00 & 0.00 & 0.00 & 0.1 & 0.00 & 0.01 & 0.00 & 0.00 \\
\hline $\mathrm{CuO}$ & 0.07 & 0.02 & 0.01 & 0.03 & 0.03 & 0.01 & 0.01 & 0.00 & 0.3 & 0.00 & 0.07 & 0.01 & 0.02 \\
\hline $\mathrm{F}^{-}$ & 1.20 & 3.08 & 4.54 & 1.76 & 1.11 & 2.88 & 1.90 & 1.85 & 30.8 & 1.11 & 4.54 & 1.87 & 2.21 \\
\hline $\mathrm{Fe}_{2} \mathrm{O}_{3}$ & 7.82 & 12.27 & 12.06 & 15.94 & 15.90 & 12.51 & 12.78 & 16.28 & 187.8 & 7.82 & 16.28 & 12.64 & 13.46 \\
\hline $\mathrm{K}_{2} \mathrm{O}$ & 0.49 & 0.35 & 0.30 & 0.26 & 0.29 & 0.31 & 0.40 & 0.17 & 4.4 & 0.17 & 0.49 & 0.31 & 0.32 \\
\hline $\mathrm{La}_{2} \mathrm{O}_{3}$ & 0.10 & 0.02 & 0.01 & 0.09 & 0.11 & 0.07 & 0.13 & 0.06 & 1.1 & 0.01 & 0.13 & 0.08 & 0.08 \\
\hline $\mathrm{Li}_{2} \mathrm{O}$ & 0.11 & 0.03 & 0.03 & 0.02 & 0.02 & 0.00 & 0.00 & 0.00 & 0.3 & 0.00 & 0.11 & 0.02 & 0.02 \\
\hline $\mathrm{MgO}$ & 1.21 & 0.28 & 0.16 & 0.79 & 0.96 & 0.06 & 0.13 & 0.02 & 6.7 & 0.02 & 1.21 & 0.22 & 0.48 \\
\hline $\mathrm{MnO}$ & 1.40 & 1.95 & 1.16 & 1.22 & 1.32 & 1.73 & 2.70 & 1.22 & 21.4 & 1.16 & 2.70 & 1.36 & 1.53 \\
\hline $\mathrm{MoO}_{3}$ & 0.16 & 0.06 & 0.05 & 0.03 & 0.03 & 0.00 & 0.00 & 0.00 & 0.6 & 0.00 & 0.16 & 0.03 & 0.04 \\
\hline $\mathrm{Na}_{2} \mathrm{O}$ & 15.08 & 24.16 & 28.64 & 19.10 & 18.78 & 25.93 & 29.90 & 23.92 & 317.3 & 15.08 & 29.90 & 24.04 & 22.75 \\
\hline $\mathrm{Nb}_{2} \mathrm{O}_{5}$ & 0.00 & 0.00 & 0.00 & 0.00 & 0.00 & 0.00 & 0.00 & 0.00 & 0.0 & 0.00 & 0.00 & 0.00 & 0.00 \\
\hline $\mathrm{Nd}_{2} \mathrm{O}_{3}$ & 0.06 & 0.04 & 0.06 & 0.05 & 0.05 & 0.00 & 0.00 & 0.00 & 0.5 & 0.00 & 0.06 & 0.04 & 0.03 \\
\hline $\mathrm{NiO}$ & 3.31 & 3.10 & 2.87 & 2.13 & 2.40 & 2.51 & 3.70 & 1.58 & 36.6 & 1.58 & 3.70 & 2.69 & 2.63 \\
\hline $\mathrm{NpO}_{2}$ & 0.00 & 0.00 & 0.00 & 0.00 & 0.00 & 0.00 & 0.00 & 0.00 & 0.0 & 0.00 & 0.00 & 0.00 & 0.00 \\
\hline $\mathrm{P}_{2} \mathrm{O}_{5}$ & 2.43 & 5.02 & 6.05 & 4.26 & 3.98 & 2.52 & 2.85 & 3.27 & 53.1 & 2.43 & 6.05 & 3.62 & 3.81 \\
\hline $\mathrm{PbO}$ & 0.61 & 0.62 & 0.64 & 0.62 & 0.64 & 0.37 & 0.38 & 0.55 & 7.9 & 0.37 & 0.64 & 0.61 & 0.56 \\
\hline $\mathrm{PuO}_{2}$ & 0.02 & 0.01 & 0.00 & 0.01 & 0.01 & 0.01 & 0.01 & 0.00 & 0.1 & 0.00 & 0.02 & 0.01 & 0.01 \\
\hline $\mathrm{Rb}_{2} \mathrm{O}$ & 0.00 & 0.00 & 0.00 & 0.00 & 0.00 & 0.00 & 0.00 & 0.00 & 0.0 & 0.00 & 0.00 & 0.00 & 0.00 \\
\hline $\mathrm{Rh}_{2} \mathrm{O}_{3}$ & 0.03 & 0.00 & 0.00 & 0.00 & 0.00 & 0.00 & 0.00 & 0.00 & 0.1 & 0.00 & 0.03 & 0.00 & 0.00 \\
\hline $\mathrm{RuO}_{2}$ & 0.01 & 0.00 & 0.00 & 0.00 & 0.00 & 0.00 & 0.00 & 0.00 & 0.0 & 0.00 & 0.01 & 0.00 & 0.00 \\
\hline $\mathrm{Sb}_{2} \mathrm{O}_{3}$ & 0.03 & 0.02 & 0.03 & 0.03 & 0.03 & 0.00 & 0.00 & 0.00 & 0.2 & 0.00 & 0.03 & 0.02 & 0.02 \\
\hline
\end{tabular}

$$
\text { C }-7
$$




\begin{tabular}{|c|c|c|c|c|c|c|c|c|c|c|c|c|c|}
\hline Batch & 38 & 46 & 47 & 54 & 55 & 63 & 64 & 68 & Total Mass & Min & Max & Median & Mean \\
\hline Mass & 169 & 147 & 162 & 216 & 207 & 150 & 145 & 199 & 1395 & 145 & 216 & & \\
\hline $\mathrm{SeO}_{2}$ & 0.01 & 0.01 & 0.00 & 0.00 & 0.00 & 0.00 & 0.00 & 0.00 & 0.0 & 0.00 & 0.01 & 0.00 & 0.00 \\
\hline $\mathrm{SiO}_{2}$ & 13.95 & 5.92 & 3.97 & 13.13 & 14.98 & 5.97 & 4.27 & 9.74 & 132.6 & 3.97 & 14.98 & 7.86 & 9.51 \\
\hline $\mathrm{Sm}_{2} \mathrm{O}_{3}$ & 0.00 & 0.00 & 0.00 & 0.00 & 0.00 & 0.00 & 0.00 & 0.00 & 0.0 & 0.00 & 0.00 & 0.00 & 0.00 \\
\hline $\mathrm{SnO}_{2}$ & 0.00 & 0.00 & 0.00 & 0.00 & 0.00 & 0.00 & 0.00 & 0.00 & 0.0 & 0.00 & 0.00 & 0.00 & 0.00 \\
\hline $\mathrm{SO}_{3}$ & 0.06 & 0.10 & 0.22 & 0.15 & 0.13 & 0.08 & 0.06 & 0.18 & 1.7 & 0.06 & 0.22 & 0.12 & 0.12 \\
\hline $\mathrm{SrO}$ & 0.14 & 1.87 & 2.73 & 0.19 & 0.16 & 1.04 & 1.09 & 1.45 & 14.2 & 0.14 & 2.73 & 1.07 & 1.02 \\
\hline $\mathrm{TcO}_{2}$ & 0.02 & 0.01 & 0.03 & 0.00 & 0.00 & 0.02 & 0.01 & 0.00 & 0.2 & 0.00 & 0.03 & 0.01 & 0.01 \\
\hline $\mathrm{TeO}_{2}$ & 0.01 & 0.00 & 0.00 & 0.00 & 0.00 & 0.00 & 0.00 & 0.00 & 0.0 & 0.00 & 0.01 & 0.00 & 0.00 \\
\hline $\mathrm{ThO}_{2}$ & 0.24 & 0.30 & 0.40 & 0.04 & 0.04 & 0.25 & 0.45 & 0.07 & 2.8 & 0.04 & 0.45 & 0.24 & 0.20 \\
\hline $\mathrm{TiO}_{2}$ & 0.02 & 0.01 & 0.01 & 0.01 & 0.01 & 0.00 & 0.00 & 0.00 & 0.1 & 0.00 & 0.02 & 0.01 & 0.01 \\
\hline $\mathrm{Tl}_{2} \mathrm{O}$ & 0.20 & 0.08 & 0.10 & 0.08 & 0.08 & 0.00 & 0.00 & 0.00 & 1.0 & 0.00 & 0.20 & 0.08 & 0.07 \\
\hline $\mathrm{U}_{3} \mathrm{O}_{8}$ & 9.91 & 12.03 & 14.11 & 11.14 & 11.21 & 6.46 & 8.80 & 6.71 & 140.4 & 6.46 & 14.11 & 10.52 & 10.06 \\
\hline $\mathrm{V}_{2} \mathrm{O}_{5}$ & 0.02 & 0.03 & 0.05 & 0.03 & 0.04 & 0.00 & 0.00 & 0.00 & 0.3 & 0.00 & 0.05 & 0.03 & 0.02 \\
\hline $\mathrm{WO}_{3}$ & 0.00 & 0.00 & 0.00 & 0.00 & 0.00 & 0.00 & 0.00 & 0.00 & 0.0 & 0.00 & 0.00 & 0.00 & 0.00 \\
\hline $\mathrm{ZnO}$ & 2.62 & 0.51 & 0.18 & 0.04 & 0.04 & 0.00 & 0.01 & 0.00 & 5.7 & 0.00 & 2.62 & 0.04 & 0.41 \\
\hline $\mathrm{ZrO}_{2}$ & 11.39 & 0.93 & 0.54 & 0.37 & 0.44 & 0.20 & 0.30 & 0.24 & 24.4 & 0.20 & 11.39 & 0.41 & 1.75 \\
\hline
\end{tabular}




\begin{tabular}{|c|c|c|c|c|c|c|c|c|c|c|c|c|}
\hline Batch & 51 & 52 & 53 & 61 & 62 & 66 & 67 & Total Mass & Min & Max & Median & Mean \\
\hline Mass & 203 & 181 & 199 & 176 & 187 & 219 & 220 & 1384 & 176 & $\begin{array}{r}220 \\
\end{array}$ & & \\
\hline $\mathrm{Ag}_{2} \mathrm{O}$ & 0.07 & 0.01 & 0.01 & 0.00 & 0.00 & 0.00 & 0.00 & 0.2 & 0.00 & 0.07 & 0.00 & 0.01 \\
\hline $\mathrm{Al}_{2} \mathrm{O}_{3}$ & 22.86 & 19.56 & 16.42 & 15.11 & 17.91 & 16.80 & 15.63 & 245.6 & 15.11 & 22.86 & 16.80 & 17.74 \\
\hline $\mathrm{Am}_{2} \mathrm{O}_{3}$ & 0.00 & 0.00 & 0.00 & 0.00 & 0.00 & 0.00 & 0.00 & 0.0 & 0.00 & 0.00 & 0.00 & 0.00 \\
\hline $\mathrm{As}_{2} \mathrm{O}_{5}$ & 0.07 & 0.02 & 0.01 & 0.00 & 0.01 & 0.00 & 0.00 & 0.2 & 0.00 & 0.07 & 0.01 & 0.02 \\
\hline $\mathrm{B}_{2} \mathrm{O}_{3}$ & 0.57 & 0.07 & 0.07 & 0.03 & 0.03 & 0.00 & 0.00 & 1.5 & 0.00 & 0.57 & 0.03 & 0.11 \\
\hline $\mathrm{BaO}$ & 0.04 & 0.03 & 0.02 & 0.03 & 0.02 & 0.01 & 0.01 & 0.3 & 0.01 & 0.04 & 0.02 & 0.02 \\
\hline $\mathrm{BeO}$ & 0.01 & 0.00 & 0.00 & 0.00 & 0.00 & 0.00 & 0.00 & 0.0 & 0.00 & 0.01 & 0.00 & 0.00 \\
\hline $\mathrm{Bi}_{2} \mathrm{O}_{3}$ & 7.77 & 8.42 & 10.69 & 11.63 & 12.88 & 8.45 & 7.79 & 132.4 & 7.77 & 12.88 & 8.45 & 9.56 \\
\hline $\mathrm{CaO}$ & 1.67 & 2.83 & 3.62 & 3.23 & 4.18 & 3.72 & 4.21 & 46.6 & 1.67 & 4.21 & 3.62 & 3.37 \\
\hline $\mathrm{CdO}$ & 0.01 & 0.00 & 0.00 & 0.00 & 0.00 & 0.00 & 0.00 & 0.0 & 0.00 & 0.01 & 0.00 & 0.00 \\
\hline $\mathrm{Ce}_{2} \mathrm{O}_{3}$ & 0.07 & 0.02 & 0.01 & 0.00 & 0.00 & 0.00 & 0.00 & 0.2 & 0.00 & 0.07 & 0.00 & 0.02 \\
\hline $\mathrm{Cl}^{-}$ & 0.01 & 0.01 & 0.01 & 0.01 & 0.01 & 0.02 & 0.01 & 0.2 & 0.01 & 0.02 & 0.01 & 0.01 \\
\hline $\mathrm{Cm}_{2} \mathrm{O}_{3}$ & 0.00 & 0.00 & 0.00 & 0.00 & 0.00 & 0.00 & 0.00 & 0.0 & 0.00 & 0.00 & 0.00 & 0.00 \\
\hline $\mathrm{CoO}$ & 0.01 & 0.00 & 0.00 & 0.00 & 0.00 & 0.00 & 0.00 & 0.0 & 0.00 & 0.01 & 0.00 & 0.00 \\
\hline $\mathrm{Cr}_{2} \mathrm{O}_{3}$ & 1.24 & 1.19 & 0.73 & 1.24 & 0.86 & 0.65 & 0.48 & 12.4 & 0.48 & 1.24 & 0.86 & 0.89 \\
\hline $\mathrm{Cs}_{2} \mathrm{O}$ & 0.00 & 0.00 & 0.00 & 0.00 & 0.00 & 0.00 & 0.00 & 0.0 & 0.00 & 0.00 & 0.00 & 0.00 \\
\hline $\mathrm{CuO}$ & 0.03 & 0.02 & 0.02 & 0.00 & 0.00 & 0.00 & 0.00 & 0.1 & 0.00 & 0.03 & 0.00 & 0.01 \\
\hline $\mathrm{F}^{-}$ & 4.06 & 5.18 & 5.09 & 2.85 & 3.46 & 2.79 & 2.37 & 50.5 & 2.37 & 5.18 & 3.46 & 3.65 \\
\hline $\mathrm{Fe}_{2} \mathrm{O}_{3}$ & 10.47 & 12.07 & 14.99 & 16.27 & 16.13 & 23.21 & 25.72 & 239.1 & 10.47 & 25.72 & 16.13 & 17.27 \\
\hline $\mathrm{K}_{2} \mathrm{O}$ & 0.17 & 0.21 & 0.15 & 0.35 & 0.30 & 0.17 & 0.14 & 2.9 & 0.14 & 0.35 & 0.17 & 0.21 \\
\hline $\mathrm{La}_{2} \mathrm{O}_{3}$ & 0.04 & 0.02 & 0.03 & 0.73 & 0.95 & 0.14 & 0.14 & 3.9 & 0.02 & 0.95 & 0.14 & 0.28 \\
\hline $\mathrm{Li}_{2} \mathrm{O}$ & 0.11 & 0.01 & 0.01 & 0.00 & 0.00 & 0.00 & 0.00 & 0.3 & 0.00 & 0.11 & 0.00 & 0.02 \\
\hline $\mathrm{MgO}$ & 1.07 & 0.16 & 0.11 & 0.06 & 0.05 & 0.02 & 0.01 & 3.0 & 0.01 & 1.07 & 0.06 & 0.21 \\
\hline $\mathrm{MnO}$ & 1.18 & 0.75 & 0.58 & 2.12 & 2.40 & 1.14 & 1.45 & 18.8 & 0.58 & 2.40 & 1.18 & 1.36 \\
\hline $\mathrm{MoO}_{3}$ & 0.03 & 0.01 & 0.01 & 0.00 & 0.00 & 0.00 & 0.00 & 0.1 & 0.00 & 0.03 & 0.00 & 0.01 \\
\hline $\mathrm{Na}_{2} \mathrm{O}$ & 22.43 & 20.47 & 19.93 & 22.81 & 20.22 & 21.78 & 20.96 & 293.9 & 19.93 & 22.81 & 20.96 & 21.23 \\
\hline $\mathrm{Nb}_{2} \mathrm{O}_{5}$ & 0.00 & 0.00 & 0.00 & 0.00 & 0.00 & 0.00 & 0.00 & 0.0 & 0.00 & 0.00 & 0.00 & 0.00 \\
\hline $\mathrm{Nd}_{2} \mathrm{O}_{3}$ & 0.05 & 0.01 & 0.01 & 0.00 & 0.00 & 0.00 & 0.00 & 0.1 & 0.00 & 0.05 & 0.00 & 0.01 \\
\hline $\mathrm{NiO}$ & 0.50 & 0.89 & 1.01 & 2.32 & 1.55 & 2.11 & 1.88 & 20.4 & 0.50 & 2.32 & 1.55 & 1.47 \\
\hline $\mathrm{NpO}_{2}$ & 0.00 & 0.00 & 0.00 & 0.00 & 0.00 & 0.00 & 0.00 & 0.0 & 0.00 & 0.00 & 0.00 & 0.00 \\
\hline $\mathrm{P}_{2} \mathrm{O}_{5}$ & 6.59 & 3.97 & 4.77 & 3.95 & 3.39 & 4.00 & 3.49 & 59.7 & 3.39 & 6.59 & 3.97 & 4.32 \\
\hline $\mathrm{PbO}$ & 0.68 & 0.76 & 0.66 & 0.59 & 0.62 & 0.69 & 0.82 & 9.6 & 0.59 & 0.82 & 0.68 & 0.69 \\
\hline $\mathrm{PuO}_{2}$ & 0.01 & 0.00 & 0.00 & 0.01 & 0.01 & 0.01 & 0.01 & 0.1 & 0.00 & 0.01 & 0.01 & 0.01 \\
\hline $\mathrm{Rb}_{2} \mathrm{O}$ & 0.00 & 0.00 & 0.00 & 0.00 & 0.00 & 0.00 & 0.00 & 0.0 & 0.00 & 0.00 & 0.00 & 0.00 \\
\hline $\mathrm{Rh}_{2} \mathrm{O}_{3}$ & 0.00 & 0.00 & 0.00 & 0.00 & 0.00 & 0.00 & 0.00 & 0.0 & 0.00 & 0.00 & 0.00 & 0.00 \\
\hline $\mathrm{RuO}_{2}$ & 0.00 & 0.00 & 0.00 & 0.00 & 0.00 & 0.00 & 0.00 & 0.0 & 0.00 & 0.00 & 0.00 & 0.00 \\
\hline $\mathrm{Sb}_{2} \mathrm{O}_{3}$ & 0.02 & 0.01 & 0.00 & 0.00 & 0.00 & 0.00 & 0.00 & 0.1 & 0.00 & 0.02 & 0.00 & 0.01 \\
\hline
\end{tabular}

$$
\text { C - } 9
$$




\begin{tabular}{|c|c|c|c|c|c|c|c|c|c|c|c|c|}
\hline Batch & 51 & 52 & 53 & 61 & 62 & 66 & 67 & Total Mass & Min & Max & Median & Mean \\
\hline Mass & 203 & 181 & 199 & 176 & 187 & 219 & 220 & \begin{tabular}{r|}
1384 \\
\end{tabular} & 176 & 220 & & \\
\hline $\mathrm{SeO}_{2}$ & 0.00 & 0.00 & 0.00 & 0.00 & 0.00 & 0.00 & 0.00 & 0.0 & 0.00 & 0.00 & 0.00 & 0.00 \\
\hline $\mathrm{SiO}_{2}$ & 8.14 & 11.62 & 9.18 & 7.77 & 6.87 & 7.92 & 8.22 & 117.7 & 6.87 & 11.62 & 8.14 & 8.50 \\
\hline $\mathrm{Sm}_{2} \mathrm{O}_{3}$ & 0.00 & 0.00 & 0.00 & 0.00 & 0.00 & 0.00 & 0.00 & 0.0 & 0.00 & 0.00 & 0.00 & 0.00 \\
\hline $\mathrm{SnO}_{2}$ & 0.00 & 0.00 & 0.00 & 0.00 & 0.00 & 0.00 & 0.00 & 0.0 & 0.00 & 0.00 & 0.00 & 0.00 \\
\hline $\mathrm{SO}_{3}$ & 0.18 & 0.18 & 0.18 & 0.15 & 0.17 & 0.32 & 0.25 & 2.9 & 0.15 & 0.32 & 0.18 & 0.21 \\
\hline $\mathrm{SrO}$ & 0.39 & 0.87 & 0.52 & 0.64 & 0.62 & 0.50 & 0.49 & 7.8 & 0.39 & 0.87 & 0.52 & 0.57 \\
\hline $\mathrm{TcO}_{2}$ & 0.01 & 0.00 & 0.00 & 0.00 & 0.00 & 0.00 & 0.00 & 0.1 & 0.00 & 0.01 & 0.00 & 0.00 \\
\hline $\mathrm{TeO}_{2}$ & 0.00 & 0.00 & 0.00 & 0.00 & 0.00 & 0.00 & 0.00 & 0.0 & 0.00 & 0.00 & 0.00 & 0.00 \\
\hline $\mathrm{ThO}_{2}$ & 0.14 & 0.10 & 0.06 & 0.25 & 0.10 & 0.17 & 0.11 & 1.8 & 0.06 & 0.25 & 0.11 & 0.13 \\
\hline $\mathrm{TiO}_{2}$ & 0.01 & 0.00 & 0.00 & 0.00 & 0.00 & 0.00 & 0.00 & 0.0 & 0.00 & 0.01 & 0.00 & 0.00 \\
\hline $\mathrm{Tl}_{2} \mathrm{O}$ & 0.05 & 0.02 & 0.01 & 0.01 & 0.01 & 0.00 & 0.00 & 0.2 & 0.00 & 0.05 & 0.01 & 0.01 \\
\hline $\mathrm{U}_{3} \mathrm{O}_{8}$ & 8.88 & 10.20 & 10.88 & 7.64 & 7.05 & 5.02 & 5.34 & 107.5 & 5.02 & 10.88 & 7.64 & 7.76 \\
\hline $\mathrm{V}_{2} \mathrm{O}_{5}$ & 0.03 & 0.01 & 0.01 & 0.00 & 0.00 & 0.00 & 0.00 & 0.1 & 0.00 & 0.03 & 0.00 & 0.01 \\
\hline $\mathrm{WO}_{3}$ & 0.00 & 0.00 & 0.00 & 0.00 & 0.00 & 0.00 & 0.00 & 0.0 & 0.00 & 0.00 & 0.00 & 0.00 \\
\hline $\mathrm{ZnO}$ & 0.13 & 0.03 & 0.03 & 0.01 & 0.01 & 0.00 & 0.00 & 0.4 & 0.00 & 0.13 & 0.01 & 0.03 \\
\hline $\mathrm{ZrO}_{2}$ & 0.21 & 0.27 & 0.18 & 0.16 & 0.14 & 0.36 & 0.46 & 3.6 & 0.14 & 0.46 & 0.21 & 0.26 \\
\hline
\end{tabular}

\begin{tabular}{|c|c|c|c|c|c|c|c|c|c|c|}
\hline Batch & 59 & 60 & 65 & 86 & 87 & Total Mass & Min & Max & Median & Mean \\
\hline Mass & 160 & 164 & 180 & 236 & 207 & 947 & 160 & 236 & & \\
\hline $\mathrm{Ag}_{2} \mathrm{O}$ & 0.00 & 0.00 & 0.00 & 0.04 & 0.03 & 0.2 & 0.00 & 0.04 & 0.00 & 0.02 \\
\hline $\mathrm{Al}_{2} \mathrm{O}_{3}$ & 22.03 & 19.67 & 34.82 & 31.50 & 25.79 & 257.7 & 19.67 & 34.82 & 25.79 & 27.23 \\
\hline $\mathrm{Am}_{2} \mathrm{O}_{3}$ & 0.00 & 0.00 & 0.00 & 0.00 & 0.00 & 0.0 & 0.00 & 0.00 & 0.00 & 0.00 \\
\hline $\mathrm{As}_{2} \mathrm{O}_{5}$ & 0.00 & 0.00 & 0.00 & 0.29 & 0.27 & 1.3 & 0.00 & 0.29 & 0.00 & 0.13 \\
\hline $\mathrm{B}_{2} \mathrm{O}_{3}$ & 0.01 & 0.02 & 0.00 & 0.47 & 0.47 & 2.1 & 0.00 & 0.47 & 0.02 & 0.23 \\
\hline $\mathrm{BaO}$ & 0.00 & 0.01 & 0.01 & 0.17 & 0.14 & 0.7 & 0.00 & 0.17 & 0.01 & 0.08 \\
\hline $\mathrm{BeO}$ & 0.00 & 0.00 & 0.00 & 0.03 & 0.02 & 0.1 & 0.00 & 0.03 & 0.00 & 0.01 \\
\hline $\mathrm{Bi}_{2} \mathrm{O}_{3}$ & 8.09 & 9.59 & 5.75 & 3.67 & 5.31 & 58.7 & 3.67 & 9.59 & 5.75 & 6.20 \\
\hline $\mathrm{CaO}$ & 2.14 & 2.23 & 2.94 & 1.65 & 2.34 & 21.1 & 1.65 & 2.94 & 2.23 & 2.23 \\
\hline $\mathrm{CdO}$ & 0.00 & 0.00 & 0.00 & 0.04 & 0.02 & 0.1 & 0.00 & 0.04 & 0.00 & 0.02 \\
\hline $\mathrm{Ce}_{2} \mathrm{O}_{3}$ & 0.00 & 0.00 & 0.00 & 0.22 & 0.21 & 1.0 & 0.00 & 0.22 & 0.00 & 0.10 \\
\hline $\mathrm{Cl}^{-}$ & 0.01 & 0.01 & 0.01 & 0.05 & 0.03 & 0.2 & 0.01 & 0.05 & 0.01 & 0.02 \\
\hline $\mathrm{Cm}_{2} \mathrm{O}_{3}$ & 0.00 & 0.00 & 0.00 & 0.00 & 0.00 & 0.0 & 0.00 & 0.00 & 0.00 & 0.00 \\
\hline $\mathrm{CoO}$ & 0.00 & 0.00 & 0.00 & 0.05 & 0.05 & 0.2 & 0.00 & 0.05 & 0.00 & 0.02 \\
\hline $\mathrm{Cr}_{2} \mathrm{O}_{3}$ & 1.54 & 1.44 & 1.15 & 1.07 & 1.67 & 12.9 & 1.07 & 1.67 & 1.44 & 1.36 \\
\hline $\mathrm{Cs}_{2} \mathrm{O}$ & 0.00 & 0.00 & 0.00 & 0.02 & 0.02 & 0.1 & 0.00 & 0.02 & 0.00 & 0.01 \\
\hline $\mathrm{CuO}$ & 0.00 & 0.00 & 0.00 & 0.03 & 0.03 & 0.1 & 0.00 & 0.03 & 0.00 & 0.01 \\
\hline $\mathrm{F}^{-}$ & 1.88 & 2.12 & 0.81 & 0.55 & 1.01 & 11.3 & 0.55 & 2.12 & 1.01 & 1.20 \\
\hline
\end{tabular}

C -10 


\begin{tabular}{|c|c|c|c|c|c|c|c|c|c|c|}
\hline Batch & 59 & 60 & 65 & 86 & 87 & Total Mass & Min & Max & Median & Mean \\
\hline Mass & 160 & 164 & 180 & 236 & 207 & 947 & \begin{tabular}{|r|}
160 \\
\end{tabular} & 236 & & \\
\hline $\mathrm{Fe}_{2} \mathrm{O}_{3}$ & 13.30 & 14.26 & 11.54 & 10.27 & 11.84 & 114.1 & 10.27 & 14.26 & 11.84 & 12.06 \\
\hline $\mathrm{K}_{2} \mathrm{O}$ & 0.38 & 0.37 & 0.15 & 2.63 & 2.03 & 11.9 & 0.15 & 2.63 & 0.38 & 1.26 \\
\hline $\mathrm{La}_{2} \mathrm{O}_{3}$ & 0.23 & 0.40 & 0.07 & 1.00 & 1.03 & 5.6 & 0.07 & 1.03 & 0.40 & 0.60 \\
\hline $\mathrm{Li}_{2} \mathrm{O}$ & 0.00 & 0.00 & 0.00 & 0.04 & 0.04 & 0.2 & 0.00 & 0.04 & 0.00 & 0.02 \\
\hline $\mathrm{MgO}$ & 0.01 & 0.02 & 0.02 & 0.60 & 0.56 & 2.7 & 0.01 & 0.60 & 0.02 & 0.28 \\
\hline $\mathrm{MnO}$ & 1.63 & 1.77 & 2.59 & 2.58 & 2.56 & 21.6 & 1.63 & 2.59 & 2.56 & 2.28 \\
\hline $\mathrm{MoO}_{3}$ & 0.00 & 0.00 & 0.00 & 0.15 & 0.14 & 0.7 & 0.00 & 0.15 & 0.00 & 0.07 \\
\hline $\mathrm{Na}_{2} \mathrm{O}$ & 23.57 & 23.12 & 20.96 & 23.53 & 22.90 & 216.2 & 20.96 & 23.57 & 23.12 & 22.84 \\
\hline $\mathrm{Nb}_{2} \mathrm{O}_{5}$ & 0.00 & 0.00 & 0.00 & 0.00 & 0.00 & 0.0 & 0.00 & 0.00 & 0.00 & 0.00 \\
\hline $\mathrm{Nd}_{2} \mathrm{O}_{3}$ & 0.00 & 0.00 & 0.00 & 0.21 & 0.20 & 0.9 & 0.00 & 0.21 & 0.00 & 0.10 \\
\hline $\mathrm{NiO}$ & 2.31 & 2.27 & 2.09 & 2.02 & 2.25 & 20.6 & 2.02 & 2.31 & 2.25 & 2.18 \\
\hline $\mathrm{NpO}_{2}$ & 0.00 & 0.00 & 0.00 & 0.00 & 0.00 & 0.0 & 0.00 & 0.00 & 0.00 & 0.00 \\
\hline $\mathrm{P}_{2} \mathrm{O}_{5}$ & 3.18 & 3.42 & 2.62 & 1.88 & 3.76 & 27.6 & 1.88 & 3.76 & 3.18 & 2.92 \\
\hline $\mathrm{PbO}$ & 0.50 & 0.54 & 0.36 & 0.34 & 0.49 & 4.1 & 0.34 & 0.54 & 0.49 & 0.44 \\
\hline $\mathrm{PuO}_{2}$ & 0.01 & 0.01 & 0.01 & 0.00 & 0.01 & 0.1 & 0.00 & 0.01 & 0.01 & 0.01 \\
\hline $\mathrm{Rb}_{2} \mathrm{O}$ & 0.00 & 0.00 & 0.00 & 0.00 & 0.00 & 0.0 & 0.00 & 0.00 & 0.00 & 0.00 \\
\hline $\mathrm{Rh}_{2} \mathrm{O}_{3}$ & 0.00 & 0.00 & 0.00 & 0.00 & 0.01 & 0.0 & 0.00 & 0.01 & 0.00 & 0.00 \\
\hline $\mathrm{RuO}_{2}$ & 0.00 & 0.00 & 0.00 & 0.00 & 0.00 & 0.0 & 0.00 & 0.00 & 0.00 & 0.00 \\
\hline $\mathrm{Sb}_{2} \mathrm{O}_{3}$ & 0.00 & 0.00 & 0.00 & 0.14 & 0.13 & 0.6 & 0.00 & 0.14 & 0.00 & 0.07 \\
\hline $\mathrm{SeO}_{2}$ & 0.00 & 0.00 & 0.00 & 0.03 & 0.02 & 0.1 & 0.00 & 0.03 & 0.00 & 0.01 \\
\hline $\mathrm{SiO}_{2}$ & 10.17 & 9.71 & 6.13 & 9.41 & 5.16 & 76.1 & 5.16 & 10.17 & 9.41 & 8.04 \\
\hline $\mathrm{Sm}_{2} \mathrm{O}_{3}$ & 0.00 & 0.00 & 0.00 & 0.00 & 0.00 & 0.0 & 0.00 & 0.00 & 0.00 & 0.00 \\
\hline $\mathrm{SnO}_{2}$ & 0.00 & 0.00 & 0.00 & 0.00 & 0.00 & 0.0 & 0.00 & 0.00 & 0.00 & 0.00 \\
\hline $\mathrm{SO}_{3}$ & 0.08 & 0.09 & 0.03 & 0.42 & 0.37 & 2.1 & 0.03 & 0.42 & 0.09 & 0.22 \\
\hline $\mathrm{SrO}$ & 0.47 & 0.48 & 0.68 & 0.16 & 0.22 & 3.6 & 0.16 & 0.68 & 0.47 & 0.38 \\
\hline $\mathrm{TcO}_{2}$ & 0.00 & 0.01 & 0.01 & 0.00 & 0.00 & 0.1 & 0.00 & 0.01 & 0.00 & 0.01 \\
\hline $\mathrm{TeO}_{2}$ & 0.00 & 0.00 & 0.00 & 0.00 & 0.00 & 0.0 & 0.00 & 0.00 & 0.00 & 0.00 \\
\hline $\mathrm{ThO}_{2}$ & 0.27 & 0.26 & 0.13 & 0.36 & 0.39 & 2.7 & 0.13 & 0.39 & 0.27 & 0.29 \\
\hline $\mathrm{TiO}_{2}$ & 0.00 & 0.00 & 0.00 & 0.03 & 0.03 & 0.1 & 0.00 & 0.03 & 0.00 & 0.02 \\
\hline $\mathrm{Tl}_{2} \mathrm{O}$ & 0.00 & 0.00 & 0.00 & 0.45 & 0.40 & 1.9 & 0.00 & 0.45 & 0.00 & 0.20 \\
\hline $\mathrm{U}_{3} \mathrm{O}_{8}$ & 8.06 & 8.04 & 6.95 & 3.42 & 6.62 & 60.3 & 3.42 & 8.06 & 6.95 & 6.37 \\
\hline $\mathrm{V}_{2} \mathrm{O}_{5}$ & 0.00 & 0.00 & 0.00 & 0.16 & 0.14 & 0.7 & 0.00 & 0.16 & 0.00 & 0.07 \\
\hline $\mathrm{WO}_{3}$ & 0.00 & 0.00 & 0.00 & 0.00 & 0.00 & 0.0 & 0.00 & 0.00 & 0.00 & 0.00 \\
\hline $\mathrm{ZnO}$ & 0.00 & 0.01 & 0.00 & 0.05 & 0.05 & 0.2 & 0.00 & 0.05 & 0.01 & 0.03 \\
\hline $\mathrm{ZrO}_{2}$ & 0.12 & 0.12 & 0.17 & 0.22 & 1.23 & 3.7 & 0.12 & 1.23 & 0.17 & 0.40 \\
\hline
\end{tabular}

C - 11 


\begin{tabular}{|c|c|c|c|c|c|c|c|c|c|}
\hline Batch & 31 & 32 & 33 & 34 & Total Mass & Min & Max & Median & Mean \\
\hline Mass & 196 & 173 & 158 & 151 & 678 & 151 & 196 & & \\
\hline $\mathrm{Ag}_{2} \mathrm{O}$ & 0.03 & 0.00 & 0.00 & 0.01 & 0.1 & 0.00 & 0.03 & 0.01 & 0.01 \\
\hline $\mathrm{Al}_{2} \mathrm{O}_{3}$ & 20.87 & 12.98 & 16.64 & 21.78 & 122.4 & 12.98 & 21.78 & 18.76 & 18.07 \\
\hline $\mathrm{Am}_{2} \mathrm{O}_{3}$ & 0.00 & 0.00 & 0.00 & 0.00 & 0.0 & 0.00 & 0.00 & 0.00 & 0.00 \\
\hline $\mathrm{As}_{2} \mathrm{O}_{5}$ & 0.06 & 0.00 & 0.02 & 0.03 & 0.2 & 0.00 & 0.06 & 0.02 & 0.03 \\
\hline $\mathrm{B}_{2} \mathrm{O}_{3}$ & 0.46 & 0.05 & 0.10 & 0.44 & 1.8 & 0.05 & 0.46 & 0.27 & 0.27 \\
\hline $\mathrm{BaO}$ & 0.06 & 0.01 & 0.01 & 0.01 & 0.2 & 0.01 & 0.06 & 0.01 & 0.03 \\
\hline $\mathrm{BeO}$ & 0.01 & 0.00 & 0.00 & 0.00 & 0.0 & 0.00 & 0.01 & 0.00 & 0.00 \\
\hline $\mathrm{Bi}_{2} \mathrm{O}_{3}$ & 0.67 & 0.28 & 0.29 & 0.24 & 2.6 & 0.24 & 0.67 & 0.28 & 0.39 \\
\hline $\mathrm{CaO}$ & 1.48 & 2.13 & 2.48 & 1.87 & 13.3 & 1.48 & 2.48 & 2.00 & 1.97 \\
\hline $\mathrm{CdO}$ & 0.04 & 0.00 & 0.00 & 0.00 & 0.1 & 0.00 & 0.04 & 0.00 & 0.01 \\
\hline $\mathrm{Ce}_{2} \mathrm{O}_{3}$ & 0.11 & 0.01 & 0.01 & 0.02 & 0.3 & 0.01 & 0.11 & 0.02 & 0.04 \\
\hline $\mathrm{Cl}^{-}$ & 0.08 & 0.22 & 0.03 & 0.04 & 0.6 & 0.03 & 0.22 & 0.06 & 0.09 \\
\hline $\mathrm{Cm}_{2} \mathrm{O}_{3}$ & 0.00 & 0.00 & 0.00 & 0.00 & 0.0 & 0.00 & 0.00 & 0.00 & 0.00 \\
\hline $\mathrm{CoO}$ & 0.03 & 0.00 & 0.00 & 0.01 & 0.1 & 0.00 & 0.03 & 0.00 & 0.01 \\
\hline $\mathrm{Cr}_{2} \mathrm{O}_{3}$ & 2.82 & 1.37 & 1.66 & 2.11 & 13.7 & 1.37 & 2.82 & 1.88 & 2.02 \\
\hline $\mathrm{Cs}_{2} \mathrm{O}$ & 0.16 & 0.71 & 0.05 & 0.00 & 1.6 & 0.00 & 0.71 & 0.10 & 0.24 \\
\hline $\mathrm{CuO}$ & 0.02 & 0.00 & 0.00 & 0.00 & 0.1 & 0.00 & 0.02 & 0.00 & 0.01 \\
\hline $\mathrm{F}^{-}$ & 1.27 & 0.78 & 0.65 & 1.43 & 7.0 & 0.65 & 1.43 & 1.02 & 1.04 \\
\hline $\mathrm{Fe}_{2} \mathrm{O}_{3}$ & 13.19 & 6.66 & 6.19 & 6.43 & 56.8 & 6.19 & 13.19 & 6.55 & 8.38 \\
\hline $\mathrm{K}_{2} \mathrm{O}$ & 1.52 & 0.30 & 0.46 & 0.66 & 5.2 & 0.30 & 1.52 & 0.56 & 0.77 \\
\hline $\mathrm{La}_{2} \mathrm{O}_{3}$ & 0.15 & 0.01 & 0.01 & 0.04 & 0.4 & 0.01 & 0.15 & 0.03 & 0.06 \\
\hline $\mathrm{Li}_{2} \mathrm{O}$ & 0.02 & 0.00 & 0.02 & 0.14 & 0.3 & 0.00 & 0.14 & 0.02 & 0.04 \\
\hline $\mathrm{MgO}$ & 0.16 & 0.02 & 0.02 & 0.04 & 0.4 & 0.02 & 0.16 & 0.03 & 0.06 \\
\hline $\mathrm{MnO}$ & 1.50 & 0.72 & 0.85 & 1.03 & 7.1 & 0.72 & 1.50 & 0.94 & 1.04 \\
\hline $\mathrm{MoO}_{3}$ & 0.07 & 0.00 & 0.01 & 0.02 & 0.2 & 0.00 & 0.07 & 0.01 & 0.03 \\
\hline $\mathrm{Na}_{2} \mathrm{O}$ & 18.53 & 21.44 & 22.23 & 22.77 & 142.8 & 18.53 & 22.77 & 21.84 & 21.08 \\
\hline $\mathrm{Nb}_{2} \mathrm{O}_{5}$ & 0.00 & 0.00 & 0.00 & 0.00 & 0.0 & 0.00 & 0.00 & 0.00 & 0.00 \\
\hline $\mathrm{Nd}_{2} \mathrm{O}_{3}$ & 0.05 & 0.00 & 0.01 & 0.02 & 0.2 & 0.00 & 0.05 & 0.02 & 0.02 \\
\hline $\mathrm{NiO}$ & 0.62 & 0.20 & 0.25 & 0.65 & 2.9 & 0.20 & 0.65 & 0.43 & 0.43 \\
\hline $\mathrm{NpO}_{2}$ & 0.00 & 0.00 & 0.00 & 0.00 & 0.0 & 0.00 & 0.00 & 0.00 & 0.00 \\
\hline $\mathrm{P}_{2} \mathrm{O}_{5}$ & 2.35 & 1.90 & 2.26 & 1.83 & 14.2 & 1.83 & 2.35 & 2.08 & 2.10 \\
\hline $\mathrm{PbO}$ & 0.75 & 0.37 & 0.41 & 0.42 & 3.4 & 0.37 & 0.75 & 0.42 & 0.50 \\
\hline $\mathrm{PuO}_{2}$ & 0.00 & 0.00 & 0.00 & 0.01 & 0.0 & 0.00 & 0.01 & 0.00 & 0.00 \\
\hline $\mathrm{Rb}_{2} \mathrm{O}$ & 0.00 & 0.00 & 0.00 & 0.00 & 0.0 & 0.00 & 0.00 & 0.00 & 0.00 \\
\hline $\mathrm{Rh}_{2} \mathrm{O}_{3}$ & 0.01 & 0.00 & 0.00 & 0.00 & 0.0 & 0.00 & 0.01 & 0.00 & 0.00 \\
\hline $\mathrm{RuO}_{2}$ & 0.00 & 0.00 & 0.00 & 0.00 & 0.0 & 0.00 & 0.00 & 0.00 & 0.00 \\
\hline $\mathrm{Sb}_{2} \mathrm{O}_{3}$ & 0.03 & 0.00 & 0.01 & 0.01 & 0.1 & 0.00 & 0.03 & 0.01 & 0.01 \\
\hline
\end{tabular}

C -12 


\begin{tabular}{|l|r|r|r|r|r|r|r|r|r||}
\hline Batch & $\mathbf{3 1}$ & $\mathbf{3 2}$ & $\mathbf{3 3}$ & $\mathbf{3 4}$ & Total Mass & Min & Max & Median & Mean \\
\hline $\mathbf{M a s s}$ & $\mathbf{1 9 6}$ & $\mathbf{1 7 3}$ & $\mathbf{1 5 8}$ & $\mathbf{1 5 1}$ & $\mathbf{6 7 8}$ & $\mathbf{1 5 1}$ & $\mathbf{1 9 6}$ & & \\
\hline \hline $\mathrm{SeO}_{2}$ & 0.01 & 0.00 & 0.00 & 0.00 & 0.0 & 0.00 & 0.01 & 0.00 & 0.00 \\
\hline $\mathrm{SiO}_{2}$ & 22.24 & 36.22 & 30.77 & 20.95 & 186.4 & 20.95 & 36.22 & 26.50 & 27.51 \\
\hline $\mathrm{Sm}_{2} \mathrm{O}_{3}$ & 0.00 & 0.00 & 0.00 & 0.00 & 0.0 & 0.00 & 0.00 & 0.00 & 0.00 \\
\hline $\mathrm{SnO}_{2}$ & 0.00 & 0.00 & 0.00 & 0.00 & 0.0 & 0.00 & 0.00 & 0.00 & 0.00 \\
\hline $\mathrm{SO}_{3}$ & 0.15 & 0.14 & 0.17 & 0.12 & 1.0 & 0.12 & 0.17 & 0.14 & 0.14 \\
\hline $\mathrm{SrO}$ & 0.12 & 0.19 & 0.09 & 0.15 & 0.9 & 0.09 & 0.19 & 0.14 & 0.14 \\
\hline $\mathrm{TcO}_{2}$ & 0.01 & 0.34 & 0.01 & 0.00 & 0.6 & 0.00 & 0.34 & 0.01 & 0.09 \\
\hline $\mathrm{TeO}_{2}$ & 0.00 & 0.00 & 0.00 & 0.00 & 0.0 & 0.00 & 0.00 & 0.00 & 0.00 \\
\hline $\mathrm{ThO}_{2}$ & 0.56 & 0.26 & 0.26 & 0.33 & 2.4 & 0.26 & 0.56 & 0.29 & 0.36 \\
\hline $\mathrm{TiO}_{2}$ & 0.01 & 0.00 & 0.00 & 0.00 & 0.0 & 0.00 & 0.01 & 0.00 & 0.00 \\
\hline $\mathrm{Tl}_{2} \mathrm{O}$ & 0.09 & 0.00 & 0.02 & 0.04 & 0.3 & 0.00 & 0.09 & 0.03 & 0.04 \\
\hline $\mathrm{U}_{3} \mathrm{O}_{8}$ & 6.91 & 12.30 & 13.09 & 11.11 & 72.2 & 6.91 & 13.09 & 11.70 & 10.66 \\
\hline $\mathrm{V}_{2} \mathrm{O}_{5}$ & 0.02 & 0.00 & 0.01 & 0.02 & 0.1 & 0.00 & 0.02 & 0.01 & 0.01 \\
\hline $\mathrm{WO}_{3}$ & 0.00 & 0.00 & 0.00 & 0.00 & 0.0 & 0.00 & 0.00 & 0.00 & 0.00 \\
\hline $\mathrm{ZnO}^{\mathrm{ZrO}_{2}}$ & 0.04 & 0.00 & 0.01 & 0.01 & 0.1 & 0.00 & 0.04 & 0.01 & 0.02 \\
\hline
\end{tabular}

\begin{tabular}{|c|c|c|c|c|c|c|c|c|}
\hline Batch & 48 & 49 & 50 & Total Mass & Min & Max & Median & Mean \\
\hline Mass & 133 & 160 & 214 & 506 & 133 & 214 & & \\
\hline $\mathrm{Ag}_{2} \mathrm{O}$ & 0.12 & 0.18 & 0.17 & 0.8 & 0.12 & 0.18 & 0.17 & 0.16 \\
\hline $\mathrm{Al}_{2} \mathrm{O}_{3}$ & 21.24 & 22.75 & 24.36 & 116.6 & 21.24 & 24.36 & 22.75 & 23.03 \\
\hline $\mathrm{Am}_{2} \mathrm{O}_{3}$ & 0.00 & 0.00 & 0.00 & 0.0 & 0.00 & 0.00 & 0.00 & 0.00 \\
\hline $\mathrm{As}_{2} \mathrm{O}_{5}$ & 1.51 & 1.82 & 0.79 & 6.6 & 0.79 & 1.82 & 1.51 & 1.30 \\
\hline $\mathrm{B}_{2} \mathrm{O}_{3}$ & 1.88 & 2.41 & 1.66 & 9.9 & 1.66 & 2.41 & 1.88 & 1.96 \\
\hline $\mathrm{BaO}$ & 0.56 & 0.67 & 0.30 & 2.5 & 0.30 & 0.67 & 0.56 & 0.49 \\
\hline $\mathrm{BeO}$ & 0.14 & 0.16 & 0.07 & 0.6 & 0.07 & 0.16 & 0.14 & 0.12 \\
\hline $\mathrm{Bi}_{2} \mathrm{O}_{3}$ & 1.33 & 0.96 & 3.47 & 10.7 & 0.96 & 3.47 & 1.33 & 2.11 \\
\hline $\mathrm{CaO}$ & 1.77 & 1.36 & 1.33 & 7.4 & 1.33 & 1.77 & 1.36 & 1.45 \\
\hline $\mathrm{CdO}$ & 0.03 & 0.03 & 0.02 & 0.1 & 0.02 & 0.03 & 0.03 & 0.03 \\
\hline $\mathrm{Ce}_{2} \mathrm{O}_{3}$ & 1.16 & 1.41 & 0.64 & 5.1 & 0.64 & 1.41 & 1.16 & 1.02 \\
\hline $\mathrm{Cl}^{-}$ & 0.02 & 0.03 & 0.03 & 0.1 & 0.02 & 0.03 & 0.03 & 0.03 \\
\hline $\mathrm{Cm}_{2} \mathrm{O}_{3}$ & 0.00 & 0.00 & 0.00 & 0.0 & 0.00 & 0.00 & 0.00 & 0.00 \\
\hline $\mathrm{CoO}$ & 0.22 & 0.27 & 0.12 & 1.0 & 0.12 & 0.27 & 0.22 & 0.20 \\
\hline $\mathrm{Cr}_{2} \mathrm{O}_{3}$ & 2.96 & 2.88 & 1.95 & 12.7 & 1.95 & 2.96 & 2.88 & 2.51 \\
\hline $\mathrm{Cs}_{2} \mathrm{O}$ & 0.00 & 0.00 & 0.00 & 0.0 & 0.00 & 0.00 & 0.00 & 0.00 \\
\hline $\mathrm{CuO}$ & 0.13 & 0.15 & 0.08 & 0.6 & 0.08 & 0.15 & 0.13 & 0.11 \\
\hline $\mathrm{F}^{-}$ & 1.08 & 0.66 & 1.69 & 6.1 & 0.66 & 1.69 & 1.08 & 1.21 \\
\hline $\mathrm{Fe}_{2} \mathrm{O}_{3}$ & 6.64 & 6.31 & 8.34 & 36.7 & 6.31 & 8.34 & 6.64 & 7.25 \\
\hline
\end{tabular}

C -13 


\begin{tabular}{|c|c|c|c|c|c|c|c|c|}
\hline Batch & 48 & 49 & 50 & Total Mass & Min & Max & Median & Mean \\
\hline Mass & 133 & 160 & 214 & $\begin{array}{r}506 \\
\end{array}$ & 133 & 214 & & \\
\hline $\mathrm{K}_{2} \mathrm{O}$ & 0.15 & 0.15 & 0.17 & 0.8 & 0.15 & 0.17 & 0.15 & 0.16 \\
\hline $\mathrm{La}_{2} \mathrm{O}_{3}$ & 0.05 & 0.06 & 0.06 & 0.3 & 0.05 & 0.06 & 0.06 & 0.06 \\
\hline $\mathrm{Li}_{2} \mathrm{O}$ & 0.26 & 0.35 & 0.28 & 1.5 & 0.26 & 0.35 & 0.28 & 0.29 \\
\hline $\mathrm{MgO}$ & 1.66 & 2.66 & 2.50 & 11.8 & 1.66 & 2.66 & 2.50 & 2.33 \\
\hline $\mathrm{MnO}$ & 1.71 & 1.87 & 1.87 & 9.2 & 1.71 & 1.87 & 1.87 & 1.83 \\
\hline $\mathrm{MoO}_{3}$ & 0.75 & 0.89 & 0.37 & 3.2 & 0.37 & 0.89 & 0.75 & 0.64 \\
\hline $\mathrm{Na}_{2} \mathrm{O}$ & 30.55 & 27.93 & 24.58 & 137.7 & 24.58 & 30.55 & 27.93 & 27.20 \\
\hline $\mathrm{Nb}_{2} \mathrm{O}_{5}$ & 0.00 & 0.00 & 0.00 & 0.0 & 0.00 & 0.00 & 0.00 & 0.00 \\
\hline $\mathrm{Nd}_{2} \mathrm{O}_{3}$ & 1.15 & 1.38 & 0.59 & 5.0 & 0.59 & 1.38 & 1.15 & 0.99 \\
\hline $\mathrm{NiO}$ & 0.83 & 0.55 & 0.46 & 3.0 & 0.46 & 0.83 & 0.55 & 0.59 \\
\hline $\mathrm{NpO}_{2}$ & 0.00 & 0.00 & 0.00 & 0.0 & 0.00 & 0.00 & 0.00 & 0.00 \\
\hline $\mathrm{P}_{2} \mathrm{O}_{5}$ & 4.71 & 5.63 & 8.04 & 32.4 & 4.71 & 8.04 & 5.63 & 6.40 \\
\hline $\mathrm{PbO}$ & 0.42 & 0.38 & 0.49 & 2.2 & 0.38 & 0.49 & 0.42 & 0.44 \\
\hline $\mathrm{PuO}_{2}$ & 0.00 & 0.01 & 0.01 & 0.0 & 0.00 & 0.01 & 0.01 & 0.01 \\
\hline $\mathrm{Rb}_{2} \mathrm{O}$ & 0.00 & 0.00 & 0.00 & 0.0 & 0.00 & 0.00 & 0.00 & 0.00 \\
\hline $\mathrm{Rh}_{2} \mathrm{O}_{3}$ & 0.00 & 0.00 & 0.00 & 0.0 & 0.00 & 0.00 & 0.00 & 0.00 \\
\hline $\mathrm{RuO}_{2}$ & 0.00 & 0.00 & 0.00 & 0.0 & 0.00 & 0.00 & 0.00 & 0.00 \\
\hline $\mathrm{Sb}_{2} \mathrm{O}_{3}$ & 0.62 & 0.75 & 0.32 & 2.7 & 0.32 & 0.75 & 0.62 & 0.54 \\
\hline $\mathrm{SeO}_{2}$ & 0.04 & 0.04 & 0.02 & 0.2 & 0.02 & 0.04 & 0.04 & 0.03 \\
\hline $\mathrm{SiO}_{2}$ & 3.78 & 3.86 & 5.18 & 22.2 & 3.78 & 5.18 & 3.86 & 4.39 \\
\hline $\mathrm{Sm}_{2} \mathrm{O}_{3}$ & 0.00 & 0.00 & 0.00 & 0.0 & 0.00 & 0.00 & 0.00 & 0.00 \\
\hline $\mathrm{SnO}_{2}$ & 0.00 & 0.00 & 0.00 & 0.0 & 0.00 & 0.00 & 0.00 & 0.00 \\
\hline $\mathrm{SO}_{3}$ & 0.12 & 0.14 & 0.17 & 0.7 & 0.12 & 0.17 & 0.14 & 0.15 \\
\hline $\mathrm{SrO}$ & 0.54 & 0.29 & 0.20 & 1.6 & 0.20 & 0.54 & 0.29 & 0.32 \\
\hline $\mathrm{TcO}_{2}$ & 0.02 & 0.02 & 0.02 & 0.1 & 0.02 & 0.02 & 0.02 & 0.02 \\
\hline $\mathrm{TeO}_{2}$ & 0.00 & 0.00 & 0.00 & 0.0 & 0.00 & 0.00 & 0.00 & 0.00 \\
\hline $\mathrm{ThO}_{2}$ & 0.28 & 0.26 & 0.22 & 1.2 & 0.22 & 0.28 & 0.26 & 0.25 \\
\hline $\mathrm{TiO}_{2}$ & 0.16 & 0.20 & 0.09 & 0.7 & 0.09 & 0.20 & 0.16 & 0.14 \\
\hline $\mathrm{Tl}_{2} \mathrm{O}$ & 2.02 & 2.42 & 0.99 & 8.7 & 0.99 & 2.42 & 2.02 & 1.71 \\
\hline $\mathrm{U}_{3} \mathrm{O}_{8}$ & 6.93 & 6.01 & 7.47 & 34.8 & 6.01 & 7.47 & 6.93 & 6.87 \\
\hline $\mathrm{V}_{2} \mathrm{O}_{5}$ & 0.87 & 1.05 & 0.45 & 3.8 & 0.45 & 1.05 & 0.87 & 0.75 \\
\hline $\mathrm{WO}_{3}$ & 0.00 & 0.00 & 0.00 & 0.0 & 0.00 & 0.00 & 0.00 & 0.00 \\
\hline $\mathrm{ZnO}$ & 0.19 & 0.24 & 0.25 & 1.2 & 0.19 & 0.25 & 0.24 & 0.23 \\
\hline $\mathrm{ZrO}_{2}$ & 1.41 & 0.82 & 0.18 & 3.6 & 0.18 & 1.41 & 0.82 & 0.70 \\
\hline
\end{tabular}




\begin{tabular}{|c|c|c|c|c|c|c|c|c|c|c|c|}
\hline Batch & 19 & 20 & 21 & 22 & 23 & 24 & Total Mass & Min & Max & Median & Mean \\
\hline Mass & 74 & 77 & 81 & 78 & 76 & 40 & 426 & 40 & 81 & & \\
\hline $\mathrm{Ag}_{2} \mathrm{O}$ & 0.14 & 0.13 & 0.13 & 0.13 & 0.14 & 0.11 & 0.6 & 0.11 & 0.14 & 0.13 & 0.13 \\
\hline $\mathrm{Al}_{2} \mathrm{O}_{3}$ & 6.61 & 6.80 & 6.77 & 6.79 & 6.81 & 5.21 & 28.1 & 5.21 & 6.81 & 6.78 & 6.61 \\
\hline $\mathrm{Am}_{2} \mathrm{O}_{3}$ & 0.00 & 0.00 & 0.00 & 0.00 & 0.00 & 0.00 & 0.0 & 0.00 & 0.00 & 0.00 & 0.00 \\
\hline $\mathrm{As}_{2} \mathrm{O}_{5}$ & 0.44 & 0.42 & 0.40 & 0.41 & 0.43 & 0.35 & 1.8 & 0.35 & 0.44 & 0.42 & 0.41 \\
\hline $\mathrm{B}_{2} \mathrm{O}_{3}$ & 0.64 & 0.62 & 0.59 & 0.61 & 0.62 & 0.51 & 2.6 & 0.51 & 0.64 & 0.61 & 0.61 \\
\hline $\mathrm{BaO}$ & 0.25 & 0.24 & 0.23 & 0.23 & 0.24 & 0.20 & 1.0 & 0.20 & 0.25 & 0.23 & 0.23 \\
\hline $\mathrm{BeO}$ & 0.04 & 0.04 & 0.04 & 0.04 & 0.04 & 0.04 & 0.2 & 0.04 & 0.04 & 0.04 & 0.04 \\
\hline $\mathrm{Bi}_{2} \mathrm{O}_{3}$ & 3.99 & 3.82 & 3.65 & 3.75 & 3.86 & 3.22 & 16.0 & 3.22 & 3.99 & 3.79 & 3.76 \\
\hline $\mathrm{CaO}$ & 0.71 & 0.71 & 0.69 & 0.70 & 0.71 & 0.55 & 2.9 & 0.55 & 0.71 & 0.70 & 0.69 \\
\hline $\mathrm{CdO}$ & 0.03 & 0.03 & 0.03 & 0.03 & 0.03 & 0.02 & 0.1 & 0.02 & 0.03 & 0.03 & 0.03 \\
\hline $\mathrm{Ce}_{2} \mathrm{O}_{3}$ & 0.38 & 0.37 & 0.35 & 0.36 & 0.37 & 0.31 & 1.5 & 0.31 & 0.38 & 0.36 & 0.36 \\
\hline $\mathrm{Cl}^{-}$ & 0.15 & 0.05 & 0.06 & 0.05 & 0.05 & 0.03 & 0.3 & 0.03 & 0.15 & 0.05 & 0.06 \\
\hline $\mathrm{Cm}_{2} \mathrm{O}_{3}$ & 0.00 & 0.00 & 0.00 & 0.00 & 0.00 & 0.00 & 0.0 & 0.00 & 0.00 & 0.00 & 0.00 \\
\hline $\mathrm{CoO}$ & 0.08 & 0.08 & 0.08 & 0.08 & 0.08 & 0.06 & 0.3 & 0.06 & 0.08 & 0.08 & 0.08 \\
\hline $\mathrm{Cr}_{2} \mathrm{O}_{3}$ & 0.15 & 0.18 & 0.20 & 0.19 & 0.18 & 0.10 & 0.7 & 0.10 & 0.20 & 0.18 & 0.17 \\
\hline $\mathrm{Cs}_{2} \mathrm{O}$ & 0.33 & 0.01 & 0.01 & 0.01 & 0.01 & 0.02 & 0.3 & 0.01 & 0.33 & 0.01 & 0.07 \\
\hline $\mathrm{CuO}$ & 0.07 & 0.07 & 0.06 & 0.06 & 0.07 & 0.05 & 0.3 & 0.05 & 0.07 & 0.06 & 0.06 \\
\hline $\mathrm{F}^{-}$ & 2.48 & 2.37 & 2.27 & 2.33 & 2.39 & 1.98 & 9.9 & 1.98 & 2.48 & 2.35 & 2.33 \\
\hline $\mathrm{Fe}_{2} \mathrm{O}_{3}$ & 14.96 & 14.40 & 13.76 & 14.13 & 14.54 & 12.07 & 60.2 & 12.07 & 14.96 & 14.27 & 14.13 \\
\hline $\mathrm{K}_{2} \mathrm{O}$ & 0.29 & 0.46 & 0.56 & 0.50 & 0.44 & 0.14 & 1.8 & 0.14 & 0.56 & 0.45 & 0.42 \\
\hline $\mathrm{La}_{2} \mathrm{O}_{3}$ & 0.21 & 0.20 & 0.19 & 0.19 & 0.20 & 0.17 & 0.8 & 0.17 & 0.21 & 0.20 & 0.19 \\
\hline $\mathrm{Li}_{2} \mathrm{O}$ & 0.06 & 0.06 & 0.06 & 0.06 & 0.06 & 0.05 & 0.2 & 0.05 & 0.06 & 0.06 & 0.06 \\
\hline $\mathrm{MgO}$ & 0.58 & 0.55 & 0.53 & 0.54 & 0.56 & 0.46 & 2.3 & 0.46 & 0.58 & 0.55 & 0.54 \\
\hline $\mathrm{MnO}$ & 6.62 & 6.35 & 6.06 & 6.23 & 6.42 & 11.60 & 29.0 & 6.06 & 11.60 & 6.39 & 6.82 \\
\hline $\mathrm{MoO}_{3}$ & 0.22 & 0.21 & 0.20 & 0.21 & 0.21 & 0.18 & 0.9 & 0.18 & 0.22 & 0.21 & 0.21 \\
\hline $\mathrm{Na}_{2} \mathrm{O}$ & 9.29 & 12.65 & 16.09 & 14.10 & 11.91 & 7.29 & 52.6 & 7.29 & 16.09 & 12.28 & 12.36 \\
\hline $\mathrm{Nb}_{2} \mathrm{O}_{5}$ & 0.00 & 0.00 & 0.00 & 0.00 & 0.00 & 0.00 & 0.0 & 0.00 & 0.00 & 0.00 & 0.00 \\
\hline $\mathrm{Nd}_{2} \mathrm{O}_{3}$ & 0.33 & 0.32 & 0.30 & 0.31 & 0.32 & 0.27 & 1.3 & 0.27 & 0.33 & 0.32 & 0.31 \\
\hline $\mathrm{NiO}$ & 0.46 & 0.45 & 0.44 & 0.45 & 0.46 & 0.37 & 1.9 & 0.37 & 0.46 & 0.45 & 0.44 \\
\hline $\mathrm{NpO}_{2}$ & 0.00 & 0.00 & 0.00 & 0.00 & 0.00 & 0.00 & 0.0 & 0.00 & 0.00 & 0.00 & 0.00 \\
\hline $\mathrm{P}_{2} \mathrm{O}_{5}$ & 0.86 & 0.74 & 0.72 & 0.73 & 0.74 & 0.61 & 3.2 & 0.61 & 0.86 & 0.73 & 0.74 \\
\hline $\mathrm{PbO}$ & 0.79 & 0.76 & 0.73 & 0.75 & 0.77 & 0.63 & 3.2 & 0.63 & 0.79 & 0.75 & 0.75 \\
\hline $\mathrm{PuO}_{2}$ & 0.01 & 0.01 & 0.01 & 0.01 & 0.01 & 0.00 & 0.0 & 0.00 & 0.01 & 0.01 & 0.01 \\
\hline $\mathrm{Rb}_{2} \mathrm{O}$ & 0.00 & 0.00 & 0.00 & 0.00 & 0.00 & 0.00 & 0.0 & 0.00 & 0.00 & 0.00 & 0.00 \\
\hline $\mathrm{Rh}_{2} \mathrm{O}_{3}$ & 0.14 & 0.14 & 0.13 & 0.13 & 0.14 & 0.11 & 0.6 & 0.11 & 0.14 & 0.13 & 0.13 \\
\hline $\mathrm{RuO}_{2}$ & 0.02 & 0.02 & 0.02 & 0.02 & 0.02 & 0.02 & 0.1 & 0.02 & 0.02 & 0.02 & 0.02 \\
\hline $\mathrm{Sb}_{2} \mathrm{O}_{3}$ & 0.24 & 0.23 & 0.22 & 0.23 & 0.23 & 0.19 & 1.0 & 0.19 & 0.24 & 0.23 & 0.23 \\
\hline
\end{tabular}




\begin{tabular}{|c|c|c|c|c|c|c|c|c|c|c|c|}
\hline Batch & 19 & 20 & 21 & 22 & 23 & 24 & Total Mass & Min & Max & Median & Mean \\
\hline Mass & 74 & 77 & 81 & 78 & 76 & 40 & 426 & 40 & 81 & & \\
\hline $\mathrm{SeO}_{2}$ & 0.09 & 0.09 & 0.08 & 0.08 & 0.09 & 0.07 & 0.4 & 0.07 & 0.09 & 0.08 & 0.08 \\
\hline $\mathrm{SiO}_{2}$ & 4.81 & 4.67 & 4.51 & 4.60 & 4.71 & 3.84 & 19.5 & 3.84 & 4.81 & 4.64 & 4.58 \\
\hline $\mathrm{Sm}_{2} \mathrm{O}_{3}$ & 0.00 & 0.00 & 0.00 & 0.00 & 0.00 & 0.00 & 0.0 & 0.00 & 0.00 & 0.00 & 0.00 \\
\hline $\mathrm{SnO}_{2}$ & 0.00 & 0.00 & 0.00 & 0.00 & 0.00 & 0.00 & 0.0 & 0.00 & 0.00 & 0.00 & 0.00 \\
\hline $\mathrm{SO}_{3}$ & 0.02 & 0.03 & 0.03 & 0.03 & 0.03 & 0.02 & 0.1 & 0.02 & 0.03 & 0.03 & 0.03 \\
\hline $\mathrm{SrO}$ & 13.27 & 12.66 & 12.06 & 12.41 & 12.79 & 24.68 & 58.5 & 12.06 & 24.68 & 12.72 & 13.75 \\
\hline $\mathrm{TcO}_{2}$ & 0.00 & 0.00 & 0.00 & 0.00 & 0.00 & 0.00 & 0.0 & 0.00 & 0.00 & 0.00 & 0.00 \\
\hline $\mathrm{TeO}_{2}$ & 0.06 & 0.06 & 0.06 & 0.06 & 0.06 & 0.05 & 0.2 & 0.05 & 0.06 & 0.06 & 0.06 \\
\hline $\mathrm{ThO}_{2}$ & 0.06 & 0.08 & 0.08 & 0.08 & 0.08 & 0.04 & 0.3 & 0.04 & 0.08 & 0.08 & 0.07 \\
\hline $\mathrm{TiO}_{2}$ & 0.05 & 0.04 & 0.04 & 0.04 & 0.05 & 0.04 & 0.2 & 0.04 & 0.05 & 0.04 & 0.04 \\
\hline $\mathrm{Tl}_{2} \mathrm{O}$ & 0.61 & 0.60 & 0.58 & 0.59 & 0.60 & 0.48 & 2.5 & 0.48 & 0.61 & 0.59 & 0.58 \\
\hline $\mathrm{U}_{3} \mathrm{O}_{8}$ & 6.43 & 6.18 & 5.91 & 6.07 & 6.24 & 5.19 & 25.8 & 5.19 & 6.43 & 6.13 & 6.07 \\
\hline $\mathrm{V}_{2} \mathrm{O}_{5}$ & 0.01 & 0.01 & 0.01 & 0.01 & 0.01 & 0.01 & 0.0 & 0.01 & 0.01 & 0.01 & 0.01 \\
\hline $\mathrm{WO}_{3}$ & 0.00 & 0.00 & 0.00 & 0.00 & 0.00 & 0.00 & 0.0 & 0.00 & 0.00 & 0.00 & 0.00 \\
\hline $\mathrm{ZnO}$ & 0.07 & 0.07 & 0.06 & 0.07 & 0.07 & 0.06 & 0.3 & 0.06 & 0.07 & 0.07 & 0.07 \\
\hline $\mathrm{ZrO}_{2}$ & 22.96 & 22.02 & 20.99 & 21.59 & 22.25 & 18.57 & 92.1 & 18.57 & 22.96 & 21.81 & 21.63 \\
\hline
\end{tabular}

\begin{tabular}{|l|r|r|r|r|r|r|r|r|r|r||}
\hline Batch & $\mathbf{1 3}$ & $\mathbf{1 4}$ & $\mathbf{1 5}$ & $\mathbf{1 6}$ & $\mathbf{1 7}$ & \multicolumn{1}{l}{ Total Mass } & \multicolumn{1}{l|}{ Min } & Max & Median & Mean \\
\hline $\mathbf{M a s S}$ & $\mathbf{4 0}$ & $\mathbf{4 2}$ & $\mathbf{4 6}$ & $\mathbf{5 3}$ & $\mathbf{5 1}$ & $\mathbf{2 3 2}$ & $\mathbf{4 0}$ & $\mathbf{5 3}$ & & \\
\hline \hline $\mathrm{Ag}_{2} \mathrm{O}$ & 0.05 & 0.05 & 0.04 & 0.04 & 0.04 & 0.1 & 0.04 & 0.05 & 0.04 & 0.04 \\
\hline $\mathrm{Al}_{2} \mathrm{O}_{3}$ & 6.42 & 6.86 & 6.77 & 6.60 & 6.65 & 15.4 & 6.42 & 6.86 & 6.65 & 6.66 \\
\hline $\mathrm{Am}_{2} \mathrm{O}_{3}$ & 0.00 & 0.00 & 0.00 & 0.00 & 0.00 & 0.0 & 0.00 & 0.00 & 0.00 & 0.00 \\
\hline $\mathrm{As}_{2} \mathrm{O}_{5}$ & 0.10 & 0.10 & 0.09 & 0.08 & 0.08 & 0.2 & 0.08 & 0.10 & 0.09 & 0.09 \\
\hline $\mathrm{B}_{2} \mathrm{O}_{3}$ & 0.20 & 0.20 & 0.20 & 0.19 & 0.19 & 0.5 & 0.19 & 0.20 & 0.20 & 0.20 \\
\hline $\mathrm{BaO}$ & 0.06 & 0.06 & 0.06 & 0.05 & 0.05 & 0.1 & 0.05 & 0.06 & 0.06 & 0.06 \\
\hline $\mathrm{BeO}$ & 0.01 & 0.01 & 0.01 & 0.01 & 0.01 & 0.0 & 0.01 & 0.01 & 0.01 & 0.01 \\
\hline $\mathrm{Bi}_{2} \mathrm{O}_{3}$ & 0.27 & 0.26 & 0.24 & 0.21 & 0.22 & 0.6 & 0.21 & 0.27 & 0.24 & 0.24 \\
\hline $\mathrm{CaO}^{\mathrm{CaO}}$ & 1.05 & 1.02 & 0.98 & 0.92 & 0.94 & 2.3 & 0.92 & 1.05 & 0.98 & 0.98 \\
\hline $\mathrm{Ce}_{2} \mathrm{O}_{3}$ & 0.04 & 0.04 & 0.04 & 0.04 & 0.04 & 0.1 & 0.04 & 0.04 & 0.04 & 0.04 \\
\hline $\mathrm{Cl}^{-}$ & 0.07 & 0.07 & 0.07 & 0.06 & 0.06 & 0.2 & 0.06 & 0.07 & 0.07 & 0.07 \\
\hline $\mathrm{Cm}_{2} \mathrm{O}_{3}$ & 0.00 & 0.00 & 0.00 & 0.00 & 0.00 & 0.1 & 0.03 & 0.07 & 0.06 & 0.06 \\
\hline $\mathrm{CoO}^{-0.03}$ & 0.02 & 0.02 & 0.02 & 0.02 & 0.02 & 0.0 & 0.00 & 0.00 & 0.00 & 0.00 \\
\hline $\mathrm{Cr}_{2} \mathrm{O}_{3}$ & 1.41 & 1.38 & 1.32 & 1.24 & 1.26 & 0.0 & 0.02 & 0.02 & 0.02 & 0.02 \\
\hline $\mathrm{Cs}_{2} \mathrm{O}$ & 0.15 & 0.01 & 0.03 & 0.03 & 0.01 & 3.1 & 1.24 & 1.41 & 1.32 & 1.32 \\
\hline $\mathrm{CuO}^{-}$ & 0.02 & 0.02 & 0.02 & 0.01 & 0.02 & 0.1 & 0.01 & 0.15 & 0.03 & 0.04 \\
\hline $\mathrm{F}^{-}$ & 0.14 & 0.12 & 0.12 & 0.11 & 0.11 & 0.0 & 0.01 & 0.02 & 0.02 & 0.02 \\
\hline \hline
\end{tabular}

C -16 


\begin{tabular}{|c|c|c|c|c|c|c|c|c|c|c|}
\hline Batch & 13 & 14 & 15 & 16 & 17 & Total Mass & Min & Max & Median & Mean \\
\hline Mass & 40 & 42 & 46 & 53 & 51 & 232 & 40 & 53 & & \\
\hline $\mathrm{Fe}_{2} \mathrm{O}_{3}$ & 5.91 & 5.73 & 5.23 & 4.58 & 4.77 & 12.0 & 4.58 & 5.91 & 5.23 & 5.19 \\
\hline $\mathrm{K}_{2} \mathrm{O}$ & 1.64 & 1.66 & 1.78 & 1.92 & 1.88 & 4.1 & 1.64 & 1.92 & 1.78 & 1.79 \\
\hline $\mathrm{La}_{2} \mathrm{O}_{3}$ & 0.09 & 0.08 & 0.08 & 0.07 & 0.07 & 0.2 & 0.07 & 0.09 & 0.08 & 0.08 \\
\hline $\mathrm{Li}_{2} \mathrm{O}$ & 0.02 & 0.02 & 0.02 & 0.02 & 0.02 & 0.0 & 0.02 & 0.02 & 0.02 & 0.02 \\
\hline $\mathrm{MgO}$ & 0.29 & 0.28 & 0.25 & 0.22 & 0.23 & 0.6 & 0.22 & 0.29 & 0.25 & 0.25 \\
\hline $\mathrm{MnO}$ & 12.39 & 11.99 & 10.89 & 9.45 & 9.87 & 25.0 & 9.45 & 12.39 & 10.89 & 10.80 \\
\hline $\mathrm{MoO}_{3}$ & 0.04 & 0.04 & 0.04 & 0.03 & 0.03 & 0.1 & 0.03 & 0.04 & 0.04 & 0.04 \\
\hline $\mathrm{Na}_{2} \mathrm{O}$ & 39.27 & 40.57 & 44.66 & 50.18 & 48.59 & 104.5 & 39.27 & 50.18 & 44.66 & 45.10 \\
\hline $\mathrm{Nb}_{2} \mathrm{O}_{5}$ & 0.00 & 0.00 & 0.00 & 0.00 & 0.00 & 0.0 & 0.00 & 0.00 & 0.00 & 0.00 \\
\hline $\mathrm{Nd}_{2} \mathrm{O}_{3}$ & 0.09 & 0.08 & 0.08 & 0.07 & 0.07 & 0.2 & 0.07 & 0.09 & 0.08 & 0.08 \\
\hline $\mathrm{NiO}$ & 0.21 & 0.21 & 0.20 & 0.19 & 0.19 & 0.5 & 0.19 & 0.21 & 0.20 & 0.20 \\
\hline $\mathrm{NpO}_{2}$ & 0.00 & 0.00 & 0.00 & 0.00 & 0.00 & 0.0 & 0.00 & 0.00 & 0.00 & 0.00 \\
\hline $\mathrm{P}_{2} \mathrm{O}_{5}$ & 1.33 & 1.36 & 1.28 & 1.18 & 1.21 & 2.9 & 1.18 & 1.36 & 1.28 & 1.26 \\
\hline $\mathrm{PbO}$ & 0.33 & 0.31 & 0.29 & 0.26 & 0.27 & 0.7 & 0.26 & 0.33 & 0.29 & 0.29 \\
\hline $\mathrm{PuO}_{2}$ & 0.01 & 0.01 & 0.01 & 0.01 & 0.01 & 0.0 & 0.01 & 0.01 & 0.01 & 0.01 \\
\hline $\mathrm{Rb}_{2} \mathrm{O}$ & 0.00 & 0.00 & 0.00 & 0.00 & 0.00 & 0.0 & 0.00 & 0.00 & 0.00 & 0.00 \\
\hline $\mathrm{Rh}_{2} \mathrm{O}_{3}$ & 0.00 & 0.00 & 0.00 & 0.01 & 0.01 & 0.0 & 0.00 & 0.01 & 0.00 & 0.00 \\
\hline $\mathrm{RuO}_{2}$ & 0.00 & 0.00 & 0.00 & 0.01 & 0.00 & 0.0 & 0.00 & 0.01 & 0.00 & 0.00 \\
\hline $\mathrm{Sb}_{2} \mathrm{O}_{3}$ & 0.04 & 0.04 & 0.04 & 0.04 & 0.04 & 0.1 & 0.04 & 0.04 & 0.04 & 0.04 \\
\hline $\mathrm{SeO}_{2}$ & 0.04 & 0.04 & 0.04 & 0.05 & 0.04 & 0.1 & 0.04 & 0.05 & 0.04 & 0.04 \\
\hline $\mathrm{SiO}_{2}$ & 1.34 & 1.35 & 1.34 & 1.32 & 1.33 & 3.1 & 1.32 & 1.35 & 1.34 & 1.34 \\
\hline $\mathrm{Sm}_{2} \mathrm{O}_{3}$ & 0.00 & 0.00 & 0.00 & 0.00 & 0.00 & 0.0 & 0.00 & 0.00 & 0.00 & 0.00 \\
\hline $\mathrm{SnO}_{2}$ & 0.00 & 0.00 & 0.00 & 0.00 & 0.00 & 0.0 & 0.00 & 0.00 & 0.00 & 0.00 \\
\hline $\mathrm{SO}_{3}$ & 0.03 & 0.03 & 0.04 & 0.05 & 0.04 & 0.1 & 0.03 & 0.05 & 0.04 & 0.04 \\
\hline $\mathrm{SrO}$ & 24.27 & 23.45 & 21.30 & 18.46 & 19.29 & 49.0 & 18.46 & 24.27 & 21.30 & 21.12 \\
\hline $\mathrm{TcO}_{2}$ & 0.01 & 0.01 & 0.01 & 0.01 & 0.01 & 0.0 & 0.01 & 0.01 & 0.01 & 0.01 \\
\hline $\mathrm{TeO}_{2}$ & 0.00 & 0.00 & 0.00 & 0.01 & 0.01 & 0.0 & 0.00 & 0.01 & 0.00 & 0.00 \\
\hline $\mathrm{ThO}_{2}$ & 0.16 & 0.16 & 0.16 & 0.17 & 0.17 & 0.4 & 0.16 & 0.17 & 0.16 & 0.17 \\
\hline $\mathrm{TiO}_{2}$ & 0.02 & 0.02 & 0.02 & 0.02 & 0.02 & 0.0 & 0.02 & 0.02 & 0.02 & 0.02 \\
\hline $\mathrm{Tl}_{2} \mathrm{O}$ & 0.14 & 0.15 & 0.18 & 0.22 & 0.20 & 0.4 & 0.14 & 0.22 & 0.18 & 0.18 \\
\hline $\mathrm{U}_{3} \mathrm{O}_{8}$ & 2.01 & 1.94 & 1.80 & 1.60 & 1.66 & 4.1 & 1.60 & 2.01 & 1.80 & 1.78 \\
\hline $\mathrm{V}_{2} \mathrm{O}_{5}$ & 0.06 & 0.06 & 0.05 & 0.05 & 0.05 & 0.1 & 0.05 & 0.06 & 0.05 & 0.05 \\
\hline $\mathrm{WO}_{3}$ & 0.00 & 0.00 & 0.00 & 0.00 & 0.00 & 0.0 & 0.00 & 0.00 & 0.00 & 0.00 \\
\hline $\mathrm{ZnO}$ & 0.08 & 0.08 & 0.07 & 0.06 & 0.07 & 0.2 & 0.06 & 0.08 & 0.07 & 0.07 \\
\hline $\mathrm{ZrO}_{2}$ & 0.10 & 0.08 & 0.08 & 0.08 & 0.08 & 0.2 & 0.08 & 0.10 & 0.08 & 0.09 \\
\hline
\end{tabular}




\begin{tabular}{|c|c|c|c|c|c|c|c|c|c|}
\hline Batch & 3 & 4 & 5 & 6 & Total Mass & Min & Max & Median & Mean \\
\hline Mass & 58 & 55 & 55 & 47 & 216 & 47 & 58 & & 216 \\
\hline $\mathrm{Ag}_{2} \mathrm{O}$ & 0.51 & 0.54 & 0.55 & 0.55 & 1.2 & 0.51 & 0.55 & 0.54 & 0.54 \\
\hline $\mathrm{Al}_{2} \mathrm{O}_{3}$ & 8.89 & 7.05 & 6.86 & 6.85 & 16.1 & 6.85 & 8.89 & 6.96 & 7.45 \\
\hline $\mathrm{Am}_{2} \mathrm{O}_{3}$ & 0.00 & 0.00 & 0.00 & 0.00 & 0.0 & 0.00 & 0.00 & 0.00 & 0.00 \\
\hline $\mathrm{As}_{2} \mathrm{O}_{5}$ & 0.78 & 0.82 & 0.83 & 0.83 & 1.8 & 0.78 & 0.83 & 0.82 & 0.81 \\
\hline $\mathrm{B}_{2} \mathrm{O}_{3}$ & 0.31 & 0.33 & 0.33 & 0.33 & 0.7 & 0.31 & 0.33 & 0.33 & 0.32 \\
\hline $\mathrm{BaO}$ & 0.38 & 0.41 & 0.41 & 0.41 & 0.9 & 0.38 & 0.41 & 0.41 & 0.40 \\
\hline $\mathrm{BeO}$ & 0.07 & 0.07 & 0.07 & 0.07 & 0.2 & 0.07 & 0.07 & 0.07 & 0.07 \\
\hline $\mathrm{Bi}_{2} \mathrm{O}_{3}$ & 0.01 & 0.01 & 0.01 & 0.01 & 0.0 & 0.01 & 0.01 & 0.01 & 0.01 \\
\hline $\mathrm{CaO}$ & 2.79 & 2.93 & 2.95 & 2.95 & 6.3 & 2.79 & 2.95 & 2.94 & 2.90 \\
\hline $\mathrm{CdO}$ & 0.09 & 0.09 & 0.09 & 0.09 & 0.2 & 0.09 & 0.09 & 0.09 & 0.09 \\
\hline $\mathrm{Ce}_{2} \mathrm{O}_{3}$ & 0.31 & 0.33 & 0.33 & 0.33 & 0.7 & 0.31 & 0.33 & 0.33 & 0.33 \\
\hline $\mathrm{Cl}^{-}$ & 0.00 & 0.00 & 0.00 & 0.00 & 0.0 & 0.00 & 0.00 & 0.00 & 0.00 \\
\hline $\mathrm{Cm}_{2} \mathrm{O}_{3}$ & 0.00 & 0.00 & 0.00 & 0.00 & 0.0 & 0.00 & 0.00 & 0.00 & 0.00 \\
\hline $\mathrm{CoO}$ & 0.14 & 0.14 & 0.14 & 0.14 & 0.3 & 0.14 & 0.14 & 0.14 & 0.14 \\
\hline $\mathrm{Cr}_{2} \mathrm{O}_{3}$ & 0.22 & 0.19 & 0.18 & 0.18 & 0.4 & 0.18 & 0.22 & 0.19 & 0.20 \\
\hline $\mathrm{Cs}_{2} \mathrm{O}$ & 0.01 & 0.01 & 0.01 & 0.01 & 0.0 & 0.01 & 0.01 & 0.01 & 0.01 \\
\hline $\mathrm{CuO}$ & 0.15 & 0.16 & 0.16 & 0.16 & 0.3 & 0.15 & 0.16 & 0.16 & 0.16 \\
\hline $\mathrm{F}^{-}$ & 0.04 & 0.04 & 0.04 & 0.04 & 0.1 & 0.04 & 0.04 & 0.04 & 0.04 \\
\hline $\mathrm{Fe}_{2} \mathrm{O}_{3}$ & 43.73 & 46.20 & 46.46 & 46.46 & 98.7 & 43.73 & 46.46 & 46.33 & 45.66 \\
\hline $\mathrm{K}_{2} \mathrm{O}$ & 0.14 & 0.15 & 0.15 & 0.15 & 0.3 & 0.14 & 0.15 & 0.15 & 0.15 \\
\hline $\mathrm{La}_{2} \mathrm{O}_{3}$ & 0.86 & 0.91 & 0.91 & 0.91 & 1.9 & 0.86 & 0.91 & 0.91 & 0.90 \\
\hline $\mathrm{Li}_{2} \mathrm{O}$ & 0.00 & 0.00 & 0.00 & 0.00 & 0.0 & 0.00 & 0.00 & 0.00 & 0.00 \\
\hline $\mathrm{MgO}$ & 1.90 & 2.01 & 2.02 & 2.02 & 4.3 & 1.90 & 2.02 & 2.01 & 1.98 \\
\hline $\mathrm{MnO}$ & 8.42 & 8.90 & 8.95 & 8.95 & 19.0 & 8.42 & 8.95 & 8.93 & 8.80 \\
\hline $\mathrm{MoO}_{3}$ & 0.03 & 0.03 & 0.03 & 0.03 & 0.1 & 0.03 & 0.03 & 0.03 & 0.03 \\
\hline $\mathrm{Na}_{2} \mathrm{O}$ & 16.22 & 14.09 & 13.87 & 13.88 & 31.5 & 13.87 & 16.22 & 13.99 & 14.57 \\
\hline $\mathrm{Nb}_{2} \mathrm{O}_{5}$ & 0.00 & 0.00 & 0.00 & 0.00 & 0.0 & 0.00 & 0.00 & 0.00 & 0.00 \\
\hline $\mathrm{Nd}_{2} \mathrm{O}_{3}$ & 0.53 & 0.56 & 0.57 & 0.57 & 1.2 & 0.53 & 0.57 & 0.57 & 0.56 \\
\hline $\mathrm{NiO}$ & 1.37 & 1.45 & 1.46 & 1.46 & 3.1 & 1.37 & 1.46 & 1.46 & 1.43 \\
\hline $\mathrm{NpO}_{2}$ & 0.00 & 0.00 & 0.00 & 0.00 & 0.0 & 0.00 & 0.00 & 0.00 & 0.00 \\
\hline $\mathrm{P}_{2} \mathrm{O}_{5}$ & 0.67 & 0.61 & 0.61 & 0.61 & 1.4 & 0.61 & 0.67 & 0.61 & 0.63 \\
\hline $\mathrm{PbO}$ & 1.38 & 1.45 & 1.46 & 1.46 & 3.1 & 1.38 & 1.46 & 1.46 & 1.44 \\
\hline $\mathrm{PuO}_{2}$ & 0.01 & 0.01 & 0.01 & 0.01 & 0.0 & 0.01 & 0.01 & 0.01 & 0.01 \\
\hline $\mathrm{Rb}_{2} \mathrm{O}$ & 0.00 & 0.00 & 0.00 & 0.00 & 0.0 & 0.00 & 0.00 & 0.00 & 0.00 \\
\hline $\mathrm{Rh}_{2} \mathrm{O}_{3}$ & 0.00 & 0.00 & 0.00 & 0.00 & 0.0 & 0.00 & 0.00 & 0.00 & 0.00 \\
\hline $\mathrm{RuO}_{2}$ & 0.00 & 0.00 & 0.00 & 0.00 & 0.0 & 0.00 & 0.00 & 0.00 & 0.00 \\
\hline $\mathrm{Sb}_{2} \mathrm{O}_{3}$ & 0.37 & 0.39 & 0.39 & 0.39 & 0.8 & 0.37 & 0.39 & 0.39 & 0.38 \\
\hline
\end{tabular}

C - 18 


\begin{tabular}{|l|r|r|r|r|r|r|r|r|r||}
\hline Batch & $\mathbf{3}$ & $\mathbf{4}$ & $\mathbf{5}$ & $\mathbf{6}$ & Total Mass & \multicolumn{1}{l|}{ Min } & Max & Median & Mean \\
\hline $\mathbf{M a s s}$ & $\mathbf{5 8}$ & $\mathbf{5 5}$ & $\mathbf{5 5}$ & $\mathbf{4 7}$ & $\mathbf{2 1 6}$ & $\mathbf{4 7}$ & $\mathbf{5 8}$ & & $\mathbf{2 1 6}$ \\
\hline \hline $\mathrm{SeO}_{2}$ & 0.71 & 0.75 & 0.76 & 0.76 & 1.6 & 0.71 & 0.76 & 0.75 & 0.74 \\
\hline $\mathrm{SiO}_{2}$ & 5.07 & 5.26 & 5.27 & 5.27 & 11.3 & 5.07 & 5.27 & 5.27 & 5.22 \\
\hline $\mathrm{Sm}_{2} \mathrm{O}_{3}$ & 0.00 & 0.00 & 0.00 & 0.00 & 0.0 & 0.00 & 0.00 & 0.00 & 0.00 \\
\hline $\mathrm{SnO}_{2}$ & 0.00 & 0.00 & 0.00 & 0.00 & 0.0 & 0.00 & 0.00 & 0.00 & 0.00 \\
\hline $\mathrm{SO}_{3}$ & 0.03 & 0.03 & 0.03 & 0.03 & 0.1 & 0.03 & 0.03 & 0.03 & 0.03 \\
\hline $\mathrm{SrO}$ & 0.15 & 0.16 & 0.16 & 0.16 & 0.3 & 0.15 & 0.16 & 0.16 & 0.16 \\
\hline $\mathrm{TcO}_{2}$ & 0.00 & 0.00 & 0.00 & 0.00 & 0.0 & 0.00 & 0.00 & 0.00 & 0.00 \\
\hline $\mathrm{TeO}_{2}$ & 0.04 & 0.04 & 0.04 & 0.04 & 0.1 & 0.04 & 0.04 & 0.04 & 0.04 \\
\hline $\mathrm{ThO}_{2}$ & 0.00 & 0.00 & 0.00 & 0.00 & 0.0 & 0.00 & 0.00 & 0.00 & 0.00 \\
\hline $\mathrm{TiO}_{2}$ & 0.09 & 0.10 & 0.10 & 0.10 & 0.2 & 0.09 & 0.10 & 0.10 & 0.10 \\
\hline $\mathrm{Tl}_{2} \mathrm{O}$ & 1.06 & 1.12 & 1.13 & 1.13 & 2.4 & 1.06 & 1.13 & 1.12 & 1.11 \\
\hline $\mathrm{U}_{3} \mathrm{O}_{8}$ & 1.36 & 1.44 & 1.45 & 1.45 & 3.1 & 1.36 & 1.45 & 1.44 & 1.42 \\
\hline $\mathrm{V}_{2} \mathrm{O}_{5}$ & 0.45 & 0.48 & 0.48 & 0.48 & 1.0 & 0.45 & 0.48 & 0.48 & 0.47 \\
\hline $\mathrm{WO}_{3}$ & 0.00 & 0.00 & 0.00 & 0.00 & 0.0 & 0.00 & 0.00 & 0.00 & 0.00 \\
\hline $\mathrm{ZnO}$ & 0.08 & 0.09 & 0.09 & 0.09 & 0.2 & 0.08 & 0.09 & 0.09 & 0.09 \\
\hline $\mathrm{ZrO}_{2}$ & 0.59 & 0.62 & 0.63 & 0.63 & 1.3 & 0.59 & 0.63 & 0.63 & 0.62 \\
\hline \hline
\end{tabular}

\begin{tabular}{|c|c|c|c|c|c|c|c|c|c|}
\hline Batch & 26 & 27 & 28 & 29 & Total Mass & Min & Max & Median & Mean \\
\hline Mass & 34 & 40 & 50 & 51 & 175 & 34 & 51 & & \\
\hline $\mathrm{Ag}_{2} \mathrm{O}$ & 0.22 & 0.19 & 0.15 & 0.15 & 0.3 & 0.15 & 0.22 & 0.17 & 0.17 \\
\hline $\mathrm{Al}_{2} \mathrm{O}_{3}$ & 5.27 & 6.56 & 8.27 & 8.34 & 12.8 & 5.27 & 8.34 & 7.42 & 7.31 \\
\hline $\mathrm{Am}_{2} \mathrm{O}_{3}$ & 0.00 & 0.00 & 0.00 & 0.00 & 0.0 & 0.00 & 0.00 & 0.00 & 0.00 \\
\hline $\mathrm{As}_{2} \mathrm{O}_{5}$ & 1.94 & 1.68 & 1.33 & 1.32 & 2.7 & 1.32 & 1.94 & 1.50 & 1.52 \\
\hline $\mathrm{B}_{2} \mathrm{O}_{3}$ & 2.26 & 1.97 & 1.59 & 1.57 & 3.2 & 1.57 & 2.26 & 1.78 & 1.80 \\
\hline $\mathrm{BaO}$ & 0.71 & 0.62 & 0.49 & 0.49 & 1.0 & 0.49 & 0.71 & 0.55 & 0.56 \\
\hline $\mathrm{BeO}$ & 0.18 & 0.16 & 0.12 & 0.12 & 0.2 & 0.12 & 0.18 & 0.14 & 0.14 \\
\hline $\mathrm{Bi}_{2} \mathrm{O}_{3}$ & 0.34 & 0.30 & 0.24 & 0.24 & 0.5 & 0.24 & 0.34 & 0.27 & 0.28 \\
\hline $\mathrm{CaO}$ & 0.94 & 0.90 & 0.84 & 0.84 & 1.5 & 0.84 & 0.94 & 0.87 & 0.87 \\
\hline $\mathrm{CdO}$ & 0.08 & 0.07 & 0.05 & 0.05 & 0.1 & 0.05 & 0.08 & 0.06 & 0.06 \\
\hline $\mathrm{Ce}_{2} \mathrm{O}_{3}$ & 1.49 & 1.29 & 1.03 & 1.02 & 2.1 & 1.02 & 1.49 & 1.16 & 1.18 \\
\hline $\mathrm{Cl}^{-}$ & 0.07 & 0.10 & 0.13 & 0.12 & 0.2 & 0.07 & 0.13 & 0.11 & 0.11 \\
\hline $\mathrm{Cm}_{2} \mathrm{O}_{3}$ & 0.00 & 0.00 & 0.00 & 0.00 & 0.0 & 0.00 & 0.00 & 0.00 & 0.00 \\
\hline $\mathrm{CoO}$ & 0.33 & 0.29 & 0.24 & 0.23 & 0.5 & 0.23 & 0.33 & 0.26 & 0.26 \\
\hline $\mathrm{Cr}_{2} \mathrm{O}_{3}$ & 0.42 & 0.45 & 0.50 & 0.50 & 0.8 & 0.42 & 0.50 & 0.47 & 0.47 \\
\hline $\mathrm{Cs}_{2} \mathrm{O}$ & 0.01 & 0.03 & 0.02 & 0.01 & 0.0 & 0.01 & 0.03 & 0.02 & 0.02 \\
\hline $\mathrm{CuO}$ & 0.16 & 0.14 & 0.11 & 0.11 & 0.2 & 0.11 & 0.16 & 0.12 & 0.13 \\
\hline $\mathrm{F}^{-}$ & 4.74 & 4.13 & 3.31 & 3.28 & 6.6 & 3.28 & 4.74 & 3.72 & 3.77 \\
\hline $\mathrm{Fe}_{2} \mathrm{O}_{3}$ & 1.74 & 1.55 & 1.30 & 1.29 & 2.5 & 1.29 & 1.74 & 1.42 & 1.44 \\
\hline
\end{tabular}




\begin{tabular}{|c|c|c|c|c|c|c|c|c|c|}
\hline Batch & 26 & 27 & 28 & 29 & Total Mass & Min & Max & Median & Mean \\
\hline Mass & 34 & 40 & 50 & 51 & 175 & 34 & 51 & & \\
\hline $\mathrm{K}_{2} \mathrm{O}$ & 0.89 & 1.00 & 1.14 & 1.15 & 1.9 & 0.89 & 1.15 & 1.07 & 1.06 \\
\hline $\mathrm{La}_{2} \mathrm{O}_{3}$ & 0.39 & 0.33 & 0.27 & 0.26 & 0.5 & 0.26 & 0.39 & 0.30 & 0.30 \\
\hline $\mathrm{Li}_{2} \mathrm{O}$ & 0.27 & 0.24 & 0.19 & 0.19 & 0.4 & 0.19 & 0.27 & 0.21 & 0.22 \\
\hline $\mathrm{MgO}$ & 2.11 & 1.82 & 1.44 & 1.43 & 2.9 & 1.43 & 2.11 & 1.63 & 1.66 \\
\hline $\mathrm{MnO}$ & 0.66 & 0.58 & 0.47 & 0.47 & 0.9 & 0.47 & 0.66 & 0.53 & 0.53 \\
\hline $\mathrm{MoO}_{3}$ & 0.95 & 0.82 & 0.65 & 0.64 & 1.3 & 0.64 & 0.95 & 0.74 & 0.75 \\
\hline $\mathrm{Na}_{2} \mathrm{O}$ & 15.65 & 24.23 & 35.67 & 36.10 & 51.3 & 15.65 & 36.10 & 29.95 & 29.27 \\
\hline $\mathrm{Nb}_{2} \mathrm{O}_{5}$ & 0.00 & 0.00 & 0.00 & 0.00 & 0.0 & 0.00 & 0.00 & 0.00 & 0.00 \\
\hline $\mathrm{Nd}_{2} \mathrm{O}_{3}$ & 1.47 & 1.27 & 1.01 & 1.00 & 2.0 & 1.00 & 1.47 & 1.14 & 1.16 \\
\hline $\mathrm{NiO}$ & 0.71 & 0.63 & 0.51 & 0.51 & 1.0 & 0.51 & 0.71 & 0.57 & 0.58 \\
\hline $\mathrm{NpO}_{2}$ & 0.00 & 0.00 & 0.00 & 0.00 & 0.0 & 0.00 & 0.00 & 0.00 & 0.00 \\
\hline $\mathrm{P}_{2} \mathrm{O}_{5}$ & 0.17 & 0.16 & 0.17 & 0.17 & 0.3 & 0.16 & 0.17 & 0.17 & 0.17 \\
\hline $\mathrm{PbO}$ & 0.51 & 0.45 & 0.36 & 0.36 & 0.7 & 0.36 & 0.51 & 0.40 & 0.41 \\
\hline $\mathrm{PuO}_{2}$ & 0.01 & 0.00 & 0.00 & 0.00 & 0.0 & 0.00 & 0.01 & 0.00 & 0.00 \\
\hline $\mathrm{Rb}_{2} \mathrm{O}$ & 0.00 & 0.00 & 0.00 & 0.00 & 0.0 & 0.00 & 0.00 & 0.00 & 0.00 \\
\hline $\mathrm{Rh}_{2} \mathrm{O}_{3}$ & 0.22 & 0.20 & 0.16 & 0.16 & 0.3 & 0.16 & 0.22 & 0.18 & 0.18 \\
\hline $\mathrm{RuO}_{2}$ & 0.03 & 0.03 & 0.03 & 0.03 & 0.0 & 0.03 & 0.03 & 0.03 & 0.03 \\
\hline $\mathrm{Sb}_{2} \mathrm{O}_{3}$ & 0.98 & 0.85 & 0.68 & 0.67 & 1.4 & 0.67 & 0.98 & 0.77 & 0.78 \\
\hline $\mathrm{SeO}_{2}$ & 0.11 & 0.10 & 0.09 & 0.09 & 0.2 & 0.09 & 0.11 & 0.10 & 0.10 \\
\hline $\mathrm{SiO}_{2}$ & 1.68 & 1.52 & 1.32 & 1.31 & 2.5 & 1.31 & 1.68 & 1.42 & 1.43 \\
\hline $\mathrm{Sm}_{2} \mathrm{O}_{3}$ & 0.00 & 0.00 & 0.00 & 0.00 & 0.0 & 0.00 & 0.00 & 0.00 & 0.00 \\
\hline $\mathrm{SnO}_{2}$ & 0.00 & 0.00 & 0.00 & 0.00 & 0.0 & 0.00 & 0.00 & 0.00 & 0.00 \\
\hline $\mathrm{SO}_{3}$ & 0.08 & 0.08 & 0.09 & 0.09 & 0.2 & 0.08 & 0.09 & 0.09 & 0.09 \\
\hline $\mathrm{SrO}$ & 0.08 & 0.07 & 0.06 & 0.05 & 0.1 & 0.05 & 0.08 & 0.06 & 0.06 \\
\hline $\mathrm{TcO}_{2}$ & 0.00 & 0.00 & 0.00 & 0.02 & 0.0 & 0.00 & 0.02 & 0.00 & 0.01 \\
\hline $\mathrm{TeO}_{2}$ & 0.09 & 0.08 & 0.07 & 0.07 & 0.1 & 0.07 & 0.09 & 0.08 & 0.08 \\
\hline $\mathrm{ThO}_{2}$ & 0.18 & 0.20 & 0.22 & 0.22 & 0.4 & 0.18 & 0.22 & 0.21 & 0.21 \\
\hline $\mathrm{TiO}_{2}$ & 0.21 & 0.18 & 0.14 & 0.14 & 0.3 & 0.14 & 0.21 & 0.16 & 0.16 \\
\hline $\mathrm{Tl}_{2} \mathrm{O}$ & 2.65 & 2.34 & 1.92 & 1.90 & 3.8 & 1.90 & 2.65 & 2.13 & 2.15 \\
\hline $\mathrm{U}_{3} \mathrm{O}_{8}$ & 12.49 & 10.82 & 8.61 & 8.53 & 17.3 & 8.53 & 12.49 & 9.72 & 9.85 \\
\hline $\mathrm{V}_{2} \mathrm{O}_{5}$ & 0.74 & 0.64 & 0.51 & 0.50 & 1.0 & 0.50 & 0.74 & 0.57 & 0.58 \\
\hline $\mathrm{WO}_{3}$ & 0.00 & 0.00 & 0.00 & 0.00 & 0.0 & 0.00 & 0.00 & 0.00 & 0.00 \\
\hline $\mathrm{ZnO}$ & 0.20 & 0.18 & 0.14 & 0.14 & 0.3 & 0.14 & 0.20 & 0.16 & 0.16 \\
\hline $\mathrm{ZrO}_{2}$ & 35.59 & 30.77 & 24.36 & 24.12 & 49.0 & 24.12 & 35.59 & 27.56 & 27.95 \\
\hline
\end{tabular}




\begin{tabular}{|c|c|c|c|c|c|c|c|c|}
\hline Batch & 10 & 11 & 12 & Total Mass & Min & Max & Median & Mean \\
\hline Mass & 57 & 57 & 57 & $\begin{array}{r}171 \\
\end{array}$ & 57 & \begin{tabular}{|l|}
57 \\
\end{tabular} & & \\
\hline $\mathrm{Ag}_{2} \mathrm{O}$ & 0.00 & 0.00 & 0.00 & 0.0 & 0.00 & 0.00 & 0.00 & 0.00 \\
\hline $\mathrm{Al}_{2} \mathrm{O}_{3}$ & 2.24 & 2.24 & 2.23 & 3.8 & 2.23 & 2.24 & 2.24 & 2.23 \\
\hline $\mathrm{Am}_{2} \mathrm{O}_{3}$ & 0.00 & 0.00 & 0.00 & 0.0 & 0.00 & 0.00 & 0.00 & 0.00 \\
\hline $\mathrm{As}_{2} \mathrm{O}_{5}$ & 0.02 & 0.02 & 0.02 & 0.0 & 0.02 & 0.02 & 0.02 & 0.02 \\
\hline $\mathrm{B}_{2} \mathrm{O}_{3}$ & 1.44 & 1.44 & 1.44 & 2.5 & 1.44 & 1.44 & 1.44 & 1.44 \\
\hline $\mathrm{BaO}$ & 0.04 & 0.04 & 0.04 & 0.1 & 0.04 & 0.04 & 0.04 & 0.04 \\
\hline $\mathrm{BeO}$ & 0.03 & 0.03 & 0.03 & 0.0 & 0.03 & 0.03 & 0.03 & 0.03 \\
\hline $\mathrm{Bi}_{2} \mathrm{O}_{3}$ & 0.01 & 0.01 & 0.01 & 0.0 & 0.01 & 0.01 & 0.01 & 0.01 \\
\hline $\mathrm{CaO}$ & 1.42 & 1.42 & 1.41 & 2.4 & 1.41 & 1.42 & 1.42 & 1.41 \\
\hline $\mathrm{CdO}$ & 0.28 & 0.28 & 0.28 & 0.5 & 0.28 & 0.28 & 0.28 & 0.28 \\
\hline $\mathrm{Ce}_{2} \mathrm{O}_{3}$ & 0.02 & 0.02 & 0.02 & 0.0 & 0.02 & 0.02 & 0.02 & 0.02 \\
\hline $\mathrm{Cl}^{-}$ & 0.00 & 0.00 & 0.00 & 0.0 & 0.00 & 0.00 & 0.00 & 0.00 \\
\hline $\mathrm{Cm}_{2} \mathrm{O}_{3}$ & 0.00 & 0.00 & 0.00 & 0.0 & 0.00 & 0.00 & 0.00 & 0.00 \\
\hline $\mathrm{CoO}$ & 0.00 & 0.00 & 0.00 & 0.0 & 0.00 & 0.00 & 0.00 & 0.00 \\
\hline $\mathrm{Cr}_{2} \mathrm{O}_{3}$ & 0.16 & 0.16 & 0.16 & 0.3 & 0.16 & 0.16 & 0.16 & 0.16 \\
\hline $\mathrm{Cs}_{2} \mathrm{O}$ & 0.00 & 0.00 & 0.00 & 0.0 & 0.00 & 0.00 & 0.00 & 0.00 \\
\hline $\mathrm{CuO}$ & 0.04 & 0.04 & 0.04 & 0.1 & 0.04 & 0.04 & 0.04 & 0.04 \\
\hline $\mathrm{F}^{-}$ & 0.10 & 0.10 & 0.10 & 0.2 & 0.10 & 0.10 & 0.10 & 0.10 \\
\hline $\mathrm{Fe}_{2} \mathrm{O}_{3}$ & 11.85 & 11.85 & 11.80 & 20.3 & 11.80 & 11.85 & 11.85 & 11.84 \\
\hline $\mathrm{K}_{2} \mathrm{O}$ & 0.34 & 0.34 & 0.34 & 0.6 & 0.34 & 0.34 & 0.34 & 0.34 \\
\hline $\mathrm{La}_{2} \mathrm{O}_{3}$ & 0.28 & 0.28 & 0.28 & 0.5 & 0.28 & 0.28 & 0.28 & 0.28 \\
\hline $\mathrm{Li}_{2} \mathrm{O}$ & 0.00 & 0.00 & 0.00 & 0.0 & 0.00 & 0.00 & 0.00 & 0.00 \\
\hline $\mathrm{MgO}$ & 0.09 & 0.09 & 0.08 & 0.1 & 0.08 & 0.09 & 0.09 & 0.09 \\
\hline $\mathrm{MnO}$ & 10.17 & 10.17 & 10.26 & 17.5 & 10.17 & 10.26 & 10.17 & 10.20 \\
\hline $\mathrm{MoO}_{3}$ & 0.01 & 0.01 & 0.01 & 0.0 & 0.01 & 0.01 & 0.01 & 0.01 \\
\hline $\mathrm{Na}_{2} \mathrm{O}$ & 9.13 & 9.13 & 9.09 & 15.6 & 9.09 & 9.13 & 9.13 & 9.12 \\
\hline $\mathrm{Nb}_{2} \mathrm{O}_{5}$ & 0.00 & 0.00 & 0.00 & 0.0 & 0.00 & 0.00 & 0.00 & 0.00 \\
\hline $\mathrm{Nd}_{2} \mathrm{O}_{3}$ & 0.03 & 0.03 & 0.03 & 0.1 & 0.03 & 0.03 & 0.03 & 0.03 \\
\hline $\mathrm{NiO}$ & 0.84 & 0.84 & 0.83 & 1.4 & 0.83 & 0.84 & 0.84 & 0.84 \\
\hline $\mathrm{NpO}_{2}$ & 0.00 & 0.00 & 0.00 & 0.0 & 0.00 & 0.00 & 0.00 & 0.00 \\
\hline $\mathrm{P}_{2} \mathrm{O}_{5}$ & 0.23 & 0.23 & 0.23 & 0.4 & 0.23 & 0.23 & 0.23 & 0.23 \\
\hline $\mathrm{PbO}$ & 0.25 & 0.25 & 0.25 & 0.4 & 0.25 & 0.25 & 0.25 & 0.25 \\
\hline $\mathrm{PuO}_{2}$ & 0.03 & 0.03 & 0.03 & 0.0 & 0.03 & 0.03 & 0.03 & 0.03 \\
\hline $\mathrm{Rb}_{2} \mathrm{O}$ & 0.00 & 0.00 & 0.00 & 0.0 & 0.00 & 0.00 & 0.00 & 0.00 \\
\hline $\mathrm{Rh}_{2} \mathrm{O}_{3}$ & 0.00 & 0.00 & 0.00 & 0.0 & 0.00 & 0.00 & 0.00 & 0.00 \\
\hline $\mathrm{RuO}_{2}$ & 0.00 & 0.00 & 0.00 & 0.0 & 0.00 & 0.00 & 0.00 & 0.00 \\
\hline $\mathrm{Sb}_{2} \mathrm{O}_{3}$ & 0.01 & 0.01 & 0.01 & 0.0 & 0.01 & 0.01 & 0.01 & 0.01 \\
\hline
\end{tabular}

C - 21 


\begin{tabular}{|l|r|r|r|r|r|r|r|r||}
\hline Batch & $\mathbf{1 0}$ & $\mathbf{1 1}$ & $\mathbf{1 2}$ & Total Mass & \multicolumn{1}{l|}{ Min } & Max & Median & Mean \\
\hline $\mathbf{M a s S}$ & $\mathbf{5 7}$ & $\mathbf{5 7}$ & $\mathbf{5 7}$ & $\mathbf{1 7 1}$ & $\mathbf{5 7}$ & $\mathbf{5 7}$ & & \\
\hline $\mathrm{SeO}_{2}$ & 0.00 & 0.00 & 0.00 & 0.0 & 0.00 & 0.00 & 0.00 & 0.00 \\
\hline $\mathrm{SiO}_{2}$ & 3.14 & 3.14 & 3.13 & 5.4 & 3.13 & 3.14 & 3.14 & 3.13 \\
\hline $\mathrm{Sm}_{2} \mathrm{O}_{3}$ & 0.00 & 0.00 & 0.00 & 0.0 & 0.00 & 0.00 & 0.00 & 0.00 \\
\hline $\mathrm{SnO}_{2}$ & 0.00 & 0.00 & 0.00 & 0.0 & 0.00 & 0.00 & 0.00 & 0.00 \\
\hline $\mathrm{SO}_{3}$ & 0.02 & 0.02 & 0.02 & 0.0 & 0.02 & 0.02 & 0.02 & 0.02 \\
\hline $\mathrm{SrO}$ & 17.05 & 17.05 & 17.28 & 29.3 & 17.05 & 17.28 & 17.05 & 17.13 \\
\hline $\mathrm{TcO}_{2}$ & 0.00 & 0.00 & 0.00 & 0.0 & 0.00 & 0.00 & 0.00 & 0.00 \\
\hline $\mathrm{TeO}_{2}$ & 0.00 & 0.00 & 0.00 & 0.0 & 0.00 & 0.00 & 0.00 & 0.00 \\
\hline $\mathrm{ThO}_{2}$ & 2.80 & 2.80 & 2.78 & 4.8 & 2.78 & 2.80 & 2.80 & 2.79 \\
\hline $\mathrm{TiO}_{2}$ & 0.04 & 0.04 & 0.04 & 0.1 & 0.04 & 0.04 & 0.04 & 0.04 \\
\hline $\mathrm{Tl}_{2} \mathrm{O}$ & 0.03 & 0.03 & 0.03 & 0.0 & 0.03 & 0.03 & 0.03 & 0.03 \\
\hline $\mathrm{U}_{3} \mathrm{O}_{8}$ & 15.85 & 15.85 & 15.78 & 27.1 & 15.78 & 15.85 & 15.85 & 15.82 \\
\hline $\mathrm{V}_{2} \mathrm{O}_{5}$ & 0.01 & 0.01 & 0.01 & 0.0 & 0.01 & 0.01 & 0.01 & 0.01 \\
\hline $\mathrm{WO}_{3}$ & 0.00 & 0.00 & 0.00 & 0.0 & 0.00 & 0.00 & 0.00 & 0.00 \\
\hline $\mathrm{ZnO}^{\mathrm{ZrO}_{2}}$ & 0.03 & 0.03 & 0.03 & 0.1 & 0.03 & 0.03 & 0.03 & 0.03 \\
\hline
\end{tabular}

\begin{tabular}{|l|r|r|r|r|r|r|r||}
\hline Batch & $\mathbf{2 5}$ & $\mathbf{3 0}$ & Total Mass & \multicolumn{1}{l|}{ Min } & Max & Median & Mean \\
\hline Mass & $\mathbf{1 0 7}$ & $\mathbf{4 3}$ & $\mathbf{1 5 0}$ & $\mathbf{4 3}$ & $\mathbf{1 0 7}$ & & \\
\hline \hline $\mathrm{Ag}_{2} \mathrm{O}$ & 0.10 & 0.04 & 0.1 & 0.04 & 0.10 & 0.07 & 0.09 \\
\hline $\mathrm{Al}_{2} \mathrm{O}_{3}$ & 14.70 & 15.65 & 22.4 & 14.70 & 15.65 & 15.17 & 14.97 \\
\hline $\mathrm{Am}_{2} \mathrm{O}_{3}$ & 0.00 & 0.00 & 0.0 & 0.00 & 0.00 & 0.00 & 0.00 \\
\hline $\mathrm{As}_{2} \mathrm{O}_{5}$ & 0.63 & 0.33 & 0.8 & 0.33 & 0.63 & 0.48 & 0.54 \\
\hline $\mathrm{B}_{2} \mathrm{O}_{3}$ & 0.86 & 0.49 & 1.1 & 0.49 & 0.86 & 0.68 & 0.76 \\
\hline $\mathrm{BaO}$ & 0.28 & 0.13 & 0.4 & 0.13 & 0.28 & 0.21 & 0.24 \\
\hline $\mathrm{BeO}$ & 0.06 & 0.03 & 0.1 & 0.03 & 0.06 & 0.04 & 0.05 \\
\hline $\mathrm{Bi}_{2} \mathrm{O}_{3}$ & 2.17 & 0.11 & 2.4 & 0.11 & 2.17 & 1.14 & 1.58 \\
\hline $\mathrm{CaO}$ & 0.86 & 0.59 & 1.2 & 0.59 & 0.86 & 0.73 & 0.78 \\
\hline $\mathrm{CdO}$ & 0.14 & 0.02 & 0.2 & 0.02 & 0.14 & 0.08 & 0.10 \\
\hline $\mathrm{Ce}_{2} \mathrm{O}_{3}$ & 0.52 & 0.27 & 0.7 & 0.27 & 0.52 & 0.40 & 0.45 \\
\hline $\mathrm{Cl}^{-}$ & 0.17 & 0.07 & 0.2 & 0.07 & 0.17 & 0.12 & 0.14 \\
\hline $\mathrm{Cm}_{2} \mathrm{O}_{3}$ & 0.00 & 0.00 & 0.0 & 0.00 & 0.00 & 0.00 & 0.00 \\
\hline $\mathrm{CoO}^{-}$ & 0.11 & 0.06 & 0.1 & 0.06 & 0.11 & 0.08 & 0.10 \\
\hline $\mathrm{Cr}_{2} \mathrm{O}_{3}$ & 3.79 & 5.41 & 6.4 & 3.79 & 5.41 & 4.60 & 4.25 \\
\hline $\mathrm{Cs}_{2} \mathrm{O}$ & 0.34 & 0.06 & 0.4 & 0.06 & 0.34 & 0.20 & 0.26 \\
\hline $\mathrm{CuO}^{-}$ & 0.07 & 0.03 & 0.1 & 0.03 & 0.07 & 0.05 & 0.06 \\
\hline $\mathrm{F}^{-}$ & 1.61 & 0.86 & 2.1 & 0.86 & 1.61 & 1.23 & 1.39 \\
\hline \hline
\end{tabular}

C - 22 


\begin{tabular}{|c|c|c|c|c|c|c|c|}
\hline Batch & 25 & 30 & Total Mass & Min & Max & Median & Mean \\
\hline Mass & 107 & 43 & 150 & 43 & 107 & & \\
\hline $\mathrm{Fe}_{2} \mathrm{O}_{3}$ & 12.68 & 6.66 & 16.4 & 6.66 & 12.68 & 9.67 & 10.96 \\
\hline $\mathrm{K}_{2} \mathrm{O}$ & 1.81 & 2.37 & 2.9 & 1.81 & 2.37 & 2.09 & 1.97 \\
\hline $\mathrm{La}_{2} \mathrm{O}_{3}$ & 0.23 & 0.16 & 0.3 & 0.16 & 0.23 & 0.20 & 0.21 \\
\hline $\mathrm{Li}_{2} \mathrm{O}$ & 0.09 & 0.05 & 0.1 & 0.05 & 0.09 & 0.07 & 0.08 \\
\hline $\mathrm{MgO}$ & 0.75 & 0.40 & 1.0 & 0.40 & 0.75 & 0.57 & 0.65 \\
\hline $\mathrm{MnO}$ & 1.38 & 1.44 & 2.1 & 1.38 & 1.44 & 1.41 & 1.40 \\
\hline $\mathrm{MoO}_{3}$ & 0.32 & 0.17 & 0.4 & 0.17 & 0.32 & 0.25 & 0.28 \\
\hline $\mathrm{Na}_{2} \mathrm{O}$ & 29.98 & 49.30 & 53.1 & 29.98 & 49.30 & 39.64 & 35.50 \\
\hline $\mathrm{Nb}_{2} \mathrm{O}_{5}$ & 0.00 & 0.00 & 0.0 & 0.00 & 0.00 & 0.00 & 0.00 \\
\hline $\mathrm{Nd}_{2} \mathrm{O}_{3}$ & 0.49 & 0.25 & 0.6 & 0.25 & 0.49 & 0.37 & 0.42 \\
\hline $\mathrm{NiO}$ & 0.63 & 0.35 & 0.8 & 0.35 & 0.63 & 0.49 & 0.55 \\
\hline $\mathrm{NpO}_{2}$ & 0.00 & 0.00 & 0.0 & 0.00 & 0.00 & 0.00 & 0.00 \\
\hline $\mathrm{P}_{2} \mathrm{O}_{5}$ & 2.32 & 2.74 & 3.7 & 2.32 & 2.74 & 2.53 & 2.44 \\
\hline $\mathrm{PbO}$ & 0.59 & 0.36 & 0.8 & 0.36 & 0.59 & 0.48 & 0.52 \\
\hline $\mathrm{PuO}_{2}$ & 0.01 & 0.00 & 0.0 & 0.00 & 0.01 & 0.01 & 0.01 \\
\hline $\mathrm{Rb}_{2} \mathrm{O}$ & 0.00 & 0.00 & 0.0 & 0.00 & 0.00 & 0.00 & 0.00 \\
\hline $\mathrm{Rh}_{2} \mathrm{O}_{3}$ & 0.07 & 0.04 & 0.1 & 0.04 & 0.07 & 0.05 & 0.06 \\
\hline $\mathrm{RuO}_{2}$ & 0.01 & 0.00 & 0.0 & 0.00 & 0.01 & 0.01 & 0.01 \\
\hline $\mathrm{Sb}_{2} \mathrm{O}_{3}$ & 0.32 & 0.16 & 0.4 & 0.16 & 0.32 & 0.24 & 0.27 \\
\hline $\mathrm{SeO}_{2}$ & 0.04 & 0.02 & 0.0 & 0.02 & 0.04 & 0.03 & 0.03 \\
\hline $\mathrm{SiO}_{2}$ & 2.64 & 0.47 & 3.0 & 0.47 & 2.64 & 1.56 & 2.02 \\
\hline $\mathrm{Sm}_{2} \mathrm{O}_{3}$ & 0.00 & 0.00 & 0.0 & 0.00 & 0.00 & 0.00 & 0.00 \\
\hline $\mathrm{SnO}_{2}$ & 0.00 & 0.00 & 0.0 & 0.00 & 0.00 & 0.00 & 0.00 \\
\hline $\mathrm{SO}_{3}$ & 0.06 & 0.05 & 0.1 & 0.05 & 0.06 & 0.05 & 0.05 \\
\hline $\mathrm{SrO}$ & 0.11 & 0.03 & 0.1 & 0.03 & 0.11 & 0.07 & 0.09 \\
\hline $\mathrm{TcO}_{2}$ & 0.02 & 0.01 & 0.0 & 0.01 & 0.02 & 0.02 & 0.02 \\
\hline $\mathrm{TeO}_{2}$ & 0.03 & 0.02 & 0.0 & 0.02 & 0.03 & 0.02 & 0.03 \\
\hline $\mathrm{ThO}_{2}$ & 0.19 & 0.22 & 0.3 & 0.19 & 0.22 & 0.20 & 0.20 \\
\hline $\mathrm{TiO}_{2}$ & 0.07 & 0.04 & 0.1 & 0.04 & 0.07 & 0.05 & 0.06 \\
\hline $\mathrm{Tl}_{2} \mathrm{O}$ & 0.86 & 0.44 & 1.1 & 0.44 & 0.86 & 0.65 & 0.74 \\
\hline $\mathrm{U}_{3} \mathrm{O}_{8}$ & 5.63 & 3.93 & 7.7 & 3.93 & 5.63 & 4.78 & 5.15 \\
\hline $\mathrm{V}_{2} \mathrm{O}_{5}$ & 0.24 & 0.13 & 0.3 & 0.13 & 0.24 & 0.18 & 0.21 \\
\hline $\mathrm{WO}_{3}$ & 0.00 & 0.00 & 0.0 & 0.00 & 0.00 & 0.00 & 0.00 \\
\hline $\mathrm{ZnO}$ & 0.09 & 0.05 & 0.1 & 0.05 & 0.09 & 0.07 & 0.08 \\
\hline $\mathrm{ZrO}_{2}$ & 11.93 & 5.99 & 15.3 & 5.99 & 11.93 & 8.96 & 10.23 \\
\hline
\end{tabular}




\begin{tabular}{|c|c|c|c|c|c|c|c|}
\hline Batch & $\mathbf{1}$ & 2 & Total Mass & Min & Max & Median & Mean \\
\hline Mass & 62 & 79 & 142 & 62 & 79 & & \\
\hline $\mathrm{Ag}_{2} \mathrm{O}$ & 0.08 & 0.14 & 0.2 & 0.08 & 0.14 & 0.11 & 0.11 \\
\hline $\mathrm{Al}_{2} \mathrm{O}_{3}$ & 14.84 & 3.18 & 11.8 & 3.18 & 14.84 & 9.01 & 8.32 \\
\hline $\mathrm{Am}_{2} \mathrm{O}_{3}$ & 0.01 & 0.01 & 0.0 & 0.01 & 0.01 & 0.01 & 0.01 \\
\hline $\mathrm{As}_{2} \mathrm{O}_{5}$ & 0.04 & 0.01 & 0.0 & 0.01 & 0.04 & 0.03 & 0.02 \\
\hline $\mathrm{B}_{2} \mathrm{O}_{3}$ & 0.34 & 1.97 & 1.8 & 0.34 & 1.97 & 1.16 & 1.25 \\
\hline $\mathrm{BaO}$ & 0.29 & 0.12 & 0.3 & 0.12 & 0.29 & 0.20 & 0.19 \\
\hline $\mathrm{BeO}$ & 0.01 & 0.01 & 0.0 & 0.01 & 0.01 & 0.01 & 0.01 \\
\hline $\mathrm{Bi}_{2} \mathrm{O}_{3}$ & 0.02 & 0.02 & 0.0 & 0.02 & 0.02 & 0.02 & 0.02 \\
\hline $\mathrm{CaO}$ & 0.86 & 0.98 & 1.3 & 0.86 & 0.98 & 0.92 & 0.93 \\
\hline $\mathrm{CdO}$ & 2.91 & 5.77 & 6.4 & 2.91 & 5.77 & 4.34 & 4.51 \\
\hline $\mathrm{Ce}_{2} \mathrm{O}_{3}$ & 0.36 & 0.17 & 0.4 & 0.17 & 0.36 & 0.27 & 0.26 \\
\hline $\mathrm{Cl}^{-}$ & 0.02 & 0.00 & 0.0 & 0.00 & 0.02 & 0.01 & 0.01 \\
\hline $\mathrm{Cm}_{2} \mathrm{O}_{3}$ & 0.00 & 0.00 & 0.0 & 0.00 & 0.00 & 0.00 & 0.00 \\
\hline $\mathrm{CoO}$ & 0.02 & 0.01 & 0.0 & 0.01 & 0.02 & 0.02 & 0.02 \\
\hline $\mathrm{Cr}_{2} \mathrm{O}_{3}$ & 0.06 & 0.15 & 0.2 & 0.06 & 0.15 & 0.10 & 0.11 \\
\hline $\mathrm{Cs}_{2} \mathrm{O}$ & 0.01 & 0.01 & 0.0 & 0.01 & 0.01 & 0.01 & 0.01 \\
\hline $\mathrm{CuO}$ & 0.11 & 0.05 & 0.1 & 0.05 & 0.11 & 0.08 & 0.07 \\
\hline $\mathrm{F}^{-}$ & 0.56 & 0.14 & 0.5 & 0.14 & 0.56 & 0.35 & 0.33 \\
\hline $\mathrm{Fe}_{2} \mathrm{O}_{3}$ & 42.85 & 51.75 & 67.8 & 42.85 & 51.75 & 47.30 & 47.83 \\
\hline $\mathrm{K}_{2} \mathrm{O}$ & 0.98 & 1.10 & 1.5 & 0.98 & 1.10 & 1.04 & 1.05 \\
\hline $\mathrm{La}_{2} \mathrm{O}_{3}$ & 1.56 & 1.61 & 2.2 & 1.56 & 1.61 & 1.58 & 1.59 \\
\hline $\mathrm{Li}_{2} \mathrm{O}$ & 0.05 & 0.00 & 0.0 & 0.00 & 0.05 & 0.03 & 0.02 \\
\hline $\mathrm{MgO}$ & 0.40 & 0.30 & 0.5 & 0.30 & 0.40 & 0.35 & 0.35 \\
\hline $\mathrm{MnO}$ & 0.52 & 1.23 & 1.3 & 0.52 & 1.23 & 0.87 & 0.92 \\
\hline $\mathrm{MoO}_{3}$ & 0.03 & 0.03 & 0.0 & 0.03 & 0.03 & 0.03 & 0.03 \\
\hline $\mathrm{Na}_{2} \mathrm{O}$ & 11.45 & 14.02 & 18.3 & 11.45 & 14.02 & 12.73 & 12.88 \\
\hline $\mathrm{Nb}_{2} \mathrm{O}_{5}$ & 0.00 & 0.00 & 0.0 & 0.00 & 0.00 & 0.00 & 0.00 \\
\hline $\mathrm{Nd}_{2} \mathrm{O}_{3}$ & 0.94 & 0.59 & 1.1 & 0.59 & 0.94 & 0.76 & 0.74 \\
\hline $\mathrm{NiO}$ & 2.35 & 1.91 & 3.0 & 1.91 & 2.35 & 2.13 & 2.10 \\
\hline $\mathrm{NpO}_{2}$ & 0.03 & 0.02 & 0.0 & 0.02 & 0.03 & 0.02 & 0.02 \\
\hline $\mathrm{P}_{2} \mathrm{O}_{5}$ & 0.03 & 0.26 & 0.2 & 0.03 & 0.26 & 0.14 & 0.16 \\
\hline $\mathrm{PbO}$ & 0.13 & 0.30 & 0.3 & 0.13 & 0.30 & 0.21 & 0.22 \\
\hline $\mathrm{PuO}_{2}$ & 0.03 & 0.03 & 0.0 & 0.03 & 0.03 & 0.03 & 0.03 \\
\hline $\mathrm{Rb}_{2} \mathrm{O}$ & 0.01 & 0.00 & 0.0 & 0.00 & 0.01 & 0.00 & 0.00 \\
\hline $\mathrm{Rh}_{2} \mathrm{O}_{3}$ & 0.08 & 0.01 & 0.1 & 0.01 & 0.08 & 0.05 & 0.04 \\
\hline $\mathrm{RuO}_{2}$ & 0.00 & 0.06 & 0.0 & 0.00 & 0.06 & 0.03 & 0.03 \\
\hline $\mathrm{Sb}_{2} \mathrm{O}_{3}$ & 0.00 & 0.00 & 0.0 & 0.00 & 0.00 & 0.00 & 0.00 \\
\hline
\end{tabular}




\begin{tabular}{|l|r|r|r|r|r|r|r||}
\hline Batch & $\mathbf{1}$ & $\mathbf{2}$ & \multicolumn{1}{l}{ Total Mass } & \multicolumn{1}{l}{ Min } & \multicolumn{1}{l}{ Max } & Median & Mean \\
\hline $\mathbf{M a s S}$ & $\mathbf{6 2}$ & $\mathbf{7 9}$ & $\mathbf{1 4 2}$ & $\mathbf{6 2}$ & $\mathbf{7 9}$ & & \\
\hline \hline $\mathrm{SeO}_{2}$ & 0.02 & 0.00 & 0.0 & 0.00 & 0.02 & 0.01 & 0.01 \\
\hline $\mathrm{SiO}_{2}$ & 0.21 & 1.53 & 1.3 & 0.21 & 1.53 & 0.87 & 0.95 \\
\hline $\mathrm{Sm}_{2} \mathrm{O}_{3}$ & 0.01 & 0.00 & 0.0 & 0.00 & 0.01 & 0.00 & 0.00 \\
\hline $\mathrm{SnO}_{2}$ & 0.00 & 0.00 & 0.0 & 0.00 & 0.00 & 0.00 & 0.00 \\
\hline $\mathrm{SO}_{3}$ & 0.17 & 0.20 & 0.3 & 0.17 & 0.20 & 0.19 & 0.19 \\
\hline $\mathrm{SrO}^{\mathrm{NeO}}$ & 0.12 & 0.05 & 0.1 & 0.05 & 0.12 & 0.09 & 0.08 \\
\hline $\mathrm{TeO}_{2}$ & 0.00 & 0.01 & 0.0 & 0.00 & 0.01 & 0.00 & 0.00 \\
\hline $\mathrm{TeO}_{2}$ & 0.04 & 0.02 & 0.0 & 0.02 & 0.04 & 0.03 & 0.03 \\
\hline $\mathrm{ThO}_{2}$ & 0.23 & 0.18 & 0.3 & 0.18 & 0.23 & 0.21 & 0.20 \\
\hline $\mathrm{TiO}_{2}$ & 0.02 & 0.02 & 0.0 & 0.02 & 0.02 & 0.02 & 0.02 \\
\hline $\mathrm{Tl}_{2} \mathrm{O}$ & 0.00 & 0.00 & 0.0 & 0.00 & 0.00 & 0.00 & 0.00 \\
\hline $\mathrm{U}_{3} \mathrm{O}_{8}$ & 2.61 & 4.43 & 5.1 & 2.61 & 4.43 & 3.52 & 3.63 \\
\hline $\mathrm{V}_{2} \mathrm{O}_{5}$ & 0.02 & 0.02 & 0.0 & 0.02 & 0.02 & 0.02 & 0.02 \\
\hline $\mathrm{WO}_{3}$ & 0.00 & 0.00 & 0.0 & 0.00 & 0.00 & 0.00 & 0.00 \\
\hline $\mathrm{ZnO}$ & 0.04 & 0.03 & 0.1 & 0.03 & 0.04 & 0.04 & 0.04 \\
\hline $\mathrm{ZrO}_{2}$ & 14.52 & 7.54 & 15.1 & 7.54 & 14.52 & 11.03 & 10.61 \\
\hline
\end{tabular}

\begin{tabular}{|c|c|c|c|c|c|c|c|c|}
\hline Batch & 7 & 8 & 9 & Total Mass & Min & Max & Median & Mean \\
\hline Mass & 43 & 43 & 43 & 128 & 43 & 43 & & 128 \\
\hline $\mathrm{Ag}_{2} \mathrm{O}$ & 0.00 & 0.00 & 0.00 & 0.0 & 0.00 & 0.00 & 0.00 & 0.00 \\
\hline $\mathrm{Al}_{2} \mathrm{O}_{3}$ & 3.97 & 3.06 & 2.97 & 4.3 & 2.97 & 3.97 & 3.06 & 3.34 \\
\hline $\mathrm{Am}_{2} \mathrm{O}_{3}$ & 0.00 & 0.00 & 0.00 & 0.0 & 0.00 & 0.00 & 0.00 & 0.00 \\
\hline $\mathrm{As}_{2} \mathrm{O}_{5}$ & 0.03 & 0.02 & 0.02 & 0.0 & 0.02 & 0.03 & 0.02 & 0.02 \\
\hline $\mathrm{B}_{2} \mathrm{O}_{3}$ & 1.88 & 1.91 & 1.91 & 2.4 & 1.88 & 1.91 & 1.91 & 1.90 \\
\hline $\mathrm{BaO}$ & 0.05 & 0.05 & 0.05 & 0.1 & 0.05 & 0.05 & 0.05 & 0.05 \\
\hline $\mathrm{BeO}$ & 0.03 & 0.04 & 0.04 & 0.0 & 0.03 & 0.04 & 0.04 & 0.03 \\
\hline $\mathrm{Bi}_{2} \mathrm{O}_{3}$ & 0.01 & 0.01 & 0.01 & 0.0 & 0.01 & 0.01 & 0.01 & 0.01 \\
\hline $\mathrm{CaO}$ & 1.84 & 1.87 & 1.88 & 2.4 & 1.84 & 1.88 & 1.87 & 1.86 \\
\hline $\mathrm{CdO}$ & 0.37 & 0.37 & 0.37 & 0.5 & 0.37 & 0.37 & 0.37 & 0.37 \\
\hline $\mathrm{Ce}_{2} \mathrm{O}_{3}$ & 0.03 & 0.03 & 0.03 & 0.0 & 0.03 & 0.03 & 0.03 & 0.03 \\
\hline $\mathrm{Cl}^{-}$ & 0.00 & 0.00 & 0.00 & 0.0 & 0.00 & 0.00 & 0.00 & 0.00 \\
\hline $\mathrm{Cm}_{2} \mathrm{O}_{3}$ & 0.00 & 0.00 & 0.00 & 0.0 & 0.00 & 0.00 & 0.00 & 0.00 \\
\hline $\mathrm{CoO}$ & 0.00 & 0.00 & 0.00 & 0.0 & 0.00 & 0.00 & 0.00 & 0.00 \\
\hline $\mathrm{Cr}_{2} \mathrm{O}_{3}$ & 0.21 & 0.21 & 0.21 & 0.3 & 0.21 & 0.21 & 0.21 & 0.21 \\
\hline $\mathrm{Cs}_{2} \mathrm{O}$ & 0.00 & 0.00 & 0.00 & 0.0 & 0.00 & 0.00 & 0.00 & 0.00 \\
\hline $\mathrm{CuO}$ & 0.05 & 0.06 & 0.06 & 0.1 & 0.05 & 0.06 & 0.06 & 0.06 \\
\hline $\mathrm{F}^{-}$ & 0.14 & 0.14 & 0.14 & 0.2 & 0.14 & 0.14 & 0.14 & 0.14 \\
\hline
\end{tabular}

C - 25 


\begin{tabular}{|c|c|c|c|c|c|c|c|c|}
\hline Batch & 7 & 8 & 9 ' & Total Mass & Min & Max & Median & Mean \\
\hline Mass & 43 & 43 & 43 & 128 & 43 & 43 & & 128 \\
\hline $\mathrm{Fe}_{2} \mathrm{O}_{3}$ & 15.52 & 15.70 & 15.72 & 20.1 & 15.52 & 15.72 & 15.70 & 15.65 \\
\hline $\mathrm{K}_{2} \mathrm{O}$ & 0.44 & 0.45 & 0.45 & 0.6 & 0.44 & 0.45 & 0.45 & 0.45 \\
\hline $\mathrm{La}_{2} \mathrm{O}_{3}$ & 0.37 & 0.38 & 0.38 & 0.5 & 0.37 & 0.38 & 0.38 & 0.38 \\
\hline $\mathrm{Li}_{2} \mathrm{O}$ & 0.00 & 0.00 & 0.00 & 0.0 & 0.00 & 0.00 & 0.00 & 0.00 \\
\hline $\mathrm{MgO}$ & 0.11 & 0.11 & 0.11 & 0.1 & 0.11 & 0.11 & 0.11 & 0.11 \\
\hline $\mathrm{MnO}$ & 3.37 & 3.41 & 3.42 & 4.4 & 3.37 & 3.42 & 3.41 & 3.40 \\
\hline $\mathrm{MoO}_{3}$ & 0.01 & 0.01 & 0.01 & 0.0 & 0.01 & 0.01 & 0.01 & 0.01 \\
\hline $\mathrm{Na}_{2} \mathrm{O}$ & 12.19 & 12.12 & 12.11 & 15.6 & 12.11 & 12.19 & 12.12 & 12.14 \\
\hline $\mathrm{Nb}_{2} \mathrm{O}_{5}$ & 0.00 & 0.00 & 0.00 & 0.0 & 0.00 & 0.00 & 0.00 & 0.00 \\
\hline $\mathrm{Nd}_{2} \mathrm{O}_{3}$ & 0.04 & 0.04 & 0.04 & 0.1 & 0.04 & 0.04 & 0.04 & 0.04 \\
\hline $\mathrm{NiO}$ & 1.10 & 1.11 & 1.11 & 1.4 & 1.10 & 1.11 & 1.11 & 1.11 \\
\hline $\mathrm{NpO}_{2}$ & 0.00 & 0.00 & 0.00 & 0.0 & 0.00 & 0.00 & 0.00 & 0.00 \\
\hline $\mathrm{P}_{2} \mathrm{O}_{5}$ & 0.30 & 0.30 & 0.30 & 0.4 & 0.30 & 0.30 & 0.30 & 0.30 \\
\hline $\mathrm{PbO}$ & 0.33 & 0.33 & 0.33 & 0.4 & 0.33 & 0.33 & 0.33 & 0.33 \\
\hline $\mathrm{PuO}_{2}$ & 0.04 & 0.04 & 0.04 & 0.0 & 0.04 & 0.04 & 0.04 & 0.04 \\
\hline $\mathrm{Rb}_{2} \mathrm{O}$ & 0.00 & 0.00 & 0.00 & 0.0 & 0.00 & 0.00 & 0.00 & 0.00 \\
\hline $\mathrm{Rh}_{2} \mathrm{O}_{3}$ & 0.00 & 0.00 & 0.00 & 0.0 & 0.00 & 0.00 & 0.00 & 0.00 \\
\hline $\mathrm{RuO}_{2}$ & 0.00 & 0.00 & 0.00 & 0.0 & 0.00 & 0.00 & 0.00 & 0.00 \\
\hline $\mathrm{Sb}_{2} \mathrm{O}_{3}$ & 0.01 & 0.01 & 0.01 & 0.0 & 0.01 & 0.01 & 0.01 & 0.01 \\
\hline $\mathrm{SeO}_{2}$ & 0.00 & 0.00 & 0.00 & 0.0 & 0.00 & 0.00 & 0.00 & 0.00 \\
\hline $\mathrm{SiO}_{2}$ & 4.26 & 4.17 & 4.16 & 5.4 & 4.16 & 4.26 & 4.17 & 4.20 \\
\hline $\mathrm{Sm}_{2} \mathrm{O}_{3}$ & 0.00 & 0.00 & 0.00 & 0.0 & 0.00 & 0.00 & 0.00 & 0.00 \\
\hline $\mathrm{SnO}_{2}$ & 0.00 & 0.00 & 0.00 & 0.0 & 0.00 & 0.00 & 0.00 & 0.00 \\
\hline $\mathrm{SO}_{3}$ & 0.02 & 0.02 & 0.02 & 0.0 & 0.02 & 0.02 & 0.02 & 0.02 \\
\hline $\mathrm{SrO}$ & 0.04 & 0.04 & 0.04 & 0.1 & 0.04 & 0.04 & 0.04 & 0.04 \\
\hline $\mathrm{TcO}_{2}$ & 0.00 & 0.00 & 0.00 & 0.0 & 0.00 & 0.00 & 0.00 & 0.00 \\
\hline $\mathrm{TeO}_{2}$ & 0.00 & 0.00 & 0.00 & 0.0 & 0.00 & 0.00 & 0.00 & 0.00 \\
\hline $\mathrm{ThO}_{2}$ & 3.65 & 3.70 & 3.71 & 4.7 & 3.65 & 3.71 & 3.70 & 3.69 \\
\hline $\mathrm{TiO}_{2}$ & 0.05 & 0.05 & 0.05 & 0.1 & 0.05 & 0.05 & 0.05 & 0.05 \\
\hline $\mathrm{Tl}_{2} \mathrm{O}$ & 0.03 & 0.03 & 0.03 & 0.0 & 0.03 & 0.03 & 0.03 & 0.03 \\
\hline $\mathrm{U}_{3} \mathrm{O}_{8}$ & 20.70 & 20.99 & 21.02 & 26.8 & 20.70 & 21.02 & 20.99 & 20.90 \\
\hline $\mathrm{V}_{2} \mathrm{O}_{5}$ & 0.02 & 0.02 & 0.02 & 0.0 & 0.02 & 0.02 & 0.02 & 0.02 \\
\hline $\mathrm{WO}_{3}$ & 0.00 & 0.00 & 0.00 & 0.0 & 0.00 & 0.00 & 0.00 & 0.00 \\
\hline $\mathrm{ZnO}$ & 0.04 & 0.04 & 0.04 & 0.1 & 0.04 & 0.04 & 0.04 & 0.04 \\
\hline $\mathrm{ZrO}_{2}$ & 28.70 & 29.11 & 29.15 & 37.2 & 28.70 & 29.15 & 29.11 & 28.98 \\
\hline
\end{tabular}




\begin{tabular}{|c|c|c|}
\hline Batch & 18 & Total Mass \\
\hline Mass & 19 & 19 \\
\hline $\mathrm{Ag}_{2} \mathrm{O}$ & 0.02 & 0.0 \\
\hline $\mathrm{Al}_{2} \mathrm{O}_{3}$ & 2.63 & 0.5 \\
\hline $\mathrm{Am}_{2} \mathrm{O}_{3}$ & 0.00 & 0.0 \\
\hline $\mathrm{As}_{2} \mathrm{O}_{5}$ & 0.04 & 0.0 \\
\hline $\mathrm{B}_{2} \mathrm{O}_{3}$ & 0.07 & 0.0 \\
\hline $\mathrm{BaO}$ & 0.02 & 0.0 \\
\hline $\mathrm{BeO}$ & 0.00 & 0.0 \\
\hline $\mathrm{Bi}_{2} \mathrm{O}_{3}$ & 0.10 & 0.0 \\
\hline $\mathrm{CaO}$ & 0.39 & 0.1 \\
\hline $\mathrm{CdO}$ & 0.02 & 0.0 \\
\hline $\mathrm{Ce}_{2} \mathrm{O}_{3}$ & 0.03 & 0.0 \\
\hline $\mathrm{Cl}^{-}$ & 0.04 & 0.0 \\
\hline $\mathrm{Cm}_{2} \mathrm{O}_{3}$ & 0.00 & 0.0 \\
\hline $\mathrm{CoO}$ & 0.01 & 0.0 \\
\hline $\mathrm{Cr}_{2} \mathrm{O}_{3}$ & 0.54 & 0.1 \\
\hline $\mathrm{Cs}_{2} \mathrm{O}$ & 0.10 & 0.0 \\
\hline $\mathrm{CuO}$ & 0.01 & 0.0 \\
\hline $\mathrm{F}^{-}$ & 0.06 & 0.0 \\
\hline $\mathrm{Fe}_{2} \mathrm{O}_{3}$ & 2.20 & 0.4 \\
\hline $\mathrm{K}_{2} \mathrm{O}$ & 0.59 & 0.1 \\
\hline $\mathrm{La}_{2} \mathrm{O}_{3}$ & 0.03 & 0.0 \\
\hline $\mathrm{Li}_{2} \mathrm{O}$ & 0.01 & 0.0 \\
\hline $\mathrm{MgO}$ & 0.11 & 0.0 \\
\hline $\mathrm{MnO}$ & 23.91 & 4.6 \\
\hline $\mathrm{MoO}_{3}$ & 0.01 & 0.0 \\
\hline $\mathrm{Na}_{2} \mathrm{O}$ & 14.50 & 2.8 \\
\hline $\mathrm{Nb}_{2} \mathrm{O}_{5}$ & 0.00 & 0.0 \\
\hline $\mathrm{Nd}_{2} \mathrm{O}_{3}$ & 0.03 & 0.0 \\
\hline $\mathrm{NiO}$ & 0.08 & 0.0 \\
\hline $\mathrm{NpO}_{2}$ & 0.00 & 0.0 \\
\hline $\mathrm{P}_{2} \mathrm{O}_{5}$ & 0.53 & 0.1 \\
\hline $\mathrm{PbO}$ & 0.12 & 0.0 \\
\hline $\mathrm{PuO}_{2}$ & 0.00 & 0.0 \\
\hline $\mathrm{Rb}_{2} \mathrm{O}$ & 0.00 & 0.0 \\
\hline $\mathrm{Rh}_{2} \mathrm{O}_{3}$ & 0.00 & 0.0 \\
\hline $\mathrm{RuO}_{2}$ & 0.00 & 0.0 \\
\hline $\mathrm{Sb}_{2} \mathrm{O}_{3}$ & 0.02 & 0.0 \\
\hline
\end{tabular}




\begin{tabular}{|l|r|r||}
\hline Batch & $\mathbf{1 8}$ & Total Mass \\
\hline Mass & $\mathbf{1 9}$ & $\mathbf{1 9}$ \\
\hline \hline $\mathrm{SeO}_{2}$ & 0.01 & 0.0 \\
\hline $\mathrm{SiO}_{2}$ & 0.51 & 0.1 \\
\hline $\mathrm{Sm}_{2} \mathrm{O}_{3}$ & 0.00 & 0.0 \\
\hline $\mathrm{SnO}_{2}$ & 0.00 & 0.0 \\
\hline $\mathrm{SO}_{3}$ & 0.02 & 0.0 \\
\hline $\mathrm{SrO}_{\mathrm{SO}}$ & 52.31 & 10.1 \\
\hline $\mathrm{TcO}_{2}$ & 0.00 & 0.0 \\
\hline $\mathrm{TeO}_{2}$ & 0.00 & 0.0 \\
\hline $\mathrm{ThO}_{2}$ & 0.06 & 0.0 \\
\hline $\mathrm{TiO}_{2}$ & 0.01 & 0.0 \\
\hline $\mathrm{Tl}_{2} \mathrm{O}$ & 0.05 & 0.0 \\
\hline $\mathrm{U}_{3} \mathrm{O}_{8}$ & 0.74 & 0.1 \\
\hline $\mathrm{V}_{2} \mathrm{O}_{5}$ & 0.02 & 0.0 \\
\hline $\mathrm{WO}_{3}$ & 0.00 & 0.0 \\
\hline $\mathrm{ZnO}_{\mathrm{ZnO}}$ & 0.03 & 0.0 \\
\hline $\mathrm{ZrO}_{2}$ & 0.03 & 0.0 \\
\hline \hline
\end{tabular}

C -28 


\section{Appendix D - Detailed Results of Waste Loading Calculations with Varying Property Constraints}

\begin{tabular}{|c|c|c|c|c|c|c|c|c|c|c|c|c|c|c|c|c|c|c|c|}
\hline \multicolumn{2}{|c|}{ Case \# $\backslash$ Cluster \# } & 1 & 2 & 3 & 4 & 5 & 6 & 7 & 8 & 9 & 10 & 11 & 12 & 13 & 14 & 15 & 16 & 17 & Total \\
\hline \multirow[t]{5}{*}{1} & WL (mass \%) & $54.1 \%$ & $54.6 \%$ & $43.2 \%$ & $44.6 \%$ & $48.0 \%$ & $41.4 \%$ & $49.5 \%$ & $39.0 \%$ & $49.9 \%$ & $37.0 \%$ & $43.8 \%$ & $43.6 \%$ & $39.2 \%$ & $23.5 \%$ & $35.8 \%$ & $50.2 \%$ & $16.7 \%$ & $46.4 \%$ \\
\hline & Glass Wt. (Mg) & \begin{tabular}{|l|}
2.69 \\
\end{tabular} & 2.85 & 2.73 & 2.73 & 2.78 & 2.63 & 2.62 & \begin{tabular}{|l|}
2.63 \\
\end{tabular} & 2.97 & 2.65 & 2.82 & 2.79 & 2.94 & 2.51 & 2.75 & 2.98 & 2.59 & 2.730 \\
\hline & Densit & 4342 & 3202 & 3815 & 3125 & 2886 & 2288 & 1369 & 1297 & 853 & 626 & 494 & 402 & 437 & 637 & 396 & 256 & 15 & 26539 \\
\hline & Glass Vol & 1612 & 1123 & 1396 & 1146 & 1040 & 869 & 523 & 493 & 287 & 236 & 175 & 144 & 148 & 253 & 144 & 86 & 44 & 9720 \\
\hline & WL lir & & \begin{tabular}{|} 
sp,v, \\
np,mv
\end{tabular} & $\begin{array}{r}\text { sp,v, } \\
\mathrm{np}, \mathrm{mv}\end{array}$ & $\begin{array}{c}\text { sp,v, } \\
\mathrm{np}, \mathrm{mv}\end{array}$ & $\begin{array}{c}\mathrm{sp}, \mathrm{v}, \\
\mathrm{np}, \mathrm{mv}\end{array}$ & $\begin{array}{c}\text { sp,np, } \\
\text { mv }\end{array}$ & cr & $\mathrm{p}$ & $\begin{array}{c}\mathrm{zr}, \mathrm{np}, \\
\mathrm{mv}\end{array}$ & $\mathrm{mn}$ & fe & $\begin{array}{c}\begin{array}{c}\text { zr,pct, } \\
\text { mv }\end{array} \\
\end{array}$ & $\mathrm{mn}$ & cr & $\begin{array}{l}\text { sp,pct, } \\
\text { mv }\end{array}$ & & $\mathrm{mn}$ & \\
\hline \multirow[t]{5}{*}{2} & WL ( & $60.3 \%$ & $55.8 \%$ & $50.4 \%$ & $52.6 \%$ & $54.8 \%$ & $48.0 \%$ & $49.5 \%$ & $39.0 \%$ & $53.0 \%$ & $37.0 \%$ & $43.8 \%$ & $48.3 \%$ & $39.2 \%$ & $23.5 \%$ & $41.8 \%$ & $53.0 \%$ & $16.7 \%$ & $51.0 \%$ \\
\hline & Glass W & 2.72 & 2.83 & 2.78 & 2.77 & 2.80 & 2.66 & 2.58 & 2.60 & 2.99 & 2.66 & 2.76 & 2.84 & 2.87 & 2.51 & 2.80 & 3.01 & 2.58 & 2.743 \\
\hline & Density & 3894 & 3132 & 3268 & 2653 & 2527 & 1971 & 1369 & 1297 & 803 & 626 & 494 & 363 & 437 & 637 & 339 & 242 & 115 & 24166 \\
\hline & Glass & 1430 & 1108 & 1177 & 959 & 903 & 740 & 530 & 499 & 269 & 235 & 179 & 128 & 152 & 254 & 121 & 81 & 44 & 8808 \\
\hline & WL li & $\begin{array}{c}\text { sp,np, } \\
\text { mv }\end{array}$ & $n$ & $\begin{array}{c}\mathrm{sp}, \mathrm{np}, \\
\mathrm{mv}\end{array}$ & $\begin{array}{c}\mathrm{sp}, \mathrm{v}, \\
\mathrm{np}, \mathrm{mv}\end{array}$ & $\mathrm{f}$ & $\begin{array}{c}\text { sp,np, } \\
\text { mv }\end{array}$ & $\mathrm{cr}$ & $\mathrm{p}$ & & $\mathrm{mn}$ & $\mathrm{fe}$ & $n m$ & in & & $\mathrm{fe}$ & $\begin{array}{c}\mathrm{zr}, \mathrm{v}, \\
\mathrm{mv}\end{array}$ & $\mathrm{mn}$ & \\
\hline \multirow[t]{5}{*}{3} & $\mathrm{WL}(\mathrm{m}$ & $60.4 \%$ & $55.8 \%$ & $57.6 \%$ & $57.8 \%$ & $54.8 \%$ & $51.4 \%$ & $49.5 \%$ & $39.0 \%$ & $56.6 \%$ & $37.0 \%$ & $43.8 \%$ & $48.3 \%$ & $39.2 \%$ & $23.5 \%$ & $41.8 \%$ & $56.7 \%$ & $16.7 \%$ & $52.8 \%$ \\
\hline & Glass W & 2.72 & 2.83 & 2.83 & 2.80 & 2.80 & \begin{tabular}{|l|}
2.68 \\
\end{tabular} & 2.58 & 2.60 & \begin{tabular}{|l|}
3.03 \\
\end{tabular} & 2.66 & 2.76 & 2.84 & 2.87 & 2.51 & 2.80 & 3.05 & 2.58 & 2.756 \\
\hline & Density & 3890 & 3132 & 2859 & 2415 & 2527 & 1840 & 1369 & 1297 & 751 & 626 & 494 & 363 & 437 & 637 & 339 & 227 & 115 & 23317 \\
\hline & Glass Vo & 1429 & 1108 & 1010 & 862 & 903 & 685 & 530 & 499 & 248 & 235 & 179 & 128 & 152 & 254 & 121 & 74 & 44 & 8462 \\
\hline & WL limite & $\begin{array}{l}\text { v,np, } \\
\text { mv }\end{array}$ & & $\begin{array}{c}\text { sp,np, } \\
\text { mv }\end{array}$ & $\mathrm{np}, \mathrm{mv}$ & $\mathrm{f}$ & $\begin{array}{l}\mathrm{v}, \mathrm{np}, \\
\mathrm{mv}\end{array}$ & $\mathrm{cr}$ & $\mathrm{p}$ & $\mathrm{zr}, \mathrm{mv}$ & & $\mathrm{fe}$ & $\mathrm{nm}$ & $\mathrm{mn}$ & $\mathrm{cr}$ & $\mathrm{fe}$ & $\mathrm{zr}, \mathrm{mv}$ & $\mathrm{mn}$ & \\
\hline \multirow[t]{5}{*}{1} & WL (mass \%) & $54.1 \%$ & $54.6 \%$ & $43.2 \%$ & $44.6 \%$ & $48.0 \%$ & $41.4 \%$ & $49.5 \%$ & $39.0 \%$ & $49.9 \%$ & $37.0 \%$ & $43.8 \%$ & $45.5 \%$ & $39.2 \%$ & $23.5 \%$ & $40.5 \%$ & $50.2 \%$ & $16.7 \%$ & $46.5 \%$ \\
\hline & Glass W & 2.69 & 2.85 & 2.73 & 2.73 & 2.78 & 2.63 & 2.62 & 2.63 & 2.97 & 2.65 & 2.82 & 2.82 & 2.86 & 2.48 & 2.83 & 2.98 & 2.57 & 2.729 \\
\hline & Density (g & 4342 & 3202 & 3815 & 3125 & 2886 & 2288 & 1369 & 1297 & 853 & 626 & 494 & 386 & 437 & 637 & 350 & 256 & 115 & 26476 \\
\hline & Glass Vo & 1612 & 1123 & 1396 & 1146 & 1040 & 869 & 522 & 493 & 287 & 236 & 175 & 137 & 153 & 256 & 124 & 86 & 45 & 9700 \\
\hline & WL limited by & $\begin{array}{c}\text { sp,np, } \\
\text { mv }\end{array}$ & $\begin{array}{c}\mathrm{sp}, \mathrm{v}, \\
\mathrm{np}, \mathrm{mv}\end{array}$ & $\begin{array}{c}\mathrm{sp}, \mathrm{v}, \\
\mathrm{np}, \mathrm{mv}\end{array}$ & $\begin{array}{c}\mathrm{sp}, \mathrm{v}, \\
\mathrm{np}, \mathrm{mv}\end{array}$ & 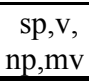 & $\begin{array}{c}\text { sp,np, } \\
\text { mv }\end{array}$ & $\mathrm{cr}$ & $\mathrm{p}$ & & $\mathrm{mn}$ & $\mathrm{fe}$ & $\mathrm{zr}, \mathrm{mv}$ & $\mathrm{mn}$ & $\mathrm{cr}$ & & $\begin{array}{c}\mathrm{zr}, \mathrm{v}, \\
\mathrm{mv}\end{array}$ & $\mathrm{mn}$ & \\
\hline \multirow[t]{5}{*}{5} & WL (mass \%) & $60.1 \%$ & $57.3 \%$ & $46.5 \%$ & $47.5 \%$ & $52.3 \%$ & $46.7 \%$ & $49.5 \%$ & $39.9 \%$ & $50.0 \%$ & $37.0 \%$ & $43.8 \%$ & $43.6 \%$ & $39.2 \%$ & $23.5 \%$ & $35.8 \%$ & $50.2 \%$ & $16.7 \%$ & 49.3 \\
\hline & Glass Wt. $(\mathrm{Mg})$ & \begin{tabular}{|l|}
2.77 \\
\end{tabular} & 2.88 & 2.78 & 2.75 & 2.81 & \begin{tabular}{|l|}
2.70 \\
\end{tabular} & 2.62 & 2.64 & \begin{tabular}{|l|}
2.97 \\
\end{tabular} & 2.63 & 2.80 & 2.79 & 2.90 & 2.52 & 2.75 & 2.98 & 2.58 & 2.764 \\
\hline & Density $\left(\mathrm{g} / \mathrm{cm}^{3}\right)$ & 3907 & 3051 & 3542 & 2936 & 2649 & 2025 & 1369 & 1269 & 851 & 626 & 494 & 402 & 437 & 637 & 396 & 256 & 115 & 24961 \\
\hline & Glass Vol. $\left(\mathrm{m}^{3}\right)$ & 1410 & 1060 & 1273 & 1068 & 943 & 74 & 522 & 480 & 287 & 238 & 177 & 144 & 151 & 252 & 144 & 86 & 45 & 9029 \\
\hline & WL limited by & $\mathrm{sp}, \mathrm{v}$, & $\begin{array}{c}\text { sp,v, } \\
\mathrm{mv}\end{array}$ & $\begin{array}{l}\begin{array}{l}\mathrm{sp}, \mathrm{v}, \\
\mathrm{mv}\end{array}\end{array}$ & & $\begin{array}{c}\mathrm{sp}, \mathrm{v}, \\
\mathrm{mv}\end{array}$ & $\begin{array}{c}\mathrm{sp}, \mathrm{v}, \\
\mathrm{mv}\end{array}$ & $\mathrm{cr}$ & $\mathrm{cr}$ & $\mathrm{zr}, \mathrm{mv}$ & $\mathrm{mn}$ & $\mathrm{fe}$ & zr,pct, & $\mathrm{mn}$ & $\mathrm{cr}$ & $\begin{array}{c}\text { sp,pct, } \\
\text { mv }\end{array}$ & zr,v, & $\mathrm{mn}$ & \\
\hline
\end{tabular}




\begin{tabular}{|c|c|c|c|c|c|c|c|c|c|c|c|c|c|c|c|c|c|c|c|}
\hline \multicolumn{2}{|c|}{ Case \# $\backslash$ Cluster \# } & 1 & 2 & 3 & 4 & 5 & 6 & 7 & 8 & 9 & 10 & 11 & 12 & 13 & 14 & 15 & 16 & 17 & Total \\
\hline \multirow[t]{5}{*}{6} & WL (mass \%) & $54.8 \%$ & $54.7 \%$ & $43.4 \%$ & $44.8 \%$ & $48.1 \%$ & $42.2 \%$ & $49.5 \%$ & $39.0 \%$ & $54.3 \%$ & $52.2 \%$ & $46.3 \%$ & $48.3 \%$ & $62.8 \%$ & $23.5 \%$ & $37.8 \%$ & $55.6 \%$ & $76.9 \%$ & $47.8 \%$ \\
\hline & Glass Wt. (Mg) & 2.74 & 2.87 & 2.77 & 2.75 & 2.80 & 2.69 & 2.66 & 2.66 & 3.06 & 2.80 & 2.87 & 2.88 & 3.26 & 2.54 & 2.81 & 3.10 & 3.47 & 2.773 \\
\hline & Density & 283 & 194 & 797 & 115 & 2879 & 2245 & 1369 & 1297 & 784 & 444 & 467 & 363 & 273 & 537 & 375 & 231 & 25 & 25779 \\
\hline & Glass Vol & & & & & & 8 & & & 256 & 59 & & & & & 33 & & & 295 \\
\hline & WL lin & $\begin{array}{l}\mathrm{sp}, \mathrm{v}, \\
\mathrm{e}, \mathrm{n}\end{array}$ & $\begin{array}{l}\text {,v, } \\
\text { pp }\end{array}$ & $\begin{array}{l}\text { sp,v, } \\
\text { e,np }\end{array}$ & $\begin{array}{l}\text { sp,v, } \\
\text { e, np }\end{array}$ & $\begin{array}{c}\mathrm{sp}, \mathrm{v}, \\
\mathrm{np}\end{array}$ & $\begin{array}{l}\text { sp,v, } \\
\text { e,np }\end{array}$ & $\mathrm{cr}$ & $\mathrm{p}$ & $\begin{array}{c}\mathrm{zr}, \mathrm{v}, \\
\mathrm{np}\end{array}$ & $\begin{array}{c}\text { pct, }, \mathrm{v}, \\
\mathrm{np}\end{array}$ & $\begin{array}{l}\mathrm{sp}, \mathrm{v}, \\
\mathrm{np}\end{array}$ & $\mathrm{nm}$ & $\begin{array}{c}\mathrm{zr}, \mathrm{v}, \\
\mathrm{np}\end{array}$ & $\mathrm{cr}$ & sp,pct & $\begin{array}{l}\mathrm{sp}, \mathrm{v}, \\
\mathrm{np}\end{array}$ & e,np & \\
\hline \multirow[t]{5}{*}{7} & & $61.4 \%$ & $55.8 \%$ & $48.0 \%$ & $50.0 \%$ & $50.4 \%$ & $48.9 \%$ & $49.5 \%$ & $39.0 \%$ & $49.1 \%$ & $37.0 \%$ & $43.8 \%$ & $44.5 \%$ & $39.2 \%$ & $23.5 \%$ & $41.8 \%$ & $53.7 \%$ & $16.7 \%$ & $49.9 \%$ \\
\hline & Glass & \begin{tabular}{|l|}
2.71 \\
\end{tabular} & 2.81 & 2.74 & \begin{tabular}{|l|}
2.71 \\
\end{tabular} & \begin{tabular}{|l|}
2.72 \\
\end{tabular} & 2.68 & 2.59 & \begin{tabular}{|l|}
2.61 \\
\end{tabular} & \begin{tabular}{|l|}
2.91 \\
\end{tabular} & \begin{tabular}{|l|}
2.63 \\
\end{tabular} & 2.75 & 2.74 & 2.82 & 2.47 & 2.77 & 3.00 & 2.55 & 2.716 \\
\hline & & 3829 & 3132 & 3430 & 2792 & 2748 & 1938 & 1369 & 1297 & 867 & 626 & 494 & 394 & 437 & 637 & 339 & 239 & 115 & 24682 \\
\hline & Glass V & 1413 & 1115 & 1253 & 1030 & 1009 & 724 & 528 & 497 & 298 & 238 & 180 & 144 & 155 & 258 & 123 & 80 & 45 & 9089 \\
\hline & & $\begin{array}{c}\text { sp,np, } \\
\text { mv }\end{array}$ & $\mathrm{p}$ & & & $\begin{array}{c}\mathrm{sp}, \mathrm{v}, \\
\mathrm{mv}\end{array}$ & $\begin{array}{c}\mathrm{sp}, \mathrm{v}, \\
\mathrm{np}, \mathrm{mv}\end{array}$ & $\mathrm{cr}$ & $\mathrm{p}$ & $\begin{array}{c}\mathrm{zr}, \mathrm{v}, \\
\mathrm{mv}\end{array}$ & $\mathrm{mn}$ & fe & & $\mathrm{mn}$ & $\mathrm{cr}$ & $\mathrm{fe}$ & & $\mathrm{mn}$ & \\
\hline \multirow[t]{5}{*}{8} & & $62.5 \%$ & $55.8 \%$ & $54.5 \%$ & $56.9 \%$ & $54.8 \%$ & $53.5 \%$ & $49.5 \%$ & $39.0 \%$ & $54.0 \%$ & $37.0 \%$ & $43.8 \%$ & $48.3 \%$ & $39.2 \%$ & $23.5 \%$ & $41.8 \%$ & $56.8 \%$ & $16.7 \%$ & $52.7^{\circ}$ \\
\hline & & 2.70 & 2.81 & 2.78 & 2.76 & 2.75 & 2.68 & 2.61 & 2.63 & 2.96 & 2.65 & 2.78 & 2.79 & 2.90 & 2.54 & 2.80 & 3.02 & 2.60 & 2.737 \\
\hline & & 759 & 132 & 3023 & 2450 & 2527 & 1769 & 1369 & 1297 & 789 & 626 & 494 & 363 & 437 & 637 & 339 & 226 & 115 & 2335 \\
\hline & Glass $\mathrm{Vc}$ & 1394 & 1113 & 1087 & 889 & 918 & 661 & 525 & 493 & 266 & 236 & 177 & 130 & 151 & 250 & 121 & 75 & 44 & 8532 \\
\hline & & & & & & & & & & & & & & & & & & $\mathrm{mn}$ & \\
\hline \multirow[t]{5}{*}{9} & & $62.5 \%$ & $55.8 \%$ & $59.3 \%$ & $60.1 \%$ & $54.8 \%$ & $51.7 \%$ & $49.5 \%$ & $39.0 \%$ & $58.6 \%$ & $37.0 \%$ & $43.8 \%$ & $48.3 \%$ & $39.2 \%$ & $23.5 \%$ & $41.8 \%$ & $60.4 \%$ & $16.7 \%$ & $53.6 \%$ \\
\hline & & 2.70 & 2.81 & 2.81 & \begin{tabular}{|l|}
2.77 \\
\end{tabular} & 2.75 & 2.69 & 2.61 & \begin{tabular}{|l|}
2.63 \\
\end{tabular} & \begin{tabular}{|l|}
3.01 \\
\end{tabular} & 2.65 & \begin{tabular}{|l|}
2.78 \\
\end{tabular} & \begin{tabular}{|l|}
2.79 \\
\end{tabular} & 2.90 & 2.54 & \begin{tabular}{|l|}
2.80 \\
\end{tabular} & \begin{tabular}{|l|}
3.06 \\
\end{tabular} & \begin{tabular}{|l|}
2.60 \\
\end{tabular} & 2.744 \\
\hline & & 3759 & 132 & 2778 & 2323 & 2527 & 1831 & 1369 & 1297 & 726 & 626 & 494 & 363 & 437 & 637 & 339 & 213 & 115 & 2296 \\
\hline & Glass Vo & 394 & 13 & 987 & 837 & 918 & 682 & 525 & 493 & 241 & 236 & 177 & 130 & 151 & 250 & 121 & 70 & 14 & 8370 \\
\hline & & & & & $\begin{array}{c}\mathrm{v}, \mathrm{np}, \\
\mathrm{mv}\end{array}$ & & $\begin{array}{c}\mathrm{v}, \mathrm{np}, \\
\mathrm{mv}\end{array}$ & & & & & & & & $c_{1}$ & & $\begin{array}{c}\mathrm{zr}, \mathrm{v}, \\
\mathrm{mv}\end{array}$ & $\mathrm{mn}$ & \\
\hline \multirow[t]{5}{*}{10} & & $54.1 \%$ & $54.6 \%$ & $29.6 \%$ & $38.2 \%$ & $48.0 \%$ & $36.8 \%$ & $24.7 \%$ & $20.0 \%$ & $49.9 \%$ & $37.0 \%$ & $43.8 \%$ & $43.6 \%$ & $39.2 \%$ & $11.8 \%$ & $35.8 \%$ & $50.2 \%$ & $16.7 \%$ & $38.1 \%$ \\
\hline & & 2.69 & 2.85 & 2.63 & 2.68 & 2.78 & 2.62 & 2.51 & 2.52 & 2.97 & 2.65 & 2.82 & 2.79 & 2.94 & 2.46 & 2.75 & 2.98 & 2.59 & 2.670 \\
\hline & Density & 4342 & 202 & 5555 & 3649 & 2886 & 2573 & 2738 & 2538 & 853 & 626 & 494 & 402 & 437 & 1273 & 396 & 256 & 115 & 32335 \\
\hline & $\mathrm{G}$ & 512 & & & 1361 & 1040 & 981 & & & 287 & 236 & 175 & 144 & 148 & 517 & 144 & 86 & 44 & 1211 \\
\hline & & $\begin{array}{c}\text { sp,np } \\
\text { mv }\end{array}$ & & & & & 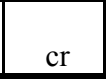 & & $\mathrm{Cr}$ & $\begin{array}{c}\text { zr,np, } \\
\text { mv }\end{array}$ & & & & IIII & & $\begin{array}{c}\text { sp,pct, } \\
\text { mv }\end{array}$ & & $\mathrm{mn}$ & \\
\hline
\end{tabular}




\begin{tabular}{|c|c|c|c|c|c|c|c|c|c|c|c|c|c|c|c|c|c|c|c|}
\hline \multicolumn{2}{|c|}{ Case \# \Cluster \# } & 1 & 2 & 3 & 4 & 5 & 6 & 7 & 8 & 9 & 10 & 11 & 12 & 13 & 14 & 15 & 16 & 17 & Total \\
\hline \multirow[t]{5}{*}{11} & WL (mass \%) & $54.1 \%$ & $54.6 \%$ & $43.2 \%$ & $44.6 \%$ & $48.0 \%$ & $41.4 \%$ & $52.8 \%$ & $39.0 \%$ & $49.9 \%$ & $37.0 \%$ & $43.8 \%$ & $43.6 \%$ & $39.2 \%$ & $33.3 \%$ & $35.8 \%$ & $50.2 \%$ & $16.7 \%$ & $46.9 \%$ \\
\hline & Glass Wt. (Mg) & \begin{tabular}{|l|}
2.69 \\
\end{tabular} & 2.85 & 2.73 & 2.73 & 2.78 & 2.63 & 2.65 & 2.63 & 2.97 & 2.65 & 2.82 & 2.79 & 2.94 & 2.61 & 2.75 & 2.98 & 2.59 & 2.736 \\
\hline & Density ( & 4342 & 202 & 3815 & 3125 & 2886 & 2288 & 1283 & 297 & 353 & 626 & 94 & 402 & 437 & 449 & 396 & 56 & 15 & 26265 \\
\hline & Glass Vol. & 1612 & 1123 & 1396 & 1146 & 1040 & 869 & 483 & 493 & 287 & 236 & 175 & 144 & 148 & 172 & 144 & 86 & 44 & 9600 \\
\hline & WL limit & $\begin{array}{c}\text { sp,np } \\
\text { mv }\end{array}$ & $\begin{array}{l}\mathrm{p}, \mathrm{v}, \\
\mathrm{mv}\end{array}$ & $\begin{array}{l}\mathrm{p}, \mathrm{v}, \\
\mathrm{s}, \mathrm{mv}\end{array}$ & $\begin{array}{l}\mathrm{sp}, \mathrm{v}, \\
\mathrm{np}, \mathrm{mv}\end{array}$ & $\begin{array}{l}\text { sp,v, } \\
\text { np,mv }\end{array}$ & $\begin{array}{c}\text { sp,np, } \\
\text { mv }\end{array}$ & & $\mathrm{p}$ & $\begin{array}{c}\text { zr,np, } \\
\text { mv }\end{array}$ & $\mathrm{mn}$ & $\mathrm{fe}$ & $\begin{array}{c}\text { zr,pct, } \\
\text { mv }\end{array}$ & $\mathrm{mn}$ & $\begin{array}{c}\text { sp,pct, } \\
\text { mv }\end{array}$ & $\begin{array}{c}\text { sp,pct, } \\
\text { mv }\end{array}$ & $\begin{array}{c}\mathrm{zr}, \mathrm{v}, \\
\mathrm{mv}\end{array}$ & $\mathrm{mn}$ & \\
\hline \multirow[t]{5}{*}{12} & $\operatorname{VL}($ & $60.3 \%$ & $55.8 \%$ & $50.4 \%$ & $52.6 \%$ & $54.8 \%$ & $48.0 \%$ & $61.9 \%$ & $9.0 \%$ & $53.0 \%$ & $37.0 \%$ & $43.8 \%$ & $48.3 \%$ & $39.2 \%$ & $35.3 \%$ & $41.8 \%$ & $53.0 \%$ & $16.7 \%$ & 52.0 \\
\hline & Glass V & 2.72 & 2.83 & 2.78 & 2.77 & 2.80 & 2.66 & 2.69 & 2.60 & 2.99 & 2.66 & 2.76 & 2.84 & 2.87 & 2.64 & 2.80 & 3.01 & 2.58 & 2.756 \\
\hline & Density (g & 3894 & 132 & 3268 & 2653 & 2527 & 1971 & 1094 & 297 & 803 & 626 & 494 & 363 & 437 & 424 & 339 & 242 & 115 & 2367 \\
\hline & Glass V & 1430 & 1108 & 1177 & 959 & 903 & 740 & 408 & 499 & 269 & 235 & 179 & 128 & 152 & 161 & 121 & 81 & 44 & 8592 \\
\hline & WL $\lim$ & $\begin{array}{c}\text { sp,np, } \\
\text { mv }\end{array}$ & $\mathrm{p}$ & $\begin{array}{c}\text { sp,np, } \\
\text { mv }\end{array}$ & $\begin{array}{c}\mathrm{sp}, \mathrm{v}, \\
\mathrm{np}, \mathrm{mv}\end{array}$ & $\mathrm{f}$ & $\begin{array}{c}\text { sp,np, } \\
\text { mv }\end{array}$ & $\begin{array}{c}\text { sp,np, } \\
\text { mv }\end{array}$ & & $\begin{array}{l}\mathrm{zr}, \mathrm{v}, \\
\mathrm{mv}\end{array}$ & $\mathrm{mn}$ & fe & $\mathrm{nm}$ & $\mathrm{mn}$ & $\mathrm{cr}$ & fe & $\begin{array}{c}\mathrm{zr}, \mathrm{v}, \\
\mathrm{mv}\end{array}$ & $\mathrm{mn}$ & \\
\hline \multirow[t]{5}{*}{13} & $\mathrm{WL}(\mathrm{n}$ & $62.5 \%$ & $55.8 \%$ & $54.5 \%$ & $56.9 \%$ & $54.8 \%$ & $53.5 \%$ & $68.6 \%$ & $39.0 \%$ & $54.0 \%$ & $37.0 \%$ & $43.8 \%$ & $48.3 \%$ & $39.2 \%$ & $35.3 \%$ & $41.8 \%$ & $56.8 \%$ & $16.7 \%$ & $54.1 \%$ \\
\hline & Glass Wt. & 2.70 & 2.77 & 2.78 & 2.76 & 2.75 & 2.68 & 2.69 & 2.58 & 2.96 & 2.63 & 2.71 & 2.77 & 2.81 & 2.58 & 2.74 & \begin{tabular}{l|l|}
3.02 \\
\end{tabular} & 2.55 & 2.732 \\
\hline & Density (g & 3759 & 3132 & 3023 & 2450 & 2527 & 1769 & 988 & 1297 & 789 & 626 & 494 & 363 & 437 & 424 & 339 & 226 & 115 & 22757 \\
\hline & Glass Vol & 394 & 131 & 1087 & 889 & 919 & 661 & 367 & 502 & 266 & 238 & 182 & 131 & 155 & 164 & 124 & 75 & 45 & 8331 \\
\hline & WL $\lim$ & $\mathrm{np}, \mathrm{mv}$ & $p$ & \begin{tabular}{|c|}
$\mathrm{sp}, \mathrm{v}$, \\
$\mathrm{np}, \mathrm{mv}$ \\
\end{tabular} & $\begin{array}{r}\mathrm{sp}, \mathrm{v}, \\
\mathrm{np}, \mathrm{mv} \\
\end{array}$ & $\mathrm{f}$ & $\begin{array}{c}\text { sp,np, } \\
\text { mv }\end{array}$ & $\begin{array}{c}\text { sp,np, } \\
\text { mv }\end{array}$ & & $\begin{array}{c}\mathrm{zr}, \mathrm{v}, \\
\mathrm{mv}\end{array}$ & $\mathrm{mn}$ & $\mathrm{fe}$ & $\mathrm{nm}$ & $\mathrm{mn}$ & cr & fe & $\mathrm{zr}, \mathrm{mv}$ & $\mathrm{mn}$ & \\
\hline \multirow[t]{5}{*}{14} & $\mathrm{WL}(\mathrm{m}$ & $61.4 \%$ & $55.8 \%$ & $29.6 \%$ & $38.2 \%$ & $50.4 \%$ & $36.8 \%$ & $24.7 \%$ & $20.0 \%$ & $49.1 \%$ & $37.0 \%$ & $43.8 \%$ & $44.5 \%$ & $39.2 \%$ & $11.8 \%$ & $41.8 \%$ & $53.7 \%$ & $16.7 \%$ & $39.0 \%$ \\
\hline & Glass W & 2.71 & 2.81 & 2.63 & 2.68 & 2.72 & 2.62 & 2.51 & 2.52 & 2.91 & 2.65 & 2.78 & 2.74 & 2.94 & 2.46 & 2.80 & 3.00 & 2.59 & 2.661 \\
\hline & Density (g & 3829 & 3132 & 5555 & 3649 & 2748 & 2573 & 2738 & 2538 & 867 & 626 & 494 & 394 & 437 & 1273 & 339 & 239 & 115 & 31546 \\
\hline & Glass Vol & 1413 & 1113 & 2111 & 1361 & 1009 & 981 & 1092 & 1009 & 298 & 236 & 177 & 144 & 148 & 517 & 121 & 80 & 44 & 1185 \\
\hline & WL limited by & $\begin{array}{c}\text { sp,np, } \\
\text { mv } \\
\end{array}$ & $P$ & $\mathrm{cr}$ & $\mathrm{cr}$ & & $\mathrm{cr}$ & $\mathrm{cr}$ & & & $\mathrm{mn}$ & $\mathrm{fe}$ & & $\mathrm{mn}$ & $\mathrm{cr}$ & $\mathrm{fe}$ & & $\mathrm{mn}$ & \\
\hline \multirow[t]{5}{*}{15} & & $60.1 \%$ & $57.3 \%$ & $46.5 \%$ & $48.4 \%$ & $52.3 \%$ & $46.7 \%$ & $49.5 \%$ & $39.9 \%$ & $50.0 \%$ & $37.0 \%$ & $43.8 \%$ & $45.5 \%$ & $39.2 \%$ & $23.5 \%$ & $41.4 \%$ & $50.2 \%$ & $16.7 \%$ & $49.6^{\circ}$ \\
\hline & Glass V & 2.77 & 2.88 & 2.78 & 2.75 & 2.81 & 2.70 & 2.63 & 2.66 & 2.97 & 2.65 & 2.80 & 2.82 & 2.87 & 2.51 & 2.82 & 2.98 & 2.58 & 2.76 \\
\hline & Density & 3907 & 3051 & 3542 & 2880 & 2649 & 2025 & 1369 & 1269 & 851 & 626 & 494 & 385 & 437 & 637 & 342 & 256 & 115 & 24834 \\
\hline & Glass Vol. $\left(\mathrm{m}^{3}\right)$ & 1410 & 1060 & 1273 & 1049 & 943 & 749 & 520 & 477 & 287 & 236 & 177 & 137 & 152 & 253 & 121 & 86 & 45 & 8975 \\
\hline & WL limited by & $\begin{array}{c}\mathrm{sp}, \mathrm{v}, \\
\mathrm{mv}\end{array}$ & $\begin{array}{c}\mathrm{sp}, \mathrm{v}, \\
\mathrm{mv}\end{array}$ & $\begin{array}{c}\mathrm{sp}, \mathrm{v}, \\
\mathrm{mv}\end{array}$ & & $\begin{array}{l}\mathrm{sp}, \mathrm{v}, \\
\mathrm{mv}\end{array}$ & $\begin{array}{l}\text { sp,v, } \\
\mathrm{mv}\end{array}$ & & & & & & zr,pct, & & & $\mathrm{sp}, \mathrm{v}$ & $\mathrm{zr}, \mathrm{v}$ & $\mathrm{mn}$ & \\
\hline
\end{tabular}




\begin{tabular}{|c|c|c|c|c|c|c|c|c|c|c|c|c|c|c|c|c|c|c|c|}
\hline \multicolumn{2}{|c|}{ Case \# $\backslash$ Cluster \# } & 1 & 2 & 3 & 4 & 5 & 6 & 7 & 8 & 9 & 10 & 11 & 12 & 13 & 14 & 15 & 16 & 17 & Total \\
\hline \multirow[t]{5}{*}{16} & WL (mass \%) & $60.4 \%$ & $55.8 \%$ & $51.4 \%$ & $53.0 \%$ & $54.8 \%$ & $50.2 \%$ & $49.5 \%$ & $39.0 \%$ & $47.9 \%$ & $52.2 \%$ & $54.0 \%$ & $48.3 \%$ & $67.7 \%$ & $23.5 \%$ & $46.5 \%$ & $60.8 \%$ & $76.9 \%$ & $52.5 \%$ \\
\hline & Glass Wt. (Mg) & 2.74 & 2.88 & \begin{tabular}{|l|}
2.84 \\
\end{tabular} & 2.81 & 2.84 & 2.73 & 2.66 & 2.66 & 2.96 & 2.80 & 2.93 & 2.88 & 3.32 & 2.54 & \begin{tabular}{|l|}
2.89 \\
\end{tabular} & 3.15 & 3.47 & 2.799 \\
\hline & Density $\left(\mathrm{g} / \mathrm{cm}^{3}\right)$ & 3892 & 3132 & 3204 & 2633 & 2527 & 1884 & 1369 & 1297 & 889 & 444 & 400 & 363 & 253 & 637 & 305 & 211 & 25 & 23465 \\
\hline & Glass Vol. $\left(\mathrm{m}^{3}\right)$ & 1419 & 1087 & 1130 & 937 & 889 & 690 & 515 & 487 & 300 & 159 & 137 & 126 & 76 & 251 & 105 & 67 & 7 & 3383 \\
\hline & WL limited by & $\begin{array}{l}\text { sp,v, } \\
\text { np }\end{array}$ & $\mathrm{p}$ & $\begin{array}{l}\text { sp,v, } \\
\text { e,np }\end{array}$ & $\begin{array}{l}\text { sp,v, } \\
\text { e,np }\end{array}$ & $\mathrm{f}$ & $\begin{array}{l}\text { sp,e, } \\
\text { np }\end{array}$ & cr & $\mathrm{p}$ & $\mathrm{zr}, \mathrm{v}$ & $\begin{array}{c}\mathrm{pct}, \mathrm{v}, \\
\mathrm{np}\end{array}$ & $\begin{array}{l}\text { sp,v, } \\
\text { np }\end{array}$ & $\mathrm{nm}$ & $\mathrm{zr}, \mathrm{v}, \mathrm{np}$ & cr & $\mathrm{sp}, \mathrm{np}$ & $\mathrm{sp}, \mathrm{np}$ & e,np & \\
\hline \multirow[t]{5}{*}{17} & WL (mass \%) & $62.7 \%$ & $55.8 \%$ & $59.2 \%$ & $60.5 \%$ & $54.8 \%$ & $54.2 \%$ & $49.5 \%$ & $39.0 \%$ & $65.8 \%$ & $52.2 \%$ & $63.5 \%$ & $48.3 \%$ & $73.2 \%$ & $23.5 \%$ & $56.1 \%$ & $67.5 \%$ & $76.9 \%$ & $55.9 \%$ \\
\hline & Glass Wt. (Mg) & 2.75 & 2.88 & 2.88 & 2.83 & 2.84 & 2.73 & 2.66 & 2.66 & 3.18 & 2.80 & 3.01 & 2.88 & 3.38 & 2.54 & 2.99 & 3.23 & 3.47 & 2.813 \\
\hline & Density $\left(\mathrm{g} / \mathrm{cm}^{3}\right)$ & 3745 & 3132 & 2783 & 2305 & 2527 & 1748 & 1369 & 1297 & 647 & 444 & 341 & 363 & 234 & 637 & 253 & 190 & 25 & 22039 \\
\hline & Glass Vol. $\left(\mathrm{m}^{3}\right)$ & 1360 & 1087 & 968 & 814 & 889 & 641 & 515 & 487 & 203 & 159 & 113 & 126 & 69 & 251 & 84 & 59 & 7 & 7833 \\
\hline & WL limited by & $\mathrm{v}, \mathrm{np}$ & $\mathrm{p}$ & cr & $\mathrm{sp}, \mathrm{np}$ & $\mathrm{f}$ & $\mathrm{v}, \mathrm{np}$ & $\mathrm{cr}$ & $\mathrm{p}$ & $\mathrm{nm}$ & $\begin{array}{c}\mathrm{pct}, \mathrm{v}, \\
\mathrm{np}\end{array}$ & $\begin{array}{c}\text { sp,v, } \\
\text { np }\end{array}$ & $\mathrm{nm}$ & $\mathrm{zr}, \mathrm{np}$ & $\mathrm{cr}$ & $\begin{array}{c}\mathrm{sp}, \mathrm{v}, \\
\mathrm{np}\end{array}$ & $\begin{array}{c}\text { sp,v, } \\
\text { np }\end{array}$ & e,np & \\
\hline \multirow[t]{5}{*}{18} & WL & $62.5 \%$ & $55.8 \%$ & $59.6 \%$ & $60.1 \%$ & $54.8 \%$ & $54.6 \%$ & $69.8 \%$ & $39.0 \%$ & $58.6 \%$ & $37.0 \%$ & $43.8 \%$ & $48.3 \%$ & $39.2 \%$ & $35.3 \%$ & $41.8 \%$ & $60.4 \%$ & $16.7 \%$ & $5.4 \%$ \\
\hline & Glass V & 2.70 & 2.77 & 2.81 & 2.77 & 2.75 & 2.66 & 2.68 & 2.58 & 3.01 & 2.63 & 2.71 & 2.77 & 2.81 & 2.58 & 2.74 & 3.06 & 2.55 & 2.736 \\
\hline & Density ( & 3759 & 3132 & 2764 & 2323 & 2527 & 1734 & 971 & 1297 & 726 & 626 & 494 & 363 & 437 & 424 & 339 & 213 & 115 & 22243 \\
\hline & Glass & 1394 & 1131 & 982 & 837 & 919 & 652 & 362 & 502 & 241 & 238 & 182 & 131 & 155 & 164 & 124 & 70 & 45 & 8130 \\
\hline & WL lin & $0, \mathrm{mv}$ & $\mathrm{p}$ & $\begin{array}{l}\mathrm{v}, \mathrm{np}, \\
\mathrm{mv}\end{array}$ & $\begin{array}{c}\mathrm{v}, \mathrm{np}, \\
\mathrm{mv}\end{array}$ & $\mathrm{f}$ & $\begin{array}{l}\mathrm{v}, \mathrm{np}, \\
\mathrm{mv}\end{array}$ & $\mathrm{np}, \mathrm{mv}$ & $\mathrm{p}$ & $\mathrm{mn}$ & $\mathrm{mn}$ & fe & $\mathrm{nm}$ & $\mathrm{mn}$ & cr & fe & $\begin{array}{c}\mathrm{zr}, \mathrm{v}, \\
\mathrm{mv}\end{array}$ & $\mathrm{mn}$ & \\
\hline \multirow[t]{5}{*}{19} & WL (mass \%) & $61.4 \%$ & $55.8 \%$ & $48.0 \%$ & $50.0 \%$ & $50.4 \%$ & $48.9 \%$ & $61.7 \%$ & $39.0 \%$ & $49.1 \%$ & $37.0 \%$ & $43.8 \%$ & $44.5 \%$ & $39.2 \%$ & $35.3 \%$ & $41.8 \%$ & $53.7 \%$ & $16.7 \%$ & $50.9 \%$ \\
\hline & Glass Wt. (Mg) & \begin{tabular}{|l|}
2.71 \\
\end{tabular} & 2.81 & 2.74 & 2.71 & 2.72 & 2.68 & 2.68 & 2.61 & 2.91 & 2.63 & 2.75 & 2.74 & 2.82 & 2.63 & 2.77 & 3.00 & 2.55 & 2.727 \\
\hline & Density $\left(\mathrm{g} / \mathrm{cm}^{3}\right)$ & 3829 & 3132 & 3430 & 2792 & 2748 & 1938 & 1098 & 1297 & 867 & 626 & 494 & 394 & 437 & 424 & 339 & 239 & 115 & 24200 \\
\hline & Glass Vol. $\left(\mathrm{m}^{3}\right)$ & 1413 & 1115 & 1253 & 1030 & 1009 & 724 & 410 & 497 & 298 & 238 & 180 & 144 & 155 & 162 & 123 & 80 & 45 & 8875 \\
\hline & WL limited by & $\mathrm{np}, \mathrm{mv}$ & $\mathrm{p}$ & $\begin{array}{l}\mathrm{v}, \mathrm{np}, \\
\mathrm{mv}\end{array}$ & $\begin{array}{l}\mathrm{v}, \mathrm{np}, \\
\mathrm{mv}\end{array}$ & $\mathrm{f}$ & $\begin{array}{l}\mathrm{v}, \mathrm{np}, \\
\mathrm{mv}\end{array}$ & $\begin{array}{l}\text { v,np, } \\
\text { mv }\end{array}$ & $\mathrm{p}$ & $\mathrm{mn}$ & $\mathrm{mn}$ & $\mathrm{fe}$ & $\mathrm{nm}$ & $\mathrm{mn}$ & $\mathrm{cr}$ & fe & $\begin{array}{l}\mathrm{zr}, \mathrm{v}, \\
\mathrm{mv}\end{array}$ & $\mathrm{mn}$ & \\
\hline \multirow[t]{5}{*}{20} & $\%$ & $61.4 \%$ & $55.8 \%$ & $48.0 \%$ & $50.0 \%$ & $50.4 \%$ & $48.9 \%$ & $61.7 \%$ & $39.0 \%$ & $49.1 \%$ & $37.0 \%$ & $43.8 \%$ & $44.5 \%$ & $39.2 \%$ & $35.3 \%$ & $41.8 \%$ & $53.7 \%$ & $16.7 \%$ & $50.9 \%$ \\
\hline & Glass & 2.71 & 2.81 & 2.74 & 2.71 & 2.72 & 2.68 & 2.68 & 2.61 & 2.91 & 2.63 & 2.75 & 2.74 & 2.82 & 2.63 & 2.77 & 3.00 & 2.55 & 2.727 \\
\hline & $\overline{\text { Density }}$ & 3829 & 3132 & 3430 & 2792 & 2748 & 1938 & 1098 & 1297 & 867 & 626 & 494 & 394 & 437 & 424 & 339 & 239 & 115 & 24200 \\
\hline & Glass Vol. $\left(\mathrm{m}^{3}\right)$ & 1413 & 1115 & 1253 & 1030 & 1009 & 724 & 410 & 497 & 298 & 238 & 180 & 144 & 155 & 162 & 123 & 80 & 45 & 8875 \\
\hline & WL limited by & $\mathrm{np}, \mathrm{mv}$ & & $\begin{array}{c}\mathrm{v}, \mathrm{np}, \\
\mathrm{mv}\end{array}$ & $\begin{array}{c}\mathrm{v}, \mathrm{np}, \\
\mathrm{mv}\end{array}$ & $\mathrm{f}$ & $\begin{array}{l}\text { v,np, } \\
\text { mv }\end{array}$ & $\begin{array}{l}\text { v,np, } \\
\text { mv }\end{array}$ & & $\mathrm{mn}$ & $\mathrm{mn}$ & $\mathrm{fe}$ & & & $\mathrm{cr}$ & fe & $\begin{array}{l}\mathrm{zr}, \mathrm{v}, \\
\mathrm{mv}\end{array}$ & $\mathrm{mn}$ & \\
\hline \multicolumn{2}{|c|}{ Case \# $\backslash \mathrm{Clu}$} & 1 & 2 & 3 & 4 & 5 & 6 & 7 & 8 & 9 & 10 & 11 & 12 & 13 & 14 & 15 & 16 & 17 & Total \\
\hline \multirow[t]{5}{*}{21} & WL (mass \%) & $62.9 \%$ & $55.8 \%$ & $48.2 \%$ & $50.4 \%$ & $52.6 \%$ & $48.9 \%$ & $49.5 \%$ & $39.0 \%$ & $53.7 \%$ & $44.0 \%$ & $50.7 \%$ & $48.3 \%$ & $63.2 \%$ & $23.5 \%$ & $45.0 \%$ & $58.3 \%$ & $51.0 \%$ & $51.6 \%$ \\
\hline & Glass Wt. (Mg) & 2.75 & 2.81 & 2.76 & 2.74 & 2.76 & 2.68 & 2.59 & 2.61 & 2.99 & 2.70 & 2.87 & 2.80 & 3.21 & 2.47 & 2.85 & 3.07 & 3.01 & 2.745 \\
\hline & Density $\left(\mathrm{g} / \mathrm{cm}^{3}\right)$ & 3735 & 3132 & 3414 & 2767 & 2633 & 1935 & 1369 & 1297 & 792 & 526 & 426 & 363 & 271 & 637 & 315 & 220 & 38 & 23870 \\
\hline & Glass Vol. $\left(\mathrm{m}^{3}\right)$ & 1359 & 1115 & 1238 & 1011 & 952 & 722 & 528 & 497 & 265 & 195 & 149 & 130 & 84 & 258 & 111 & 72 & 13 & 8697 \\
\hline & WL limited by & $\begin{array}{c}\mathrm{sp}, \mathrm{np}, \\
\mathrm{e}\end{array}$ & & $\begin{array}{c}\text { sp,v, } \\
\text { np }\end{array}$ & $\begin{array}{c}\mathrm{sp}, \mathrm{np}, \\
\mathrm{v}\end{array}$ &, $\mathrm{v}$ & $\begin{array}{c}\text { sp,np, } \\
\text { v }\end{array}$ & cr & & $\begin{array}{c}\mathrm{zr}, \mathrm{np}, \\
\mathrm{V}\end{array}$ & $\begin{array}{c}\mathrm{pct}, \mathrm{v}, \\
\mathrm{e}\end{array}$ & $\begin{array}{c}\text { sp,np, } \\
\text { V }\end{array}$ & nm & $\mathrm{zr}, \mathrm{v}, \mathrm{e}$ & $\mathrm{cr}$ & $\begin{array}{c}\mathrm{sp}, \mathrm{np}, \\
\mathrm{v}\end{array}$ & $\mathrm{zr}, \mathrm{v}$ & $\mathrm{N}, \mathrm{e}$ & \\
\hline
\end{tabular}




\title{
Appendix E - Estimated Waste Loading for Each Cluster
}

\author{
$\underline{\text { Cluster \#1(High alumina, soda, and silica) }}$
}

Maximum waste loading for a glassy waste form is estimated at 35 mass $\%$. This waste loading is limited by the alumina (19.6 mass\%) content of the waste, which tends to increase the melting temperature and the crystallization tendency at higher waste loadings, as well as the low $\mathrm{Fe}_{2} \mathrm{O}_{3}$ and high soda content, which tend to limit the chemical durability.

The maximum waste loading for a glass-ceramic waste form is estimated at 50 to 55 mass \%. Again, the high alumina content is the limiting factor as it affects the melting temperature. The soda content of the waste form is also expected to be limiting as it affects the chemical durability.

Cluster \#2 [Highest bismuth oxide (12.1\%) and high phosphate]

The maximum waste loading for a glassy waste form is estimated at $40 \mathrm{mass} \%$. No one particular oxide limits the loading, but overall the loading is limited by the $\mathrm{O} / \mathrm{P}$ ratio. The high combined percentage of $\mathrm{Fe}_{2} \mathrm{O}_{3}$ and $\mathrm{P}_{2} \mathrm{O}_{5}$ $(26 \%)$ in this waste is an advantage for vitrification in an FeP glass since it minimizes the amounts of these materials that must be added to the waste from external sources.

The maximum waste loading for a glass-ceramic waste form is estimated at 55 to 60 mass $\%$. The soda content is a limiting factor since at higher waste loadings the higher soda content may reduce chemical durability.

$\underline{\text { Cluster \#3 (High alumina and zirconia and low iron) }}$

Maximum waste loading for a glassy waste form is estimated at 35 mass \%. The limiting factor is the high zirconia content combined with the low $\mathrm{Fe}_{2} \mathrm{O}_{3}$ and $\mathrm{P}_{2} \mathrm{O}_{5}(10.1 \%)$ content of the waste. The additional $\mathrm{Fe}_{2} \mathrm{O}_{3}$ that must be added for chemical durability purposes limits the maximum waste loading.

The maximum waste loading for a glass-ceramic waste form is estimated at $50 \%$. The combined alumina and zirconia content limit higher waste loadings due to the expected higher melting temperature.

\section{$\underline{\text { Cluster \#4 }}$}

This waste has the highest calcium and nickel oxide content, but these components are not expected to limit the maximum waste loading for a glassy waste form, which is estimated at $40 \mathrm{mass} \%$. The limiting factor is the amounts of $\mathrm{Fe}_{2} \mathrm{O}_{3}$ and $\mathrm{P}_{2} \mathrm{O}_{5}$ in the waste form, which cannot be lowered substantially without sacrificing the glass formation tendency and chemical durability.

The maximum waste loading for a chemically durable, glass-ceramic waste form is estimated at $60 \%$. The soda content limits the maximum waste loading since at $60 \%$ loading it is reaching the point where the chemical durability may become unacceptable.

\section{Cluster \#5}

Maximum waste loading for a glassy waste form is estimated at 43 mass \%. Limiting factors are the amounts of alumina and soda, both of which are approaching the limit of waste loading shown in Table 4.13 of this report. The high combined percentage of $\mathrm{Fe}_{2} \mathrm{O}_{3}$ and $\mathrm{P}_{2} \mathrm{O}_{5}(21.6 \%)$ contributes to the high waste loading.

The maximum waste loading for a chemically durable, glass-ceramic waste form is estimated at $65 \%$. At this waste loading, the percentages of all the components will not exceed the maximum values in Table 4.13, which have been used previously. 


\section{Cluster \#6 [Highest alumina (27.2\%) content]}

Maximum waste loading for a glassy waste form is estimated at 40 mass $\%$ for this high alumina waste. The waste limit is due to the expected high melting point, above $1200^{\circ} \mathrm{C}$, at higher waste loadings and the onset of crystallization.

The maximum waste loading for a chemically durable, glass-ceramic waste form is estimated at 55 to 60 mass $\%$, the maximum percentage being dependent on the maximum allowable melting temperature.

\section{Cluster \#7 [Highest silica (27.5\%) content]}

The maximum waste loading for a glassy waste form is estimated at 35 mass $\%$. The high silica content and, to a lesser extent, the soda content combined with the low percentage of iron and $\mathrm{P}_{2} \mathrm{O}_{5}(10.5 \%)$ limit the waste loading. Silica was not considered to be a limiting component for Cluster \#7 (or for Clusters \#1 or \#2). The maximum waste loading could reach 40 to $45 \%$ if higher silica content was acceptable. As the $\mathrm{SiO}_{2}$ concentration increases in glass, increases in melt temperature may also be required so waste loading would ultimately depend on the maximum allowable melting temperature.

The maximum waste loading for a chemically durable glass-ceramic waste form is estimated at 60 mass $\%$. This limit stems from the silica content (higher melting temperature) and, to a lesser extent, from the soda content, which is approaching the maximum for acceptable chemical durability.

Cluster $\# 8$ [Highest $\mathrm{P}_{2} \mathrm{O}_{5} \underline{(6.4 \%) \text { and second highest alumina and chromium content] }}$

The maximum waste loading for a glassy waste form is estimated at 35 mass\%. Factors limiting the waste loading are the high alumina (higher melting temperature) and soda (lower durability) contents of the waste. Another factor limiting the waste loading is the small amount of iron and $\mathrm{P}_{2} \mathrm{O}_{5}(9.4 \%)$ in this waste, which requires that significant amounts of these components be added from external sources.

The maximum waste loading for a chemically durable glass-ceramic waste form is estimated at 55 mass $\%$, this limit being primarily due to the alumina and soda content.

\section{Cluster \#9 [High zirconia $(21.6 \%)$ content]}

The maximum waste loading for a glassy waste form is estimated at 35 mass $\%$, which is due to the zirconia content of the waste. At higher waste loadings, the zirconia content exceeds the typical value listed in Table 4.13 and is expected to increase the melting temperature.

The maximum waste loading for a glass-ceramic waste form is estimated at 60 mass $\%$. This limit is primarily determined by the zirconia content and the maximum acceptable melting temperature.

\section{Cluster \#10 [Highest soda (45.1\%) and $\mathrm{MnO}(10.8 \%)$ content]}

While the high $\mathrm{MnO}$ content is not expected to be limiting in an FeP glass, the high soda content and its effect in lowering the chemical durability is expected to limit the maximum waste loading for a glassy waste form to 40 mass\%. At 40\% waste loading, the soda content will be 18 mass \%, which is approaching the maximum value given in Table 4.13. However, FeP waste forms containing up to 22 mass \% soda, made with a simulated Hanford waste that contained 54.6 mass\% soda, have been found (Day et al. 1998) to have an acceptable chemical durability when tested in water at $90^{\circ} \mathrm{C}$. Thus, loadings above 40 mass $\%$ of a waste compositionally similar to Cluster 10 may be possible. Another factor limiting the maximum loading is the low percentage of $\mathrm{Fe}_{2} \mathrm{O}_{3}$ and $\mathrm{P}_{2} \mathrm{O}_{5}$ (only 6.4\%), which means that significant amounts of these components must come from external sources. 
The maximum waste loading for a glass-ceramic waste form is estimated at 50 mass $\%$ based on the high soda content. As mentioned above, this limit could be higher depending upon the measured chemical durability.

\section{Cluster \#11 [Highest silver oxide and second highest $\mathrm{Fe}_{2} \underline{\mathrm{O}}_{3}$ (45.7\%) content]}

This waste contains the largest amount of silver oxide (0.54\%) of all the 17 wastes, but this should be easily accommodated in FeP glasses. Phosphate glasses have been made (Rawson 1967) that contain more than 40 mass\% silver-oxide.

The maximum waste loading for a glassy waste form is estimated at 50 mass $\%$ and could be as high as $55 \%$. This high limit is attributable to the high $\mathrm{Fe}_{2} \mathrm{O}_{3}$ content of this waste, which provides nearly all the $\mathrm{Fe}_{2} \mathrm{O}_{3}$ that will be needed in the waste form for good chemical durability. The factors limiting the waste loading are the soda content and the need for sufficient $\mathrm{P}_{2} \mathrm{O}_{5}, 40 \%$ in most cases, to form a glass.

This waste is particularly well suited for vitrification in a FeP glass, since it contains a combined $\mathrm{P}_{2} \mathrm{O}_{5} \mathrm{plus}^{\mathrm{F} \mathrm{F}_{2} \mathrm{O}_{3}}$ content of 46.3 mass\%. Thus, a large percentage of the required $\mathrm{P}_{2} \mathrm{O}_{5}$ and $\mathrm{Fe}_{2} \mathrm{O}_{3}$ is provided by the waste and need not come from external sources.

The maximum waste loading for a glass-ceramic waste form is estimated at 70 to 75 mass $\%$. This limit will be determined by the amount of $\mathrm{P}_{2} \mathrm{O}_{5}$ needed to form a melt below $1150^{\circ} \mathrm{C}$ and the inherent chemical durability of this waste composition. The low soda content $(7.5 \%)$ of this waste is an advantage.

\section{Cluster \#12 [High zirconia (28\%) and soda (29.3\%) content]}

The maximum waste loading for a glassy waste form is estimated at $30 \mathrm{mass} \%$ and is limited by the high zirconia content along with the very small amount of $\mathrm{Fe}_{2} \mathrm{O}_{3}$ and $\mathrm{P}_{2} \mathrm{O}_{5}$ (total of $1.6 \%$ ) in this waste. At higher waste loadings, the zirconia content is expected to increase the melting temperature, and it would not be possible to add enough $\mathrm{Fe}_{2} \mathrm{O}_{3}$ and $\mathrm{P}_{2} \mathrm{O}_{5}$ for good glass formation and chemical durability. The low $\mathrm{Fe}_{2} \mathrm{O}_{3}$ and $\mathrm{P}_{2} \mathrm{O}_{5}$ content in this waste is a disadvantage to a $\mathrm{FeP}$ waste form.

The maximum waste loading for a glass-ceramic waste form is estimated at 45 mass $\%$. Since glass formation is not required, the amount of $\mathrm{Fe}_{2} \mathrm{O}_{3}$ and $\mathrm{P}_{2} \mathrm{O}_{5}$ from external sources can be reduced so that waste loading can be increased. However, the higher waste loading will be eventually limited by the melting temperature.

Cluster \#13 [High zirconia (22\%), thoria (2.8\%) and urania (15.8\%) content]

The maximum waste loading for a glassy waste form is estimated at 32 mass $\%$. The thoria and urania contents are not considered limiting, but the high zirconia content (melting point), coupled with the need to add substantial $\mathrm{Fe}_{2} \mathrm{O}_{3}$ and $\mathrm{P}_{2} \mathrm{O}_{5}$ to this waste, limit the waste loading.

The maximum waste loading for a glass-ceramic waste form is estimated at 55 to 60 mass $\%$. This limit is due to the high zirconia content and the maximum allowable melting temperature.

Cluster \#14 [Highest chromium oxide (4.3\%) and high soda (35.5\%)]

The maximum waste loading for a glassy waste form is estimated at 35 mass $\%$. This waste contains the largest amount of chromium oxide of all the wastes, but this amount should be no problem in FeP glasses. The limiting factor is the soda content, which is $12.4 \%$ at a 35 mass $\%$ waste loading. This exceeds the upper limit of the typical range in Table 4.13. However, a waste loading of 40 to $45 \%$ could be achievable depending upon the degree of chemical durability. Iron phosphate waste forms containing up to $20 \%$ soda have been made [Day et al. 1998] with simulated Hanford wastes (from tank Farm B) that meet all DOE chemical durability requirements (PCT). 
The maximum waste loading for a glass-ceramic waste form is estimated at 50 to 55 mass $\%$. This limit is due to the high soda content, which could lower the chemical durability below acceptable limits.

\section{Cluster \#15 [Highest combined $\mathrm{Fe}_{2} \underline{\mathrm{O}}_{3}$ and $\mathrm{P}_{2} \underline{\mathrm{O}}_{5}$ (48 \%) content]}

Because of the high $\mathrm{Fe}_{2} \mathrm{O}_{3}$ concentration, this waste is well suited for vitrification as an $\mathrm{FeP}$ waste form. The maximum waste loading for a glassy waste form is estimated at 50 mass $\%$, since very little $\mathrm{Fe}$ must be added to this waste. The limiting factor is the low $\mathrm{P}_{2} \mathrm{O}_{5}$ content $(0.2 \%)$ in the waste, which means that about 35 to $45 \%$ $\mathrm{P}_{2} \mathrm{O}_{5}$ must be added from external sources to assure glass formation.

The maximum waste loading for a glass-ceramic waste form is estimated at 65 to 70 mass $\%$, with a loading as high as $75 \%$ possible. The limiting factor is the concentration of $\mathrm{P}_{2} \mathrm{O}_{5}$ that must be added to produce a material that will melt below $1150^{\circ} \mathrm{C}$. Even at $75 \%$ loading, the concentration of all the other components are expected to be acceptable. The chemical durability could become limiting, although the soda content at $75 \%$ waste loading would still be within acceptable limits.

\section{Cluster \#16 [Highest zirconia (29\%), thoria (3.7\%) and urania (20.9\%) content]}

The maximum waste loading for a glassy waste form is estimated at 30 mass $\%$, primarily because of the high zirconia content (which increases the melting temperature). The total iron and $\mathrm{P}_{2} \mathrm{O}_{5}$ content $(15.9 \%)$ of this waste are also limiting, since substantial amounts (see Table 4.13) must be added to the waste for purposes of glass formation. Because of these factors, vitrifying this waste in an FeP glass is questionable.

The maximum waste loading for a glass-ceramic waste form is estimated at 60 mass $\%$, depending on the maximum allowable melting temperature. A higher waste loading is acceptable, since less iron and $\mathrm{P}_{2} \mathrm{O}_{5}$ must be added from external sources because glass formation is no longer required.

\section{Cluster \#17 [Highest strontium oxide (52.3\%) content]}

The maximum waste loading for a glassy waste form is estimated at 30 mass $\%$, although 35 to $40 \%$ could be possible. The limiting factors are the high $\mathrm{SrO}$ content, which is approaching the maximum value (the data for $\mathrm{CaO}$ in Table 4.13 is used to estimate the effect of $\mathrm{SrO}$ since no data is available for $\mathrm{SrO}$ ), and the low combined amount of $\mathrm{Fe}_{2} \mathrm{O}_{3}$ and $\mathrm{P}_{2} \mathrm{O}_{5}$ (only $2.7 \%$ ) in the waste.

The maximum waste loading for a glass-ceramic waste form is estimated at 50 to 55 mass $\%$. The limiting factor is expected to be the combined percentages of soda and $\mathrm{SrO}$ in the waste form that could potentially lead to an unacceptable chemical durability. 


\section{Appendix F - Questions for High-Level Waste Vitrification Personnel}

1. What process requirements restrict achieving higher production rates?

- Predefined composition ranges?

- Waste and glass former batching schemes or models?

- Conduct of operations?

2. What melter processing limits restrict achieving higher production rates?

- Slurry concentration?

- Plenum temperature constraints?

- Glass processing constraints?

- Glass surface coverage limits?

- Limits set to meet regulatory permit conditions?

3. What operational constraints restrict achieving higher production rates?

- Slow response time of melter to input changes?

- Lack of temperature, visual or other sufficient feedback data?

- Power/current limitations?

- Delay due to other plant activities upstream or downstream of the melter?

4. Is the handling and disposal of high-level waste-contaminated equipment a measurable cost to operations and on-line efficiency?

5. What is the estimated time to replace a failed melter and return to operations?

6. Are there constraints or factors that were thought to be very important that been shown through operations to be inconsequential?

- Cold cap coverage?

- Plenum temperature?

- Rate of change of electrode power?

- Glass redox control?

- Instrumentation or other secondary system reliability?

7. Are any materials of construction found to be less than reliable?

8. Are any materials of construction found to be overly conservative?

9. Have projected glass production rates based on pilot-scale equipment been found to be accurate? 
This page left intentionally blank

F - 2 


\section{Appendix G - Process and Design Requirement Impacts on Vitrification Technology Comparisons}

\begin{tabular}{|c|c|c|c|}
\hline Requirement & Basis for Requirement & Potential Modifications to Requirement & Potential Impacts \\
\hline $\begin{array}{l}\text { This column lists the process and } \\
\text { technology requirements that are } \\
\text { currently "imposed." }\end{array}$ & $\begin{array}{l}\text { This column describes the } \\
\text { "bases" for the requirement. }\end{array}$ & $\begin{array}{l}\text { This column describes the potential modifications to } \\
\text { the requirements or technology or waste form that } \\
\text { can be achieved. }\end{array}$ & $\begin{array}{l}\text { This column describes } \\
\text { the positive (pros) and } \\
\text { negative (cons) impacts } \\
\text { (success or failure) of } \\
\text { the proposed } \\
\text { modifications. }\end{array}$ \\
\hline \multicolumn{4}{|l|}{ Waste Form Considerations } \\
\hline $\begin{array}{l}\text { Liquidus temperature } \\
\text { requirement - Liquidus } \\
\text { temperature of glass } 100^{\circ} \mathrm{C} \text { below } \\
\text { average bulk glass temperature. }\end{array}$ & $\begin{array}{l}\text { Prevents large amounts of } \\
\text { crystalline material from forming } \\
\text { and possibly accumulating in the } \\
\text { melter and affecting operating } \\
\text { conditions (viscosity, melter life, } \\
\text { glass transfer, etc.) or glass } \\
\text { quality properties. }\end{array}$ & $\begin{array}{l}\text { The liquidus temperature constraint currently limits } \\
\text { waste loading at the Defense Waste Processing } \\
\text { Facility (DWPF) and is expected to do the same for } \\
\text { Hanford wastes. } \\
\text { Relaxing this constraint through the use of alternate } \\
\text { melter technologies (e.g., higher temperatures, forced } \\
\text { glass mixing and/or bottom drain devices) has the } \\
\text { potential to significantly increase waste loading for } \\
\text { some wastes. } \\
\text { Collecting additional data to better define a model } \\
\text { may also allow the safety factor of } 100^{\circ} \mathrm{C} \text { to be } \\
\text { reduced, thereby allowing an increase in waste } \\
\text { loading. }\end{array}$ & $\begin{array}{l}\text { Pros: Increased waste } \\
\text { loading and } \\
\text { proportionately reduced } \\
\text { throughput requirements. } \\
\text { Cons: Reduced melter } \\
\text { life if mixing or } \\
\text { discharge techniques are } \\
\text { inadequate. }\end{array}$ \\
\hline $\begin{array}{l}\text { Phase stability - During } \\
\text { production and under prolonged } \\
\text { idling conditions, glass must } \\
\text { remain vitreous. }\end{array}$ & $\begin{array}{l}\text { Glasses that are unstable in } \\
\text { processing and idling temperature } \\
\text { ranges can produce crystal phases } \\
\text { that could impact melter } \\
\text { operations and operating life. }\end{array}$ & $\begin{array}{l}\text { Alternate technologies (e.g., forced glass mixing } \\
\text { and/or bottom drain devices) may permit formation } \\
\text { of secondary phases with time, assuming material } \\
\text { can be discharged to prevent accumulations over } \\
\text { time. However, during non-feeding periods, } \\
\text { potential effects on viscosity, melter operability, and } \\
\text { glass quality could be severe. } \\
\text { The bases for certain limits could be better defined } \\
\text { with additional research that could allow waste } \\
\text { loadings to be increased. }\end{array}$ & $\begin{array}{l}\text { Pros: Increases in waste } \\
\text { loading will have a } \\
\text { proportionate impact on } \\
\text { reducing glass volume } \\
\text { and throughput } \\
\text { requirements. } \\
\text { Cons: Reduced melter } \\
\text { life and higher operating } \\
\text { costs if glass/crystalline } \\
\text { behavior is not well } \\
\text { understood, and new } \\
\text { technologies do not }\end{array}$ \\
\hline
\end{tabular}




\begin{tabular}{|c|c|c|c|}
\hline Requirement & Basis for Requirement & Potential Modifications to Requirement & Potential Impacts \\
\hline & & & perform as intended. \\
\hline $\begin{array}{l}\text { Solubility limits - Limit waste } \\
\text { loading to prevent the formation } \\
\text { of secondary phases (e.g., } \\
\text { spinels, molten salt layer, and } \\
\text { reduced metal phases). }\end{array}$ & $\begin{array}{l}\text { Certain components have } \\
\text { limitations on how much can be } \\
\text { incorporated into the glass matrix. } \\
\text { Especially important are } \\
\text { chromium; zirconium; the noble } \\
\text { metals; silver; palladium; } \\
\text { rhodium and ruthenium; and } \\
\text { sulfate, iron, and nickel. If } \\
\text { limitations are exceeded, separate } \\
\text { phases in the glass can occur or } \\
\text { phases can segregate in the melter } \\
\text { and compromise glass } \\
\text { performance. }\end{array}$ & $\begin{array}{l}\text { Alternate melter technologies (e.g. use of higher } \\
\text { temperatures) would increase solubility limits for } \\
\text { many critical components (e.g., iron, chromium, and } \\
\text { nickel). } \\
\text { Alternate technologies (e.g., forced glass mixing } \\
\text { and/or bottom drain devices) may permit steady state } \\
\text { discharge of the insoluble materials and prevent } \\
\text { accumulations over time. } \\
\text { The bases for certain limits could be better defined } \\
\text { with additional research that could allow waste } \\
\text { loadings to be increased. }\end{array}$ & $\begin{array}{l}\text { Pros: Increases in waste } \\
\text { loading will have a } \\
\text { proportionate impact on } \\
\text { reducing glass volume } \\
\text { and throughput } \\
\text { requirements. } \\
\text { Cons: Reduced melter } \\
\text { life and higher operating } \\
\text { costs can occur if new } \\
\text { technologies do not } \\
\text { perform as intended. }\end{array}$ \\
\hline \multicolumn{4}{|c|}{ Operational and Processing Considerations } \\
\hline $\begin{array}{l}\text { Operating temperature - } \\
\text { Nominal processing temperature } \\
\text { of } 1150^{\circ} \mathrm{C} \text {. }\end{array}$ & $\begin{array}{l}\text { Inconel electrode material } \\
\text { constrains maximum operating } \\
\text { temperature based on expected } \\
\text { electrode face temperature, } \\
\text { electrode design, and service life } \\
\text { requirements. As a result, } \\
\text { borosilicate glass compositions } \\
\text { are formulated and optimized for } \\
\text { a nominal operating temperature } \\
\text { of } 1150^{\circ} \mathrm{C} \text {. }\end{array}$ & $\begin{array}{l}\text { Increasing temperature up to } 1250^{\circ} \mathrm{C} \text { is possible if } \\
\text { Inconel electrode design provides sufficient air } \\
\text { cooling to maintain electrode temperature within } \\
\text { reasonable limits. The FZK VEK melter electrode } \\
\text { design permits operations up to } 1250^{\circ} \mathrm{C} \text { with active } \\
\text { air cooling. The West Valley Demonstration Project } \\
\text { (WVDP) melter also employs air cooling channels in } \\
\text { the electrodes. The DWPF electrode design only } \\
\text { cools the electrode busbar. } \\
\text { Use of alternate melter technology that replaces or } \\
\text { eliminates Inconel electrodes has the potential to } \\
\text { significantly increase process temperature. }\end{array}$ & $\begin{array}{l}\text { Pros: Increase waste } \\
\text { loading and increased } \mathrm{T}_{\mathrm{L}} \\
\text { is possible. } \\
\text { Wider flexibility in } \\
\text { operating temperature to } \\
\text { respond to poor melting } \\
\text { flowsheets (e.g., DWPF } \\
\text { Macrobatch 2 } \\
\text { composition). } \\
\text { Cons: Alternative } \\
\text { electrode materials } \\
\text { compatible with high- } \\
\text { level waste (HLW) } \\
\text { glasses requires } \\
\text { significant development } \\
\text { New melter technology } \\
\text { (e.g., cold wall melter) } \\
\text { will require significant } \\
\text { U.S. testing and design } \\
\text { to verify Russian and } \\
\text { French claims. }\end{array}$ \\
\hline
\end{tabular}




\begin{tabular}{|c|c|c|c|}
\hline Requirement & Basis for Requirement & Potential Modifications to Requirement & Potential Impacts \\
\hline $\begin{array}{l}\text { Glass Viscosity - Current } \\
\text { viscosity limits for Joule-heated } \\
\text { melters similar to DWPF's are } \\
\text { defined as between } 20-100 \text { poise } \\
\text { at } 1150^{\circ} \text { C. }\end{array}$ & $\begin{array}{l}\text { Levels were developed based on } \\
\text { glass industry practice and HLW } \\
\text { Joule-heated ceramic melter } \\
\text { development experience. } \\
\text { Minimum limit imposed to } \\
\text { prevent excessive penetration into } \\
\text { brick joints, minimize erosion of } \\
\text { refractories and probes, and } \\
\text { maximize convective mixing. } \\
\text { Maximum limit imposed to } \\
\text { ensure that glass can be poured } \\
\text { from melter into canister. } \\
\text { Significant amounts of testing } \\
\text { have not been performed beyond } \\
\text { these ranges, thus, these limits } \\
\text { can be dependent on the melter } \\
\text { technology. }\end{array}$ & $\begin{array}{l}\text { Experience points to working in the lower region of } \\
\text { the viscosity range. } \\
\text { Alternate melter technologies may allow the } \\
\text { viscosity limits to be expanded. Also, additional } \\
\text { research may allow the definition of better models } \\
\text { and testing to better understand and define these } \\
\text { limits. However, the practical benefits are not } \\
\text { readily apparent. } \\
\text { Viscosity, electrical conductivity, and durability are } \\
\text { all functions of waste loading, alkali metal, and } \\
\text { alkaline earth concentrations. Therefore, } \\
\text { consideration for changing viscosity limits cannot be } \\
\text { done without considering the other two properties. }\end{array}$ & $\begin{array}{l}\text { Pros: Wider constraints } \\
\text { will provide wider glass } \\
\text { composition regions for } \\
\text { glass formulation } \\
\text { development with some } \\
\text { potential improvements } \\
\text { in waste loading. } \\
\text { Cons: Potentially } \\
\text { decreased melter life } \\
\text { (fused-cast, refractory- } \\
\text { lined melters only) and } \\
\text { possibly reduced } \\
\text { production (due to } \\
\text { reduced convection). }\end{array}$ \\
\hline $\begin{array}{l}\text { Glass REDOX - prohibit the } \\
\text { ferrous-to-total iron ratio falling } \\
\text { below detection limits and from } \\
\text { exceeding } 0.33 \text {. }\end{array}$ & $\begin{array}{l}\text { U. S. alkaline HLW compositions } \\
\text { containing concentrations of } \\
\text { multivalent metals, especially } \\
\text { manganese, iron, and nickel, can } \\
\text { produce significant quantities of } \\
\text { oxygen during vitrification. The } \\
\text { gas can either form foam, } \\
\text { interfering with heat transfer to } \\
\text { the solids, or engulf the cold cap } \\
\text { altogether. Either condition } \\
\text { causes unstable and unpredictable } \\
\text { melter conditions and should be } \\
\text { avoided. Reductants are added to } \\
\text { the melter feed slurry to react } \\
\text { with these metals in the cold cap } \\
\text { and lower their oxidation states. } \\
\text { Based on testing in the } 1980 \text { s, } \\
\mathrm{Fe}^{+2}: \mathrm{Fe}^{\text {total }} \text { has been shown to be a } \\
\text { reliable gauge of melt stability. If }\end{array}$ & $\begin{array}{l}\text { No significant impact on glass volume. However, } \\
\text { technologies that can avoid this requirement will } \\
\text { have a simplified flowsheet. }\end{array}$ & Negligible. \\
\hline
\end{tabular}




\begin{tabular}{|c|c|c|c|}
\hline Requirement & Basis for Requirement & Potential Modifications to Requirement & Potential Impacts \\
\hline & $\begin{array}{l}\text { some ferrous ion is measured in } \\
\text { the product glass, the melt will } \\
\text { not foam. } \\
\text { Conversely, over reduction of the } \\
\text { melt will lead to the formation } \\
\text { and precipitation of reduced } \\
\text { metals. When over-reduced, } \\
\text { phases such as nickel sulfide and } \\
\text { ruthenium sulfide have been } \\
\text { found as coalesced "buttons" on } \\
\text { the floor of nonradioactive } \\
\text { demonstration melters. As a } \\
\text { production process control goal, } \\
\text { maximum redox targets } 50 \% \text { to } \\
70 \% \text { of the maximum value have } \\
\text { been established. }\end{array}$ & & \\
\hline $\begin{array}{l}\text { Glass electrical conductivity - } \\
\text { Glass conductivity must be } \\
\text { compatible with melter tank } \\
\text { geometry design and power } \\
\text { supply capabilities. }\end{array}$ & $\begin{array}{l}\text { Conductivity is a based on melter } \\
\text { tank geometry, electrode surface } \\
\text { area, and current flux limitations } \\
\text { placed on electrode materials } \\
\text { (e.g., nickel-alloy composition, } \\
\text { molybdenum, or graphite). For } \\
\text { current melter/glass "systems" } \\
\text { glass tank conductance is } \\
\text { typically in the range of } 0.2 \text { to } 0.5 \\
\text { (ohm-cm) }\end{array}$ & $\begin{array}{l}\text { If optimum waste loadings and glasses are identified, } \\
\text { some flexibility in Joule-heated melter design is } \\
\text { possible. However, Task } 2 \text { results indicate very few } \\
\text { cases in which electrical conductivity is a primary } \\
\text { factor in defining waste loading limitation. } \\
\text { Research into alternative electrode materials that } \\
\text { support higher current densities would permit } \\
\text { increased waste loading where the combined } \\
\text { concentration of sodium+potassium+lithium is } \\
\text { constraining. } \\
\text { Induction heated melters have similar constraints and } \\
\text { flexibility. } \\
\text { "Externally heated" melter technologies (e.g., plasma } \\
\text { or combustion heated) would not have this } \\
\text { constraint. }\end{array}$ & $\begin{array}{l}\text { Pros: Wider constraints } \\
\text { will provide wider glass } \\
\text { composition regions for } \\
\text { glass formulation } \\
\text { development with some } \\
\text { improvements in waste } \\
\text { loading. } \\
\text { Cons: Reduced melter } \\
\text { life and higher operating } \\
\text { costs could occur if new } \\
\text { technologies do not } \\
\text { perform as intended. }\end{array}$ \\
\hline $\begin{array}{l}\text { Magnetic permeability (induction } \\
\text { heating only) - Glass must be } \\
\text { formulated to allow sufficient } \\
\text { induction coupling and heating. }\end{array}$ & $\begin{array}{l}\text { Effective induction heating is a } \\
\text { function of glass composition, } \\
\text { induction heating frequency, and } \\
\text { tank size. }\end{array}$ & $\begin{array}{l}\text { "Externally heated" melter technologies (e.g., plasma } \\
\text { or combustion heated) would not have this } \\
\text { constraint. However, even for induction heating, this } \\
\text { is a weak requirement compared to electrical } \\
\text { conductivity. }\end{array}$ & $\begin{array}{l}\text { Pros: Wider constraints } \\
\text { will provide wider glass } \\
\text { composition regions for } \\
\text { glass formulation } \\
\text { development with some } \\
\text { improvements in waste }\end{array}$ \\
\hline
\end{tabular}




\begin{tabular}{|c|c|c|c|}
\hline Requirement & Basis for Requirement & Potential Modifications to Requirement & Potential Impacts \\
\hline & & & $\begin{array}{l}\text { loading. } \\
\text { Cons: Reduced melter } \\
\text { life and higher operating } \\
\text { costs could occur if new } \\
\text { technologies do not } \\
\text { perform as intended. }\end{array}$ \\
\hline \multicolumn{4}{|l|}{ Design Considerations } \\
\hline $\begin{array}{l}\text { Size }- \text { Melter must be sized } \\
\text { sufficiently to meet maximum } \\
\text { plant production requirements. }\end{array}$ & $\begin{array}{l}\text { DWPF and WVDP melters are } \\
\text { sized based on glass production } \\
\text { rates of } \sim 1 \mathrm{MT} / \mathrm{m}^{2} \cdot \mathrm{d} \text { and } \sim 0.5 \\
\mathrm{MT} / \mathrm{m}^{2} \cdot \mathrm{d} \text {, respectively. Glass } \\
\text { holdup in excess of } \sim 40 \text { hours to } \\
\text { guarantee homogeneity and } \\
\text { complete melting was also a } \\
\text { basis. }\end{array}$ & $\begin{array}{l}\text { Technologies that increase production capacities on a } \\
\text { per unit surface area basis will permit smaller } \\
\text { melters. } \\
\text { With study, technical bases for reducing residence } \\
\text { time could be provided. }\end{array}$ & $\begin{array}{l}\text { Pros: Reduced melter } \\
\text { costs and solid waste } \\
\text { disposalcosts. } \\
\text { Cons: Reduced melter } \\
\text { life and higher operating } \\
\text { costs could occur if new } \\
\text { technologies do not } \\
\text { perform as intended. }\end{array}$ \\
\hline $\begin{array}{l}\text { Maintainability - Under remote } \\
\text { radioactive facility conditions }\end{array}$ & $\begin{array}{l}\text { Technology must be maintainable } \\
\text { to permit continuous operations } \\
\text { with minimal interruptions to } \\
\text { support attainment of the plant's } \\
\text { total operating efficiency (TOE) } \\
\text { goals. }\end{array}$ & $\begin{array}{l}\text { Current baseline technology has been a preferred } \\
\text { U.S. Department of Energy (DOE) technology } \\
\text { because of its simplicity and reliability. Potential } \\
\text { rate enhancements such as mixing and bottom drains } \\
\text { introduce a level of added complication that must be } \\
\text { able to be designed, understood, and operated in } \\
\text { ways that preserve or enhance the plant's TOE. } \\
\text { Technologies that reduce melter replacement time } \\
\text { and/or provide increased throughput capabilities } \\
\text { (without increased maintenance requirements) will } \\
\text { support higher TOE levels. }\end{array}$ & $\begin{array}{l}\text { Pros: Increased } \\
\text { production efficiency, } \\
\text { reduced operating costs, } \\
\text { and reduced radioactive } \\
\text { solid waste volumes. } \\
\text { Cons: Negligible or } \\
\text { reduced melter life and } \\
\text { higher operating costs } \\
\text { could occur if new } \\
\text { technologies do not } \\
\text { perform as intended. }\end{array}$ \\
\hline $\begin{array}{l}\text { Operability - Under remote } \\
\text { radioactive facility conditions }\end{array}$ & $\begin{array}{l}\text { Technology must be remotely } \\
\text { operable to permit continuous } \\
\text { operations with minimal } \\
\text { interruptions to support } \\
\text { attainment of the plant's TOE } \\
\text { goals. }\end{array}$ & $\begin{array}{l}\text { Current baseline technology has been a preferred } \\
\text { DOE technology because of its simplicity and } \\
\text { reliability. Potential rate enhancements such as } \\
\text { mixing and bottom drains introduce a level of added } \\
\text { complication that must be able to be designed, } \\
\text { understood and operated in ways that preserve or } \\
\text { enhance the plant's TOE. } \\
\text { Technologies that require fewer remote operator } \\
\text { interactions will support higher TOE levels. }\end{array}$ & $\begin{array}{l}\text { Pros: Increased } \\
\text { production efficiency, } \\
\text { reduced operating costs, } \\
\text { and reduced radioactive } \\
\text { solid waste volumes. } \\
\text { Cons: Negligible or } \\
\text { reduced melter life and } \\
\text { higher operating costs } \\
\text { could occur if new } \\
\text { technologies do not }\end{array}$ \\
\hline
\end{tabular}




\begin{tabular}{|c|c|c|c|}
\hline Requirement & Basis for Requirement & Potential Modifications to Requirement & Potential Impacts \\
\hline & & & perform as intended. \\
\hline $\begin{array}{l}\text { Volatility - For existing facilities, } \\
\text { emissions must not exceed } \\
\text { capabilities of installed off-gas } \\
\text { technologies to effectively } \\
\text { operate and meet permit and site } \\
\text { requirements. }\end{array}$ & $\begin{array}{l}\text { Some components are more likely } \\
\text { to volatilize from the melter and } \\
\text { be removed through the off-gas } \\
\text { system. Volatility of certain } \\
\text { components is undesirable due to } \\
\text { environmental concerns and } \\
\text { efficiency in incorporation of the } \\
\text { waste components into the waste } \\
\text { form. }\end{array}$ & $\begin{array}{l}\text { Technologies that maintain a covered glass surface } \\
\text { typically produce fewer off-gas stream emissions. } \\
\text { Higher volatility can be permitted to the extent that } \\
\text { they can be captured by the off-gas equipment, do } \\
\text { not cause equipment plugging or other failures, and } \\
\text { can be managed in the secondary waste treatment } \\
\text { systems. } \\
\text { If excessive, product qualification strategy options } \\
\text { may be complicated or constrained. } \\
\text { Significantly increasing waste loading, especially in } \\
\text { conjunction with higher temperature melter } \\
\text { technologies, might potentially increase volatility. } \\
\text { Technologies with significant forced mixing may } \\
\text { have enhanced volatility. }\end{array}$ & $\begin{array}{l}\text { Expected to be } \\
\text { negligible }\end{array}$ \\
\hline Operational life & $\begin{array}{l}\text { Hanford WTP design basis is } 4 \\
\text { years, in part, based on extended } \\
\text { WVDP and DWPF JHCM } \\
\text { performance. } \\
\text { DWPF design basis is } 2 \text { years. } \\
\text { WVDP design basis is } 3 \text { years. }\end{array}$ & $\begin{array}{l}\text { Melter life is a factor in plant TOE, radioactive solid } \\
\text { waste costs, and operating costs. Extended service } \\
\text { life through elimination of potential failure modes, } \\
\text { such as noble metals accumulation, electrode, } \\
\text { refractory and glass discharge system failures, is } \\
\text { desirable. } \\
\text { The use of technologies that either have a } \\
\text { demonstrably longer service life or are significantly } \\
\text { easier and more economical to replace are also } \\
\text { desirable. }\end{array}$ & $\begin{array}{l}\text { Pros: Increased } \\
\text { production efficiency, } \\
\text { reduced operating costs, } \\
\text { and reduced radioactive } \\
\text { solid waste volumes. } \\
\text { Cons: Negligible or } \\
\text { reduced melter life and } \\
\text { higher operating costs } \\
\text { could occur if new } \\
\text { technologies do not } \\
\text { perform as intended. }\end{array}$ \\
\hline $\begin{array}{l}\text { Glass mixing and removal of } \\
\text { settled phases }\end{array}$ & No requirement currently & $\begin{array}{l}\text { Increased production rate per unit surface area or } \\
\text { volume of glass in melter can be achieved and } \\
\text { require smaller melters. } \\
\text { Capability to suspend crystals or metal particles can } \\
\text { permit higher waste loading or glass/crystalline glass } \\
\text { compositions to be processed. } \\
\text { There is a possibility that mixing will lead to larger } \\
\text { particle agglomeration. Phenomenon and impact on } \\
\text { crystal size would need to be investigated. }\end{array}$ & $\begin{array}{l}\text { Pros: Increased waste } \\
\text { loading and } \\
\text { proportionately reduced } \\
\text { throughput requirements. } \\
\text { Reduced melter costs } \\
\text { and solid waste disposal } \\
\text { costs. } \\
\text { Cons: Reduced } \\
\text { throughput and/or melter } \\
\text { life if mixing technique }\end{array}$ \\
\hline
\end{tabular}




\begin{tabular}{|c|c|c|c|}
\hline Requirement & Basis for Requirement & Potential Modifications to Requirement & Potential Impacts \\
\hline & & $\begin{array}{l}\text { Higher viscosity melts may be possible, assuming } \\
\text { glass discharge design is compatible. } \\
\text { Periodic mixing for the purpose of suspending settled } \\
\text { crystals and noble metals would also be beneficial. } \\
\text { However, modeling, development, and } \\
\text { demonstration of practical techniques are required. }\end{array}$ & $\begin{array}{l}\text { is inadequate, also } \\
\text { leading to increased } \\
\text { operating costs. }\end{array}$ \\
\hline $\begin{array}{l}\text { Refractory materials of } \\
\text { construction - glass contact } \\
\text { refractory must contain the melt. }\end{array}$ & $\begin{array}{l}\text { Refractory specifications } \\
\text { (materials and sizing) for WVDP } \\
\text { and DWPF were based on 1980s } \\
\text { work that established corrosion } \\
\text { rate allowances on the order of } \\
\text { one inch per year. } \\
\text { Glass contact refractory is } \\
\text { selected mainly for its chemical } \\
\text { resistance to glass corrosion and } \\
\text { erosion and thermal shock } \\
\text { resistance. } \\
\text { WVDP and DWPF glass contact } \\
\text { refractory thickness criteria is } \\
\text { based on accommodating } 1 \text { inch } \\
\text { of corrosion per year and } \\
\text { maintaining } 50 \% \text { of its original } \\
\text { thickness at the end of melter's } \\
\text { design operating life. These } \\
\text { guidelines have not been } \\
\text { challenged. }\end{array}$ & $\begin{array}{l}\text { The elimination of glass contact refractories would } \\
\text { prove most beneficial for this requirement. } \\
\text { Permitting glass penetration to backup refractory } \\
\text { linings or the shell itself would allow for small } \\
\text { incremental decreases in melter size (on the order of } \\
\text { inches to a foot). Ultimate disposal of the melter } \\
\text { could be complicated if glass contamination into } \\
\text { other regions of the melter box were allowed to } \\
\text { occur. } \\
\text { Less corrosive melts could result in longer operating } \\
\text { life, the use of lower cost refractories, or thinner } \\
\text { refractory liners. These factors would all contribute } \\
\text { to lower capital and plant operating costs. }\end{array}$ & $\begin{array}{l}\text { Pros: Reduced melter } \\
\text { costs and solid waste } \\
\text { disposal costs. } \\
\text { Cons: Reduced melter } \\
\text { life and higher operating } \\
\text { costs could occur if new } \\
\text { technologies do not } \\
\text { perform as intended. }\end{array}$ \\
\hline $\begin{array}{l}\text { Electrode materials of } \\
\text { construction (Joule-heating only) }\end{array}$ & $\begin{array}{l}\text { Electrode specifications } \\
\text { (materials and sizing) for WVDP } \\
\text { and DWPF were based on late } \\
1970 \text { s and early } 1980 \text { s work that } \\
\text { established Inconel- } 690^{\circledR} \text { as the } \\
\text { optimum electrode material based } \\
\text { on corrosion resistance, current } \\
\text { flux limits, and mechanical } \\
\text { properties in the working } \\
\text { temperature range of } 1050^{\circ} \mathrm{C} \text { to } \\
1250^{\circ} \mathrm{C} \text {. }\end{array}$ & $\begin{array}{l}\text { The elimination of electrodes would prove most } \\
\text { beneficial for this requirement. } \\
\text { Evaluation and testing of alternative electrode } \\
\text { materials for use in a relatively oxidizing melt have } \\
\text { not been fruitful. Limited success is projected for } \\
\text { this area. } \\
\text { Current DWPF and WVDP experiences do not } \\
\text { indicate this as a significant issue. }\end{array}$ & $\begin{array}{l}\text { Pros: Increase in } \\
\text { temperature range of } \\
\text { operation will permit } \\
\text { increased waste loading } \\
\text { and increased operations } \\
\text { flexibility. } \\
\text { Cons: Reduced melter } \\
\text { life and higher operating } \\
\text { costs could occur if new }\end{array}$ \\
\hline
\end{tabular}




\begin{tabular}{|c|c|c|c|}
\hline Requirement & Basis for Requirement & Potential Modifications to Requirement & Potential Impacts \\
\hline & $\begin{array}{l}\text { WVDP and DWPF electrode } \\
\text { cooling design thickness criteria } \\
\text { are based on accommodating } 1 \\
\text { inch of material loss from the face } \\
\text { due to corrosion per year and } \\
\text { maintaining } 50 \% \text { of its original } \\
\text { thickness at the end of a melter's } \\
\text { design operating life. These } \\
\text { guidelines have not been } \\
\text { challenged. }\end{array}$ & & $\begin{array}{l}\text { technologies do not } \\
\text { perform as intended. }\end{array}$ \\
\hline Glass discharge & No requirement currently & $\begin{array}{l}\text { Bottom drain designs in conjunction with sloped } \\
\text { melter walls would permit a high percentage of noble } \\
\text { metal to be discharged from the melter. Theses } \\
\text { metals would otherwise settle in the melter and } \\
\text { ultimately lead to melter failure. } \\
\text { Bottom drain designs would also permit the use of } \\
\text { glasses with higher liquidus temperatures and } \\
\text { presence of a yet-to-be-defined volume percent } \\
\text { crystal concentration. }\end{array}$ & $\begin{array}{l}\text { Pros: Increased melter } \\
\text { life for HLW containing } \\
\text { high noble metals } \\
\text { concentrations. } \\
\text { Increased waste loading } \\
\text { and proportionately } \\
\text { reduced throughput } \\
\text { requirements. } \\
\text { Cons: Remotely } \\
\text { maintainable bottom } \\
\text { drains have been used in } \\
\text { Europe and Japan. Some } \\
\text { components are not } \\
\text { replaceable. Early } \\
\text { failures could require } \\
\text { melter replacement. }\end{array}$ \\
\hline
\end{tabular}




\title{
Appendix H - Request for Information
}

\author{
SOURCES SOUGHT ANNOUNCEMENT -- HIGH-LEVEL RADIOACTIVE WASTE VITRIFICATION \\ TECHNOLOGY. THIS IS NOT A SOLICITATION ANNOUNCEMENT FOR PROPOSALS AND NO \\ CONTRACT WILL BE AWARDED FROM THIS ANNOUNCEMENT. NO REIMBURSEMENT WILL BE \\ MADE FOR ANY COSTS ASSOCIATED WITH PROVIDING INFORMATION IN RESPONSE TO THIS \\ ANNOUNCEMENT AND ANY FOLLOW-UP INFORMATION REQUESTS. NO TELEPHONE CALLS \\ REQUESTING A SOLICITATION WILL BE ACCEPTED OR ACKNOWLEDGED. THIS SOURCES \\ SOUGHT ANNOUNCEMENT MAY OR MAY NOT RESULT IN A SOLICITATION.
}

This Request for Information is being issued to support a U. S. Department of Energy (DOE) program responsible for the solidification and preparation for disposal of hazardous and radioactive materials defined as high-level radioactive waste (HLW). As part of this effort, DOE seeks to determine the availability and applicability of technologies that may offer improvements in operational efficiency and reductions in final product volume and lifecycle costs. Vendors and developers of vitrification technologies that may be applicable to the immobilization of HLW are requested to provide descriptive and technical information to the points of contact listed below. Descriptions of the information sought are also provided below.

\section{Background}

At three sites within the United States, DOE is responsible for management and ultimate treatment of almost 88 million gallons of highly radioactive waste stored in 230 large underground tanks. Approximately 54 million gallons of this waste are stored in 177 tanks located at the Hanford Site in southeastern Washington State. The waste, which was generated by plutonium production activities supporting the nation's nuclear defense program, has been accumulating at Hanford since 1944. Once the waste is retrieved from the tanks, it will be separated into high-level waste and low-activity waste fractions for processing. This Request for Information addresses only the high-level waste fraction.

Table 1 provides a list of chemical compounds typically found in the HLW at the Hanford Site. As currently stored, the HLW at Hanford is an alkaline solution with a pH of between 12 and 14. Chemical adjustment of the HLW can be proposed to optimize its performance during vitrification. As currently planned, the waste will be combined with glass-forming chemicals (e.g., silica sand, boron oxide, aluminum silicate, and alkali and alkaline earth compounds) and pumped to a vitrification unit. The "melter feed" will consist of an approximately 50weight-percent solids slurry mixture with a glass yield of approximately 500 grams of glass per liter of melter feed. The ratio of HLW oxides to glass-forming chemical oxides in the final glass product will typically range between $1: 2.5$ and 1:4.

The initial waste processing activity at the Hanford Site, known as Phase I, will accomplish treatment and immobilization of a minimum 10 percent by mass and 25 percent by radioactivity of the tank waste by 2018 . The remainder of the work, referred to as the Balance of Mission, will accomplish disposition of the remainder of the waste and final closure of facilities over the following 30-year period. Waste treatment facilities will be constructed for treating the waste through vitrification, packaging the waste for long-term storage, and transporting the waste for either interim or long-term storage. Vitrification facilities will be designed to assure a minimum 40-year operational life. Equipment that will not meet the 40-year operating life requirement will be designed to be replaceable.

The HLW vitrification process throughput rate will be 1.5 metric tons of glass per day (MTG/d) in Phase I. During the Balance of Mission phase, the HLW facility capacity will be increased to $6 \mathrm{MTG} / \mathrm{d}$. Waste products produced during the vitrification process must meet the characteristic limits of the U.S. Environmental Protection Agency Toxicity Characteristic Leaching Procedure and land disposal requirements and must comply with applicable codes and standards for disposal in an underground geologic repository. Additional information can be reviewed electronically via the Internet at http://www.hanford.gov/orp/index.html. 
As part of its ongoing waste vitrification program, DOE has identified a joule-heated, ceramic-lined melter as the baseline technology and borosilicate glass as the waste form to be produced. Even with the current technology, incremental increases in waste loading and glass volume reduction may be possible. However, as a result of technology advancements and understanding of borosilicate glass and other glass system properties since 1982, opportunities also exist to refine or supplant the waste form and technology in the future. For this reason, DOE is interested in receiving and evaluating information from vendors and developers of vitrification technologies that may offer advantages relative to the current baseline technology.

DOE HAS INTEREST IN RECEIVING INFORMATION FROM ALL INTERESTED PARTIES WITH A TECHNOLOGY THAT COULD FULFILL THESE REQUIREMENTS. ANY INTERESTED PARTY SHOULD SUBMIT A BRIEF CAPABILITY STATEMENT (MAXIMUM 10 PAGES). STANDARD COMPANY BROCHURES ARE NOT DESIRED. A TEMPLATE FOR THE CAPABILITY STATEMENT IS PROVIDED AT NETL'S WEB SITE: http://www.netl.doe.gov/business/solicit. DO NOT INCLUDE PROPRIETARY AND/OR BUSINESS CONFIDENTIAL DATA. THE DEADLINE FOR SUBMISSION OF THE CAPABILITY STATEMENT IS February 16, 2001. Four (4) copies of this document should be submitted as follows: Two (2) copies to Jagdish Malhotra, U.S. DOE/NETL, P.O. Box 880, 3610 Collins Ferry Road, Mail Stop E06, Morgantown, WV 26507-0880, and two (2) copies to Lance Mamiya, U.S. DOE/RL, P.O. Box 550, 825 Jadwin Avenue, Mail Stop K8-50, Richland, WA, 99352. 


\section{DO NOT INCLUDE PROPRIETARY AND/OR BUSINESS CONFIDENTIAL DATA}

It is recognized that potential vitrification technologies will be in various states of development, demonstration, or deployment. As such, it is expected that this template may not be completed in its entirety. Submitters are requested to complete as much of this template as possible and to either leave open any items that cannot be addressed at this time or provide a best estimate or comment.

\section{COVER PAGE}

1. Technology Trade Name:

2. Organization or Company Name:

3. Street Address:

4. City, State, Zip Code:

5. Contact Name:

6. Phone Number:

7. Facsimile Number:

8. Internet Address:

\section{Section 1, Technology Description}

1. Provide a general description of the technology that could be applied or adapted to HLW immobilization and its basis of operation. Information of interest would include:

- a description of the technology, including schematics;

- the basic principal of operation (e.g., joule-heated, induction-heated, DC arc-heated)

- a description of key or major elements of the technology and any support equipment/systems, including:

a. feeding methods;

b. description of any mechanical or moving parts;

c. product and off-gas discharge methods;

- whether the technology provides hot-top or cold-top operation or both;

- the glass-melt holdup volume and residence time;

- the method of removing settled phases (e.g., slags, reduced metals, crystalline phases, etc.).

2. Describe plant service requirements (e.g., power, gas, water, compressed air, steam, inert gases, etc.).

3. Describe any chemical compounds identified in Table 1 or otherwise known that are incompatible with your technology and reasons for incompatibility of specific compounds.

4. Describe power, control, and monitoring requirements, including:

- power supply requirements;

- energy balance/efficiency data;

- any co-location or close proximity requirements between systems (e.g., power supplies and vitrification units or vitrification units and off-gas treatment equipment);

- method of control (e.g., temperature feedback, constant power, etc.);

- instrumentation necessary for control and monitoring (e.g., temperature, pressure, level, power input, etc.). 
5. Describe materials of construction and constraint, including:

- operating periods between rebuilds or maintenance;

- requirements for oxidizing or reducing melt and/or plenum atmosphere.

6. Describe methods employed to initially start the melter; or for the case of an unplanned shutdown, the methods employed to restart the melter.

\section{Section 2, Performance}

1. Provide a summary of operating experience of the technology, including:

- types of waste streams that have been successfully demonstrated, especially those similar to the HLW materials (e.g., nonradioactive surrogates or slurries);

- the scale of demonstration performed (e.g., bench through commercial scale) (if only development units have been tested, provide the operating experience for each size of the unit);

- the number and sizes of units placed in industrial operation;

- glass and feed processing rates on a per unit area or per unit volume of glass inventory or other generally accepted basis;

- energy efficiency;

- partitioning of feed materials between the glass and off-gas streams;

- years of operation between rebuild or replacement and the reasons for rebuild or replacement (i.e., observed modes of failure);

- secondary waste stream considerations;

- available testing or operational data that can support an independent viability assessment for HLW application by experts.

2. Define the technology's annual online productivity percentage and basis (taking into consideration outage times for replacement and routine equipment maintenance), e.g., (\#/yr)*100/(\#/hr)(days/yr)(hr/day). Describe whether the estimate is based on experience operating in a remotely maintained radioactive facility.

3. Describe the design basis, or that advertised, and actual demonstrated temperature operating ranges (e.g., $1000^{\circ} \mathrm{C}-1400^{\circ} \mathrm{C} ; 1000^{\circ} \mathrm{C}-1600^{\circ} \mathrm{C}$; etc.) and reasons for temperature limits (e.g., failure of melter components, excessive losses to offgas, etc.).

4. Describe the product characteristics and constraints (e.g., glass, glass plus crystalline phases, molten ceramic, viscosity ranges, electrical property ranges that have been demonstrated to date).

\section{Section 3, Application to Radioactive HLW Processing}

Because of the high levels of radiation generated by the HLW, the vitrification technology is required to be placed in shielded cells that isolate the HLW from the operating staff. Therefore, operation and control, replacement of instrumentation, movement of product canisters, and any necessary maintenance are performed using operator-controlled cranes, manipulator arms, and other robotic devices.

1. Describe the process features that establish reliable remote-operating and maintenance and replacement capability, or modifications that would establish such capability for the melter system.

2. Describe how the technology might be applied to this waste stream, including:

- melter feed pre-processing requirements (e.g., calcination, drying, chemical adjustment); 
- number, size, and weight (empty and with glass inventory [assuming a specific gravity of glass of 2.7]) of vitrification units required for $1.5 \mathrm{MTG} / \mathrm{d}$ and $6 \mathrm{MTG} / \mathrm{d}$;

- operating time between major maintenance activities (e.g., torch or electrode replacement, rebuild, or melter change-out);

- off-gas treatment requirements for removal of particulates and condensable and non-condensable aerosols and effluents.

3. For application at the Hanford Site, describe the technology's ability to produce both borosilicate glass and glass plus crystalline phases, or a molten ceramic waste form.

4. Describe any alternative or secondary waste forms envisioned to be co-produced [e.g., a heterogeneous waste form (separate or combined mixture of glass, metal, slag, or crystal phases)].

5. Describe any "foreign" materials that may be introduced into the waste form during processing (e.g., graphite from graphite electrodes, refractory crystals from refractory linings, etc.).

6. Given the state of the technology development and deployment and the HLW processing requirements, describe what development, demonstration, and engineering activities and associated costs and time periods would be required to support assessment and deployment for HLW treatment.

7. Describe pilot-plant and engineering facilities available to support technology assessment and development.

8. Provide estimates of capital and operating costs that may be available, including:

- per unit capital cost;

- energy costs;

- cost of replaceable components;

- any typical royalty or license fees;

- operating costs.

Describe whether these estimates are based on actual cost data or are estimated based on scale-up or conceptual data.

9. Describe the disposal approach proposed for the radioactive melter at the end of its service life (e.g., melter draining capabilities, separation of glass contact materials from the balance of melter materials, ability to segment melter into smaller fractions, disposal as a unit, etc.).

10. Include any schematics, photographs, drawings, and published reports that may be useful in the evaluation. 
This page left blank intentionally

H - 6 


\title{
Appendix I - Workshop Agenda and Participants
}

\author{
Melter Review - Study Team Melter Technology Evaluation Workshop \\ Monday, March 19-Tuesday, March 20, 2001 \\ Richland, WA
}

\begin{abstract}
Attendees:
Study Team - JM Perez, PNNL; MB Triplett, PNNL; RL Russell, PNNL; DF Bickford, SRTC; WW Grunewald, FZKGermany

Review Team - ET Weber, Consultant; Frank Woolley, Consultant

Technical Expert Invitees - LK Holton, PNNL; RW Goles, PNNL; GJ Sevingy, PNNL
\end{abstract}

\begin{tabular}{|c|c|}
\hline $\begin{array}{l}\text { March 19, 2001, Monday - EESB, } \\
\text { Snoqualmie Room }\end{array}$ & $\begin{array}{l}\text { March 20, 2001, Tuesday - ETB, } \\
\text { Columbia River Room }\end{array}$ \\
\hline 8:30 Welcome/Introductions - JM Perez & $\begin{array}{l}\text { 8:00 Review previous day's results and objectives } \\
\text { for today }\end{array}$ \\
\hline $\begin{array}{l}\text { 8:45 Review meeting objectives and agenda - } \\
\text { JM Perez }\end{array}$ & $\begin{array}{l}\text { 8:15 Complete RFI reviews and compile technology } \\
\text { versus requirements matrix }\end{array}$ \\
\hline 9:00 Overview of Project Scope - JM Perez & 10:15 Break \\
\hline 9:15 Review Task 1 Activities - JM Perez & $\begin{array}{l}\text { 10:30 Discussions of technology merits and } \\
\text { deficiencies }\end{array}$ \\
\hline 9:30 Review Task 2 Activities - DS Kim & 12:00 Break for Lunch \\
\hline 10:00 Break & $\begin{array}{l}\text { 1:00 Develop technology concepts that: } \\
\text { Incorporate key technology features, and }\end{array}$ \\
\hline 10:15 Review Task 3 Activities - JM Perez & $\begin{array}{l}\text { 2. Either meet WTP requirements, or } \\
\text { 3. Document required WTP modifications. }\end{array}$ \\
\hline 10:45 Review Task 4 Activities - JM Perez & $2 \cdot 45$ Break \\
\hline 11:30 Review Task 5 Activities - MB Triplett & $\begin{array}{l}\text { 3:00 Capture key development requirements and } \\
\text { estimated budget and schedule }\end{array}$ \\
\hline & 4:30 Convene \\
\hline $\begin{array}{l}\text { 1:00 Establish Key Technology Evaluation Factors - } \\
\text { JM Perez (lead) - Including Waste Treatment } \\
\text { Plant constraints }\end{array}$ & \\
\hline $\begin{array}{l}\text { 1:30 Review RFI technology submittals and } \\
\text { summaries }\end{array}$ & \\
\hline 2:30 Break & \\
\hline $\begin{array}{l}\text { 2:45 Review RIC "movie" and continue RFI } \\
\text { technology submittals and summaries }\end{array}$ & \\
\hline 4:30 Convene & \\
\hline
\end{tabular}


This page left blank intentionally 


\section{Appendix J - HLW Candidate Melter Evaluation Criteria ${ }^{23}$}

After identification of available HLW treatment technologies, the application of the evaluation criteria will be a two step process. The first step will be to eliminate the technologies that do not meet the minimum requirements as follows:

\section{MINIMUM REQUIREMENTS (used in June 1994 Phase 1 evaluation)}

- The ability to meet minimum TPA waste form specifications (glass as the waste form)

- The ability to meet TPA milestones - complete lack of information or development

- The ability to meet the required processing rate unless more that 10 parallel lines are used

- Interest by the company

The second step will be to evaluate the melters that meet the minimum requirements using a more rigorous set of criteria. For now the criteria are only qualitative. They will be quantified at a later date and this document will be reissued. The rigorous evaluation criteria are as follows:

\section{RIGOROUS EVALUATION (used in September 1994 Phase 1 evaluation)}

A. $\quad$ System Attributes

i. Product quality

a. Durability - must perform better than the EA reference glass for a 7-day

PCT:

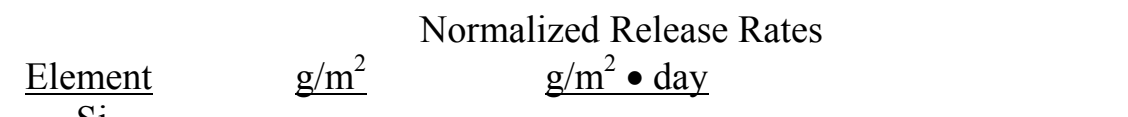

Si...... 0.26

B

$\mathrm{Li}$

$\mathrm{Na}$
8.64

3.83

6.59
1.23

0.55

0.94

b. Phase Separation - Allowable as long as the glass does not stratify in the melter and affect durability

c. Crystallinity - Allowable as long as the crystals do not cause melter operational problems and affect durability

d. Waste homogenization capabilities - No undissolved feed and identify residence time

ii. Processing rate - Assumed rate is 3.88 metric tons waste oxides/day at $60 \%$ total on-line efficiency, e.g. 15.53 metric tons/day for $25 \%$ waste loading, 7.76 metric tons/day for $50 \%$ waste loading.

iii. Range of waste handling capabilities

a. Identify physical properties and compositions of waste that can be handled

b. Incorporation of semivolatiles - Melter must allow the overall system (melter + offgas) to meet clean air requirements (minimize recycle ratios)

c. Ability to handle insoluble and conductive compounds - It is acceptable if the melter cannot handle these compounds if melter life is $\geq 3$ yrs.

d. Ability to handle slurry feeds of at least $20 \%$ undissolved solids

${ }^{23}$ The criteria in this appendix are from Calmus 1995. 
e. Identify maximum solids content that can be processed

f. Ability to handle fissile materials with no accumulation - Identify

iv. Effect on repository

a. Identify number of canisters produced

b. Identify ability to fill/handle 2' diameter x 10' tall canisters

B. Technical Availability

i. Availability of data or access to data to allow evaluation - identify what testing is required to obtain data necessary for evaluating against the important criteria

ii. Additional technical development required to allow assessment - identify what technology must be developed to obtain data necessary for evaluating against the important criteria

iii. Additional technical development required for deployment - identify what technology must be developed before the melter can be used in the HLW vitrification facility

iv. Demonstrated scale of operation - identify $\mathrm{kg}$ glass $/ \mathrm{hr}$ demonstrated

C. Facility/System Integration

i. Feed preparation requirements - identify limitations on feed characteristics (e.g. acid feed, max. solids, etc.)

ii.Offgas system requirements - identify flow rate and complexity of offgas treatment system required

iii. Canister handling requirements - identify

iv. Plant service requirements - identify steam, water, air, energy, etc. required

v. Melter dimensions and weight - identify

vi. Melter cell heat loading - identify

vii. Ability to operate in a canyon remote environment - identify

D. Operability

i. Ease of control - describe controls required

ii. Remotability - identify

iii. Reliability - identify on-line efficiency and demonstrated maximum

iv. Maintainability - describe normal maintenance requirements

v. Estimated lifetime - identify

E. $\quad \underline{\text { Cost }}$

i. Development costs - identify

ii. Deployment costs - identify

iii. Replacement and repair costs - identify

iv. Solid waste disposal costs - identify mass and volume of waste per time period, including melter change out

F. $\quad$ Safety and Environment

i. Plant safety - identify

ii. Worker safety - identify 
iii. Public acceptance of waste form - identify

iv. Public acceptance of technology - identify

v. Environmental compatibility

vi. Offgas - can it meet side release rates and Clean Air Act requirements for Nox, radionuclides, etc.

vii. Site cleanup

viii. Generation of secondary waste streams

- Identify mass and volume of waste per time including melter change outs above as well as compositions

- Identify suggested methods of disposal for secondary wastes 
This page left blank intentionally 


\title{
Appendix K - Information Provided by RFI Respondents
}

\author{
Technology Trade Name: Chemical Bonding HLW Immobilization \\ Organization or Company Name: Clean Technologies International Corporation
}

Section 1, Technology Description

1. Technology Description: Radioactive nuclear metals dissolve into the molten metal bath. Upon dissolving, they are absorbed, stabilized, immobilized, diluted, and contained, as an alloy, into the reactant molten metal medium. The dissolved metals that are absorbed become a diluted portion of the alloy bath, and any organic contaminants are broken down into elemental carbon gas, which physically separates from all the other waste. The major equipment for contaminated alkaline HLW waste treatment consists of a modified, off-the-shelf 200,000 pound capacity molten aluminum reverberating furnace. These furnaces are natural gas fired and operate at around $850^{\circ} \mathrm{C}$. No drying, calcination, or any chemical adjustments are needed. Standard off-the-shelf particulate scrubbers are utilized to capture carbon vapor and aluminum chloride gas. There are no aerosols or effluents created by a chemical reduction technology.

2. Plant Service Requirements: $220 \mathrm{~V}$ of electricity and about 50 square feet of operating space for a demonstration unit that contains 50 pounds of reactive metal.

3. Chemical Compounds that are incompatible with technology: No chemical compounds are incompatible with this technology.

4. Describe Power, Control, and Monitoring Requirements: $220 \mathrm{~V}$ of electricity

5. Describe Materials of Construction: Basic aluminum melting furnaces are used. The refractory linings are replaced at five to ten year intervals.

6. Describe Methods Employed to Initially Start the Melter: A cascade-looped computer controls the firing start-up and automatic restart. Three restarts are automatically programmed. Alarm lights and sound alarms activate upon restart failure.

\section{Section 2, Performance}

1. Provide a summary of operating experience: All RCRA and TSCA waste has been processed with no controlled effluents. DOD RRS post-treatment neutralent material containing high volumes of halogenated hydrocarbon compounds in a $\mathrm{pH}$ of 14 was successfully processed.

2. Define technologies annual online productivity percentage: Actual commercial scale testing experiences have shown that the processing units have run 24 hours per day, seven days per week, for four months before any routine maintenance may be required. No maintenance was required after four months of continuous operation. Normal wear items did not require any maintenance during this four month inspection.

3. Describe the design basis and actual demonstrated temperature operating ranges: Operates at $850^{\circ} \mathrm{C}$.

4. Describe the product characteristics and constraints: There are no constraints involving the cooled metal HLW storage ingots. Superior containment and immobilization of the radioactive elements was accomplished by chemical metallic bonding. No leaching of the radioactive atoms is possible from the metal storage ingots. Non-ionic, pure, chemicallyreduced metals are not soluble. Neither are they soluble out of a metallic bonded alloy.

Section 3, Application to Radioactive HLW Processing

Describe the process features that establish reliable remote-operating and maintenance and replacement capability: Normal on-site, radioactive waste certified, remote pumps and plumbing, including stainless seamless secondary containment and leak detection systems, is all that is required to pump the HLW directly into the treatment plant. Computer-controlled motors and valves will pour the radioactive metal storage ingots upon demand. New non-radioactive alloys will be loaded by remote operated fork lifts. All other systems are automatic and computer-controlled. This is a very safe and simple HLW treatment system. Non-metallic treated residuals are removed in remote operated roll-off equipment.

1. Describe how the technology might be applied to this waste stream: Flow meters are used to meter the waste into the treatment plants. No pretreatment is required. The ceramic refractory lining will need to be replaced approximately every five years. This is a standard two week job. Standard off-the-shelf particulate scrubbers are utilized to capture carbon vapor and aluminum chloride gas. There are no aerosols or effluents created by a chemical reduction technology. 
2. Describe the technology's ability to produce both borosilicate glass and glass plus crystalline phases, or a molten ceramic waste form: This chemical reduction immobilization technology does not produce any form of glass. It produces chemically bonded, radioactive emission moderated metal storage ingots.

3. Describe any alternative or secondary waste forms envisioned to be co-produced: Secondary waste consists of separated alkaline bases, salts, and mineral materials. These materials will be separated from all of the radioactive waste materials. These materials are skimmed and collected for storage.

4. Describe any "foreign" materials that may be introduced into the waste form during processing: Any foreign objects will simply float on the surface and be skimmed with other treated floating residuals. Only metals will be captured in the metal alloy. No acids, bases, or salts enter the bath or become any part of the storage ingots. All of these materials float on the surface as a treated slag.

5. Describe the development, demonstration, and engineering activities and associated costs and time periods that would be required to support and deployment for HLW treatment: A commercial-sized 5,000 pound holding furnace has been built and fully tested. This is the basic sized unit required for the phase one treatment. This technology is fully developed and ready for deployment for use for the treatment of HLW.

6. Describe pilot-plant and engineering facilities available to support technology assessment and development: Mobilization for a HLW demonstration on site will require about 30 days notice. These demonstration units are assembled and ready to demonstrate the treatment of HLW. Demonstration and pilot-plants have been engineered, built, and fully demonstrated and tested. DOE experienced engineering facilities are utilized for the design and construction of treatment plants.

7. Provide estimates of capital and operating costs that may be available: The phase one HLW treatment plant is estimated at around $\$ 37,500,000$. Energy cost for the phase one treatment plant is less than any glass melter. A twentyfour hour per day, seven days per week, processing schedule is planned for the treatment of HLW waste. The cost of replacement components is estimated to be around \$20,000 per year. These costs are based on actual cost data. All contracts are fixed bid priced.

8. Describe the disposal approach proposed for the radioactive melter at the end of its service life: The furnaces can be cut up and processed in yet another furnace to dissolve the contaminated machine and reduce it to long-term storage ingots.

9. Include any schematics, photographs, drawings, and published reports that may be useful in the evaluation: Presentation by Sandia was included. 


\title{
Technology Trade Name: DC Graphite Arc Melter Technology Organization or Company Name: Electro-Pyrolysis, Inc.
}

\author{
Section 1, Technology Description
}

1. Technology Description: DC graphite arc melter that operates in a pyrolytic mode (in the absence of air). The energy input is electrical and combines arc/plasma energy and joule heating. The current is carried to the hearth and out through the conducting crucible. It relies on mechanical moving parts to raise and lower the central electrode. Hydraulics are avoided. By lowering the electrode the electrode may be submerged and the energy is all transferred into the bath. $95 \%$ of the energy goes into the melter vs. $60 \%$ for an induction heated system or $70 \%$ for a plasma torch. Melter can handle solids, liquids, metals, and combustibles. It can be fed by a slurry pump. Due to the reducing environment in the melter, the ferrous metals are removed as iron. It produces a stable product as measured by TCLP and PCT tests. The product may be removed by either an overflow or underflow discharge. The melter may be operated in either a hot top or a cold top mode. The holding time may be designed into the system. For the 750lb unit, the bath is approximately one ton and yields a holding time of two hours. If a large quantity of crystalline phase is anticipated, the operation may consider a batch type processing.

2. Plant Service Requirements: Power required is calculated at $0.75 \mathrm{~kW} / \mathrm{lb}$ of feed. Cooling water for the shell and clamps is recirculated and nitrogen is used as a purge gas at the start and finish of a campaign.

3. Chemical Compounds that are incompatible with technology: Sodium salts must be kept to a minimum of less than 5\% since they have an adverse impact on glass formers.

4. Describe Power, Control, and Monitoring Requirements: The design requirement for a 1.5 metric ton/day is a small unit requiring approximately $150 \mathrm{~kW}$ power supply. It is estimated to have a $95 \%$ energy efficiency. The power supply may be placed outside the hot area and power cabled to the melter. The gas system must be close coupled to the melter. Temperature is monitored but the system is normally operated under a constant power input. Monitored parameters include temperature, system pressure, amps, and volts.

5. Describe Materials of Construction and Constraint: Due to the graphite refractory in normal design, it is best to keep the headspace reducing.

6. Describe Methods Employed to Initially Start the Melter: The EPI patented coaxial electrode system allows one to initiate an arc in a cold start mode, non-transferred arc, and after sufficient melting has taken place the operation is switched to a transferred mode of operation.

\section{Section 2, Performance}

1. Provide a summary of operating experience: Both radioactive and nonradioactive materials have been treated including simulated sludges containing high nitrate sludges and high Cs waste. Other wastes treated include metal nitrate salts, metal hydroxides, ion exchange resins, and water content to $50 \%$. Units have been built and demonstrated in sizes from bench scale to $750 \mathrm{lb} / \mathrm{hr}$. About 5 units have been placed in industrial operation. Design feed rates are approximately 1 $\mathrm{lb} / \mathrm{min} / \mathrm{sq}$. ft of bath surface. The Clemson unit has had more than five years of operation history. Dry gas handling systems produce "baghouse" dust that is fed back into the melter. HEPA filtration media may be fed to the melter or disposed of as radioactive waste.

2. Define technologies annual online productivity percentage: Not known.

3. Describe the design basis and actual demonstrated temperature operating ranges: The demonstrated melting temperature of $1600^{\circ} \mathrm{C}$ has been measured. Surface temperatures in excess of this value were measured by pyrometer measurements.

4. Describe the product characteristics and constraints: This melter operates preferably in a pyrolytic mode. This reducing environment extends into the melt. Each melt system has the potential for crystalline material formation. This melter has been used to melt materials such as firebrick that had pour points that were too high to pour without fluxing.

\section{Section 3, Application to Radioactive HLW Processing}

1. Describe the process features that establish reliable remote-operating and maintenance and replacement capability: This melter has not been designed for this type of operation at this time.

2. Describe how the technology might be applied to this waste stream: No preprocessing is required for materials to be processed in this melter system other than it being sized appropriately. Operating time between major maintenance activities is calculated as one/month based on electrode erosion. Off-gas treatment requirements can only be provided after pilot runs with surrogate materials in a test unit. 
3. Describe the technology's ability to produce both borosilicate glass and glass plus crystalline phases, or a molten ceramic waste form: Based on previous work and the use of this melter to produce frits at Clemson, there is no reason to suspect difficulty in producing borosilicate glass in the melter.

4. Describe any alternative or secondary waste forms envisioned to be co-produced: Due to the reducing environment, it is anticipated that ferrous metals will be produced as well as glass/ceramic material. It is possible to oxidize the metal with proper additives.

5. Describe any "foreign" materials that may be introduced into the waste form during processing: Foreign materials such as broken and spalled electrode material are possible.

6. Describe the development, demonstration, and engineering activities and associated costs and time periods that would be required to support and deployment for HLW treatment: We will be pleased to develop a program related to the treatment of HLW using this technology based on a more detailed RFP.

7. Describe pilot-plant and engineering facilities available to support technology assessment and development: A 50kg batch melter is available for testing and demonstration at Clemson University.

8. Provide estimates of capital and operating costs that may be available: $\$ 15-20$ million per unit capital cost. 2-3\% of operating costs for royalty or license fees. Operating costs for commercial $\$ 300-500 /$ ton, for DOE probably $\$ 1500$ $5000 /$ ton. These costs were developed on conceptual data.

9. Describe the disposal approach proposed for the radioactive melter at the end of its service life: End of life service, depending upon design criteria, may be placed in a disposal cask for landfilling or cut up and melted.

10. Include any schematics, photographs, drawings, and published reports that may be useful in the evaluation: Papers and brochures were attached. 


\title{
Technology Trade Name: Resonant Shock Compaction Organization or Company Name: RSC, LLC at the University of Denver
}

\author{
Section 1, Technology Description
}

1. Technology Description: RSC is best suited to waste streams that are largely granular in nature, but is not limited to $100 \%$ granularity. The waste is blended with a finely ground glass with composition depending on several features of the particular waste composition, then placed on a massive shake table and vigorously vibrated at a frequency of $20 \mathrm{~Hz}$. The top of the mold accommodates a pneumatic ram which controls the vibrational amplitude. The glass component typically comprises $5-15 \%$ of the blend and upon sintering or melting constitutes the binder for the monolithic waste form. The waste form in its "green" state is then ejected from the mold and transported to a furnace for heat treatment at temperatures appropriate to the waste material and glass properties. During this process, the molten glass wets the surfaces of the waste material and, upon cooling, provides a strong interparticle bond that yields an impermeable, robust monolith.

2. Plant Service Requirements: not answered

3. Chemical Compounds that are incompatible with technology: not answered

4. Describe Power, Control, and Monitoring Requirements: not answered

5. Describe Materials of Construction: not answered

6. Describe Methods Employed to Initially Start the Melter: not answered

Section 2, Performance

1. Provide a summary of operating experience: They have worked with DOE for the past 4 years on LLW and LLMW and toxic heavy metals at Rocky Flats and Argonne National Laboratory.

2. Define technologies annual online productivity percentage: Not answered

3. Describe the design basis and actual demonstrated temperature operating ranges: Some RSC test blocks were fired at $1,000^{\circ} \mathrm{C}$ to sinter them.

4. Describe the product characteristics and constraints: Typical sample mixes were compacted into 10 pound ( 3 in. X 3 in. $\mathrm{X} 12$ in.) blocks that were then tested for compressive strength, freeze-thaw durability and leachability (TCLP and PCT). The mix contained about $80-90 \%$ contaminated soil and/or ash waste, $10 \%$ moisture and $10 \%$ binder. Some surrogate samples contained scraps of iron pipe and waste plastic representative of contaminated debris. Mixes of $40 \%$ concrete rubble, $40 \%$ asphalt rubble, $10 \%$ soil and $10 \%$ binder were compacted with $50 \%$ volume reduction. Large 600 pound blocks ( $3 \mathrm{ft}$. X $4 \mathrm{ft}$. X $0.5 \mathrm{ft}$ ) were formed from $80 \%$ ash and $10 \%$ cement binder and $10 \%$ moisture. Forming time is about $2 \mathrm{~min}$. The blocks were then cured in a warm humid environment.

\section{Section 3, Application to Radioactive HLW Processing}

1. Describe the process features that establish reliable remote-operating and maintenance and replacement capability: Remote operation should be readily achievable.

2. Describe how the technology might be applied to this waste stream: Pneumatic ram seals and motor bearings should be replaced as routine maintenance perhaps every 6 months to 1 year under heavy use; the mold ejection equipment should also be quite serviceable. The most likely components for failure are the steel molds which should be inspected after each use, as part of normal operations.

3. Describe the technology's ability to produce both borosilicate glass and glass plus crystalline phases, or a molten ceramic waste form: The RSC process has been licensed to compact granular refractory material into many engineered shapes which are then fired to make exceptionally dense and durable refractories. Mixes of silica, silicon nitride, magnesia and other materials are combined with binders, formed in the RSC machine and then fired to make the refractories. This same procedure can be used to vitrify DOE waste. Alternatively lower temperature sintering or even room temperature phosphate chemical bonding may be used, depending upon the desired waste form properties.

4. Describe any alternative or secondary waste forms envisioned to be co-produced: not answered

5. Describe any "foreign" materials that may be introduced into the waste form during processing: not answered

6. Describe the development, demonstration, and engineering activities and associated costs and time periods that would be required to support and deployment for HLW treatment: not answered

7. Describe pilot-plant and engineering facilities available to support technology assessment and development: The machine that Argonne was using is in the process of being returned to Denver University and this machine will be available for testing. All of the local testing was performed on the full scale machine located at the University of Denver, Environmental Materials Laboratory. This machine will continue to be available for future tests. 
8. Provide estimates of capital and operating costs that may be available: not answered

9. Describe the disposal approach proposed for the radioactive melter at the end of its service life: not answered

10. Include any schematics, photographs, drawings, and published reports that may be useful in the evaluation: References and pictures included. 


\title{
Technology Trade Name: Stir Melters Organization or Company Name: Stir-Melter, Inc.
}

\author{
Section 1, Technology Description
}

1. Technology Description: Stir-Melter systems are a class of advanced vitrification systems that employ aggressive mechanical stirring action in combination with joule heating in the glass melt. These melters are built either as lowtemperature, metal lined Alloy systems or as high-temperature ceramic lined Refractory systems.

2. Plant Service Requirements: An Alloy WV-2.5 Stir-Melter unit (1.5 MTG/d output) will require a primary single phase electrical feed of 480 volt and $600 \mathrm{amp}$ to enable a joule heating circuit in the range of $200 \mathrm{KVA}$ and a secondary three phase electrical feed of 480 volt and $60 \mathrm{amp}$ to support auxiliary heating, spindle drive, column lift and control/monitoring functions. An alloy WV-12 unit (6.0 MTG/d output) will require a primary single phase electrical feed of 480 volt and $2000 \mathrm{amp}$ to enable a joule heating circuit in the range of $600 \mathrm{KVA}$ and a secondary three phase electrical feed of 480 volt and $60 \mathrm{amp}$ to support auxiliary heating, spindle drive, column lift and control/monitoring functions. Stir-Melter systems have external water cooled panel enclosures and water-cooling of the stirrer, power supply, power lugs to vessel, top head components and drain/pour freeze valves. A total of approximately 35 GPM water flow will be required for the WV2.5 system. The requirement of compressed air, steam and/or inert gas for transitional applications of the valves from cold to hot operational state is minimal.

3. Chemical Compounds that are incompatible with technology: Sir-Melter, Inc. is confident that this type of feed can easily be handled by this vitrification system. Glass melt material only contacts the liner components which are constructed of Inconel 690 or other appropriate material. The impact of feeds containing "high amounts" of phosphorus, sulfate, and chlorine has not been fully demonstrated.

4. Describe Power, Control, and Monitoring Requirements: Temperature control in the melter system is accomplished by way of external and internal redundant thermocouples insuring the reliability and safety of the system and glass product quality. In addition to temperature control, the melt process status is monitored by means of a closed circuit video system. Melt depth is typically monitored by means of a conventional bubbler system. All cooling circuits are also monitored for temperature and flow.

5. Describe Materials of Construction: The Alloy vessel construction facilitates design for negative pressure operation with minimal head space in-leakage at feed ports, exhaust ports, stirrer access and control systems locations. The patented double-wall Alloy system constrains HLW within the vessel. The alloy vessel will weigh considerably less and be of considerably smaller volume than an equivalently sized conventional refractory melter. The Refractory Stir-Melter system has a modular design approach which provides for component independence.

6. Describe Methods Employed to Initially Start the Melter: A recommended start-up routine is that of placing a partial frit charge into the melting vessel and the external heater system is programmed to bring the partial charge up to a predetermined melting temperature. When this function has been achieved, the impeller is then lowered from the vapor space region, until it is submerged in the partially filled vessel. Rotation of the stirrer is begun which will speed up the frit melting time. At this point an electric circuit is established between the impeller and the melt vessel through the partial glass charge to begin the electric melting mode of operation in the Alloy system. As additional fit and/or waste are added to the system, the impeller is raised to its operating height in the vessel.

\section{Section 2, Performance}

1. Provide a summary of operating experience: Stir-Melter's systems have been designed and operated at various scales (bench to production) and are highly adaptable to process a variety of feed streams. Several melters were built for many commercial and government clients.

2. Define technologies annual online productivity percentage: Actual plant productivity data for a Stir-Melter System has not been developed. Long-term operation can only be estimated from various performance data. About $65-80 \%$ total operating efficiency of the melter system on an annual basis is reasonable, assuming that the interfacing systems don't cause melter system shutdowns. Such an estimate is not based on any operation data.

3. Describe the design basis and actual demonstrated temperature operating ranges: Alloy Stir-Melter systems are designed to maintain glass melt temperatures at $1050^{\circ} \mathrm{C}$ when using Inconel alloys. With the rapid stirring and extensive shear action that takes place within the melt region, the glass produced has proven to meet and/or exceed the quality of glass produced from conventional cold top melters at $1150^{\circ} \mathrm{C}$. A glass holding tank or superheater can also be used to condition the glass for a set period of time at $1100^{\circ} \mathrm{C}$ or higher. In addition, Alloy systems of specialty alloys such as platinum/rhodium can be operated at $1500^{\circ} \mathrm{C}$. Refractory Stir-Melter systems have been successfully operated at temperatures up to $1500^{\circ} \mathrm{C}$. The temperature limit is put in place to safeguard stirrer/electrode life. The key to both configurations is the inherent mixing capability of the systems to maintain uniform temperature of the melt. 
4. Describe the product characteristics and constraints: Stir-Melter operation can be adjusted to support numerous glass formulations. Glass material has been made from a variety of materials. Glass properties vary, depending on glass formulations and operating conditions. Required viscosities were achieved to facilitate pouring characteristics and product qualification boundaries. Molten ceramic glass has not been tested in the Refractory system. They feel that they can produce acceptable glass products either borosilicate glass or ceramics.

\section{Section 3, Application to Radioactive HLW Processing}

1. Describe the process features that establish reliable remote-operating and maintenance and replacement capability: The design-space configuration was found to be compatible with the modular concept of installation and replacement. A WV-20 Stir-Melter system was developed to fit in the reference melter space envelope having a 1,000 pounds per hour glass output, using a $50 \%$ water feed in a canyon type facility. Within the scope of work, a close examination was made of the mechanical, thermal, electrical, and process requirements and was determined to be essentially compatible with the defined HWVP parameters. Jumpers were used to achieve remotability of components and service connections.

2. Describe how the technology might be applied to this waste stream: Stir-Melter systems can easily "fit" into any process scheme developed for vitrification of DOE HLW streams. The melter was found to be suitable as a replacement melter for the DWPF and HWVP facilities. Stir-Melter systems do not impose any special pre-processing or feed preparation requirements. Conventional off-gas system can easily be interfaced.

3. Describe the technology's ability to produce both borosilicate glass and glass plus crystalline phases, or a molten ceramic waste form: Stir-Melter systems have been shown to produce borosilicate glass with an acceptable durability and leachability. These systems have been tested for vitrification of various kinds of feed material. No specific tests have been performed using Stir-Melter systems to produce ceramic glass form for Hanford type waste feed. Both Alloy and Refractory Stir-Melter systems provide uniform melt pool temperature thus reducing upper temperature bound by $30-100^{\circ} \mathrm{C}$ as is required for conventional melters.

4. Describe any alternative or secondary waste forms envisioned to be co-produced: In most cases, no secondary waste form is anticipated to be co-produced with the glass product. With the proper glass formulation control, the melt glass pool phase can easily be controlled to avoid formation of slag or metal due to reduction or accumulation of crystalline phases at the bottom of the melter. Proper agitation will enhance mixing of any crystalline phase that may develop due to the characteristic of the feed material. Such phase will be evenly distributed in the melt pool and will be poured out as a homogeneous glass product. Sufficient melter atmosphere control features have been developed to achieve this type of operation.

5. Describe any "foreign" materials that may be introduced into the waste form during processing: The amount of foreign material detected in glass produced in Stir-Melter systems does not exceed that typically observed with conventional cold top glass melters. The extent of wear or erosion in relationship to product yield has not been found. Lab experiments conducted with alloy units in borosilicate applications showed comparable levels of nickel or chrome as reported by conventional style glass melters.

6. Describe the development, demonstration, and engineering activities and associated costs and time periods that would be required to support and deployment for HLW treatment: A complete deployment program will have to be developed to implement this system. Stir-Melter systems have been demonstrated for various production levels. Even though previous systems were not designed or built for remote operation, remote operation of the systems can be easily achieved by using Hanford or PUREX type jumpers in the design. Such jumpers would provide flexibility of operation and future replacement activities. Stir-Melter systems can also be designed with fixed piping rather than jumpers. For application at Hanford for HLW treatment, necessary engineering calculations and design will have to be performed for a full-scale production system. The first full scale non-remote melter for the DWPF project was designed, built and delivered in less than 16 months. In a more expedited manner, a similar system could be fully designed with all remote features within 12-18 months. A demonstration system should be developed to operate and test various glass formulas for processing Hanford feed. Additional development should be undertaken in the area of melt-power optimization as related to feed stream characterization and resulting glass resistivity.

7. Describe pilot-plant and engineering facilities available to support technology assessment and development: Stir-Melter has performed all melter development activities at its facilities in Perrysburg, Ohio. The main laboratory can house up to five different small-scale melters operating at the same time. The facility is equipped with various process off-gas system interface equipment. This facility is available for non-hazardous melting activities.

8. Provide estimates of capital and operating costs that may be available: Cost of a Stir-Melter system depends on many factors and it would be unwise to quote a unit cost without specific details of the project. The cost of a $1 \mathrm{sq}$. $\mathrm{ft}$. Alloy lab unit for melter operation testing can be easily developed can would cost approximately \$1.0-1.5 million. This is the cost of just a basic unit without interfacing system and equipment. Operating cost also depends on the size and the chemicals used for glass formulation. A full-scale Alloy test melter $(100 \mathrm{~kg} / \mathrm{hr})$ for testing, without remote components, can be 
built for approximately \$3.5-4.0 million. Costs for government certified nuclear applications would need to be developed.

9. Describe the disposal approach proposed for the radioactive melter at the end of its service life: Cost effective melter disposal is an advantage of the Stir-Melter system. Alloy and Refractory systems utilize a modularization approach. As such, any module can be replaced at any time with a minimal amount of effort and/or time. This approach provides for minimal size components to deal with at the time of disposal. Stir-Melter systems are significantly smaller than a conventional joule heated cold top melter for the same output capacity and the disposal costs would be lower.

10. Include any schematics, photographs, drawings, and published reports that may be useful in the evaluation: See Exhibits 1-20. 


\title{
Technology Trade Name: Electric Arc Plasma Heating Systems Organization or Company Name: Phoenix Solutions Co. and Plasma Energy Corp.
}

\author{
Section 1, Technology Description
}

1. Technology Description: The PSC/PEC electric arc plasma system delivers a controlled column of plasma gas into a reactor/furnace for purposes of melting and/or hot gas heating. The arc column can be generated from a variety of gases that match the chemical kinetics of the process of interest. Power levels from $100 \mathrm{~kW}$ to over $2 \mathrm{MW}$ can be delivered to the process. The electric arc plasma heating systems are capable of generating temperatures which allow virtually any material to be vitrified or encapsulated in a glass matrix. The electric arc plasma system offers greater flexibility in adapting to various feedstocks, both from a quantity as well as type viewpoint. Offgas flow handling requirements are typically an order of magnitude less than in typical combustion systems.

2. Plant Service Requirements: not answered

3. Chemical Compounds that are incompatible with technology: not answered

4. Describe Power, Control, and Monitoring Requirements: Torch power is typically modulated according to the feed characteristics of the raw fibers. The raw fiber does not flow easily and the feed rate is not uniform. Torch power also needs to be reduced at times when it is necessary to hold the liquid bath without feed. The PHOENIX Solutions central console and proprietary software provide for these changes to be made easily. When power needs to be reduced, the arc is moved close to the bath and vice versa, as applied power is influenced by arc length between the torch and the grounded bath. The melting process is manually controlled by regulating the feed rate, plasma arc power and plasma arc position. This control is instituted by the operator based on observation of the furnace interior and melt process via a video camera directed at the tap outlet (drain). The operator observes the build-up of asbestos in the melt zone and regulates the torch power, the torch position and the asbestos feed rate to achieve the desired condition.

5. Describe Materials of Construction: The furnace is configured with a solid roof of castable high-alumina refractory with the outlet penetrations cast into shape. The melter bowl and sidewalls were constructed from refractory bricks and ram refractory, with a high temperature sealing material between the top of the sidewall and the roof. A propane-air torch is used to add local heat to the slag in the tap area.

6. Describe Methods Employed to Initially Start the Melter: The torch can be started in either the non-transferred or transferred mode. In the transferred mode, the arc uses the molten raw material as one of the electrodes. The molten bath is grounded via a bottom electrode connection. Therefore, in a transferred arc application, heating occurs by a combination of convection, radiation, and some degree of electrical Joule-heating. When started in the non-transferred mode, the torch may be changed to transferred mode "on-the-fly". After the system has been cold between campaigns, the surface or all of the melt may be solid and non-conductive. In this condition, non-transferred operation may be necessary for 15 minutes to $1-1 / 2$ hours to melt the slag layer before changing on-the-fly to the transferred mode.

Section 2, Performance

1. Provide a summary of operating experience: A production scale, regulatory-accepted, mobile plasma waste treatment system has been constructed and demonstrated on asbestos material by ARCPROCESS, Inc. at the DOD storage site in Port Clinton, Ohio.

2. Define technologies annual online productivity percentage: It is typically used in 24 hour per day campaigns 12 days in length. This schedule is the norm so that inspection, adjustment and maintenance of the entire processing system may be accomplished approximately every 300 hours. Processing rates of up to 12,000 pounds per day have been achieved.

3. Describe the design basis and actual demonstrated temperature operating ranges: not answered

4. Describe the product characteristics and constraints: Produces a vitreous slag.

Section 3, Application to Radioactive HLW Processing

1. Describe the process features that establish reliable remote-operating and maintenance and replacement capability: not answered

2. Describe how the technology might be applied to this waste stream: The off-gas treatment system is a simple filtration system, consisting of heat exchangers and a baghouse followed by a HEPA filter, a blower, and exhaust stack. The offgas is generated by the plasma torch, the propane torch exhaust products, water vapor from water in and on the asbestos, ambient air sucked in through the feed auger and other points due to maintenance of a negative pressure in the melter system.

3. Describe the technology's ability to produce both borosilicate glass and glass plus crystalline phases, or a molten ceramic waste form: Produces a vitreous slag when vitrifying asbestos fibers. 
4. Describe any alternative or secondary waste forms envisioned to be co-produced: not answered

5. Describe any "foreign" materials that may be introduced into the waste form during processing: not answered

6. Describe the development, demonstration, and engineering activities and associated costs and time periods that would be required to support and deployment for HLW treatment: not answered

7. Describe pilot-plant and engineering facilities available to support technology assessment and development: not answered

8. Provide estimates of capital and operating costs that may be available: not answered

9. Describe the disposal approach proposed for the radioactive melter at the end of its service life: not answered

10. Include any schematics, photographs, drawings, and published reports that may be useful in the evaluation: None 


\title{
Technology Trade Name: Simplified Integrated Immobilization Process (SIIP) Organization or Company Name: Hanford Nuclear Services, Inc.
}

\author{
Section 1, Technology Description
}

1. Technology Description: The details of the SIIP process are currently proprietary and business sensitive and involve confidential, trade secret information. Steps are underway to permit this technology to be fully described and discussed in an open, non-proprietary, non-confidential setting. For the following areas of interest, SIIP's approach to these issues is to control and purify the feed stream to optimize the life, performance and characteristics of the melter. There are no slurries. There are no minor contaminants adversely affecting life, performance or characteristics of the glass process, with the possible exception of noble metals, which still are being evaluated. The feed stream is predominantly dry, metal oxides prepared in such a way as to optimize the glass making process. This melter feed preparation process allows glass melter designers and technologists to revisit optimization melting schemes that heretofore have not been practical. Consequently, we are not down-selecting any candidate melter technology at this time that offers the potential for high performance, long life, ease of operation, high throughputs, and produces quality, stable, leach-resistant, repositorysuitable glass.

2. $\quad$ Plant Service Requirements: Not answered

3. Chemical Compounds that are incompatible with technology: Not answered

4. Describe Power, Control, and Monitoring Requirements: Not answered

5. Describe Materials of Construction: Not answered

6. Describe Methods Employed to Initially Start the Melter: Not answered

Section 2, Performance

1. Provide a summary of operating experience: Simulant HLW streams most typical of Hanford's HLW were processed beginning with the simulated volumes, mass, and liquid fractions, and concentrations most likely to be found in the Hanford HLW tanks. The scale of operation was bench scale only except for actual processing and separation of Cs-137 and Sr-90 in a hot lab. No SIIP "Six Easy Steps to Borosilicate Glass" units have been placed in industrial operation. However, virtually every processing step involved in the SIIP process has an industrial grade process or product that can be used to demonstrate the robust, proven, industrial-grade nature of the SIIP process. Off-gas streams are reduced to a minimum because of the preparation of the feed stream to the melter. Secondary waste streams can be typically disposed of on-site using existing infrastructure. As soon as we have legal clearance to provide full and open disclosure, any experts that you would like can be invited to assess this unique approach to improving melter technology.

2. Define technologies annual online productivity percentage: Not answered

3. Describe the design basis and actual demonstrated temperature operating ranges: Not answered

4. Describe the product characteristics and constraints: Not answered

\section{Section 3, Application to Radioactive HLW Processing}

1. Describe the process features that establish reliable remote-operating and maintenance and replacement capability: Our unique feed preparation minimizes off-gassing, troublesome minor contaminants, and inhomogeneities in the melt.

2. Describe how the technology might be applied to this waste stream: not answered

3. Describe the technology's ability to produce both borosilicate glass and glass plus crystalline phases, or a molten ceramic waste form: not answered

4. Describe any alternative or secondary waste forms envisioned to be co-produced: not answered

5. Describe any "foreign" materials that may be introduced into the waste form during processing: Small amounts of zeolite may be introduced into the glass. Due to the other contaminants being removed from the melter feed, the life of preferred melters should be extended with far less degradation of components.

6. Describe the development, demonstration, and engineering activities and associated costs and time periods that would be required to support and deployment for HLW treatment: Estimates are currently being made for an early, hot processing demonstrating of actual Hanford wastes using available instrumented hot cells.

7. Describe pilot-plant and engineering facilities available to support technology assessment and development: Hanford Nuclear Services, Inc. is prepared to manage, and help finance, if necessary, a pilot demonstration of the entire SIIP process, starting with raw wastes removed directly from the Hanford HLW tanks. Our capabilities statement is included as an attachment to this template.

8. Provide estimates of capital and operating costs that may be available: not answered

9. Describe the disposal approach proposed for the radioactive melter at the end of its service life: not answered 
10. Include any schematics, photographs, drawings, and published reports that may be useful in the evaluation: Their capability statement was attached. 


\title{
Technology Trade Name: Advanced Vitrification System Organization or Company Name: Radioactive Isolation Consortium, LLC (RIC)
}

\author{
Section 1, Technology Description
}

1. Technology Description: Essentially a batch in-can melting technology with a canister "module" consisting of an outer stainless steel canister and an internal graphite crucible with alumina coating the inner surface that contacts the HLW/glass. A 1-cm annulus space between the stainless steel and graphite crucible is filled with graphite fiber for thermal insulation purposes (thermal conductivity $\sim 0.1 \mathrm{watt} / \mathrm{m} *{ }^{\circ} \mathrm{K}$. The module is lowered into an induction furnace and connected to a headpiece through which feed enters and off-gas exits. Feed must be dried prior to introduction into the module. The induction heating is by low frequency $(\sim 30 \mathrm{~Hz})$, externally applied, alternating current magnetic field ( $\sim 300$ Gauss). The graphite couples to the frequency and can be heated up to $1,500^{\circ} \mathrm{C}$. The outer stainless steel shell is air cooled to maintain its temperature near "room temperature". Feed is added in batches until the module is $\sim 95 \%$ full of glass. After cooling the graphite ports are plugged and the module is removed from the cell. The lid is then welded and the outer stainless steel surfaces are decontaminated. Each process line is projected to produce a $450 \mathrm{~cm}$-tall by $62 \mathrm{~cm}$-diameter module every three days.

The electrical field couples to the stainless steel and graphite crucible. The ratio of canister heating to crucible heating is $2: 1$. The heat generated in the stainless steel is considered lost and unusable.

2. Plant Service Requirements: The conceptual facility layout would include 12 vitrification modules all supported by a single crane for module transport. Services would include: power, Argon with which to inert "the HLW process systems and the vitrification modules, demineralized water for decontamination activities, and copious quantities of cooling air with which to cool the stainless steel canisters.

3. Chemical Compounds that are incompatible with technology: No known incompatibilities with HLW.

4. Describe Power, Control, and Monitoring Requirements: Method of heating has been described above. Control is primarily through the heating rate. Temperature can be measured by thermocouples built into each module. "Radiation monitors and other thermal detectors are used to detect upset conditions in the cells during processing steps."

5. Describe Materials of Construction: Described above.

6. Describe Methods Employed to Initially Start the Melter: Batch process, AVS modules are heated from room temperature up through processing temperature and back down to final glass steady-state temperature.

Section 2, Performance

1. Provide a summary of operating experience: Total of 19 bench-scale tests in $12.5 \mathrm{~cm}$-dia. $\left(1 / 5^{\text {th }}\right.$-scale by diameter) modules. Plans are underway to demonstrate the technology at full-diameter scale over next two years. Demonstrations with acid and alkaline simulants tested; including Hanford HLW simulants (Env. D with high Bismuth ( 13\%), high chromium ( 10\%), high zirconium ( 10\%). B-Si glass waste loadings up to $70 \%$ demonstrated as well as a $100 \%$ waste loading "highly leach resistant and durable glass ceramics".

2. No industrial units in operation. Estimate $12 \mathrm{AVS}$ lines producing a total of $7.2 \mathrm{MTG} / \mathrm{d}$ (1.8 MTG per module). Secondary wastes from evaporating, drying, and treatment of vitrification off-gases. System DF's not yet available.

3. Define technologies annual online productivity percentage: Insufficient data to estimate system reliability and on-line availability.

4. Describe the design basis and actual demonstrated temperature operating ranges: Breakthrough of the alumina liner observed after operation at $1,650^{\circ} \mathrm{C}$ for 4 hours. Material being processed was not described. Anticipate operating the plant-scale system at 1,400 to $1,450^{\circ} \mathrm{C}$.

5. Describe the product characteristics and constraints: B-Si glass with waste loadings up to $70 \%$. Above $\sim 70 \%$ the waste form becomes a glass-ceramic. PCT testing of test specimens are as much as $100 \mathrm{X}$ better than the EA reference glass.

Section 3, Application to Radioactive HLW Processing

1. Describe the process features that establish reliable remote-operating and maintenance and replacement capability: Only conceptual designs exist to date. Anticipate crane, manipulator and robotic devices will be acceptable. 
2. Describe how the technology might be applied to this waste stream: Developers state the technology was designed specifically for Hanford HLW wastes. Pretreatment would involve only a caustic wash and rinse according to RIC response. No off-gas system specifics have been defined yet.

3. Describe the technology's ability to produce both borosilicate glass and glass plus crystalline phases, or a molten ceramic waste form: Both B-Si and glass-ceramic waste forms have been demonstrated.

4. Describe any alternative or secondary waste forms envisioned to be co-produced: None expected.

5. Describe any "foreign" materials that may be introduced into the waste form during processing: Aside from the module components, no foreign materials are expected.

6. Describe the development, demonstration, and engineering activities and associated costs and time periods that would be required to support assessment and deployment for HLW treatment: Large scale demonstration from 2001 through 2003 for \$24M, radioactive demo from 2003 through 2006 for \$76M, and full-scale facility design and construction from 2006 through 2010 for $\$ 236 \mathrm{M}$ (source of information is not provided).

7. Describe pilot-plant and engineering facilities available to support technology assessment and development: Benchscale and laboratory-scale facilities being put in place in DIAL, Mississippi State University.

8. Provide estimates of capital and operating costs that may be available: Pre-conceptual design information states total life cycle costs at $\sim \$ 2 \mathrm{~B}(\sim \$ 500 / \mathrm{kg}$ of waste treated). No operating period stated.

9. Describe the disposal approach proposed for the radioactive melter at the end of its service life: Disposal module is the melting unit.

10. Include any schematics, photographs, drawings, and published reports that may be useful in the evaluation: $\mathrm{CD}$ with topical reports and Company letters to DOE. 


\title{
Technology Trade Name: Advanced Cold-Crucible, Induction-Heated Melter (CCM) Organization or Company Name: Cogema, Inc.
}

\author{
Section 1, Technology Description
}

1. Technology Description: The advanced CCM (ACCM) differs from the previous CCM design in that the induction coil is located below the melter rather than around the side of the melter. As a result, the maximum diameter of the melter is no longer constrained by induction frequency limitations. The former CCM design would limit the maximum diameter that could be achieved with CCM technology. This maximum diameter is thought to be between 1 meter and 1.5 meters. For direct liquid feeding the HLW can be metered directly on top of the glass surface. Alternatively, a pre-calcination or pre-drying step can be included to reduce the processing load on the melter. This would result in a reduced melter size requirement. However, the calciner or dryer operation could well negate any reduced cell space requirements that would otherwise thought to be gained. Based on direct inspection of the Marcoule facility, the advanced CCM includes two water-cooled, mechanical mixers extended into the glass. It is believed to be necessary because the heat generation in the ACCM takes place very close to the floor and natural convection alone is not sufficient to convey the heat to the glass surface at the necessary rate.

Both CCM designs are stainless steel construction. The ACCM has water cooled sides, headspace, and floor. The segmented floor design is a proprietary design but should include stainless steel cooling tubes separated to allow transmission of the induction field. The CCM side walls are segmented to permit transmission of the induction field. A glass "skull" forms between the stainless steel and the molten glass. Heat losses through the skull accounts for a majority of the input energy requirements. The glass is discharged near the bottom of the melter through a side channel that is controlled by a water-cooled slide gate valve.

The technology is capable of operating temperatures in excess of $2,000^{\circ} \mathrm{C}$. Tank holdup volumes are as high as 400 liters $(\sim 1,000 \mathrm{~kg})$. A $50-100 \mathrm{~kg} / \mathrm{h}$ glass production rates, residence time would range from 10 to 20 hours. The combination of agitation and pouring near the floor prevent the accumulation of secondary phases.

Off-gas leaves the melter at about $200^{\circ} \mathrm{C}$ (assume under dry-feed conditions). The CCM water-cooled lid and melter have not experienced any melter failures due to corrosion. The original bench and pilot-scale CCMs are still in service.

Melter replacement is simplified compared to a refractory-lined melter in that most of the glass will spall or release from the cold-wall surface and directly removed from the melter. Therefore, the melter should be easily released as LLW incidental to HLW processing.

2. Plant Service Requirements: Water (DI, heated, standard, and chilled), steam, compressed air, pressurized air, $\sim 1 \mathrm{MW}$ power, and normal, uninterrupted, and emergency power.

3. Chemical Compounds that are incompatible with technology: None noted.

4. Describe Power, Control, and Monitoring Requirements: $\sim 1$ MW power - there is typically a $75 \%$ loss to cooling and induction heating losses. High frequency capacitor bank should be located within $\sim 6 \mathrm{~m}$ of the melter. The power generator should be located within $\sim 10 \mathrm{~m}$ of the capacitor bank. Normal control instrumentation includes glass temperature and level, power input parameters, and plenum space temperature.

5. Describe Materials of Construction: CCM is $316 \mathrm{~L}$ stainless steel.

6. Describe Methods Employed to Initially Start the Melter: A metallic (titanium) ring is placed on top of the initial glass charge via an access port. The field couples to the ring that heats up and melts glass in contact with the ring.

\section{Section 2, Performance}

1. Provide a summary of operating experience: Seven operating commercial industrial lines with a total of 25,000 pouring cycles (includes experience from hot-wall AVH and R7/T7 production lines). 400 pouring cycles per valve have been attained without mechanical failure (for hot-wall melter, this may coincide with melter changeout). Development work has goal of at least 1,000 valve cycles without mechanical failures. First CMM (550mm-dia.) was built $\sim 15$ years ago, has logged $\sim 5,000$ hours of operation, producing $\sim 50$ MT of glass, and is still used in development work. No CCM melter failures have occurred to date during development demonstration and testing. Eight CCMs ranging in size from $550 \mathrm{~mm}$-dia. to $1,200 \mathrm{~mm}$-dia have been designed and built to date. Two commercial (presumably Ferro Corp. of France) 1,200mm-dia. units are in operation and have accumulated 9,000 hours of operation. In 1999, one of the units produced 500 MT of product (dry feeding conditions). 
Hanford HLW simulant was calcined and fed to a CCM with acceptable results. Waste loadings up to $43 \%$ are felt possible based on glass formulation work at melter temperatures up to $1,220^{\circ} \mathrm{C}$. Ability to tolerate crystals and operate and higher temperatures will allow higher waste loadings as well as possibility for alternative waste forms such as phosphate glasses, and glass-crystalline waste forms.

2. Define technologies annual online productivity percentage: $70 \%$ based on $90 \%$ industry experience of CCM and LaHague and Marcoule HLW vitrification "balance of plant" experience.

3. Describe the design basis and actual demonstrated temperature operating ranges: 1,000 to $3,000^{\circ} \mathrm{C}$-temperature capability (depending on power supply and glass properties).

4. Describe the product characteristics and constraints: Glass, glass-crystalline and molten ceramics have been produced in the CCM. Typical glass property requirements included electrical resistivity (typically 1 to $15 \mathrm{ohm}-\mathrm{cm}$ ) and "appropriate" viscosity.

\section{Section 3, Application to Radioactive HLW Processing}

1. Describe the process features that establish reliable remote-operating and maintenance and replacement capability: Remote design features based on successful LaHague and Marcoule experience; including redundancy, simplicity, significant prototype and mockup testing.

2. Describe how the technology might be applied to this waste stream: Based on past Hanford contract involvements, a preliminary design and cost estimate have been done. Recommended flowsheet includes drying alkaline feed, $\mathrm{pH}$ adjustment, and liquid feeding to the CCM. One 1,000mm-dia. CCM required for $1.5 \mathrm{MT} / \mathrm{d}$ glass production requirements. Two 1,600 CCMs are anticipated to meet the $6 \mathrm{MT} / \mathrm{d}$ glass production requirements.

3. Describe the technology's ability to produce both borosilicate glass and glass plus crystalline phases, or a molten ceramic waste form: Each has been demonstrated under previous programs, e.g., CEA Mo-U waste vitrification development program and Hanford Privatization Part A project.

4. Describe any alternative or secondary waste forms envisioned to be co-produced: None.

5. Describe any "foreign" materials that may be introduced into the waste form during processing: None.

6. Describe the development, demonstration, and engineering activities and associated costs and time periods that would be required to support and deployment for HLW treatment: No further technology development work anticipated. Pilot testing for optimization purposes are required. Waste form qualification testing is also required/anticipated. A two year program is envisioned.

7. Describe pilot-plant and engineering facilities available to support technology assessment and development: Marcoule 1,100mm-dia. pilot-plant ACCM is being commissioned this spring.

8. Provide estimates of capital and operating costs that may be available: Estimate life-cycle cost savings of $\$ 2.4 \mathrm{~B}$, 15 month schedule reduction, and \$182M capital equipment savings (due in part to Cogema's assumption of using the "simplified" French off-gas treatment, canister decontamination and canister lid-welding systems.

9. Describe the disposal approach proposed for the radioactive melter at the end of its service life: Melter replacement is simplified compared to a refractory-lined melter in that most of the glass will spall or release from the cold-wall surface and directly removed from the melter. Therefore, the melter should be easily released as LLW incidental to HLW processing.

10. Include any schematics, photographs, drawings, and published reports that may be useful in the evaluation: No additional materials provided in response. 
Technology Trade Name: Penberthy Melter

Organization or Company Name: Penberthy Vitrification Associates

Technology Description: Response did not respond to RFI questions.

NON-RESPONSIVE 
Technology Trade Name: None

Organization or Company Name: Hemispheric Center for Environmental Technology - Florida International University

Section 1, Technology Description

Technology Description: Response describes a batch glass tank / test stand used to support DWPF downspout knife-edge design evaluations.

NON-RESPONSIVE 


\title{
Technology Trade Name: RPP Reference High Level Waste DuraMelter Organization or Company Name: Duratek Inc.
}

\author{
Section 1, Technology Description
}

1. Technology Description: Technology description described in terms of the pilot-test melter designed for HLW simulant testing. Inconel- $690^{\circledR} / \mathrm{K}-3^{\circledR}$ based melter design similar to past DOE JHCM melters with Duratek proprietary improvements. The plant melter glass surface is $3.75 \mathrm{~m}^{2}$, while the test melter has a $1.25 \mathrm{~m}^{2}$ glass surface area. Production rate is $\sim 0.5 \mathrm{MTG} / \mathrm{d} / \mathrm{m}^{2}$ without bubblers used and $\sim 4 \mathrm{MTG} / \mathrm{d} / \mathrm{m}^{2}$ with bubblers. To accommodate the accumulation of secondary phases, particularly noble metal precipitates, the side electrodes are raised significantly above the floor and a floor electrode is placed in the center of the melter floor. Unlike the WVDP melter design the Duratek design does not angle or slope the sidewalls to the center electrode. No known modeling or verification testing has been done to date to verify the operational performance of the design. Glass inventory is $2,000 \mathrm{~kg}$, and a pool depth of $0.6 \mathrm{~m}$. Glass discharge is via a standard riser/trough design using an airlift bubbler lance.

2. Plant Service Requirements: 480/3ph power, $20 \mathrm{gpm}$ water cooling, 100scfm cooling air for the off-gas film cooler.

3. Chemical Compounds that are incompatible with technology: Insoluble constituents, i.e., noble

4. Describe Power, Control, and Monitoring Requirements: Power requirements are $300 \mathrm{~kW}$ for the electrodes, $30 \mathrm{~kW}$ for resistance heaters placed in the overflow.

5. Describe Materials of Construction: Inconel- $690^{\circledR}$ electrodes, $\mathrm{K}-3^{\circledR}$ glass-contact refractory, E-block riser, refractory crown.

6. Describe Methods Employed to Initially Start the Melter: Charge melter with startup glass (typically lower melting point than HLW glass) and insert temporary electric heaters into the plenum space.

Section 2, Performance

1. Provide a summary of operating experience: Basic Duratek design has been operated at pilot-plant scale for seven years, at production scale at the Savannah River M-Area. Study Team Note: The particular RPP design has not been tested. A 1/40-th scale melter (the DM-100) was built during the Privatization Part-1B period and operated in FY 2000 and into 2001 with simulated feeds. Data reports on performance are just now being submitted but have not been distributed for review yet. However, comparing the performance of a 12in. x 12in. melter that is $\sim 24$ in. deep with the full-scale plant is not expected to be included in these reports.)

2. Define technologies annual online productivity percentage: Duratek projects a minimum $75 \%$ design TOE and notes that WVDP, DWPF, M-Area, the LAW pilot, and the German/Belgium PAMELA melters have surpassed $75 \%$.

3. Describe the design basis and actual demonstrated temperature operating ranges: Maximum glass temperature is $1,250^{\circ} \mathrm{C}$ due to Inconel material limits.

4. Describe the product characteristics and constraints: State that melter is designed to B-Si but that Fe-P glasses should be compatible and worth consideration.

Section 3, Application to Radioactive HLW Processing

1. Describe the process features that establish reliable remote-operating and maintenance and replacement capability: Unit is for non-radioactive use only, however, based on WVDP and DWPF and PAMELA experience, "remotizing " the design is felt to be straightforward. Attractive features include, no moving parts, passive operation, and accessable lid-mounted components.

2. Describe how the technology might be applied to this waste stream: Basic U.S. technology designed for HLW, pilot-plant also has current RPP reference off-gas unit operations.

3. Describe the technology's ability to produce both borosilicate glass and glass plus crystalline phases, or a molten ceramic waste form: Not demonstrated but believed ("conceivable") to be compatible for producing glass plus crystalline waste forms and iron phosphate glass waste forms.

4. Describe any alternative or secondary waste forms envisioned to be co-produced: Settled phases in the melter, particularly platinum group metals $\mathrm{Ru}, \mathrm{Rh}$, and $\mathrm{Pd}$, due to there essentially insoluble nature in HLW B-Si glass. Melter components (thermowells, circulation bubblers, etc.) would be routinely replaced. Some might fail and fall to the melter floor. Disposal at end of life is another secondary waste.

5. Describe any "foreign" materials that may be introduced into the waste form during processing: Trace refractory brick contamination form corrosion, principally trace chrome oxide introduction into the glass. 
6. Describe the development, demonstration, and engineering activities and associated costs and time periods that would be required to support and deployment for HLW treatment: No significant requirements given (Perez note significant differences from previous Duratek and DOE geometry is believed to require analysis and verification to determine robustness and capabilities of this design)

7. Describe pilot-plant and engineering facilities available to support technology assessment and development: DM1200 installed at Catholic University of America's Vitreous State Laboratory. Integrated feed, off-gas, and facility utilities already exist.

8. Provide estimates of capital and operating costs that may be available: Capital and operating costs for pilot-plant: $\$ 10 \mathrm{M}$ capital, energy costs: $2.4 \mathrm{kWhr}$ idling, $7 \mathrm{kWhr}$ testing, replacement components: thermowells $(\$ 20 \mathrm{~K})$, level bubbler $(\$ 10 \mathrm{~K})$, circulation bubblers $(\$ 50 \mathrm{~K})$.

9. Describe the disposal approach proposed for the radioactive melter at the end of its service life: Empty melter, including use of vacuum canisters. No details on additional glass removal prior to filling with grout and disposal of melter as a single unit.

10. Include any schematics, photographs, drawings, and published reports that may be useful in the evaluation: None provided. 
Technology Trade Name: High Temperature Melter Organization or Company Name: Duratek Inc.

Section 1, Technology Description

1. Technology Description: Text described the PNNL HTM that was built and operated for a short period at low temperature $\left(1,150^{\circ} \mathrm{C}\right.$ range) prior to termination of HWVP and transition of PNNL from the 324 building. Capability of unit and components to operate at high temperature for extended period was not demonstrated. 


\section{Technology Trade Name: Westinghouse Plasma Torch System Organization or Company Name: Westinghouse Plasma Corporation}

Note: response materials were not prepared to reply to the RFI. Materials submitted were originally prepared for the August 25, 2000 DOE CBD RFI on alternative non-incineration technology process applicable to the treatment of Mixed Alpha and Mixed Transuranic wastes stored at the INEEL. Therefore, the material is rather broad and general.

Section 1, Technology Description

1. Technology Description: Non-transferred arc plasma torch mounted to one side of reactor vessel. Reactor is refractory lined with corrosion resistant refractory. A large vertical shaft is typical of the Westinghouse reactor design. However, it is unclear that this would be required for HLW processing; as its function, other than to promote low gas velocities and thereby minimize entrainment is not stated. Current reactor/melter design has a low capacity glass holdup and no means to maintain the temperature of a larger holdup tank. Product (metal, slag, or glass) is held as a batch or tapped using standard industry tapping techniques to discharge from the crucible. Refractory (alumina-chromia ceramic) is expected to be able to operate up to $1,400^{\circ} \mathrm{C}$ with little corrosion from alkaline $\mathrm{HLW}$ processing. Torch and working gas temperatures themselves are as high as $5,500^{\circ} \mathrm{C}$. Ten to 14 standard cubic meters per minute ( 350 to $500 \mathrm{scfm}$ ) are required as process torch gas and shroud (cooling) gas to the torch nozzle.

2. Plant Service Requirements: Not answered

3. Chemical Compounds that are incompatible with technology: High flame temperatures will cause higher volatility and aerosols of HLW compounds to be generated, e.g., alkali metals, $\mathrm{Cs}, \mathrm{Pb}, \mathrm{Cd}$, etc., compared to other melter technologies.

4. Describe Power, Control, and Monitoring Requirements: Torches are rated in excess of $2 \mathrm{MW}$ electric power input with an electrical-to-thermal efficiency of 80 to $90 \%$.

5. Describe Materials of Construction: Not answered

6. Describe Methods Employed to Initially Start the Melter: Not answered

Section 2, Performance

1. Provide a summary of operating experience: In 1993 3.5 MT of Hanford simulated HLW slurry were fed to a plasma reactor, producing $1,300 \mathrm{~kg}$ of molten calcine. In 1994, 13,400 kg of glass were produced from simulated Hanford LLW in four tests over a 48 hour test period.

2. Define technologies annual online productivity percentage: Torch life estimated at $>1,000 \mathrm{hr}$ by Westinghouse.

3. Describe the design basis and actual demonstrated temperature operating ranges:

4. Describe the product characteristics and constraints: Not answered

Section 3, Application to Radioactive HLW Processing

1. Describe the process features that establish reliable remote-operating and maintenance and replacement capability: Not designed for remote operation.

2. Describe how the technology might be applied to this waste stream: Not answered

3. Describe the technology's ability to produce both borosilicate glass and glass plus crystalline phases, or a molten ceramic waste form: Not answered

4. Describe any alternative or secondary waste forms envisioned to be co-produced: Not answered

5. Describe any "foreign" materials that may be introduced into the waste form during processing: Not answered

6. Describe the development, demonstration, and engineering activities and associated costs and time periods that would be required to support and deployment for HLW treatment: Not answered

7. Describe pilot-plant and engineering facilities available to support technology assessment and development: Test facility at Westinghouse available.

8. Provide estimates of capital and operating costs that may be available: Not answered

9. Describe the disposal approach proposed for the radioactive melter at the end of its service life: Not answered

10. Include any schematics, photographs, drawings, and published reports that may be useful in the evaluation: None provided. 
Technology Trade Name: None provided

Organization or Company Name: University of North Dakota Energy and Environmental Research Center

Section 1, Technology Description

Technology Description: Response describes technologies for sulfate and chlorine removal from HLW. 
Technology Trade Name: None provided

Organization or Company Name: dmc2, Degussa Metals Cerdec Corp

Section 1, Technology Description

Technology Description: Response proposes to supply frits for the WTP. 
This page left blank intentionally

K - 26 


\title{
Appendix L - Literature Search Summary Abstracts
}

04514555 AIX-30-043125; EDB-99-095234

Title: Using the method of induction melting in a cold crucible for the synthesis of mineral-like materials containing simulated radioactive waste

Author(s)/Editor(s): Knyazev, O.A.; Lifanov, F.A.; Lopukh, D.B.; Lyubomirov, A.M.; Pechenkov, A.Yu.; Stefanovskii, S.V. (Radon Scientific and Production Association, Moscow (Russian Federation)

\begin{abstract}
In the area of ensuring the ecological safety of the life of people, a special position is occupied by the problem of making safe various radioactive waste (RAW), formed in the process of processing nuclear fuel. To solve this problem, a number of methods and apparatus-technological systems of processing RAW into forms, stable to the effect of the environment, have been developed recently. Promising in this direction are the materials SYNROC (synthetic rock) and the glass ceramics based on titanite. The method of hot pressing has been developed for the production of SYNROC material, although the possibilities of producing several modifications of this material from the melt have also been discussed. The glass ceramics was produced by the crystallization of the alumotitanosilicate melt. To realize the systems, including the melting stage, it is necessary to develop melting equipment capable of liver operation at high temperatures. Recently, special interest has been attracted by the system providing the application of high-frequency power technology. Work has been continuing since the beginning of the Eighties with the application of the method of induction melting in cold crucibles (IMCC) for the vitrification of RAW. The IMCC method has the following main advantages: it makes it possible to harden the waste into more refractory and chemically stable glass-like and crystalline matrixes; there is no direct contact of the chemically active melt with the crucible material; this creates suitable conditions for solving the problem of erosion of the material of the melting system and increasing its service life; the deep heating of the melt with the high-frequency field and convective mixing of the melt make it possible to intensify the melting process and decrease the removal of radionuclides; the increase of the specific productivity of the furnace makes possible to develop a compact, remote-controlled cold crucible. Because of these advantages of the IMCC method, the method has been used for the high-temperature synthesis of new materials, which may include in their structure also the radionuclides of the RAW. The aim of this work was to examine in detail the conditions of the IMCC and the melting conditions of SYNROC material and glass ceramics based on sphene.
\end{abstract}

\section{SRS-98-M98052903; EDB-98-104918}

Title: The Defense Waste Processing Facility: Two Years of Radioactive Operation Author(s)/Editor(s): Marra, S.L. (Westinghouse Savannah River Company, AIKEN, SC (United States)); Gee, J.T.; Sproull, J.F.

\begin{abstract}
The Defense Waste Processing Facility (DWPF) at the Savannah River Site in Aiken, SC is currently immobilizing high-level radioactive sludge waste in borosilicate glass. The DWPF began vitrification of radioactive waste in May, 1996. Prior to that time, an extensive startup test program was completed with simulated waste. The DWPF is a first of its kind facility. The experience gained and data collected during the startup program and early years of operation can provide valuable information to other similar facilities. This experience involves many areas such as process enhancements, analytical improvements, glass pouring issues, and documentation/data collection and tracking. A summary of this experience and the results of the first two years of operation will be presented.
\end{abstract}




\title{
04240149 EDB-98-000565; EDB-98-000564
}

Title: Vitrification operational experiences and lessons learned at the WVDP

Author(s): Hamel, W.F. Jr. (Dept. of Energy, West Valley, NY (United States); Sheridan, M.J.; Valenti, P.J. (West Valley Nuclear Services, Inc., NY (United States)

Abstract: The Vitrification Facility (VF) at the West Valley Demonstration Project (WVDP) commenced full, high-level radioactive waste (HLW) processing activities in July 1996. The HLW consists of a blend of washed plutonium-uranium extraction (PUREX) sludge, neutralized thorium extraction (THOREX) waste, and cesiumloaded zeolite. The waste product is borosilicate glass contained in stainless steel canisters, sealed for eventual disposal in a federal repository. This paper discusses the WVDP vitrification process, focusing on operational experience and lessons learned during the first year of continuous, remote operation.

\section{EDB-97-024483}

Title: Multiple applications of cold crucible melting

Author(s): Jouan, A.; Monocouyoux, J.P.; Merlin, S.; Roux, P.

Abstract: Induction-heated cold crucible melting is an increasingly promising technique in the international scientific and technical radioactive waste management community. It is capable of achieving high temperatures and power densities with virtually no melter corrosion, making it an ideal solution for many applications, from simple melting of metals, molten salts, or glass, to complex processes involving chemical reactions in molten baths, or even to the incineration of combustible waste or ion-exchange resins.

\section{EDB-96-117797}

Title: Penberthy molten glass process for the destruction/sequestering of mixed chemical/radioactive wastes Author(s): Penberthy, L.

Abstract: The Penberthy Molten Glass Process for the destruction/sequestering of mixed chemical/radioactive wastes is based on the electric glass melting technology using rod molybdenum electrodes, originated in 1952. Application of this basic technology has spread worldwide, melting in total an estimated 40,000 tons of glass per day. The basic technology is well proven. The walls are special refractory brick in a steel casing. The lower sidewalls contain a pool of molten glass. The upper sidewalls and roof form a combustion chamber. Wastes are introduced into one end of the tunnel and redox offgas and molten glass exit from the other.

\section{AIX-27-057157; EDB-96-117754}

Title: The development of nuclear waste vitrification in France

Author(s)/Editor(s): Jouan, A.; Moncouyoux, J.P. (CEA Centre d'Etudes de la Vallee du Rhone, 30 - Marcoule, France. Dept. d'Exploitation du Retraitement et de Demantelement); Merlin, S. (Societe Generale pour les Techniques Nouvelles (SGN), 78 - Saint-Quentin-en-Yvelines, France)

\begin{abstract}
The conversion of an ultimate waste form into a stable, inert product is a beneficial operation, especially in the case of potentially toxic waste materials. One widely recognized approach today is vitrification, in which a glass or crystalline material is fabricated from a particular waste composition. This is a hightemperature process involving the use of selected additives - notably silica - to form a glass network. The waste is thus contained in a stable, inert and nontoxic material suitable for safe disposal; the process also generally results in a significant volume reduction that has a decisive effect on disposal costs. The nuclear industry was a forerunner in this area. Research on containment of uranium fission products began in 1957, and has been extensively developed in France, where industrial vitrification facilities are now operating at Marcoule and La Hague. Glass is now a universally recognized containment medium. Research is continuing in France, not only to enhance the quality of the matrix and increase production capacities, but also to extend the process to low and intermediate level radioactive waste produced in nuclear power plants. New melting equipment has been designed to implement a "cold crucible" melting technique, in which glass is heated by induction inside a cooler
\end{abstract}


solidified layer of the same material. Recent work by SGN, an engineering subsidiary of the CEA and COGEMA, substantiates the technical and economic advantages of vitrifying this type of waste.

03993283 INS-96-011059; EDB-96-077043

Title: Vitrification of intermediate level radioactive waste by induction heating

Author(s): Sobolev, I.A.; Dmitriyev, S.A.; Lifanov, F.A.; Stefanovsky, S.V.; Kobelev, A.P.; Kornev, V.I.; Knyazev, O.A.; Tsveshko, O.N. (SIA Radon, Moscow (Russian Federation)

Abstract: Vitrification of intermediate level liquid and solid radioactive wastes is an effective method of their immobilization. A new type of melter -- cold crucible -- suitable for production of high fusible materials has been developed. No refractories and internal electrodes are used in this melter. Based on the preliminary experience of SIA Radon with lab-scale and pilot plants, the full-scale plants for vitrification of liquid and solid radioactive wastes have been constructed. The main process variables such as melt capacity, melting ratio, cesium volatilization as well as materials properties have been determined. Advantages of cold crucible over Joule heated ceramic melter have been shown. Process flow sheets have been described.

\section{$03941636 \quad$ EDB-96-025396}

Title: Plasma processing for the treatment and immobilization of radioactive tank waste Author(s): McLaughlin, D.F.; Gass, W.R.; Dighe, S.V.; Swensrud, R.L.; Yang, W.C.; Darr, M.F.; D'Amico, N. (Westinghouse Science and Technology Center, Pittsburgh, PA (United States). Environmental Technologies Dept.)

Abstract: Plasma melting technology has been applied by the Westinghouse Science and Technology Center to treatment of radioactive tank wastes from the DOE complex, containing high sodium content, nitrates, hazardous organics, and a wide range of radioactive species. In simulant tests, successful continuous calcination of tank waste has been demonstrated at pilot plant scale, forming a free-flowing molten product which solubilizes aluminum and heavy metals, and which when quenched in water yields a solution from which strontium and transuranics may be separated by filtration. One-step vitrification of tank waste liquid has also been demonstrated at the pilot scale, in which 7 metric tons per day of good quality waste glass were produced by plasma vitrification of tank waste simulant with glassformer frit additive. This technology is reliable and readily scaled to the 200 tonne/day throughput required to meet DOE milestones for remediation of tank waste stored at the Hanford Reservation in eastern Washington State.

\section{$04325490 \quad$ INEL-98-M98054118; ELC-98149; EDB-98-092411}

Title: Volatilization of heavy metals and radionuclides from soil heated in an induction cold" crucible melter Author(s)/Editor(s): Aloy, A.S.; Belov, V.Z.; Trofimenko, A.S. Khlopin Radium Inst., St. Petersburg (Russian Federation); Dmitriev, S.A.; Stefanovsky, S.V. SIA Radon, Moscow (Russian Federation); Gombert, D.; Knecht, D.A. Lockheed Martin Idaho Technologies Co., Idaho Falls, ID (United States)

Abstract: The behavior of heavy metals and radionuclides during high-temperature treatment is very important for the design and operational capabilities of the off-gas treatment system, as well as for a better understanding of the nature and forms of the secondary waste. In Russia, a process for high-temperature melting in an induction heated cold crucible system is being studied for vitrification of Low Level Waste (LLW) flyash and SYNROC production with simulated high level waste (HLW). This work was done as part of a Department of Energy (DOE) funded research project for thermal treatment of mixed low-level waste (LLW). Soil spiked with heavy metals $(\mathrm{Cd}, \mathrm{Pb})$ and radionuclides $(\mathrm{Cs}-137, \mathrm{U}-239, \mathrm{Pu}-239)$ was used as a waste surrogate. The soil was melted in an experimental lab-scale system that consisted of a high-frequency generator $(1.76 \mathrm{MHz}, 60 \mathrm{~kW})$, a cold crucible melter (300 $\mathrm{mm}$ high and $90 \mathrm{~mm}$ in diameter), a shield box, and an off-gas system. The process temperature was 1,350--1,400 C. Graphite and silicon carbide was used as sacrificial conductive materials to start heating and initial melting of the soil batch. The off-gas system was designed in such a manner that after each experiment, it can be disconnected to collect and analyze all deposits to determine the mass balance. The off-gases were also sampled during an experiment to analyze for hydrogen, $\mathrm{NO}[\mathrm{sub} \mathrm{x}]$, carbon dioxide, carbon monoxide and 
chlorine formation. This paper describes distribution and mass balance of metals and radionuclides in various parts of the off-gas system. The leach rate of the solidified blocks identified by the PCT method is also reported.

\title{
04086017 EDB-96-169777
}

Title: Materials performance in a high-level radioactive waste vitrification Author(s)/Editor(s): Imrich, K.J.; Chandler, G.T.

system

\begin{abstract}
The Defense Waste Processing Facility (DWPF) is a Department of Energy Facility designed to vitrify highly radioactive waste. An extensive materials evaluation program has been completed on key components in the DWPF after twelve months of operation using nonradioactive simulated wastes. Results of the visual inspections of the feed preparation system indicate that the system components, which were fabricated from Hastelloy C-276, should achieve their design lives. Significant erosion was observed on agitator blades that process glass frit slurries; however, design modifications should mitigate the erosion. Visual inspections of the DWPF melter top head and off gas components, which were fabricated from Inconel 690, indicated that varying degrees of degradation occurred. Most of the components will perform satisfactorily for their two-year design life. The components that suffered significant attack were the borescopes, primary film cooler brush, and feed tubes. Changes in the operation of the film cooler brush and design modifications to the feed tubes and borescopes are expected to extend their service lives to two years. A program to investigate new high temperature engineered materials and alloys with improved oxidation and high temperature corrosion resistance will be initiated.
\end{abstract}

\section{$04507303 \quad$ EDB-99-087982}

Title: An alternative host matrix based on iron phosphate glasses for the vitrification of specialized nuclear waste forms. Annual progress report, September 15, 1996--September 14, 1997

Author(s)/Editor(s): Day, D.E.; Marasinghe, K.; Ray, C.S.

Abstract: 'Objectives of this project are to: (1) investigate the glass composition and processing conditions that yield optimum properties for iron phosphate glasses for vitrifying radioactive waste, (2) determine the atomic structure of iron phosphate glasses and the structure-property relationships, (3) determine how the physical and structural properties of iron phosphate glasses are affected by the addition of simulated high level nuclear waste components, and (4) investigate the process and products of devitrification of iron phosphate waste forms. The glass forming ability of about 125 iron phosphate melts has been investigated in different oxidizing to reducing atmospheres using various iron oxide raw materials such as $\mathrm{Fe}$ [sub 2] O [sub 3], FeO, Fe[sub 3] $[$ sub 4], and $\mathrm{FeC}$ [sub 2] $\mathrm{O}$ [sub 4] 2H[sub 2]O. The chemical durability, redox equilibria between $\mathrm{Fe}(\mathrm{II})$ and $\mathrm{Fe}(\mathrm{III})$, crystallization behavior and structural features for these glasses and their crystalline forms have been investigated using a variety of techniques including Mossbauer spectroscopy, X-ray absorption spectroscopy (XAS), X-ray photoelectron spectroscopy (XPS), Extended x-ray absorption fine structure (EXAFS) and X-ray absorption near edge structure (XANES) analysis, differential thermal and thermogravimetric analysis (DTA/TGA), and X-ray and neutron diffraction.'

\section{$04325498 \quad$ EDB-98-092419}

Title: Chemical durability of soda-lime-aluminosilicate glass for radioactive waste vitrification Author(s): Eppler, F.H.; Yim, M.S. North Carolina State Univ., Raleigh, NC (United States)

Abstract: Vitrification has been identified as one of the most viable waste treatment alternatives for nuclear waste disposal. Currently, the most popular glass compositions being selected for vitrification are the borosilicate family of glasses. Another popular type that has been around in glass industry is the soda-lime-silicate variety, which has often been characterized as the least durable and a poor candidate for radioactive waste vitrification. By replacing the boron constituent with a cheaper substitute, such as silica, the cost of vitrification processing can be reduced. At the same time, addition of network intermediates such as $\mathrm{Al}[\mathrm{sub} 2] \mathrm{O}$ [sub 3] to the glass composition increases the environmental durability of the glass. The objective of this study is to examine the 
ability of the soda-lime-aluminosilicate glass as an alternative vitrification tool for the disposal of radioactive waste and to investigate the sensitivity of product chemical durability to variations in composition.

\section{EDB-95-076056}

Title: Evaluation of the three-phase, electric arc melting furnace for treatment of simulated, thermally oxidized radioactive and mixed wastes. Part 1: Design criteria and description of integrated waste treatment facility Author(s)/Editor(s): Oden, L.L.; O'Connor, W.K.; Turner, P.C.; Hartman, A.D.

Abstract: The US Bureau of Mines and the Department of Energy (DOE), through its contractor EG and G Idaho Inc., are collaborating on a multiyear research project to evaluate the applicability of three-phase, electric-arc furnace melting technology to vitrify materials simulating low-level radioactive and mixed wastes buried or stored at the Idaho National Engineering Laboratory and other DOE sites. The melter is sealed, 1-t (1.1-st), threephase, $800-\mathrm{kV}$ [center dot] A electric arc melting furnace with 10.2-cm- (4-in-) diameter graphite electrodes, water-cooled roof and sidewalls, and four water-cooled feed tubes. A water-cooled copper fixture provides for continuous tapping of slag. An instrumented air pollution control system (APCS) with access ports for analysis and a feeder based on screw conveyors and a bucket elevator are dedicated to the facility. Test data are provided by an arc furnace analyzer and by sensors indicating feed rate; slag temperature; and temperature, pressure, and velocity in the APCS. These data are received by a data logger, digitized, and transmitted to a personal computer for storage and display. This unique waste treatment facility is available for public and private use on a costsharing basis.

\section{AIX-26-038187; EDB-95-055569}

Title: Building a third vitrification line at Sellafield

Author(s): Moore, A. British Nuclear Fuels plc, Sellafield (United Kingdom)

Abstract: Additional equipment and modified designs to overcome some of the initial difficulties encountered in operating lines 1 and 2 will be used for the new vitrification line under construction at Sellafield. (author).

\section{$03790653 \quad$ EDB-95-034421}

Title: Evaluation of plasma melter technology for verification of high-sodium content low-level radioactive liquid wastes: Demonstration test No. 4 preliminary test report

Author(s)/Editor(s): McLaughlin, D.F.; Gass, W.R.; Dighe, S.V.; D'Amico, N.; Swensrud, R.L.; Darr, M.F.

Abstract: This document provides a preliminary report of plasma arc vitrification testing by a vendor in support of the Hanford Tank Waste Remediation System Low-Level Waste (LLW) Vitrification Program. Phase I test conduct included 26 hours (24 hours steady state) of melting of simulated high-sodium low-level radioactive liquid waste. Average processing rate was $4.9 \mathrm{~kg} / \mathrm{min}$ (peak rate $6.2 \mathrm{~kg} / \mathrm{min}$ ), producing $7330 \mathrm{~kg}$ glass product. Free-flowing glass pour point was $1250 \mathrm{C}$, and power input averaged $1530 \mathrm{~kW}(\mathrm{e})$, for a total energy consumption of $19,800 \mathrm{~kJ} / \mathrm{kg}$ glass. Restart capability was demonstrated following a 40-min outage involving the scrubber liquor heat exchanger, and glass production was continued for another 2 hours. Some volatility losses were apparent, probably in the form of sodium borates. Roughly 275 samples were collected and forwarded for analysis. Sufficient process data were collected for heat/material balances. Recommendations for future work include lower boron contents and improved tuyere design/operation.

\section{$04209236 \quad$ E.I. No: EIP95072777720}

Title: French nuclear waste vitrification: state of the art and future developments Author: Ladirat, C.; Boen, R.; Jouan, A.; Moncouyoux, J.P.

Abstract: The feasibility of the French vitrification process has demonstrated at industrial scale for disposal of very high-level radioactive liquid wastes. In the 1950s, this process was selected as a means of containment when initial research confirmed that a glass matrix could easily accommodate most radionuclides. Today, the cold crucible direct-induction glass melting technology being developed will allow new containment matrices to be 
produced in facilities with larger capacities. The technology may be applied to nuclear wastes and also to toxic inorganic industrial wastes.

$1935652 \quad$ NTIS Accession Number: DE96001857

Title: Corrosion assessment of refractory materials for high temperature waste vitrification Author(s): Marra, J.C.; Congdon, J.W.; Kielpinski, A.L.

Abstract: A variety of vitrification technologies are being evaluated to immobilize radioactive and hazardous wastes following years of nuclear materials production throughout the Department of Energy (DOE) complex. The compositions and physical forms of these wastes are diverse ranging from inorganic sludge to organic liquids to heterogeneous debris. Melt and off-gas products can be very corrosive at the high temperatures required to melt many of these waste streams. Ensuring material durability is required to develop viable treatment processes. Corrosion testing of materials in some of the anticipated severe environments is an important aspect of the materials identification and selection process. Corrosion coupon tests on typical materials used in Joule heated melters were completed using glass compositions with high salt contents. The presence of chloride in the melts caused the most severe attack. In the metal alloys, oxidation was the predominant corrosion mechanism, while in the tested refractory material enhanced dissolution of the refractory into the glass was observed. Corrosion testing of numerous different refractory materials was performed in a plasma vitrification system using a surrogate heterogeneous debris waste. Extensive corrosion was observed in all tested materials.

\section{$2173162 \quad$ NTIS Accession Number: DE00013670/XAB}

Title: Alternative host matrix based on iron phosphate glasses for the vitrification of specialized nuclear waste forms. 1998 annual progress report

Author(s): Day, D.E.; Fang, X.; Karabulut, M.; Marasinghe, G.K.; Ray, C.S.

Abstract: Certain high level wastes (HLW) in the US contain components such as phosphates, heavy metals, and halides, which make them poorly suited for disposal in borosilicate glasses. Iron phosphate glasses appear to be a technically feasible alternative to borosilicate glasses for vitrifying these HLWs. The iron phosphate glasses mentioned above and their nuclear waste forms are relatively new, so little is known about their atomic structure, redox equilibria, structure-property relationships, and crystallization products and characteristics. The objective of this research is to gain such information for the binary iron-phosphate glasses as well as iron phosphate waste forms so that a comprehensive scientific assessment can be made of their usefulness in nuclear waste disposal. This report summarizes the work undertaken and completed in the first 20 months of a three-year project. Approximately 250 samples, binary iron phosphate glasses and iron phosphate glasses containing one or two common nuclear waste components such as $\mathrm{UO}($ sub 2), $\mathrm{Na}(\mathrm{sub} 2) \mathrm{O}, \mathrm{Bi}(\mathrm{sub} 2) \mathrm{O}($ sub 3), $\mathrm{Cs}($ sub 2)O, $\mathrm{SrO}$, and $\mathrm{MoO}($ sub 3) have been prepared. Weight loss has been used to measure the chemical durability and the redox equilibria between $\mathrm{Fe}(\mathrm{II})$ and $\mathrm{Fe}(\mathrm{III})$ has been investigated using Moessbauer spectroscopy. The atomic structure has been investigated using a variety of techniques including Mossbauer, Raman, X-ray absorption (XAS), and Xray photoelectron (XPS) spectroscopies and neutron/high-energy X-ray scattering. Glass forming and crystallization characteristics have been investigated using differential thermal analysis (DTA). In addition, information necessary for glass manufacturing such as suitable refractories and Joule heating parameters also have been obtained.

\section{$2109916 \quad$ NTIS Accession Number: DE98059428/XAB}

Title: Melting, solidification, remelting, and separation of glass and metal Author(s): Ebadian, M.A.; Xin, R.C.; Liu, Y.Z.

Abstract: Several high-temperature vitrification technologies have been developed for the treatment of a wide range of mixed waste types in both the low-level waste and transuranic (TRU) mixed waste categories currently in storage at DOE sites throughout the nation. The products of these processes are an oxide slag phase and a reduced metal phase. The metal phase has the potential to be recycled within the DOE Complex. Enhanced slag/metal separation methods are needed to support these processes. This research project involves an 
experimental investigation of the melting, solidification, remelting, and separation of glass and metal and the development of an efficient separation technology. The ultimate goal of this project is to find an efficient way to separate the slag phase from the metal phase in the molten state. This two-year project commenced in October 1995 (FY96). In the first fiscal year, the following tasks were accomplished: (1) A literature review and an assessment of the baseline glass and metal separation technologies were performed. The results indicated that the baseline technology yields a high percentage of glass in the metal phase, requiring further separation. (2) The main melting and solidification system setup was established. A number of melting and solidification tests were conducted. (3) Temperature distribution, solidification patterns, and flow field in the molten metal pool were simulated numerically for the solidification processes of molten aluminum and iron steel. (4) Initial designs of the laboratory-scale DCS and CS technologies were also completed. The principal demonstration separation units were constructed. (5) An application for a patent for an innovative liquid-liquid separation technology was submitted and is pending.

\section{NTIS Accession Number: DE96012093}

Title: Technical evaluation of proposed Ukrainian Central Radioactive Waste Processing Facility Author(s): Gates, R.; Glukhov, A.; Markowski, F.

Abstract: This technical report is a comprehensive evaluation of the proposal by the Ukrainian State Committee on Nuclear Power Utilization to create a central facility for radioactive waste (not spent fuel) processing. The central facility is intended to process liquid and solid radioactive wastes generated from all of the Ukrainian nuclear power plants and the waste generated as a result of Chernobyl 1,2 and 3 decommissioning efforts. In addition, this report provides general information on the quantity and total activity of radioactive waste in the 30$\mathrm{km}$ Zone and the Sarcophagus from the Chernobyl accident. Processing options are described that may ultimately be used in the long-term disposal of selected 30-km Zone and Sarcophagus wastes. A detailed report on the issues concerning the construction of a Ukrainian Central Radioactive Waste Processing Facility (CRWPF) from the Ukrainian Scientific Research and Design Institute for Industrial Technology was obtained and incorporated into this report. This report outlines various processing options, their associated costs and construction schedules, which can be applied to solving the operating and decommissioning radioactive waste management problems in Ukraine. The costs and schedules are best estimates based upon the most current US industry practice and vendor information. This report focuses primarily on the handling and processing of what is defined in the US as lowlevel radioactive wastes.

\section{$1967243 \quad$ NTIS Accession Number: DE96006781}

Title: Vitrification of high level nuclear waste inside ambient temperature disposal containers using inductive heating: The SMILE system

Author(s): Powell, J.; Reich, M.; Barletta, R.

Abstract: A new approach, termed SMILE (Small Module Inductively Loaded Energy), for the vitrification of high level nuclear wastes (HLW) is described. Present vitrification systems liquefy the HLW solids and associated frit material in large high temperature melters. The molten mix is then poured into small ( $\sim \mathrm{m}$ (sup 3)) disposal canisters, where it solidifies and cools. SMILE eliminates the separate, large high temperature melter. Instead, the BLW solids and frit melt inside the final disposal containers, using inductive heating. The contents then solidify and cool in place. The SMILE modules and the inductive heating process are designed so that the outer stainless can of the module remains at near ambient temperature during the process cycle. Module dimensions are similar to those of present disposal containers. The can is thermally insulated from the high temperature inner container by a thin layer of refractory alumina firebricks. The inner container is a graphite crucible lined with a dense alumina refractory that holds the HLW and frit materials. After the SMILE module is loaded with a slurry of HLW and frit solids, an external multi-turn coil is energized with

30 cycle AC current. The enclosing external coil is the primary of a power transformer, with the graphite crucible acting as a single turn "secondary". The induced current in the "secondary" heats the graphite, which in turn heats the HLW and frit materials. The first stage of the heating process is carried out at an intermediate temperature to drive off remnant liquid water and water of hydration, which takes about 1 day. The small fill/vent tube to the 
module is then sealed off and the interior temperature raised to the vitrification range, i.e., $\sim 1200 \mathrm{C}$.

Liquefaction is complete after $\sim 1$ day. The inductive heating then ceases and the module slowly loses heat to the environment, allowing the molten material to solidify and cool down to ambient temperature.

1988247 NTIS Accession Number: DE97000419

Title: Vitrification of simulated radioactive Rocky Flats plutonium containing ash residue with a Stir Melter System

Author(s): Marra, J.C.; Kormanyos, K.R.; Overcamp, T.J.

\begin{abstract}
A demonstration trial has been completed in which a simulated Rocky Flats ash consisting of an industrial fly-ash material doped with cerium oxide was vitrified in an alloy tank Stir-Melterä System. The cerium oxide served as a substitute for plutonium oxide present in the actual Rocky Flats residue stream. The glass developed falls within the $\mathrm{SiO} 2+\mathrm{Al} 2 \mathrm{O} 3 /$ Sigma-Alkali/B2O3 system. The ash simulant was mixed with water and fed to the Stir-Melter as a slurry with a $60 \mathrm{wt} \%$ water to $40 \mathrm{wt} \%$ solids ratio. Glass melting temperature was maintained at $\sim 1,050 \mathrm{C}$ during the melting trials. Melting rates as functions of impeller speed and slurry feed rate were determined. An optimal melting rate was established through a series of evolutionary variations of the control variables' settings. The optimal melting rate condition was used for a continuous sixhour steady state run of the vitrification system. Glass mass flow rates of the melter were measured and correlated with the slurry feed mass flow. Melter off-gas was sampled for particulate and volatile species over a period of four hours during the steady state run. Glass composition and durability studies were run on samples collected during the steady state run.
\end{abstract}

\title{
04514555 AIX-30-043125; EDB-99-095234
}

Title: Using the method of induction melting in a cold crucible for the synthesis of mineral-like materials containing simulated radioactive waste

Author(s): Knyazev, O.A.; Lifanov, F.S.; Lopukh, D.B.; Lyubomirov, A.M.; Pechenkov, A.Yu.; Stefanovskii, S.V.;

Abstract: In the area of ensuring the ecological safety of the life of people, a special position is occupied by the problem of making safe various radioactive waste (RAW), formed in the process of processing nuclear fuel. To solve this problem, a number of methods and apparatus-technological systems of processing RAW into forms, stable to the effect of the environment, have been developed recently. Promising in this direction are the materials SYNROC (synthetic rock) and the glass ceramics based on titanite. The method of hot pressing has been developed for the production of SYNROC material, although the possibilities of producing several modifications of this material from the melt have also been discussed. The glass ceramics was produced by the crystallization of the alumotitanosilicate melt. To realize the systems, including the melting stage, it is necessary to develop melting equipment capable of liver operation at high temperatures. Recently, special interest has been attracted by the system providing the application of high-frequency power technology. Work has been continuing since the beginning of the Eighties with the application of the method of induction melting in cold crucibles (IMCC) for the vitrification of RAW. The IMCC method has the following main advantages: it makes it possible to harden the waste into more refractory and chemically stable glass-like and crystalline matrixes; there is no direct contact of the chemically active melt with the crucible material; this creates suitable conditions for solving the problem of erosion of the material of the melting system and increasing its service life; the deep heating of the melt with the high-frequency field and convective mixing of the melt make it possible to intensify the melting process and decrease the removal of radionuclides; the increase of the specific productivity of the furnace makes possible to develop a compact, remote-controlled cold crucible. Because of these advantages of the IMCC method, the method has been used for the high-temperature synthesis of new materials, which may include in their structure also the radionuclides of the RAW. The aim of this work was to examine in detail the conditions of the IMCC and the melting conditions of SYNROC material and glass ceramics based on sphene.

04034053 EDB-96-117813

Title: Framatome technologies' vitrification process 
Author(s): Hellman, S.P.; Draus, L.E.; Guiroy, J.J.; Murray, J.R.

Abstract: One of the major difficulties encountered in vitrifying low- and medium-activity radioactive wastes is ensuring that volatile components, such as cesium $(\mathrm{Cs})$, are integrated into the requisite waste glass matrix and not carried over, in vapor or particulate form, into the off-gas system. The inability to retain these volatile components within the glass matrix can result in radioactive carryover into the off-gas system requiring separate treatment and/or extraction processes. This difficulty is of particular concern in vitrifying wastes that generate large amounts of gas or vapor when broken down by heat. In these cases, the gases or vapors generated may transport the volatile particles or vapors into the off-gas system before they can be integrated into the glass matrix of even before they come in contact with the liquid glass medium, such as in the [open quotes] cold-cap [close quotes] vitrification process. This phenomenon is further aggravated if the waste is in the form of a fine, easily entrained powder or contains excessive moisture, such as in spent resins in bead or powder form, sludge, or concentrates.

Title: Advancement in Evaporation and Calcination Techniques for Radwastes in India Author: D.P. Pande, Process Engineering \& Systems, Development Division, Nuclear Waste Management Group, Bhabha Atomic Research Center, Bombay, India.

Abstract: The evaporation technique is very effective in concentrating the volume of the liquid waste and separating the low-activity distillate. Water is removed in the vapor phase leaving behind nonvolatile radioactive content in the solution. Extensive experimental and theoretical investigations were carried out to optimize the design and operation of the evaporators. The experiments revealed that fouling of tubes and scaling increases at higher chemical concentrations. Therefore, for further removal of moisture, dehydration and denitration of the waste, calciners are used. The nitrates are water soluble and corrosive therefore, these are converted into solid oxides. The oxides are granular solids and chemically stable with good heat conductivity. This facilitates uniform mixing and good compatibility with glass matrix. In order to remove moisture, dehydrate, denitrify and oxidise the heterogeneous waste into a granular product, various types of calcinations techniques have been examined. A brief review of state of art and present state of technology is presented in this paper.

Title: Noble Metal (NM) Behavior During Simulated HLLW Vitrification in Induction Melter with Cold Crucible

Author(s): A.V. Demin, Yu I. Matyunin, M.I. Fedorova, A.A. Bochvar, All-Russia Scientific Institute of Inorganic Materials (ARSRIIM), Moscow, Russia.

Abstract: The investigation of noble metal ( $\mathrm{Ru}, \mathrm{Rh}, \mathrm{Pd})$ properties in glass melts are connected with their specific behaviors during HLLW vitrification. Ruthenium, Rhodiurn and Palladium volatilities and heterogeneous platinnoid phases forming on melts are investigated in reasonable details conformably tojoule's heating ceramic melters. The vitrification conditions in melters with induction heating of melts are differ from the vitrification ones. in ceramic melters on some numbers of parameters (the availability of significant temperature gradients and convection flows in melts, short time of molten mass updating in melter and probability of definite interaction between high-frequency field and melt inhomogeneities). The results of simulated HLLW solidification modelling of the vitrification process in induction melter.with cold crucible to produce phosphate and boronsilicate materials are presented. The properties of received glasses and behavior of platinoids are shown to have analogies and distinctions in comparison with compounds, synthesized in ceramic melter. The structures of dispersed particles of NM heterogeneous phases forming in glass melts prepared in induction melter with cold crusible are identified. The results of investigations show, that the marked distinctions between two processes can influence (in definite degree) as on property of synthesized materials, as on behavior of platinoid during vitrifications.

Title: Production of SYNROC Through Melting in "Cold Crucible"

Author(s): Fyodor A. Lifanov, Igor A. Sobolev and Sergy V. Stefanovsky, SIA "Radon” Moscow, Russia; Dmitry B. Lopukh, University of Electric Engineering, St. Petersburg, Russia 
Abstract: SYNROC is titanate-based material consisting of congruently melting minerals. An experiments on production of SYNROC-C composition under oxidizing and reducing conditions were performed. The SYNROC batch melts at temperature close to $1400^{\circ} \mathrm{C}$. A high frequency facilities with $\sim 60 \mathrm{~kW}$ of vibrating power operated at 5.28 or $1.76 \mathrm{MHz}$ were applied. Internal crucible diameter was $80-160 \mathrm{~mm}$. SYNROC melt is very mobile and "short". It is necessary to overheat a melt for melting process stabilization. The operating temperature was determined to be depended on operating frequency and crucible dimensions. and was ranged between 1320-1330 and $1600-1700^{\circ} \mathrm{C}$. Continuous and semi-continuous modes of operation were tested. A melt capacity was widely varied depended on crucible dimensions, operating frequency and power. For crucible with round cross-section, $100 \mathrm{~mm}$ in diameter, operated at frequency of $1.76 \mathrm{MHz}$ with $60 \mathrm{~kW}$ of output power of hf generator the capacity measured was approximately $\mathrm{I} 0-15 \mathrm{~kg} / \mathrm{h}$ at semi-continuous mode of operation. In SYNROC-C produced in cold crucible under reducing condition only the same crystalline phases as hot-pressed SYNROC-C were found. Production of SYNROC-C under oxidizing condition yielded minor additional powellite phase. The basic properties of melted and hot-pressed SYNROC-C were established to be similar.

\section{Title: Vitrification Process Development and Design for Large Scale Plant}

Author(s): M. Kitamura, K. Miwa, M. Ayabe, Ishikawajima-Harima Industries Co., Ltd.

Abstract: The construction of the commercial reprocessing plant at Rokkasyo is being planned by Japan Nuclear Fuel Limited (JNFL) in Japan. The high active liquid wastes from the reprocessing process will be immobilized in a borosilicate glass through vitrification process for interim storage. The vitrification process with joule-heated ceramic melter has been selected. Ishikawajima-Harima Heavy Industries Co., Ltd. (IHI) has been engaged in the design and development of the vitrification process based on the technology, which has been established by Power Reactor and Nuclear Fuel Development Corporation (PNC) in Japan. A series of studies comprised of liquid treatment and off gas treatment have been performed for the design of the process.

Title: Design and Full-Scale Testing of Nuclear Waste Glass Melter Technology Developed by INE for Application in China.

Author(s): G. Roth, W. Grunewald and S. Weisenberger, Forschungszentrum Karlsruhe, Institut für Nukleare Entsorgungstechnik (INE) 76021 Karlsruhe, Postfach 3640, Germany; Sun Dong Hui, China National Nuclear Corporation (CNNC) Peoples Republic of China.

Abstract: In the scope of a technology transfer project with China, a large-scale ceramic waste glass melter, designated BVPM, had been designed and constructed at the Institut für Nukleare Entsorgungstechnik (INE) of the Forschungszentrum Karlsruhe. Before its delivery to China, the melter was operated in INE's V-W1 vitrification mock-up facility under Chinese participation. Within two continuous long-term test runs $45 \mathrm{M} 3$ of HLLW simulate were converted to 29 tons of glass product. The simulated feed was composed according to analytic data of radioactive HLLW solutions currently stored in China. In the second test run, about $20 \mathrm{M} 3$ of Simulate with a content of $70 \mathrm{~kg}$ of noble metals were processed to demonstrate the noble metals compatibility of the melter. A description of the BVPM melter and the mock-up facility is given. The results of the test runs, especially the process behavior, the operation of the glass pouring systems, the noble metals removal efficiency, and the performance of a new glass level detection device are reported. The melter feed contained a significant concentration of sulphur, which is one of the most troublesome elements in vitrification. The sulphur incorporation data is given as well. The overall test results of the BVPM melter indicated that the technology is well applicable for use in China's mock-up test facility at the Sichuan Nuclear Fuel Plant (SNFP). It is not only suitable for the considered waste solutions but also works convincingly when processing highly noble metalscontaining melter feed (3-4 g/l).

Title: Innovative Pretreatment and Vitrification Technology For Waste Remediation Author(s): J. Hnat, M Pineda, D. Detwiler, M. Schaffer, Vortec Corporation. 
Abstract: The Department of Energy and its contractors have been evaluating the development of various innovative technologies to solve its waste remediation needs. Vitrification and other treatment technologies are being evaluated for the processing of a wide variety of organic, heavy metal, and radionuclide contaminated wastes. Vortec Corporation has developed innovative waste pretreatment and vitrification systems for the treatment and remediation of contaminated soils. Wastes that have the potential of being processed using the Vortec pretreatment and -vitrification technologies include low-level radioactive (LLW), mixed hazardous and low level radioactive waste (MLLW), and Toxic Substance Controlled Act (TSCA) waste containing regulated substances such as PCBS. This paper describes the progress of a demonstration program for the pretreatment and vitrification of these waste materials.

Title: Information Provision of Plant Induction Melter Author(s): N.V. Vitik, V.N. Popkov, I.A. krokhin, S.A. Vladimirov, S.A. Dmitriev, and F.A. Lifanov, Moscow Sicentific \& Industrial Association "Radon".

Abstract: Automatic system for controlling liquid radioactive waste (LRAW) vitrification in an industrial plant of Moscow SIA "Radon" is discussed. Two-level control system allows to control all the parameters, to adjust the basic ones, to display and to registrate the obtained information. Specialized complex with the thermovisor controlling the temperature on the surface and in the depth of melt is designed. The complex is a part of controlling system. The control system comprises mathematical models of thermo-phisic and electromagnetic processes in crucible. Analysis of data from measuring devices and mathematical models gives a complete information about processes in the induction melter. The designed automatic system provides effective and unfailure controlling after the LRAW vitrification plant.

Title: 10 Years of Vitrification in La Hague's R7/T7 Facilities: From R\&D to Production

Author(s): Herve Masson, COGEMA; Jean-Louis Devaux and Eric Pluche, COGEMA; Antoine Jouan, CEA/VALHRO

Abstract: Reprocessing of spent nuclear fuels is the industrial operation through which valuable materials uranium and plutonium - are sorted out prior to their reuse in fresh fuels. High level waste, i.e., fission products and actinides are separated and incorporated in glass matrix in order to be safely stored and disposed of.

\title{
04338008 EDB-98-098423
}

Title: Vitrification of High-Level Liquid Waste: Glass Chemistry, Process Chemistry and Process Technology Author(s): G. Roth, S. Weisenburger

\begin{abstract}
The management of high-active liquid waste includes the solidification and the subsequent isolation in a deep geological formation. Vitrification is internationally accepted as the technology of choice for its immobilization. It is the best-demonstrated available technology. The advantages of the glass waste form are its tolerance of chemical variability, chemical durability and processability. About one dozen of vitrification plants are worldwide being operated or in the planning stage. One of the latter is the Karlsruhe vitrification plant (VEK) at Karlsruhe, which makes use of the liquid-fed ceramic melter process. This process is described with respect to the process technique, especially the melter technique and the process chemistry. Also basic aspects of the glass chemistry are discussed.
\end{abstract}




\section{$5607383 \quad$ INSPEC No.: A9714-2875-086}

Title: Development of Glasses for the Vitrification of High Level Liquid Waste (HLLW) in a Joule Heated Ceramic Melter

Author(s): B. Luckscheiter and M. Nesovic

Abstract: A vitrification process was developed at Forschungszentrum Karlsruhe, Institut für Nukleare Entsorgungstechnik (INE), for solidifying in borosilicate glasses High Level Waste (HLW) solutions from the nuclear fuel cycle. To optimize melter operation the glass melt should have a flat viscosity curve and a relatively high specific electrical resistance of a $6.5 \mathrm{~A} \mathrm{~cm}$ at $1150 \mathrm{oC}$. Further requirements are: no liquid-liquid immiscibility and no crystallization of the glass, waste loading $\mathrm{c} 15 \mathrm{wt} \%$ and, in view of repository storage of the HLW glass, a chemical durability comparable to that of other HLW glasses. The main emphasis of experimental work was put on finding out how the viscosity, the slope of the viscosity curve, the specific electric resistance and the chemical durability depend on the chemical composition of the glasses. Especially the effect of the mixed alkalis $\mathrm{Li}$ and $\mathrm{Na}$ on the glass properties was studied. It was found that by increasing from 0 to 1 the $\mathrm{Li} 2 \mathrm{o} /(\mathrm{Na} 2 \mathrm{O}$ + Li2O) molar ratio of the glass FRIT WAW, the viscosity of the melt decreases roughly linearly and the slope of the viscosity curve decreases as well. The specific electric resistance passes through a maximum and the Soxhlet leach rate through a minimum at an alkali ratio of about 0.5 . As a final result, a range of optimum glass compositions was determined which meet the required properties.

\section{EDB-99-077874}

Title: Progress in Nuclear Waste Vitrification by Ceramic Melter Technique Author(s): S. Weisenburger

Abstract: Nuclear waste vitrification by using the liquid-fed ceramic-lined waste glass melter process started in 1973 with the pioneering development at Battelle Pacific Northwest Laboratory. The first radioactive plant applying this technique was the PAMELA plant in Mol/Belgium, which was put into hot operation in 1985. A main part of the technology for this plant including the melter was developed by the Institut für Nukleare Entsorgungstechnik (INE) of Forschungszentrum Karlsruhe (FZK). For the time being there is an increasing demand for the availability of small-scale vitrification units for processing of small stocks of high level liquid wastes (HLLW). Limited quantities of HLLW solutions were obtained during the period of development of reprocessing techniques at various international sites. One example is the former WAK (Wiederaufarbeitungsanlage Karlsruhe) reprocessing plant. It is located at the site of Forschungszentrum Karlsruhe and is now under decommissioning. The overall decommissioning program includes vitrification of $70 \mathrm{~m} 3$ of stored HLLW with a total of $\mathrm{J} / \mathrm{K}$ radioactivity of $8.9 \mathrm{x}$ e17 Bq. This paper focuses on progress achieved in the design of small-scale liquid-fed ceramic glass melters for these purposes. Improvements are described regarding extension of power electrode life time by optimized air cooling, glass pouring operation, off-gas pipe cleaning, glass level detection system in the melt tank, and arrangement of a small-scale melter in a hot a cell. Some test results achieved with the new melter are also outlined. 


\section{Distribution}

No. of

Copies

\section{OFFSITE}

J. Ahearne

Sigma Xi, The Scientific Research Society PO Box 13975

Research Triangle Park, NC 27709

C. Anderson

U.S. Department of Energy

Savannah River Operations

Office Bldg. 704-

Aiken, SC 29802

T. Bessman

Oak Ridge National Laboratory

P.O. Box 2008,

Oak Ridge, TN 37831

D.F. Bickford

Westinghouse Savannah River Company 773-43A Bldg./Rm. 113

Aiken, SC 29808

J.T. Case

U.S. Department of Energy

Idaho Operations Office

850 Energy Drive

Idaho Falls, ID 83401

C.R. Cooley

U.S. Department of Energy

12800 Middlebrook Road, Suite 100

Germantown, MD 20874

D.E. Day

University of Missouri-Rolla

1870 Miner Circle

109 Straumanis Hall

Rolla, MO 65409
No. of

Copies

J.A. Gentilucci

JAG Technical Services, Inc.

127 Savannah Drive

Aiken, SC 29803

T.S. Gutmann

U.S. Department of Energy

Savannah River Operations

Office Bldg. 704-

Aiken, SC 29802

E.W. Holtzscheiter

Westinghouse Savannah River Company

Savannah River Technology Center

Bldg. 773-A/A-229, Rm. MS: 28

Aiken, SC 29802

C. Jantzen

Westinghouse Savannah River Company Bldg. 773-A/B-104 Rm

Aiken, SC 29808

K.A. Lockie

U.S. Department of Energy

Idaho Operations Office

750 Doe Place (MS 1145)

Idaho Falls, ID 83402

S. Marra

Westinghouse Savannah River Company Bldg. 704-1T/206 Rm.

Aiken, SC 29808

C.A. Musick

Idaho National Engineering and

Environmental Laboratory

PO Box 1625, MSIN 5218

Idaho Falls, ID 83415

D.K. Peeler

Westinghouse Savannah River Company 773-43A Bldg./Rm. 111

Aiken, SC 29808 
No. of

Copies

D. Pye

New York State College of Ceramics

Alfred University

2 Pine Street

Alfred, NY 14802

K. Reuter

Bechtel National Inc.

3170 George Washington Way

MSIN: MS1-C

Richland, WA 99352

E.T. Weber

6622 W. Victoria

Kennewick, WA 99336

F. Woolley

114 Weston Lane

Painted Post, NY 14870

ONSITE

DOE-ORP

$\begin{array}{ll}\text { H.L. Boston } & \text { H6-60 } \\ \text { R. Carreon } & \text { H6-60 } \\ \text { J. Cruz } & \text { H6-60 } \\ \text { L. Erickson } & \text { H6-60 } \\ \text { B.M. Mauss } & \text { H6-60 } \\ \text { W.J. Taylor } & \text { H6-60 }\end{array}$

CH2M Hill Hanford Group

TW Crawford R1-04

K.A. Gasper LO-47

J.O. Honeyman H6-18

\section{Numatec Hanford Company}
A.M.F. Choho
R2-58
J.S. Garfield
LO-47
S.L. Lambert
R3-73
R.S. Wittman
R3-73

No. of

Copies

Pacific Northwest National Laboratory

B.W. Allen K9-69

R.A. Brouns H6-61

T.M. Brouns K9-69

J.L. Buelt K7-73

B.A. Carteret K9-91

A.C. Ettesvold K9-69

P.A. Gauglitz K6-28

R.L. Gilchrist K9-91

J.H. Holbrook H6-61

L.K. Holton H6-61

P.R. Hrma K6-24

G.B. Josephson K9-69

D.S. Kim K6-24

G.B. Mellinger H6-61

E.V. Morrey P7-28

C.L. Nickola K9-69

T.L. Page K9-18

R.K. Quinn K2-20

G.L. Smith K6-24

D.M. Strachan K6-24

M.B. Triplett K6-04

J.D. Vienna K6-24

J.H. Westsik K9-91

B.J. Williams K9-69

Washington Group International

J. Perez H6-61 